PACIFIC LINGUISTICS

Series C - No. 54

\title{
AUSTRALIAN LINGUISTIC STUDIES
}

\author{
S.A. Wurm, ed.
}

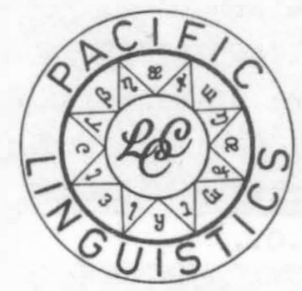

Department of Linguistics

Research School of Pacific Studies

THE AUSTRALIAN NATIONAL UNIVERSITY 
PACIFIC LINGUISTICS is issued through the Linguistic Circle of Canberra and consists of four series:

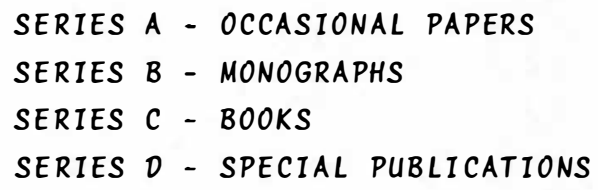

EDITOR: S.A. Wherm.

ASSOCIATE EDITORS: D.C. Laycock, C.L. Voorhoeve, D.T. Tryon, T.E. Dutton. EDITORIAL ADVISERS:

B. Bender, University of Hawaii

D. Bradley, Australian National University

A. Capell, University of Sydney

S. Elbert, University of Hawaii

K. Franklin, Summer Institute of Linguistics

w.w. Glover, Summer Institute of Linguistics

G. Grace, University of Hawaii

M.A.K. Halliday, University of Sydney

A. Healey, Summer Institute of Linguistics

L. Hercus, Australian National University

N.D. Liem, University of Hawaii
J. Lynch, University of Papua New Guinea

K.A. MCElhanon, University of Texas

H. McKaughan, University of Hawaii

P. Muhlhausler, Technische Universitat Berlin

G.N. O'Grady, University of Victoria, B.C.

A.k. Pawley, University of Hawaii

K. Pike, University of Michigan; Summer Institute of Linguistics

E.C. Polome, University of Texas

G. Sankoff, Université de Montréal

$E$. Uhlenbeck, University of Leiden

J.W.M. Verhaar, University of Indonesia, Jakarta

ALI CORRESPONDENCE concerning PACIFIC LINGUISTICS, including orders and subscriptions, should be addressed to:

The Secretary,

PACIFIC LINGUISTICS,

Department of Linguistics,

School of Pacific Studies,

The Australian National University,

Canberra, A.C.T. 2600.

Australia.

Copyright (C) The Authors.

First published 1979.

The editors are indebted to the Australian National University for help in the production of this series.

This publication was made possible by an initial grant from the Hunter Douglas Fund.

National Library of Australia Card Number and ISBN 0858831856 


\section{PREFACE}

The present volume offers thirteen contributions to Australian linguistics problems of a rather wide, general, high-level or off-themalnstream nature whose discussion has been largely outside the scope of the quite numerous publications in Australian linguistics which have appeared during the last few years. Since the early seventies, these have very predominantly concentrated on 1ndividual Australian languages or on narrow aspects of particular languages or language groups.

In the light of this, the present volume contributes to the generalistic approach to the study of Australian linguistics which constitutes a necessary background and counterbalance to recent studies of a narrower nature in this field.

Michael Walsh offers a discussion of Australian linguistics research over the last ten years, with extensive bibliographical information, and a blbliography supplement for the years 1957-68 by M1chael Walsh and Lols Carrington. Peter Sutton addresses himself to the problems of the writing and spelling of Australian language names. Geoff O'Grady gives an over-view of the very speclal problems confronting the worker in Australian comparative and historical linguistics, and puts forward his 1deas in connection with them. Arthur Capell, the doyen of Australian linguistics and of linguistics In Australia, contributes three extensive papers summarising aspects of findings arlsing from his life-long study of Australian languages. One of these deals with Australian languages in general, hypothetical questions of their origin and possible development, and overall problems presented by their study. The other two address themselves in great detall to problems of the classification of nouns and verbs in Australian languages. Barry Blake offers extensive typological and historical observations on the case systems in Australian languages. 
Jeffrey Heath writes in considerable detall on problems and perspectives of diffusional linguistics in Australia. Luise Hercus contributes a paper on problems of Australian comparative linguistics as exemplified by special phenomena observable in Arabana and Wanganuru. Nell Chadwick presents an overview of the languages of the West Barkly Tablelands. Peter Sutton and Bruce Rigsby offer a sociolinguistic discussion of linguistic communities and social networks in Cape York Peninsula and of the problems for Australian linguistics in general as highlighted by their findings. Margaret Sharpe's paper deals with Alice Springs Aboriginal children's English and sociolinguistic questions connected with it.

The contributions to the volume draw attention to many areas and questions for rich further study by Australian linguists, and highlight the need for studies of a wider and general nature in this vast field of linguistic research. 
TABLE OF CONTENTS

Page

Preface

111

RECENT RESEARCH IN AUSTRALIAN LINGUISTICS - M.J. Walsh

1. INTRODUCTION 1

2. THE INSTITUTIONAL FRAMEWORK 1

2.1. Australian Institute of Aboriginal Studies 1

2.2. Australian National University 2

2.3. Macquarie University 4

2.4. Monash University 4

2.5. University of New England 4

2.6. University of Queensland 5

2.7. University of Sydney 6

2.8. University of Western Australia 6

2.9. Summer Institute of Linguistics 6

3. SURVEYS 7

4. DESCRIPTIONS OF AUSTRALIAN LANGUAGES 7

5. LEXICON 11

6. SONG WORDS 11

7. ETHNOCLASSIFICATION 12

8. TEXTS 12

9. DISCOURSE STRUCTURE 13

10. TRANSLATIONS AND RESEARCH ON EARLY SOURCES 13

11. NOTES ON TYPOLOGICAL STUDIES 14

12. HISTORICAL AND COMPARATIVE LINGUISTICS 15

13. TASMANIAN 16

14. AUXILIARY LANGUAGES 16

15. SIGN LANGUAGE 17

16. ABORIGINAL ENGLISH, PIDGINS AND CREOLES 18

17. SOCIOLINGUISTICS 18

18. CONCLUSION 19

Notes 20

Bibliography 21 
AN AUSTRALIAN LINGUISTIC BIBLIOGRAPHY - FROM GREENWAY

TO THE LATE SIXTIES - M.J. Walsh and Lois Carrington

AUSTRALIAN LANGUAGE NAMES - P. Sutton 87

1. SPELLING THE NAMES $\quad 87$

2. WHAT DO THE NAMES MEAN? 89

3. NOMENCLATURES IN THE LITERATURE DEALING WITH THE

$\begin{array}{ll}\text { AREA BATHURST HEAD, FLINDERS GROUP, TO BARROW POINT } & 94 \\ \text { (CAPE YORK PENINSULA) } & \end{array}$

3.1. Roth, W.E. 94

3.2. Hale and Tindale (1933) 94

3.3. Tindale, N.B. 95

3.4. Capell, A. 95

3.5. West, L.M. 96

3.6. Trezise, P.J. 96

3.7. Oates, W.J. and L.F. (1970) 96

3.8. Sutton, P.J. (1970) 97

3.9. Dixon, R.M.W. (1972) 97

3.10. Sommer, B.A. 97

3.11. Thompson, D. (1972 97

4. INTERPRETATION OF SOURCES AS LISTED 97

4.1. Roth (1898, 1910) 97

4.2. Hale and Tindale (1933) 98

4.3. Tindale (1940, 1974) 98

4.4. Capell (1955) 98

4.5. West (1962, 1965) 98

4.6. Trezise (1969, 1973) 98

4.7. Oates (1970) 99

4.8. Sutton (1970) 99

4.9. Dixon (1972) 99

4.10. Sommer (1972, 1974) 99

4.11. Thompson (1972) 99

5. COMMENTS 100

6. CONCLUSION 101

Notes 102

Bibllography 103

PRELIMINARIES TO A PROTO NUCLEAR PAMA-NYUNGAN STEM LIST - 
GRAMMATICAL CLASSIFICATION IN AUSTRALIA - A. Capell 141

$\begin{array}{ll}\text { 1. INTRODUCTION: Types of Classification - } & 141 \\ \text { Nouns and Verbs }\end{array}$

2. DICHOTOMY OF FEMININE v. NON-FEMININE 144

3. GRAMMATICAL CLASSIFICATION OF NOUNS 147

4. CLASSIFICATION BY DETERMINATIVES 148

4.1. Cape York Peninsula Languages 148

4.2. The DJ1rbal Phenomenon 149

5. CLASSIFICATION OF PREFIXATION 151

5.1. The Northern Kimberley Languages 151

5.1.1. The Principles of Noun-Classification 155

5.2. Multiple Classification in Arnhem Land Languages 159

5.2.1. Preliminary 159

5.2.2. Laragiya 162

5.2.3. Gagadju 163

5.2.4. Urningangg and Manger1 165

5.2.5. Northern Arnhem Land 167

5.2.6. Southern Arnhem Land 169

5.3. Multiple Classification Outside Arnhem Land 174

5.3.1. Yanjuwa 174

5.4. Isolated South-western Languages 176

$\begin{array}{ll}\text { 5.4.1. Nungal1 } & 177\end{array}$

5.4.2. Wardaman 178

5.5. The Daly River Languages 179

6. MULTIPLE CLASSIFICATION BY SUFFIXATION 182

6.1. Introduction 182

6.2. Djingil1 182

6.3. Wambaya Group 183

7. DUAL CLASSIFICATION 185

7.1. Introduction 185

7.2. Bathurst and Melville Islands 186

7.3. Northern Group 186

7.3.1. Gunavidj1 186

7.3.2. Nagara 187

7.4. Southern Group 189

7.4.1. Alawa 189

7.4.2. Mangaray 190

7.5. Dual Classification by Suffixation 191

7.5.1. Languages of East K1mberley 191 
8. ISOLATED CLASSIFYING LANGUAGES 193

8.1. East Coast Languages of Queensland and
New South Wales

9. A HISTORICAL VIEW OF NOUN CLASSIFICATION 200

9.1. Introduction 200

9.2. Characteristics of Classification Systems 202

9.3. Stages in the Development of Class Marking 204

9.3.1. The Free Forms called Determinatives 207

9.3.2. The History of the 'Determiners' 210

9.3.3. Stages of Noun-classing 212

9.3.4. Syntactic Factors in the Development 216

9.4. The East Coast Classifying Languages 221

Bibliography 224

Map 1: Noun Classification 142

Map 2: The Languages of the Northern Kimberley 152

Map 3: Languages of North-western Arnhem Land 161

Map 4: The Daly River Languages 180

Map 5: Languages of the Central Eastern Coast
of New South Wales

CLASSIFICATION OF VERBS IN AUSTRALIAN LANGUAGES - A. Capell 229

0. INTRODUCTION 229

1. SIMPLE CONJUGATION 233

2. COMPOUND CONJUGATION 235

2.1. Phrasal Verbs 239

2.1.1. Phrasal Verb Compounding 239

2.2. Auxiliarles 242

2.2.1. Free Auxiliaries 242

2.2.1.1. Cape York Languages 242

2.2.1.2. South-western Languages 243

2.2.1.3. The Dampler Land Languages 244

2.2.1.4. Daly River Languages 245

2.2.1.5. Languages along Southern Arnhem Land 247

2.2.1.6. The Northern Arnhem Land Languages 250

2.2.1.6.1. Laragiya 250

2.2.1.6.2. Other Western Arnhem Land Languages 251

2.2.1.6.3. Gunwinggu Group of Languages 251

2.2.1.6.4. Other Arnhem Land Languages 257

2.2.1.7. South Australian Languages 257

2.2.1.7.1. Diyar1 258 
2.2.1.7.2. Dh1rar1 260

2.2.1.7.3. Ngamini 261

2.2.1.7.4. Midhaga 262

2.2.1.7.5. Yandruwanda 262

2.2.1.7.6. Yarluyand1 263

2.2.2. The 'Catalyst' Languages 264

2.2.3. Languages Using Free Auxiliaries 267

2.2.3.1. Western Desert Languages 269

2.2.3.2. North-east Arnhem Land 276

2.2.4. Bases with Bound Morphemes 278

2.2.4.1. Durubul (Djandawal, Yagarabal, etc.) 280

2.2.4.2. Bandfalong Dialects 281

2.2.4.3. Gumbainggar 282

2.2.4.4. Dhanggad1 and Gadhang 283

2.2.4.5. Awaba and Guringgay 284

2.2.4.6. The Sydney Area 287

2.2.4.7. South Coast of New South Wales 290

2.2.4.8. Languages Inland from the Dividing Range 292

3. THE NATURE AND HISTORY OF THE SYSTEMS 294

3.1. Introduction 294

3.2. The Phrasal Verb 297

3.3. Compounding by Auxiliary 299

3.3.1. Free Auxiliaries 300

3.3.2. The Degradation of Auxiliaries 304

3.4. Other Systems of Verb Derivation 304

3.5. Summary and Probable History 309

$\begin{array}{ll}\text { Bibliography } & 314\end{array}$

Map: Confugation Systems in Australia 231

AUSTRALIAN CASE SYSTEMS - SOME TYPOLOGICAL AND HISTORICAL 323

$\begin{array}{ll}\text { OBSERVATIONS - B.J. Blake } & 323 \\ \text { refatory Note } & \end{array}$

Acknowledgments $\quad 323$

1. TYPOLOGICAL OUTLINE 327

1.1. The Major Syntactic Case Relations 327

1.2. Dative 330

1.3. Concrete Cases 332

1.4. Pama-Nyungan Case Systems 332

1.5. Transitivising Mechanisms 333

2. MORPHOLOGICAL DEVELOPMENT 335 
2.1. Nouns 335

2.1.1. Ergative(-Instrumental) 335

2.1.2. Locative 341

2.1.3. Accusative 342

2.1.4. Dative 343

2.1.5. Summary 343

2.2. Free Pronouns 344

2.2.1. General 344

2.2.2. Major Syntactic Relations 345

2.2.2.1. Pronoun Augmentation 345

2.2.2.2. Free Pronouns in an Ergative Paradigm 352

2.3. Bound Pronouns 356

2.3.1. Languages with no Bound Pronouns or 356

2.3.2. Languages with Bound Pronouns Distinctly
Different from the Free Pronouns

2.3.3. Languages with Fused, etc. Bound Pronouns 367

2.3.4. Summary 368

3. SYNTAX 369

3.1. Walbir1 369

3.2. Pitta-Pitta 371

3.3. Kalkatungu 372

3.4. Dyirbal 376

$\begin{array}{lll}3.5 & \text { Summary } & 377\end{array}$

3.6. Some Suggested Historical Developments 377

3.6.1. Kalkatungu 377

3.6.2. Pitta-Pitta 379

4. GENERAL SUMMARY 381

Notes $\quad 383$

B1bllography $\quad 387$

Map: Languages and Isoglosses 325

DIFFUSIONAL LINGUISTICS IN AUSTRALIA: PROBLEMS AND
PROSPECTS - J. Heath

1. INTRODUCTION 395

2. DIFFUSIONAL vs. AREAL LINGUISTICS 397

3. DEMOGRAPHIC AND CULTURAL FACTORS 401

4. DIFFUSION OF VOCABULARY 404

5. DIFFUSION OF PHONOLOGY 410 
6.

DIFFUSION OF MORPHOLOGY AND SYNTAX

Page THE FUTURE

412

7.
Bibliography
Map: Language Situation in Part of Northern Australla

414

417

399

THE HISTORY OF AUSTRALIAN LANGUAGES: A FIRST APPROACH -

419

A. Capell

1 .

1.1 .

1.2.

1.3 .

2.

2.1 .

2.2 .

2.2 .1 .

2.2.2.

2.2.3.

2.3 .

2.3.1.

2.3 .1 .1

2.3.1.2.

2.3 .2 .

2.3.3.

2.3 .4 .

2.4.

2.4.1.

2.4.2.

3.

3.1 .

3.2 .

3.3 .

3.3.1.

3.3.2.

3.3.3.

3.3.4.

3.3 .4 .1 .

3.3 .4 .2 .

3.4 .

3.5 .
INTRODUCTION

Preliminary Note

419

419

Characteristics of the Languages

423

Structural Development of Australian Languages

431 HISTORICAL PHONOLOGY

431

Preliminaries

431

The Australian Sound Systems 434

The Consonants $\quad 434$

The Vowels 438

Other Phonological Features 441

Processes of Sound Change 443

The Cape York Languages 445

Northern CY Languages (Northern Paman or NP) 445

The Southern CY Languages 446

Central Australian Languages $\quad 447$

The Western Desert (WD) Languages 450

The Archa1c Languages of the South-East and 452 Extreme North

Historical Phonological Change In Deta1l 459

Consonants $\quad 460$

The Puzzle of Root Establishment 464

STRUCTURE OF AUSTRALIAN LANGUAGES 466

Establishing Historical Stages $\quad 466$

Languages Lacking True Pronouns 470

Other Non-CA Groups of Languages 474

Languages of the Daly River Area 475

The Tiw1 Language of Bathurst and Melville Islands 476

Dampler Land Languages 478

Other Areas $\quad 479$

Yugulda, Garawa and Galgadungu 481

Lard11, Bidabida and Gurnu 492

The EA na- Serles of Pronouns 495

Pronouns of the Western Desert Languages 507 
3.6 .

3.7 .

3.8 .

3.8.1.

3.8 .2 .

3.8 .3 .

3.9 .

3.10 .

4.

4.1 .

4.2 .

4.3 .

4.4 .

4.5 .

4. 5.1 .

4.5.2.

4.5 .3 .

4.5 .4 .

4.6 .

5 .

5.1 .

5.2 .

5.2.1.

5.2 .2 .

5.2 .3 .

5.2 .4 .

6.

6.1 .

6.2 .

6.3.

6.3.1.

6.3.2.

6.3 .3 .

6.4 .

6.4 .1 .

6.4 .2 .

6.5 .
Possible History of Affix Transference

Page

Cape York Pronominal Systems

The 'Catalyst' Systems

The Western Desert Languages

Catalysts other than Western Desert

Auxiliary Verbs

Summary Survey

Evolution of the Pronouns in Australia

MORPHOSYNTACTIC HISTORY IN AUSTRALIAN LANGUAGES

Basic Concepts

Ergativity

Case Formation in General

Number in Nouns and Adjectives

Case in the NP

Group Declension

Parallel Declension

Cumulative Declension

Transitivisation

Historical Development of the Noun Phrase THE VERB PHRASE

Theoretical Development of the Verb Phrase

Historical Development of the Verb Phrase

Volce in Verbs

Reflexive.and Reciprocal

Tense

Non-Finite Forms of the Verbs

THE AUSTRALIAN LEXICON

Introduction

Corridors - the Paths of Peoples and Languages through Australia

Regional Vocabularies

Tiw1

Arnhem Land Languages

Other Areas

The EA/CA Element: Corridors Revisited

Regional Studies of EA/CA

Distribution of EA Material

Summary

B1bl1ography
516

522

522

522

529

529

530

531

533

533

537

541

546

547

547

548

549

552

555

556

556

561

562

564

566

568

570

570

575

581

582

585

588

591

593

594

600

605 
Map 1: Phonological Tra1ts, Occurrence of 432 Less Common Phonemes

Map 2: Distribution of Pronoun Forms in Australia 468

Map 3: The Yugulda Language - Gulf of Carpentaria - 480 in Relation to its Neighbours

Map 4: Tentative Map Showing Distribution of 515 Affix-transferring Languages in Australia

Map 5: Australian Verbal Systems 525

Map 6: Occurrence of the Ergative Construction 536

Map 7: Distribution of Common Australian 597

IN THE MARGINS OF AN ARABANA-WANGANURU DICTIONARY:

THE LOSS OF INITIAL CONSONANTS - L.A. Hercus 621

0. ABBREVIATIONS 621

1. INTRODUCTION 621

2. LANGUAGES ON THE PERIPHERY OF THE SOUTH 624

2.1. Bägandj1 624

2.2. Yạ̣1 Languages 625

3. CENTRAL LANGUAGES 626

3.1. Aranda 626

3.2. The Yura Languages 626

3.3. Diyari Sub-group 629

4. ARABANA-WANGANURU 630

4.1. Plosives 630

4.2. Inttial $\mathrm{N}$

4.3. Pronouns 631

4.4. Kinship Terms 632

4.5. Interfections and Adverbs 633

4.6. Proper Nouns 634

4.7. Song Language 635

4.8. Special Words 636

4.9. Other Words 636

5. CONCLUSIONS 637

Notes $\quad 639$

Bibliography $\quad 640$

Map 1: Genet1c Affiliations of Languages in 622 South-Central Australia

Map 2: Initial Consonants 623

Illustrations $\quad 645$ 
THE WEST BARKLY LANGUAGES: AN OUTLINE SKETCH - N. Chadwick 653

List of Abbreviations 653

1 . INTRODUCTION 655

1.1. Characteristics of the West Barkly Languages 655

2. THE PEOPLE 656

3. GRAMMAR 658

3.1. Consonants, Vowels and Stress 658

3.2. Noun Classification 659

3.2.1. General Remarks 659

3.2.2. Are the Classes Natural or Arb1trary? 659

3.2.3. Divisions of Case 661

3.2.4. Suffixes for Noun Class 661

3.2.4.1. Direct/Oblique Distinction 661

3.2.4.2. The Most Commonly Occurring Masculine and 661

3.2.4.3. Lists of Class Suffixes (most commonly occurring) 663

3.2.5. Extent of Concord for Noun-class 665

3.3. Pronouns 666

3.3.1. General 666

3.3.2. Comments on the Composition of Pronouns 671

3.3.3. Djamindjung Pronouns 672

3.3.4. Characteristics in Common Between Djamindjung and 673

3.3.5. Bound Subject and Object Trans1tive Pronouns 674

3.3.5.1. Bound Third Person Singular Transitive 675

3.3.6. Object Pronouns 676

3.3.6.1. Bound Forms 676

3.4. Possessive Adjectives and Demonstratives 678

3.5. The Verb-complex 681

3.5.1. General Structure 681

3.5.2. Inflexion of the Main Verb in W. and Ng. 682

3.5.3. Structure of the E.Gp. Person-tense Units 683

3.5.4. Imperative 684

3.5.5. Vowel Harmony in Dj. 685

3.5.6. Direction - Function and Suffixes 685

3.5.7. Other Tense Affixes 686

3.6. Structure of the Noun-Complex 686

3.6.1. General 686

3.6.2. Case Marking 688 
Page

3.6.3. The Most Commonly Occurring Case Suffixes 689

3.6.4. Most Commonly Occurring Number Suffixes 690

3.7. Sentence Structure 691

3.7.1. General Sentence Structure in all W.By. Languages 691

3.7.1.1. General Traits of W.By. Languages 691

3.7.2. Sentence-structure in the Eastern Group 692

3.7.2.1. Sentences with Both Direct and Indirect 693

3.7.3. Sentence Structure in DJing111 694

3.8. Characteristics of Vocabulary 696

3.8.1. Cognate Densitjes within the W.By. Languages 696

3.8.2. Comparison with Surrounding Languages 697

3.8.3. Comparison of W.By. Vocabulary with CA Vocabulary 697

3.9. Similarities with the Djamindjungan Family 699

3.9.1. Morphology 699

3.9.2. Comparison of Vocabulary 704

$\begin{array}{ll}\text { Bibliography } & 709\end{array}$

Map: The West Barkly Languages: Map of Region 654

LINGUISTIC COMMUNITIES AND SOCIAL NETWORKS ON CAPE YORK

PENINSULA - P. Sutton and B. Rigsby

ALICE SPRINGS ABORIGINAL CHILDREN'S ENGLISH - M.C. Sharpe 733

1. INTRODUCTION 733

2. PHONOLOGICAL DIFFERENCES 734

3. GRAMMATICAL DIFFERENCES 137

3.1. Non-standard Forms used as Standard in AbE 737

3.2. Contractions $\quad 738$

3.3. Passives 741

4. COMMENTS $\quad 742$

$\begin{array}{ll}\text { B1bliography } & 746\end{array}$

BIOGRAPHICAL NOTES ON THE CONTRIBUTORS TO THIS VOLUME 749 


\title{
RECENT RESEARCH IN AUSTRALIAN LINGUISTICS
}

\author{
Michael J. Walsh
}

\section{INTRODUCTION}

This overview of research into Australian Aboriginal languages over the past ten years is intended to be a catalogue of research. ${ }^{l}$ It is not intended to be a critical review partly because this would require a book-length study but more importantly because the writer feels that a critical survey at this stage would be premature. The past ten years has seen an explosion in the quantity of research undertaken; obviously not all that is produced will be of the same quality but it is certainly very likely that the value of some recent research can only be adequately assessed when there is a clearer picture of the nature and development of Australian languages in general. At present there is a great need for detalled descriptions of Australian languages (whether or not they are cast into any particular theoretical framework). Without such a pool of basic grammars of a large number of Australian languages it is difficult to see how typological or.comparative/ historical studies of a pan-Australian nature cannot be doomed to being rapidly superseded. It will be seen below that such grammars are now appearing, many as a result of the larger number of institutions involved so that it seems appropriate to outline some recent research within the institutional framework before moving on to a coverage of the research in terms of 1 ts subject matter.

\section{THE INSTITUTIONAL FRAMEWORK ${ }^{2}$}

\subsection{Australian Institute of Aboriginal Studies}

As has been mentioned elsewhere (Capell 1971a, Wurm 1971, 1972a,b) linguistic research recelved considerable impetus following the establishment of the Australian Institute of Aboriginal Studies (A.I.A.S.) In Canberra in 1961 and of the Australian branch of the 
Summer Institute of Linguistics (S.I.L.) in the same year.

The A.I.A.S. Initiated a linguistics programme in the mid-sixties which encouraged universities around Australia to establish scholarships and fellowships specifically for the study of Australian languages. A number of universities participated in this programme to the extent that they supervised, or provided a base for, researchers but 1t was not until the early seventies that the other aim of the programme, namely the creation of an active policy and interest in Australian linguistics including the setting up of teaching departments, saw fruition.

\subsection{Australian National University}

Perhaps the best known course in Australian Linguistics is offered at the Department of Linguistics, School of General Studies, at the Australian National University. This course, regularly presented by R.M.W. Dixon, includes a survey of work carried out on Australian languages with an account of their typological features as well as detalled study of a particular language. While this course has been a valuable precursor to later research many students have carried out field research as a part of the course. Worth mentioning in this context are Brasch's work on Gureng Gureng (1975), Beale's work on Bir1 (1974) and his survey of the Marl languages (1976a), Crowley's work on the Bandfalang1c group (1975, 1976b, 1978), Eades' study of two remnant languages of the South Coast of New South Wales (1976a) and her work on Gumbaynggir (1976b, to appear), Austin's study (w1th Wurm) of Gamilraay (1976) and his work on Dhirar1 (1975), and Williams' work on Yuwaal1yaay and Yuwaalaraay (1976). Other students have carried out useful research by reworking early writings on extinct or near extinct languages. Recently a sociolinguistic study dealing with mult1lingualism at Maningrida, Northern Territory has been carried out in connection with this course (Elwell, 1977a).

Apart from an increase in teaching and preparation for fleldwork a considerable amount of postgraduate study has been carried out over the last ten years. In particular, at the Department of Linguistics, School of General Studies of the Australian National University, Carroll has worked on Kunwinyku $(1976 a, b)$, Donaldson has completed a remarkably detalled study of the near extinct Ngiyambaa language of the Wangaaybuwan people of central western New South Wales (1977) as well as producing a number of other studies on particular aspects of this language (in Dixon, ed. 1976, and, forthcoming). Donaldson's work demonstrates the sort of depth account that can st1ll be salvaged from a language with 
only a handful of speakers. McKay has carrled out a depth study of Rembarnga, Arnhem Land, Northern Territory (1975) and later worked in depth on the nelghbouring Gunavidj1 (DJeepana) language (McKay, to appear) under the auspices of the Department of Education (Northern Territory). Walsh worked in the Port Keats area of the Northern Territory in depth on Murinypata (1976a,b) and to a lesser extent on Maringarr, Maridyabin, Magadige and Dyamindyung; he also carried out some survey work around Darwin demonstrating that useful work can still be done on languages formerly thought to be extinct.

In the same department, research on Australian languages has been carrled out by research fellows such as Haviland on Guugu Yimidhirr producing a number of studies (for instance, 1972a,b,c, 1974, forthcoming) and Rigsby on Kuku Thaypan (1976a,b) as well as by members of staff. Andrews has commenced work on Anmadyera whlle Koch has been engaged for some years in the study of Kaltitf (forthcoming). Rensch also carried out some work on Pitfantfatjara. Dixon has studied the languages of the Cairns rain forest area and published widely on them as well as on general aspects of Australian languages (1968, 1969, 1970a,b, c,d, 1971, 1972, 1973, 1975a,b, 1976a, b, c, d,e,f, 1977a,b,c, and forthcoming a,b,c,d, Dixon, ed. 1976).

At the Australian National University's other Department of Linguistics, in the Research School of Pacific Studies, a number of postgraduate studies have been completed on Australian languages. Birk worked on the near extinct language of the Daly River area, Malakmalak (1975, 1976). Kilham (1974a,b, 1977) studied Wik-Munkan (Cape York) with special reference to discourse structure, while Kinslow Harris worked on the Gunwingguan group (1969a,b, 1970). Metcalfe (1971, 1975) carried out a detalled study of Bardi (Western Australia) concentrating on verbal morphology and presenting the results of his research in a transformational framework. Members of the academic staff of the same department have been involved in Australian studies including Laycock who has worked on the Lamalamic languages of Cape York (1969), Tryon who surveyed the Daly River area (1968, 1970a,c, 1974) and produced studies on particular languages such as Wageman (1971b) and Maranunggu (1970b) and Wurm, who has published widely on Australian Iinguistics, (1967, 1969, 1970a,b, 1971, 1972a,b,c, 1973, 1975a) giving general accounts of linguistic classification and research in Australia as well as studies of Individual languages for instance on Duungidjawu (Waga-Waga) (1976a), Guṇu (Wurm and Hercus, 1976) Malyangaba (Austin, Hercus and Wurm, to appear), Gamilraay (Austin and Wurm 1976) and Wanggumara (Gaḷal1) (McDonald and Wurm, to appear). 
L. Hercus, of the Department of South Asian and Buddhist Studies, School of General Studies, Australian National University, has carried out extensive research in Aboriginal languages of Victorla and South Austral1a (1969, 1971a,b, 1972, 1973, 1974a,b, 1976a,b,c,d, 1979, to appear, Hercus and Sutton to appear, Hercus and White 1971, 1973).

\subsection{Macquarie University}

A number of studies have issued from Macquarie University Including Sutton's salvage work on Gugu Badhun and 1ts nelghbours (1973), Trefry's work on Dier1 (1970, 1974) which will be complemented by Austin's additional study (1978) and Yallop's study of the Alyawarra (1969, 1977, n.d.) and the Narinfari (1975). Keen described Yugulda for an M.A. degree (1972). A course in Australian linguistics is offered at Macquarie University. (Further information can be found in a recent account of Aboriginal Studies courses offered in Australia: Barlow, H1ll and Jurcevic, 1977.)

\subsection{Monash University}

At Monash University, Platt undertook postgraduate studies concentrating on Gugadja, Pitfantfatjara and Wirangu with special emphasis on Gugada (1968, 1970, 1972, 1974). Jernudd carried out work on the articulatory phonetics of Gunwinggu (1974) as well as devoting attention to sociolinguistic aspects of Australian languages (1969, 1971, 1973). Tsunoda has worked on Warungu (Queensland) (1974a,b, 1975) towards the M.A. degree and then focussed his attention on DJaru in the Kimberleys (1978) for his Ph.D. dissertation. From the same department, Blake has been engaged in the study of Australian languages over the last ten years, being concerned with particular languages such as Kalkatungu, Jalanga (1969, 1971a,b, 1974b, 1976c, to appear) and the P1tta-P1tta dialects in collaboration w1th Breen (Blake and Breen 1971), as well as with more general studies including work on case systems and ergativity (1970, 1972, 1974a, 1976a,d,e, 1977, 1979). Breen has worked on a large number of languages (with only a few speakers remaining in each) in the 'corner country', the area around the borders of the Northern Territory, Queensland and New South Wales, as well as other languages In Queensland (1970, 197la,b, 1973, 1974a,b, 1976a-k, 1977, forthcoming). A course in Australian Iinguistics is offered at Monash University.

\subsection{University of New England}

The University of New England fostered a number of postgraduate students through the Institute's Iinguistic programme and also has a 
continuing interest in the study of Australian languages. Bolt, Cleverly and Kofod worked on the DJamindjungan famlly and produced a number of studies in collaboration with Hoddinott (Bolt, Cleverly and Hoddinott 1970; Bolt, Hoddinott and Kofod 197la,b). Cleverly completed a description of the DJamindjung language (1968). Kofod and Hoddinott have worked on a number of languages in the north-west including Miriwung (Western Australia) (Kofod 1976a,b) and Ngangkikurrungkurr (Northern Territory) (Hoddinott and Kofod 1976a,b). Chadwick, starting as a postgraduate student, surveyed the languages of the Barkly Tablelands and has completed a description of DJing1l1 (1968, 1971, 1974, 1975). Hoddinott's continuing interest in the New England area is demonstrated by his recent study of the languages and myths of that region (1978).

\subsection{University of Queensland}

Margaret Sharpe (née Cunningham) was supported as a Research Fellow in her work in the Roper River area of the Northern Territory, where she has worked on Alawa (1970a, 1972, 1976a) and Roper Creole (1974, 1975, 1976c; Sharpe and Sandefur 1976). Apart from more general studies $(1970 b, c)$ she has recently worked on Alice Springs Aboriginal English (1977) and on the Bandfalangic languages of the Lismore area, following on from an earlier study of Yugumbir, one of the Bandjalangic group (Cunningham 1969). Dutton worked on Aboriginal English (1969) and Torres Straits Island English (1970) before shifting his attention to the linguistics of Papua New Guinea. Flint, a member of the Department of English at the University of Queensland, has also worked on Aboriginal English in Queensland (1968, 1970, 1971, 1973). Hall carried out a depth study of Thaayorre at Edward R1ver (1968, 1972, 1976a,b) and is at present involved in the bilingual education programme in that language. Osborne worked for a number of years on Tiwl attached to the University of Queensland and then completed this study at University College, London (1974). Osborne has carrled out some salvage work in the Darwin area as well as working on a number of languages in Queensland such as Garawa and Waany1. He is at present engaged in the study of song words in the Tiwl language, an area which has recelved scant attention from linguists to date. De $\mathrm{Zwaan}$, another postgraduate student, carried out work on Gogo-Yimidjir (Guugu-Yimidhirr) (1969a,b,c). Recently, fresh 1mpetus has been given to Australian linguistic study at the University of Queensland by the appointment of B. Rigsby to a Chair in Anthropology. As mentioned previously in connection with the Australian National University, he has worked on languages in Cape York. 
At present one of his postgraduate students, Peter Sutton, is engaged In the study of speech forms around Aurukun, Queensland, with particular emphasis on their social context (1978). A course in Australian linguistics is offered at the University of Queensland.

\subsection{University of Sydney}

Although Trefry and Yallop were attached to the University of Sydney in the first instance, they subsequently completed their studies at Macquarie University. Little work has come out of the University of Sydney apart from that of A. Capell (1968a,b, 1969, 1970a,b, 1971a, 1972a,b, 1975, 1976a,b,c,d, 1977, 1979a,b,c; Capell and Coate to appear; Capell and Hinch 1970) during the period under consideration, although A.I. Jones of the Department of English carried out some work on Gurindj1 (Northern Territory). It is to be hoped that with the recent appointment of Alan Rumsey to the Department of Anthropology, greater attention will be focussed on Australian linguistics. Rumsey is completing a doctoral dissertation for the University of Chicago on Ungarinyin (1978) and has already completed a number of general works on Australian languages (forthcoming, n.d.). It is likely that the University of Sydney will initiate a course in Australian Iinguistics in 1ts Anthropology Department in the near future.

\subsection{University of Western Australia}

N.F. Kerr undertook work on Nyigina (1968). For much of the period being considered von Brandenstein conducted fleldwork in the Pilbara area (1969, 1970a,b,c,d,e, 1977; von Brandenstein and Thomas 1974) while attached to the University of Western Australia. On the staff Kaldor has concentrated on sociolinguistic problems (e.g. Kaldor 1976) while presenting courses on Anthropological Linguistics. A course in Australian linguistics is offered at the University of Western Australia.

\subsection{Summer Institute of Linguistics}

The Australian Aborigines Branch of the Summer Institute of Linguistics has been responsible for a considerable amount of linguistic research over the past ten years. A good coverage of the research carried out by the branch can be found in the bibliography up to 1975 (Huttar, Hudson and Richards 1975) which also lists vernacular literacy materials prepared by members of the branch. Members of the Summer Institute of Linguistics have been fortunate in having the opportunity not shared by linguistic colleagues attached to universities and other 
Institutions to have a long and intimate exposure to the language being studied. Two recent (not mentioned in their bibliography) works of special interest should also be mentioned: Hudson and Richards' account of Walmadjari language and culture (1976) and a collection of papers on Australian Phonologies (Hudson, ed. 1977).

So far I have been giving a necessarlly brlef account of Australian studies within an institutional framework. I now propose to catalogue recent research in terms of its subject matter.

\section{SURVEYS ${ }^{3}$}

The most comprehensive survey of Australian languages has been produced by the Australian Institute of Aboriginal Studies (Oates and Oates 1970). This survey provides information on the location of languages, current research and bibliographical detalls as well as an assessment of the total known linguistic knowledge for each language. This useful research tool has recently been supplemented by more recent Information (Oates 1975). Tindale (1974) has produced 'a catalog of Australian Aboriginal tribes' which provides information on the location of Aboriginal groups, alternative spellings and bibliographical references. It is accompanied by useful discussions on the people and their habits, the naming of the tribes and tribal boundaries which are lilustrated in a large map (also published separately, Tindale 1976). In the context of more general studies including classification, Wurm (1971, 1972a) has listed the Australian languages with brief notes on their features. As well as being valuable research tools, these surveys have provoked considerable discussion among researchers familiar with particular areas, discussion which, it is hoped, will improve our knowledge of linguistic distribution throughout Australia by refining these general works rather than fostering non-constructive criticism.

\section{DESCRIPTIONS OF AUSTRALIAN LANGUAGES}

The simple listing of 'full-scale' descriptions of languages presented here is enough to indicate the extent to which detailed research in Australian languages has increased over the past ten years. While some of the studies mentioned here are short on detall because already the information is no longer avallable, other very full descriptions are supplemented by separate papers dealing in detail with particular aspects of languages. 


\begin{tabular}{|c|c|c|}
\hline Alawa & Sharpe & 1972 \\
\hline Alyawarra & Yallop & 1977 \\
\hline Andegerebinha & Breen & $1976 a$ \\
\hline $\mathrm{Ba}:$ gand 1 & Hercus & to appear \\
\hline Bandjalang & Crowley & 1978 \\
\hline Bard1 & Metcalfe & 1975 \\
\hline Bidha-Bidha & Blake and Breen & 1971 \\
\hline B1dyara & Breen & 1973 \\
\hline B1r1 & Beale & 1974 \\
\hline Dharawal & Eades & $1976 a$ \\
\hline Dhirar1 & Austin & 1975 \\
\hline Dhurga & Eades & $1976 a$ \\
\hline Dhurwal & Heath & forthcoming (c) \\
\hline Diyar1 & Trefry & 1974 \\
\hline Diyar1 & Austin & 1978 \\
\hline Djaabugay & Cassells & 1977 \\
\hline Djamindjung & Cleverly & 1968 \\
\hline DJaru & Tsunoda & 1978 \\
\hline Djawonf & Merlan & to appear (a) \\
\hline Djing1li & Chadwick & 1975 \\
\hline Djirbal & Dixon & 1972 \\
\hline Garlal1 & McDonald and Wurm & to appear \\
\hline Galgadungu & Blake & 1969 \\
\hline Gam1lraay & Austin and Wurm & 1976 \\
\hline Garadyar1 & McKelson & $1974 a, 1975$ \\
\hline G1dabal & Geytenbeek and Geytenbeek & 1971 \\
\hline Gugada & Platt & 1972 \\
\hline Gugadj & Breen & $1976 c, 1977$ \\
\hline Gug-Nar & Breen & $1976 c, d$ \\
\hline Gugu-Badhun & Sutton & 1973 \\
\hline Gumbaynggir & Eades & to appear \\
\hline
\end{tabular}




\begin{tabular}{|c|c|c|}
\hline Gunabidf1 (DJeepana) & Mc Kay & to appear \\
\hline Gunbalang & Harris & $1969 b$ \\
\hline Gungabula & Breen & 1973 \\
\hline Gunwinygu & Carroll & $1976 \mathrm{~b}$ \\
\hline Gurdjar & Black & to appear (a) \\
\hline Gureng-Gureng & Brasch & 1975 \\
\hline Guugu-Y1midh1rr & Haviland & $1975 a, b$ \\
\hline Guugu (Gogo Y1midir) & de Zwaan & $1969 a, b$ \\
\hline Guurindj 1 & McConvell & to appear \\
\hline Laragiya & Capell & to appear \\
\hline Lard11 & Kloke1d & $1976 a, b, c$ \\
\hline Mad1 Mad1 & Hercus & 1969 \\
\hline Malag-Malag & Birk & 1976 \\
\hline Malyangaba & Austin, Hercus and Wurm & to appear \\
\hline Mangaray1 & Merlan & to appear (b) \\
\hline Mara & Heath & to appear (b) \\
\hline Maranunggu & Tryon & $1970 \mathrm{~b}$ \\
\hline Maung & Capell and Hinch & 1970 \\
\hline Mbabaram & Dixon & forthcoming (b) \\
\hline Malyangaba & Austin, Hercus and Wurm & forthcoming \\
\hline Murinypata & Walsh & $1976 b$ \\
\hline Mangala & McKelson & $1974 b$ \\
\hline Ngal1wuru & Bolt, Hoddinott and Kofod & $1971 a$ \\
\hline Ngarinj in & Coate and Oates & 1970 \\
\hline Ngarinjin & Rumsey & 1978 \\
\hline Ngand1 & Heath & forthcoming (a) \\
\hline Ngawun & Breen & $1976 \mathrm{e}$ \\
\hline Ngiyambaa & Donaldson & 1977 \\
\hline Nungal1 & Bolt, Hoddinott and Kofod & $1971 b$ \\
\hline Nunggubuyu & Heath & forthcoming $b$ \\
\hline Nyangumarda & McKelson & 1968 \\
\hline
\end{tabular}




\begin{tabular}{|c|c|c|}
\hline Olgolo (Kungen) & Sommer & 1972 \\
\hline Pintupi & Hansen and Hansen & 1975 \\
\hline Rembarrnga & McKay & 1975 \\
\hline R1tharrngu & Heath & to appear (c) \\
\hline Thaayorre & $\mathrm{Hall}$ & 1968,1972 \\
\hline Thargar1 & Kloke1d & 1969 \\
\hline TIw1 & Osborne & 1974 \\
\hline Wagaya & Breen & $1974 c$ \\
\hline Walangama & Black & to appear (b) \\
\hline Walmadjarr1 & Hudson & forthcoming \\
\hline Wargamay & Dixon & forthcoming (c) \\
\hline Warlpir1 & Reece & 1970 \\
\hline Warluwara & Breen & $1971 b$ \\
\hline Warndarrang & Heath & to appear (d) \\
\hline Warungu & Tsunoda & $1974 a$ \\
\hline Wemba Wemba & Hercus & 1969 \\
\hline Werga1a & Hercus & 1969 \\
\hline Wik-Mungkan & K1lham & 1974 \\
\hline Yandruwantha & Breen & 1975 \\
\hline Yanyuwa & Kirton & $1970,1971 a, b, 1976$ \\
\hline Yarald1 & McDonald & 1977 \\
\hline Yaygir & Crowley & 1975 \\
\hline Y1diny & Dixon & $1977 b$ \\
\hline Y1ndy1barnrd1 & Word1ck & to appear \\
\hline Y1r-Yoront & Alpher & 1973 \\
\hline Yugulda & Keen & 1972 \\
\hline Yugumb1r & Cunningham (later Sharpe) & 1969 \\
\hline Yuwaalaraay & W1lliams & 1976 \\
\hline Yuwaal1yaay & W1lliams & 1976 \\
\hline
\end{tabular}




\section{LEXICON}

In 1971 O'Grady outlined the state of lexicographic research in Australian languages lamenting the lack of avallable materials and the urgent need for the compilation of complete dictionaries. Regrettably few published dictionaries have appeared since O'Grady's overview (1971):

$\begin{array}{lll}\text { Coate and Elkin } & (1974) & \text { Ngarinfin } \\ \text { Hansen and Hansen } & (1974) & \text { Pintupl (2nd edn 1977) } \\ \text { Reece } & (1975) & \text { Walbirl }\end{array}$

However, Heath's work in north east Arnhem Land has produced dictionaries of a number of languages which are to be published over the next few years: Mara (to appear b), Ngand1 (forthcoming a), Nunggubuyu (forthcoming b), Ritharngu (to appear $c$ ), Warndarang (to appear d) and Dhuwal (forthcoming $c$ ). In addition Capell has complled 600-word lists for forty Australian languages which exist in typescript form (Capell n.d.).

Otherwise the many dictionaries which do exist are in unpublished form, for instance: Dixon's dictionaries of Dylrbal (1975a) and of Y1diny (1975b), Kofod's wordlist of Miriwung (1976b), Haviland's Guugu-Y1midhirr dictionary (1975b), R. Hershberger's Gugu-Yalandf1 dictionary (n.d.), Hale's dictionary of Walbirl (1974) and Blundell's (1976) lexical materials from Worora with Ngarinfin equivalents concentrating on terms for material culture and environmental features.

To assist in the arrangement of lexical materials for comparative purposes the Australian Institute of Aboriginal Studies has compiled a comprehensive wordlist (to be published in the near future). The wordlist runs to over two thousand 1tems arranged in twenty-six semantic domains and will be accompanied by a finder list. Apart from providing a standard format for comparing lexical materials from various languages the wordlist should prove useful as an elicitation tool particularly in filling 'gaps' in otherwise fairly complete dictionaries.

\section{SONG WORDS}

Although linguists often record Aboriginal music during the course of their work scant attention has been pald to analyzing the material at the lexical level. It is to be hoped that further work will be carried out in this area in the future perhaps on a collaborative basis between linguists and ethnomusicologists. 
The most significant work carried out in recent years can be found in T.G.H. Strehlow's 'Songs of Central Australla' (1971). Osborne has been working on song words of the Tiwl and Alpher on Yir Yoront (1976a), while some other linguists have directed their attention to this area although they have not published as yet. Among these should be mentioned Heath's work on Nunggubuyu and nelghbouring languages (see References under Heath).

\section{ETHNOCLASSIFICATION}

It is partly a factor of the large number of unstudied languages with the few people to work on them that may explain the almost total lack of material on ehtnoclassification in Australian languages. Unt1l very recently researchers needed to establish basic facts like which languages were spoken in the area quite aside from attaining the depth of knowledge of a particular language required to carry out adequate work in ethnoclassification. Now that a relatively large number of linguists are avallable who have worked intensively on particular languages it is to be hoped that ten years from now there will be considerable material avallable.

Some short pleces have appeared in recent years, for instance, Heath 1976c, 1978a,b, and Pelle 1976a,b,c, 1977a,b, and wh1le these are good as far as they go one must turn to non-lingulsts for larger-scale works, for example, Rudder's (1977) general work on Yolpu science and Levitt's (forthcoming) comprehensive coverage of Anindhllyagwa ethnoflora and ethnofauna. Other information from linguists generally appears in an indirect form, for example in studies of noun-classification and in dictionaries arranged in semantic (non-Aboriginal) domains which, however, often lack precise species identification.

\section{TEXTS}

Although linguists usually collect substantial quantities of text material in the course of their investigation of a language, the resulting texts have of ten been used to assist the linguist in analyzing the language and have not been readily avallable. Typically, a few sample texts are published with a description of a language but few substantial collections of texts have yet appeared in print. This is a pity since texts (analyzed morpheme-by-morpheme) are not only of interest to linguists but to any student of Aboriginal culture.

Texts frequently deal with subjects such as Aboriginal-white contact, food preparation, manufacture of material culture 1tems, various aspects 
of dally life, bellefs about the world, etc. In short, they are a valuable source (practically untapped) of information on Aboriginal life as told by the participants themselves providing a useful balance to interpretations presented by outside observers.

Fortunately a few collections of texts are already available: C.G. von Brandenstein's narratives from Western Australia (1970c), and collection of songs (von Brandenstein and Thomas 1974) and Lucich's (1969) children's storles from the Worora group. Hercus has published a number of texts on mythological subjects (1971a,b, 1974b) and is editing with P. Sutton a volume of texts illustrating white contact (to appear). Schebeck has produced a volume of texts on the social system of the Atynyamathanha of South Australia (1974), while Heath's descriptions of languages from north-east Arnhem Land will be accompanied by substantial collections of texts (to appear b,c,d; forthcoming $a, b, c)$. Holmer and Holmer (1969) have assembled a collection of stories from two groups in Eastern Australia.

\section{DISCOURSE STRUCTURE}

Even at this stage in Australian linguistics little attention (at least which has appeared in print) has been pald to discourse structure elther to pragmatic aspects of conversations or to suprasentential structure. Probably the most ambitious study in this area has been carried out by Kilham (1974) on Wik-Munkan. In addition, the work of Dixon (1972) on Dyirbal, particularly in regard to 'topic chains', and Marsh (1970) on Mantj1ltjara should be mentioned as well as the recent study of suprasentential structure in Rumsey's description of Ungarinyin (1978).

\section{TRANSLATIONS AND RESEARCH ON EARLY SOURCES}

While there is an ever increasing output from research in progress, there are many important works from earlier times which are rendered less accessible through appearing in other languages. Particularly where works have very general interest or provide a very full account of a particular Aboriginal group it is very useful to have a translation.

Recently Schmldt's Die Gliederung der australischen Sprachen (Vienna: Mechitharisten-Buckdruckere1 1919) has been translated into English by D. Clark (1972). This work should prove useful to comparativists as well as being of interest to any student of Australian studies. P. Scherer (1974-) has been working on a translation of J.G. Reuther's massive account of the Diarl. This careful 
translation, st1ll in progress, includes an already completed dictionary of Diarl running to over two thousand pages. It is as yet not generally available but a restricted copy is held at the Australian Institute of Aboriginal Studies.

It is usual for a linguist to take into account early sources on the language he is studying, transliterating and reinterpreting the material where necessary so that much of the research on early sources is subsumed under more general works. A few studies, however, have appeared which are devoted specifically to examining early sources in the light of modern knowledge. Among these should be mentioned Breen's (1970) re-examination of Cook's Gogo-Yimidjir wordlist, followed up by Haviland (1974) who has been engaged in a depth study of that language. Chadwick (1972) examined a wordlist of 'Chingalee' by R.H. Mathews with the advantage of a long acqualntance with the language. Soravia (1975) has studied the early manuscript on Jiwadja (Y1wa1dja) by Father Confalonier1. Yallop (1975) has presented an account of the Narinfari language over one hundred years, while Grimwade (1975) has examined the linguistic work of the early investigator, Georpe Taplin.

\section{NOTES ON TYPOLOGICAL STUDIES}

A major contribution to the examination of particular aspects of Australian languages was made by the 1974 Australian Institute of Aboriginal Studies Symposium on Grammatical Categories in Australian Languages (Dixon, ed. 1976). See Comrle's review, 1978. As well as bringing together a large number of data papers (see Bibliography under the various authors) on five topics:

A. The derivational affix 'having'.

B. Ergative, Locative and Instrumental case inflections.

C. The bivalent suffix -ku.

D. Are Australian Languages Syntactically NominativeErgative or Nominative-Accusative?

E. Simple and compound verbs: confugation by auxiliaries in Australian verbal systems.

each of these sections being accompanied by a summary presenting general conclusions and comments, there are a number of more general papers among which should be mentioned Hale's study of relative clauses (1976a) and on ergative and locative suffixial alternations (1976d) and Silverstein's paper dealing with ergativity (1976). 
Considerable attention has been directed to the last-mentioned topic in recent years, a general account of which can be found in Dixon's 'Ergativity' (forthcoming a). Recent contributions to this general area include the following: Blake (1976c,e, 1977, this volume), Ban1 and Kloke1d (1976), Hale (1970), Heath (1976a,b, to appear a), Hudson (1976b) and Mel'cuk (1977).

As with many of the other sections discussed, the basis of further work lies in the increasing number of depth studies of individual languages appearing, comprehensive descriptions of all aspects of the structure of the language which will provide the raw materlal for typological and comparative studies.

\section{HISTORICAL AND COMPARATIVE LINGUISTICS}

In the area of historical and comparative linguistics considerable attention has been focussed on the languages of Cape York, Including the work of Hale on phonological developments in Middle Paman (1976h), Northern Paman (1976e,f), as well as commenting more generally on language change (for Instance 1970, 1973a), Black on Norman Pama historical phonology (1976), Rigsby on Kuku Thaypan (1976a), Alpher on south-western Cape York languages (1972, 1976b), Dixon on Wargamay with particular reference to grammatical reanalysis (forthcoming d) and on the languages of the Cairns Rain Forest area (1970a), O'Grady on Umpila (1976). Other historical and comparative studies on the languages of Cape York appear in the volume of papers edited by Sutton (1976).

In other parts of Australia should be mentioned Crowley's work on phonological change in the New England area of New South Wales (1976b) and Tryon's survey of the Daly Fam1ly (1968, 1970a, 1974). Koch has been working on Kaltitj with an interest in the Arandic group as a whole and has already produced a paper dealing with nominal inflections in Kaltitf suggesting sources for the inflections (Koch, forthcoming).

In addition a number of more general comparative works have appeared including Capell's work on affix-transferring languages (1972a), Dixon's study of proto-Australian laminals (1970c) and the syntactic development of Australian languages (1977d). Attention has been drawn to the relevance of linguistics in connection with Aboriginal origins particularly by Tryon (1971a) and Wurm (1970a, 1972c, 1973, 1975b,c). Dixon (1976e) has highlighted the problem of diffusion in his discussion of 'tribes' and their boundaries, while Heath (1976a, 1978) has discussed the same problem with special reference to languages of 
north-east Arnhem Land. O'Grady (1979) and Capell (1979a) discuss the problem from an Australia-wide point of view. Wurm (1971) surveys the various proposed classifications of Australian languages from which it is evident that previous classifications have needed alteration and it is likely that this process will continue for some time to come.

\section{TASMANIAN}

The languages of Tasmania appear to have had a particular fascination for students of Australian languages. They remain one of the unsolved mysteries of Australian language classification especially after Crowley 1dentified 'Anewan' as an Australian language (1976b). It is likely that the relationship of Tasmanian with languages on the Australian malnland (through lack of data) may never be clearly established. Capell (1968b), Wurm (1971, 1972a) have reviewed the linguistic knowledge ava1lable and Jones (1974) non-linguistic information as well, while Plomley (1976) has brought together the Iexical information into one valuable source book. Crowley and Dixon (to appear) have also recently reviewed the sources.

Concerning Tasmania specifically, there is falrly general agreement that there were at least two Tasmanian languages although some belleve there were five distinct languages. At this stage it seems unlikely that much more will be discovered.

\section{AUXILIARY LANGUAGES}

It is not uncommon for there to be two distinct 'languages' or styles in use by members of a linguistic group. Generally one style is for use in the presence of certain taboo relatives (thus the descriptive labels: 'mother-in-law' language, 'brother-in-law' language) while the other is used in all other situations. The auxiliary styles have not been well documented in the past and it is becoming difficult to record them now since such 'special languages' fall more quickly into disuse than the 'everyday' language.

What has been recorded is of considerable linguistic interest particularly in semantics. Dixon (1971, 1972) has demonstrated for Dyirbal the many-to-one relationship between the everyday language and the mother-in-law language. This can be revealing for the semantic structure of the everyday language. In a nearby language, Y1diny, the same principles appear to be in operation (Dixon 1977b). Haviland (forthcoming) presents an account of brother-in-law language for 
Guugu-Yimidhirr. Harris has reported on a mother-1n-law language from Arnhem Land, Gunkurrng (1971). A quite different semantic relation between an auxillary language and an everyday language is found in the tylliwiri style of the Warlpiri language. As reported by Hale (1971) the relation is one of antonymy whereby 'fire' is substituted for 'water', 'other' for lst person singular and so on where the antonym pairs are not (and presumably could not be) strictly opposites.

\section{SIGN LANGUAGE}

Although early investigators such as Roth, Spencer and C. Strehlow documented sign language in some detall in the course of their studies, surprisingly little work has been carried out in the period under consideration. In the past many linguists, although aware of the fact that sign language was in use, found it difficult to record the material in the absence of a suitable notation. One exception is the work by Kegl, Nash, Granites and Hale (1976) on Warlpirl sign language which does transcribe the signs themselves by linking them to a chart of 'standard' hand gestures. Recent work on American sign language (for Instance, Stokoe, Casterline and Croneberg 1976, and Friedman 1976 , 1977 ) demonstrates that notations can be developed for sign languages. Hopefully sultable notations will be developed for the study of Australian sign languages.

In the absence of a suitable notation researchers have recorded sign language by photographic means, elther still photographs or movie films. La Mont West carried out extensive fleldwork on sign language in Arnhem Land and Northern Queensland recording individual signs and signed conversations on movie film. W. Laade has also filmed sign language on Sa1ba1, Eastern Torres Stra1ts Islands. E. Banl has recently produced a film of Mabuyag sign language from the western Torres Straits. De $\mathrm{Z}$ waan has written on sign language of the Gogo Yimidjir (Guugu-Yimidhirr) (1969a,b) as well as producing a film which accompanies his thesis (1969a). Noel Wallace has made sign language films of the Pitjantjatjara, McConvell of the Guurindj1, while G. McBryde has filmed sign language at Aurukun. J. Armstrong has recorded sign language at Papunya on still photos, as has P. Black at Normanton (1975) as well as making a sign language film. Wick Miller worked on Western Desert sign language at Warburton around 1969-70 and has produced a report (1970). At Yuendumu, Northern Territory, Adam Kendon recently began a study of Warlpirl sign language and has made films for close analysis of the signs in use. 
Probably the most comprehensive documentation of sign language for a single linguistic group is the sign language dictionary of (Warrabri) Warlpiri being prepared by $C$. Wright (forthcoming); this dictionary w1ll contain around 1500 still photographs.

\section{ABORIGINAL ENGLISH, PIDGINS AND CREOLES}

For many years forms of English used by Australian Aborigines which differ markedly from so-called 'standard' Australian English have recelved scant attention. For this particular area there is little material avallable which precedes the period under consideration. In recent years various forms of Aboriginal English, some of which have been creolized, have been described and attention is being focussed on the educational implications of speech forms which are not simply 'bad' English but dialects of English or languages in their own right.

In Queensland, Alexander (1968) has described Woorabinda Aboriginal English, Dutton the English of Palm Island (1969) and of the Torres Stra1ts (1970), Laade (1971) English of the Torres Straits, Crowley (1976a) and Rigsby (1974) the English of Bamaga (at the tip of Cape York Peninsula) while Flint (1968, 1973) has written generally of the situation in Queensland. With the exception of Sutton's (1975b) work on the English of Cape Barren Island, and Fesl's study of Melbourne Aboriginal English (1977) most of the study of Aboriginal English is concentrated in the Northern Territory including Steffensen's (1975) work on Bamyll1 Creole, the study of Roper River Creole by Sharpe (1974, 1975, 1976c) and Sharpe and Sandefur (1976), and Sharpe's work on the English of Alice Springs (1977, 1978a).

As mentioned priviously, work is being carried out on the educational Implications of non-Standard English. The Bernhard van Leer Foundation Project through the Queensland Department of Education (1971-3, 1972) has carried out work on the sultability of non-Standard English as an educational medium. In this context could also be mentioned Brumby and Vászoly1 (1977), Dwyer (1974), Gardiner (1977) and Sommer and Marsh (1969).

\section{SOCIOLINGUISTICS}

In the past linguists have often studied languages giving little attention to the language in day to day use and to 1ts social context. Perhaps the most ambitious projects so far undertaken which deal with language in its social context are Sutton's study (forthcoming) in the Aurukun (Queensland) area and Schebeck's (1970) little known 
(unfortunately unpublished) study of north-east Arnhem Land.

Haviland's work on Guugu-Yimidhirr brother-in-law language (forthcoming) gives special attention to how the language is used by its speakers rather than just describing the structure of the language. Elwell's recent study of multi-lingualism at Maningrida (1977a) provides one of the few explicit accounts of the extent of the linguistic resources avallable to members of a group. Brumby and Vászoly1's collection of papers Language Problems and Aboriginal Education (1977) reflects the growing concern with the application of vernaculars to educational ends both for whites and blacks as does Tryon's (1976) account of bilingual education in the Northern Territory. This concern has thrown up less technical but more general accounts of language and its relation to the culture of the speakers, for Instance Hudson and Richards' account of the Walmadjar1 (1976) or Pfitzner and Schmal's account of Aranda (197?).

In connection with the soclology of language in Aboriginal communities should be mentioned Flint's work in Queensland (1973), the work of Jernudd (1969, 1971, 1973), Kaldor's studies in Western Australia (1976, 1977), Sommer's review of sociolinguistic issues in Australian language research (1976d), and Sutton and Rigsby's work on soclolinguistic problems in Cape York Peninsula (1979).

\section{CONCLUSION}

In the past decade a remarkable expansion in the number of specialists in Australian languages has taken place. Many languages have become extinct while many others are on the verge of extinction. In the future it is unlikely that the newcomer to Australian inguistics will be able to take his pick from numerous hitherto unstudied languages although there is still much salvage work to be done. Hopefully more scholars will be attracted to Australian linguistics and among their tasks will be the study of 'known' languages in greater depth and the consolidation of what is already known. 


\section{NOTES}

1. For this reason scanning the Bibliography may be more valuable than reading the brief notes on the state of research. In compling the Blbliography special attention has been given to published works because of their avallablilty. In choosing which of the numerous unpublished works to include I have chosen studies which are substantial and in more or less finished form: dissertations arising from higher degrees, for instance. Other works have been included because they have been referred to in the text. The cholce of other works is essentially arbitrary.

In the absence of standard spellings for Australian Aboriginal language names in general the spelling adopted by the particular researcher for a language is used when referring to that researcher's work on that language.

2. Discussion of research within an institutional framework has been confined to the main institutions within Australia although it is realised that outside bodies have been responsible for important language study in Australia.

3. See especially South's (1971/2) review of Queensland Aboriginal linguistics. 


\section{BIBLIOGRAPHY}

For those 1tems where the title has not yet been decided a notional title has been supplied in the following format: BLACK, P. to appear [a description of Gurdjar].

AGUAS, E.F.

1968 'Gudandj1'. Papers in Australian Linguistics No. 3:1-20. $P L, A-14$. Canberra: Pacific Linguistics.

ALEXANDER, D.H.

1968 Woorabinda Aboriginal Australian English. M.A. thesis, University of Queensland.

ALPHER, B.

1972 In the Genetic Subgrouping of the Languages of Southwestern Cape York Peninsula, Australia'. Oceanic Linguistics 11/2:67-87.

1973 Son of Ergative. The Y1r Yoront Language of Northeast Austral1a. Ph.D. thesis, Cornell University.

1976a 'Phonological Peculiarities of Y1r-Yoront Song Words'. In: Sutton, ed. 1976:78-83.

1976b 'Some Linguistic Innovations in Cape York and their Soclocultural Correlates'. In: Sutton, ed. 1976: 84-101.

1976c 'Y1r Y1rond'. In: Dixon, ed. 1976:269-81 (Top1c A). 


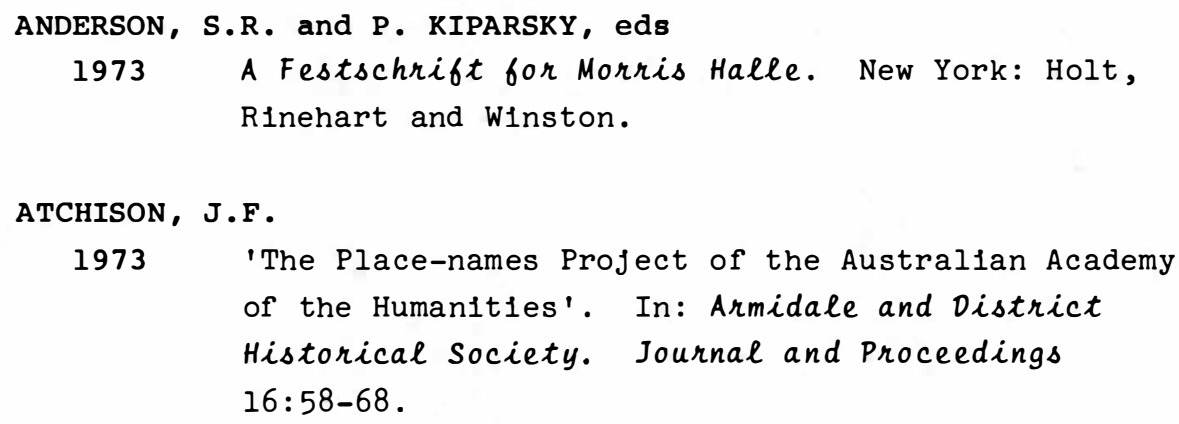


AUSTIN, P. and S.A. WURM

1976 A Sketch Grammar of Gamilaraay. MS. Australian National University. To be published in Pacific Linguistics, $B$.

BANI, E.

1976 'The Language Situation in Western Torres Strait'. In: Sutton, ed. 1976:3-6.

1977 'Summary Report of Fieldwork'. Australian Institute of Aboriginal Studies Newsletter n.s. 7:30-4.

BANI, E. and T.J. KLOKEID

1972 Kala Lagau Langgus - Yagar Yagar: the Western Torres Stra1t Language. MS.

1976 'Ergative Switching in Kala Lagau Langgus'. In: Sutton, ed. 1976:269-83.

BARKER, G.H. and J.F. O'CONNELL

1977 'A.I.A.S. Ethnobotany Workshop'. Australian Institute of Aboriginal Studies Newsletter n.s. 7:41-3.

BARLOW, A., M. HILL and W. JURCEVIC

1977 'Aboriginal Studies Courses at Australian Universities and Colleges of Advanced Education'. Australian Institute of Aboriginal Studies Newsletter n.s. 8:59-68.

BEALE, A.

1974 'A Grammar of the B1r1 Language'. Typescript. 60pp.

1976a The Mar1 Languages. B.A. (Hons.) subthes1s, Australian National University, Canberra.

1976b 'B1r1'. In: D1xon, ed. 1976:266-9 (A).

BERNDT, R.M. and C.H. BERNDT

1970 'Time for Relaxation'. In: Wurm and Laycock, eds 1970:557-91. 
BERNDT, R.M., ed.

1977 Aborigines and Change: Australia in the '70s. Australian Aboriginal Studies, SAll. Canberra: Australlan Institute of Aboriginal Studies.

BIRK, D.B.W.

1975 'The Phonology of MalakMalak'. Papers in Australian Linguistics No. 8:59-78. PL, A-39. Canberra:

Pacific Linguistics.

1976 The MalakMalak Language, Daly River lwestern Arnhem Land). PL, B-45. Canberra: Pacific Linguistics.

BLACK, P.

1975 'Sign Language in Normanton, Queensland'. Australian Institute of Aboriginal Studies xerox. 10pp. Including 23 photos of signs with descriptions.

1976 'Norman Pama Historical Phonology'. To appear in: Rigsby, ed. forthcoming.

to appear a [a description of Gurdjar]

to appear b Walangama. In: Black, ed. to appear.

BLACK, P., ed.

to appear [salvage studies]

BLAKE, B.J.

1969 The Kalkatungu Language: A Brief Description. AAS 20, L8. Canberra: Australian Institute of Aboriginal Studies.

1970 'Acoustic Phonetics and the Study of Aboriginal Languages'. In: Laycock, ed. 1970:27-38.

197la 'Jalanga and Kalkatungu: Some Comparisons'. Papers on the Languages of Australian Aboriginals:28-33. AAS 38, L16. Canberra: Australian Institute of Aboriginal Studies. 
1971b 'Jalanga: An Outline Morphology'. Papers on the Languages of Australian Aboriginals:12-27. AAS 38, L16. Canberra: Australian Institute of Aboriginal Studies.

1972 'Salvage Work in Australian Aboriginal Languages'. Linguistic Communications $6: 1-10$.

1974a The Case Systems of Australian Aboriginal Languages. Ph.D. thesis, Monash University, Victoria.

1974b 'The Causative in Kalkatungu'. In: Blake, ed. $1974: 1-21$.

1976a 'Are Australian Languages Syntactically NominativeErgative or Nominative-Accusative?: Rapporteur's Introduction and Summary'. In: Dixon, ed. 1976: 485-94.

1976b 'The Bivalent Suffix -ku: Rapporteur's Introduction and Summary'. In: Dixon, ed. 1976:421-4.

1976c 'Case Mechanisms in Kalkatungu'. Anthropological Linguistics 18/7:287-93.

1976d 'Galgadungu'. In: Dixon, ed. 1976:464-6 (Top1c C)

1976e 'On Ergativity and the Notion of Subject: Some Australian Cases'. Lingua 39:281-300.

1977 Case Marking in Australian Languages. L23. Canberra: Australian Institute of Aboriginal Studies.

1979 'Australian Case Systems: Some Typological and Historical Observations'. (In this volume.)

to appear 'A Grammar of Kalkatungu'. To be published In $P L, B$. BLAKE, B.J., ed.

1974 Papers in Australian Aboriginal Languages. Linguistic Communications 14 . 
BLAKE, B.J. and J.G. BREEN

1971 The Pitta-Pitta Dialects. Linguistic Communications 4.

BLAKE, B.J., J.G. BREEN and P. SUTTON

1975 Notes on Guwa, an Extinct Language of Western Queensland. Typescript.

BLAKE, B.J. and R.M.W. DIXON

n.d. Roneod Instructions for Contributors to Handbook of Australian Languages. 29pp.

BLUNDELL, $V . J$.

1976 A Dictionary of Worora Terms for Materlal Culture, Environmental Features and Related Items, w1th Ngarinfin Equivalents. Typescript.

BOLT, J.E., J.R. CLEVERLY and W.G. HODDINOTT

1970 'Pronominalisation in DJamindjungan'. In: Wurm and Laycock, eds 1970:593-615.

BOLT, J.E., W.G. HODDINOTT and F.M. KOFOD

1971a An Elementary Grammar of the Ngaliwurru Language of the Northern Territory. Mimeo.

1971b An Elementary Grammar of the Nungal1 Language of the Northern Territory. Typescript.

BRANDENSTEIN, C.G. VON

1969 'Tab1 Songs of the Aborigines'. Hemisphere 13/11:28-31.

1970a 'Linguist1c Salvage Work on the Eastern Goldfields and the South Coast of Western Australia'. Bulletin of the International Committee on urgent Anthropological and Ethnological Research 12:49-59 (V1enna).

1970b 'The Meaning of Section and Section Names'. Oceania 41/1:39-49.

1970c Narratives from the North-west of Western Australia in the Ngarluma and Jindjiparndi Languages. 3 vols. (W1th a 7" record.) AAS 35, L14. Canberra: Australian Institute of Aboriginal Studies. 
1970d 'Portuguese Loan-words in Aboriginal Languages of North-western Australia (A Problem of Indo-European and Finno-Ugrian Comparative Linguistics)'. In: Wurm and Laycock, eds 1970:617-50.

1970e 'Some New Aspects of Australian Aboriginal Language'. In: Laycock, ed. 1970:75-95.

1970 'What is next in Aboriginal Australian Linguistics'. Etruscan 19:11-15.

1977 'Aboriginal Ecological Order in the South-west of Australia - Meaning and Examples'. Oceania 47/3:169-86.

BRANDENSTEIN, C.G. von and A.P. THOMAS

1974 Taruru: Aboriginal Song Poetry from the Pilbara. Adela1de: Rigby.

BRASCH， S .

1975 Guren Guren. A Language of the Upper Burnett River South-east Queensland. B.A. (Hons.) subthesis, Australian National University, Canberra.

BREEN, J.G.

1970 'A Re-examination of Cook's Gogo-Yimidjir Word List'. Oceania $41 / 1: 28-38$.

1971a 'Aboriginal Languages of Western Queensland'. Linguistic Communications 5:1-88.

1971b A Description of the Waluwara Language. M.A. thesis, Monash University, Victoria.

1973 Bidyara and Gungabula: Grammar and Vocabulary. Linguistic Communications 8 .

$1974 a$ 'Notes on an Original Orthography (or The Dixon System of Spelling)'. In: Blake, ed. 1974:59-68.

1974b 'On Bivalent Suffixes'. In: Blake, ed. 1974:22-58. 
1974c Wagaya Grammar. MS. (Copy held at Australian Institute of Aboriginal Studies.)

1975 Innamincka Talk (the Innamincka Dialect of Yandruwandha), Preliminary Version. MS. (Copy held at Australian Institute of Aboriginal Studies.)

1976a Andegerebinha Grammar. MS. (Copy held at Australian Institute of Aboriginal Studies.)

1976b 'Bldfara'. In: Dixon, ed. 1976:339 (Top1c B).

1976c 'Gugadj and Gog-Nar: a Contrastive Sketch'. In: Sutton, ed. 1976:151-62.

1976d 'An Introduction to Gog-Nar'. In Sutton, ed. 1976: 243-59.

1976e 'Ngaminl, and a Note on M1dhaga'. In: Dixon, ed. 1976:745-50 (Topic E).

$1976 f$ Ngawun Grammar. MS. (Copy held at Australian Institute of Aboriginal Studies.)

1976g 'Proprietive Markers and Kinship Terms'. In: Dixon, ed. 1976:290-7 (Top1c A).

1976h 'Wagaya'. In: Dixon, ed. 1976:340-2 (Top1c B); 590-4 (Top1c D).

1976 'Wangkumara'. In: Dixon, ed. 1976:336-9 (Top1c B).

1976j 'Warluwara and Bularnu'. In: D1xon, ed. 1976:331-5 (Topic B); 586-90 (Topic D).

1976k 'Yandruwandha'. In: Dixon, ed. 1976:594-7 (Top1c D); 750-6 (Topic E).

1977 Kukatj Grammar. MS. (Copy held at Australian Institute of Aboriginal Studies.) 
to appear 'Andegerebinha Vowel Phonology'. To appear In Phonetica.

BRIDGES, B.J.

1970 'Blackfellow Talk'. In: Royal Australian Historical Society Newsletter 96:4-5.

BRUMBY, E. and E.G. VASZOLYI, eds

1977 Language Problems and Aboriginal Education. Perth: Aboriginal Teacher Education Program, Mount Lawley College of Advanced Education.

CAPELL, A.

1968a 'The Aborigine and his Language'. The Open Door (March) : 12-16.

1968b 'What do we know of Tasmanian Languages?'. Records of the queen Victoria Museum, Launceston 30:1-7.

1969 'Économie des changements phonétiques en Australie'. In: Linguistic Studies Presented to André Martinet. word 25/1-3:39-58.

1970a 'Aboriginal Languages in the South Central Coast, New South Wales: Fresh Discoveries'. Oceania 41/1: 20-7.

1970b 'Review Article: Current Research in Australian Aboriginal Linguistics'. AUMLA 33:88-100.

1970c 'Linguist1c Change in Australla'. In: P1lling and Waterman, eds 1970:240-55.

1971a 'History of Research in Australian and Tasmanian Languages'. In: Sebeok, ed. 1971:661-720.

1971b 'The Tragedy of the Disappearing Sounds'. In: Leach, ed. 1971:92-109.

1972a 'The Affix-transferring Languages of Australia'. Linguistics $87: 5-36$. 
1972b Cave Painting Myths: Northern Kimberley. Sydney: Oceania Linguistic Monographs 18.

1972c 'The Languages of the Northern K1mberley, W.A.: Some Structural Princlples'. Oceania 43/1: 54-65.

1975 'Ergative Constructions in Australian Languages'. working Papers in Language and Linguistics 2:1-7.

1976a 'Dier1'. In: Dixon, ed. 1976:742-5 (Topic E).

1976b 'Ngarinfin'. In: Dixon, ed. 1976:625-9 (Topic E).

1976c 'Simple and Compound Verbs: Confugation by Auxiliaries In Australian Verbal Systems: Rapporteur's Introduction and Summary'. In: Dixon, ed. 1976:615-25 (Top1c E).

1976d 'Tasmanians - Were They Earller in Australla?'. oceania 47/2:157-60.

1977 'A Time and Space Probe Into Australian Languages'. working Papers in Language and Linguistics 5:1-15.

1979a 'Classification of Verbs in Australian Languages'. (In this volume.)

1979b 'Grammatical Classification in Australia'. (In this volume.)

1979c 'The H1story of Australian Languages: a First Approach'. (In this volume.)

to appear 'A Grammar of Laragiya'. To appear in PL.

n.d. A Vocabulary of 600 Words in 40 North Australian Languages. Sydney. Typescript.

CAPELL, A. and H.H.J. COATE

to appear 'Comparative Studies in Northern Kimberley Languages, Australia'. To be published in $P L, C$. 
CAPELL, A. and H.E. HINCH

1970 Maung Grammar, Texts and Vocabulary. The Hague: Mouton.

CAPP, R.

1976 'Aboriginal Literacy. Insights from Sarah Gudschinsky'. South Australian Reading Association Journal 2/1:8-15.

CARROLL, P.J.

1969 A Discussion of Gunwinggu Orthography Problems. MS.

1976a 'Gunwinfgu'. In: Dixon, ed. 1976:704-8 (Top1c E).

1976b Kunwinjku. A Language of Western Arnhem Land. M.A. thes1s, Australian National University, Canberra.

CASSELLS, $\mathrm{H}$.

1977 Dja:bugay: a Language of the Calrns Rainforest Area.

MS. (Copy held at Australian Institute of Aboriginal Studies.)

CHADWICK, N.

1968 'DJing1l1 (North Australia) In a Comparative Perspective'. Oceania 38/3:220-8.

1971 'Ngarndf1 Wordlist and Phonolog1cal Key'. Papers on the Languages of Australian Aboriginals:34-45. AAS 38, L16. Canberra: Australian Institute of Aboriginal Studies.

1972 'Mathews' Chingalee Vocabulary: Appraisal and Comments'. Oceania $42 / 4: 276-82$.

1974 'H1storical Considerations in some Australian Languages and some Typological Comparisons with European Languages'. In: Blake, ed. 1974:69-82.

1975 A Descriptive Study of the Djingili Language. AAS, RRS2. Canberra: Australian Institute of Aboriginal Studies.

1976 'The Western Barkly Languages'. In: Dixon, ed. 1976: 390-6 (Top1c B); 432-7 (Topic C). 
1979 'The West Barkly Languages'. (In this volume.)

CHRISTIE, M.

1975a Jinang Grammar. MS.

1975b Jinang Phonology. MS.

CLARK, D.

1972 Classification of the Australian Languages, by W. Schmidt. (Translation of Die Gliederung der australischen Sprachen. 1919, Vienna.) (Avallable at Australian Institute of Aboriginal Studies Library .)

CLEVERLY, J.R.

1968 A Preliminary Study of the Phonology and Grammar of Djamindfung. M.A. thesis, University of New England, Armidale.

CLYNE, M., ed.

1976 Australia Talks: Essays on the Sociology of Australian Immigrant and Aboriginal Languages. $P L, D-23$. Canberra: Pacific Linguistics.

COATE, H.H.J.

1970 Ngarinjin Stress and Intonation. Tape Transcription Series 1. Canberra: Australian Institute of Aboriginal Studies.

COATE, H.H.J. and A.P. ELKIN

1974 Ngarinjin-English Dictionary. Sydney: Oceania Linguistic Monographs 16. 2 vols.

COATE, H.H.J. and L.F. OATES

1970 A Grammar of Ngarinjin, western Australia. (With a companion 3" tape 1llustrating stress and intonation and an interlinear translation and transcription booklet.) AAS 25, L10. Canberra: Australian Institute of Aboriginal Studies.

COLLIVER, F.S.

1971 'Aboriginal Place Names'. In: Anthropological Society of Queensland, Newsletter 36:1-4. 
COMRIE, B.

1978 Review of R.M.W. Dixon, ed. Grammatical Categories in Australian Languages. Lingua 45:79-90.

CROWLEY, T.M.

1975 A Brief Sketch of Yaygir. Typescript. (Copy held at Australian Institute of Aboriginal Studies.)

1976a Langgus Bla Keplok - Cape York Creole. MS. Canberra.

1976b 'Phonological Change in New England'. In: Dixon, ed. $1976: 19-50$

1978 The Middle Clarence Dialects of Bandjalang. RRS 12. Canberra: Australian Institute of Aboriginal Studies.

CROWLEY, T.M. and R.M.W. DIXON

to appear 'Tasmanian'.

CUNNINGHAM, M.C. (SHARPE)

1969 'A Description of the Yugumbir Dialect of Bandjalang'. University of Queensland Papers, Faculty of Arts $1 / 8: 69-122$.

DIXON, R.M.W.

1968 'Noun Classes'. Lingua 21:104-25.

1969 'Relative Clauses and Possessive Phrases In Two Australian Languages'. Language 45/1:35-44.

1970a 'Languages of the Calrns Rain Forest Region'. In: Wurm and Laycock, eds 1970:651-87.

1970b 'Olgolo Syllable Structure and What They are Doing About It'. Linguistic Inquiry 1/2:273-6.

1970c 'Proto-Australian Laminals'. Oceanic Linguistics 9/2:79-103.

1970d 'Syntactic Orientation as a Semantic Property'. In: Mathematical Linguistics and Automatic Translation, 
Report NSF-24:1-22. Cambridge, Massachusetts: Harvard University Computation Laboratory. Republished in: J.D. McCawley, ed. Syntax and Semantics, vol.7: Notes from the Linguistic underground. New York: Academic Press, 1976.

1971 'A Method of Semant1c Description'. In: Steinberg and Jakobovits, eds 1971:436-71.

1972 The Dyirbal Language of North queensland. London: Cambridge University Press.

1973 'The Semantics of Giving'. In: Gross, M., M. Halle and M.-P. Schützenberger, eds 1973:205-23.

1975a Dyirbal Dictionary with Illustrative Sentences. Typescript. (Copy held at Australian Institute of Aboriginal Studies.)

1975b Y1diny-English Dictionary. Typescript. (Copy held at Australian Institute of Aboriginal Studies.)

1976a 'The Derivational Affix "having": Rapporteur's Introduction'. In: Dixon, ed. 1976:203-4;

'Rapporteur's Summary' 306-10.

1976b 'Dy1rbal'. In: Dixon, ed. 1976:242-4 (Top1c A).

1976c 'Ergative, Locative and Instrumental Case Inflections: Rapporteur's Introduction'. In: Dixon, ed. 1976: 313-15; 'Rapporteur's Summary' 411-14.

1976d 'More on Yidinf'. In: Dixon, ed. 327-9 (Topic B).

1976e 'Tribes, Languages and Other Boundarles in Northeast Queensland'. In: Peterson, ed. 1976:207-38.

$1976 f$ 'Y1dinf'. In: Dixon, ed. 1976:212-14 (Top1c A); 315-20 (Topic B).

1977a 'Delocutive Verbs in Dy1rbal'. In: Hopper, ed. 21-38. 
1977b A Grammar of Vidin. Cambridge Studies in Linguistics 19, Cambridge University Press.

1977c 'Some Phonological Rules In Y1diny'. Linguistic Inquiry $8 / 1: 1-34$.

1977d 'The Syntactic Development of Australian Languages'. In: C.N. L1, ed. $1977: 365-415$.

forth- 'Ergativity'.
coming a

forth- 'A Grammar of Mbabaram'. coming $b$

forth- 'A Grammar of Wargamay'. coming $c$

forth- 'Grammatical Reanalysis: an Example of Linguistic coming d change in Wargamay, North Queensland'.

DIXON, R.M.W., ed.

1976 Grammatical Categories in Australian Languages.

AAS, L22. Canberra: Australian Inst1tute of

Aboriginal Studies.

[Topic A: The Derivational Affix 'having'.

Top1c B: Ergative, Locative and Instrumental Case Inflections.

Topic C: The Bivalent Suffix -ku.

Top1c D: Are Australian Languages Syntactically Nominative-Ergative or NominativeAccusative?

Topic E: Simple and Compound Verbs: Confugation by Auxillaries in Australian Verbal Systems.]

DOBSON, A.J. and P. BLACK

1977 Multidimensional Scaling of Some Lexicostatistical

Data. Typescript.

DONALDSON, T.

1976 'Wangaybuwan'. In: D1xon, ed. 1976:231-8 (Top1c A);

348-50 (Top1C B); 475-82 (Top1C C); 763-8 (Top1C E).

1977 A Description of Ngiyamba:, the Language of the Wana:ybuwan People of Central Western New South Wales. Ph.D. thesis, Australian National University, Canberra 
(to be published in revised form by Cambridge University press).

to appear 'Subordination of Finite Sentences in Ngiyamba:

(Wana:ybuwan), a Language of Central Western

New South Wales'. In: Rigsby, ed. to appear.

DOUGLAS, W.H.

1968 The Aboriginal Languages of South-west Australia.

AAS 14, L4. Canberra: Australian Institute of Aboriginal Studies.

1970 'Transemics'. In: Wurm and Laycock, eds 1970:689-96.

1972 'Dialect Differentiation in the Western Desert A Comment'. Anthropological Forum 3/1:79-82.

1973 'The Languages of Southwestern Austral1a'. In: Merrilees, D. et al. 'Aboriginal Man in Southwestern Australia'. Journal of the Royal Society of western Australia 56/1-2:44-55.

1975 'The Problems Experlenced by Vernacular-Speaking Aboriginal Children When English Only is Used as the Medium of Their Formal Education'. The Aboriginal child at school 3/4:28-36.

1976a 'Aboriginal Categorisation of Natural Features (as 1llustrated in the Western Desert)'. The Aboriginal child at School 4/5:51-64.

1976b The Aboriginal Languages of the South-west of Australia. 2nd edition. AAS RRS 9. Canberra: Australian Institute of Aboriginal Studies.

1976c 'Comment on the Paper "Metamorphosis and Process in Kitja"'. Talanya 3:37-43.

1977 Illustrated Topical Dictionary of the Western Desert Language. 2nd edition. AAS RRS 11. Canberra: Australian Institute of Aboriginal Studies. 
DUTTON, T.E.

1969 The Informal English Speech of Palm Island Aboriginal Children, North Queensland'. Journal of English Linguistics $3: 18-36$.

1970 'Informal English in the Torres Stra1ts'. In: W.S. Ramson, ed. English Transported: Essays on Australasian English, 137-60. Canberra: Australian National University Press.

DWYER, J .

1974 'The School and the Aboriginal Child'. The Aboriginal child at school 2/1:3-19.

EADES, D.K.

1976a The Oharawal and Ohurga Languages of the New South wales South Coast. AAS, RRS8. Canberra: Australian Institute of Aboriginal Studies.

1976b 'Gumbaynggir'. In: Dixon, ed. 1976:238-42 (Top1c A). to appear [a description of Gumbaynggir]

EDMUNDS, M.P.

1975 Culture and Cognition: A Study of the Bilingual Program of Education in Aboriginal Schools of the Northern Territory. B.A. (Hons.) thesis, University of Queensland.

ELKIN, A.P.

1970 The Aborigines of Austral1a: "One in Thought, Word and Deed"'. In: Wurm and Laycock, eds 1970:697-716.

ELWELL, V.M.R.

1977a Multilingualism and Lingua Francas among Australian Aborigines: a Case Study of Maningrida. B.A. (Hons.) thesis, Australian National University, Canberra.

1977b A Preliminary Analysis of Gungurugon1: a Language of Northern-Central Arnhem Land. Typescript. (Copy held at Australian Institute of Aboriginal Studies.) 
FESL, E.D.

1977 Melbourne Aboriginal English: an Investigation into the Differences in Speech between Aboriginal Persons Living in Melbourne and Australians of European Descent. B.A. (Hons.) thesis, Monash University.

FLINT, E.H.

1968 'Aboriginal English, Linguistic Description as an A1d to Teaching'. English in Australia 6:3-21.

1970 The Influence of Prosodic Patterns upon the Mutual Intelligibility of Aboriginal and General Australian English'. In: Wurm and Laycock, eds 1970:717-40.

1971 The Aboriginal English of Informants in the 40-60+ Age Group in a Far North-Western Queensland Community. Paper delivered at the 43rd ANZAAS Congress.

1973 The Soc1ology of Language in Queensland Aboriginal Communties'. Linguistic Communications 10:11-25.

FRASER, J .

1977 'A Phonological Analysis of Fitzroy Crossing Children's Pidgin'. In: Hudson, ed. 1977:145-204.

FRIEDMAN, L.A.

1976 Phonology of a Soundless Language: Phonological Structure of the American Sign Language. Ph.D. thesis, University of California, Berkeley.

1977 'Formational Properties of American Sign Language'. In: On the other Hand. New Perspectives on American Sign Language. New York: Academic Press.

FURBY, C.E.

1972 'The Pronominal System of Garawa'. Oceanic Linguistics $11 / 1: 1-31$.

1974 'Garawa Phonology'. Papers in Australian Linguistics No. 7:1-11. PL, A-37. Canberra: Pacific Linguistics. 
FURBY, C.E. and E.S. FURBY

1976 'Garawa Compass Directions'. Talanya 3:1-13.

FURBY, E.S. and C.E. FURBY

1977 A Preliminary Analysis of Garawa Phrases and clauses. $P L, B-42$. Canberra: Pacific Linguistics.

GARDINER, J .

1977

'Teaching Standard English as a Second Dialect to Speakers of Aboriginal English'. In: Brumby and Vászoly1, eds 1977:165-99.

GEYTENBEEK, B. and H. GEYTENBEEK

1971 Gidabal Grammar and Dictionary. AAS 43, L17.

Canberra: Australian Institute of Aboriginal Studies.

GLASGOW, D.I. and K. GLASGOW

1975 Burarra Dictionary File. Darwin. MS. 285pp.

GLASGOW, $\mathrm{K}$.

1970 Burera Discourse and Paragraph Structure. Typescript. Darwin: S.I.L., Australian Aborigines Branch.

GLAS S, Amee

1971 A Tentative Description of Ngaanyatjara Discourse and Paragraph. Typescript. United Aborigines Mission Language Department.

1976 'Four Problems in Ngaanyatjarra Primer Construction'. Linguistic Communications 16:11-19.

GLASS, A. and D. HACKETT

1969 Pitjantjatjara Texts. AAS 19, L7. Canberra: Australian Institute of Aboriginal Studies.

1970 Pitjantjatjara Grammar: A Tagmemic View of the Ngaanyatjara (warburton Ranges) Dialect. AAS 34, L13. Canberra: Australian Institute of Aboriginal Studies. 
GODFREY, M.

1967 Notes on Word, Phrase, Clause and Sentence Levels in Wik-Munkan. Typescript. Darwin: Summer Institute of Linguistics. Australian Aborigines Branch.

1970 'Wik-Munkan Verb Morphology'. In: Wurm and Laycock, eds 1970:741-56.

GREENBERG, J.H.

1971 'The Indo-Pacific Hypothesis'. In: Sebeok, ed. $1971: 807-71$.

GRIMWADE, G.

1975 George Taplin and His Work on Aboriginal Languages. Sydney: Oceania Linguistic Monographs 17 (Part 2).

GROSS, M., M. HALLE and M.-P. SCHÜTZENBERGER, eds

1973 The Formal Analysis of Natural Languages. Proceedings of the First International Conference. The Hague: Mouton.

HALE, K.L.

1968 Preliminary Remarks on Walbir1 Grammar: II.

Massachusetts Inst1tute of Technology. Mimeo.

1970 The Passive and Ergative in Language Change:

The Australian Case'. In: Wurm and Laycock, eds $1970: 757-81$.

1971 'A Note on a Walbiri Tradition of Antonymy'. In:

Stelnberg and Jakobovits, eds 1971:472-82.

1973a 'Deep-surface Canonical Disparities in Relation to Analysis and Change: an Australian Case'. In: Sebeok, ed. 1973:401-58.

1973b 'Person Marking in Walb1r1'. In: Anderson and K1parsky, eds 1973:308-44.

1974 Warlpiri-English Vocabulary: an Elementary Dictionary of the Warlpir1 Language. Cambridge, Massachusetts. 97pp. 
1975 Gaps in Grammar and Culture. Belgium: The Peter de Ridder Press.

1976a 'The Adjolned Relative Clause in Australia'. In: Dixon, ed. 1976:78-105.

1976b 'DJa:bugay'. In: Dixon, ed. 1976:321-6 (Top1c B).

1976c 'Linguistic Autonomy and the Linguistics of Carl Voegelin'. Anthropological Linguistics 18/3:120-8.

1976d On Ergative and Locative Suffixial Alternations in Austral1an Languages'. In: Dixon, ed. 1976:414-17.

1976e 'Phonological Developments in a Northern Paman Language: Uradh1'. In: Sutton, ed. 1976:41-9.

1976 'Phonological Developments in Particular Northern Paman Languages'. In: Sutton, ed. 1976:7-40.

$1976 \mathrm{~g} \quad \mathrm{~T}^{\mathrm{y}} \mathrm{a} \cdot \mathrm{pukay}$ (DJaabugay)'. In: Sutton, ed. 1976:236-42.

1976h 'Wik Reflections of Middle Paman Phonology'. In:

Sutton, ed. 1976:50-60.

HALL, A.H.

1968 A Depth-Study of the Thaayorr Language of the Edward River Tribe, Cape York Peninsula. M.A. thesis, University of Queensland.

1972 A Study of the Thaayorre Language of the Edward River Tribe, Cape York Peninsula, Queensland. Ph.D. thesis, University of Queensland.

1976a 'Methods of Negation in Kuuk Thaayorre'. In: Sutton, ed. 1976:299-307.

1976b 'Morphological Categorles of Nouns in Kuuk Thaayorre'. In: Sutton, ed. 1976:308-14. 
HALL, H.A.

1971 A Partial Vocabulary of the Ngalooma Aboriginal

Tribe. With Concordance and Commentary by

C.G. von Brandenstein. AAS 46, L18. Canberra:

Australian Institute of Aboriginal Studies.

HANSEN, K.C. and L.E. HANSEN

1969 'Pintup1 Phonology'. Oceanic Linguistics 8/2: 153-70.

1970 The Sentence in Pintup1. Typescript. Darwin:

Summer Institute of Linguistics, Australian

Aborigines Branch.

1974 Pintupi Dictionary. Darwin: Summer Institute of

Linguistics, Australian Aborigines Branch (2nd edn 1977).

1975 The Core of Pintupi Grammar. Alice Springs:

Institute for Aboriginal Development.

HARRIS, B.P. and G.N. O'GRADY

1976 'An Analysis of the Progressive Morpheme in

Umpila Verbs: a Revision of a Former Attempt'.

In: Sutton, ed. 1976:165-212.

HARRIS, J.K.

1968 'Linguistics and Aboriginal Education: a Practical Use of Linguistic Research in Aboriginal Education in the Northern Territory'. Australian Territories $8 / 10: 24-34$.

1969a Descriptive and Comparative Study of the Gunwingguan Languages, Northern Territory. Ph.D. thesis, Australian National University, Canberra.

1969b 'Preliminary Grammar of Gunbalang'. Papers in Australian Linguistics No. 4:1-49. PL, A-17. Canberra: Pacific Linguistics.

1970 'Gunkurrng, a Mother-1n-law Language'. In: Wurm and Laycock, eds 1970:783-89. 
HAVILAND, J.B.

1972a Guugu Y1midhirr Case Forms. Canberra: Australian National University mimeo.

1972b Guugu Yimidhirr Verb Conjugations. Canberra: Australian National University mimeo.

1972c Guugu Yimidhirr Word List. Canberra: Australian National University mimeo.

1974 'A Last Look at Cook's Guugu Y1midhirr Word List'. Oceania 44/3:216-32.

1975a Guugu-Y1midhirr Brother-1n-law Language. 52 [23] pp. Canberra: Australian National University.

1975b Guugu-Y1midhirr Word List. Computer Printout. 175pp. Canberra: Australian National University.

forth- 'How to Talk to your Brother-in-law in Guugu Yimidhirr'. coming In: Shopen, ed. forthcoming.

HEATH, J .

1975 'Some Functional Relationships in Grammar'. Language $51: 89-104$.

1976a 'Antipassivization: a Functional Typology'. Berkeley Linguistics Society II:202-11.

1976b '"Ergative/Accusative" Typologies in Morphology and Syntax'. In: Dixon, ed. 1976:599-611.

1976c Linguistic Diffusion in Arnhem Land. Ph.D. thesis, University of Chicago. (Published by Australian Institute of Aboriginal Studies as Heath 1978c.)

1976d 'North-east Arnhem Land'. In: Dixon, ed. 1976: 735-40 (Topic E).

1976e 'Nunggubuyu'. In: D1xon, ed. 1976:408-11 (Top1c B). 
1976f 'Nunggubuyu and Ritharngu'. In: Dixon, ed. 1976: 444-50 (Topic C).

1976g Nunggubuyu Flora and Fauna Terminology. Typescript. (Copy held at Australian Institute of Aboriginal Studies. )

1976h 'R1tharngu'. In: Dixon, ed. 1976:285-7 (Top1c A).

1976i 'Substantival Hierarchies: Addendum to Silverstein['s paper: "Hierarchy of Features and Ergativity"]'. In: Dixon, ed. 1976:172-90.

1977a Warramunga-English Wordlist. Typescript. Australian Institute of Aboriginal Studies.

1977b Warramunga Grammatical Notes. Typescript. Australian Institute of Aboriginal Studies.

1978a 'Linguist1c Approaches to Nunggubuyu Ethnozoology and Ethnobotany'. In: L.R. Hiatt, ed. Australian Aboriginal Concepts, 40-55. Canberra: Australian Institute of Aboriginal Studies.

1978b Linguistic Diffusion in Arnhem Land. AAS, RRS 13. Canberra: Australian Institute of Aboriginal Studies.

1979 'Diffusional Linguistics in Australia: Problems and Prospects'. (In this volume.)

to appear a 'Is Dylrbal Ergative?'. In: Rigsby, ed. to appear.

to appear b 'Basic Materials in Mara: Grammar, Texts and Dictionary'. To be published in Pacific Linguistics, $B$.

to appear c 'Basic Materials in Ritharngu: Grammar, Texts and Dictionary'. To be published in Pacific Linguistics, B.

to appear d 'Basic Materials in Warndarang: Grammar, Texts and Dictionary'. To be published in Pacific Linguistics, B. 
forth-

coming a 'Ngand1 Grammar, Dictionary and Texts'. To be published by Australian Institute of Aboriginal Studies.

forth-

coming $b$ 'Nunggubuyu Grammar, Dictionary and Texts'.

forth-

coming c 'Dhuwal Grammar, Dictionary and Texts'.

HERCUS, L.A.

1969 The Languages of Victoria: A Late Survey. AAS 17, L5 and L6. Canberra: Australian Institute of Aboriginal Studies.

1971a 'Arabana and Wanganuru Traditions'. Oceania 42/2: 94-109.

1971b 'Eaglehawk and Crow: A Madimadi Version'. Mankind $8: 137-40$.

1972 The Pre-stopped Nasal and Lateral Consonants of Arabana-Wanganuru'. Anthropological Linguistics $14 / 8: 293-305$.

1973 'Only Old Allce can Talk Gujan1'. Aboriginal News $1 / 4: 4-6$.

$1974 a$ 'Important Aboriginal Languages'. Hemisphere $18 / 1: 16-21$.

1974b 'Texts in V1ctorian Languages'. Papers in Australian Linguistics No. 7:13-43. PL, A-37. Canberra:

Pacific Linguistics.

1976a 'Arabana-Wangganguru'. In: Dixon, ed. 1976: 263-6 (Top1c A); 467-71 (Top1c C); 740-2 (Top1c E).

1976b 'Arabana-Wangganguru and Bāgandj1'. In: Dixon, ed. 1976:598 (Topic D).

1976c 'Bāgandj1'. In: Dixon, ed. 1976:229-31 (Top1c A);

'Southern Bāgandj1'. In: Dixon, ed. 1976:350-2 (Top1c B). 
1976d 'Kulin'. In: Dixon, ed. 1976:249-50 (Top1c A).

1979 In the Margins of an Arabana-Wanganuru Dictionary: The Loss of Initial Consonants'. (In this volume.)

to appear 'Ba:gandj1 Grammar'.

HERCUS, L.A. and P. SUTTON, eds

to appear 'This is What Happened'. Canberra: Australian Institute of Aboriginal Studies.

HERCUS, L.A. and I.M. WHITE

1971 'The Last Madimad1 Man'. Victorian Naturalist 88/1:11-19.

1973 'Perception of Kinship Structure Reflected in the Adnjamathanha Pronouns'. Papers in Australian Linguistics No. 6:47-72. PL, A-36. Canberra: Pacific Linguistics.

HERSHBERGER, H. and E.V. PIKE

1970 'Stress as Related to the Grammar of Gugu-Yalanj1'. In: Wurm and Laycock, eds 1970:791-810.

HERSHBERGER, R.

1970 'Sentence Types in Gugu-Yalanj1'. In: Wurm and Laycock, eds 1970:811-24.

n.d. Gugu-Yalanj1 (Dictionary Notes). Darwin: 2 vols. Typescript and MS.

HIATT, L.R., ed.

1978 Australian Aboriginal Concepts. Canberra: Australian Institute of Aboriginal Studies.

HILL, D.L. and S.J. HILL

1975 Notes on the Narangga Tribe of Yorke Peninsula. Adela1de.

HOARD, J.E. and G.N. O'GRADY

1976 'Nyangumarda Phonology: a Preliminary Report'.

In: Dixon, ed. 1976:51-77. 
HOCKADAY, M. and I. MARKER

n.d. Wallbri Phonology. MS.

HODDINOTT, W.G.

1978 'The Languages and Myths of the New England Area'.

In: I. McBryde, ed. 1978:52-64. Records of Times

Past: Ethnohistorical Essays on the Culture and

Ecology of the New England Tribes, 52-64. Canberra:

Australian Institute of Aboriginal Studies.

HODDINOTT, W.G. and F.M. KOFOD

1976a 'DJamindjungan'. In: Dixon, ed. 1976:397-401

(Top1c B); 437-41 (Top1C C); 698-704 (Top1C E).

1976b 'Ngang1kurungur'. In: Dixon, ed. 1976:401-5

(Topic B); 691-8 (Top1C E).

HOLMER, N.M.

1970 Traces of Australian-Amerindian Morpheme Categories

in East As1a'. In: Wurm and Laycock, eds 1970:67-74.

1971 Notes on the Bandjalang Dialect: Spoken at Coraki

and Bungawalbin Creek, New South wales. AAS 32, LIl.

Canberra: Australian Institute of Aboriginal Studies.

HOLMER, N.M. and V.E. HOLMER

1969 Stories from Two Native Tribes of Eastern Australia.

Australlan Essays and Studies, vol.6. Upsala:

Lundequistska Bokhandeln.

HOPPER, P.J., ed.

1977 Studies in Descriptive and Historical Linguistics.

Festschrift for Winfred $P$. Lehmann. Amsterdam:

John Benjamins B.V.

HUDSON, J .

1970 Walmatjar1 Paragraph Types. MS.

1971 Some Features of High Level Phonology in Walmatjar1.

Typescript. Darwin: Summer Institute of Linguistics, Australian Aborigines Branch.

1976a 'Walmadjar1'. In: Dixon, ed. 1976:205-8 (Top1c A); 653-67 (Topic E). 
1976b 'Walmatjar1: Nominative-Ergative or NominativeAccusative?'. Papers in Australian Linguistics No. 9:1-30. PL, A-42. Canberra: Pacific Linguistics.

forth- 'The Core of Walmatjar1 Grammar'. coming

HUDSON, J., ed.

1977 Five Papers in Australian Phonologies. Work Papers of SIL - AAB, Series A vol.l. Darwin: Summer Institute of Linguistics. Australian Aborigines Branch.

HUDSON, J. and E. RICHARDS

1969 'The Phonology of Walmatjar1'. Oceanic Linguistics $8 / 2: 171-89$.

1976 The Walmatjari: An Introduction to the Language and culture. Work Papers of Summer Institute of Linguistics - AAB vol.l. Darwin: Summer Institute of Linguistics.

HUGHES, E.J.

1971 Nunggubuyu-Fnglish Dictionary. Sydney: Oceania Linguistic Monographs 14.2 vols.

HUGHES, E.J. and A. HEALEY

1971 'The Nunggubuyu Verb'. Papers on the Languages of Australian Aboriginals: 46-57. AAS 38, L16. Canberra: Australian Institute of Aboriginal Studies.

HUGHES, E.J. and V.J. LEEDING

$1971 \mathrm{a}$ 'The Phonemes of Nunggubuyu'. Papers on the Languages of Australian Aboriginals:72-81. AAS 38, L16. Canberra: Australian Institute of Aboriginal Studies.

1971b 'A Tentative Description of Nunggubuyu Clauses'. Papers on the Languages of Australian Aboriginals: 58-71. AAS 38, L16. Canberra: Australian Institute of Aboriginal Studies. 


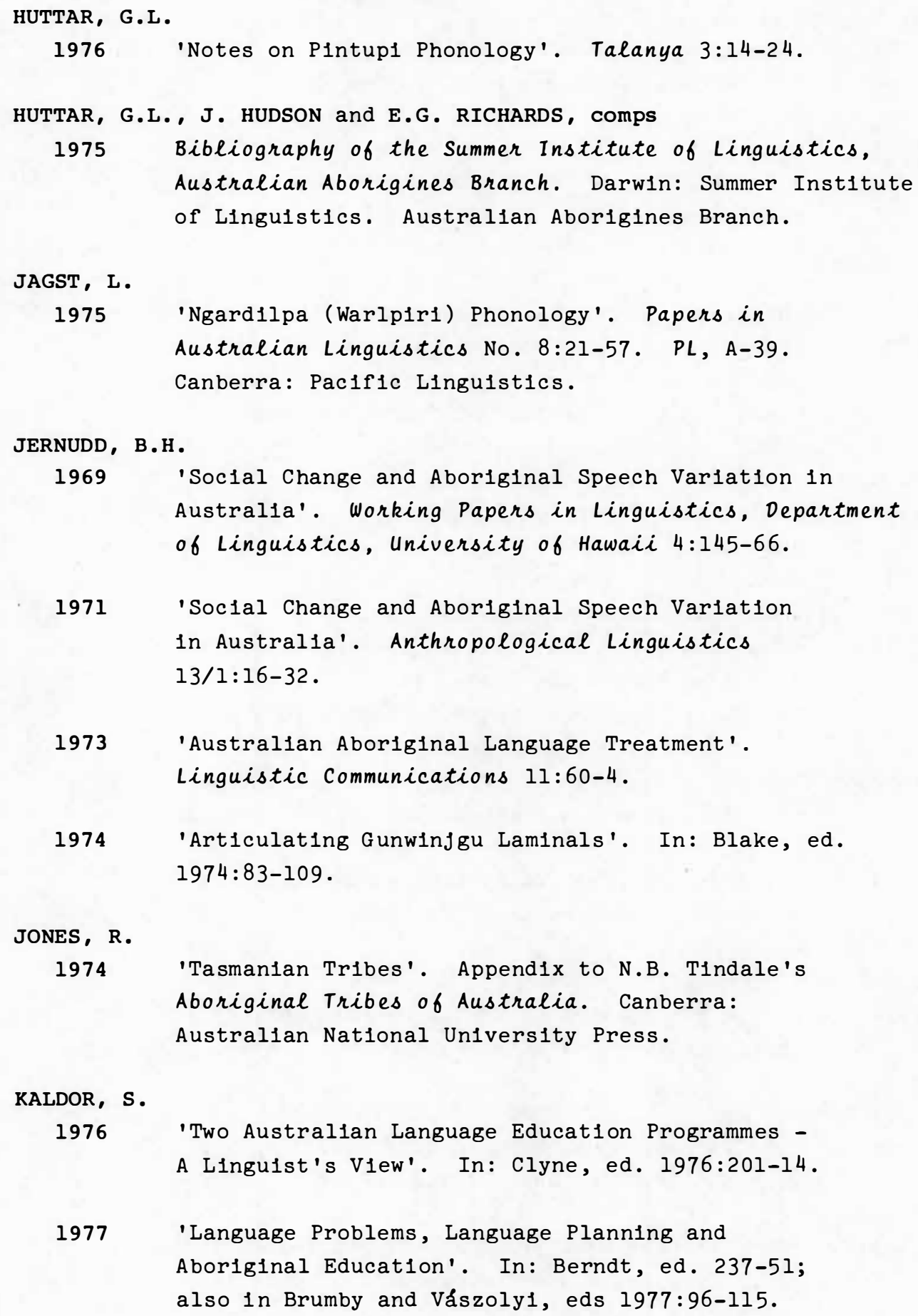


KEEN, I .

1977 'Amb1guity in Yolngu Religious Language'. Canberra Anthropology $1 / 1: 33-50$.

KEEN, S.L.

1972 A Description of the Yukulta Language - an Australian Aboriginal Language of North-west Queensland. M.A. thesis, Monash University.

KEGL, J., D. NASH, R.J. GRANITES and K. HALE

1976 Transcription and Comments on a Tape of Warlpiri Sign Language: Spoken and Signed. Cambridge, Mass.: Massachusetts Institute of Technology mimeo.

KERR, N.F .

1968 Preliminary Report of Fieldwork (on Nyigina), Part I. Australian Institute of Aboriginal Studies mimeo.

KILHAM, C.A.

$1974 \mathrm{a}$ 'Compound Words and Close-kn1t Phrases in W1k-Munkan'. Papers in Australian Linguistics No. 7:45-73. PL, A-37. Canberra: Pacific Linguistics.

1974b Thematic Organization of W1k-Munkan Discourse. Ph.D. thesis, Australian National University, Canberra.

1977 Thematic Organization of Wik-Munkan Discourse. PL, B-52. Canberra: Pacific Linguistics.

KIRKE, B.

1974 Simple Explanation of Aranda. Alice Springs:

Institute for Aboriginal Development. Mimeo.

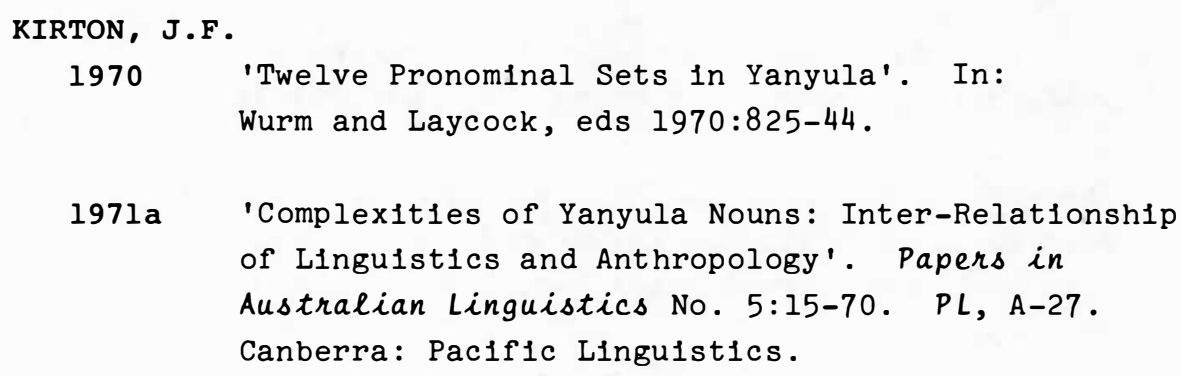


1971b 'Yanyula Noun Modifiers'. Papers in Australian

Linguistics No. 5:1-14. PL, A-27. Canberra:

Pacific Linguistics.

1976 'Yanyuwa Nominative and Ergative-Allative Cases'.

Papers in Australian Linguistics No. 10:1-12.

PL, A-47. Canberra: Pacific Linguistics.

KIRTON, J.F. and N. TIMOTHY

1977 'Yanyuwa Concepts Relating to "Skin"'. Oceania

$47 / 4: 320-2$.

KLOKEID, T.J.

1969 Thargari Phonology and Morphology. PL, B-12.

Canberra: Pacific Linguistics.

1970 Relative Clauses in Mabulag. Massachusetts

Institute of Technology mimeo.

1976a 'Lard11'. In: Dixon, ed. 1976:550-84 (Topic D).

1976b Tense, Topic and Focus in Lardil Complement Sentences. Mimeo.

1976c Topics in Lard1l Grammar. Ph.D. thesis, Massachusetts Institute of Technology.

КОСН, $\mathrm{H}$.

forth- 'Ka1titj Nominal Inflections'. In: Rigsby, ed. coming forthcoming.

KOFOD, F.M.

$1976 a$

'M1riwung'. In: Dixon, ed. 1976:584-6 (Top1c D);

646-53 (Top1c E).

1976b Mirlwung-English [word-list]. Typescript and MS.

LAADE, W.

1970 'The Position of the Language of Salba1'.

Anthropos 65:271-77.

1971 A Brief Gulde to Island-P1dgin. Typescript, 14pp.

Revised edn. n.p.:the author. 
LAYCOCK, D.C.

1969 'Three Lamalamic Languages of North Queensland'.

Papers in Australian Linguistics No. 4:71-97.

$P L, A-17$. Canberra: Pacific Linguistics.

LAYCOCK, D.C., ed.

1970 Linguistic Trends in Australia: Papers Presented

to the A.I.A.S. Linguistics Group May 1968. AAS 23, L9.

Canberra: Australian Institute of Aboriginal Studies.

LEACH, B . ed.

1971 The Aborigine Today. London: Paul Hamlyn.

LEEDING, $\mathrm{V} . \mathrm{J}$.

1973 'The Linguist's Role in a Bilingual Education

Program'. Paper delivered to Summer Institute of

Linguistics, Australian Aborigines Branch, October 1973.

1976 'Garawa'. In: Dixon, ed. 1976:382-90 (Topic B).

LEEDING, V.J. and S.C. GUDSCHINSKY

1974 'Towards a More Un1form Orthography for Australian Aboriginal Languages'. In: Australian Institute of Aboriginal Studies Newsletter n.s. 1:26-31.

LEVITT, D.

forth-

coming Groote Eylandt Plants and Their Use.

LI, C.N., ed.

1977 Mechanisms of Syntactic Change. Austin:

University of Texas Press.

LOWE, B.M.

1973, Gupapuyngu Primer 1,4. Galiwinku Adult Education

1975 Centre.

n.d. Gupapuynu Lessons. M1ling1mb1. Mimeo. 
to appear [a description of Gunabidf1 (DJeepana)]

MCKELSON, K.

1968 'Teach Yourself Njañumada'. Broome.

$1974 a$ 'Studies in Garadyar1'. La Grange, Western Australia.

1974b 'Studies in Mañala'. La Grange, Western Australia.

1975 'Learn a Language'. La Grange Mission, Western

Austral1a. 140pp. +4 cassettes. (Garadyar1)

MARSH, J .

1969 'Mantj1ltjara Phonology'. Oceanic Linguistics

$8 / 2: 131-52$.

1970 Paragraph Structure of Mantj1ltjara. MS.

Darwin: Summer Institute of Linguistics, Australian Aborigines Branch.

MEL 'ّ̊UK, I.A.

1977 The Predicative Construction in the Dyirbal Language: Towards the Notions 'Grammatical Subject',

'Transitivity', 'Accusative Case', 'Ergative

Construction' and 'Grammatical Voice'. Bloomington,

Indiana: Indiana University LInguistics Club.

MERLAN, F .

1977 Wadaman Infinitive Complements. Australian

Institute of Aboriginal Studies mimeo.

to appeara [a description of DJawonf]

to appear b [a description of Mangaray1]

METCALFE, C.D.

1971 'A Tentative Phonemic Statement of the Bardi Aboriginal Language'. Papers on the Languages of Australian Aboriginals: 82-92. AAS 38, L16. Canberra: Australian Institute of Aboriginal Studies. 
1973 'New Light on Aboriginal Languages'. In:

D. Douglas, ed. 1973 Linguistics and the Mind. Sydney University Extension Board.

1975 Bardi Verb Morphology (Northwestern Australia). PL, B-30. Canberra: Pacific Linguistics.

MILLER, W.R.

1970 'Sign Language Used at the Warburton Ranges

in Western Australia'. 22pp. with related prints.

1972 'Dialect Differentiation in the Western Desert

Language'. Anthropological Forum 3/1:61-78.

MILLIKEN, E.P.

1976 'Aboriginal Language Distribution in the Northern

Territory'. In: Peterson, ed. 1976:239-42 (+ map).

MORPHY, F.

1977 'Language and Molety: Soclolectal Varlation in a

Yu:Ingu Language of North-east Arnhem Land'.

Canberra Anthropology 1/1:51-60.

MULVANEY, D. and J. GOLSON, eds

1971

Aboriginal Man and Environment in Australia. Canberra:

Australian National University Press.

MURTONEN, A.

1969a Outline of a General Theory of Linguistics....

Melbourne: the author. 67pp. (Bound with

1969b. )

1969b Pintupi, Statistical and Comparative Survey of

an Australian Great Western Desert Language.

Melbourne: the author. v111 and 6lpp.

NASH, D.

1976 Is Ngarluma Split-ergat1ve?. Mimeo. 
OATES, L.F.

1975 The 1973 Supplement to a Revised Linguistic Survey of Australia. 2 vols. Armidale: Armidale Christian Book Centre.

1976 'Muruwar1'. In: Dixon, ed. 1976:244-9 (Top1c A); 342-7 (Top1C B); 472-5 (Top1C C).

OATES, W.J. and L.F. OATES

1970 A Revised Linguistic Survey of Australia. AAS 33, L12. Canberra: Australian Institute of Aboriginal Studies.

O'GRADY, G.N.

1970 'Nyangumarda Conjugations'. In: Wurm and Laycock, eds $1970: 845-64$.

1971 'Lexicographic Research in Aboriginal Australia'. In: Sebeok, ed. 1971:779-803.

1976 'Umpila Historical Phonology'. In: Sutton, ed. 1976:61-7.

1979 'Preliminaries to a Proto Nuclear Pama-Nyungan Stem List'. (In this volume.)

O'GRADY, G.N. and K.L. HALE

1974 'Recommendations Concerning Bilingual Education in the Northern Territory'. Report prepared for Department of Education, Darwin, July 1974.

O'GRADY, G.N. and T.J. KLOKEID

1969 'Australian Linguistic Classification: a Plea for Coordination of Effort'. Oceania 39/4:298-311.

O'GRADY, G.N. and K.A. MOONEY

1973 'Nyangumarda Kinship Terminology'. Anthropological Linguistics 15/1:1-23.

OSBORNE, C.R.

1974 The Tiwi Language. AAS 55, L21. Canberra: Australian Institute of Aboriginal Studies. (A tape/ cassette of Tiw1 myths from the text is also avallable.) 
PEILE, A.R.

1976a Gugadja Ethno-botany. Typescript.

1976 (?)b Gugadja Ethno-medical Terminology. Typescript.

1976(?)c The Gugadja People and Frogs. Typescript.

1977a Some Comments on Ethno-herpetology (Gugadja).

Typescript.

1977b 'Good Mediclne, Good Dry'. Aboriginal Health Worker Australian Institute of Aboriginal Studies.

PETERSON, N., ed.

1976 Tribes and Boundaries in Australia. SA 10. Canberra:

Australian Institute of Aboriginal Studies.

PFITZNER, J. and J. SCHMAAL

197? Learning Aranda. Typescript. 56pp.

PILLING, A.R.

1970 'Changes in Tiw1 Language'. In: P1lling and Waterman, eds $1970: 256-74$.

PILLING, A.R. and R.A. WATERMAN, eds

1970 Diprotodon to Detribalization. Studies of Change Among Australian Aborigines. East Lansing: Michigan

State University Press.

PLATT, J.T.

1968 'Some Features of the Verb in Kukata'. Anthropological Linguistics 10/5:1-7.

1970 'Some Notes on Gugada and Wirangu'. In: Laycock, ed. 1970:59-63.

1972 An Outline Grammar of the Gugada Dialect: South Australia. AAS 48, L20. Canberra: Australian

Institute of Aboriginal Studies.

'What's Becoming What? - A Note on Inchoatives in 
P1tjantjatjara'. In: Blake, ed. 1974:110-19.

1976 'Pitjantjatjara'. In: Dixon, ed. 1976:427-31 (Topic C); 667-73 (Top1c E).

PLOMLEY, N.J.B.

1976 A word-List of the Tasmanian Aboriginal Languages. Launceston: Author in association with the Government of Tasmania.

PROFFIT, W.R. and R.E. MCGLONE

1975 'Tongue-Lip Pressures During Speech of Australian Aborigines'. Phonetica 32:200-20.

PYM, N.

1975 Yiwaldfa Dictionary Notes. Darwin: Summer Institute of Linguistics. $124 \mathrm{pp}$.

QUEENSLAND: DEPARTMENT OF EDUCATION - Bernhard van Leer Foundation

1971-73 Handbook for First Year Experimental Language

Development Programme: Books One-Three. 3 vols.

Brisbane: Department of Education.

1972 Research Report on Some Effects of an Experimental

Language Development Program on the Performance of

Aboriginal children in Their First year at School.

Brisbane: Department of Education.

RAA, E. ten and S.T. WOENNE

1973 Research Dictionary of the Western Desert Language

of Australia. Computer printout. Perth:

Department of Anthropology, Western Australia.

REECE, L.

1970 Grammar of the Wailbri Language of Central Australia.

Oceania Linguistic Monographs 13. Sydney.

1975 Dictionary of the Wailbri (walpiri) Language of

Central Australia, Part 1 wailbri-English. Oceania

Linguistic Monographs 19. Sydney. 
REINECKE, J.E.

1971 'Australian and Torres Straits P1dgin English'.

Linguistic Communications 3:113-20.

RIGSBY, B.

1974 Pidgin-Talk lo Bamaga: Aboriginal English on North Cape York Peninsula. Paper presented at the University of Queensland Anthropology Department, June 1974 .

1976a 'Kuku-Thaypan Descriptive and H1storical Phonology'. In: Sutton, ed. 1976:68-77.

1976b 'Possession In Kuku-Thaypan'. In: Sutton, ed. 1976:260-8.

RIGSBY, B., ed.

to appear Proceedings of the 1976 A.I.A.S. Biennial Conference (Linguistics Section). Canberra: Pacific Linguistics.

ROGERS, J.H.

1976 'A Note on Disfunctive Categories in Kinship

Terminology'. Anthropological Linguistics 18/4:183-5.

RUDDER, J .

1977 Introduction to Yolnu Science. Galiwinku, Northern Territory: Galiwinku Adult Education Centre.

RUMSEY, A.L.

1978 [a description of Ungarinyin] Ph.D. thesis, University of Chicago.

to appear 'Prolegomena to a Theory of Australian Grammatical Case Systems'. In: Rigsby, ed. to appear.

n.d. Proto-Indo-European from the Standpoint of the (Other?) Ergative Languages. Typescript.

RYAN, J.S.

197la 'Austral English and the Native Languages: Problems 
Confronting the Modern Researcher'. Journal of Dialectology n.s. 4:743-60.

1971b A Methodology for the Collecting and Processing of Australian Place Names. Australian Academy of the Humanities.

SANDEFUR, J. and D. GENTIAN

1977 'A Tentative Description of the Phonemes of the Ngalkbun Language (Including a Small Word L1st)'. In: Hudson, ed. $1977: 57-96$.

SAYERS, B.J .

1973 Interpenetration of Stress and P1tch in W1k-Munkan Grammar and Phonology, Part II. The Word, the Foot, the Syllable and the Phoneme. MS.

1975 What are Contrastive Syllables? The W1k-Munkan P1cture. MS.

1976a 'Interpenetration of Stress and P1tch in W1k-Munkan Grammar and Phonology'. Papers in Australian Linguistics No. 9:31-79. PL, A-42. Canberra: Pac1f1c Linguist1cs.

1976b The Relevance of Stress and P1tch in the Grammatical Hierarchy of W1k-Mungkan (W1k-Munkan)'. In: Sutton, ed. 1976:284-98.

1976c The Sentence in Wik-Munkan: a Description of Propositional Relationships. PL, B-44. Canberra: Pac1fic Linguistics.

1977a 'Aborlg1nal World V1ew and Tense, Mood and Aspect In W1k-Munkan'. Workpapers in Papua New Guinea Languages 20:69-85.

1977b 'Prosodies in Some Aborlginal Languages'. Workpapers in Papua New Guinea Languages 20:91-100.

1977c 'What are Contrastive Syllables? The W1k-Munkan P1cture'. In: Hudson, ed. 1977:131-43. 
SAYERS, B.J. and N. PYM

1977 'Notes on Rhythmic Patterning in Iwaidja'. In: Hudson, ed. 1977:97-130.

SCHEBECK, B .

1968 Soclal and Dialectal Differences in North-east Arnhem Land. Paris.

1970 Dialect and Soclal Groupings in North-east Arnhem Land. Typescript. (Copy held at Australian Institute of Aboriginal Studies.)

1972 Les systèmes phonologiques des langues Australiennes. Doctoral thesis, Paris. (M1crofilm copy held at Australian Institute of Aboriginal Studies Library.)

1973 The Adnjamathanha Personal Pronoun and the "Wa1lp1 Kinship System"'. Papers in Australian Linguistics No. 6:1-45. PL, A-36. Canberra: Pacific Linguistics.

1974 Texts on the Social system of the Atyn $y_{\text {amatana People. }}$ with Grammatical Notes. PL, D-2l. Canberra: Pacific Linguistics.

1976a 'Thangu and Atfnjamathanha'. In: Dixon, ed. 1976: 516-50 (Topic D).

1976b 'Yuulngu'. In: Dixon, ed. 1976:352-82 (Top1c B).

SCHERER, P.A.

1974- The Diar1 by J.G. Reuther. (Includes a Diarl dictionary, derivation and meaning of Aboriginal names, Diarl myths and legends, description of toas with associated stories.) Copy held at Australian Institute of Aboriginal Studies (restricted).

SCHMIDT, w.

1919 Die Gliederung der australischen Sprachen (Vienna).

(1972) English translation by D. Clark 1972. Australian Institute of Aboriginal Studies typescript. 
SEBEOK, T.A., ed.

1971 Current Trends in Linguistics, vol.8: Linguistics in Oceania. The Hague: Mouton.

1973 Current Trends in Linguistics, vol.11: Linguistics in Oceania. The Hague: Mouton.

SEE, R.E.

1976 Comparison of Some Australian Languages. Ann Arbor, Michigan: University Microfilms International.

SHARPE, M.C. (see also CUNNINGHAM)

1970a 'Alawa Case Relationships'. In: Laycock, ed. 1970: 39-50.

1970b Cognitive Studies with Aboriginal Subjects. Linguistic Field Report No. 17 presented at Australian Institute of Aboriginal Studies General MeetinE, May 1970. 5pp.

1970c 'Vo1ce Qual1ty: a Suggested Framework for Description and Some Observations'. In: Wurm and Laycock, eds 1970:115-34.

1972 Alawa Phonology and Grammar. AAS 37, L15. Canberra: Australian Institute of Aboriginal Studies.

1974 'Notes on the "Pidgin English" Creole of Roper River'. Australian Institute of Aboriginal Studies Newsletter n.s. 2:2-12.

1975

'Notes on the "Pidgin English" Creole of Roper River'. Linguistic Communications 13:38-60. Also published in: Papers in Australian Linguistics No. 8:1-20. PL, A-39. Canberra: Pacific Linguistics.

1976a 'Alawa'. In: Dixon, ed. 1976:257-63 (Top1c A); 505-15 (Top1c D).

1976b 'Alawa, Mara and Warndarang'. In: Dixon, ed. 1976:708-34 (Top1c E). 
1976c 'Roper Creole Dictionary with English and Alawa'. (Draft of Roper Creole section of Alawa dictionary [in process].)

1977 'Alice Springs Aboriginal English'. In: Brumby and Vászoly1, eds 1977:45-50.

1978 'Report on a Research Project on Alice Springs Aboriginal Children's English'. A.I.A.S. Newsletter n.s. $9: 57-61$.

1979 'Alice Springs Aboriginal Children's English'. (In this volume.)

SHARPE, M.C. and J. SANDEFUR

1976 The Creole Language of the Katherine and Roper River Areas, Northern Territory'. In: Clyne, ed. 1976:63-77.

SHEPPARD, N.

1975 Alitjinya ngura tjukurtjarangka: Alitji in the Dreamtime; Adapted and Translated from Lewis Carroll's Story Alice's Adventures in Wonderland. Adela1de: Department of Adult Education, University of Adela1de.

SHOPEN, T., ed.

forth- Languages and Their Speakers. Cambridge: Winthrop.

SILVERSTEIN, M.

1976 'Hierarchy of Features and Ergativity'. In:

Dixon, ed. 1976:112-71.

SIMPSON, B., A. SIMPSON and V. LEEDING

1973 The Phonology of the Western Torres Stra1t Language (Mabulag Dialect). Typescript.

SOMMER, B.A.

1969 Kunjen Phonology: Synchronic and Diachronic. PL, B-ll. Canberra: Pacific Linguistics.

1972 Kunjen Syntax: a Generative View. AAS 45, L19. Canberra: Australian Institute of Aboriginal Studies. 
1974

'Aboriginal Non-standard English'. English in Australia 26:39-46.

1976a 'Agent and Instrument in Central Cape York Peninsula'. In: Sutton, ed. 1976:144-50.

1976b 'A Problem of Methathes1s'. In: Sutton, ed. 1976:139-43.

1976c 'Ogh Unjdjan'. In: Dixon, ed. 1976:425-6 (Topic C).

1976d 'Sociolinguistic Issues in Australian Language Research: a Review'. In: Clyne, ed. 1976:229-44.

1976e 'Umbuygamu: the Classification of a Cape York Peninsula Language'. Papers in Australian Linguistics No. 10:13-31. PL, A-47. Canberra: Pac1f1c Linguistics.

1976 'W.E. Roth's Peninsula Vocabularies'. In:

Sutton, ed. 1976:127-38.

SOMMER, B.A. and J. MARSH

1969 'Vernacular and English: Language Comprehension by some North Queensland Aborigines'. Anthropological Linguistics 11/2:48-57.

SOMMER, B.A. and J. TAYLOR

1973 Linguistic Evidence for Tribal Movement in South Western Cape York Peninsula. MS.

SORAVIA, G.

1975

'Father Angelo Confalonieri's Manuscript in

Jiwadja in Propaganda Fide Archive, Rome'.

Istituto Orientale di Napoli Annali 35

(n.s. 25):377-99.

SOUTH, T.R.

1971/2 'Giyam': A Review of Queensland Aboriginal Linguistics

1770-1963. B.A. Hons thesis, University of Queensland.

STEFFENSEN, M.

1975 Bamy1l1 Creole. Department of English, 
University of Wisconsin-Madison mimeo.

STEINBERG, D.D. and L.A. JAKOBOVITS, eds

1971 Semantics: an Interdisciplinary Reader in Philosophy, Linguistics and Psychology. Cambridge: Cambridge University Press.

STOKES, J .

1971 Anindilyaugwa Discourses and Paragraphs. Typescript. Northern Territory, Australia: Church Mission Society.

1977 'Anindilyakwa Ayakwa'. BHP Journal 1:12-17.

STOKOE, W.C., D.C. CASTERLINE and C.G. CRONEBERG

1976 A Dictionary of American Sign Language on Linguistic Principles. New edition. Silver Spring, MD:

Linstok Press.

STREHLOW, T.G.H.

1971 Songs of Central Australia. Sydney: Angus and Robertson.

SUTTON, P.J.

1973 Gugu-Badhun and 1ts Nelghbours. M.A. thesis, Macquarie University, Sydney.

1975a Australian Language Names. Australian Institute of Aboriginal Studies typescript.

1975b 'Cape Barren English'. Linguistic Communications $13: 61-97$.

1976a 'The Diversity of Inftial Dropping Languages in Southern Cape York'. In: Sutton, ed. 1976:102-23.

1976b 'Gugu-Badhun and the Flinders Island Language'. In: Dixon, ed. 1976:225-9 (Top1c A).

1976c 'The "having" Affix and Other Morphemes in Fifty Australian Languages'. In: Dixon, ed. 1976: 297-305 (Topic A). 
1976d Linguist1c Aspects of Ethnobotanical Research. Typescript. 18pp.

1976e 'A Note on Cape York Laminals'. In: Sutton, ed. $1976: 124-6$.

1978

W1k: Aborlginal Soclety, Territory and Language at Cape Keerweer, North Austral1a. Ph.D. thes1s, University of Queensland.

1979 'Australian Language Names'. (In this volume.)

SUTTON, P.J., ed.

1976 Languages of Cape York. AAS, RRS 6. Canberra: Australian Institute of Aboriginal Studies.

SUTTON, P.J. and B. RIGSBY

1979 'Linguist1c Communities and Soc1al Networks on Cape York Peninsula'. (In this volume.)

TAYLOR, P. and J. TAYLOR

1971 'A Tentative Statement of Kitja Phonology'.

Papers on the Languages of Australian Aboriginals: 100-19. AAS 38, L16. Canberra: Australian Institute of Aboriginal Studies.

TAYLOR, P. and J. HUDSON (w1th comment by W.H. Douglas)

1976 'Metamorphosis and Process in Kitja'. Talanya $3: 25-36,37-43$.

TEASDALE, G.R.

1972 Psycholinguistic Abilities and Early Experience:

A Study of Children from Different Ethnic and Socio-Economic Backgrounds. Ph.D. thesis, University of New England, Armidale.

THOMPSON, D.A.

1973 A Preliminary Grammar of Kuuku Ya?u. MS. 55pp. 
1976a 'Kuuku Ya?u'. In: D1xon, ed. 1976:208-11 (Top1c A); 329-31 (Top1C B); 450-2 (Top1C C).

1976b 'A Phonology of Kuuku-Ya?u'. In: Sutton, ed. $1976: 213-35$.

TINDALE, N.B.

1974 Aboriginal Tribes of Australia. Berkeley: University of California Press; Canberra: Australian National University Press.

1976 Map of Tribal Areas of Australia. (4 sheets each 838 x 990mm [33" x 39"].) Canberra: Australian Institute of Aboriginal Studies.

TREFRY， D.

1970 'The Phonological Word In Dier1'. In: Laycock, ed. $1970: 65-73$.

1974 The Theory of Segmental Phonology and 1ts Application to Dier1. Ph.D. thesis, Macquarle University, Sydney.

TREFRY， J .

1971 'Possible Clause Types in Muruwar1'. Papers on the Languages of Australian Aboriginals:93-9. AAS 38, L16. Canberra: Australian Institute of Aboriginal Studies.

TRYON, D.T.

1968 'The Daly River Languages: A Survey'. Papers in Australian Linguistics No. 3:21-46. PL, A-14. Canberra: Pacific Linguistics.

1970a 'The Daly Language Fam1ly: A Structural Survey'. In: Laycock, ed. 1970:51-7.

1970b An Introduction to Maranungku (Northern Australia). $P L, B-15$. Canberra: Pacific Linguistics.

1970c Noun Classification and Concord in the Daly River Languages'. Mankind 7:218-22. 
1971a 'Linguistic Evidence and Aboriginal Origins'.

In: Mulvaney and Golson, eds 1971:344-55.

1971b 'The Wageman Language'. Papers on the Languages of Australian Aborigines:1-11. AAS 38, L16. Canberra: Australian Institute of Aboriginal Studies.

1974 Daly Family Languages, Australia. PL, C-32. Canberra: Pacific Linguistics.

1976a 'Bilingual Education of Aborigines in the Northern Territory of Australia'. In: Clyne, ed. 1976:215-28.

1976b 'The Daly Fam1ly'. In: Dixon, ed. 1976:673-91 (Top1c E). TSUNODA, T.

1974a A Grammar of the Warupu Language, North Queensland. M.A. thes1s, Monash University (3 vols).

$1974 \mathrm{~b}$ 'A Note on Volce in Warungu'. In: Blake, ed. $1974: 120-5$.

1975 'Gal1 Constructions and Volce Expressions in Warupu'. Gengo Kenkyu 69:58-75.

1976 'Warungu'. In: Dixon, ed. 1976:214-25 (Topic A); 456-64 (Topic C).

1978 The DJaru Language of Kimberley, Western Australia. Ph.D. thesis, Monash University.

TURNER, D.H.

1974 Tradition and Transformation: a Study of the Groote

Eylandt Area Aborigines of Northern Australia.

(W1th accompanying cassette or 5" tape.) AAS 53, SA 8. Canberra: Australian Institute of Aboriginal Studies.

TURTLE, N.

1977 'Alyawarra Phonology'. In: Hudson, ed. 1977:1-56. 


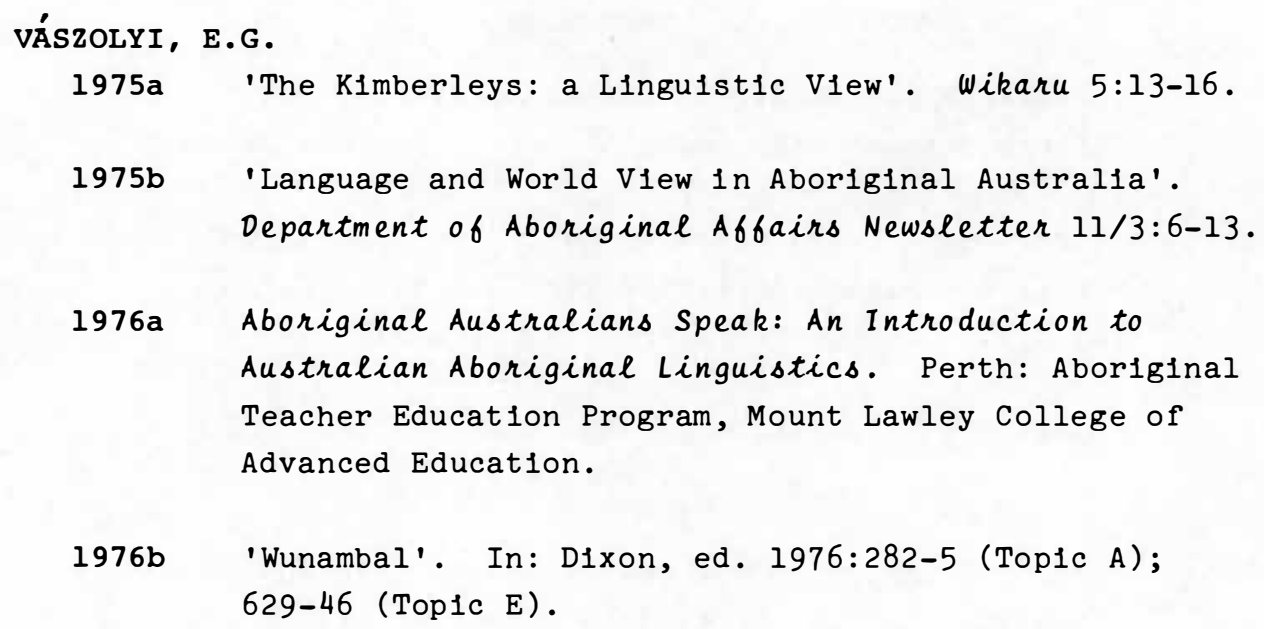

WALSH, M.J.

1976a 'Murinfpata'. In: Dixon, ed. 1976:287-90 (Topic A);

405-8 (Topic B); 441-4 (Topic C).

1976b The Murinypata Language of North-West Australia.

Ph.D. thesis, Australian National University, Canberra.

1979 'Recent Research in Australian Linguistics'.

(In this volume.)

WALSH, M.J. and Lois CARRINGTON

1979 'An Australian Linguistic Bibliography - from Greenway to the Late Sixties'. (In this volume.)

WHITE, N.G.

1976 'A Preliminary Account of the Correspondence Among Genetic, Linguistic, Social and Topographic Divisions In Arnhem Land, Austral1a'. Mankind 10:240-7.

WILLIAMS, C.J.

1976 Yuwaaliyaay and Yuwaalaraay Dialects of North-Central N.S.W. B.A. (Hons.) subthesis, Australian National University, Canberra.

WORDICK, F.J.

to appear [a description of Yinydyibarnrd1]

WRIGHT, C.

forth- [Warrabri Warlpir1 Sign Language Dictionary]

coming Darwin: Department of Education. 
WURM, S.A.

1967 Linguistic Fieldwork Methods in Australia. M3.

Canberra: Australian Institute of Aboriginal Studies.

1969 'Person Marker Sequences in Australian Languages'.

Papers in Australian Linguistics No. 4:51-70.

$P L, A-17$. Canberra: Pacific Linguistics.

1970a 'Linguistic Classification and the Prehistory of Australia'. In: Laycock, ed. 1970:7-25.

1970b 'Recent Progress in New Guinea and Australian Linguistics'. In: Actes de Xe Congres International des Linguistes. Bucarest 1967, 339-42. Bucarest: Editions de l'Académie de la Republique Socialiste de Roumanie.

1971 'Classification of Australian Languages, Including Tasmanian'. In: Sebeok, ed. 1971:721-78.

1972a Languages of Australia and Tasmania. The Hague: Mouton.

1972b 'Linguistic Research in Austral1a, New Guinea, and Ocean1a'. Linguistics 87:87-107.

1972c 'Torres Stra1t - a Linguistic Barrier?'. In:

D. Walker, ed. Bridge and Barrier: the Natural and Cultural History of Torres Strait, 345-66.

Canberra: Australian National University Press.

1973 'What the Languages Reveal of our History'. In:

R. Crocombe and S. Latukefu, eds 1973: An Introduction to the History of the Pacific. London: Longmans Green.

1975a 'Australian Aboriginal Languages'. In: Encyclopaedia Britannica 15th edition, vol.2:430-1.

1975b 'Possible Wider Connections of Papuan Languages: Papuan and Australian; Greenberg's Indo-Pacific Hypothes1s'. In: Wurm, ed. 1975:925-32. 
1975c 'Possible Wider Connections of Papuan Languages: Torres Stra1t and North Australia'. In: Wurm, ed. 1975:915-24.

1976 'Accusative Marking in Duung1djawu (Waga-Waga)'. In: Dixon, ed. 1976:106-11.

WURM, S.A., ed.

1975 New Guinea Languages and Language Study, vol.1:

Papuan Languages and the New Guinea Linguistic Scene.

$P L, C-38$. Canberra: Pacific Linguistics.

1979 Australian Linguistic Studies. PL, C-54. Canberra: Pacific Linguistics.

WURM, S.A. and L. HERCUS

1976 'Tense-Marking in Gunu Pronouns'. Papers in Australian Linguistics No. 10:33-55. PL, A-47. Canberra: Pacific Linguistics.

WURM, S.A. and D.C. LAYCOCK, eds

1970 Pacific Linguistic Studies in Honour of Arthur capell. $P L, C-13$. Canberra: Pacific Linguistics.

YALLOP, C.

1969 'The Alfawara and their Territory'. Oceania 39/3:187-97.

1975 The Narinjari Language 1864-1964. Sydney: Oceania Linguistic Monographs 17 (Part I).

1976 'Phonology and Orthography'. Linguistic Communications 16:1-9.

1977 Alyawarra. An Aboriginal Language of Central Australia. AAS, RRS 10. Canberra: Australian Institute of Aboriginal Studies.

n.d. Alyawarra. An Introduction to the Language. (For Use in course 07361.) Macquarle University, Sydney. 
ZWAAN, J.D. de

1969a An Analysis of the Gogo-Yimidjir Language. Ph.D. thesis, University of Queensland.

1969b A Preliminary Analysis of Gogo-yimidjir. AAS 16, L5. Canberra: Australian Institute of Aboriginal Studies.

1969c 'Two Studies in Gogo-Yimidfir'. Oceania 39/3:198-217. 


\title{
AN AUSTRALIAN LINGUISTIC BIBLIOGRAPHY - FROM GREENWAY TO THE LATE SIXTIES
}

\author{
M.J. Walsh and Lois Carrington
}

This bibliography is not intended to be a critical review of material on Australian linguistics published (or presented) during the period c.1959 to c.1967, but merely a checklist to bridge the gap between what may be found in John Greenway's Bibliography of the Australian Aborigines and the Native Peoples of Torres Strait to 1959 and the bibliography given in the preceding paper in this volume, Michael Walsh's 'Recent Research in Australian Linguistics'.

We have not included manuscript materlal lodged with the Australian Institute of Aboriginal Studies (or, Indeed, elsewhere) between those years, much of which has subsequently been published in revised forms.

\section{AUSTRALIAN INSTITUTE OF ABORIGINAL STUDIES}

1965 Linguistic Materials for Fieldworkers in Australia. M 1. Canberra: Australian Institute of Aboriginal Studies.

BRANDENSTEIN, C.G. VON

1965 'Ein Abessiv im Gemein-Australischen'. Anthropos $60: 646-62$.

1967 The Language Situation in the P1lbara - Past and Present'. Papers in Australian Linguistics 2. PL, A-11:1-20a, + maps. Canberra: Pacific Linguistics.

1968 Some New Aspects of Australian Aboriginal Language Based on Fleldwork in North-west Austral1a, 1964-1967. Perth. Mimeo. 44pp. 
CAPELL, A.

1960

'Language and World Vlew in the Northern K1mberley, Western Australla'. Southwestern Journal of Anthropology 16:1-14.

1960 'Myths and Tales of the Nunggubuyu, S.E. Arnhem Land'. Oceania $31: 31-62$.

1960 'The Wandarang and Other Tribal Myths of the Yabuduruwa R1tual'. Oceania 30:206-24.

1961 The Development of Language in Austral1a. Paper presented at ANZAAS Conference, Brisbane.

1962 'Language and Soc1al Distinction In Aboriginal Austral1a'. Mankind 5/12:514-21.

1962 'Linguistic Research Needed In Austral1a'. Bulletin of the International Committee on urgent Anthropological and Ethnological Research 5:23-8.

1962 A New Approach to Australian Linguistics. 2nd edn (1st edn 1956). Oceania Linguistic Monographs 1. 1966 - 3rd 1mpression (= 1962 edn).

1962 Some Linguistic Types in Australia. Oceania Linguistic Monographs 7 .

1963 'Commentary on "Aboriginal Languages" by S.A. Wurm'. In: Shiels, ed. 1963:149-58.

1963 Linguistic Survey of Australia. Sydney: [prepared for the] Australian Institute of Aboriginal Studies.

1964 'Linguist1c Research in Austral1a'. PL, D-1:4-6. Canberra: Pac1fic Linguistics.

1965 'Early Indonesian Contacts with North Austral1a'. Journal of the Oriental Society of Australia $3: 67-75$. 
1965 'Language in Aboriginal Australia'. In:

R.M. and C.H. Berndt, eds Aboriginal Man in

Australia: Essays in Honour of A.P. Elkin, 101-18. Sydney: Angus and Robertson.

1965 'A Typology of Concept Domination'.

Lingua 15:451-62.

1967 The Analysis of Complex Verbal Forms with Special

Reference to Tiw1 (Bathurst and Melville Islands, North Austral1a)'. Papers in Australian Linguistics 2. PL, A-11:43-62. Canberra: Pacific Linguistics.

1967 'Pronominalisation in Australian Languages'. PL, A-11:21-41.

1967 'Sound Systems in Austral1a'. Phonetica 16:85-110.

COATE, H.H.J.

1966 The Ra1 and the Third Eye: North-west Australian Bellef's'. Oceania 37:93-123.

COURT, C.

1963 Notes on Gam1lraay, Yugambal, Nganfaywana, Gumbaynggir, DJangad1, U.N.E.M. MS.

(Copy held in Australian Institute of Aboriginal Studies, Canberra.)

CUNNINGHAM, M.C. (SHARPE)

1968 Wangkumara Data. Typescript. Brisbane. Ilpp.

DIXON, R.M.W.

1965 'Mbabaram Phonology'. Transactions of the

Philological Society (Oxford) 1965:41-96.

1966 'Mbabaram: A Dying Australian Language'. Bulletin of the School of Oriental and African Studies 29:97-121.

1968 The Dyirbal Language of North Queensland. Ph.D. thesis, University of London. 
DOUGIAS, W.H.

1958 An Introduction to the Western Desert Language... Oceania Linguistic Monographs 4. (2nd edn 1964.)

1959 Illustrated Topical Dictionary of the Western Desert Language, Warburton Ranges Dialect, Western Australia. Perth: United Aborigines' Mission - Language Department.

1961 'The Vernacular Approach to the Australian Aborigines'. Practical Anthropology 8/2:63-70.

1963 'Blble Translating in Australla'. The Bible Translator $13: 171-6$.

DUTTON, T.E.

1964 Some Aspects of Palm Island Aboriginal English. Paper presented to the First Conference of the Linguistic Circle of Canberra, 21 May 1964.

1964 Some Phonological Aspects of Palm Island Aboriginal English: a Study of the Free Conversational Speech of Four Aboriginal Children at Palm Island Aboriginal Settlement in North Queensland. M.A. Qual. dissertation, University of Queensland.

1965 The Informal English Speech of Palm Island Aboriginal Children. M.A. thesis, University of Queensland.

ELKIN, A.P.

1963 'Aboriginal Languages and Assimilation'. Oceania $34: 147-54$.

GEYTENBEEK, B.B.

1964 'Morphology of the Regular Verbs of Gidabul'.

In: P1ttman and Kerr, eds 1964:101-8.

GEYTENBEEK, H.

1964 'Personal Pronouns of Gidabul'. In: P1ttman and Kerr, eds 1964:91-100. 
GLASGOW, D .

1966 Notes on the Burera Sound System (North Arnhem

Coast). Darwin: Education Section of the

Welfare Branch, Northern Territory Administration.

GLASGOW, D. and K. GLASGOW

1967 'The Phonemes of Burera'. Papers in Australian

Linguistics 1. PL, A-10:1-14. Canberra:

Pacific Linguistics.

GLASGOW, D. and H.B. KERR

1964 'Burera Verb Prefixes'. In: Pittman and Kerr, eds 1964:119-28.

GLASGOW, $K$.

1964 'Four Principal Contrasts in Burera Personal

Pronouns'. In: P1ttman and Kerr, eds 1964:109-17.

1964 'Frame of Reference for Two Burera Tenses'.

In: P1ttman and Kerr, eds 1964:118.

GODFREY, M.

1964 'Tentative Outline Grammar of Wik-Munkan'.

In: Oates et al. 1964:57-78.

GODFREY, M. and H.B. KERR

1964 'Personal Pronouns in Wik-Munkan'. In: P1ttman and Kerr, eds 1964:13-34.

GREENWAY, $J$.

1963 Bibliography of the Australian Aborigines and the Native Peoples of Torres Strait to 1959.

Sydney: Angus and Robertson.

HALE, K.L.

1961 Towards a Genetic Classification of Australian

Languages. Paper presented to the $36 \mathrm{th}$ Annual

Meeting of the Linguistic Soclety of America.

1962 Internal Relationships in Arandic of Central

Australla'. In: Capell, Some Linguistic Types

in Australia, 171-83. 
1964 'Classification of Northern Paman Languages, Cape York Peninsula, Austral1a: A Research Report'. Oceanic Linguistics 3/2:248-65.

1965 'Australian Languages and Transformational Grammar'. Linguistics 16:32-41. [Examples from Lard11.]

1966 'Linngithig'. In: O'Grady, Voegelin and Voegelin, eds 1966:176-97.

1966 The Paman Group of the Pama-Nyungan Phylic Family'. In: O'Grady, Voegelin and Voegelin, $1966: 162-97$.

1967 'Some Productive Rules in Lardil (Mornington Island) Syntax'. PL, A-11:63-73. Canberra: Pac1f1c Linguistics.

1967 Case and Volce in Some Australian Languages. Paper presented to the ANZAAS Conference, Melbourne.

1967 Preliminary Remarks on Walb1r1 Grammar: I. Mimeo. Massachusetts Institute of Technology.

1968 'Review of Nyangumata Grammar, by Geoffrey N. O'Grady'. Language 44:174-81.

n.d. Sketch Grammar and Vocabulary of Warumungu. Unpublished fieldnotes.

HERCUS, L.A.

1965 'The Survival of Victorian Languages'. Mankind 6/5:201-6.

1966 'Notes on Some Victorian Aboriginal Names for Plants and Animals'. Victorian Naturalist 83/8:189-92.

1966 'Some Aspects of the Form and Use of the Trial Number in Victorian Languages and in Arabana'. Mankind 6/8:335-7. 


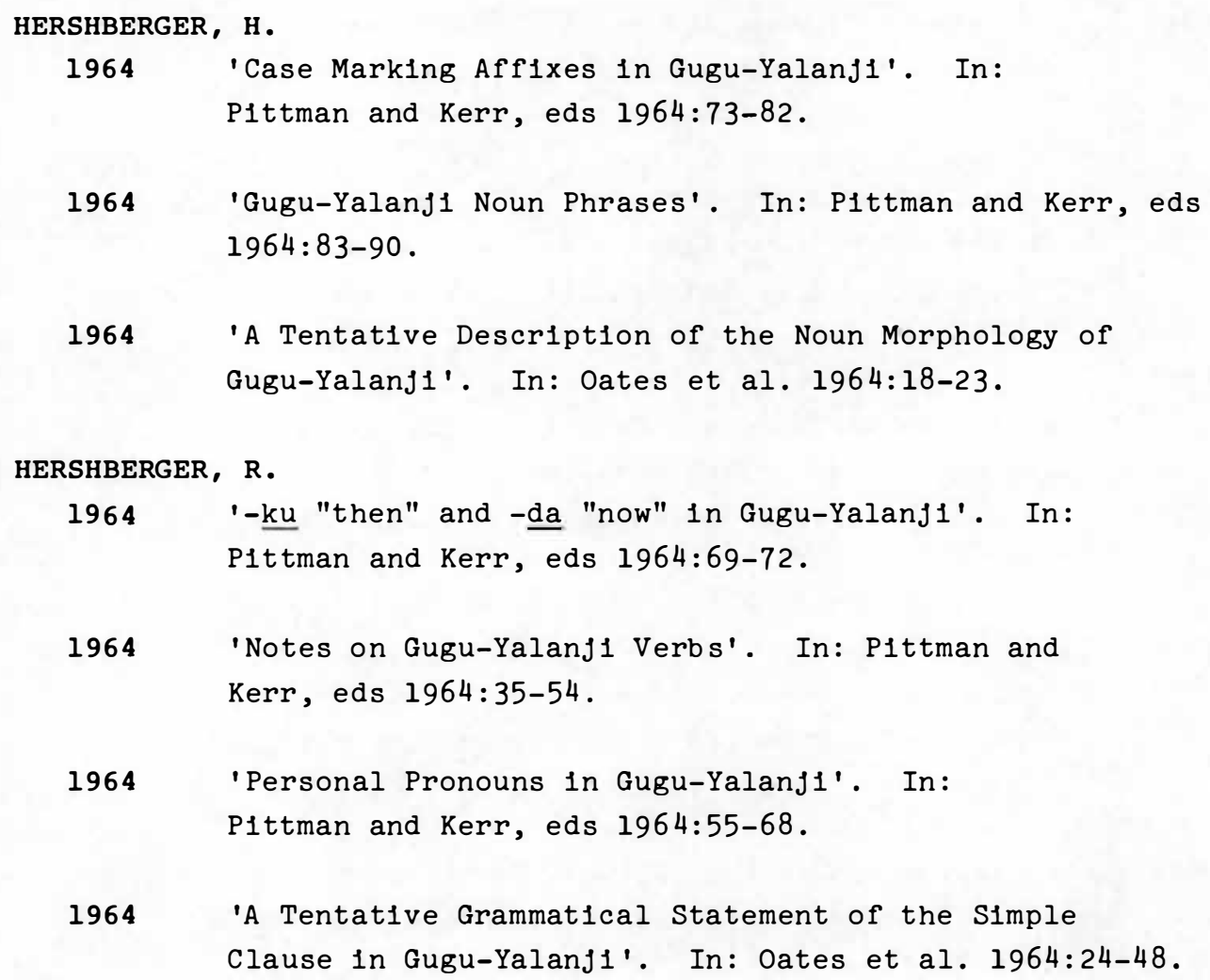

1964 'A Tentative Grammatical Statement of the Simple Clause in Gugu-Yalanf1'. In: Oates et al. 1964:24-48.

HINCH, H.E.

1964 'The Maung Personal Pronoun'. In: P1ttman and Kerr, eds 1964:129-38.

HODDINOTT, W.G.

1962 'Some Notes on the Aboriginal Languages of New England'. Journal and Proceedings, Armidale and District Historical Society 4:42-7.

1967 'The Ba:nbal Language of Northern New South Wales'. Oceania $38: 56-60$.

HOLMER, N.M.

1963 On the History and Structure of the Australian Languages. Australian Essays and Studies 3. Uppsala: Lundequist./Copenhagen: Munksgaard. 
1966

An Attempt Towards a Comparative Grammar of Two Australian Languages. AAS 5, L3, part 1.

Canberra: Australian Institute of Aboriginal Studies.

1966 Oceanic Semantics: A Study in the Framing of Concepts in the Native Languages of Australia and Oceania.

Australian Essays and Studies 5. Uppsala: Lundequist.

1967 An Attempt Towards a Comparative Grammar of Two

Australian Languages. Part II: Indices and

Vocabulary of Kattang and Thangatti. AAS 5, L3,

part 2. Canberra: Australian Inst1tute of

Aboriginal Studies.

KERR, H.B.

1964 'Comparison of Anyula Base Pronouns with Burera, Maung, and Wik-Munkan'. In: P1ttman and Kerr, eds 1964:149-50.

1964 'Specific and Generic Lexical Contrast in Pronominal Systems'. In: P1ttman and Kerr, eds 1964:157-66.

KILHAM, C.A.

1968 Terms Frequently used in the Description of the Grammatical Hierarchy. Berrimah, Northern Territory: Summer Institute of Linguistics. 111,56pp.

KIRTON, J.F.

1964 'Anyula Person[al] Pronouns'. In: P1ttman and Kerr, eds 1964:139-48.

1967 'Anyula Phonology'. PL, A-10:15-28. Canberra: Pacific Linguistics.

LANYON-ORGILL, P.A.

1961 'An Early Record of the Bulponara Language of Queensland'. Journal of Austronesian Studies (V1ctoria, B.C.) 2/2:51-53. 
LAYCOCK, D.C.

1960 'Language and Soclety: Twenty Years After'.

Lingua 9:16-29.

LUCICH, P.

1968 The Development of Omaha Kinship Terminologies

in Three Australian Aboriginal Tribes of the

Kimberley Division, Western Australia.

AAS 15, SA 2. Canberra: Australian Institute

of Aboriginal Studies.

MacDONALD, E.

1964 'Notes on the Noun Classes of Anyula'. In:

P1ttman and Kerr, eds 1964:151-6.

OATES, L.F.

1964 'Distribution of Phonemes and Syllables in

Gugu-Yalanj1'. Anthropological Linguistics

$6 / 1: 23-6$.

1964 A Tentative Description of the Gunwinggu Language.

Oceania Linguistic Monographs 10. University of

Sydney .

OATES, W.J.

1967 Ion the Naming of Australian Aboriginal Tribes'.

AIAS Newsletter 2/5:30-4.

1967 'Syllable Patterning and Phonetically Complex

Consonants in Some Australian Languages'.

PL, A-10:29-52. Canberra: Pac1fic Linguistics.

OATES, W.J. and L.F. OATES

1964 'Gugu-Yalanj1 Linguistic and Anthropological

Data'. In: Oates et al. 1964:1-17.

1964 'Gugu-Yalanf1 Vocabulary'. In: Oates et al.

1964:79-146. 
OATES, W.J. et al.

1964 Gugu-Yalanji and Wik-Munkan Language Studies. AAS 2, Ll. Canberra: Australian Institute of Aboriginal Studies.

O'GRADY, G.N.

1959 Significance of the Circumcision Boundary in Western Austral1a. B.A. thesis, University of Sydney .

1960 'More on Lexicostatistics'. Current Anthropology $1: 338-9$.

1960 'New Concepts in Nyanumada: Some Data on Linguist1c Acculturation'. Anthropological Linguistics 2/1:1-6.

1964 Nyangumata Grammar. Oceania Linguistic Monographs 9. University of Sydney.

1966 'Proto-Ngayarda Phonology'. Oceanic Linguistics $5 / 2: 71-130$.

O'GRADY, G.N., C.F. VOEGELIN AND F.M. VOEGELIN

1966 Languages of the world: Indo-Pacific Fascicle Six. Anthropological Linguistics $8 / 2$.

O'GRADY, G.N., S.A. WURM AND K.L. HALE

1966 Aboriginal Languages of Australia la Preliminary classification). Map, drawn by Robert M. Watt. Victoria, B.C.: Department of Linguistics, University of Victoria.

PITTMAN, R.S. and H.B. KERR

1964 Papers on the Languages of the Australian Aborigines. AAS 3, L2. Canberra: Australian Institute of Aboriginal Studies.

PLATT, J.T.

1967 'The Kukata-Kukatja Distinction'. Oceania $38: 61-4$. 
RAMSON, W.S.

1964 'Aboriginal Words in Early Australian English'. Southerly 24/1:50-60.

1964 The Currency of Aboriginal words in Australian

English. Occaslonal Paper No. 3. Sydney:

The University of Sydney Australian Language Research Centrè.

1966 Australian English: An Historical Study of the Vocabulary, 1788-1898. Canberra: Australian National University Press.

RYAN, J.S.

1963 Papers on Australian Place Names. Armidale:

Department of University Extension, University of New England.

1964 The Land of Ulitarra: Early Records of the Aborigines of the Mid-North Coast of New South wales. Grafton: Mid-North Coast Regional Office, University of New England.

1964 'Plotting an Isogloss - the Location and Types of Aboriginal Names for Native Dog in New South Wales'. Oceania 35:111-23.

SAYERS, B.J.

1964 'The Phonemes of Coen Wik-Munkan'. In: Oates et al. $1964: 51-6$.

SAYERS, B.J. and M. GODFREY

1964 'Outline Description of the Alphabet and Grammar of a Dialect of Wik-Munkan Spoken at Coen, Nth. Q'land'. In: Oates et al. 1964:49-50.

SAYERS, B.J. and H.B. KERR

1964 'Wik-Munkan Locative, Temporal and Demonstrative Pronouns'. In: P1ttman and Kerr, eds 1964:1-12. 
SCHÜRMANN, C.W.

1844 A Vocabulary of the Parnkalla Language Spoken by

(1962) the Natives...of Spencer's Gulf. [Adela1de:

George Dehane.] Public Library of South Australia:

South Australian Facsimile Editions 40, 1962.

SEE, R.E.

1965 Comparison of Some Australian Languages.

$\mathrm{Ph} . \mathrm{D}$. dissertation, University of California, Los Angeles.

SHARPE, M.C. (née CUNNINGHAM)

1969 A Description of the Yugumbir Dialect of Bandjalang. University of Queensland Papers, Faculty of Arts $1 / 8: 69-122$.

SHEILS, H, ed.

1963 Australian Aboriginal Studies. A symposium of papers presented at the 1961 research conference. (W.E.H. Stanner, Chalrman.) Melbourne: Oxford University Press, for Australian Institute of Aboriginal Studies.

SOMMER, B.A. and E.G. SOMMER

1967 'Kunjen Pronouns and Kinship'. Papers in Australian Linguistics 1. PL, A-10:53-9. Canberra:

Pacific Linguistics.

1968 Kunjen Wordlist. Computer printout. University of Hawa11.

STANNER, W.E.H. (see SHEILS, H., ed.)

TAPLIN, G., ed.

1967 The Folklore, Manners, Customs, and Languages of

the South Australian Aborigines... [Adela1de:

Government Printer, 1879.] New York: Johnson

Reprint Corp. 
VOEGELIN, C.F., F.M. VOEGELIN, S.A. WURM, G.N. O'GRADY and T. MATSUDA

1963 'Obtaining an Index of Phonological Differentiation from the Construction of Non-existent Minimax Systems'. International Journal of American Linguistics 29:4-28.

WEST, La Mont

1962 Alphabetical First Name Finder List for Linguistic Informants Contacted by West in Northeastern Australia 1960-62. MS. Canberra: Australian Institute of Aboriginal Studies.

1963 'Aboriginal Sign Language: a Statement'. In: She1ls, ed. 1963:159-65.

1964 Alphabetical First Name Finder List of Lockhart River Mission Residents and KIn. MS. Canberra: Australian Institute of Aboriginal Studies.

1964 Esoteric Dalabon Sketch Dictionary. Sydney: Typescript. 214pp. [Copy held at Australian Institute of Aboriginal Studies; restricted use.]

1965 Unpublished Field Tape Report Sheets. Canberra: Australian Institute of Aboriginal Studies.

WORMS, E.A.

1957 The Poetry of the Yaoro and Bad, North-western Austral1a. Annali del Pontifico Museo Missionario Etnologico gid Lateranensi 21:213-29.

1959 'Verbannungslied elnes australischen Wildbeuters: Ein Beltrag zur Lyrik der Bād. Anthropos $54: 154-68$.

1960 'Tasmanian Mythological Terms'. Anthropos 55:1-16.

WORSLEY, P.

1961 The Utilization of Natural Food Resources by an Australian Aboriginal Tribe'. Acta Ethnographica Academiae Scientarum Hungaricae 10:153-190. 
WURM, S.A.

'The Question of Aboriginal Place Names in Australla'. Cartography 3/3:134-9.

1961 'Australian Languages'. Grolier Encyclopedia. New York.

1961 'Tasmanian Languages'. Grolier Encyclopedia. New York.

1963 'Aboriginal Languages: the Present State of Knowledge'. In: Shells, ed. 1963:127-48.

1963 Some Remarks on the Role of Language in the Assimilation of Australian Aborigines. PL, A-1. Canberra: Pacific Linguistics.

1964 'Aboriginal Languages and the Law'. University of western Australia Annual Law Review, 1-10. Also published in The Australian Police Journal (1964) $18 / 4: 289-300$.

1964 The Present State of New Guinea (non-Melanesian or Papuan) and Australian H1storical and Comparative Linguistics'. Proceedings of the Ninth International Congress of Linguists, Cambridge, Mass. 1962, 575-9. The Hague: Mouton.

1965 'Recent Developments in Australian Linguistics'. Lingua 14:371-80. Also in: G.B. M1lner and E.J.A. Henderson, eds Indo-Pacific Linguistic Studies, Part I: Historical and Comparative Studies, 371-80. Amsterdam: North-Holland.

1967 'Pitch and Intensity Recording Devices for the Study of Australasian Languages'. Zeitschrift für Phonetik $20 / 3: 251-7$. 


\title{
AUSTRALIAN LANGUAGE NAMES
}

\author{
Peter Sutton
}

\section{SPELLING THE NAMES}

The names of Australian languages (and also 'tribes', etc.) have always been spelt rather impressionistically and inaccurately by most of those non-linguists who have written them down. Isolated scholars of the last century attempted to introduce some orderly system into the spelling of 'tribal' and language names in Australia. Roth and Mathews, for example, had worked out phonetic systems of orthography which were reasonably consistent and Mathews, in particular, was capable of quite accurate phonetic observation. However, the first major attempt to standardise the spelling of language names on a consistent basis for the whole continent was that by Tindale (1940, revised version 1974). Tindale used a script based on the International Phonetic Alphabet and attempted to record the names as he heard them spoken by Aborigines, where this was possible. His notations are not always accurate in the light of more intensive research, and he did not attempt to phonemicise spellings, but his work represented the next major advance in establishing a general picture of the distribution of Australian linguistic groups since Schmidt (1919) first collated all the available published sources. Tindale's revised map (1974) uses a spelling system known as 'Geographic II' which contains only the symbols found on a typewriter.

Capell's Linguistic Survey of Australia (1963), in which the languages were arranged in large groups worked out 'on ecological lines' by David Moore, then of the Australian Institute of Aboriginal Studies (AIAS), basically builds on the work of Tindale, supplemented by Information from Capell, La Mont West, Hale, O'Grady, Wurm and others. The orthography used in this book was designed to eliminate diacritics and non-typewriter symbols and standardise the representation of 
certain sounds. In particular, it standardised on a 'volced' stop inventory and used digraphs such as $d h, n h, i h$ (lamino-dentals), dj, $n j, i j$ (lamino-palatals), rd, rn, rl (aplco-domals), and $n g$ (velar nasal). The names as given in this inventory are still those forms used by the Blbliographical Section of the AIAS. Research carried out on Australian languages has expanded so much in recent years that Capell's Survey, which stimulated and directed a good deal of that research, is now very much out of date.

The revision of Capell's work by W.J. and Lynette F. Oates, A Revised Linguistic Survey of Australia (1970), attempted to update 1ts predecessor and give a more detalled assessment of the state of knowledge for each language or dialect, but was less rigorous in 1 ts re-spelling of established names. A wholesale revision was carried out by the Linguistics Advisory Committee of the AIAS in 1973 when 1t decided to establish an 'official' orthography for the representation of linguistic and 'tribal' names, as part of its attempt to create a systematic yearly survey of linguistic work in Australia. In 1974 this orthography was slightly modified to avold some confusions which had arisen, and to allow it more flexibility. Basically, the new orthography aims to be consistent, phonemic, and yet readable by the lay public. The symbols to be used (some languages require more than these) are:

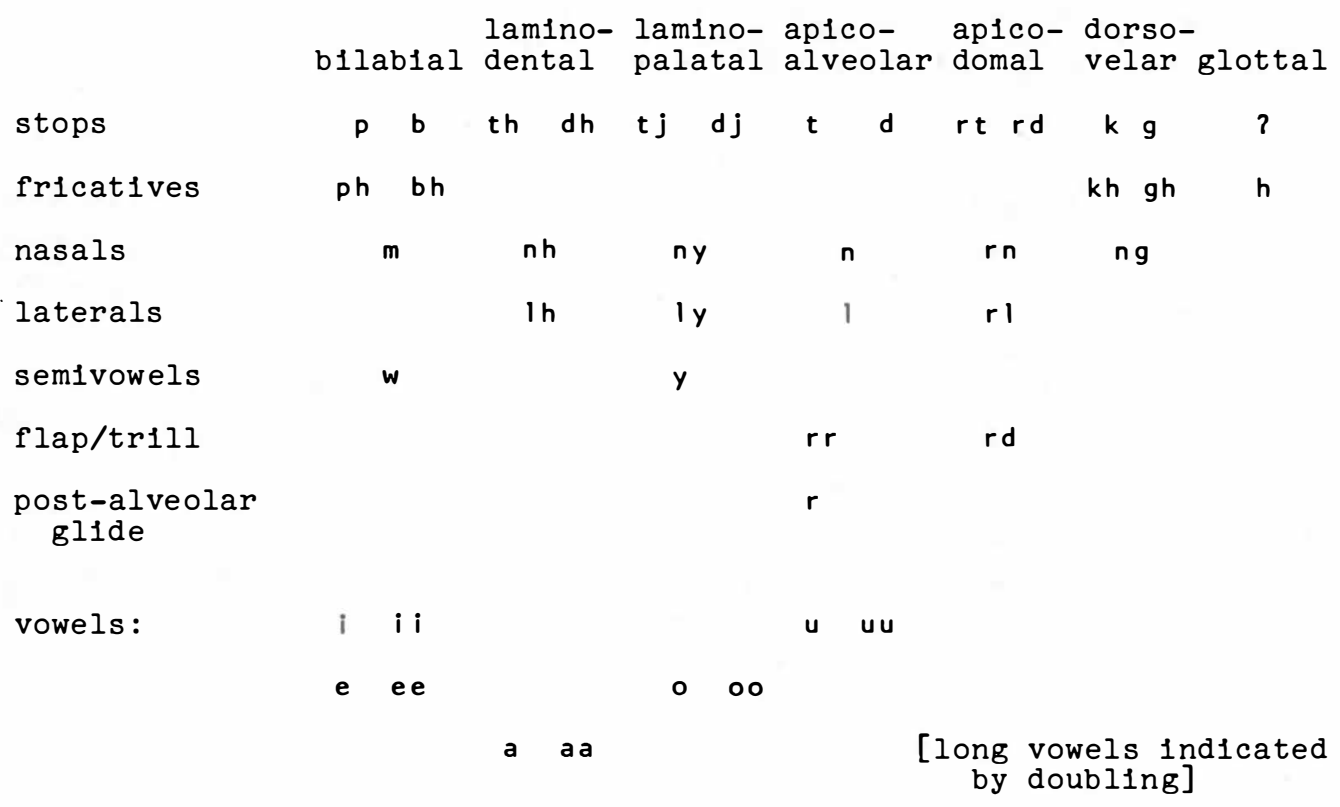


In some languages, the cholce between using the 'volced' series of stop symbols (b, dh, dj etc.) or the 'volceless' set ( $p, t h, t j$ etc.) may be somewhat arbitrary, since many Australian languages do not have a phonemic contrast between two such sets. In some languages, however, although there is no volcing contrast, the cholce is still not entirely arbitrary, since they may have as the most common allophones of stops the volceless, tense $p, t h, t j$ etc. as in Tiwi or Kuuku-Ya?u. H1storically speaking, where a 'volced-volceless' stop contrast has evolved in an Australian language, the voiced (etc.) series is normally innovative, whlle the contrasting voiceless (etc.) series is normally original.

\section{WHAT DO THE NAMES MEAN?}

Perhaps the greatest problem in this area has been not so much arriving at an accurate and standardised form of names as working out Just what such names refer to. Some lingulsts, for example K.L. Hale, have generally preferred to use established spellings, however inaccurate, simply as a recognisable label for a language. For instance, Hale refers to the language of Mornington Island, Queensland, as 'Lardi1' but gives the phonemic form of the name in brackets as /Re.til/ (and the initiation-language of the same people as 'Demin' $=/$ temi.n/). This practice has been especially favoured where a traditional spelling is well-known in published literature. However, the question of what language 'names' or labels actually refer to, and how they function in Aboriginal socleties, has in general been rather neglected. Schebeck's work on the Yuulngu dialects of north-east Arnhem Land (1968) has been a ploneering essay in this area. He attempted to set out the basis of the interrelationship between language and soclety for that particular culture. Lack of anthropological sophistication among linguists and lack of linguistic expertise among anthropologists can be partly blamed for the great gaps in knowledge of such interrelationship elsewhere in Australia. Linguists have not been forced to investigate these matters partly because the Aboriginal people with whom they work are no longer demographically distributed according to a traditional pattern (this prevents direct observation of residential groups ranging under traditional territorial and social restraints), and partly because unt1l recently western academic linguistic traditions have concentrated on the formal properties of languages, without very much regard for the intricate social networks of which they are a prominent element. It is unlikely that any reasonable model of 
linguistic change can be developed for Australia without detalled studies of the traditional role of language in Aboriginal social structuring and the functioning of communication networks. It is almost too late for knowledge of this type to be recovered from enough areas for a balanced picture of the Australian situation to be reconstructed. The two areas where work of this kind has been going on in recent years, the Western Desert and Arnhem Land, are not necessarily at all typlcal of the rest of Australia, and they certainly differ clearly from each other.

There has been little concentrated attention from anthropologists on the question of what is language? One of their greatest controversies has been over determining relationships between the composition of food-seeking or residential groups, totemic and/or lineal categorles of $\mathrm{kin}$, and other social structures. The domain of discourse often assumed by anthropologists is the 'tribe' or named dialectal/linguistic unit. It has not always been made clear what were such units (see for example Hiatt 1962), whether such named units were in fact dialectally different according to comparative linguistic criterla, nor what degree of geographical immobility characterised their members. There has in general been a fallure to keep Aboriginal dialect definitions distinct from those that might be made by a trained observer comparing the speechforms 'objectively'. There has also been a fallure to separate names which refer primarily to speech characteristics from names which refer primarily to other soclal characteristics or to some place, totemic story or whatever. Some so-called language names are in fact everyday phrases such as 'the speech of this place' and amount more to brief descriptions than to proper-name labels. Aboriginals recognise linguistic and dialectal similarities and differences but this should not be taken to imply that they always have set terms for what they consider distinct speechforms. Some languages, originally perhaps many, have no names. Many languages have several alternative names, and usually a different one used by each or several of the different linguistic communities in contact with them. Sometimes two grossly different dialects may be subsumed under a single term, while another two which differ by little more than a single common word may be distinguished by a reference to that word. A complicating factor, overriding all the above, is that perhaps all defining terms (such as language names, territorial group names, etc.) may have different meanings depending on their immediate context and function. It is not absurd, for example, to refer to one's language as 'belonging to my story' (1.e., the language is that used 
by members of one's totemic land-owning unit), and therefore a possible name for one's 'language' is the title of one's patriclan or 1ts owned sites or one of 1ts major totemic stories. The fact is that language, land (hence mythology) and human groups and categorles are inextricably interrelated in Aboriginal society, which is why the names of languages found in the literature are dominated by terms which, narrowly defined, often refer to primarlly dialect character1stics, places, totemic stories, human categories such as patriclans etc., while other terms may be single labels with no recoverable literal meaning which refer equally to a language and its traditional 'owners'. In some parts of Australia, some overt distinction is drawn between the term for a language and the term for 1 ts owners (at least theoret1cally speakers). Roth notes (1910:83): '... In the Calrns district, the Kungganf1 [Gunggandf1], Y1rkanf1 [Y1rgandf1] and Y1dinf1 [Y1dindf1] speak kungga1 [Gunggay], y1rka1 [Y1rgay] and y1d1 [Yidiny] respectively.'

These points can be 1llustrated:

Names referring to dialect characteristics:
Wemba-Wemba
a dialect with wemba for no
Beraba-Beraba
a dialect with beraba for no (mutually intelligible with Wemba-Wemba)
Biyaygir1
a dialect with biyay for no
Pitjantjatjara
a dialect with pitjantja for come
Kuku-Min1
literally good Zanguage (evaluative term)
Kuku-Wara
literally bad language (evaluative term)

Names referring to locations:

$\begin{array}{ll}\text { Rarmal } & \text { Morehead River } \\ \text { Gunggarl north }\end{array}$

Names referring to totemic stories:
Awu-Laya
(language) taipan snake
$\left.\begin{array}{l}\text { 'Koko-Geese' } \\ \text { Alwangara }\end{array}\right\}$
(language) goose
Kalkatungu
bandicoot + ablative (?) 
Names referring to human categorles:

Gububara

Ama Althanmungu

Aba Y11rrkuy1

Adnyamathanha leaf people

people from Althan

people owning Yiirrku

stone group
Properly these are patriclan names, but may be used as labels for languages.

Of course, there are also many names given for languages which cannot be translated or traced in this sort of way. For example, Bidjara, DJ1rbal, Umpila and many others.

Where a language lacks a name at all, it is common for place, patriclan or other names to be given instead. One problem with this is that the cholce of which place or clan to mention of ten depends on the personal connections of the speaker himself; this may lead to a number of so-called 'tribes' or languages appearing on a map where there was in fact only one language spoken. Scholars have sometimes had to 'invent' a name for a language (e.g., Tiwl, literally male person).

W.E. Roth, who was a brilliant fleld-worker in his time (see for example his analysis of naming practices in Australia [1910:81-3]), worked briefly in the Princess Charlotte Bay area in 1898, making some notes on the peoples whose country included Bathurst Head, the Flinders Island Group, Cape Melville and Barrow Polnt. Roth was usually careful to state the sources of his information, and did not attempt to go beyond immediate data to extravagant claims about social organisation. One must point out that many such claims are $1 \mathrm{mplic1t}$ in some of the discussions of Australian languages that have been indulged. In up to the present. We have tended to take for granted such unfustified notions as 'contiguous vs. non-contiguous' languages, as if the extent of land- and language-ownership claims were 1somorphic with population-distributions. We have also of ten assumed that the population claiming a particular language is somehow the primary gross unit of an Aboriginal society, and have tended to discuss these units (usually called 'tribes') rather than others when dealing with linguistic questions. Ownership of and access to land were related to structures such as patrilineages, and children normally claimed as their 'own' language that of their fathers. However, people did not normally range about in groups containing only those of the one patriclan, nor did they range about only on country to which they had a direct claim. Therefore while a patriclan is, according to typical Aboriginal theory, the primary linguistic unit, the 
residential group containing a fluctuating mixture of people from different lineages is, demographically, the primary linguistic unit. ${ }^{1}$ Whether or not one accepts my use here of the term 'primary', it is notable that proper names are given to dialectal or linguistic units at different levels of generality, and that it is normally the patriclan which is the domain of names of the least generality. This does not mean that patriclans necessarily are the smallest named dialectal units. To 1llustrate: there were about forty or more defined clan countries between the Annan River and Red Point (and going inland) on the Queensland coast in the Cooktown area. These clans are sald to have spoken a single language, referred to now as Guugu-Yimidhirr. At least some of the clan names are assoclated with discrete dialect names, and one of them with two such names ${ }^{2}$ :

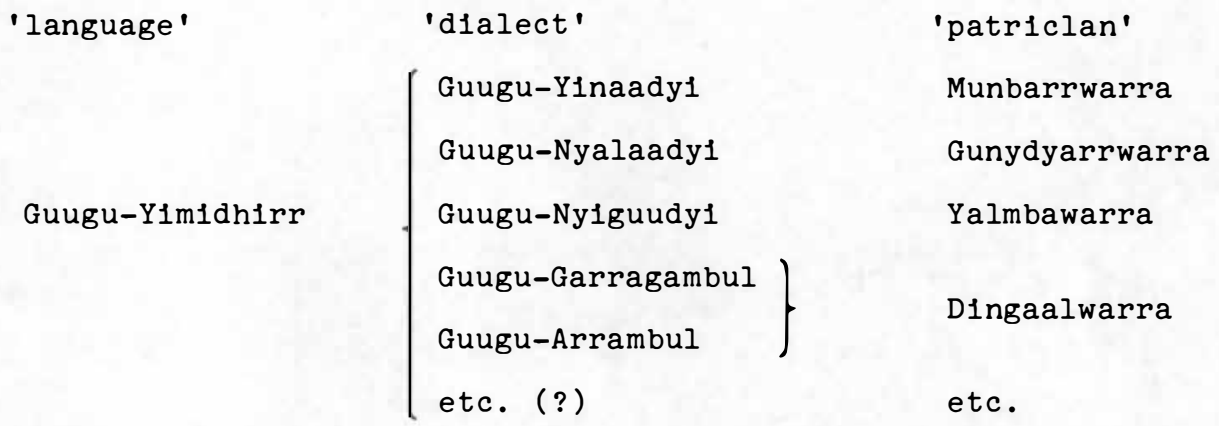

The last two lines of this list derive from Mr Flinders' comment that 'Dingaalwarra they half of them talk Guugu-Garragambul and half GuuguArrambul'.

Unless individual family groups or foraging groups can be shown to have separate dialectal labels, 1t seems that the domain of the least general labels is commonly the clan. A hierarchy of generality extends though the dialect name (covering more than one clan), the language name (covering a cluster of all the clans held to speak the same language), a 'nation' name (see below), and - at the most general level - a name with a very vague connotation, sometimes stretching of $f$ to infinity in one particular direction. Some of these labeliings are decidedly ethnocentric and their connotations subject to some amount of vagueness or at least negotiation and disagreement between discussants. Others have a more objective basis, more precision, and are less subject to dispute. These facts pose great problems for fleld-workers and it normally takes long familiarity with a particular community to gain a sophisticated grasp of the socio-linguistic terminology in use. 
In order to 1llustrate some of the pitfalls of trying to obtain reliable information on this type of nomenclature, I w1ll give a brief account of the history of attempts to name places, 'tribes' and 'languages' in one particular area where I am currently engaged in field research.

3. NOMENCLATURES IN THE LITERATURE DEALING WITH THE AREA BATHURST HEAD, FLINDERS GROUP, TO BARROW POINT (CAPE YORK PENINSULA) ${ }^{3}$

3.1. Roth, W.E.

\begin{tabular}{|c|c|c|}
\hline \multirow[t]{4}{*}{ a. $(1898)$} & yă 1 -ngă-bă-ră & $\begin{array}{l}\text { Refers to an inhabitant of yal-nga } \\
\text { (Cape Melville). }\end{array}$ \\
\hline & 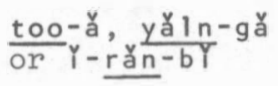 & Names for Cape Melville in Kokowara. \\
\hline & $\begin{array}{l}\bar{a}-p \not \check{l}-l i ̌ n \\
\underline{m o}-y \bar{e} r\end{array}$ & $\begin{array}{l}\text { Local name of Barrow Point. } \\
\text { Name of Barrow Point used by } \\
\text { Starcke River people. }\end{array}$ \\
\hline & $\begin{array}{l}\text { pâr- } \underline{c h a ̆ m-m o ̄-k a ̆ ~} \\
\text { mǒr-kǒn-dĕn }\end{array}$ & $\begin{array}{l}\text { Name of Barrow Polnt used by Kokowara. } \\
\text { Local name of Noble Island. }\end{array}$ \\
\hline \multirow[t]{3}{*}{ b. $(1910)$} & $\begin{array}{l}\text { Yalnga-bara } \\
\text { Yalnga } \\
\text { tu-a, yaln-ga } \\
\text { vel irán-bai }\end{array}$ & $\begin{array}{l}\text { Group of natives at Cape Melville. } \\
\text { Name of Cape Melville. } \\
\text { Names for Cape Melville In Kokowara. }\end{array}$ \\
\hline & $\begin{array}{l}\text { e-polin } \\
\text { apólín } \\
\text { aríng-u }\end{array}$ & $\begin{array}{l}\text { Local name of Barrow Point. } \\
\text { Name of Barrow Point used by Kokowara. } \\
\text { Name of Bathurst Head and Flinders } \\
\text { Group in Kokowara. }\end{array}$ \\
\hline & Koko-nego-di & $\begin{array}{l}\text { Term applied by the Cape Bedford } \\
\text { blacks to the people (and language) } \\
\text { along the coastline from Barrow } \\
\text { Polnt to Cape Melville. }\end{array}$ \\
\hline
\end{tabular}

3.2. Hale and Tindale (1933)

'tribes'

'languages '

Walmbaria 'clans'

(Wurelmu (on Flinders Group)

Tartal1 (on Bathurst Head) 4 


$\begin{array}{lll}\text { 'tribes' } & \text { 'languages' } & \text { 'clans' } \\ \text { Mutumu1 } & \text { Eibole } & \begin{array}{l}\text { Ongwara (Mack River) } \\ \text { Yinin1 (Cape Melville) } \\ \text { Eibole (Barrow Polnt) } \\ \text { Wurkuldi (Noble Island) } \\ {[\text { un-named] (Starcke River) }}\end{array}\end{array}$

[place-names omitted here]

3.3. Tindale, N.B.

a. (1940) ('tribes')
I : tu
( $I: t u)$
Noble Island and 1slands off Barrow Point
(data scant, possibly a horde of Mutumu1).
Alt: Wurkuldi (map has $I: t ̦ u$ ).
Walmbaria
(Walmbaria)
Flinders Island Group and extensive reefs
north of Princess Charlotte Bay; on the
mainland at Bathurst Head. Alt: Walmbar.
'Mutumu1, 'Baulam,
Bas $\theta$ om
From Bathurst Bay and Cape Melville south
(Mutumu1)
to Starcke River. Alt: Baulam
(Bakanamb1a term), Basthom (Bakanamb1a variation, ? Individual).

b. (1974) ('tribes') (Only noted where different from [1940] version.)

Ithu

Walmbar1a

Mutumu1

3.4. Capel1, A.

a. (1955)

Aj 1
(Map shows territory mainly comprising How Ick Group.)

Adds: 'visiting the mainland only at Bathurst Head and Cape Melville on sufference'. Alt: (adds:) Yalnga-bar (Yalnga $=$ Cape Melville).

Bathurst Bay and Cape Melville south to near Starcke River; at Barrow Point and Jeannie River. Name of language is E1bole, and there is a dialect called Ongwara in the north of the area; Karbungga (name, probably hordal, at Jeannie River), Ongwara (name of dialect, means northern taik), Jugalwatha, Mbambylmu (horde or subtribe at Jack River).

Given as name of language; (N.B.: this wordlist is in the Flinders Island language). 
b. (1963)

Ju'galwadha Language, country is Barrow Point, Cape
Melville and King Island (Information
from West).

3.5. West, L.M.

a. (1962)

Mbambitmu(pwa) (Used for people now known to speak rather different languages, Princess Charlotte Bay area.)

b. (1964)

Cape Melville (Used for reference to languages of various Lockhart residents.)

Flinders Island

"

$"$

"

Barrow Point

$"$

"

"

$n$

c. $(1965)$

Manpulmunu

(? language of Barrow Point area.)

3.6. Trezise, P.J.

a. (1969)

$\begin{array}{ll}\text { Gugu-Almura } & \text { Barrow Point tribe. } \\ \text { Woolcooldin } & \text { Local name of Noble Island. }\end{array}$

b. (1973)

(Repeats Dingo story published in [1969]; note the same story is further re-published under the name of Dick Roughsey [1973]; this story belongs to the Barrow Point area.)

3.7. Oates, W.J. and L.F., (1970)

Mentions a few names not found elsewhere: (I can't trace the sources).

Under Walmbaria: Alternatives:

Buruman

Flinders Group and reefs in Princess Charlotte Bay (= Walmbardha?).

sub-group:

Mug-Ngambaram (No location given.) 
3.8. Sutton, P.J., (1970)

Wurima

Gamb 1 lmugu

Almura
Flinders Island tribe.

Barrow Point tribe.

- Appears to be a dialect of Gugu Yimidyir with influence from a language with typical Peninsular loss of initial consonant.'

3.9. Dixon, R.M.W. (1972)

Bayalgay 1

Flinders Island language.

3.10. Sommer, B.A.

a. (1972)

$\begin{array}{ll}\text { Biyalgeyi } & \text { Language of Flinders Island. } \\ \text { Malthanmungu } & \text { Language of Barrow Polnt area. } \\ \text { Kambilmuku } & ?=\text { Mbambilmu. }\end{array}$

b. (1974)

$\begin{array}{ll}\text { AlmuRa } & \text { Barrow Point area. } \\ \text { Pipon Island } & \text { Language. } \\ \text { Mba wilaRnu } & \text { Mt Starcke area. } \\ \text { Mba rmbuRma } & \text { Cape Melville. }\end{array}$

3.11. Thompson, D. (1972)
Batalpirr 1
Bathurst Head tribe.
Bagart 1
Bathurst Bay tribe.
B1yargo1 ya
Cape Melville tribe.

4. INTERPRETATION OF SOURCES AS LISTED

4.1. $\operatorname{Roth}(1898,1910)$ :

$$
\begin{aligned}
& \text { Yalngabara (see variants in spelling) = Aba Yalgay1 (clan name) } \\
& \text { (F-I-speaking).6 } \\
& \text { e-polin, apollin = Ipulyin (name of Barrow Point). } \\
& \text { morkonden = wurrkulthin (name of Noble Island). } \\
& \text { Koko-negod1 = Guugu-Nylguudy1, a northern dialect of } \\
& \text { Guugu-Yimidhirr. }
\end{aligned}
$$


4.2 Hale and Tindale (1933):

\begin{tabular}{|c|c|}
\hline Wa $1 \mathrm{mbar} 1 \mathrm{a}$ & $\begin{aligned} &= \text { Term in Flinders Island language referring } \\
& \text { to 'nation' of Lama-Lamic and other speakers } \\
& \text { west from Marrett River to Stewart River. }\end{aligned}$ \\
\hline Mutumu1 & $\begin{array}{l}=\text { muthumuy (place-name) (In B-P-speaking } \\
\text { country). }\end{array}$ \\
\hline Yalgawara & $\begin{aligned}= & \text { Aba Yalgay } 1 \text { (alt. Yalgawarra) (clan name) } \\
& (F-I-\text { speaklng). }\end{aligned}$ \\
\hline Elbole (etc.) & $=1$ pulyin (name of Barrow Point). \\
\hline Wureimu & $=$ wurriyima (name of Flinders Island(s)). \\
\hline Tartal1 & $\begin{aligned}= & \text { thartali (name of beach area west of } \\
& \text { Bathurst Head, also used to refer to } \\
& \text { BH In total). }\end{aligned}$ \\
\hline Ongwara & $=$ ?ungkarra (literally north). \\
\hline Yinfn1 & $=$ ?Aba Thalp1rriy1 (clan name, BH). \\
\hline Wurkuld 1 & urrkulthin (name of Noble Island \\
\hline
\end{tabular}

4.3. Tindale $(1940,1974)$ :
I : thu
$=$ Y1Idhu, term in Guugu-Yimidhirr for the F-I and Barrow Polnt-speaking peoples.
Mbamby lmu
= Lama-Lamic term for a clan, possibly Ama Aampilmungu (B-P-speaking) (the term comes from West qv.).

4.4. Cape11 (1955):

Aj1 = Possibly ay1, vegetable food (F-I).

4.5. West $(1962,1965)$ :

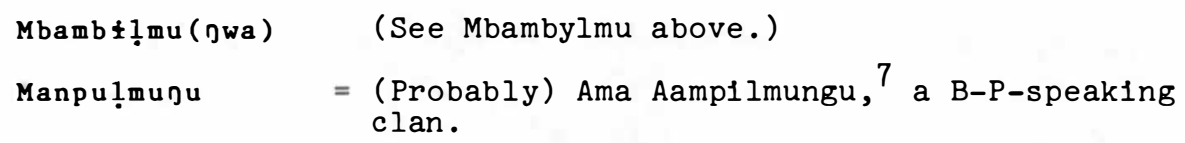

4.6. Trezise $(1969,1973)$ :

$\begin{aligned} \text { Gugu-Almura }= & \text { Local pidgin: 'Kuku' (speech), plus } \\ & \text { Almura, probably a place-name, forms } \\ & \text { basis of clan name, properly Ama } \\ & \text { Almurangu (B-P-speaking). } \\ \text { Woolcooldin }= & \text { wurrkulthin (name of Noble Island). }\end{aligned}$


4.7. Oates (1970):

Buruman

Wa lmbardha
$=$ (Possibly) Guugu-Yimidhirr version of place-name in F-I-speaking country, central to Aba Wurrumuniya clan.

$=A$ (possibly garbled) version of GuuguY1midhirr (Bama) Walmbaarrga, cognate w1th F-I Aba Walmbarriya, refers to a 'nation' speaking several languages in Princess Charlotte Bay area.

4.8. Sutton (1970):

Wur 1ma

= wurriyima (name of Flinders Island(s)).

Gamb11mugu

Almura

$=$ Gambillmugu, probably the Guugu-Yimidhirr version of a $B-P-s p e a k i n g ~ c l a n$ (Ama Aamp1lmungu?) name.

(See Gugu-Almura above.)

4.9. Dixon (1972):

Bayalgay 1

= Aba Yalgay1, F-I-speaking clan.

4.10. Sommer $(1972,1974)$ :

B1yalgey 1

(See Bayalgay1 above.)

Malthanmungu

= Ama Althanmungu, a B-P-speaking clan.

Kamb1lmuku

(See Gamb1lmugu above.)

AlmuRa

(See Gugu-Almura above.)

Pipon Island

Language

Mba w11aRgu

Mba $\tilde{\text { rmbuRma }}$
= Flinders Island language as I shall be defining $1 t$.

= A clan name in a Lama-Lamic language, but the clan itself speaking something else.

= A clan name in a Lama-Lamic language, but the clan itself speaking something else.

4.11. Thompson (1972):

Bata 1 p 1 r 1

Bagart 1

B1 yargo1 ya
= Aba Thalpirriy1, a F-I-speaking clan.

= Aba Agath1(y1), a F-I-speaking clan.

= Aba Y11rrkuy1, a F-I-speaking clan. 


\section{COMMENTS}

5.1. One of the reasons for all the confusions over 'tribes', 'languages', 'clans', 'place-names' etc. In this area is that no previous scholars have worked for very long with the Aborigines from the area, and none have attempted to elicit information in one of the local languages. I was able to do this in 1974, and I have also checked much of the information with at least two local people. There is st1ll much room to doubt my conclusions, but rather less than in the case of the earlier sources.

5.2. Another reason for the confusion is that languages in the area under consideration do not have names, at least not in the usual sense. People w1ll offer a name for thelr language when asked for 1t, usually replying with a place-name (e.g., Wurriylma, Flinders Island), patriclan name (e.g., Aba Yalgay1), or sometimes a phrase such as uuku malayi ngathun my own Zanguage.

5.3. There were two languages spoken in the area under consideration (1.e., from Bathurst Head through to Cape Melville, and from North Bay Polnt to Red Point; the former I call the Flinders Island language and the latter the Barrow Polnt language, since these are the commonest terms for them in the English of the people who speak them).

5.4. Some of my interpretations may look unfustifled without explanation. For example, 'Yalngabara' = Aba Yalgay1. In this case, the former is a term applied to a clan in a language other than that of the clan 1tself, a language which incidentally preserves the proto-form (*Yalngaparra) of the less common varlant of Aba Yalgay1, namely Yalgawarra (yalga < *yalnga, -warra < *-parra). Th1s connection would not be obvious if one was not aware that the Flinders Island language has undergone strengthening of intervocalic nasals to stops (hence $* n g>g$ ) and lenition of stem-initial stops to corresponding glides (hence ${ }^{*} p>w$ ). This emphasises the need for a lingulstically trained person to be used in any meaningful investigation of nomenclature in Aboriginal soclety. 


\section{CONCLUSION}

I have discussed two aspects of language-naming in Australia, one rather trivial (spelling the forms), and the other not so trivial (the semantic contents). The range of examples indicate that languagenaming is done differently in different Aboriginal sub-cultures. Linguistic scholars have sometimes gone to Aborigines with a 'standard' set of questions about their languages - such as 'What is your tribe?', 'What is your language called?' etc. - and have accordingly been tempted to fit the responses into a traditional (simplified) European stereotype of Aboriginal geographical, social and linguistic organisation. As more detailed studies of particular Aboriginal speech communities become avallable, the picture that emerges may be expected to be varlegated and diverse rather than unfform. Types of socio-linguistic organisation reported from the Western Desert (Berndt 1959, M1ller 1971a,b, Douglas 1971), north-east Arnhem Land (Schebeck 1968), south-east Arnhem Land (Heath 1975) and south-eastern Cape York Peninsula (R1gsby 1974, Sutton 1975) appear to be of rather different types and each generates rather distinct models of linguistic change and interaction for pre-European Australia. 


\section{PETER SUTTON}

\section{NOTES}

1. The former is connected with what Silverstein calls the 'language community' and the latter the 'speech community' (see Rigsby 1974, Sutton and Rigsby this volume).

2. Data from my own fleldwork 1974; Information from Mr Bob Flinders of Hope Vale Mission; I follow Haviland's practical orthography for Guugu-Yimidhirr.

3. Primary sources only.

4. Speaking the 'Tartali' dialect of 'Yalgawara'.

5. Also 'Ebole' or 'Elpolin'.

6. The two languages in the area under discussion are abbreviated as F-I (Flinders Island language) and B-P (Barrow Point language). The territory of the clans speaking F-I includes Bathurst Head, Flinders Group, Bathurst Bay, Cape Melville; territory of B-Pspeaking clans goes from Ninian Bay to Red Point, including Barrow Point. On Yalngabara see my comment 5.4. below.

7. Note that initial vowels are optionally deleted following silence In both B-P and F-I, hence, e.g. /ama a.mpilmugu/ = [m a mpilmunu] (B-P) and /aba talpiriyi/ = [ba talpiriyi] (F-I). 


\section{BIBLIOGRAPHY}

BERNDT, R.M.

1959 'The Concept of "the Tribe" in the Western Desert of Austral1a'. Oceania 30/2:81-107.

CAPELL, A.

1955 Af1. Unpublished fieldnotes. Lockhart River Mission.

1963 Linguistic Survey of Australia. Sydney .

DIXON, R.M.W.

1972 Unpublished fleldnotes and tape. Cooktown.

DOUGLAS, W.H.

1972

'Dialect Differentiation in the Western Desert -

A Comment'. Anthropological Forum 3/1:79-82.

HALE, H.M. and N.B. TINDALE

1933 'Aborigines of Princess Charlotte Bay, North

Queensland'. Records of the South Australian

Museum 5:63-172.

HEATH, J.

1975 'The Great Morpheme Robbery'. MS. Canberra.

HIATT, L.R.

1962 'Local Organization Among the Australian Aborigines'. Oceania $32 / 4: 267-86$. 
MILLER, W.R.

1972a 'Dialect Differentiation in the Western Desert Language'. Anthropological Forum 3/1:61-78.

1972b 'A Reply to Douglas's Comment'. 1b1d. 83-5.

OATES, W.J. and L.F. OATES

1970 A Revised Linguistic Survey of Australia. AAS 33, L12. Canberra: Australian Institute of Aboriginal Studies.

RIGSBY, B.J .

1974 Speech Communities and Social Networks on Cape York Peninsula. MS. Albuquerque.

ROTH, W.E.

1898 A Report to the Commissioner of Police on the Aboriginals Occupying the 'Hinterland' of Princess Charlotte Bay Together with a Preface Containing Suggestions for thelr Better Protection, and Improvement. MS. Cooktown.

1910 'North Queensland Ethnography Bulletin 18'. Records of the Australian Museum 8/1.

ROUGHSEY, D.

1973 The Giant Devil Dingo. Sydney: Collins.

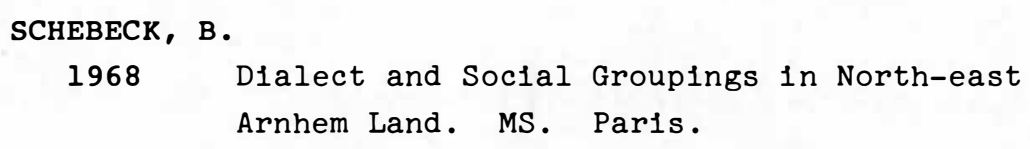


Institute of Aboriginal Studies.

SUTTON, P.J.

1970 Unpublished fleld report. Canberra: Australian

Institute of Aboriginal Studies.

1975 The Flinders Island Language. Unpublished draft. Canberra.

THOMSON, D.F.

1972 Kinship and Behaviour in North Queensland.

Canberra: Australian Inst1tute of Aboriginal

Studies.

TINDALE, N.B.

1940 'D1stribution of Australian Tribes'. Transactions

of the Royal Society of South Australia 64:140-231.

1974 Aboriginal Tribes of Australia. Canberra:

Australian National University Press.

TREZISE, P.J.

1969 Quinkan Country. Sydney.

1973 Last Days of a Wilderness. Sydney.

WEST, L.M.

1962 Alphabetical First Name Finder List for

Linguistic Informants Contacted by West in

Northeastern Austral1a 1960-62. MS.

Canberra: Australian Institute of Aboriginal

Studies.

1964 Alphabetical First Name L1st of Lockhart River Mission Residents and K1n. MS. Canberra:

Australian Institute of Aboriginal Studies.

1965 Unpublished field tape report sheets. Canberra:

Australian Institute of Aboriginal Studies. 


\title{
PRELIMINARIES TO A PROTO NUCLEAR PAMA-NYUNGAN STEM LIST
}

\author{
Geoffrey N. O'Grady
}

It was A. Capell who pioneered the diachronic study of the lexicons of Australian languages. Since the publication of his A New Approach to Australian Linguistics in 1956, much additional progress has been made in the study of the languages.

In 1967, with the generous support of the University of Hawa11, the National Science Foundation ${ }^{1}$ and the Australian Institute of Aboriginal Studies, I initiated work on the reconstruction of ProtoNyungic lexicon and affixes. The pressure of other duties forced a temporary curtallment of this work - in which Kenneth L. Hale, Terry J. Klokeld and Bruce and Elalne Sommer were assoclated - when 1t was already well advanced. Further substantial progress had to awa1t a study leave from the University of Victoria in 1974-5, here gratefully acknowledged.

But by this time the focus had changed radically. Repeatedly it turned out that a form showing cognation among several Nyungic languages appeared in other far-flung Pama-Nyungan languages also (a good example is *kami, with reflexes commonly meaning mother's mother). The time therefore seems ripe to zero in on Pama-Nyungan 1tself. I do this entirely on my own responsibility. At the same time, I deem 1t prudent to restrict the study to languages for which given sufficlently large dictionaries - one could confidently expect to marshall cognates in the hundreds. For this reason, languages such as Lardil and Gunwinygu, though unquestionably members of the Pama-Nyungan Family, are excluded from the study at the present time. Since the number of cognates which they share with other Pama-Nyungan languages appears to run to some dozens only, and thelr grammatical evolution has diverged correspondingly, I take it that they split of $f$ from the main Pama-Nyungan stream quite early - concelvably 4,000 to 
5,000 years ago. Thus for the present I find it a useful working arrangement to make a distinction between 'Proto Pama-Nyungan' and 'Proto Nuclear Pama-Nyungan' (hereafter PPN and PNPN respectively). The present study has as 1 ts focus the reconstruction and attestation of PNPN stem shapes. The quite separate task of reconstructing the meanings of stems in PNPN promises to be truly monumental; I earnestly hope that this chapter may play a role in stimulating others to take up this challenging work. Ancestral stem meanings are thus only occasionally proposed here.

Given that the present chapter has as its focus the PNPN lexicon, It will be evident that the target set falls very far short of a detailed reconstruction of Proto-Australian. This is a goal which I believe to be essentially unattainable. ${ }^{2}$ If by 'Proto-Australian' we mean something more or less analogous to Proto Indo-European, then I belleve that we are deluding ourselves utterly. If, on the other hand, by 'Proto-Australian' we mean an ancestral stage comparable in time depth to a putative and entirely ephemeral Alta1c, Finno-Ugric, Semitic and Indo-European super-famlly or phylum, then well and good:

My reason for making the above claim is as follows: adequate reconstruction of a proto-language demands, among other things, the assembling of a large number of cognate sets - some hundreds, say. Only in this way can such detalls as the patterns of consonant clustering in the ancestor language be adequately worked out. This task has been essentially completed for Indo-European, and I am confident that It can be done for Pama-Nyungan also. But not all Australian languages are members of the Pama-Nyungan Fam1ly, just as not all the languages of Europe are Indo-European. I would like to put it to my fellowAustralianists that the position of Tiwi among the Australian languages might usefully be compared to the position of Hungarian among the European. If we were to make a serlous attempt to demonstrate genetic relationship between Hungarian and English, we might bring together pleces of potential evidence such as the following:

Hungarian $\mathrm{m}$, as in látom $I$ see (definite object): English $\mathrm{m}$, as in am.

Hungarian $n$, as in the negative words nem and ne: English $n$, as in not, no.

Hungarian $t$, as in the second person singular familiar pronoun te : $\delta$ in archaic English thou (< PIE *tü).

Excluding presumed loans into Hungarian such as hét seven and száz hundred, we might be able to double or even treble the number of the above nebulous strands, given an exhaustive study of the grammars and 
lexicons of both languages. But this would still fall far short of an adequate demonstration of genetic relationship. Not1ce, too, however, that such a study could not demonstrate that Hungarian and English are NOT genetically related - It could merely fall to produce the evidence necessary for demonstrating such a relationship.

Thanks largely to the publication of C.R. Osborne's The Tiwi Language in 1974, we are in a position to make a serious attempt to demonstrate genetic relationship between Tiw1 and, say, Nyangumarda. 3 Granted that the documentation of these two languages is not as exhaustive as that of Hungarian and English, we still cannot but be amazed at the near-total lack of even the most tentative kinds of potential evidence. We seek cognates for such Nyangumarda case markers as -lu - ju 4 'ERGATIVE' and -ku 'DATIVE' - entirely without success; Tiwl, in fact, entirely lacks case marking! What we do find is as follows:

Tiwi ngia $I$ : Nyangumarda ngaju $I$

Tiwi ngintha you (sing.) : Nyangumarda nyuntu you (sing.)

Tiwi nua you (plur.) : Nyangumarda nyurra you (plur.)

Tiw1 -ma -mi do, go, say : Nyangumarda ma-n-take, grab; -ma-r- verb formative

Tiwi ngagha and Nyangumarda nganyjurru we (plur. Inclusive) and Tiw1 ngawa, Nyangumarda nganarna we (plural exclusive) seem to point, along with the first person singular forms given, to an extremely ancient shared first person pronominal base *na- - but the same kind of highly tentative claim could be made for the $m$ in Hungarian látom and the $m$ in English am:

In comparing the lexicon of Tiwi with those of Australian languages in general, we find a single 1tem (additional to the above) which shows promise. This is Tiwi kukuni (w1th masculine noun class suffix -ni) fresh water. The root, kuku-, is matched by Gunwinygu kuku water, and this shape evidently appears in north-eastern New South Wales also witness Yugambal (?) kookoo and 'Glen Innes' goko, both meaning water, c1ted in Curr (1887: III: 295-7). In Bayal1 we have koongo water, evidently /kuju/, (1b1d: 115), supported by the Geytenbeeks' contemporary transcription of the Gidabal word for water: /gur/, 1.e. kung in the system of transcription adopted here. Tiwi kuku- also compares well with Proto-Pamic * juku, Mara nguku, Yagar-Yagar nguuki and Yaralde nguke, all meaning water - as well as with Pintup1 nguka-lswallow; Nyangumarda nguka-y-steal, abduct also comes to mind. 
Assuming for a moment that Tiw1 kuku- shows denasalization of the initial consonant of *nuku under the influence of the $*_{k}$ in the following syllable, we now need further cognates in order to firmly establish denasalization as a historical rule of the language. And this is exactly the essence of the problem of demonstrating genetic relationship between Tiw1 and other Australian languages: there are no further putative cognates! Moreover - who knows? - the similarity in form and meaning between TIw 1 kukuni and the other forms cited may be purely accidental - just as in the celebrated example of Modern Greek mati and Malay mata, both meaning eye, c1ted by Bloomfleld (1933:297). Alternatively, Tiwl could have borrowed kuku- from a mainland language, especially in the period subsequent to Indonesian and/or European contact.

It seems inconcelvable that Tiwi kuku- could be directly descended from a 'Proto-Australian' root * guku, and not have been subject to far more drastic phonological change (and reanalysis?) after a presumed time span of ten to forty millenia.

I would like to take issue with Osborne (1974) In connection with his assertion (p. 3) that
"Lexical comparisons are quite useless for the purpose of establishing Tiwi's genetic relationships, as all that such comparisons ever reveal is that Tiwi has virtually no lexical cognates with any other Australian language."

It seems to me that he is putting the cart before the horse here; would it not be more reasonable to recognize T1w1 as a LANGUAGE ISOLATE - 1.e., a language which, like Basque, const1tutes a 'language family' all by 1tself? This is essentially what O'Grady, Voegelin and Voegelin did in their 1966 classification. Tiwl would then not be a demonstrated member of the large Pama-Nyungan family. For those who are fond of speculating about extremely remote linguistic relationships, Tiw1, along with all other Australian languages, could be assigned to a nebulous grouping called the 'Australian Phylum' pending further investigation. This phylum would also contain putatively, but presumably st1ll very nebulously, interrelated languages such as Larakia, Gunavidj1 and Anind1lyaugwa.

And this is, after all, the kind of situation which might be expected to obtain in Australia, given 30,000 years or more of continuous occupation by Homo sapiens. Bolinger (1975), clting Bender (1973), suggests that

\footnotetext{
"The rate of change observed in all living languages, if it operated in the past as it does today, would have w1ped out traces of any language spoken 30,000 years ago."
} 
I would like to relterate that we come very close indeed to observing this effect when we place the Nyangumarda lexicon side-byside with the Tiw1. The situation is very different indeed when we place the Nyangumarda lexicon side-by-side, say, with those of languages such as Pintup1, Wadjuk, Aranda, Wembawemba, Gidabal, Umplla, Yagar-Yagar and Gupapuyngu - even though these languages are spoken in widely separated parts of the continent. Generous numbers of cognates appear. We get very much of the feeling which

Kenneth Hale once Imagined Sapir would have had if he could have looked in on the Australian linguistic scene today: that Nyangumarda, Wembawemba and the other languages just named are ABSOLUTELY OBVIOUS members of a language family (in contradistinction to Tiw1, Larakia, Gunavidj1, Anindilyaugwa and others), and that the time depth during which this family evolved must be of the order of 3,000 to 5,000 years only. I would remind the reader that the same Kenneth Hale, source of so many deep insights concerning Australian languages, named the famlly 'Pama-Nyungan' over a decade ago. There seems to me to be absolutely no reason why this name should not be used in perpetuity.

To return to Osborne's observation about the uselessness of lexical comparisons in attempting to establish the genetic relationships of Tiw1: even granted that the rate of lexical replacement in Australian languages appears to be rather high relative to languages spoken in other parts of the world, it seems to me that the following analogy is still valid: suppose, for a moment, that a linguist makes the claim that lexical comparison is useless for the purpose of establishing genetic relationship between Hungarian and English. Such a claim could be countered by pointing out that lexical comparisons had been of service in establishing genetic relationship between Hungarian and the other Finno-Ugric languages, as well as between English and the other Indo-European languages; ergo, the methodology is valuable, and if it does not produce positive results in the comparison of Hungarian with English, maybe there is something special about the languages Hungarian and English. The 'something special' is, of course, that relatedness between Hungarian and English simply has not as yet been demonstrated, and these two languages have presumably enfoyed separate histories for 10,000 years or more. And if they did in fact evolve from a common ancestral language spoken, for argument's sake, 16,000 years ago, the once numerous shared features and elements have dwindled almost to zero, so that the most insightful and rigorous application of comparative method linguistics is of no avall. 
I would heartily recommend the reader to consider adopting a convention (if he or she has not already done so) used by C.F. and F.M. Voegelin over the years: that of using the term FAMILY in cases where a proto-language can be reconstructed in considerable detail, with cognate sets presumably numbering in the hundreds at least; the term PHYLUM is reserved for situations where a little tentative and spotty reconstruction is possible, but detail is essentially lacking; putative cognates might run to a score or so. Relationships among the members of a language family are amenable to the application of scientific rigour. Those among the members of a supposed phylum are not.

The linguistic situation in Australia 15,000 years ago can presumably in no way ever be recovered. Whether there were fifty languages spoken at that time or five hundred, none of us now living can ever know. I would like, however, to be permitted to give my imagination some rein in trying to confure up what to me seems a fairly plausible scenario. This scenario is predicated on the assumption that from $95 \%$ to $99 \%$ of the languages spoken in Australia 15,000 years ago have long since become extinct. Before dying, however, some exerted powerful influences on their geographic nelghbours at varlous levels - phonology, morphosyntax and lexicon. The resulting plcture might have been something like that given below.

The format of the chart is based on Bolinger (1975:321). What it portrays is entirely my own responsibility, however. The assumption is that even in very anclent times - in 35,000 B.P., say - the number of languages spoken in Australia was quite large. At least one of these represented a continuation of Capell's OA (Original Australian).

One of the ancient tongues, $C$, survived in a single offshoot, $\mathrm{C}_{6}$, long enough to end 1 ts days as a contemporary of Old English. Another, E, had become extinct thirty-two millenia ago. D was more fortunate: one of 1 ts daughter languages, $D_{2}$, not only survived but flourished right up into modern times, and is now the well-studied Anindilyaugwa of Groote Eylandt. $G$ had a more spectacular history st1ll: after at times barely surviving in a very small area of northern Australia for about 15,000 years, it began to gain in prestige and supplanted a number of nelghbouring languages $\left(A_{2}, D_{5}, F_{3}\right.$ and others). Around 15,000 B.P. a small band of speakers, $G_{1}$, migrated on to a peninsula 
HYPOTHETICAL GENEALOGY OF SELECTED AUSTRALIAN LANGUAGES

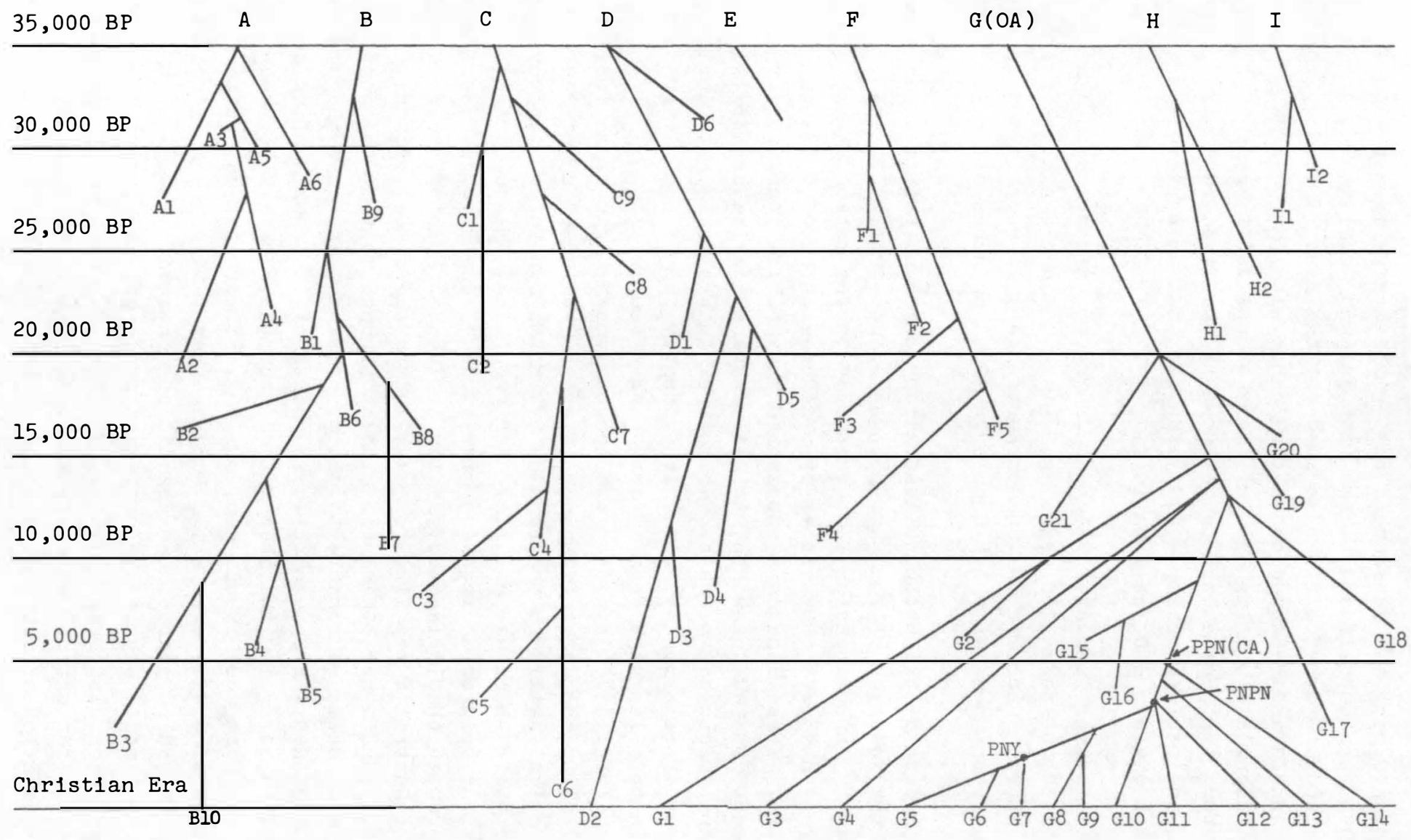


which during the subsequent post-glacial rise in sea level was cut off and became Bathurst and Melville Islands. Powerful tides scoured out the newly formed channels and rendered contact by canoe with the mainland all but impossible. Many thousands of years later, the people came to be known as the Tiw1. $G_{2}$ became extinct nearly 6,000 years ago, but $G_{3}$ survived as Larakia and $G_{4}$ as Gunavidji.

Several other languages which according to this scenario 'had diverged 10,000 to 14,000 years ago' - e.g., Maung - are not represented in the chart. Capell's CA (Common Australian) is represented approximately by the node at which Gunwinygu $\left(G_{14}\right)$ branches off 5,000 years ago. ${ }^{5}$

The modern distribution of Australian languages points to an almost explosive expansion of the Pama-Nyungan speech-area 4,000 to 5,000 years ago. This expansion led eventually to the establishment of Pama-Nyungan speech communities over seven-elghths of the area of Australia. These languages supplanted many earlier tongues, or in some cases donated loanwords; Anindllyaugwa mungamina breast (with which comparison can be made over most of Australia, e.g., Dier1, Nyangumarda ngama breast, milk) is evidently one of the rather rare loans in this language from a Pama-Nyungan source.

Wurm (1972:165), in noting the abrupt Pama-Nyungan expansion, draws a parallel to the dramatic manner in which the imparting of new technological skills to the Papuans by the Malayo-Polynesian voyagers changed their whole way of life. For one thing, the cultural innovations triggered extensive migrations by the Papuans. Wurm goes on to propose that Malayo-Polynesian influence reaching the northwest coast of Australia may likewise have led to the spread of a new technology and a new linguistic element through most of the continent.

While 1t seems reasonable to cla1m, as Wurm does, that the homeland of Pama-Nyungan was somewhere in the north of the continent, I see problems in according the area inland from the Eighty-Mile Beach this honour (as Wurm does in his map, p. 166). If present-day patterns of linguistic diversity within the Pama-Nyungan family are any indication, then the northern part of the Arandic speech-area, as well as the territory immediately to the northeast and east, seems more plausible as a centre of dispersal. Notice that the languages to the west of this area - for example Walbir1, Walmadjarri and Nyangumarda, show every indication of quite close genetic relationship, so that the area 
In which they are spoken loses 1 ts attractiveness as a Pama-Nyungan homeland.

If, then, a more easterly locus for the centre of dispersal of Pama-Nyungan can be accepted, Aranda would be a language whose present special features have evolved in situ: universal loss of initial consonants, loss of distinctiveness in final vowels, development of two series of nasals (plain and pre-stopped), and complete levelling of the old Pama-Nyungan scheme of conjugations - to name a few innovations. Other Pama-Nyungan languages would have spread in all directions from this Urhelmat - including northwards towards the northeast corner of Arnhem Land and northeastwards towards Cape York Peninsula and the Western Torres Strait Islands.

From the point of view of a modern Nyangumarda speaker, the scenario for the last 5,000 years might have unfolded in something like the following manner:

The ancestor of Lardil $\left(G_{13}\right)$ diverged very soon after Gunwinygu. $G_{5}$ through $G_{12}$ began to diverge from their common ancestor, Proto Nuclear Pama-Nyungan, a mere 4,000 years ago. Speakers of the language ancestral to Wembawemba $\left(G_{10}\right)$ and 1 ts congeners began a southward migration at about the time when the early ancestors of the Murngin tribes $\left(G_{12}\right)$ began to move northwards. Numerous languages were supplanted in the process. The common ancestor of the modern Pamic languages $\left(G_{8}\right)$ and the Western Torres Strait language $\left(G_{9}\right)$ branched off next - at around 1,000 B.C. Soon afterwards, with the original linguistic community now expanding to the west, southwest and southeast as well, the speech of the 'stay-at-homes' began its uniquely Arandic $\left(G_{11}\right)$ line of evolution, with the language ancestral to Wadjuk $\left(G_{7}\right)$ belng transplanted by 1 ts carriers into the southwest corner of Australia soon after. The ancestral Wat1-Marrngu speech community, by now located somewhat to the west of present-day Aranda country, held together until the fourth century of the present era. Little further movement was necessary to bring the Pintupis $\left(G_{6}\right)$ into their ultimate homeland. The early Nyangumardas $\left(G_{5}\right)$ emerged from the Great Sandy Desert on to the E1ghty-Mile Beach while Marco Polo was at the court of Kubla1 Khan. 
The above picture represents, of course, a very great simplification; an attempt has been made to depict a general outline by focussing on just a few representative languages. Notice that $1 \mathrm{f}$ finer Iines had been drawn, the majority of modern Australian languages would turn out to belong among $G_{5}-G_{14}$ : the numbers could have been extended approximately to $G_{160}$ had space been avallable in the chart. How much of the earlier scenario corresponds to fact and how much to fancy will presumably never be known. The state of the art of modern linguistics, together with what is now known of the $G$ languages, lead us to have excellent expectations of being able to test thoroughly the scenario presented for the last 4,000 years (given time). As of now, I believe that the histories of the $G$ languages might in point of fact be similar to that depicted.

Rising sea levels eventually formed Bass Stra1t, and a linguistically rather homogeneous population speaking $\mathrm{B}_{3}$ in southeastern Australia was quite suddenly and irrevocably cut into two segments (once the sea made the initial sixty-metre breach - all in the space of one day the drastically different tidal regimes on the two sides ensured that veritable torrents of water poured back and forth; after fourteen days, the gap was over a kilometre wide and elght metres deep). The 'Tasmanian' language spoken to the north of the breach survived for another five millenia; but as the speakers adopted the PamaNyungan languages spoken by the technologically more advanced newcomers from the north, the descendant $\mathrm{B}_{3}$ speech forms were gradually reduced to substrate status. The people to the south of the new strait, lacking the technology needed to cross large bodles of stormy water, gave up further thought of visiting their kinsfolk across the channel after the severe winter of 6,057 B.C., when a series of westerly gales, pushing up phenomenally high tides over a wide stretch of still shallow sea, washed away the remaining low islands in the narrowest part of the channel. Their language, $\mathrm{B}_{10}$, continued to evolve in total isolation for a further 79 centuries - until the unparalleled tragedy wrought on the people by the Europeans.

Authorities such as Mulvaney (1969) and Shutler and Shutler (1975) indicate that Tasmania has been an 1sland for about 8,000 years. In 
view of the truly immense gulf of time during which the people were isolated, I find it difficult to make out what Crowley means when he claims (1976:23) that Tasmanian is a 'phonologically absolutely normal Australian language'. First of all, one would like to know which languages on the mainland have 'absolutely normal Australian' phonologies: Arabana - in which all words end in vowels? Kunjen - in which all words begin with vowels? Ngarluma - in which words begin with consonants other than apicals? I think that the point could be made well enough that the mainland Australian languages exhibit considerable typological diversity in their phonological systems. If Tasmanian did have a phonology closely congruent with that of a mainland language (or languages), then this surely must be a typological similarity and not a similarity resulting from common descent: Notice that one could make a falrly strong claim that Modern Greek has a phonology which, if not exactly 'absolutely normal Spanish', still shares impressively many features with the latter. Genetically, though, the languages belong in different branches of Indo-European; and French, a language which is genetically close to Spanish, has a phonological system which is typologically very different from that of Spanish.

Unless the Tasmanian linguistic materials turn out to be data from a southern Australian mainland language which was unwittingly implanted in Tasmania by the early whalers (and which supplanted native Tasmanian), then my expectation that Tasmanian will turn out to be a Pama-Nyungan language is virtually zero. I am very curious indeed to see evidence for sound correspondences in the demonstration of genetic relationship between Tasmanian and 'Australian' to be offered by Crowley and Dixon.

Over the years, but especlally in $1967^{\circ}-8$ and 1974-5, I have been able to assemble 850 cognate sets from varlous mainland languages. About half of these can be brought to bear in the reconstruction of PNPN. The remalning half yleld sub-PNPN ancestral forms such as ProtoNyung1c (PNY), Proto-Pamic (PP) and Proto-northern New South Wales (PNNSW) as reconstructed by Crowley. An example of a set which can be used to justify a PNPN protoform is provided by Bayungu ngajaru (with non-etymological -ru suffix of as yet undetermined function and/or meaning) and Gupapuyngu natha. Both of these forms mean vegetable food, so that the question of semantic change does not obtrude 1tself here. The short first vowel in the Gupapuyngu form leads us to posit a short first vowel in the protoform also. Hence PNPN *naca. It is clear that Nyangumarda ngaji sugar belongs here also; but the Bayungu and Gupapuyngu forms alone suffice for the reconstruction of PNPN *naca. 
Notice that the attempt which I am making here to reconstruct as far back in time as possible at times seems to raise more questions than it answers. It might well be argued that the writer of this paper would be better advised to restrict himself to a tightly controllable body of data in very closely related languages (such as he did when writing up 'Proto-Ngayarda Phonology'). But regularities such as are exemplified in the following encourage him to continue:

\begin{tabular}{|c|c|c|c|c|}
\hline PNPN & *caca & $>$ & Nyangumarda & $\begin{array}{l}\text { jaji person on restricted } \\
\quad(\text { non-fat) mourning diet }\end{array}$ \\
\hline PNPN & *paca-1- & $>$ & Nyangumarda & paji-r-bite \\
\hline PNPN & $\star_{\text {m }}$ in ja & $>$ & Nyangumarda & stench \\
\hline PNPN & * $\cap A \mid j a$ & $>$ & Nyangumarda & ngalyi neck \\
\hline PNPN & *kuya & $>$ & Nyangumarda & kuyi animal, meat \\
\hline
\end{tabular}

The point being made here is that the rule whereby PNPN *naca is reflected as ngaji in Nyangumarda is not invoked on an ad hoc basis, but in point of fact has wide applicability in the language. 6

The remaining half of the cognate sets - those which yield shallower reconstructions - can be exemplified by Nyangumarda walya.ka ${ }^{7}$ leaves, foliage, Bandjima walha.rn leaf, Ngarluma walha.rn Zungs, Yindflbarnd1, Kurrama watha.rn leaf, Zungs, Bayungu walha.rri walha.rti leaf and Neo-Nyungar walya.ly Zungs, 'Zights'. Although an Impressive array of languages is represented here, all are quite closely related, being members of the Nyung1c Group, characterized by universal merger of the old PNPN long and short vowels (only in the Yura languages of South Australia do the effects of the old vocalic length distinction show up in the development of double series of nasals and liquids). Granted that the semantic relationship between LEAVES and LUNGS is explainable on the basis of shape, we reconstruct PNY *walja. Part of the task of future researchers w1ll be to search for cognates of PNY *walja in other branches of Pama-Nyungan such as Pamic. For unless *walja simply 'materialized' (concelvably in song) at the PNY stage, then evidence of 1 ts prior existence must surely be traceable outside of the Nyunglc speech-area. Then, too, we will have to face the question of whether the first vowel of this form was short or long in PNPN. For the present, protoforms such as PNY *walja must be taken to reflect what Capell called 'regional vocabularies'. Such are also strongly in evidence in Indo-European, where Proto-Germanic *hand-hand and *drenk-drink are generally held to be unique to Germanic (and perhaps reflect a pre-IE substrate). 
The 850 cognate sets assembled so far include, then, only about 400 on which PNPN protoforms can be justifled. But another parameter is involved here also: that of semantics. Again, approximately a half of the 850 sets require no explanation or justification of the semantics involved, but the other half have occasioned the writer much soulsearching over the last twenty years or so.

In the realm of sets which are entirely stralghtforward from a semantic point of view are Bayungu ngajaru, Gupapuyngu natha, considered above. A further example is provided by Umpila mathuy and Kunjen adhor. Both of these forms mean pelican and can be taken to reflect Proto-Pamic (PP) *macur (w1th * $r$ representing the rhotic glide - see below). The further question of whether PP *macur is in turn cognate with a Galbu form for turtle recorded by Capell as mädjur, with Thalandj 1 and Bayungu majun and Southern Y1nggarda majunpa turtle, and with Nyangumarda maju children's 'tag' game does not affect the validity of PP *maacur.

At a deeper level, taken to be PNPN, we have Nyangumarda winpal-pi1-, 8 Walbirl wirnpi.rli-y-, Gawurna winbi.rra whistle, pipe, flute, Gadhang winpa-1- (and possibly Gumbainggar wireinbei-). All of these forms other than the Gawurna mean whistle (vb.) and are ascribable to PNPN *wIrnpa- (none of the daughter languages involved here happen to be diagnostic for PNPN vowel length; hence the convention of indicating the present indeterminacy with the symbols $\left.*_{1}, \star_{A}, \star_{U}\right)$. Once again, the problem of varying semantic reference does not intrude 1tself.

Among instances of evident semantic change, very many could well have been culled from a handbook on Indo-European. I think that the lesson to be learned from this is as follows: insofar as universal principles of semantic change can be validated, it is neither here nor there whether Homo sapiens has been isolated in Australla from the rest of his kind for 40,000 years or whatever. The point is that we are investigating natural human languages, and we can expect instances of semantic change in Russian, say, to be replicated in Nyangumarda or Dyirbal. This is not to say that we will not have to contend with types of semantic change which might turn out to be entirely unique to Australian languages. But more of these anon.

Mulurudj1 tawar star, Umpila taway moon and Yagar-Yagar dapar sky could well be taken as a classic example of meanings 'related as whole and part' - Bloomfleld's synecdoche. The ancestral form had the shape *tapad (with rhotic flap/trill represented by *d). St1ll further back In time, it can be shown that the $*-d$ was a suffix, supportable by evidence from Nyangumarda and elsewhere. Note, for example, Pintupi 
taputapu Japujapu ball, round object (with inclpient shift of Inftial laminals to ap1cals) and Thalandf1, Bayungu japu.rta, Yindjibarnd1 jawu.rta beard (In each of which the shift is fully accomplished). The reader who may - with excellent reason - feel sceptical about a semantic association between SKY and BEARD is referred to Pintupl ngarnka $s k y$, blue $s k y$, heavens (with which compare, for example, Nyangumarda ngarnka beard) and to Pintupi ngarnkurrpa beard, whiskers; the latter form, too, reflects the $*-d$ suffix as in Umpila tawa.y and Yagar-Yagar dapa.r.

A further example of synecdoche is provided by Umpila walu cheek and Walbirl walu head, both reflecting PNPN *walu. Also of an IndoEuropean ring is the semantic difference between Ngarluma, Yindjibarnd1, Bandflma thurla, Nyamarl jurla eye and Southern Aranda (Wychinga) url forehead. This set we take to exemplify metonymy, in which meanings are near each other in space or time. Consider, too, Walbiri milpa eye, Umplla miil'a face and Adnyamathanha milpi.rri forehead, all of whlch reflect PNPN *mi ilpa.

The traditionally recognized type of semantic change which is probably exemplified in Australian languages the most lavishly of all is metaphor. Thus PNPN *miilpa, just cited in another context, descends in Nyangumarda as milpi.ny fingernail, toenail. The assumption here is that an earlier word for nail was tabooed or otherwise fell into disuse in the language, and nail was renamed as being the eye of the hand or foot. Metaphor is exemplified twice over in the following set: Ngarluma, Bandjima yalhu.ru, Yindjibarndi yathu.u tongue, Adnyamathanha yalhu flame (compare also Lardil yalulu flame), Nyangumarda yilyu tear (lachrymal) and king George sound yal-yu-ret wet, clted by Moore. These forms go back to PNPN *yaalju - the plain lateral in the Adnyamathanha form is taken as evidence for an original preceding long vowel.

The single most important principle in establishing the plausibility of a given instance of apparent semantic divergence is that of independent documentation. Thus, although TONGUE and FLAME are assoclated in many semantic systems outside of Australia, we are particularly concerned here to uncover supportive evidence within Australia. Such is provided, in fact, by Linngithigh mælan flame, which is a compound of mæ fire (< PP *cuma) and lan tongue (< PNPN *calanj), clted in Hale (1966).

Turning now to more uniquely Australian types of semantic correspondence, it is appropriate to c1te Umplla kani up: Nyangumarda kaniny down, below, < PNPN *kaninj. Taken alone, this palr could well be 
ascribed to the operation of chance factors rather than to common descent. To infect plausibility into our claim of cognation for these two forms, we seek to bulld up a chaln of mutually supportive evidence. Consider the following:

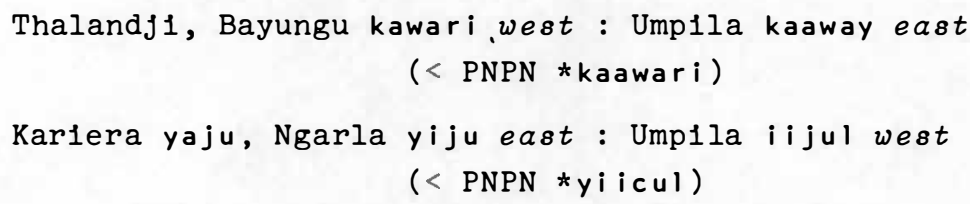

In this case, the chains of mutually supportive evidence have as their common theme a most dramatic and revealing principle of semantic change In Australian languages. This principle is aptly encapsulated in Kenneth Hale's recent term unity of the opposites (personal communication). Once this principle is accepted, the number of cognates which can be recognized among Pama-Nyungan languages undergoes a quantum leap. We can now confidently claim cognation for sets such as the following:

Ngarluma, Yindjıbarnd1 thama fire: Wadjuk djam water

(< PNY * cama)

Walb1r1 jama generous : Nyangumarda jami-r-ni-kiti stingy

(-r-conjugation marker, - niInfinitive, $-k i t i$ habituative)

$(<$ PNY *cami)

Bayungu, Thargarl yinha this : Walb1r1 yinya that beyond

$$
\text { ( }<\text { PNPN *y } \ln \mathbf{j a})
$$

Karıera, Bandjıma ngaji-y-, Yındjıbarnd1 ngayhi-y-, Yınggarda, Malgana ngathi-y-, Gupapuyngu näthi cry (and Pintup1 ngaji-l-ask for, beg) : Ump1la ngaji-1- Zaugh (< PNPN * gaaci-)

Pintup1 ngara-y-stand, wait, be : Umpila nga'a- $\emptyset$ - enter (< PNPN *nara-y-)

Thalandj1 yuka.rri-y-, Wirangu uka-stand : Arabana, Wangkangurru yuka-go : Yagar-Yagar yuka- Zie down (< PNPN *yUka-)

Nyangumarda - jarra-y-, Bayungu -tharri-y-, Walb1r1 -jarri-yINCHOATIVE, become, Wembawemba jerri.ka, Dyırbal jarra-l (tr.), 


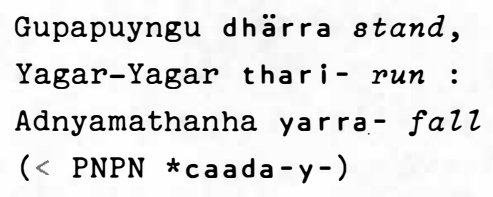

Nyangumarda -kurlu PRIVATIVE : Walbir1 -kurlu PROPRIETIVE

(< PNY *-kurlu)

Walbirl -wangu PRIVATIVE : Duungidjawu -wangu COMITATIVE 9

(< PNPN *-WAgu)

Thalandj1 -nha PAST (In Y-Conjugation verbs) : Arabana -nha FUTURE (< PNPN *-y-na)

But this is not all. Once the principle of the unity of the opposites is recognized, the floodgates are opened with respect to those aspects of antonymy - enigmatic to the non-native speaker which are unique to Australian semantic systems. An absolute 'must' for the development of deeper insight into the nature of such systems is Kenneth Hale's A Note on a Walbiri Tradition of Antonymy. Needless to say, a person who is a native speaker of an Australian language and is deeply aware of his people's notions concerning antonymy AND is also trained in modern linguistics, anthropology and philosophy would be in the best possible position to enlighten the scientific world on this rich area of study.

And so we cross the threshold from the known to the previously unknown. Even so, it must be recognized that we are barely scratching the surface of this area of study. For if it should make sense to the outsider that the antonym of FIRE should be WATER, by the same token there is presumably no way in which he can deduce the antonym of EAR (to take one possible example). The following set of forms is suggestive, but by itself proves absolutely nothing:

Nyangumarda jungka, Y1ndfibarnd1 thungka, Bayungu thungka.ra

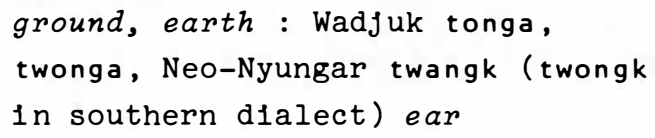

Even though the sound correspondences show excellent 'fit', there is no reason a priori why there should not have been homophonous forms in the proto-language, one meaning ground and the other ear. Notice that there has apparently been a replacement of initial dental stop with alveolar /t/ in Neo-Nyungar, concelvably through latter-day pressure from English sound patterns, so that there is no reason why all of the 
forms cited should not be ascribed to Proto-Nyungic *cunka. Nevertheless, the semantic vold which a speaker of a European language such as English concelves of as existing between GROUND and EAR is so great that for a decade the writer of these lines could see no way out of this seeming conundrum. Eventually, a method of at least partially resolving it came to mind: to examine words for GROUND and EAR in a large number of Australian languages, and so hopefully gain further insights. If one takes the Gupapuyngu word for EAR as one's point of departure, the following comparisons come into focus:

Gupapuyngu buthu.ru ear (and, probably, Yagar-Yagar poewth

$$
\begin{aligned}
& \text { forehead) : Malgana puthu, } \\
& \text { Nhanda uthu.lu, Wadjuk budjor } \\
& \text { ground, Neo-Nyungar puju.rr } \\
& \text { ground, earth, dust }
\end{aligned}
$$

Once again, the phonological correspondences work out. So long as the former suffixal status of -ru in the Gupapuyngu form, - Iu in the Nhanda and the final rhotic consonant in the Wadjuk and Neo-Nyungar is recognized, the ancestral root can be 1dentified as *pucu; and it is of PNPN age. The short first vowel in the Gupapuyngu reflex, as well as the retention of the inftial * $p$ in Yagar-Yagar, both indicate that the first vowel in the protoform was short.

Alternatively, one can, albelt arbitrarlly, choose the Gupapuyngu word for GROUND as a point of reference:

Gupapuyngu muna.tha earth, ground, sand : Yulbaridja muna.rta ear Once again, if the non-etymological - tha and - $r$ ta are accounted for, we are left with a clear indication of a PNPN root *muna.

And what of the Yulbaridja word for GROUND? Consider:

Yulbaridja, Pintup1, Wadjarri parna ground: Thalandj1, Burduna parna head

In view of the fact that shifts in meaning between HEAD and EAR are well documented in Australian languages, the set of forms given can be taken as providing further corroboration of the correlation which is emerging; the Implied ancestral form *parna goes back to ProtoNyungic (PNY).

The most impressive documentation of all emerges when one considers Walbirl. Here is the clinching evidence:

Walbir1, DJaru langa ear : Warnman langa ground My reason for making this claim is based on the quite unusual word 
shape here: both initial lateral and intervocalic velar nasal occur with rather low frequency in Pama-Nyungan languages. O'Grady (1957) and Dixon (1972a) present statistical evidence for this. The chance that the Warnman word for GROUND shares an accldental resemblance with the Walbirl and DJaru words for EAR is thus exceedingly remote. Both go back to *lana, though at no great time depth (the three languages concerned are quite closely related). This root can be ascribed to Proto Northern Nyung1c (PNNY).

Five ancestral forms can thus be reconstructed on the basis of the above interlocking evidence. As already indicated, I am delighted to leave to others the task of working out the original meaning of each. The five forms are, then:

$\begin{array}{lll}\text { PNPN } & \text { *muna } & \text { *pucu } \\ \text { PNY } & \text { *cunka } & \text { *parna } \\ \text { PNNY } & \text { *lana }\end{array}$

A further comment is in order concerning the approach used: comparison was made in the first instance between those languages whose grammars and lexicons show ample evidence of genetic relationship - in fact, between pairs of Pama-Nyungan languages. If, then, we are looking for a cognate of a root which appears in Nhanda, for example, we will look to Gupapuyngu far more than to Tiw1. If we do find a resemblant form in Tiwl, we will be strongly inclined to ascribe the similarity to the factor of chance (though one should not lose sight of the possibility of eventually demonstrating cognation).

The task of rigorously establishing phonological correspondences throughout a large network of Pama-Nyungan languages is a formidable one. In the first phase of the work, it was necessary to restrict the data to sets such as Bayungu ngajaru, Gupapuyngu natha. As already indicated, these forms essentially agree in meaning (vegetable food). It should be further pointed out that this meaning can be argued for strongly as being in some sense 'basic'. One of Morris Swadesh's many valuable contributions to linguistics was his notion concerning the nature of the 'basic vocabulary' of a language. There is a very direct way, moreover, to demonstrate that the concept vegetable food is basic in Australian languages: to check whether there are any forms (other than reflexes of PNPN *naca) with this meaning which have a wide distribution; and any reputable Australianist will observe, of course, that reflexes of PNPN *mayi foot the bill here.

Once reasonably tight control of the sound correspondences is achleved on the above basis, the knowledge of the correspondences can 
then be turned around and used as a handle in the task of uncovering examples of semantic change. Thus, because of a rule which operated In the history of Adnyamathanha such that PNPN initial *c is reflected as $y$, we are not tempted to consider Adnyamathanha yarra- fazz and Nyangumarda ya-rra go! (1mperative singular) as cognates. Our conviction is strengthened by the knowledge that although the handful of PNPN monosyllabic verb roots were indeed reanalyzed during the history of Adnyamathanha (or 1ts immediate ancestor) in such a way as to make them agree in syllable count with the disyllabic majority, the extension was made via the old PNPN *-ku-suffix. Hence, for example, Adnyamathanha nga.l.ku- eat (with which compare verb root nga- eat in Nyangumarda, with optative nga-l-ku-) and nha.ku- see (vs. nya-see In Yulbaridja, optative nya-ku-ra).

In the light of the above considerations, the Adnyamathanha verb root yarra- is thus considered as a cognate of Gupapuyngu dhärra stand and the other reflexes of PNPN *caada-y-already presented herein.

The lesson which we learn from examples such as Nyangumarda jungka ground and Neo-Nyungar twangk ear is that no meanings can be considered a priori to be so far apart as to be unrelated. The evidence for the relatedness of the concepts GROUND and EAR in the languages so far examined appears to be overwhelming. It remains for the cultural context to be explained.

Procedures for establishing further such connections can usefully be 1llustrated through PP *minja animal, meat (reflected, for example, In Kuku-Thaypan nhye, Umpila minya, Wik Mungkan minh and Linngithigh nya, all of which descend with meaning unchanged). In any connections outside of Pamic which we will propose, we will not content ourselves with making off-the-cuff assertions, but will rather seek the most effective possible motivation for such assertions.

Some knowledge of the sound correspondences leads one to expect that a Wadjuk or Nyangumarda cognate of PP $\star_{m i n j a}$ will have an inftial $m$, followed by 1 , which in turn will be followed by a laminal nasal; in Nyangumarda only, the vowel corresponding to the PP *a can in this environment (1.e. following a laminal in the second syllable) be expected to be $i$. The leads, then, are very specific indeed, and we expect that the cognate shapes in Wadjuk and Nyangumarda, if they do turn up in these languages, will be minya and minyi respectively. The reader is urged to mark well the notion 'if they turn up'; one way in which language change manifests 1 tself is in the total disappearance of a morph from a language (as in the loss of quoth from modern English). Nevertheless, 'Seek and ye shall find'! Moore (1884:54) contains the 
entrles min-ya a sme $z z$ and min-ya dew; and in Nyangumarda minyi stench has already been cited. Bearing in mind the POTENTIAL:ACTUAL feature of Australian semantic systems discussed in O'Grady (1960) and Dixon $(1972 b)$, It seems reasonable to conclude that just as ANIMAL is the potential counterpart of (actual) MEAT, so also could MEAT be regarded as the potential counterpart of (actual) PUTREFACTION. And this supposition is borne out by the evidence from Karlera and Yulbaridja: in the former, mantu means meat, and in the latter we have mantu rotten.

If we now extend the search for cognates of PP *minja to the whole of Australia (but with our main hopes for success centring on the Pama-Nyungan languages, naturally enough), we are immediately struck by the existence of a whole swathe of languages in which minya = what?. In the far north, Yagar-Yagar miya.y what? evidently belongs with this assemblage, along with Dyirbal minya, Wangkangurru and Arabana minya, Dier1 minha and 'Narrinyer1' 'minye'- to c1te just a few examples - all of which mean what?. Languages in which the cognate form has undergone Idlosyncratic truncation (as with a high-frequency 1tem of English such as because > 'cause) Include Gidabal, in which nya.ng answers to what?; note also Antakirrinya and Pintupi nyaa, Mudbura nya.mpa, Walbir1 nyi.ya (nya.yi in Eastern dialect) what? and Walbiri nya.ngu.rla, Nyangumarda nya.nga when?. An underlying a is indicated for the second syllable of the 'Narrinyer1' form by 'minyai' what number? and 'minyandai' what times?, how often?.

It is interesting to note that the Pama-Nyungan languages in which

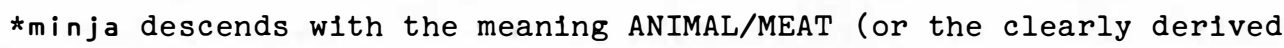
meaning SMELL-STENCH) and the languages in which the 'other' $\star_{m i n j a}$ is reflected are more or less mutually exclusive (and jolntly make up the major part of the roster of Pama-Nyungan languages). It is even tempting to suggest that one of the hallmarks of a Pama-Nyungan language

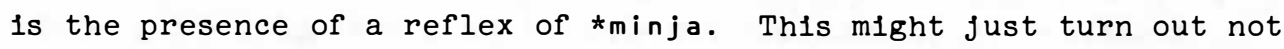
to be taking things too far! Moreover, it is also tempting to speculate that the first major breakup of the original Proto Pama-Nyungan speech community can be traced through the root which is under

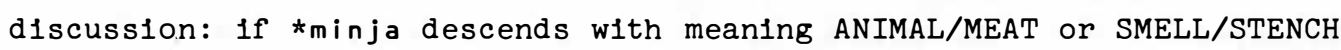
in a given language, then the language is a member of Group $A$; and if the meaning of the reflex of $\star_{m i n j a}$ is WHAT, then the language is a member of Group B. In other words, Pama-Nyungan languages might be thought of as having undergone a MEAT:WHAT split, Just as IndoEuropean languages divide themselves (according to an important phonological criterion) into Centum-languages and Satem-languages. 
But we are 'Jumping the gun' here a little. Can substantive evidence be brought to bear to demonstrate that all of the minya-forms in PamaNyungan languages descended from a single root? My claim is that there is such evidence, and that 1 t is to be found in the reflexes of a PNPN root so far not discussed herein, namely *wara. But more of *waara anon.

After their dally forays for game in their small Urhelmat in central northern Australia, members of the original Pama-Nyungan speech community must regularly have been greeted with a stock phrase, * naana minja what meat?. Over a period of time, a segment of the community came to accept successive truncations of this basic query: first *'na minja, and finally just *minja, which thus came to be interpreted by succeeding generations of speakers as an alternative non-human interrogative pronoun; * gaana, the old word for what?, was gradually crowded out.

Returning now to the question of *wara, we will find it appropriate to take the Pamic languages once again as a starting point. The human interrogative pronoun is reconstructed in PP by Hale as *wari(-na). Reflexes Include Umpila wa'i who?, which in the ERGATIVE case takes the form wadin.ju-lu (in which, historically, ergative has been marked twice over - cf. English child.r-en). I take this ergative form to be evidence for a pre-Umpila root shape, namely *waarin(a) < *warinj(a). This in turn was made up of root *wara plus suffixed $*-n j(a)$, the latter reflecting PNPN *-nja, which appears In Pama-Nyungan languages commonly as an object marker on proper nouns, and in some cases marks proper nouns as such.

Other Pamic evidence for PP *wari(-na) Includes Wik Mungkan wee', Uradhi arri-, Linngithigh a'i-who?. Far to the south, we have Dier wara.nha and Wangkangurru, Arabana wara who?. The comparative evidence, for example Ump1la ma'a, Wangkangurru and Arabana mara hand < PNPN *mara allows us full confidence in assigning cognation here.

The question arises, what was the referent of PNPN *waara? The answer appears to be that it was not who?. The evidence for this claim comes especially from Gumbalnggar wan face, forehead and Wirangu waa face. Notice that glide deletion occurs in a number of Australian languages, although it is by no means easy to determine the precise conditions under which it operates (borrowing no doubt contributes to obscuring the picture). Nonetheless, Wirangu maa vegetable food < PNPN *mayi is instructive.

It is very plausible that in PNPN times another stock question frequently heard was * gaana-nja wara what-HUMAN face?, 1.e. who is it?, 
asked in situations where a visitor's 1dentity was unknown. This likewise came to be truncated to *wara by some speakers, so that their descendants came to use *wara in the sense of who?/somebody. Meanwhile, the laminal nasal of the $*-n j a$ suffix exerted a fronting effect on the preceding *a in the form *naana-nja (as used by another segment of the original PNPN speech community); *naana was subsequently reanalyzed as *naani by some speakers.

The original FACE referent of *wara showed semantic specialization in another direction also. Conceptually, FACE/FOREHEAD and VERTICAL are interrelated in Australian languages. Consider, for example, the following reflexes of PNPN *IAlja:

$\begin{array}{lll}\text { Nyangumarda } & \text { ngalyi } & \text { neck } \\ \text { Yulbaridja } & \text { ngalya } & \text { face } \\ \text { Pintup1, Walbirl } & \text { ngalya } & \text { forehead } \\ \text { Plttapitta } & \text { ngalya } & \text { cheek } \\ \text { Walbir1 } & \text { ngalya.rr-pa } & \text { sandhill and, perhaps - } \\ \text { Walbirl } & \text { ngalya.lki } & \text { flame, fire without smoke } \\ \text { Warburton Ranges } & \text { yapungalya cliff (yapu stone) }\end{array}$

So also, then, in Walbir1 wara.rra is cliff, precipitous mountainside. It is worth pointing out that English face is used in a very comparable way, as in sheer face of rock. Nyangumarda wara.rr (noun) standing and Gadhang wara-stand (up), step from opposite sides of the continent could be taken as evidence that the semantic development FACE $\longrightarrow$ (BE) VERTICAL is quite ancient in Pama-Nyungan.

Still another line of semantic development led to Nyangumarda wara.ja one and wari.ny other, as well as to Yagar-Yagar wara other. Finally, Ngarluma wara clothing and Nyangumarda wara rag appear to be derived from the general notion THING, which is a very plausible antonym of FACE/PERSON. The intimate relationship between FACE and PERSON is generally evident in languages of the world, including English. More particularly, however, note PNY * nadka > Ngarluma ngarrka face, Yulbarldja ngarrka chest and Walbirl ngarrka fully initiated man; also PNPN * guumpa > Karlera, Nyangumarda ngumpa (and, with as yet unaccountable Initial k, Yindjibarnd1, Bandjima, Nyamarl kumpa) face, Pintupi ngumpa shade or shade shelter, DJaru ngumpin man and Umpila nguumpa large black stingray. The connection between FACE and STINGRAY should be acceptable to anyone who has contemplated the striking but spurious face on the underside of these creatures.

It may well be that future research will show some of the lines of semantic shift suggested in the previous pages to be unsupportable. By and large, though, it does seem that correlations are beginning to 
emerge which further work can be expected to make fully acceptable. To this writer at least, several of the more extensive interlocking networks of evidence presented here appear to be well-nigh unassallable. In any event, it is cruclal that further research take fully into account the tangled web which Pama-Nyungan diachronic semantics - let alone Australian diachronic semantics! - promises to be.

The above hopefully constitutes an intelligible outline of some of the problems inherent in Nuclear Pama-Nyungan comparative reconstruction. The establishment of the principles stated above has resulted in an increase in the number of cognate sets to the point where their sheer volume has begun to pose real problems of manageability. What was indicated was a narrowing of the focus so that protoforms containIng a given initial consonant could be researched en bloc. Thus, after assembling 850 cognate sets, I began to focus my attention exclusively on the 120 sets which descended from protoforms beginning with the laminal stop *c. Since 850 divided into 120 is $14 \%$ or approximately oneseventh, it follows that whatever percentage of increase in the number of the *c- sets was made possible by exclusively concentrating on this Initial could be predicted to apply approximately to the entire body of sets. The *c-sets were in fact ultimately increased in number to 200 - 1.e., an Increase of two-thirds was effected. There is thus good reason to expect that the overall number of reconstructions will eventually 'bottom out' at around 1,400.

My cholce, albelt arbitrary, of *c- as a starting point for preparIng the material for possible publication forced a further decision namely to follow up immediately with work leading to protoforms in *yand $*_{n j-}$, since residual problems centring on forms with initial *c might well turn out to be resolvable once careful attention is given to other laminal-initial forms. It is hoped that two years will be sufficient for the preparation of a fascicle for each initial consonant (or group of initials, in the case of the low-frequency apicals). Thus the first version of the work may be complete by 1994.

Brief illustration of some of the phonological pitfalls in PNPN comparative reconstruction can be given here. If, for example, one's focus is PNPN protoforms in *c-, then Nyangumarda japa.rtu father is not relevant (it reconstructs back to PNPN *yapa). Nor is Ngarluma thaka-l-take, grasp (from ancestral *taka), Ngarluma japu.rta beard (< PNPN *tapu) or Ngarluma thumpu anus (< PNY *lumpu).

On the other hand, Uradhi forms with initial /// are grist for our mill: lalan tongue goes back to PP *calan, and further, to PNPN *calanj; lutpi stomach reflects $P P{ }^{*} c u l p i$; and lipa liver (wh1ch need not be taken as a loan from English!) reflects PNPN *cipa perfectly 
regularly. Then again, since one of the sources of Umplla Initial $\mid y /$ is $P P * c$, we w1ll be concerned to take account of such forms as yuma fire (< PP *cuma) and yipa liver, also < PNPN *cipa.

Then, too, Arabana, etc. parrku.lu two might not at first blush seem at all relevant to protoforms beginning with *c. Yet if considered in the light of Thalandj1 jarrku.rti, Yindjibarnd1 and Kurrama jarrwu.rti, Warriyangka jarrku three, then the parrkulu forms in Arabana, Wangkangurru and a number of nelghbouring languages can be viewed as the result of reanalysis of the initial consonant in PNPN *cAdku; and the pressure leading to this reanalysis was exerted by a reflex of PNPN *pula two. In Indo-European, a comparable development can be seen in the effect which the word for ten exerted on the initial consonant of the word for nine in Proto-Slavic, so that modern Russian has alongside дЕсять déśat ten дЕвять dévát nine, with Initial $d$ in place of the expected Indo-European reflex, $n$.

Let us conclude this preliminary presentation of some aspects of Pama-Nyungan comparative linguistics with a short wordlist in five of the languages arranged on the basis of the referent range of each 1tem, but with cognates 1dentifled by 1dentical numbering.

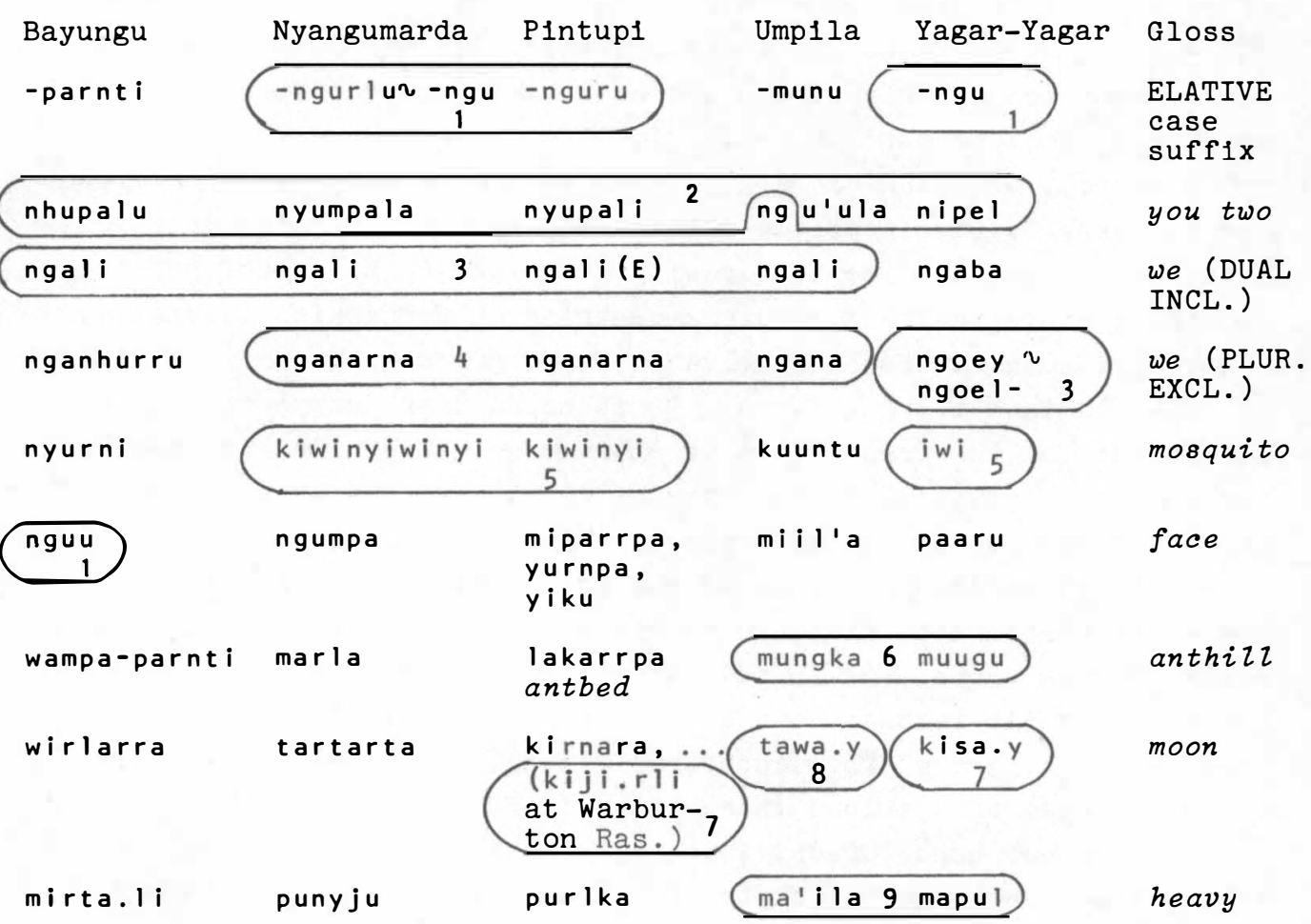




\begin{tabular}{|c|c|c|c|c|c|}
\hline Bayungu & Nyangumarda & Pintup1 & Umpila & Yagar-Yagar & Gloss \\
\hline kamu 10 & janparr & $\begin{array}{l}\text { parljaji- } \\
\text { rraja }\end{array}$ & uuli & yaraaga & hungry \\
\hline jitarn & & nyanka & kupun & kothey & nape \\
\hline$\underset{8}{j a p u} \cdot r t a$ & $\begin{array}{c}\text { ngarnka } \\
12 \\
\end{array}$ & ngarnkụr & puujan & yatha & beard \\
\hline - & kawu & yarna.ngu & ya $1 \mathrm{mp}$ & $\begin{array}{c}\text { ga amu } \\
10\end{array}$ & body \\
\hline karta.ra & ngalkungalku & murramurra & walu & daaka & cheek \\
\hline mangku.rtu & $p \mathbf{i} \mathbf{j} \mathbf{i} \cdot r \mathbf{r}$ & milka.rli & $\begin{array}{c}\text { kamu } \\
10\end{array}$ & $k u l u . k a$ & blood \\
\hline jirnti & parlparr & $\begin{array}{c}\text { ngarnka } \\
12\end{array}$ & - & $\begin{array}{c}\text { dapa.r } \\
8\end{array}$ & $s k y$ \\
\hline
\end{tabular}

Note that Umpila ngu'ula shows the effect of reanalysis in the initial consonant, with earlier laminal nasal being replaced by $n$ g under the pressure of first person forms such as ngali. Not given in the table is Umpila ngampu.la we(PLURAL INCLUSIVE), which reflects the first alternant of PP *nampul(a) nampa; the second alternant is reflected, for example, in Wik Mungkan ngamp with 1dentical meaning, and answers well to Yagar-Yagar ngaba.

Proto Nuclear Pama-Nyungan distinguished fourteen consonants and three vowels. In addition, the vowel in the first syllable of a root showed distinctive length. The stops were articulated at four positions: $\star_{p}$ (bilablal), $\star_{t}$ (apical), ${ }^{*} c$ (laminal) and $\star_{k}$ (velar). These were matched by nasals $\star_{m}, \star_{n}, \star_{n j}$ and $\star_{n}$. There were two laterals - apical $* l$ and laminal $* 1 j$; one rhotic with apical contact, hereln symbolized as *d; and three glides - lablovelar ${ }^{*} w$, rhotic * $r$ and laminal $* y$. The vowels were high front $* i$, high back $*_{u}$, low back

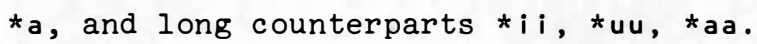

Most conspicuous in the phonetic realization of forms were:

1. All words were stressed on the first syllable.

2. All consonants had fortis allophones following a short stressed vowel, and lenis allophones elsewhere.

The PNPN Inventory of distinctive sound segments was, then: 


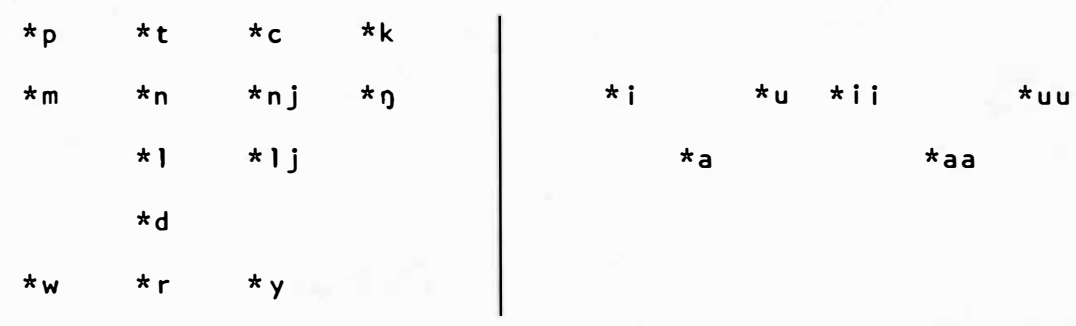

Adequate validation of this system will have to await the publication of full comparative data from representative Pama-Nyungan languages. In the meantime, it is hoped that this paper will serve two purposes. Firstly, it should provide the reader with some preliminary orientation concerning the writer's views on a number of aspects of phonological, analogic and semantic change in the languages under study; secondly, the assertions made will hopefully open this arena to further productive dialogue. 


\section{NOTES}

1. The work was supported through Grant No. GS-1624, administered by the University of Hawa11. I would like especially to thank Dr George Grace, Dr Bob Hsu and Dean Howard McKaughan for their guidance, support and encouragement.

2. For this reason $I$ am at a loss to understand what Dixon means by 'Proto-Australian'. The very title of his article, 'Proto-Australian Laminals', cries out for explanation, though the paper itself is an excellent contribution to the study of diachronic Pama-Nyungan phonology.

3. Methodologically, the appropriate procedure would be to compare Tiw1 to the remotest possible reconstructible ancestor of Nyangumarda Proto Pama-Nyungan. If this were done, however, the result would be the same: there would be virtually no potentially related material to work with.

4. Forms are presented in a spelling which adheres, for the most part, to the present-day Walbirl orthography. If allowance also be made for sounds not occurring in Walbirl, the scheme of symbols for consonants is as follows:

\begin{tabular}{|c|c|c|c|c|c|c|}
\hline & B1lablal & $\begin{array}{l}\text { Lamino- } \\
\text { Dental }\end{array}$ & $\begin{array}{l}\text { Apico- } \\
\text { Alveolar }\end{array}$ & $\begin{array}{l}\text { Ap1co- } \\
\text { Domal }\end{array}$ & $\begin{array}{l}\text { Lamino- } \\
\text { Alveolar }\end{array}$ & $\begin{array}{l}\text { Dorso- } \\
\text { Velar }\end{array}$ \\
\hline STOPS & p & th & $\mathrm{t}$ & $r t$ & j & k \\
\hline FRICATIVES & & & $s, z$ & & & $g h$ \\
\hline NASALS & m & $\mathrm{nh}$ & $n$ & $r n$ & ny & ng \\
\hline LATERALS & & Ih & 1 & $r l$ & Iy & \\
\hline FLAP/TRILL & & & $r r$ & rd & & \\
\hline GLIDES & $w$ & $y h$ & $r$ & $y$ & & \\
\hline
\end{tabular}


In languages with two serles of stops, the volced (or lenis) serles is symbolized $b, d h, d, r d, d y, g$; in languages with a rhotic trill contrasting with a flap (such as Adnyamathanha), the trill is written as rrr. No confusion arises from assigning rd double duty (apicodomal flap and volced/lenis apico-domal stop), since no single language has been encountered in which both are distinctive. Notice that I consider $r t, r n, r l$ to be clusters, as proposed in Hoard and O'Grady (1976). I have now abandoned the earlier claim that the rhotic flap/ trill in languages such as Nyangumarda is to be analyzed as a cluster consisting of two $r$ glides; the spelling convention $r r$ is thus held to be merely a convenient way of symbolizing rhotic flap/trill /ř/. Vowels are written $\mathbf{i}, \mathbf{e}, \mathbf{a e}, \mathbf{a}, \mathrm{o}, \mathrm{u}$, and with digraph oe for schwa. Where length is contrastive, the symbols are doubled: ii, ee, etc., and with ooe for long schwa. Since Gupapuyngu has a well-established orthography and literature, I am adhering to the accepted usage, in which short vowels /i, a, u/ are written $\mathbf{i}, \mathbf{a}, \mathbf{u}$, and the symbols for long vowels /i:, a:, u:/ are e, ä, o. The Gupapuyngu velar nasal is written as $\mathrm{j}$. In the case of pre-scientific materials, experience teaches that tampering with the spellings has all too often been counterproductive. I therefore choose to leave spellings used in Moore and other 19th century sources strictly alone; the reader is reminded of their status by the use of single quotation marks. If sensibilities are affected by these conventions, I gladly apologize in advance. To me their justification is that they immeasurably facilitate Australian comparative work.

5. As indicated elsewhere, I prefer to refer to the family dominated by this node as 'Pama-Nyungan', following Hale (1966).

6. See Hoard and O'Grady (1976) for a discussion of the synchronic aspect of the same rule.

7. O'Grady (1966) discusses frozen suffixes such as this ka in some deta1l. The convention used for 1dentifying them continues to be dot.

8. Quite possibly a mistranscription of wirnpal-pi-1-.

9. The Duungidjawu example is from Wurm (1976:109) and was brought to my attention by Kenneth Hale. 


\section{BIBLIOGRAPHY}

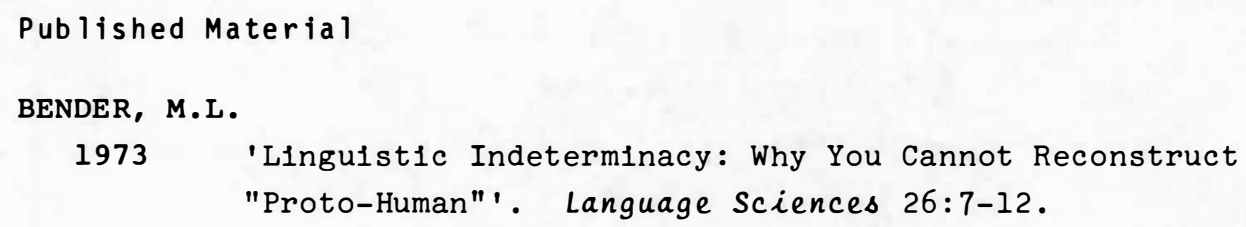

1956 A New Approach to Australian Linguistics. Oceania Linguistic Monographs 1. University of Sydney.

CROWLEY, T.M.

1976 'Phonological Change in New England'. In: Dixon, ed. 1976:19-50.

CURR, E.M.

1886-87 The Australian Race. 4 vols. Melbourne: John Ferres, Government Printer; London: Trübner. 
DIXON, R.M.W.

1970 'Proto-Australian Laminals'. Oceanic Linguistics 9/2:79-103.

1972 The Dyirbal Language of North queensland. Cambridge:

Studies in Linguistics 9. Cambridge Univers1ty Press.

DIXON, R.M.W., ed.

1976 Grammatical Categories in Australian Languages. AAS, L22. Canberra: Australian Institute of Aboriginal Studies.

DOUGLAS, W.H.

1958 An Introduction to the Western Desert Language. Sydney: Oceania Linguistic Monographs 4.

1968 The Aboriginal Languages of South-west Australia. AAS 14, L4. Canberra: Australian Institute of Aboriginal Studies.

EADES, D.K.

1976 'Gumbaynggir'. In: D1xon, ed. 1976:238-42.

GEYTENBEEK, B. and H. GEYTENBEEK

1971 Gidabal Grammar and Dictionary. AAS 43, L17.

Canberra: Australian Institute of Aboriginal Studies.

HALE, K.L.

1966 'The Paman Group of the Pama-Nyungan Phyl1c Fam1ly'.

In: O'Grady, Voegelin and Voegelin, eds 1966:162-97.

1976 'Phonological Developments in a Northern Paman Language: Uradh1'. In: Sutton, ed. 1976:41-9.

HANSEN, K.C. and L.E. HANSEN

1974 Pintupi Dictionary. Darwin: Summer Institute of Linguistics, Australian Aborigines Branch.

HERCUS, L.A.

1969 The Languages of Victoria: A Late Survey (Part II).

AAS 17, L6. Canberra: Australian Institute of Aboriginal Studies. 
HOARD, J.E. and G.N. O'GRADY

1976 'Nyangumarda Phonology: a Preliminary Report'. In: Dixon, ed. 1976:51-77.

HOLMER, N.M.

1967

An Attempt Towards a Comparative Grammar of Two

Australian Languages. Part II. Indices and

Vocabulary of Kattang and Thangatti. AAS 5, L3, part 2. Canberra: Australian Institute of

Aboriginal Studies.

KLOKEID, T.J.

1969 Thargari Phonology and Morphology. PL, B-12.

1976 'Lard11'. In: Dixon, ed. 1976:550-84.

MOORE, G.F.

1884 Diary of an Early Settler in Western Australia, 1830-1841; and A Vocabulary of the Language of the Aborigines. Sydney: Selwyn and Co.

MULVANEY, D.J.

1969 The Prehistory of Australia: Ancient Peoples

and Places. London: Thames and Hudson.

O'GRADY, G.N.

1957 'Statistical Investigations into an Australian

Language'. Oceania 27/4:283-313.

1960 'More on Lexicostatistics'. Current Anthropology $1: 338-9$.

1966 'Proto-Ngayarda Phonology'. Oceanic Linguistics $5: 71-130$.

O'GRADY, G.N., C.F. VOEGELIN and F.M. VOEGELIN

1966 Languages of the world: Indo-Pacific Fascicle Six. Anthropological Linguistics $8 / 2$.

OSBORNE, C.R.

1974 The Tiwi Language. AAS 55, L21. Canberra: 
Australian Institute of Aboriginal Studies.

RIGSBY, B.

1976 'Kuku-Thaypan Descriptive and Historical Phonology'. In: Sutton, ed. 1976:68-77.

SCHEBECK, B.

1976 'Yuulngu'. In: Dixon, ed. 1976:352-82.

SHUTLER, R., Jr and M.E. SHUTLER

1975 Oceanic Prehistory. Menlo Park: Cummings

Publishing Co.

SMYTHE, W.E.

1948 Elementary Grammar of the Gumbaingar Language

(North Coast, N.S.W.). Oceania Monograph 8.

Sydney.

STREHLOW, T.G.H.

1942 Aranda Phonetics and Grammar. Oceania Monograph 7. Sydney.

SUTTON, P.J., ed.

1976 Languages of Cape York. AAS, RRS 6. Canberra:

Australian Institute of Aboriginal Studies.

TAPLIN, G.

1879 'Grammar of the Language Spoken by the Narrinyer1

Tribe in South Australia', in (his) The Folklore

Manners and Customs of the South Australian

Aborigines. Adela1de: Government Printer.

WURM, S.A.

1972 Languages of Australia and Tasmania. Janua Linguarum, Series Critica 1. The Hague: Mouton.

1976 'Accusative Marking in Duungidjawu (Waga-Waga)'. In: Dixon, ed. 1976:106-11. 


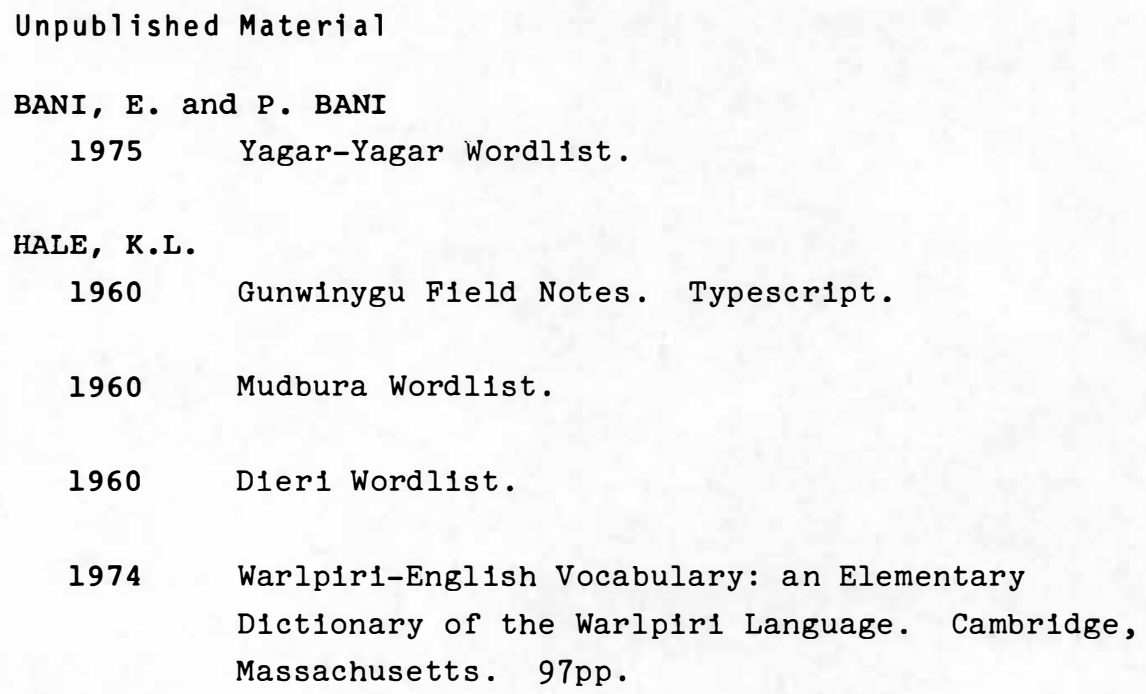




\section{GRAMMATICAL CLASSIFICATION IN AUSTRALIA}

A. Capell

\section{INTRODUCTION: Types of Classification - Nouns and Verbs}

Australian languages as a whole are not amongst those which recognise gender or other forms of classification in nouns and dependent categories. There are, however, certain limited areas where phenomena of this kind appear, and these are indicated in Map I. They are subdivisible as follows:

1. regions in which a distinction between feminine and non-feminine is found;

2. regions in which nouns are classified into sensegroups by a method here called 'determination';

3. regions in which nouns are classifled into groups marked by suffixes or prefixes, or both in combination, involving a grammatical concord within the utterance, in a manner resembling those of the Bantu languages of Africa, but less complicated.

With one exception, all these languages are found in an area north of $18^{\circ}$ south latitude, and spread over the continent from the Northern Kimberley Division to Cape York Peninsula. Marking by a dichotomy of feminine $v$. non-feminine is found occasionally south of this latitude, and a multiple class system by suffix occurs in isolation on the north coastal area of New South Wales.

The first part of this paper discusses the phenomena of the different languages and suggests ways in which these may have developed, though it still remains impossible, for lack of diachronic evidence, to assign any time scale for their establishment. 


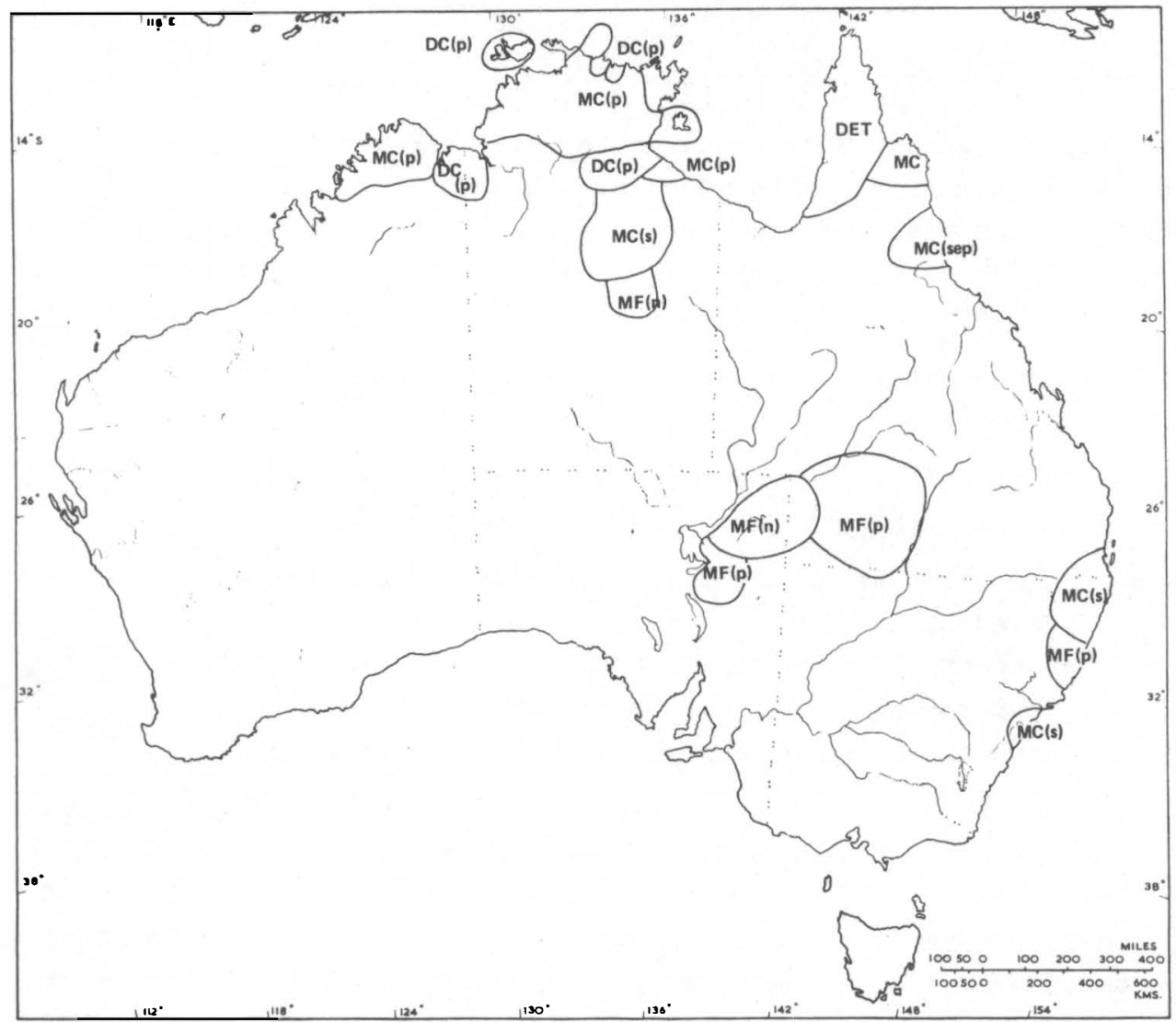

Map I: Noun Classificstion 


\section{LEGEND TO MAP 1: NOUN CLASSIFICATION}

KEY :

MC

Multiple classifying, either

MC (p) multiple classifying by prefix

or

MC (s) multiple classifying by suffix;

MC (sep) multiple classifying by separate markers.

DC Dual classifying, either

DC (p) dual classifying by prefix

or

DC (s) dual classifying by suffix.

DET Use of determinatives.

MF Distinction of masculine-feminine, either

MF ( $n$ ) distinction in noun forms

or

MF (p) distinction only in third singular pronouns. 
One instance at least will appear in which the noun itself carries no marker, but is preceded by a local demonstrative which varies for class. Th1s language is DJ1rbal, in north-eastern Queensland. In the heart of the most complicated area in Arnhem Land, there is a case in which a kind of 'article' occurs, which is repeated along with an adjective following a noun; here some stem variation is simultaneously possible. This happens in Mawng, in north-western Arnhem Land.

In certain instances also, the grammatical feature of possession of an object may exert influence on the form of the noun, apart from the class-marker such a noun may bear. Th1s has been called 'prefixpossessive' concord.

Noun classification, however, is not the only type of classification found in Australian languages, although it has been so stressed that in practice 1t is the type most thought of when the term 'classification' as a grammatical process is thought of. There is, however, classification of verbs also. In some languages the verbal stem is confugated by suffix or less commonly by prefix, as, for instance, in Latin and European languages as a whole. The Latin type is represented by such roots as am-o, hab-e-o, etc. But there is also a Latin type such as gratias ag-o, I thank, I give thanks. Here a noun stem is supported by a verbal stem without which 1t cannot be confugated. In Australia, many languages have such double verbs. In Ngarinfin, for instance, one says a-n-ulu-n, him-I-give-pres,; but one says wula n-ama-nanga, speech I-do-to-him, I speak to him. It is impossible to say simply *a-n-wula-n. In the Northern Kimberley and some areas of Arnhem Land, it seems that the decision depends on whether the verb stem begins with a vowel (when it can be conjugated as a simple verb) or a consonant, when it is confugated as a compound verb with some kind of auxiliary. The matter is not really quite as simple as this. Different auxiliaries may change the nuance of meaning. In Ngarinjin, maRa a-n-o-ni, seeing I-him-do-past, I saw him, Implies a simple act of vision; but maRa a-n-ela-ni, seeing him-I-hold-past, is rather I stared or gazed at him. In Ngarinjin there are eleven such auxiliaries, all of which have specifled uses.

\section{DICHOTOMY OF FEMININE v. NON-FEMININE}

The languages included in this group have a system of classification very like those of the modern Romance languages, 1.e. they distinguish feminine from masculine among living creatures; inanimate nouns are not marked. For this reason it is inappropriate to speak of a masculinefeminine division. Any noun that is not feminine falls into the other 
class. Feminine is marked (usually by suffix) non-feminine is unmarked. Perhaps Latin may provide a rough parallel in that the basic gender system in Latin is masculine-feminine: the neuter is really a special subgroup of the masculine, agreeing with the latter in most of 1 ts endings (except a formal nominative-accusative division in the neuter), but having a separate set of case markings for feminine. The difference is that in Latin and the Romance languages, the gender is 'grammatical', 1.e. largely independent of actual fact, while in the Australian languages, as in English, only female reference is marked as feminine. Pronouns under this system mark she as distinct from he and $i t$, but do not distinguish the latter two.

The area of occurrence of this type of noun classification is listed by Schmidt (1919b:11-12) as that of the Kana languages of his South Central Group, those of his Middle and North Kurl Group, Bandjalong and Halifax Bay in North Queensland. For these he gives the following forms :

\begin{tabular}{lllll} 
& \multicolumn{2}{c}{ Masculine } & \multicolumn{2}{c}{ Feminine } \\
Nom. & Erg. & Nom. & Erg. \\
Diyarl & nau & nulu & nani & nandru \\
Kana-type & nu: & nu:du: & nun & nundu \\
Darginjung & njuwa & nowa(ngay) & nunduwa nona (ngay) \\
Awaba & njuwawa nuwa & buwundua \\
Gadhang & njuwa & & njunda, njuduwa \\
Bandjalong & njuli & njulaju & njan njandu ${ }^{1}$ \\
Yugumbir & $n j u l a$ & & $n j u l a g a n$
\end{tabular}

Schmidt's entry for 'North Hallfax Bay' 1 s masc. baiu, fem. ya:lu., but the allocation to precise languages is uncertain and these are better disregarded.

There is one occurrence of a masculine-feminine distinction that has been noted by Capell in the Roper River area, among prefixing languages: Mara has a distinction of two genders in the 3rd person singular pronoun and in the demonstratives. This distinction is found

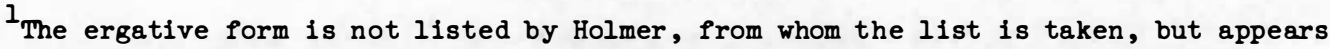
to be likely in the language. It may be noted in passing that ergative and nonergative languages both share these features.
} 
also in Alawa, but in the latter language the adjective is involved along with the verbal subject in the concord. Alawa is therefore classed with the dual-classifying languages, while Mara belongs to the group here under consideration. Mara is not an ergative language, and the pronominal forms are only nangaya, he and jayara, she. The two sentences this man is dead and this woman is dead appear in Mara as:

$$
\begin{aligned}
& \text { 1. gariyimar ninja gabar uma } \\
& \text { man this dead is } \\
& \text { 2. giriya ginda gabar uma } \\
& \text { woman this dead is }
\end{aligned}
$$

as against the Alawa equivalents:

$$
\begin{aligned}
& \text { 1. lilmi ni:nda waynma niri } \\
& \text { man this dead is } \\
& \text { 2. giriya anninda anwaynma ari } \\
& \text { woman this dead is }
\end{aligned}
$$

where a prefix an- marks the feminine in both demonstrative and adjective, with the verb differently marked for gender.

In Mara, however, a delctic nana serves to define nouns elther masculine or feminine or referring to things: nana barawu, the ship (Malay prau); nan djanawa, the little girl. It is usable even with a noun that carries a bullt-in possessive: nana wabimar, your father a special 2nd person form.

A short form na- is very frequently prefixed to non-feminine nouns: na-bulan, the bucket; even place names such as na-Darwin and as in the sentence naggaya na-wambi-yu, he (is) the-house-at or he is in the house. There is a much rarer feminine prefix $n j a-$, as in $n j a-r a d b u r-y u$ wa-lindu, the camp-to he-goes; dala gunbu nja-nalwar-yu, she fell the ground-to, or nja-jugu-yu, into the water. In most cases this does not seem to be considered necessary when the noun refers to a feminine person, as in the two sentences

$$
\begin{aligned}
& \text { bandi wu:wa djawulba, head give (to) old-man } \\
& \text { wu:wa du:la djawulba ginja, give leg (to) old-woman that }
\end{aligned}
$$

The definite appears in the last element of the following sentence but not in the first element which is clearly feminine:

$$
\text { giriya badada gudid gaganja na-ralga }
$$

(the) woman baby wizl-carry (in) the-bag 
there is no corresponding plural or dual, unless the normal markers of the noun (wuru-dual, and wala-plural) are to be so considered.

The same prefix na- will appear in the MC languages of Rose River and Groote Eylandt, where they can be preceded in turn by the noun class marker, e.g. Rose River: a-Ranag, a-na-Ranag, wood, tree. There is a similar difference of degree of definiteness.

\section{GRAMMATICAL CLASSIFICATION OF NOUNS}

Amongst the systems in which the classification of nouns is different from those known in European languages, several subgroups can be distinguished.

1. The languages of Cape York area of North Queensland.

2. The languages of north-eastern New South Wales.

3. The languages of Arnhem Land and the Northern Kimberley,

(a) classification by suffix,

(b) classification by prefix.

Both types may occur at once: a noun may carry prefix and suffix at the same time - sometimes but not always the same morpheme: the form is $P+R+S$, where $P=$ prefix, $R=$ root, and $S=$ suffix. Some languages have $R+S$, some have $P+R+S$, and some have $P+R$. The impression that grows up in a comparative study of these languages is that the real pattern is $P+R+S$, but that in some areas it becomes $\phi+R+S$, and in others $P+R+\phi$. In areas where one of the $\phi$ forms occurs, the $\phi$ can often be filled in adjectives or other parts of speech by the missing member of the pair, 1.e. the $P+R+S$ system would seem to be original. This claim will be abundantly 1llustrated in subsequent pages. In the rarer cases in which possession is marked by a prefix, this prefix may, in a very few languages, supplant $P$, and occur in the concord of the noun phrase and even the verb phrase. Here, using $p=$ possession, the pattern would be $N=p+R \pm S$, and the noun phrase would appear as

$$
N P=p+R \pm S \rightarrow p+A \pm S \rightarrow
$$

Here, my strong right arm would be represented by a pattern such as $\mathrm{p}+\operatorname{arm} \pm \mathrm{S} \rightarrow \mathrm{p}+$ strong $\pm \mathrm{S} \rightarrow \mathrm{p}+$ right $\pm \mathrm{S}$, $\mathrm{p}$ belng in each case the prefix representing $m y$.

In most of these complicated classification systems, the number of the noun is either not represented, or only in nouns referring to living human beings. 


\section{CLASSIFICATION BY DETERMINATIVES}

\subsection{Cape York Peninsula Languages}

In the languages of Cape York, a type of classification is often found in which a generic noun precedes a specific, e.g. animal horse for horse. The generic noun $c$ an be used independently if desired, but as a rule the specific noun will not be used alone. The term 'determinative' applied to such compound expressions rests on the hleroglyphic 'determinative' frequently found in Assyrian and Egyptian scripts, which precedes (or at times follows) a word in hieroglyphic or cuneiform script, to make clear what particular object is intended. A certain word may be a common noun, but in the context is referring to a person or place, and 1s preceded by the symbol for town, god, king, etc. This is precisely the function of the generic term in the languages under discussion. The term was introduced by Capell (in Capell 1956:44).

One of the clearest examples of this type of classification is seen in the Thayorre language of Cape York (Hall 1972:70). Hall finds that 'at least 15 indeclinable classifiers distinguish all nouns by their presence or absence', e.g. min, huntable prey; yak, snakes; Rur, insects; raak, times; nan, relatives; nok, liquids, etc. These are then followed by a specific noun, the two in compounding acting as a single word-phrase, e.g. min mopjun, pied goose; Rur mopjun, butterfly, moth. Sometimes the specific can be used alone, but then with a different significance, e.g. wan, ghost, devil, white man > min wan, enormous eagle. Once the phrase has been used, the determinative may replace the spec1f1c: min koton... min iñ'n... this... In this situation there is no parallel with prefixes of noun class farther west: they can never be independent forms. Hall adds: 'Classifiers are phonologically, not grammatically, bound to a head. All are obligatory except (kuta) yarman, horse.'

This phenomenon has considerable spread in this part of Australia; nor is it actually limited to Australia. More frequently such markers appear as numeral coefficlents in languages of South-East Asia and elsewhere. They seem to be quite an old device of language to specify meaning. It will appear later that some, at least, of these determinatives have served as points of origin for class markers found farther west. This applied especially to a root *mayi, vegetable food, which appears in the more westerly languages of this type as ma-, prefix for trees, foods, and showing, in spite of varying uses in different languages, 1ts origin as a free determinative. In Maranunggu of the Daly River area, the word appears in reverse shape as miya, vegetable 
food, and as an element in mlya berlya, water $z_{i} z_{y}$ and other food names (Tryon 1970:52. See 5.5. infra.).

\subsection{The Djirbal Phenomenon}

There is one region in Australla where free forms are used to mark noun classes. This is in North Queensland, in the region of Cairns, amongst what has been called the Rain Forest peoples. The language best known and used here as 1llustration is Dflrbal, a detalled study of which is to be found in Dixon's The Dyirbal Language of North queensland (Dixon 1972:44 and refs.).

There are several features which mark this language of from others:

1. The markers, four in number, precede the noun, but do not require concord throughout the NP, and do not influence the VP at all, except for certain directionals.

2. They are not equivalent to a definite article, although they occupy the same position in the sentence as the articles do in English. At the same time they are not equivalent to the similar markers in Mawng (Capell and Hinch 1970), although they occupy the same position in the sentence - moreover the latter are repeated with each element of the NP. Semantically they do not carry the same idea of definiteness.

3. There is a strong localising idea in them.

4. Each class has three markers, which are concerned with the distance of the referent from the speaker:

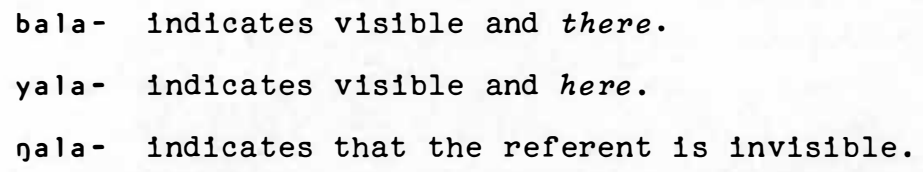

5. The number of referents is not involved, as is the case with some of the prefixed markers in other languages.

The nominative forms of the indicators are somewhat irregular. They are formulated as follows:

\begin{tabular}{|c|c|c|c|c|c|c|c|}
\hline Cl. I. & $\begin{array}{l}\text { bayl } \\
\text { glyi }\end{array}$ & II. & $\begin{array}{l}\text { balan } \\
\text { ginjan }\end{array}$ & III. & $\begin{array}{l}\text { balam } \\
\text { ginjam }\end{array}$ & IV. & $\begin{array}{l}\text { ba la } \phi \\
\text { ginja } \varnothing\end{array}$ \\
\hline & Dayi & & galan & & galam & & gala $\phi$ \\
\hline
\end{tabular}

(Dixon 1972:45). 
These are not comparable with the forms used in any of the other Australian languages treated here. They locate rather than define in the sense that articles define in most European languages, 1.e.

$\begin{array}{llll}\text { balan djugumbil nangul } & \text { yaRangu bayan } \\ \text { there woman } & \text { (invisible) } & \text { man sings }\end{array}$

man is heard, but not seen, singing to woman there (D1xon 1972:46).

The semantic range of each class often seems hard to define. Dixon elsewhere (1968:120) summarises them in terms of certain basic concepts:

C1. I (bayi): animateness; (human) masculinity.

Cl. II (balan): (human) femininity; water; fire; lightning.

Cl. III (balam): edible vegetables and fruit.

C1. IV (bala $\phi$ ): is a residue class, dealing with everything else.

He admits that the scope of Class IV is very unsatisfactorily defined but a similar problem has come up in other MC languages concerning a corresponding class. He goes on to specify some more detalled rules for classification which are not required here. The concern here at present is rather with the forms than the usage of these classes. It is quite clear that in DJirbal the same problem of classification as in other languages has been solved in a very different way. The historical question is whether this represents a later or an earlier solution than in the north of Australia. This question will be reserved for the closing section of the paper.

Another important point is that DJirbal is an ergative language, and therefore the ergative is expressed in the markers. This is done in a rather complicated way; the marker carries three parts: stem, case, class sign. The nominative is zero, and in most cases irregular. Taking Cl. I marker bala-, the nominative is ba-yi; the ergative (instrumental) ba-ggu-1; dative ba-gu-1, genitive ba-gu-1; in Cl. I yala-forms replace the stem itself by giyi, giving giyi, ya-gu-1, ya-gu-l and ya-ju-l respectively. The gala-forms replace the root by nayi in the nominative but otherwise are the same. This suggests that three place markers, originally taking case endings only, have later developed into class markers as a kind of supplement by suffix, and that these languages therefore belong to the suffixing group. This also will be a matter for later consideration.

For the present, the detall here given is enough to set out the patterning in this area of Australia. Certainly it is enough to show the differences between the DJirbal system and the others already mentioned or to be mentioned later, and to suggest that in D I irbal 
classification has possibly been a late development.

There is no formal pluralisation of these markers; plural of nouns may be marked by reduplication where necessary.

\section{CLASSIFICATION OF PREFIXATION}

\subsection{The Northern Kimberley Languages ${ }^{1}$}

In the Northern Kimberley Division of Western Australia there are three communalects which may rightly be ranked as 'languages' in terms of mutual intelligibility tests. These are the 'northern' languages (with dialectal subdivisions), Ngarinfin and Worora. Other forms of speech should rather be classed as dialects. Those on which some information is avallable are the following:

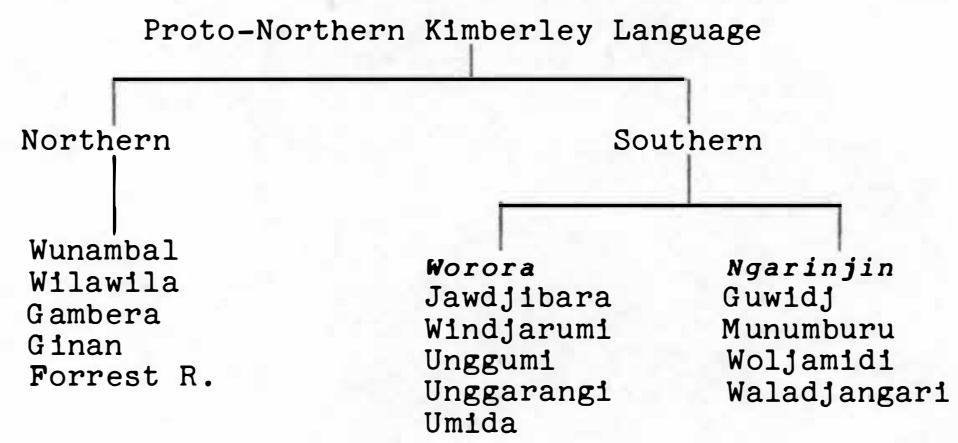

The locations of these languages and dialects are shown on Map 2 which embodies also a number of the surrounding languages. The latter are of two kinds: those on the south-west belong to the Dampler Land group. One of them, Warwa, is elther a meeting place of both groups, or at least has been very strongly influenced by the neighbouring Northern Kimberley languages. (For an account of Njigina and Warwa, see Capell 1953.) On the south, adjolning the Dampler Land languages on the east, is Bunaba. This seems to be genetically related to the Northern Kimberley languages, for there is shared vocabulary, and the verbal system is closely akin to that of the Northern Kimberley, but Bunaba lacks noun classes. Thirdly, on the east, covering the ord Valley and extending into the Northern Territory, is the DJerag Group. This seems to be more closely akin to the Northern Kimberley languages than is Bunaba; its verbal system. Is practically the same in principle as that of the Northern Kimberley. There is shared vocabulary, and

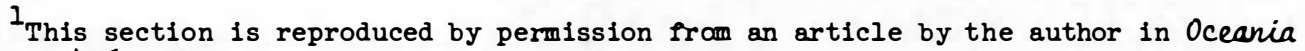
53:54-65, 1972 . 


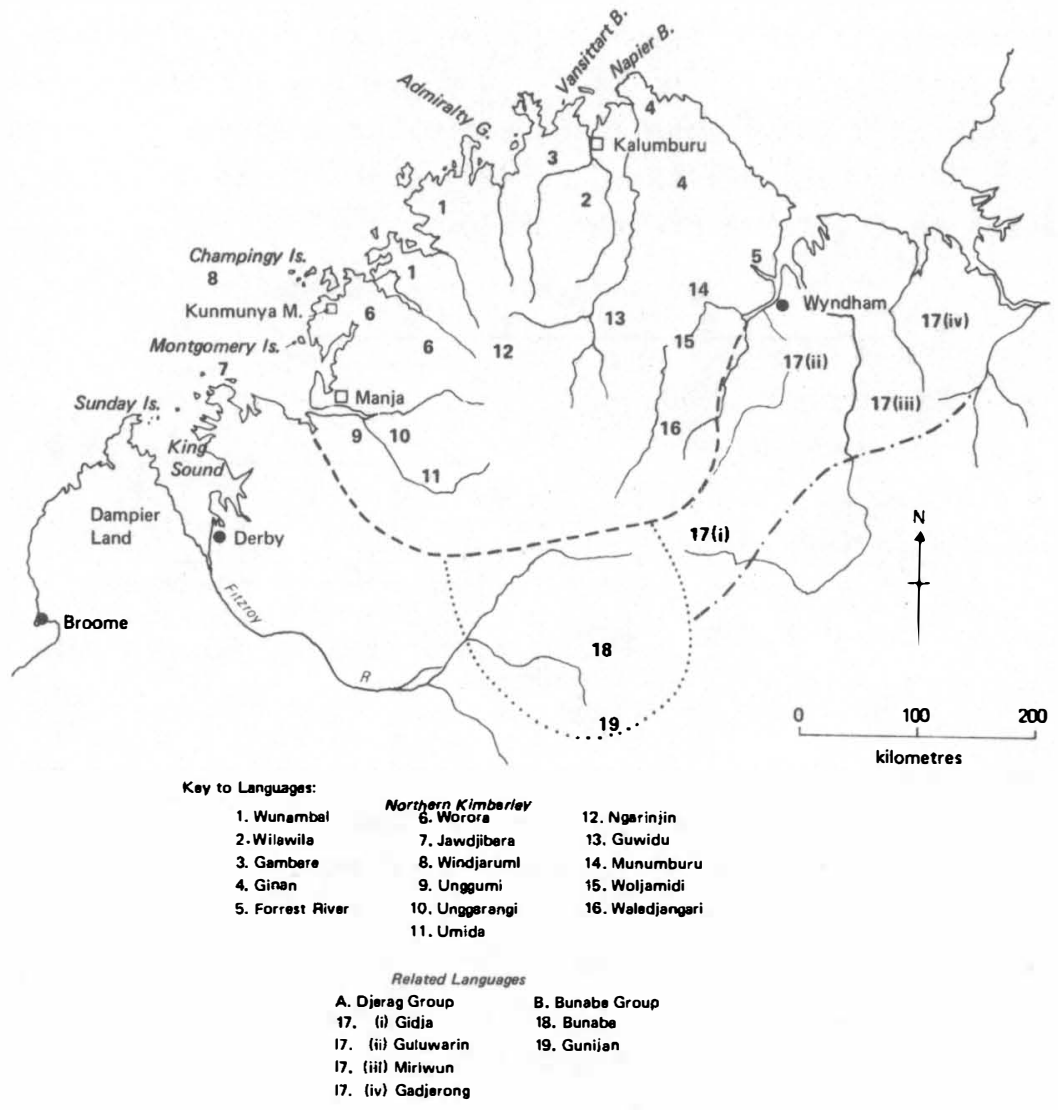

Map 2: The Languages of the Northern Kimberley Division, W:A. 
there are noun classes, but only two of them. The classes are not only of different content from those of the Northern Kimberley, but work on different principles, and are marked entirely by suffixes, not a combination of prefixes and suffixes, like those of the Northern Kimberley. Ne1ther Bunaba nor the DJerag languages are considered in the present paper.

In the dlagram preceding, no 'type language' has been 1taliclzed for the northern section, but only for the other two. Th1s has been done because the northern dialects are all more or less mutually intelligible. Between southern Wunambal and Forrest River there is probably the greatest difference, but even this does not make the two mutually unintelligible. Between any of these and Worora and Ngarinfin there is much more difference, including difference of grammatical principles in the noun-phrase (NP), and it is probable that in the older days when peoples did not $\mathrm{mix}$ so much there would not have been mutual intelligibility between them and elther of them and the north.

The adjective may be disposed of briefly because it is the simpler case. The Northern Kimberley languages all have multiple classification of nouns. The number of noun classes varles between four in southern Wunambal and six in the other northern languages. ${ }^{l}$ Ngarinjin, Worora and the other southern languages have each five classes on this reckoning.

The semantic content of the classes does not concern the present discussion, though it will be set out below. The classes are formally marked by prefixes, though Worora and Unggumi in particular also use suffixes, often concurrently with the prefixes. Both are used concurrently in Laragiya, the language of Darwin, Northern Territory, now almost extinct. There is concord of prefix between the noun and all its dependencles within the NP: pronoun, adjective, and numeral. Ngarinfin examples of this concord system are shown in the diagram following:

Class I ari djiri aner anganari mara anoni
man that big who-went seeing I-did-to-him
Class II wonaj njindi njaner njanganari mara njanoni
woman that big who-went seeing I-did-to-her

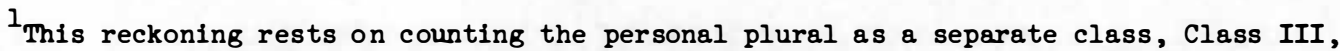
which is being done in the present series of studies. The patterning is borrowed from standard Bantu practice. 


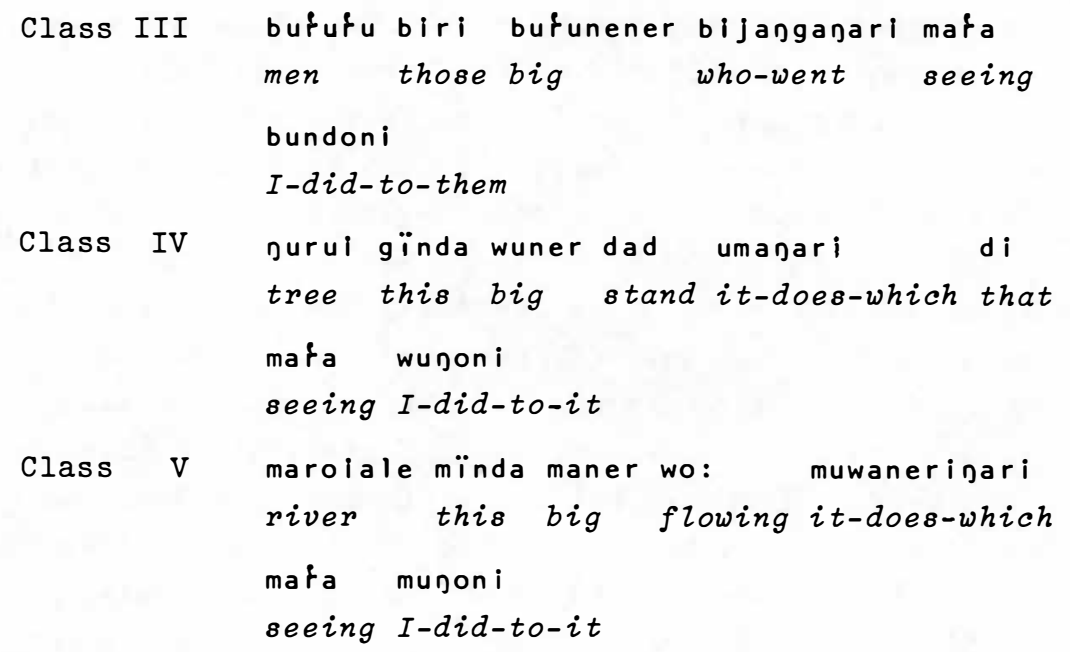

Pluralization is possible only for people (Cls. I and II), and Cl. III serves for this case; other classes do not distinguish number.

From these examples it is clear that prefixation is a basic principle of grammatical process in these languages, and this applies to person as well as to class. In fact, person seems to be only a special example of classification. It is possible under certain conditions to vary nouns and adjectives for person as well as for class. In the Drysdale area, where endjin is man, one can say nura-mija gur-endjin-mija, youtwo are men, literally you-two you-men-two.

Amongst the nouns that, theoretically at least, take personal prefixes are those referring to parts of the body. These do have their own class assignments, but if used with possessive prefix the latter runs through the whole concord, and not that of the class. The prefixes are in general identical with those of the subjects of intransitive verbs. In Ngarinfin, for instance, one can say a-langun, his head, bïr-aiangun, their heads, and alsow-aiaggun and m-alangun if the possessors are $\mathrm{Cls}$. IV or $\mathrm{V}$. The a- of $\mathrm{Cl}$. I amalgamates with the a- of the stem. Other than third person possession is marked similarly: ni-alangun, my head, njan-alangun, your head, etc.

However, many body parts are not constructed in this way: fangu, heart, gives fangu ne:nanga, my heart, fangu njanananga, your heart, fangu ananga, his heart. Here the independent possessives are used, such as are used with objects in general - spears, yams, canoes or what not.

In trying to determine why some body parts take a prefixed possessive while others do not, the student examines the semantic field in vain. Finally, it becomes clear that another principle is involved. Examination shows that it is a matter of initial consonants 
as against inftial vowels. Nouns which begin with a consonant are invarlable for person (including the person of the possessor). 'No prefixation without initial stem vowel' stands out as clearly as the old political slogan, 'no taxation without representation'. The semantic principle - part of body - is overruled by the phonological principle - Initial stem vowel.

Adjectives yleld the same result when the question of prefixation 1s examined. Only adjectives whose stems begin with a vowel can be inflected for class. In Ngarinfin budu, little is invariable; -alwa, bad, can take all the class prefixes. Suffixation for number (applied only to personal nouns) is not thus limited: Ngarlnjin bir-alwa-ri, they two bad..., carries the dual marker - $r i$, but this can produce also budu-ri, they two little.... There is no semantic question at all, only a problem as to whlch sounds are allowed to occur together a problem of phonotactics.

\subsubsection{The Principles of Noun-Classification}

Noun-classification in the Northern Kimberley languages is not connected with any phonotactic rule, so far as appears nowadays, though the absence of a class-marker on the noun 1tself could possibly owe 1ts origin to that rule. It is something quite separate and forms the second principle to be discussed in the present paper. Students have found the question so difficult that in general they have concluded that there is no princlple at all, and at an earlier stage the present writer felt moved to the same conclusion.

Not only the Northern Kimberley languages classify nouns, but there is $a$ whole area of noun-classifying (NC) languages in Arnhem Land, stretching as far as Groote Eylandt, Yanjuwa (at Boroloola) and on the Barkly Tablelands. ${ }^{1}$ In these areas the actual prefixes used in the Northern Kimberley languages frequently recur in a way that cannot be accidental, and some principle is therefore to be expected. Further, some of the languages, e.g. Barkly Tablelands, use suffixes as markers on the nouns themselves, and these resemble the morphemes that serve as concord prefixes in the Northern Kimberley languages. Other languages use both prefix and suffix simultaneously, and these include some Northern K1mberley languages such as Unggum1. It seems that a clear and anclent Australian princlple is being followed, even if it is not possible diachronically to trace its history. The second part of

${ }^{1}$ See infra 5.2 .5 . 
this section will therefore consider what can safely be sald at this stage concerning the NC system in the Northern Kimberley languages.

What has not been noticed hitherto - because there has been no overall comparison of the various Northern Kimberley languages, is that two quite different principles are found north and south of the Northern Kimberley area respectively. The north disregards sex distinction, and man and woman belong to the same NC. The second makes the distinction man belongs to $\mathrm{Cl}$. I and woman to $\mathrm{Cl}$. II. The northern is concerned with the grouping of nouns on certain lines; the south also groups nouns, but allows sex a volce in the grouping. The two subsets of NC languages in the Northern Kimberley region are therefore:

Type I: Forrest River, Ginan, Gambera, Wunambal (north and south).

Type II: Worora, Jawdf1bara, Windfarum1, Unggarang1, Umida, Unggumi, and all Ngarinjin dialects.

The DJerag languages have only two classes which are marked by suffixes that are not morphologically identiflable with those of the Northern Kimberley. ${ }^{I}$ Bunaba does not classify. Type I languages have six classes, except southern Wunambal, which has only four; the southern Type II languages each have five.

The southern group will be discussed first, using Worora as the type language because its forms are fuller than those of Ngarinjin.

The interchange of prefix and suffix is not uncommon in these languages. Nouns in Ngarinfin and the northern group do not have $s$ suffixes - this seems to be due to a sort of phonetic breakdown that cannot be discussed here. In Worora many non-nominals carry suffixes of class, e.g. na'nija? where (is he); nalnam? where (is it)?, e.g. a place; dambiju-m m-ananga-m, $i \pm s$ place. Unggum1, namu-nga milk, Ngarinjin jamu-n (both Cl. IV); maraju-nja, sun (Cl. II), Worora and

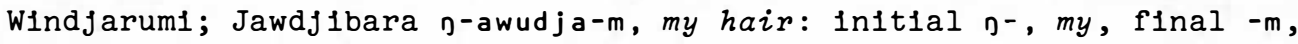
Cl. V.

${ }^{1}$ See infra 7.5 .1 . 


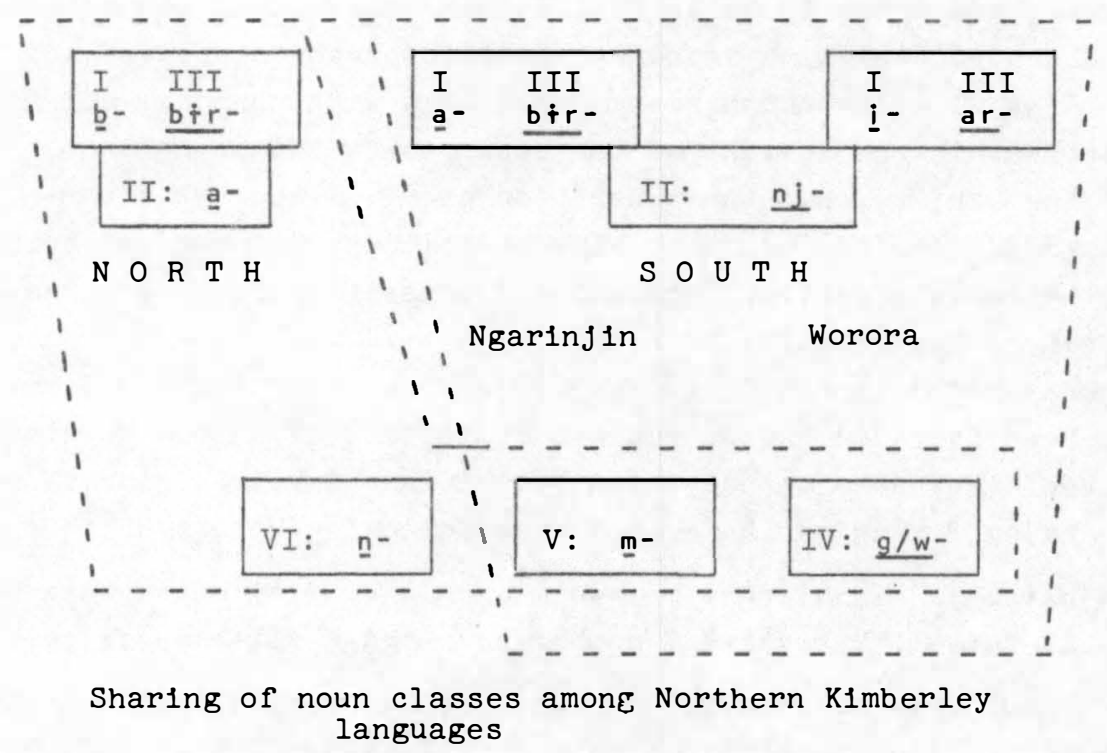

\begin{tabular}{|c|c|c|}
\hline Masculine & $\begin{array}{l}\text { Rational males } \\
\text { Irrational males } \\
\text { Associated objects (with males) }\end{array}$ & $\begin{array}{l}\mathbf{i}: \mathbf{d j a}, \operatorname{man} \\
\text { gananguri, dog } \\
\text { djinalja, spear }\end{array}$ \\
\hline Feminine & $\begin{array}{l}\text { Rational females } \\
\text { Irrational females } \\
\text { Associated objects (with females) }\end{array}$ & $\begin{array}{l}\text { wonajinja, woman } \\
\text { ganangudj, bitch } \\
\text { jangaldja, wommera }\end{array}$ \\
\hline Neuter & $\begin{array}{l}\text { Non-animates (not associated with } \\
\text { male or female) } \\
\text { 1. General } \\
\text { 2. Local or terrestrial connection }\end{array}$ & $\begin{array}{l}\text { nuwonu, tree } \\
\text { dambijum, camp }\end{array}$ \\
\hline
\end{tabular}

Number Indication is confined to personal and - In this language assoclated non-personal nouns.

Gender system in Worora as compared vilth class 
In Worora, the principles of classification, so far as they are st1ll regular, are shown in Table 1; the term 'assoclated nouns' has been introduced to deal with inanimate objects, such as spears, which become $\mathrm{Cl}$. I or $\mathrm{Cl}$. II through beling assoclated with personal belngs. The spearthrower is the servant of the spear as the woman is the servant of the man, so that the spear becomes $\mathrm{Cl}$. I and the spearthrower Cl. II. They are not masculine or feminine but used by beings who are - theirs is a derived, conditional classification. Diagram 2 shows the scheme that results in Worora.

The Worora system is based on a gender system, to which a class system has been fitted. The possible complication of such a double system, given a method of concord indication that involves simultaneous prefixing and suffixing can be seen in the following Worora NP wonaji-nja njind-ja m-ajaru-m m-arun- andu-m nj-anga-nanga-ndu-m woman-II II-this-II V-house-V V-number base-two-V II-she-of-two-V this woman's two houses. Not all phrases are as complicated as this, and the Ngarinfin languages do not have suffixation of this kind, but that pattern is typical of the southern languages.

The northern languages know nothing of gender indication, and the system is entirely one of class, 1.e. nouns are grouped into certain sense-groups, which are not 1deal, especially with regard to the placing of body parts, but which do represent a real patterning. The scheme for the north is as follows:

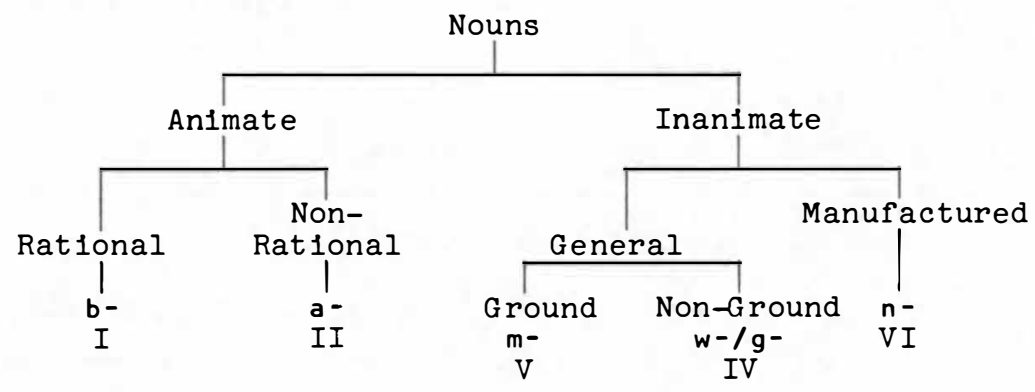

Gender system in Worora as compared with class

'Manufactured' is here substituted for the term 'artificial' used earlier. It refers to things such as the boomerang, canoe, and even honey (manufactured by bees), and European goods have a tendency to find themselves in Cl. VI. In Cl. I both male and female are found, and they share a common plural, Cl. III, bï. In Forrest River dialect, then, big man is b-endjin bi-newir, big woman, gali bi-newir, as against 
Ngarinjin a-tu -newïr and wojaj nj-ane-wïr respectively. Nouns can be transferred from class to class with change of meaning. Forrest River ga:li Cl. I, woman represents Cl. IV na:li, paperbark; the woman is the carrier of the paperbark basket. In the Drysdale region there has been a mysterious interchange of $\mathrm{Cl}$. I and II: endjin a-mrïge a-newïr, man big one, and a-mba bu-mrïge bïnewir, kangaroo big one, which is very hard to explain.

This type of classification is found in Laragiya, of the Darwin area of the Northern Territory, but the gender-class system is commoner in Arnhem Land, dealt with next.

\subsection{Multiple Classification in Arnhem Land Languages}

\subsubsection{Preliminary}

MC languages are by no means limited to the Northern Kimberley area; a considerable number of them are found also in Arnhem Land. They are the following:

A. Northern Arnhem Land

I. 1. Laragiya

2. Mangeri-Urningangg

3. Mawng

II. 1. Gunwinjgu

2. Gunbalang

3. Burera-Gudjalavia-Gungorogone

B. Southern Arnhem Land

1. Nunggubuyu

2. Anindiljawgwa

3. Wandarang

4. Ngand1

5. Ngalagan

6. Yanjuwa

C. Daly River Area

1. Mulluk Subgroup

2. Daly Subgroup

3. Maranunggu Subgroup

4. Wogadj Subgroup

5. Djemer1 Subgroup 


\section{Victoria River \\ 1. Nungal1 \\ 2. Wardaman}

In addition there is a group of MC languages spoken in the Barkly Tablelands area: these, however, mark class by suffixes, not prefixes, although some of the suffixes are morphological variants of the prefixes of the northern languages. These will be discussed in the following section.

Certain other languages, both in the Kimberley area (East Kimberley) and in Arnhem Land, are dual classifying, 1.e. have only two noun classes. These are treated in subsections 6 and 7 infra.

The subdivisions indicated in the Arnhem Land MC languages are based on (a) the number of noun classes and (b) the forms of the prefixes. At the basis of all the languages there are certain prefixes held in common, especially ma- of plant and arboreal nouns, and a general Inanimate group marked by gu-. The languages of the south deviate considerably from those of the north, although the ma- and gu-classes are generally present. The southern languages are much more complicated than those of the north and it is not easy to decide on how to arrange the classes, especially in Nunggubuyu and Anindilyawgwa. The seemingly more 'archalc' languages of Mangerl and Urningangg stand apart in many ways from the others, but bear some still uncertain relationship to Mawng. In this part of the area also there are two instances of palrs of languages, one of which has noun classes and the other does not, yet both share a considerable amount of vocabulary and a number of features of grammar. Jiwadja has no noun classes, but is clearly closely related to Mawng. Ngandi shares a large area of vocabulary with the north-eastern languages of the Murngin or Wulamba group. The latter have no noun classes. In Ngand1, where the same roots occur, they have class prefixes, e.g. Ridarngu waḍ, dog, Ngandi awaḍ; Ridarngu dagal, cheek, Ngandi gudagal. Verb roots are also shared, e.g. Gubabwiyngu nara maRggi, I know, Ngand 1 namaRngi. Some agreements with the Gunwinjgu area are also present; both languages have classes but Ngandi classification differs: Gunwinjgu gun-djen, fish, Ngand1 a-djen. Yet Ngand1 has the gu-class also, but it has the extra 'animal' class that Gunwinjgu does not have. South of the Daly River, DJamindfung has no noun classes but its 'sister' language Nungali has five classes. The following sentences show this curious parallelism: 


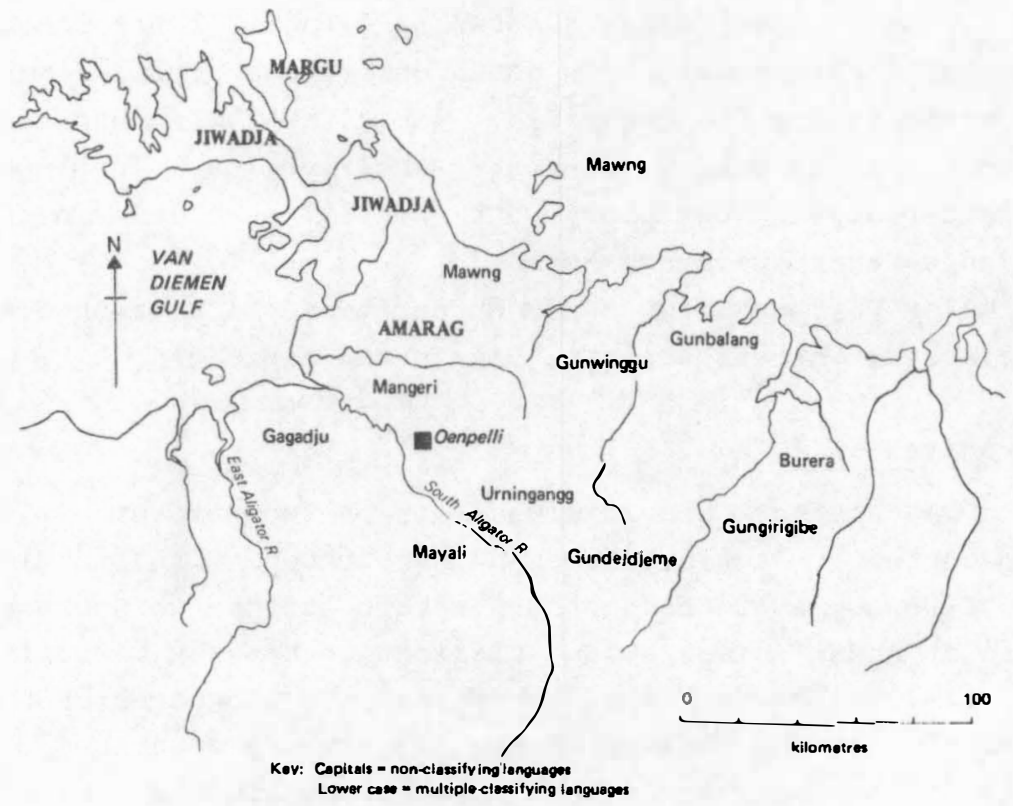

Mep 3:

Lengueges of North wersern Arnhern Lond 


\section{Men these three big}

Nungal1 diyimbul yida:bu yidanmulu dina:dj

Djamindjung djumbul yundju murgunmulu luba

\section{Women these three big}

Nungal1 njanarun yinjambu yinjanmulu njana:dj

Djamindjung maleyi yundju murgunmulu luba

No reason can be given so far for such parallel occurrences. Nungal1 concordance is full, as in other MC languages; DJamindfung has never developed classes. Djamindjung gunbuwa jargina, my birthplace, becomes Nungal1 ni-la!an ni-nargina, both nouns carrying a prefix (and Nungal1 la lan is Ngarinjin for the dreamtime). So also Djamindjung djuwud pungina, your eye, is Nungall mi-yanargin mi-nungina. The languages differ considerably in vocabulary, but are yet 'parallel' in the same way as Jiwadja-Mawng, Ridarngu-Ngand1.

In a similar way, Wardaman in the Katherine section of the Daly River, has noun classes, whereas Wageman, DJawan and Yangman do not.

\subsubsection{Laragiya}

Laragiya was spoken - and st1ll has one or two speakers - in the area now occupled by Darwin and 1ts nelghbourhood. It is a five-class language, of the type of the northern section of the Northern Kimberley, 1.e. It has a 'human' class but no distinction between masculine and feminine: It is a 'Bantu' type, as against the languages of the southern section of the Northern Kimberley already described. Another peculiarity of the language is that markers are simultaneously prefixed and suffixed: b-ilu-va, man; m-adbar-ma, forehead. The former points back to an early Australian root *badun, man, and the latter to a root * malara, forehead. While this paper is not concerned to any degree with historical restoration, it is worth noting that the root *badun, which has retained 1ts inftial consonant in Laragiya, has then used that inftial consonant as a prefix for nouns of this class, while $1 t$ has again added a final vowel and used it as a suffix. The stop has become a bilabial fricative $v$ (a rare sound in Australia) in the process, producing - va. While the consonant is retained in the plural (Cl. II: -bira), this seems to be a special case of the *bara that expresses a personal plural so widely in this part of Australia, and has been noticed earlier in this paper. It may also be added that Ngarinjin has aRu, man < *badun, and has used the initial a- similarly 
to mark the masculine class. These facts suggest that noun classing, at least here, is a comparatively late phenomenon. Something more will be sald on these matters in the concluding section.

Laragiya noun classes are as follows:

Class I: b-...-va, e.g. b-ilu-va, man; b-injid-ba, woman.

Class II: b-...(bi)ra, personal plurals: b-ili-ra men; b-injid-bira, women.

Class III: $g-\ldots(g) w a$, general impersonal: g-aRu-wa, water; g-win-gwa, nose

Class IV: m...-ma: liquids and some other nouns: d-amu:l-ma, river; m-alu-ma, head.

Class V: d-...-da/la: lesser animals and some other nouns: g-udgi-da, opossum; da-madji-la, blood.

There is some rather strange crossing of groups, by which the prefix of one class is combined with the suffix of another, e.g. m-uya-gwa, bone $(I V+I I I)$. Here possession has played a part in that suffix is to be taken as its. dalira, sun, has probably been affected by mythology; guwa:guwa:va, crow, is really Cl. I (va) in spite of beginning with gu- (III). A Laragiya grammar at present under preparation will endeavour to deal with these matters more satisfactorily than is possible here.

Interchange of class also arises from semantic causes, e.g. birilva (I) human hair > biril-ma (IV), hairbelt, damadji-la (V), blood > damadjidamadji-gwa (III), red paint.

Laragiya concord is exactly like that of the Kimberley region, including its presence in some words that in European languages are local adverbs, such as where in where are you going? Class enters into the object of transitive verbs - the language is not ergative; yaba bidlan, he speared him or her; yaba nadlan, he speared me.

This is one of the more complicated languages of the area, but serves as a direct link with the languages of the Northern Kimberley, especially the northern section of them.

\subsubsection{Gagadju}

Gagadju appears to have been spoken on the lower part of the south Alligator River, across to the west Alligator. Today there are only a few speakers and these usually live at Oenpelli Mission. It is an 
extremely interesting language, and presents a number of unusual features. Besides marking gender in the noun classes, by means of prefixes, it has a set of suffixed gender markers that combine with number markers on the pronouns and verbs.

The pronoun set is basically a singular set of four (including a 3rd person feminine), to which suffixes are added marker number and gender. The personal stems are: person 1. panj-; 2. ninj-; 3. masc. na:yu-, and 3. fem. na:yu-. These take usually suffix -ma, which looks like an agentive marker - not ergative, for this is not an ergative language. Between stem and agentive are added gender and number markers: dual masc. -mana-, dual fem. -ndja-; plural masc.-da-, fem. -mba-. The resulting set is:

\section{Singular}

Dual

Plural

1. Incl. $\mathrm{m}$

$$
\begin{aligned}
& \text { ma'nerama } \\
& \text { (ma'nedjama) }
\end{aligned}
$$$$
\text { ma' } n \in d a m a
$$

f.

ma' nembana

1. excl. m.

$$
\text { f. ( Janjma }
$$$$
\begin{aligned}
& \text { ( na'manama } \\
& \text { ( na'ndjama }
\end{aligned}
$$

' nadama

' nambama

2. $\mathrm{m}$.

f.

$\{$ Iinjma

ni nja ' manama

gi 'n jadama

n in' jand jama

o i ' njambama

3. $\mathrm{m}$.

'na: ruma

nano'rondjama

no' rodama

f.

' ja: yuma

jo' Yond jama

Do' Yombama

Short forms of the bases are used to mark possession, e.g. manera wa'la:lu camp of you-and-I; ginanda ga'bo:ndji, your (pl.m.) house. Certain types of nouns prefix possessives; the number of 1tems possessed is marked by suffixes - or it may be the possessors: jadj-barana-mana, my two brothers.

Nouns are grouped into five classes, as are adjectives and demonstratives. These are by prefix as a rule, but one demonstrative uses infixes, and yana, where? uses suffixes. The noun itself carries no marker of class. The forms are:

$$
\begin{aligned}
& \text { big this that where? } \\
& \text { Cl. I. miniwara na- } \phi-r i \text { na-biri yana } \\
& \text { II. nji-miniwara nja-na- }-r i \text { njina-biri jana-nja } \\
& \text { III. } \\
& \text { IV. gu-miniwara na-ıga-ri na-nabiri yana-lja } \\
& \text { V. ma-miniwara na-ma-ri ma-nabiri yana-ma }
\end{aligned}
$$


These are very reminiscent of the Northern Kimberley, especially the southern subgroup (Worora-Unggum1, etc.) where a similar set of prefixes and suffixes is found, though without the infixing. There is very clear evidence also in the variety of the above tables that both prefixes and suffixes originally co-occurred.

The adoption of forelgn words often helps to show up class concepts. A motor car to the Tiw1 is mútika, and ending in -ka 1 s feminine; to the Gagadju $1 t$ is módoga and beginning with $m$ is $\mathrm{Cl}$. V: módoga marayni, the motor car comes. Sex plays a part in class allocation as in Worora and Ngarinjin; so does mythology, e.g. the moon as a male is madba, Cl. I; the sun as a female is go'bolbara, Cl. II. Cl. V contains trees and wooden objects, also manufactured goods made from wood; Cl. IV embraces many lifeless objects such as gu'dnali, fire, and wu'pari, smoke.

\subsubsection{Urningangg and Mangeri}

The very few speakers of these two languages - Uṇina:ng, Mane:Ri are domiciled nowadays at Oenpell1. They would seem to have lived earlier about the east Alligator River, and the differences between them seem to be only at dialect level: no actual test of status has been made. Both have a comparatively small CA content, but such CA elements - or EA - belong to the same stratum as in Mawng and nelghbouring languages. Thus $I$ is ga:b in Manger1, no:g In Urningangg; water 1s ogog in both - apparently a reversal of *gugu. Each is a four-class language, and it is noticeable that a fifth class answering to the personal plurals (Cl. III) of the other languages studied here is not found, for these two languages have a system of non-singular marking by suffixes. Th1s is reminiscent of Gagadju, but morphologically different. The dual number is marked by a suffix -mun: garga, we > garga-minuwu-mun, you and $I$ and gane-minu, we (excl.) > ganeminuwu-mu, he and $I$. Here a dual 1 s being shown by -minu(wu) and a non-singular by -mun. In Mangeri similarly nana:nj, we (excl.) go and gana:njamun, he and $I$ go. The verb incorporates a pronoun object, and the object forms of a transitive verb therefore exhibit the class of the object, as in most languages of this group. There is full concord of all varlable parts of the sentence. Some of the Urningangg prefixes appear in the following paradigms: 
this dead short good

$\begin{array}{rllll}\text { Class } & \text { n. namenann } & \text { yawul } & \text { aningurb anbiyamulal } \\ \text { II. nadjenadj } & \text { indjiwul } & \text { iningurb njinbiyamulal } \\ \text { III. ana:jan } & \text { ugul } & \text { uningurb unbiyamulal } \\ \text { IV. manèman } & \text { mindjagul maningurb manwiyamulal }\end{array}$

Number is then indicated by a suffix to the required class form, so that necessity for Cl. III of the other languages is not felt - and the numbering of the above classes is not semantically equivalent to those of the languages earlier set out in this paper: see below on this question. The usual pluraliser is -ad: for short, Cl. I munu-ningurb-ad; Cl. II miraningurb-ad; Cl. III u-ningurb-ad; Cl. IV man-ingurb-ad. The pluraliser -ad is found in Mawng and Jiwadja also. The dual instead of -ad suffixes -uwuman as in the pronouns: dead, Cl. I min-yulu-wuman; Cl. II mira-gul-amun; Cl. III u-gul-amun; Cl. IV mindjagul-amun. The changes in stem and the morphophonemics have not yet been worked out in full. There is no parallel to these dual forms in the other two languages. Mangerl forms differ very little from Urningangg. The Mangerl numeral one for instance, is : Cl. I iyawa:m; Cl. II indjawa:m; Cl. III wiyawa:m; Cl. IV mayawa:m. It is hoped to publish later a fuller study of these languages in comparison with Maung and Jiwadja.

The incorporation in the verb is the same in Mawng: intransitive verbs mark class in the subject, transitive verbs mark it in the object, and both are prefixal; the object preceding the subject.

Example: stand, present, Urningangg

\begin{tabular}{|c|c|c|c|}
\hline & Singular & Plural & Dual \\
\hline 1. Incl. & - & muyand j & mu-yandj-amun \\
\hline 1. excl. & Dayand j & Danyand $j$ & nan-yandj-amun \\
\hline 2. & $i n d j$ and $j$ & inyandj & in-yandjamun \\
\hline I. & $\mathrm{j}$ and $\mathrm{j}$ & munyand $\mathbf{j}$ & mun-yandj-amun \\
\hline II. & ind $\mathrm{j}$ and $\mathrm{j}$ & muradjand $\mathbf{j}$ & mura-yandj-amun \\
\hline III. & uyand $\mathbf{j}$ & uyand $\mathbf{j}$ & $u-y$ and $j$-amun \\
\hline IV. & mandjand j & mandjandj & mand-yandj-amun \\
\hline
\end{tabular}

There is also a trial possible here: mu-yandj-o:ndj, etc. suffixing the root of the numeral uno:ndj, three. 
While pronouns are used before nouns to indicate possession, some kinship terms and body parts are least prefix possessives, adding number suffixes if required. A few of the object prefixes are exhibited in the following Urningangg sentences:

$$
\begin{aligned}
& \text { 1. wurig ounja wa:dja-ma-waRag } \\
& \text { man us came-us-after } \\
& \text { The man came after us. } \\
& \text { 2. } \quad \text { im-bai-ja-waRag } \\
& \text { you-came-me-after } \\
& \text { You folzowed me. } \\
& \text { jagiwendj arabilm menj-ar-uwemb } \\
& \text { crocodize Zeg IV-I-bit } \\
& \text { The crocodize bit his Zeg. }
\end{aligned}
$$

From the verb imewemb, I bite it, forms such as the following can be produced on the basis of object - subject - root: Cl. I subject

$$
\begin{aligned}
& \text { menj-ar-uwemb } \\
& m e-I-b i t \\
& \text { nj-ar-uwemb } \\
& \text { you-I-bit } \\
& \text {-am-uwemb } \\
& I-I-b i t
\end{aligned}
$$

From these few notes, which the length of this paper does not allow to be increased, it is clear that these languages present a number of complications not seen in the other languages of North Australia, except so far as they appear in Mawng or Jiwadja. The very small number of recognisable CA roots, as well as the complex phonemic structures, point to an old stage of language, which is seen also in, for example, Margu.

\subsubsection{Northern Arnhem Land}

For the purpose of the present survey, languages A.I. and the whole of B may be taken together.

The class markers in these languages are as follows: 


$\begin{array}{rlllll}\text { Class } & \text { Mawng } & \text { Gunwinggu } & \text { Gunbalang } & \text { Gungorogone } & \text { Burera } \\ \text { I } & \text { yi- } & \text { na- } & \text { na- } & \text { a- } & \text { an- } \\ \text { II } & \text { ninj- } & \text { gal- } & \text { gal- } & \text { dju- } & \text { djun- } \\ \text { III } & \text { wi- } & \text { biri- } & & \text { awiri- } & \text { abiri- } \\ \text { IV } & \text { wu- (n)- gu(n)- } & \text { gu(n)- } & \text { gu- } & \text { gun- } \\ \text { V } & \text { ma- } & \text { man- } & \text { ma }(n)- & \text { mu- } & \text { mun- } \\ \text { VI } & \text { aw- } & & & & \end{array}$

There are other languages (or dialects: no examination has been made) such as Gundjebmi, Mayal1, which belong to the Gunwing gu group; Gungorogone is very closely related to Burera, as also is Gudjalavia. These are not listed separately here.

The coverage of the different classes shows a good deal of local variation, and it is difficult to give detall in a short space. For Mawng reference should be made to Capell and Hinch 1970:44 ff. Roughly the Mawng classes cover: Cl. I names of male belngs; Cl. II names of female beings, both elther rational or irrational; Cl. III plurals of Cll. II and III for rationals only; Cl. IV objects associated with the ground and general Inanimates, except plants; $\mathrm{Cl}$. V trees and their parts, Cl. VI vegetable foods and plants in general. One important point is the ability of Mawng and some other languages to cross classes. Thus taking mawur, arm, it may be yi-mawur, a man's arm; ninj-mawur, a woman's arm; wu-mawur, arm of a river; ma-mawur, arm of a tree, branch; or a-bawur, arm or tendriz of vine. Some of the other languages share to a limited extent in this power of cross-classing. The concord extends through the whole sentence (and any dependent clauses may be involved), and includes not only the subject of intransitive and the object of transitive verbs, but in Mawng the subject of a transitive verb may also be involved, e.g. nanna-, subject of Cll. II, IV, V, or VI does it to me; ganbunba-, you (sing.) will do it to Cl. III, and many other complicated combinations. There is more differentiation here than in the Forrest River dialects of the Northern Kimberley.

In addition, Mawng has what can only be described as an 'article', which also varies for class. It occurs before a noun and dependent adjectives, e.g. dja nani-malgbanj, my father; mada gargbin mada walg, art. big art. tree, the big tree. There is much 1diomatic use of these articles which is detalled in the Maung Grammar.

The other languages behave similarly but most are simpler in their usages. In Burera an-glgaliye an-muṇu, man big; gigali-yiridje 
This language also has a dual for feminine and masculine as well as a plural. The reduplication of forms for plurals is worth noting. Animal names use practically the same prefixes as personal plurals, but do not form plurals and do not take the personalising suffix -njun, etc. Thus:
yani waru-muwa:dj
wa-landurg war
waru-wawa waru-Rungal
what III-name
III-dog
III-that III-big
nara-na-ni?
What is the name of the big dog that I saw?

The same sentences are constructed on very similar lines in Anindilyawgwa but of course with different morphemes. The prefixes in the two languages (retaining Capell's count for the same of simpler setting out) are:

$\begin{array}{rlc}\text { Class } & \text { Nunggubuyu } & \text { Anindilyawgwa } \\ \text { I } & \text { na- } & \text { ni- } \\ \text { II } & \text { wini- } & \text { wuna- } \\ \text { III } & \text { wara- } & \text { wura- } \\ \text { IV } & \text { na(ra)- } & \text { da- } \\ \text { V } & \text { wini- } & \text { wurna- } \\ \text { VI } & \text { a- } \text { ana- } & \text { a- } \\ \text { VII } & \text { ma- } \text { mana- } & \text { ma- } \\ \text { VIII } & \text { wa- } & \text { yi- }\end{array}$

In Nunggubuyu, examples are:

I: na-walja-yun, male person (-yun marks personality); II: na-walja-wa, two male persons; III: wara-walja-walja, persons, male (reduplication of stem included here); IV: nara-manin-jun, aboriginal woman; V: naramanim-ba, two aboriginal women; (III: nara-manan-un, aboriginal women; this is an irregular noun); VI: $\phi$ or a- or ana-; a (na)Ranag, tree; VII: ma(na)larda, spear.

In those languages also there is concord within the verb for class of both subject and object throughout, so that they present a very complicated pattern of sometimes very lengthy words. Practically nothing has yet been published about Anindilyawgwa, but Miss Judith Stokes, of the Church Missionary Soclety, has studied it for many years and is producing local reading matter in 1t. She has not published a grammar as yet. It is quite likely that, like Hughes, she 
w1ll ultimately adopt a different arrangement of classes.

P.M. Worsley, however, has discussed the nature of these classes in an interesting article (Worsley 1954:275-88), and has pointed to 'a cross-cutting system of noun classification by means of prefixes, entirely unconnected with the known noun-classes, and most definitely based on semantic considerations'. He has listed some twenty secondary prefixes, such as -uru(r)gwa- for birds, some animals, e.g. d-urugwin names for fowl, cockatoo, curlew, horse; m-urugw- in names for lorikeet and emu; -embirg- for round things, as embirg-(Cl. VI) water l1ly roots; m-embirg- a wh1te berry; y-embirg- (Cl. VIII), stingray species, egg, red love-apple. Obviously much more analysis needs to be done on this language.

The southern nelghbour of Nunggubuyu is Wandarang. There would seem to have been some territorial changes in this region, as Wandarang has more vocabulary in common with Mara than with Nunggubuyu, while adding classification which is not present in Mara. Mara radbur, camp becomes Wandarang wu-radbur; Mara dunal, spear becomes ma-dunal (the 'wood' connotation of ma- remains - although 1t apparently derives from an original *mayi, vegetable food), while Mara wungan, dog is Wandarang (R) awuggan. Another Mara touch is a great fondness for compound confugation (to be discussed in the second part of this paper) which is not found in Nunggubuyu.

Wandarang has five noun classes, but $C l$. III is not the plural of I and II but a separate class. Dual is indicated by a suffix wulu-, and plural by yiri-. The former is shared by Mara. The class forms are shown in the following phrases (a couple of which are theoretical and would hardly occur in dally life, certainly not Cl. I). They are:

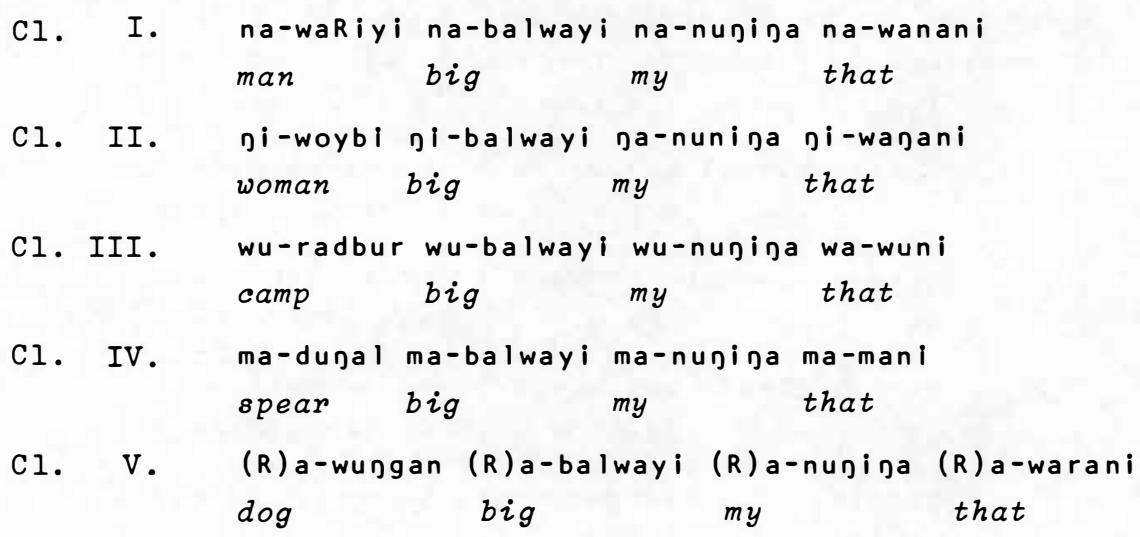

It is noticeable that the demonstrative takes a kind of double concord within 1tself: such an infixing of class marker was seen in Gagadju. 
The initial consonant of $\mathrm{Cl} . \mathrm{V}$ is optional: both $\mathrm{Ra}$ - and a- are used. The a- form is found in Mawng, and the ra- form in Yanjuwa, but the class is relatively uncommon in the group.

The number markers are seen in the following sentence:

$$
\begin{aligned}
& \text { yiri-waRiyi yiri-balwayi wawuruni waR? galnu-windima-ni } \\
& \text { pl. man pl. big those seeing } I \text {-them-do }
\end{aligned}
$$

The class prefixes play a part in the transitive verb, following the general pattern (common throughout these MC languages) obj + actor + verb, e.g. Dagu-ni-ban. me-I-bites; nagu-Ra-ban, me-V-bites; but without -gu- In IV na-ma-ban, me-IV-bites, as ma-wanga na-ma-ban, bandicoot bites me. There is one difference: duals and plurals of objects are marked differently from nouns: WaR? gaRa-windimani, he or she sees me; waR? nja-raru-windimani, he sees us two (Incl.); waR? nji-liluwindimani, he sees us (excl.). This is all very like Mara.

While this is not put forward as an example of a so-called 'mixed' language, there are certainly some cross influences at work in 1t, that may well have historical information to yleld. Something more will be sald in the general section of this paper.

Between the Phelp and Wilton Rivers the Ngandi language is domiclled. In general it is very similar to Wandarang, but 1 ts borrowIngs (if such they are) are mostly from the Ridarngu language, which belongs to the 'Yulngu' languages of north-east Arnhem Land, an enclave that is not classifying. Here there are six classes; Cl. III is again a common plural for personal members of I and II, but a dual is formed by the addition of -bula to a stem of any class. This is the early Australian root *buladj, two, and it means that originally this language did not provide for the expression of a dual. The same set of sentences as were used for Nunggubuyu will serve again in Ngand1 translation to 1llustrate the classes:

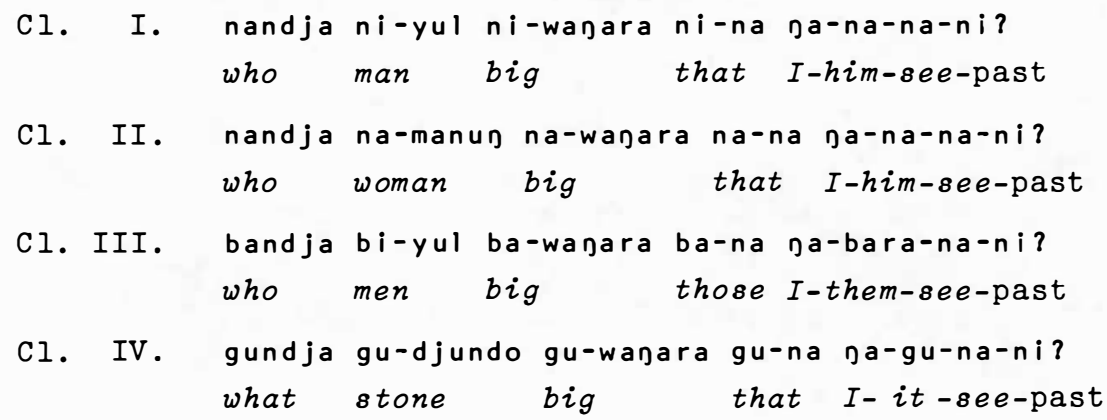




\section{V. mand ja ma-wangara ma-wanara ma-na na-ma-na-nl? what bandicoot big that I-it-see-past}

CI. VI. andja a-waḍu a-wanara a-na gaRa-na-ni? what dog big that I-it-see-past

The development of class and number have been distinct in this language. The Murngin wangan, one, is added to a word for two, to make three, and both carry the plural prefix ba-: ba-yabban ba-wangin, $2+1$. The word gabbul of Ranjbarngu, etc. can be used in Ngand1 as the suffix of a paucal plural.

The remaining language of this group is Ngalagan, which belongs to the west of Wilton River, between 1 t and the Roper. Here there are considerable varlations on the common pattern: (1) four classes only; duals and plurals are marked by suffixes, like Ngand1: -bira, dual and -gabbul plural; (2) the Cl. prefixes are: I nu(gu)-; II dju- (as in Burera); III gu-; IV ma-. This is then rather a northern type language, influenced by those on the west (which are not classifying). (3) The class prefixes are separable, and sometimes the noun appears without them, sometimes with a strengthened form of prefix. The previous sentences here become:

Cl. I. nu-yana? ne: nugu-n?biri nugu-bigur nugu-jolggo what name that man big

nu-na-ni-n?

I-him-see-pres.

Cl. II. dju-yana? ge: djugu-n?biri bolo?bolo djugu-nolggo what name that woman big

nu-na-ni-n?

I-her-see-pres.

In an example of a plural formation:

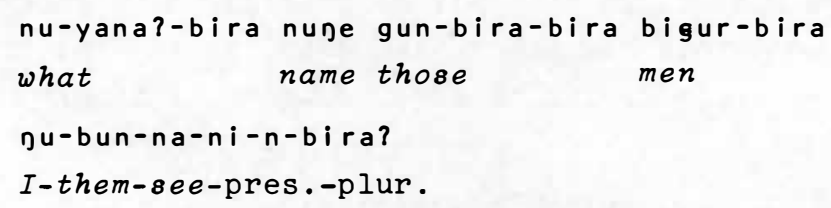

It is unusual for plural to be marked with Classes III and IV. Another peculiarity of this language is that it is ergative: this also will have been taken over from languages to west, some of which have 1 . 


\subsection{Multiple Classification outside Arnhem Land 5.3.1. Yanjuwa}

Th1s language, which has been called at different times Anyula or Yanyula, but which 1ts own speakers call Yanjuwa (Yanyuwa), is spoken about Boroloola and the lower Macarthur River. It is quite definitely the most complicated structurally of the MC languages - more so than Anindilyawgwa or Nunggubuyu. The formations point to stages in the formation of the MC languages and for this reason are particularly important for the present study. They are therefore given in some detall here, because reference to them will be necessary in the general discussion in the following section of the study. The first beginnings of an analys1s was made by Capell in 1941; workers from the Summer Institute of Linguistics have been stationed among the people for a number of years past, and reference should be made especlally to the work of Jean K1rton of the SIL (K1rton 1964, 1967, 1970, 1971a,b) and also to Elfreda MacDonald (MacDonald 1964) and on more general grounds to Dixon on Noun Classes (D1xon 1968). A study of the Yanjuwa 1s st1ll awalted; practically all the above references refer chlefly to the noun phrase, although K1rton (1970) does go beyond th1s. The present concentration 1s, of course, on the noun-classing system.

Th1s system has complications not only in range of classes and their contents, but in the formatives as well. Yanjuwa is an ergative language, as are some of the others which have been looked at in the preceding pages, but Yanjuwa has the speclal feature that ergativity is marked in the prefix as well as in the normal manner of indication by suffix to the complete noun. This feature was noticed to a small extent in Nungal1; it is more noticeable in Yanjuwa.

One of these other phenomena, Indeed the most important, is the form of the ergative case in Yanjuwa. In Nungall words beginning with dchange this to $\mathrm{nj}$ - In the ergative. In Yanjuwa all nouns mark ergative in the prefix as well as in the ending. The ergative marker is the normal Australian suffix - lu. Th1s is added to the noun in a Yanjuwa sentence, but the class prefix is also modifled by change of final vowel to -u. Thus:

$$
\begin{aligned}
\text { Intrans. } & \text { giya-winga nja-mininiya } \\
& \text { he-walks the-man } \\
\text { Trans. } & \text { ganj-ilu-yambina-njdji nju-minginiya-lu } \\
& \text { him-he-make-well-pres. the-man }
\end{aligned}
$$

The change of nja-mininiya to nju-mininiya-lu is a characteristic of Yanjuwa. It will be argued later that this points directly to a time 
when the class pref1x was a free determiner, not a bound form at all, and 1 will be further argued that this stage preceded noun classification in all the languages (see 9.3. below). In a meeting of the Linguistic Society of Australia at Macquarie University, Sydney, In 1975, Miss Kirton presented a paper on Yanfuwa nominative and ergative-allative cases, concluding with a diagram that is here reproduced as a summary of the present argument:

\begin{tabular}{|c|c|c|c|}
\hline & $\begin{array}{l}\text { Nouns, noun-modifiers } \\
\text { Interrogatives }\end{array}$ & $\begin{array}{l}\text { Free } \\
\text { Pronouns }\end{array}$ & Participles \\
\hline Nominative & $\phi$ & $-\alpha$ & \\
\hline Ergative & \multirow{2}{*}{$-1 u$} & & $-1 u$ \\
\hline Allative & & $-1 u$ & \\
\hline
\end{tabular}

This patterning is peculiar to the Yanjuwa language amongst the classifying group of Australian languages.

Basic class prefixes in Yanjuwa are the following:

$\begin{array}{rll}\text { Class } & \text { Prefix } & \text { Category } \\ \text { I } & \text { nja- } & \text { male } \\ \text { II } & \text { ra- } & \text { female } \\ \text { III } & \text { ri- } & \text { personal dual } \\ \text { IV } & 1 \mathbf{i}- & \text { personal plural } \\ \text { V } & \text { ma- } & \text { food, and certain other 1tems } \\ \text { VI } & \text { na- } & \text { arboreal and some other 1tems } \\ \text { VII } & \text { nang- } & \text { abstract }\end{array}$

Examples :

C1. I nja-mininiya, man; nja-duwara, initiated boy.

C1. II ra-nanawaya, woman; ra-wamalani, girl in early adolescence; ra-wunamuḍ, female opossum.

Cl. III ri-baḍibaḍi, two old women; ri-wulu, two aboriginal men.

C1. IV li-yumbuwara, young people.

${ }^{1}$ This diagram is a conflation of Capell's original arrangement and Kirton 1971b:20. It does not give as much information as the latter, but follows the building up of what has to be said below with less complication. 
Cl. V ma-nara, food (same word as Nungal1); ma-yulbu, rope; ma-wudawuda, stone knife.

Cl. VI na-alanjdji, camp; na-wulgu, bark canoe; na-wulani, river; na-wunan, breast.

Cl. VII nạ̣u-njirga, corroboree ground; nạ̣u-waḍi, evil, badness (waḍi, bad), naṇu-yagayaga, madness (yagayaga, deaf).

There is also a masculine class marked by zero prefix, but taking masculine concords: awara, earth, country; wurundula, male dingo; galabir, ghost gum; wuga, word, language; yiliri, blood and many others. The numerous nature of this zero class is an indication, perhaps, of a late adoption of classification into the language which is suggested by certain other phenomena also.

This language has elaborate sets of prefixes for person - including first and second person, as well as all the Classes of 2nd person some of which apply to body parts, three separate sets applicable to kinship terms - and, of course - still others applicable to verbal stems and not to nouns. There are sets of suffixes labelled by Kirton as nuclear, referent, directive and accessory. These cannot be dealt w1th here (see K1rton 1970, 1971). Some of these are prefixes, others suffixes, if case markers are included. A full analysis in terms of generative linguistics in its various branches, would probably throw a lot of light on the linguistic history and on the psychology of the speakers at the same time. The functional divisions between prefixation and suffixation could also provide profitable studies along these lines - but they are beyond the scope of the present paper.

There may also be historical information hidden in the fact that Yanjuwa, on the north-eastern border of the prefixing MC languages and Worora on the north-western border, are both among the most complicated languages of their type. On the south of Yanjuwa there are other MC languages, but these act by suffixation only, and they form the next section to be studied. They, in their turn, have languages of rather similar construction, but much greater simplicity, in an area of northeastern New South Wales, far away to the south-east of the central core.

\subsection{Isolated South-western Languages}

There are two 1solated MC languages which may be discussed along with the Daly River languages, although they do not belong to this group in any more than a geographical setting. They belong to the mainstream of the MC languages as far as their actual formatives are 
concerned. These are Nungall and Wardaman, both of wh1ch were chronicled by the writer in 1939.

\subsubsection{Nungali}

Nungali is spoken in an area between the Daly and Fitzmaurice Rivers. It is a 'sister' language to Djamindfung and Yilngali fairly close to them in vocabulary, but both of them are classless languages, whereas Nungali has five noun classes of the common form, not of the Daly River type.

Examples in sentence form of the resemblances between DJamindfung and Nungali were given in an earlier section of this paper (5.2.1.). Some additional matter and clearer analysis is added here.

Where vocabulary is shared, the Nungali words of ten - but not necessar1ly - have class markers prefixed: Djamindjung wiRa, hair; Nungali ni-wiRa; DJamindjung djaRa, mouth; Nungali ni-yaRa. A different case is Djamindjung dju-wiya, nose; Nungal1 ni-wiya; the first could be a class marker in Burera, but in Djamindjung apparently is not.

Nungal1 noun classes are:

$\begin{array}{rll}\text { I } & \text { di- } & \text { chiefly male beings } \\ \text { II } & \text { nja- } & \text { chiefly female beings } \\ \text { III } & \text { wiri- } & \text { plurals of I and II (persons) } \\ \text { IV } & \text { ma- } & \text { vegetable foodstuffs } \\ \text { V } & \text { na- } & \text { objects in general, and meat foods }\end{array}$

In the plural class given here, the common prefix wi-, wu- is marker of the 3rd person plural in the verb: in Djamindjung it is buru-, bu-. Nungali extends the concord through all the usual categories excluding verbal objects.

Nungali nouns do not necessarlly carry a class marker: ni-yab, liver, but du!u, heart. Curiously enough, vegetable food, manara is Cl. I (yidabu, this), the same as meat di-yanara, which is also kangaroo.

There is an ergative suffix - ni which occurs in some of the collected examples, but 1ts use does not seem to be consistent, e.g. baba-ni nargu ganimilim numurun di-yanara-g, brother-erg. my dug a hole kangaroo-for: baba-jiram-ni di-nargina-jiram winginjdji dumurgum di-yanara, my two brothers killed three kangaroos. But the plural was recorded as baba di-nargina birijada... not baba-ni: and also the ergative seems not to occur with a dependent word such as adjective after the subject noun.

Examples of the concords are given as follows: di-yimbul yl-dabu, man this; daruwuru yi-njambu, married man that; but there is infixing 
In these demonstratives: ma-nara yi-ma-mbu, that food; nja-narun yi$n j a-m b u$, that woman - so that $C l$. I form is actualjy yi- $\phi$-mbu just as In Gagadju na- $\phi-r i$, this, rather than *yi-yi-mbu.

There is another pecularity: Nungali does not appear to be an ergative language, but initial $d>n j$ in $\mathrm{Cl}$. I nouns as subjects of a transitive verb, e.g. dulga ganijuburag father told them...; but njulga nenannani, father gave it to me; duRib, dog, but njuRib naniwa, the dog bit you; njuRib nananbawa miRi, the dog bit my leg. Other initials do not seem to change in this way.

No fuller recording has been possible, and a search for speakers of Nungal1 about 1970 failed to locate any.

\subsubsection{Wardaman}

Wardaman belongs to the Upper Daly, towards Katherine, but it is not Identical with Wageman, as stated in A Revised Linguistic Survey of Australia (Oates and Oates 1970:14). The latter has no noun classes, but Wardaman has three, and, like Nungal1, they are formally consistent with the northern languages, not with those of the Daly River. The information drawn on was gathered in 1940 by Capell.

The noun classes are three:

\footnotetext{
Cl. I yi $\sim$ yu- yi-biwan yi-yibi, man living; banbun yi-man, woman bad; gajman yu-guRul, kangaroo big

Cl. II wu-

yumin wu-guRul, tree big; yumin wu-man, tree bad; gulina wu-djuda, firestick short

Cl. III ma-

may?yin ma-naḍu, food little; govin ma-guRul, honey plenty; may?yin ma-Rioun, food no good

Class I contains names of living beings, whether human or animal, male or female. Some names of valued implements such as the spear, and such an important 1tem as water are included. Class I contains all other names of objects, except vegetable food - and this may also be treated as a valued item and go into $\mathrm{Cl}$. I, though 1 t is also Cl. III, the general class of vegetable foodstuffs.

Wardaman does not extend the concord to the pronoun, numeral or verb, as most of the MC languages do. Plurals are indicated when necessary by suffix or marked in the verb, there is a dual suffix -wiya, as in baba-wiya, two brothers. There is also an ergative suffix-yi
} 
(Nungal1-ni); for example

$$
\begin{aligned}
& \text { baba-wiya-yi Danlgin-yl wurmin djarin ganma-wu } \\
& \text { brother-two-erg. my-erg. they-dug hole kangaroo-for } \\
& \text { My two brothers dug an oven for the kangaroo (gamman) }
\end{aligned}
$$

In both Nungali and Wardaman the feeling grows that noun-classing is a foreign process that has been introduced. The general kinship is with the northern languages, perhaps through the Gunwinjgu group. The ergative will be a still later introduction; evidence will be cited in the closing section of this paper for considering ergavity to have been introduced to these languages after noun-classing. This becomes particularly apparent in Yanjuwa (Kirton 197la,b).

\subsection{The Daly River Languages}

The Daly River languages not only form an obvious group, but there is good documentation for them. They differ from the other multiple classifying languages to a certain degree in features, most of which are shared among them, and these are not limited to the system of noun classification. Verb classification is also a similar shared feature (see Tryon 1970). Hence the position assigned them in the present paper. There is a detalled study of the Daly River and neighbouring languages ava1lable (see Tryon 1974). It is therefore sufficient to indicate their general features and to give short specimens to 1llustrate the points drawn out by Tryon. The chief references here are based on Tryon's closing chapter ('Overview', Tryon 1974:287-305), recommending the work itself to students requiring more detall.

Tryon states (1974:292) that 'unmodified noun classes within the Daly Family number between four and seven'. All the languages have four classes in common, arranged as follows:

Class 1: Body parts, kinship terms, natural phenomena.

2: Animals hunted for meat.

3: Vegetable food and plants.

4. Wooden implements, trees, weapons.

In most of the languages masculine and feminine animates are provided for specifically. The four classes found are more limited, and no language actually shows all. They are:

Class 5: Trees (as opposed to implements, wood products).

6: Male humans.

7: Female humans.

8: Domesticated animals. 


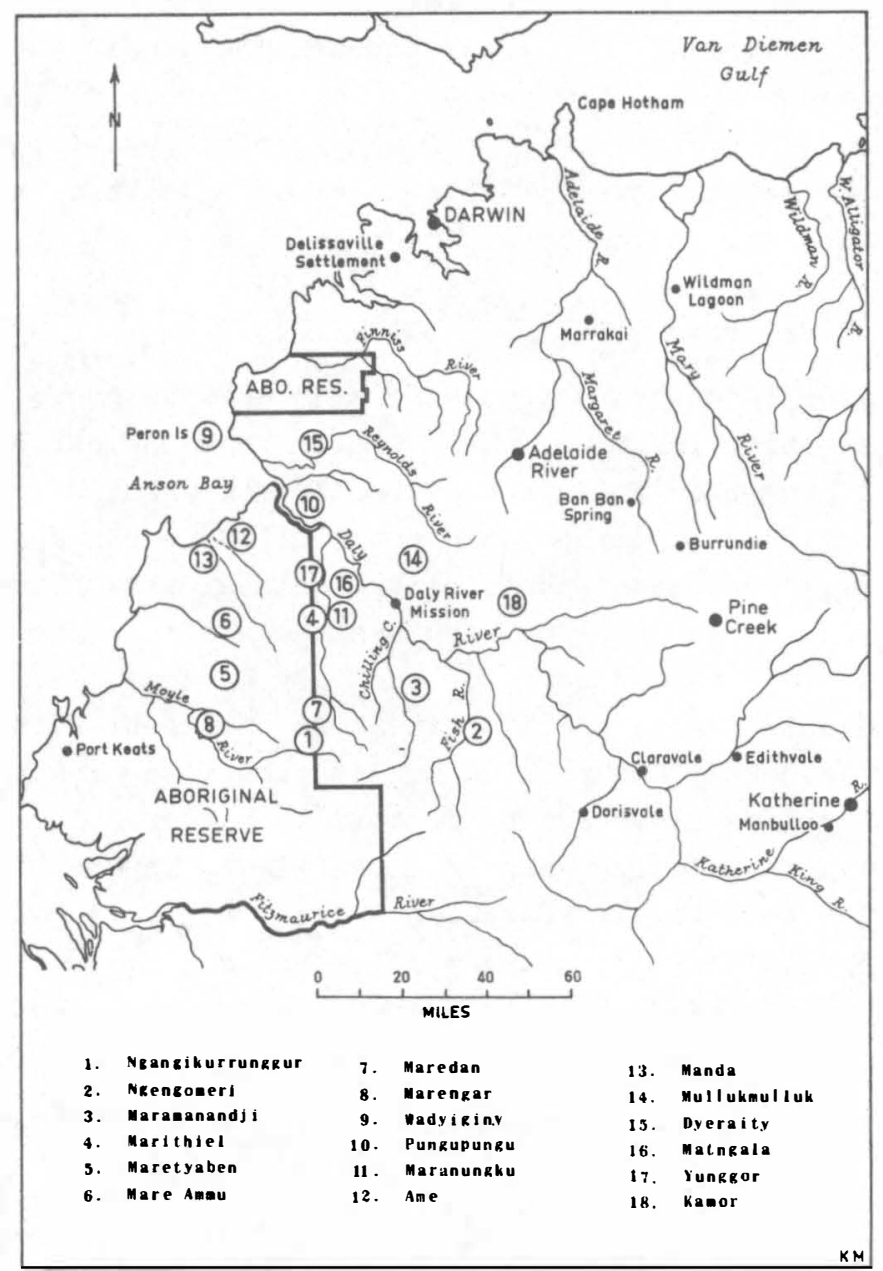

MAP 4: The Daly River Languages (From D.T. Tryon, "Daly Family Languages in Australia". p.xv.) 
Table 1: Noun Class Prefix in the Daly River Languages (After Tryon 1974:293.)

\begin{tabular}{|c|c|c|c|c|c|c|c|c|c|}
\hline \multicolumn{2}{|c|}{ Language } & \multirow{2}{*}{ Class: } & \multirow{2}{*}{$\begin{array}{l}2 \\
\mathrm{te}-\end{array}$} & \multirow{2}{*}{$\begin{array}{l}3 \\
\mathrm{mi}-\end{array}$} & \multirow{2}{*}{$\begin{array}{l}4 \\
\text { t jön- }\end{array}$} & \multirow[t]{2}{*}{5} & \multirow[t]{2}{*}{6} & \multirow[t]{2}{*}{7} & \multirow[t]{2}{*}{8} \\
\hline 1. & Mulluk-Mulluk & & & & & & & & \\
\hline 2 & Dferadf & & te- & miyu- & tjunu- & & & & \\
\hline 3. & Madngala & & pinya- & miyi- & yim- & & & & \\
\hline $3 a$. & Yunggor & & yinja- & yiyi- & y im- & & & & \\
\hline $3 b$. & Gamor & & pinja- & meyi- & yim- & & & & \\
\hline 4. & Maridhiel & & $a-$ & mi - & yeli- & tar- & wat i - & nunku- & \\
\hline $4 a$. & Marıdjabın & & $a-$ & mi - & yeli - & $\underline{t} a_{-}^{-}$ & $\mathrm{ma-}$ & munti- & \\
\hline 5. & Maramanand 1 & & $a-$ & mi - & yali- & tar- & wat i - & wugku- & \\
\hline 6. & Marengar & & $a-$ & mi - & yeri- & & ma- & muli- & \\
\hline 7 . & Maranunggu & & awa- & miya- & yili- & & wat i - & wunku- & \\
\hline $7 a$. & Am1 & & awa- & miya- & yili- & & & & \\
\hline $7 \mathrm{~b}$. & Manda & & awa- & miya- & yili- & & & & \\
\hline 8. & Bungubungu & & met jem- & menenj- & win- & & & & \\
\hline $8 a$ & WadfIgInf & & met jem- & menenj- & win- & & & & \\
\hline 9. & Ngang1gurunggur & & $a-$ & mi- & yer- & & wa- & wur- & wu- \\
\hline a. & Nangomer1 & & $a-$ & mi - & yer- & & wa- & wur- & wu- \\
\hline
\end{tabular}




\section{MULTIPLE CLASSIFICATION BY SUFFIXATION}

\subsection{Introduction}

The languages included in this group are two sets of dialects and languages spoken orlginally on the Barkly Tablelands, Northern Territory, 1mmedlately south of Yanjuwa-Alawa-Mangaray. The languages are Df1ng1l1, w1th Ngarndf1 on 1ts northern border related to 1 t practlcally at dlalect level (no count has been made), and Wambaya, with Gudandf1 and Blnbinga at dlalect level. No full account of any of these has been published. N. Chadw1ck has given a short account of DJ1ng1l1 and Ngarandj1 (Chadw1ck 1968, 1971); K.L. Hale has gathered manuscript notes on Wambaya and 1ts relative which remain unpublished, though he has kindly supplied the materlal for the present purpose.

The characteristic of these languages is that they are multiple class languages, each having four classes, but they act by suffix, not by pref1x. There is no personal plural class, but plural is indicated by suffixes, as is also the dual. In this regard they depart from the more northerly MC languages. Moreover, they are also ergative languages, and the ergat1ve markers (or 'operat1ve' as they are called in Chadw1ck's arrangement) are both suffixal, but differ in form from each other. The operation of the entire system is greatly complicated, at least in DJ1ng1l1, by a system of retrograde vowel harmony, in

'the vowel of the affix determines the vowel of the stem'. Thus a base wiwi, girl, has a nomlnat1ve wiwi-ṇi, Cl. II but ergat1ve wawa-na, because the vowel of the suffix reacts on those of the stem. Th1s type of formation is present also in Waramunga and Walfbirl, and there have apparently been mutual influences at work throughout this area. The $C A * l u$ of the ergative is therefore missing, and is replaced by a *na/ga which is not $\mathrm{CA}$.

\subsection{Djingili}

The suffixes glven by Chadwick (1968:225-6) for DJ1nglli are as follows: 
Class I. Predominantly masculine and objects associated with males; also acts as common gender for small fauna:

Nom. $-a /-i /-d j i /-1 j i /-r /-1$

Erg. - n̨i/ -da/ - a (*)

Class II. Predominantly feminine - some 1mplements and parts of body; also acts as common gender for small fauna:

Nom. $\quad-n \underline{i} /-d i$

Erg. - - na/-ga/-ḍga (*)

Class III. Is a general neuter, some implements and parts of the body. All flora, except some fruits and vegetables.

Nom. $-u /-i /-a$ or cons.

Erg. $-u /-i /-a$ or cons. (*)

Class IV. Mostly nouns related to vegetables and fruits but also any rounded or full-shaped object:

Nom. $-m i /-b i$

Erg. -ma/-ba (*)

It w1ll be seen that there is very little resemblance between these endings and the northern prefixes, except $C l$. IV which in the north is \{-ma\}, and as w1ll appear later, derives from a CA root *mayi, vegetable food. It is just possible that DJinglil mami, food, may derive from *mayi, but one would be right in putting a question mark after 1 .

\subsection{Wambaya Group}

For Wambaya, K.L. Hale's notes give a plcture that is similar but differs in many details. The class suffixes are: I - yi (masculine); II -ṇa (feminıne); III - (w)a (inanımate); IV - (u)ma (vegetable). Number is marked in Wambaya by suffixing again to these -wulu for dual (EA) *buladj, two, and for plural-gunjdji (I), -gunja (II), gunjdja (III), -gunjma (IV) as substitutes for the singulars, 1.e. singular is $\mathrm{N}+\mathrm{Cl}$., plural is $\mathrm{N}+\mathrm{pl}+\mathrm{Cl}$. Wambaya demonstratives are a little more complicated. Hale's notes give yini, $I$, this and yiniya, $I$, that. The forms are:

(*) Altered by Chadwick from his 1968 publication and communicated in a private letter to Capell. 


$$
\begin{aligned}
& \text { this: I yini, II ṇana, III yana, IV mama } \\
& \text { that: I yiniya, II naniya, III yaniya, IV mamiya }
\end{aligned}
$$

The ergative and dative forms of that vary again rather unexpectedly:

$$
\begin{aligned}
& \text { Erg. Cl. I ningiya II nangiya II yangiya IV mangiya } \\
& \text { Dat. ninagiya nanagiya }
\end{aligned}
$$

The surface appearance of these two sets is that the class markers are prefixed instead of suffixed. It is possible, however, to interpret them as compounds resulting from reduction of formerly free forms to bound forms, with postpositions. This is not the place in which to consider these developments; that belongs to the historical consideration later.

The Gudandf1 forms given in a second manuscript by Hale are very similar, and so far as can now be ascertained about Binbinga those also fit the same pattern.

A set of examples from Hale's notes will show the concord of the adjective in Wambaya in predicative position in the sentence. There is no space to give a complete set; some examples must be sufficient:

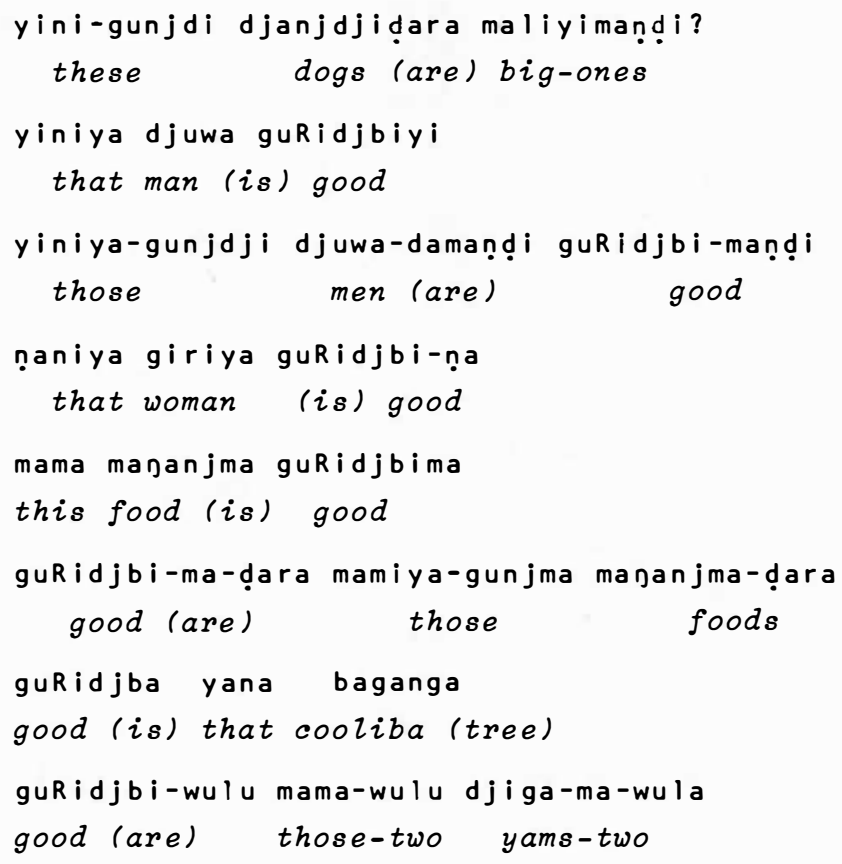

Person in the verb is also involved in the concord, as in 


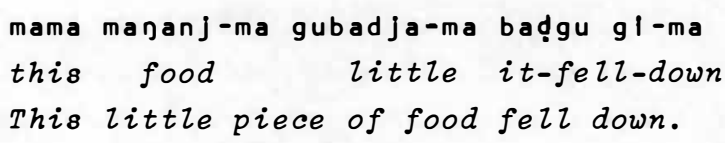

The class is marked in the subject only for third person, 1t does not appear in 3rd person object, which is zero but objects of other persons are indicated by bound forms, e.g. gadbi gi-nja see I-you. Tense is then added after the person forms: djanjini gini-na-ma gudayiba dog it-me-did bite, the dog bit me.

This group of languages completes the MC class. The dual classifyIng class will be studied next, and it is noticeable that these tend to surround the suffixing MC languages - Mangaray and Alawa to the north, and Wagaya to the south. Map 1 shows that feature.

7. DUAL CLASSIFICATION

\subsection{Introduction}

The term dual classification implies that nouns are divided into two classes only. In Europe such types are provided by the Romance languages and by some of the modern Scandinavian languages.

There are three discontinuous areas in which dual classification is found in Australia:

1. The Eastern Kimberley division, athwart the northern half of the Ord River Valley.

2. In Arnhem Land, near the mouth of the Liverpool River on the north coast.

3. Two languages on the south-eastern edge of Arnhem Land.

4. In certain areas of New South Wales.

These are areas in which classification is made by the use of prefixes, as in the MC languages, with the difference that here there are only two classes. Most of these languages operate by suffixation, like their European counterpart, but those on the north and south of Arnhem Land operate by prefixes, like the MC languages, though formally there is little resemblance between the morphemes involved.

Nelther in form nor in function do the classes in the dual systems overlap to any great degree. It would seem to be a case of separate development in each area. Historically the problem is considerable, for 1t does not seem easy to see why such a type - a minority type in Australia - should have developed. In the case of New South Wales it is almost certainly a local evolution. 
It is convenient to discuss the prefixing dual languages first, then the suffixing languages. The language of Bathurst and Melville Islands is an 1solate; in Arnhem Land there are five languages in which dual classification has been found - two in the north, Gunavidj 1 and Nagara, both on the south of the Liverpool River - Gunavidj1 on the eastern side and Nagara about Boucault Bay, and two in the south, Alawa on the south of the Roper River and Mangaray farther west, about Elsey Station.

\subsection{Bathurst and Melville Islands}

The Tiw language of Bathurst and Melville Islands is formally a dual classifying language, logically it has four classes. Reference may be made to Osborne's The Tiwi Language (Osborne 1974) and only the barest reference will be made here. He states that 'the conceptual scheme which underlies the classification of Tiwl nouns is twodimensional, one dimension having the poles masculine and feminine and the other human and non-human' (p. 51). As actual endings are masculine $\{-n i\}$ and feminine $\{-k a\}$, with a common plural $-w i$, there are formally only two classes to take care of. There is concord of dependent words, including verbal subjects, but verbal objects differ: Osborne says that 'third person-singular direct object is inferred from the absence of a prefix, and gender of such an object (except when it co-occurs with third person-singular subject in past tense verbs) is expressed by means of the tense marker po- or to-, depending on the tense of the verb' (Osborne 1974:39).

It will be seen that this language differs considerably from the general run of Australian languages in this as in most other regards. The formal agreement of the plural -wi with Northern Kimberley and Arnhem Land biri-, bara- (also suffix -bira in Laragiya) may be only accidental: detalled comparative study of Tiwl has yet to be made.

\subsection{Nerthern Group}

\subsubsection{Gunavidji}

In Gunavidj1 there are two class divisions, which may be satisfactorily labelled masculine and feminine. Special forms are found in pronouns of the 3rd person singular, but in all other word classes there is a regular feminine prefix in the singular, $-n j i$, which links with the NK $n j a-$. Gender is not marked in the plural, just as in the Djerag languages. The feminine marker $n j i-1$ s actually replaced by $n j a-$ in some of the demonstratives. The masculine noun, unlike those of DJerag, does not carry a marker, but in demonstratives there is a marker dji-. Adjectives use $n j i-\sim n j a-$ but not $d j i-$. Examples: 


this: root -ja masc. djija fem. nja:ja plur. barija
that: root -ja-ba masc. djejaba fem. -ija-ba plur. barijaba
good: masc. madjan fem. njimadjan plur. baramadjan
bad: masc. bo:ga fem. njabo:ga plur. barabo:ga

Some adjectival roots are invariable for class, e.g. do:dbalg, good (syn. of madjan). Further examination will probably show that as in the NK, it is a question of initial vowel or consonant, and that as in Ngarinjin, etc. only adjectives with initial vowel can take the prefixes. This has not been examined in detail as yet.

The plural marker for both classes is bara-, again comparable to the NK and DJerag biri-. Example: gaRama, woman, plur. bararama-ba. ${ }^{l}$

Rules of concord are well marked in the following verbless sentences, which represent the contrastive forms used to mark comparisons in Gunavidj1:

$n j a: j a$ DaRama $n j$-raragarawa:dba; $n j \varepsilon: j a b a$ gaRama $n j i-n d \varepsilon l a: d j a$
this woman (is) tall that woman (is) short

1.e. this woman is taller than that one. Plural:

barija baraRa:maba bara-ragama:dba; bara-re:ndjea bara-ndeladja

It should be remarked in passing that the 'adjectival' can be verbalised but taking on person markers of all persons as prefiyes. The noun in general does not carry a class marker, and class assignment - 'gender' is grammatical, as in the Romance languages. 2

\subsubsection{Nagara}

Present study of this language is limited to Capell's investigations in 1941, which have not yet been followed up; but the notes then made suggest that noun classes are two in number, and that dual and plural prefixes are found as well as singulars. Gender appears to be masculine and feminine, each marked, and the gender system is found in the pronoun, adjective and verb: the noun 1tself bears no marker. As

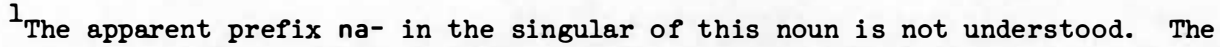
language still awaits depth study, and the present statements are taken from the author's field notes which it has not been possible to follow up.

2 The word man is identical with Worora idja; but it has already been pointed out that Gunavidji shares some vocabulary with the western Torres Strait Islands (Capell 1942, 13/1:29).
} 
far as the evidence goes, gender is 'natural', 1.e. female creatures are marked as such, otherwise masculine markers are used. An example among the list of nouns shows that in some cases nouns can be marked: yawurin, young man (a word shared with the Gunwinjgu group) > $n j a-$ wurin, young woman. This is unexpected in that in Gunwinjgu jawurin is monomorphemic; in Nagara 1ts treated as ja-prefix with a stem wurin. In any case the masculine marker is na-, so that *nawurin would be expected. There are also some other such terms, e.g. galugwona, boy > ngalugwona, girl, formed on normal procedures. It is possible that some such procedures are to be found that have been noted in Laragiya, where kinship terms can take prefixes not otherwise used in the language. Capell was given $d j a: b a, e z d e r$ brother, but for younger brother dja:ba galugwon(a), which looks like an ad hoc translation by a speaker at a loss - but at least shows the masculine term for boy.

As a rule, however, the noun does not carry a gender marker: the other members of the NP do. So balbal $n i-j a n g a$, the wind comes is marked as masc. by the verb pref1x; lgara go:ga, this water is marked similarly by the adjective, like ngaRa nagajara gabulawa, this (is) camp my.

The demonstratives are:

NEAR Singular Plural

Masc. Dga: Ra

Fem.

arabuga:Ra
arabugi : Ra
FAR Singular Plural ngaña arabugaña arabugi : ṇa

These have both adjectival and pronominal reference.

In the pronouns three numbers are marked, and gender is shown in the third person of all numbers. The dual involves as an infix the numeral root -gagaRa-, two; the pronouns carry the -ba suffix shared by a number of languages elsewhere in Australia. ${ }^{1}$

The third person forms are in Nagara:

$$
\text { Singular Dual }
$$

Plural

masc. na-ga-ba

$$
\text { ba-na-gagaRa-ba }
$$$$
\text { ba-baRa-ba }
$$

fem.

$$
\text { Di-ga-ba }
$$

bara-na-gagaRa-ba

bara-baRa-ba

This is a falrly complicated formation, and quite peculiar to the language.

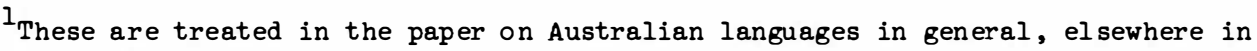
this volume.
} 
In the verb, person markers are prefixed, and the object is incorporated into a portmanteau prefix. The intransitive masculine prefix in 3rd singular is $n \mathbf{i}$, the feminine gini-as in ni-yanga, he comes, gini-yanga, she comes. It would seem, however, that the transitive prefix does not distinguish between the two genders. In the dual number there are ba-ni-yanga, masculine, and bara-ni-yanga, feminine, and in the plural bi-ni-yanga, masculine, and bi-ri-ni-yanga, feminine. In these two the feminine marker is clearly -ra-/-ri-. This is of interest in that the usual pluralisers in the MC languages of north Australia have some form of bara-/biri-, regardless of class. There are also changes of prefix for future tense - a contrast of future v. non-future. Capell's examples also include

$$
\begin{gathered}
\text { wunagalaya na-ga:ya maladj(a) } \\
\text { man brought turtle }
\end{gathered}
$$

and a phrase ginaga:ya nawaRa, translated as he brought the woman, but it is possible that this was a mistake on the informant's part and really means the woman brought it.

The non-singular forms are not quite clear and will not be adduced here. The language needs to be studled afresh whlle it is st1ll avallable. It seems to have many peculiarities of its own.

\subsection{Southern Group}

\subsubsection{Alawa}

The Alawa language is spoken on the southern side of the Roper River and has been studied by the writer, and much more thoroughly by M.C. Sharpe. Here also there are two noun classes, a feminine marked by the prefix an-, and a masculine which is unmarked. Mrs Sharpe (Sharpe 1969) says: 'most feminine gender nouns have a feminine gender prefix and denote human beings. The feminine suffix is occasionally dropped from feminine stems. It is always absent from wunaru, sun' and she adds 'this noun is sometimes masculine, as in wunaru mal arala/nala, sun up he/she goes, the sun is rising'. She also adds that in a few Instances nouns regarded by English-speakers as nonhuman or inanimate are marked for gender in Alawa, nawanga, totem; anmunamuna, women's corroboree; anyaraman, mare. The last is the only animal name marked for gender, and it is derived from a commonly adopted aboriginal term yaraman, horse, whose origin is apparently not established. Gender is marked in adjectives if they are applied to feminine gender nouns, but not otherwise. Examples from Capell (1942) 
Include nula waylnma, he is dead; nadula anwaylnma, she is dead. Object forms appear in gun gerenu, I see him; gun gerendiguru, I see her. Here the gender is marked by a change of suffix, but the case is not always so simple. A few further examples from Capell: nanaja gun djana, did you see my father?; angudjaga gun djandanuru, did you see my mother?; Daru dul juranana nananarana wagar niri, we two saw my father sitting there; garu dul gurananuru angudjaga wagar ari, we two saw my mother sitting there.

\subsubsection{Mangaray}

Th1s language, spoken in the region of Elsey Station, to the west of Alawa, shares with 1 t the marking of two genders. The feminine prefix is gala- in this instance, and there is frequently a masculine marker na-. Demonstrative and third person pronouns are not always easy to distinguish. The forms recorded are:

\begin{tabular}{|c|c|c|c|}
\hline & Singular & Dual & Plural \\
\hline 1. Incl. & - & Di: & Dala \\
\hline 1. excl. & Daya & DiR & gila \\
\hline 2. & njangi & nuR & nula \\
\hline 3. m. & $\begin{array}{l}\text { ni (wa) } \\
\text { nariwa }\end{array}$ & garan & gala(riwa) \\
\hline 3. $\mathrm{f}$. & $\begin{array}{l}\text { gi (wa) } \\
\text { ginariwa }\end{array}$ & $"$ & $"$ \\
\hline
\end{tabular}

There 1s also a set of oblique pronouns, which can be elther datives or possessives, but as possessives - gu can be superadded to them.

Demonstratives found in the sentence material to hand seem to point to a 'natural' gender system. Phrases recorded Include niwa muyig, that dog; niwa malam, that man; giwa landi, this tree; gi: gugu, this water; ni: garawi, that kangaroo. There 1s a masculine prefix na- and a feminine prefix nala-: na-wawa, brother; nala-wawa, sister. These do not always appear in sentences: banam, camp (c1tation) but gila garagwa nabanam nilananiwainji, we were talking in the camp suggests that the prefix acts rather as a definite article. More often a separate demonstrative is used:

Cook me some meat: yalaR naya nandju meat cook for-me

Don't cook that meat: olndjag njanaya jalaR giwa don't you-cook meat that 
Whose meat are you cooking?: djagi-nangu ginariwa yalaR ganyanaya who-his that meat you-are-cooking

What is that (mark) on your hand?: djagi-na ginariwa na-ngayma-gan what-it that the-hand-on

In such a case the prefix does not appear: malam, not namaiam in:

$$
\begin{aligned}
& \text { Dindja bayibub giwa malam? } \\
& \text { who kizzed that man? }
\end{aligned}
$$

Nouns In Mangaray can also recelve person markers: na-wangidj, I (am) a child, when I was a child, so that the na- pref1x may be construed as 3 rd sing. masc. of the verb. Compare:

$$
\begin{aligned}
& \text { bada-nga na-djilig } \\
& \text { father-your he-alive Is your father alive? } \\
& \text { na-laia-nga nala-djilig } \\
& \text { mother-your she-alive Is your mother alive? }
\end{aligned}
$$

There is also an example of a reduplicated prefix: na-nangariwa banam, that country in a context, I'm afraid to go to that country. But reversed word order may also produce a full pronoun in final position, as in nanga niwa, it is for you, which may be analysed as na (masc.) gga, your (suffix) followed by the pronoun niwa; it was tobacco, giwa baga, that tobacco. Also of a flsh: giwa balgur, that fish - balay giwa, long one it.

As verbal objects, the gender prefixes do not appear in all cases:

$$
\begin{aligned}
& \text { na-yumbub malam nandju } \\
& \text {-left man mine }=I \text { left my husband. } \\
& \text { nja-yumbub na-ngaḍgu } \\
& \text { her-left fem. wife }=\text { He left his wife. }
\end{aligned}
$$

In the absence of a full study of this language fuller notes have been given; they may act as a guide for future investigation.

\subsection{Dual Classification by Suffixation}

\subsubsection{Languages of East Kimberley}

These languages are referred to as the 'DJerag' group, from the verb speak which is commonly djerag amongst these languages. Geographically, they are found chlefly between the Durack Range and the Western Australian border with the Northern Territory, 1.e. In the valley of the Ord River, where they are bounded on the north by the sea, and on 
the south by the Malngin language, the northernmost member of the Western Desert languages. On the east they are bounded by the MudburaNgarinman languages, also of the WD type.

In the present reference no detall is given on the languages apart from the grammatical features belng discussed. They are reckoned usually as Gidja (or Lungga) on the south towards the Fitzroy River, Mirlwun, Gadjerong, Guluwarin. They st1ll need more investigation.

As the languages are all falrly closely related, they are simply termed 'DJerag' in the following pages. Most of the examples are given in Gidja, but no matter of princlple is involved in the cholce of such examples.

Djerag nouns fall into two classes, a masculine and feminine - this nomenclature is recognised by native speakers themselves and so the gender terms may rightly be kept, though they are better not used in the more complicated systems of the Northern K1mberley. W1th the noun, the adjective and pronoun (Including demonstratives) must agree, and the pronoun object of the verb agrees with the noun to which it refers in gender and number. This object is often incorporated into the verb. The typical ending of the masculine noun is the interdental $n$, and for this reason it is hardly necessary to indicate the interdental varlety of this sound. Unlike d, it does not occur except at the end of a masculine noun. The feminine nouns are usually indicated by a final 1 . In the absence of elther distinguishing consonant, the gender must be learned empirically. The change of $n$ to 1 often shows a change in the sex of the person or animal mentioned: banarin is a male plains turkey, banaril the female of the same specles. So with many other words, but relationship terms can only in some instances bs thus changed over, though each ends in 1 ts proper gender-consonant. So ja:li1, a woman (Northern Kimberley gali). ${ }^{l}$

In the plural both genders change the ending to $-\mathrm{m}$. The following table (Table 2) shows typlcal words:

Masculine: singular djilan

winjagin

malambar ga: lin

Feminine: singular na:lil

ja: $\mid \mathrm{d} \mathbf{j}$ a 1

wanjagi 1

$$
\begin{aligned}
\text { plural djilim } & \operatorname{dog} \\
\text { winjagim } & \text { boy } \\
\text { malba ga: lim } & \text { sorcerer }
\end{aligned}
$$

$$
\begin{array}{r}
\text { plural na:lim woman } \\
\text { naldjam frog } \\
\text { wanjagim girl }
\end{array}
$$

$1_{\text {See page }} 156$. 
Both genders have a dual number formed by adding -warln to the stem: djilawarin, galiwarln, etc.

The adjective tends to end in the interdental - $n$, in the masculine, and this changes to -1 in the feminine, but the final vowel of the feminine sometimes undergoes modification also. The plural of both genders ends in $-m$. The following examples show agreement for both gender and number.

\begin{tabular}{|c|c|c|c|}
\hline \multirow[t]{2}{*}{ English } & \multicolumn{2}{|c|}{ Singular } & \multirow[t]{2}{*}{ Plural } \\
\hline & masculine & feminine & \\
\hline Zarge & naweran & naweril & naweram \\
\hline smazz & wudon & wudol & wudojm \\
\hline alive & mo:lin & mo: 111 & mo: $11 \mathrm{~m}$ \\
\hline bad & gi lwangin & gilwangil & gilwangim \\
\hline good & jilgin & اוأوانز & سأوا زأز \\
\hline
\end{tabular}

As a general rule these agreements are not made when the adjective stands in the predicate; but the rule is not absolute. Thus one does ask:

gulgalna mo:lil? nowan, njaginwad. Is your wife alive? No, she is dead.

These languages have a concord system that is as strict as that of the multiple-classifying languages of the NK. In Gidja for instance:

janani-n dji:yili-n nawara-n maranl-n nare:nari n-amangi?
who man that big seeing him-I-did?
janani-l ga:li-l nawara-l marani-l nare:nari njil-amgi?
who woman that big seeing her-I-did?
janan-bi dji:Yili-m biri-jana marani-m nare:nari ni-mangi?
who men those big seeing them-I-did?

The plural prefix biri- is 1dentical with that of NK. Further remarks on this will be made later. The sharing of gali, woman, with these languages has already been noticed.

\section{ISOLATED CLASSIFYING LANGUAGES}

8.1. East Coast Languages of Queensland and New South Wales

An 1solated area of noun classifying languages by suffixation is found on the north-east coast of New South Wales, overlapping into 


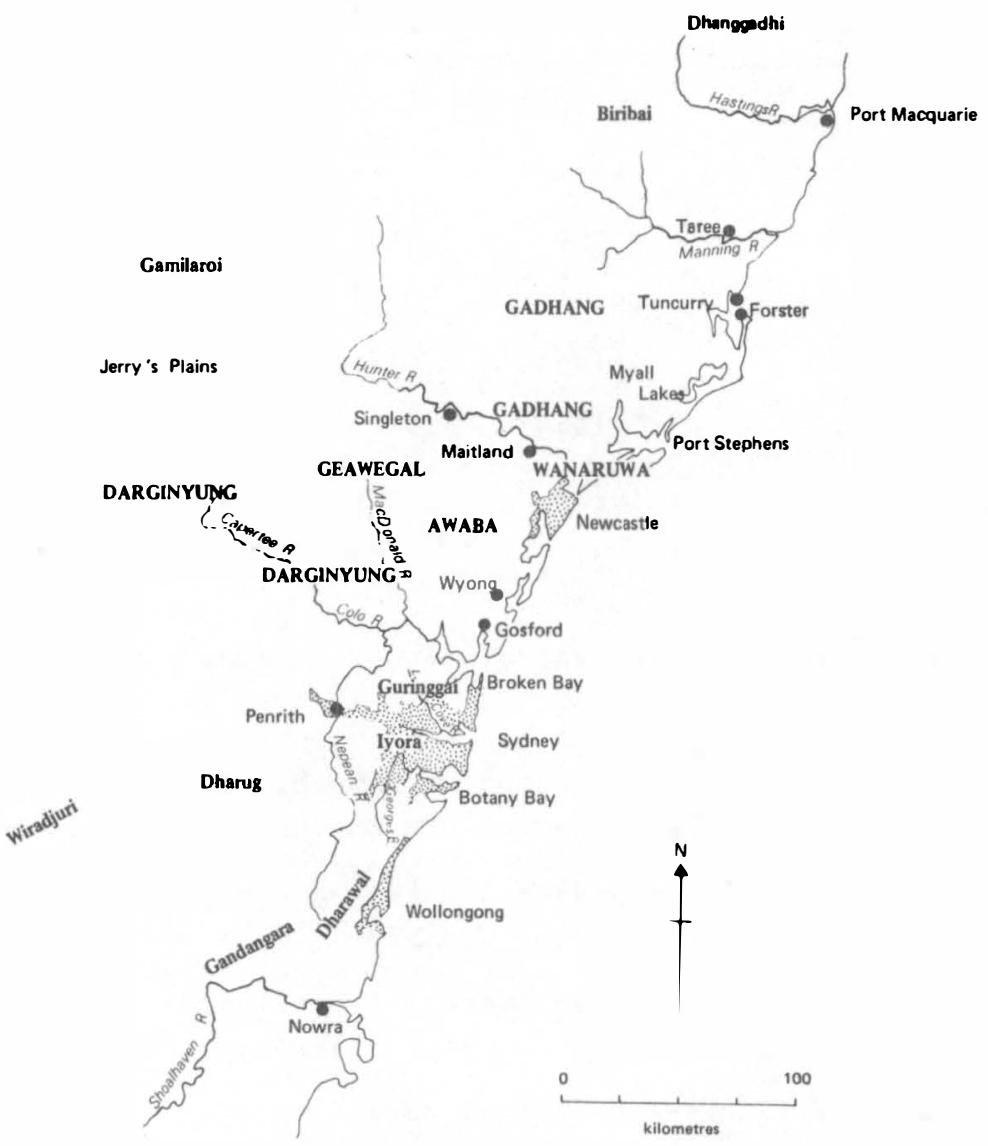

Map 5: Lonquages of the Central East Coast of Now South Wales 
Queensland, from approximately Evans Head to that coast opposite Stradbroke Island, and stretching inland as far as the Dividing Range. This group of dialects forms the Banfalong language. The best known of the dialects is Gidabal, studied by the Geytenbeeks (1971). These students define it as follows: 'at least nine dialects mutually intelligible are still extant.... The names of most of the dialects end in -bal, the ones who say (sometimes spelled-bul ${ }^{l}$ ): Dinggabal those who say dingga, that's right; Gallbal, those who say gall, this (in sight); Gidabal, those who say gida, that's right; Ngara:ngbal, those who say nara:, what?; We:lubal, those who say we:lu, you; Wiyabal, those who say wiya, you; Wudjebal, those who say wudje, you; Yugumbe:, those who say yugumbe:, no.' This last dialect has also been studied by Margaret Sharpe (Sharpe 1969) and is also called Yugumbir.

An older, more generalised study, was made by Livingstone for Fraser's edition of Threlkeld's An Australian Language (Threlkeld, Fraser, ed., 1892). There are vocabularies in Curr's The Australian Race and mentions in later authors. In the earlier accounts, such as Livingstone's, the language is called Minyung (what?) and as such is discussed by Schmidt (1919a,b).

Although these languages distinguish four classes, and the neighbourIng languages are clearly akin to them, the full system is not found in the others, with one exception: the feminine ending -gan appears in a number of the languages north and west of the Bandjalong group in Queensland. Gab1gab1, for instance, is one of these languages. At the end of this section there will be found some discussion of this problem of apparent 'overlap' of systems, for it is not easy to decide whether this is really a remnant of a once more widespread series of classifying languages, or a borrowing from Bandjalong into the nelghbouring tongues.

The bulk of the discussion here will be based on the Geytenbeeks' work on Gidabal, and Livingstone's more generalised Minyung. There is no need as a rule to specify the dialect quoted. In Minyung, there are sald to be four classes of nouns, a masculine, whose adjective ends in -bin, a feminine using an ending -na-gan, a 'things' class in-njon, and a double set of animates and places using zero marking. For Gidabal the description is more complicated. The adjectival endings are easier to use in this connection. The Geytenbeeks state that with adjectives the endings are optional, with certain limiting cases in

${ }^{1}$ This etymology for the ending is open to doubt; it seems to be a form of an early Australian *-gallg, a group of people. There is discussion of the matter in the section on the origin and spread of Australian languages in the earlier part of this volume. 
which they do not occur at all. There are four classes:

$\begin{array}{ll}\text {-gail } & \text { masculine } \\ \text {-gall, -gan } & \text { feminine (normal quality) } \\ \text {-gan } & \text { weaker quality feminine } \\ \text {-Ca:gan } & \text { feminine, adjectives of size } \\ \text {-Ca:n } & \\ \text {-gay } & \text { arboreal } \\ & \text { neuter }\end{array}$

This list differs from Livingstone's considerably. 'Size' adjectives consist of four words only, one of which will serve to 1llustrate the actual usage, 1.e. gamay, big, which shows gamay-gali, big (man); gamay-nja-gan, big (woman); gama-nja:n, big (tree); gamay-gay, big (neuter); gamadi:n-gam, big (plural); gama-nja-nbil, big (trees arboreal plural). This system differs considerably from those of the northern languages and is clearly based on different premises from theirs. The marking of plurals by different suffixes is only one point amongst a number. Case endings (including ergative) are added to the first of a set of units in a noun phrase, e.g. the example given, gadanmir-u bulunj-dju, hard plur.-with clay lumps-with, i.e. with hard clay Zumps.

In Gidabal there are other suffixes with class nouns but not in the same way as these; there 1s, for instance, -gir, class of, e.g. gawangir, mother's brother class of person; wulbun-gir, teenage girl class, a teenage girl. This suffix occurs only with human kin terms. Some of the variants in Livingstone's list seem to be accounted for as parts of this system of semantic suffixes, which are disregarded here. Plural number is indicated in Bandjalong in a way quite different from those seen in the northern languages: -man is suffixed to words for boy and girl; -djali to words for man and woman, while 'other human status nouns' take -girmam, most other animate nouns e1ther -ge:n or -gara:, trees and a few place words - „bil, and other place words, some foods and animals -mir. Obviously there are completely different premises behind these languages and those of North Australia. The latter is a relatively homogeneous group, at least in principle; these of the east coast are not historically related to them.

The optional nature of the suffixes is stressed also by Livingstone, who says: 'Adjectives generally agree in termination with the nouns

${ }^{1} \mathrm{C}$ - indicates a variable form preceding. 
they qualify; but it should be noticed that they do not follow any hard and fast rule. The suffix may be dropped from the adjective; more frequently it is dropped from the noun and retained with the adjective; and rarely, when the sentence can be understood without 1 , It is dropped from them both' (Threlkeld 1892:Append1x p. 11). Th1s, again, is in complete opposition with the North Australian languages. It rather suggests that the historical basis of this system is a number of free forms which have lost status first of all on the phonological level of stress, and then on the semantic level as well.

This suggestion gains strength from the next remarks of Livingstone, 'On the other hand, this rule is carried out to an extent that surprises us. For instance, nubun ${ }^{l}$ and nubuggan ${ }^{l}$ mean husband and wife, but the longer form of nubun-gan is nubun-djar-gan. Now, Kibbin-baia means Kibbin has, and to say Kibbin has a wife would generally be Gibin-baja-gan nubun-djar-gan. Again, bura djin nayabaya mia would mean take the speck out of my eye; where naya-baya and mia agree in termination, yet mia has the shorter non-life form and naya-baja has the longer life form'.

It is obvious that a system different from those of North Australia is present here. Firstly, the class markers are stem-final, not steminftial. Secondly, they are often omitted altogether. Again, other suffixes may be added after them, unt1l the whole word pattern becomes one of a not always quite simple agglutination. This last fact suggests that in this area of Australia, the class marking is almost an afterthought, at least, not a true part of the essential structure of the language. There is an unmarked class, that of the general neuter, and this covers a wider semantic fleld than the corresponding class does in the north. In the northern regions, moreover it is never the neuter class (so far as there is one) that is unmarked. It is therefore to be presumed that class marking is a development of comparatively later date, and that originally these languages did not have 1t. Some of them developed a feminine, -gan, and this is found in Gablgabi and a few other languages outside Bandjalong. The suggestion is that Bandjalong dialects first become dual classifying, then further distinctions were made. At first there was lack of marking, then females were picked out for marking, and then in Bandjalong alone, further subdivisions were made.

The lack of concord in many instances also suggests a later development of a marking system, which is only imperfectly developed.

${ }^{1}$ Livingstone's spellings here have been adjusted to those of this work. 
In the nelghbouring languages such as Gabigab1 and Durabal, there is no concord even when the feminine ending occurs. In Durabal for instance, that man and that woman are wunmal dagay and wunmal djandal respectively, omitting the 'locational' question of where they are in regard to the speaker. In Bandfalong the phrases would be gile baygal and gile:gan dubay.

Again, Bandjalong adjectives display much uncertainty about their form in the sentence. The Geytenbeeks (1971:20) speak of 'quality' adjectives and four - four only - 'slze adjectives', which take somewhat different forms of suffix, and both groups subdivide the feminine class, giving the sets previously quoted here. Moreover, individual adjectives have individual 1diosyncrasies: gamay, big, has a plural allomorph of the root, gamadi:n, and no other adjective has such. Words for smazl (bidaj) and short (mul) use with masculine reference -galan in preference to -gali without complete rejection of the former. On the semantic level, reduplication of the root is possible: guli-gali, active man, but gulilguli:l-gali, fairly active man. Size adjectives take a feminine - Ca:gan (where C represents a morphophonemically changed consonant) which mul, short and dalgay, dry, share also in Classes III and IV, and the Geytenbeeks describe the difference by '-galigan, Fem. (normal quality) and -gan, Fem. (weaker quality)'. All this makes one feel that the entire system is not really at home in Bandfalong, and is a local development of perhaps relatively late date. This, of course, can only be speculation, but the facts do strongly suggest 1t, and there is no reason to count these languages as historically part of the 'multiple-classifying' languages of Australia as a whole.

The Impression that a local cause has been at work here is strengthened when comparison is made with the Gumbainggar language Immediately to the south of Bandjalong. Smythe's grammar (Smythe 1952:156-7) rejects the term 'noun classes' for certain differences in Gumbainggar words, and prefers to speak of 'noun categories', of which, he says, there are nine, marked by endings. Some of these endings are found also in the Geytenbeeks' lists of noun-markers for Bandjalong, and not all of them have been accepted here as 'class' markers. Thus the soclal 'section' called wirunga has a feminine wir-gan-na; garbunga has gar-gan-na; and in both cases -gan- marks the female members of the class. Other terminations have formal correspondences in Bandjalong but the uses are different. There has been a tendency to 'classify' In the se areas but 'noun-classes' as such have generally not developed. In point of fact there are instances of the feminine 
ending -gon as far south as Awaba about Lake Macquarie, Newcastle district, but in all instances only on the coastal side of the Dividing Range. Examples are seen in yi'nal, son, yi'nal-gan, daughter; borlbay, husband, bori-gan-bay, wide. The suffixed -bay occurs also in biyanbay, father, but is not explained, and the vocative of this is biyan. It does not appear even in the related languages, Darginjung or the remains of the Guringgay language, and this is remarkable, because these are hardly more than dialects of the Awaba. Nor does it appear in Dharug or Iyora (Sydney).

Awaba does contain a system of noun classification that has not hitherto been remarked on. It is both complex and unique in Australia in that it is based on principles different from those found in the other languages, even the Bandjalong group. It is therefore justiflable to deal with it at some length here, and to give the analysis that came to light in the preparation of this paper.

The Awaba system of classification depends on the case suffixes, and comes to light only in the processes of declension. First of all, there are two sets of case endings, one of which is added to proper nouns and to pronouns. The other is common to all other types of nouns, but certain particles are used between stem and suffix which varies according to a system that can only be called noun classification. In this way the surface form of the noun becomes $\mathrm{N}+\mathrm{Cl}+\mathrm{c}$, where $\mathrm{N}=$ noun, $\mathrm{Cl}=$ class and $\mathrm{c}=$ case. There is no inflection for number in the noun as such. Apart from proper nouns and pronouns, nouns can be dichotomised into those that take the suffixes direct and those that interpose a class marker. The feature of masculine and feminine pronouns was mentioned in the opening section of this paper, and on a superficlal view Awaba is simply one of the languages in which a masculine-feminine division is recognised, at least as far as pronouns are concerned. Nouns can be classified into six groups, one of which has a zero marker $(\phi)$, but the markers are not permanently attached to one particular noun: a man can be 'personal animate' and so the marker -gin- is used with the word guRi, man; or he can be a place of origin of an action and then the marker is -ga-. The same facts apply also to pronouns and proper nouns. The lst person singular pronoun naduwa, $I$, has an oblique base emowun: emowun-ga-duwa is by me as, e.g. a place to sit; emowun-gin-birun is from me as a personal source of action; and similarly, guRi-gin-gu, to the man as a person; guRi-ga-gu, to the man as a place reached, 1.e. allative case. Threlkeld (1892) gives as examples: governor-umba-ban, I am the governor's (man); governor-gaygal ban, I belong to the governor's place; muruRan-gu-ba guRi-gu-ba, 
belonging to a good man (something unspecifled, with but a genitivedative marker -gu [the common Australian form] plus a -ba of location, as in the name Awa-ba, a plain surface with accent on the first syllable). Other suffixes can then be added, e.g. Awa-ba-gal-in-du, Awa-place-inhabitant-feminine-ergative in the normal manner of agglutinative languages.

The above classes can then be formalised as follows:

$\begin{array}{ll}\text { Class } & \text { Formative } \\ \begin{array}{l}\text { proper noun or } \\ \text { pronoun }\end{array} & \text {-um- } \\ \text { personal } & \text {-gin- } \\ \text { animate } & \text {-la- } \\ \text { people or place } & \text {-gal- (masc.) } \\ & \text {-gal-in (fem.) } \\ \text { location or time } & \text {-gay- } \\ \text { unspecified } & -\phi-\end{array}$

There can be crossing from one to another or combination of two, e.g. bun, today, bun-gay-gal, belonging to today (as though today were the inhabitant of something); nigu-wun-gin-gu, him-of-person-to, to him (allative). The complexities possible cannot be illustrated here.

Case forms themselves also are complicated, and there are numbers of morphophonemic modifications. The ergative starts from -*lu as in most parts of Australia, but takes on forms such as $-1 u,-(r) u,-g u$, -du. The dative-gu can be combined with -ba (place where) to form -guba, 'possessive' and -guwa, 'accompanitive'; -gay is not only used alone but combined as -ga-ba (assoclative), -ga-birun (ablative), -ga-gu (allative) and other shapes. There is also a-din which is causative but not ergative, whlle personal nouns use -nun as accusative and dative marker, and -um-ba as possessive. The full analysis of this system will, it is hoped, be published later. Languages north and south of Awaba have not developed such elaborate nominal forms.

\section{A HISTORICAL VIEW OF NOUN CLASSIFICATION}

\subsection{Introduction}

At this point the thoughtful student will ask how the present processes of noun classification in various parts of Australia came about. That question cannot be answered apart from the entire history of language within the Continent, and this is not known. In fact, 
time depths considered, it is doubtful whether it can ever be properly answered. What follows is an attempt to reach a logical answer which however, will still lack documentary historical proof.

The present situation is statable as follows: (a) In various parts of Australia there are languages which classify nouns in a number of different ways. (b) These areas are not continuous. It seems, then, elther that they developed separately and have no historical connection with each other, or that they developed in one area and spread. (c) In the latter case their present separation is due to subsequent movements of other types of languages, which have broken a formerly continuous sequence. But on the other hand such an argument is not necessary. A similar principle may have come into use discontinuously: there are other examples in the world of such happenings. Each of these theorles will be taken into account, though each may not be argued in full.

The present noun classing systems fall into a number of types:

1. Multiple classification, 1.e. a number of classes greater than two, and Involving concord between the noun and all other parts of the utterance logically dependent upon 1 t.

2. A similar system, but involving only two classes, which can sometimes be regarded as a masculine-feminine division, or a feminine-nonfeminine division, only the feminine being marked.

3. Each of these types of classification may be elther prefixal or suffixal. The regions in which each type occurs show no logical determination: the Northern Kimberley languages are multiple-classing by prefixation, the Eastern Kimberley dual-classing by suffixing, while east of these, In Arnhem Land, multiple classifying by prefixation prevalls, with an enclave of dual classification by prefixing at two points on the north coast, and multiple classifying by suffix to the south and south-east of the area. There seems to be complete geographical confusion.

4. In coastal New South Wales (with a corner of Queensland) there is multiple classification by suffix, but the actual forms and even the principles of classification do not show any apparent connection with those of North Australia. In the central coastal area of New South Wales there is an example of multiple classification (in Awaba) based on seemingly entirely different root principles as well as different morphemes. Awaba, in fact, seems to be quite disparate and to be local in origin. 
5. In the Cape York Peninsula region, there are languages which employ the system here called 'determinatives' to class nouns, and this is a logical, not a linguistic process at all in the strict sense: no morphology is involved, but only Juxaposition of a general and a specific noun. This may actually, in spite of appearances, provide a possible point of origin for the whole principle of classification.

These, then, are the bas1c facts as they appear today. The problem is now to arrange them historically, if it is possible to do so. At the same time, the 1dentity or otherwise of the actual morphemes markIng the various classes, must be considered, as any historical explanation depends finally on such an identity. The occurrence of a ma- (-ma) class almost everywhere - even in northern New South Wales is an example of what is meant here.

In passing, it may be remarked that typological similarities between the Australian MC languages and Bantu are often very noticeable, but the differences in principle must not be overlooked (Capell 1951). The unclassifled Burushask1 language of north-western Indla also recalls the Australian types in many regards: but in all these cases there is no morphological overlap, so that historical connection is not to be presumed.

\subsection{Characteristics of Classification Systems}

While there are obviously considerable formal differences in the various systems by which classing is marked, these can be reduced to the undermentioned patterns:

Classification by

1. determinatives

2. de1ct1c formants

3. determiners preposed

or

postposed dual

or multiple concordant

or

non-concordant

The term 'determinatives' has been used earlier in this paper; the terms delctic formant and determiners need to be explained; this will come out of the 1dealised examples below.

The various types of classification can be exemplified by using an English example set in what seem to be the deep structures of the aboriginal expressions used in the various languages. If a type sentence $I$ threw that long spear is set out in terms of the basic expressions lying behind the various aboriginal languages, the following four types will appear: 
Type I: that-spear that-Zong-one that-one that-I-threw

Type II: spear-that Zong-one-that that(-that) (that)-I-threw
$\mathrm{N}+\mathrm{d}$
$A+d$
$\mathrm{D}( \pm d)$
$( \pm d)+S+V$

Type III: S-spear S-long-one S-that S-I-threw

$\mathrm{F}+\mathrm{N} \quad \mathrm{F}+\mathrm{A} \quad \mathrm{F}+\mathrm{D} \quad \mathrm{F}+\mathrm{S}+\mathrm{V}$

Type IV: spear-r Zong-one-r that-r I-threw-r

$$
\mathrm{N}+\mathrm{F} \quad \mathrm{A}+\mathrm{F} \quad \mathrm{D}+\mathrm{F} \mathrm{S}+\mathrm{V}+\mathrm{F}
$$

The symbols used in the diagram are:

$d=$ delctic; prefixed if preceding, suffixed if following;

$F=$ delctic formant, similarly prefixed or suffixed.

It 1s doubtful whether Type IV occurs in Austral1a; it is, however, a theoretical possibility which must be allowed for in setting out a pattern. The diagram itself provides for full concord; the languages do not always have such concord, but parts of 1t are present in almost all cases except those of New South Wales-southern Queensland.

The Dfirbal pattern is unique in that only the demonstrative is affected. The possible historical setting of this fact will be dealt with at a later point. For the moment it is enough to set out a diagram of what can happen. When this is correlated with what does happen in various parts of the continent, it will be possible to study also possible historical sequences and developments.

The terms used in abbreviations need a little further definition. Although 'determinatives' were defined in the earliest section of this paper, a little more clarity may perhaps not be out of place. As there stated, the word is derived from the use made of 1 t by Egyptologists and Assyriologists. By them it is applied to the written language, not to the spoken. In Sumerian, for instance the determinatives placed before a sign were actually (in the earliest times) pronounced before 1t. One writer has compared such a sign with the 'St' used in English before, e.g. 'St Paul' - to signify Just which Paul is spoken of. Those instanced in the Cape York languages are all of this kind, and so it seems a sultable term for such compounded words as were 1llustrated above from those languages. The use of determinatives of this kind involves no grammatical concord. If, however, they are to be regarded as precursors of the prefixal concordmarkers in other languages, it would be necessary to assume a period in which the determinative actually was repeated aloud before each 
element of the utterance. There is no evidence whatever for this, so that determinatives must rather be looked upon as sui generis and not as a historical part of the multiple-class developments. They would be more closely akin to the suffixed determiners used in the Bandjalong and Awaba types of language, e.g. Awaba emowumba-gin-gu, my person-to, to me; emowumba-ga-gu, my place-to, to me.

This interpretation would then serve to set of $f$ the Cape York languages from the others, connecting them possibly with those of eastern New South Wales. This is possible, because there is considerable lexical agreement between the two groups - a feature which does not come out in the present paper.

On the other hand, there has clearly been usage of the determinative type elsewhere than in Cape York - but of delctics, not of noun forms, for the whole 'concord' principle in Australia seems to rest on the use of delctic determinatives before (or after) each 1tem to which the idea applies, and the multiple-classifying language seems to have come into being through some such process.

\subsection{Stages in the Development of Class Marking}

This is an instance where internal reconstruction is the only means avallable to establish the history of a phenomenon. The outcome of such an internal examination points to classification of nouns as a relatively late phenomenon, and to the development of concord as later still.

In ergative languages, the class marker tends to be declined as a separate element from the marker, 1.e. In such a language as Yanjuwa, the vowel of the marker assumes an ergative case form as does the noun stem. This implies that the ergative process was already functioning when noun classification appeared. Noun classification is therefore historically later than ergativity, and as this seems to be later than non-ergavity, the historical sequence must be: non-ergative : ergative : classification. This applies, of course, only to classification of nouns; that of verbs is an independent occurrence.

Another fact that suggests that classification is relatively late, is that $C A$ roots have been involved in the process, and these represent a secondary stratum of Australian language. For example, in the Northern Kimberley languages, the root for man, CA *badun has developed into bendjin in the north (endjin in one area), plural bir-endjin. In the south, Ngarinjin has developed aRu, a later formation. In the northern languages, the $\mathrm{Cl}$. I prefix is $\mathrm{b}-$, while in Ngarinfin it is a-. The relative sequences are clear. In both cases, Cl. III prefix 
GROUP OR STAGE: A. No recognition of Gender or Class.

B. Masc./fem. (a) pronoun only, (b) NP also.

C. Classification-concord System.

c. CLASSIFICATORY LANGUAGES

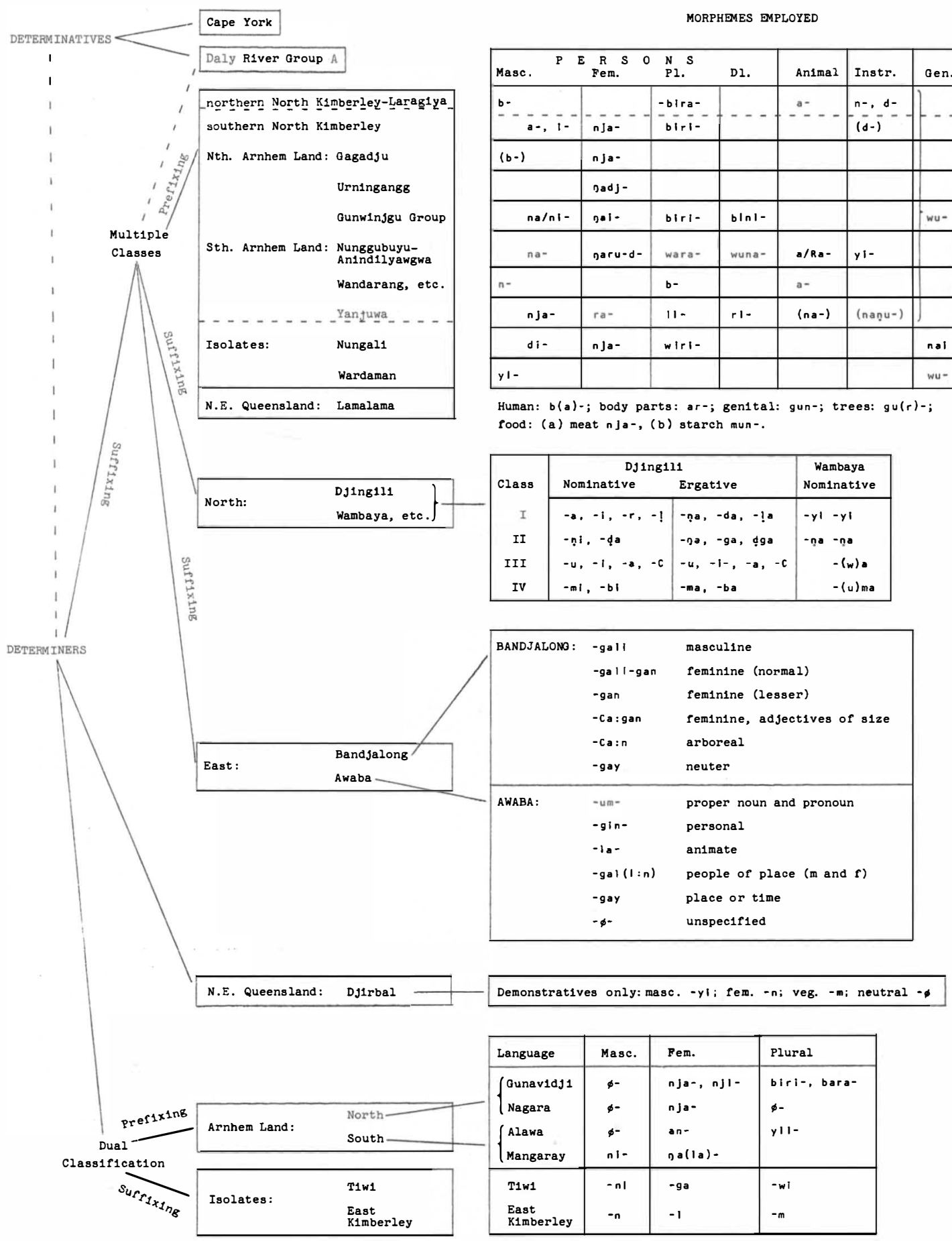



is blr-, giving FR bir-endjin but Ngar. Irregularly bur-uRu. The NK languages were in essentials developed (without classification, presumably) when the change of structure came about.

Again, where CA words appear in the classifying languages - in many the percentage is rather low - they are not always treated the same way as regards classification. The same applies to widespread EA words occurring in these northern languages. For example, *maRa, eye, light, seems to be at the base of Worora maRa-ma, Zight; Ngarinjin maRa. These are $\mathrm{Cl}$. V, as though the stem were *ma-Ra. Worora has suffixed the marker: ma-Ra-ma, as though the inftial ma- of $\mathrm{Cl}$. $\mathrm{V}$ had been mistakenly supposed to be present in a non-root *-Ra- > *ma-Ra-ma . Ngarinfin does not suffix markers, so the base remains maRa > *ma-Ra. In Laragiya, however, the base was classed differently, giving da-maRa, eye. Even local roots are sometimes treated in a similar way. A word common in the Fitzroy Basin, djiridj, magpie lark, has been borrowed into Laragiya as djirjdjiridba, Cl. I as non-human animate. In some cases, transference of 1dea may take place without change of class where 1 might well be expected, e.g. Laragiya da-mbar-gwa, (1) tooth; (2) knife edge.

\subsubsection{The Free Forms called Determinatives}

It needs no argument to suggest that the earliest type of classification in Australia is represented in the free forms, generic nouns preceding specific nouns, which have been called above 'determinatives'. Such a device for classing nouns is by no means limited to Australia. It is very widely used in the languages of South East Asia, to mention only one group. So 1 w 111 be taken for granted here that such a practice represents the first stage of classification in Australia, so far as historical processes can be established at the present time. The historical problem is how to account for the transition from determinatives to determiners.

The Daly River languages (5.5. above) are the first to be considered in this setting.

The probable stage of development from the use of determinatives is presented by the main bulk of these languages, which use class markers before the noun - with some exceptions - and these are in most cases actually 1dentical with the independent nouns. As one uses the Cape York $\mathrm{N}+\mathrm{N}$, so does one in this area of the Daly River. The pattern then becomes:

spear long that I threw wood-spear wood-that wood-Zong I threw 
The languages which are not of this type are the small dialect group Nos. 4, 4a, 5 and 6 in Table I. In these another principle appears which will be discussed below.

The analysis of this Table (Table 3 ) is as follows:

Table 3

\begin{tabular}{|c|c|c|}
\hline Class & Marker & Root in Individual languages \\
\hline 2 & te, awam matjem pinja & meat: te, awu, metjem, pinja \\
\hline 3 & miyi & vegetable food: miyi \\
\hline 4 & $t j o ̈ n, y i l i$ & tree: tjön, tjuıu \\
\hline 5 & tar & tree: tawur (groups 4-7b) \\
\hline 6 & wati, ma, wa & $\begin{array}{l}\text { forms of } C A \text { *badul, man. } \\
\text { See below. }\end{array}$ \\
\hline 7 & nuggu, wur & (unidentified) \\
\hline 8 & wu & wuwu, dog in 9 and $9 a$ \\
\hline
\end{tabular}

As this list stands, therefore, it is just a case of putting a noun of general meaning before a noun of specific meaning, but with the difference that the first $\mathrm{N}$ is beginning to exhibit phonetic changes, and that not all belong to precisely the same language.

The forms in No. 6 for man are more remarkable. They just do not belong to the series: *badun is part of the WD languages, and its usual modern form there is wadi. That is to say, that the Mara- languages are beginning to show true class prefixes, and these are derived from outside the Daly River area.

These Daly River languages thus show a clear step towards the development of class marking by prefix. At the moment, this is a typological matter, not a historical one. Whether it can also be read as historical remains still to be proved or disproved.

The matter of concord becomes of interest at this point, for one of the features of MC languages is usually a more or less elaborate concord between the noun and 1ts dependent elements. But this is not always the case.

Tryon summarises the Daly River languages as follows: 


\begin{tabular}{|c|c|cc|}
\hline & Classes & Concord: Poss. Adf. \\
\hline Mulluk Group: & & - & + \\
Mulluk subgroup & 4 & - & - \\
Daly subgroup & 4 & + & + \\
Brinken-Wogadj Group: & & - & - \\
Brinken & 7 & - & - \\
Maranunggu & 6 & + & + \\
Wogadj & 4 & 7 & + \\
\hline
\end{tabular}

See Tryon 1974:294, and the whole paper for deta1ls. It is clear that there is no original unity in these languages as regards anything more than the fact that nouns are classed.

The further problem, of the interconnection of the morphemes used in various languages to mark noun classes, depends on the possibility of 1dentifying the markers and providing at least feasible original meanings for them. Can this be done?

The Table following (Table 4) shows the actual prefixes occurring in the different language groups. It should be noted at this stage, that in some cases, prefixes occur in one language with a certain set of nouns - a limited set only - which are not normal components of the language as a whole. Laragiya kinship terms sometimes distinguish sex by the use of prefixes $n i$ - and nal-for males and females respectively, but as normal markers of sex these are found only in the Gunwing gu group, while Laragiya usually does not distinguish sex but uses a prefix b-for animate, like the $m(u)$ - of the African Bantu languages.

In Laragiya, son (m.s.) is ni-marg, daughter nal-marg; nu-wag is younger brother, while nal-ag is younger sister (-w- being simply a glide); nu-gunji, sister's son (m.s.), and gal-gunji, sister's daughter. This can hardly be accidental. Moreover, in Gunwinjgu, only monosyllabic nouns appear to take the masculine prefix at all (e.g. bininj, man, rather than na-binin, as against gun-djem, tooth). What the exact history in these phenomena is lies outside the present scope and perhaps even possibility of knowing, but the facts need to be borne in mind. 


\subsubsection{The History of the 'Determiners'}

It is presumable that these forms here called 'determiners' began life as free forms. It might appear that they, being descriptives, would have a closer connection with delctics than with other categories, but the most clearly distinguishable of them, - $m$ or $m-$, for vegetable food, points back to a noun, *mayi which in various shapes is still in use. Certainly delctics were used, and in some languages their Influence is very clear, so that must be rejected out of hand. It can still be assumed that as a rule, suffixed markers represent an older word order $\mathrm{N}+\mathrm{D}, 1 . \mathrm{e}$. noun follows defctic, and prefixed markers and order $\mathrm{D}+\mathrm{N}$, 1.e. delctic followed by noun. What then of the reduplicated forms, simultaneous prefix and suffix of some language, built on the pattern det $+\mathrm{N}+$ det? Th1s double ordering seems to point back to an ordering of the delctic for which there is very little evidence anywhere in Australia. It would seem to entall some original mistake. The commonest occurrence of delctics in normal Australian languages is after the noun. This would suggest that the $N+N$ is the older pattern, leading to suffixed determiners when this stage was reached. When the further stage was reached that origin of the determiners had been forgotten (as, e.g. the fact that $-m$ or $m-s t o o d$ for *mayi) and emphasis was needed as against generalisation, then the determiner began to be repeated for emphasis after the noun, through a probably brief stage when the delctic, in 1ts required class, was used before the noun, in 1ts required class marked by suffix. This is the intention behind the diagrammatisation as Type IV, *this-F spear-F long-one-F this-F, in formula

$$
\text { (d) }+[\mathrm{N}+\mathrm{F}]+[\mathrm{A}+\mathrm{F}][\mathrm{d}+\mathrm{F}] \text {. }
$$

It may be suitable to take Djirbal as a starting point (w1thout any historical implications). Here there is distinction between male and female (the latter including other 1tems which probably have mythological connections), vegetable foods (-m) and a general group including all other 1tems, marked by $\phi$. This zero class belongs to a time when classing was not practised at all in DJirbal; the distinctive markers belong to the period in which classing took place. The male class recelved most distinction (as might be expected in an Aboriginal soclety), and the root forms of the marker were changed, the second syllable being lost, and a substitution made for 1t. This substitution was -yi, which 1tself appears as a masculine marker in one area of Arnhem Land. The vegetable food was marked by $-m$ which clearly represents *mayi, and points back to the system of determinatives 
already discussed. The marking by $-n$ takes in the feminine and other groups that seem to be interrelated. The three distance markers work on similar lines and may be tabulated as:

$$
\begin{aligned}
& \text { bala } \rightarrow \text { ba(la)yi - bala-n - bala-m } \\
& \text { ginja } \rightarrow \text { gi(nja)yi - ginja-n - ginja-m } \\
& \text { gala } \rightarrow \text { ga(la)yi gala-n - gala-m }
\end{aligned}
$$

These sets then present a consistent pattern. They began with distinction between masculine and feminine (a dual classification) as against all others, which were zero-marked (bala-, ginja-, gala-). Next for this language came a setting apart of vegetable foods, marked by the initial m- of *mayi.

Although this is a purely logical analysis, it may suggest itself as very likely also a historical analysis of the development which took place in this part of Australia. Is it possible that similar states of development are represented by the other languages as well, 1.e. that dual classification preceded multiple and that multiple classification came last of all?

These suggestions need testing against the languages. Do any of the other groups suggest a similar development from zero classing, through dual, to multiple, the latter capable of indefinite expansion (if the languages had chosen to carry on such subdivision as it was carried on, for instance, outside Australia, in Nauru and Bougainville, to mention only two)?

The answer seems to be only a very limited assent. In the Eastarn Kimberley languages it is a negative answer, for these have a masculine ending - $n$, a reminine - 1 , with a common plural - $m$. The marking of a plural is unusual in Australia. The multiple classifying languages mark a plural only for rational animates, and usually it is a form of -biri. Research published elsewhere ${ }^{l}$ shows that a plural in $-r(a)$ is characteristic of certain areas in Australian pronouns, and has nothing to do with the formations now under study. The -*birl or *bira forms, whether prefixed or suffixed, can be ruled out; those in $-m$ have no parallel elsewhere at all. The T1w1 language has masculine - $n i$ (which fits another pattern, but not the Dfirbal), feminine-ga, also different, and plural -wi, which belongs to the -*bira tradition. The answer would seem to be that the Dfirbal serles is not a universal model, even as a theoretical reconstruction, let alone a historical

${ }^{1}$ See general paper on the Australian languages in this volume. 
precedent. Yet the vegetable class in $-m<*$ mayl does stand. It is needful, then, to look for correlates to the other common class forms. Table 4 presents the commonest markers of the various classes found in MC languages. They appear to have originated in a number of centres, not in any one, and represent the clothing of a principle in forms which differed from region to region.

If it is true that $-m, m-$ stands for *mayi, were all the prefixes/ suffixes originally independent semantemes? This is not easy to prove, because there is so much varlety among them, and at the best they could have been only of local validity. It has appeared that the EA root *badun, man, can account for the Cl. I prefix b in Laragiya and becoming *aRu and also *aRi in Ngarinfin, for the $C l$. I a- of that language. In Worora the prefix $i$ - could easily point back to indja *badun in precisely the same way.

\subsubsection{Stages of Noun-classing}

Certain features of some of the languages involved in the present study suggest that what are now bound prefixes were once free forms preceding the noun. Yanjuwa (5.3.1.) is one of the languages in which this feature is clearest, for in Yanjuwa the class prefix to the noun varies for case. A prefix whose vowel is -a-changes this to - $u$ - in the ergative form, while still adding the ergative suffix $-*$ lu to the noun as well. It is clear that the prefix was only a free form preceding the noun, and that it agreed in case with the noun to which it belonged. Thus Kirton (1971:39) gives the prefix sets:

Table 4

\begin{tabular}{|l|l|l|l|}
\hline & Class 5 & Class 6 & Class 7 \\
\hline nuclear & ma- & na- & naṇu- \\
referent & mu- & nu- & nuwaṇu- \\
directive/accessory & mungu- & nungu- & nungaṇu- \\
\hline
\end{tabular}

as specimens of prefix changes, the corresponding suffixes to the same nouns being $-\phi,-w u,-1 u /-1$ a respectively. Uses such as these suggest very clearly an original independence of what are now prefixes.

If it is now asked, what free forms would originally have stood before the nouns, the answer is elther an article or a demonstrative. 
of these two, for Australian languages the demonstrative is the more likely choice. So the theory accepted here is that the present class markers in the languages that now prefix them were originally demonstratives preceding the noun.

Yet some of the languages suffix class markers. This would suggest that in the earlier stages of these languages the demonstratives followed their nouns. Given the originally rather free word order of Australic.n languages - still preserved in many of them - there is no difficulty in this suggestion. There is therefore no difference in principle between the prefixing and the suffixing of class markers. Deta1ls will have to be discussed infra in regard to individual languages and forms, but the princlple is hardly controvertible.

There are languages in which the class markers are simultaneously prefixed and suffixed. These would seem to point back to the expression of the demonstrative both before and after the noun. This is less to be expected, but there are indications to be discussed later that some such process actually did take place. The phenomenon of 'class crossing' seems to point in this direction. Laragiya is one of the languages in which such events can take place, and Mawng is another.

Can anything be sald about the forms of the demonstratives that were originally used? Their forms and their nature need to be studied together, because form and meaning naturally go together: if there is no meaning to be expressed no form is needed. The first question will then be: what noun classes are 'original' in a given area; then where did they come from? What are the principles of classification at work? The forms will naturally follow the meanings they are intended to express. Some of the languages give clearer indications than others. The Daly River languages are 'primative' in this sense and in some cases it is easy to see that the class prefix is an abbreviation of an independent noun. The $\mathrm{Cl}$. V prefix ma- which generally refers to vegetable foods (amongst other things), is clearly linkable with the root *mayi, vegetable food. Its application to such things in the abbreviated form of a prefix or suffix is reasonable: the only problem arises as to the 'other things' subsumed into such a class.

It is desirable to make distinction between classifying languages as such and gender marking languages. In the former there is no differentiation of masculine and feminine: one prefix marks human beings of elther sex. Bantu languages are classifying in this sense. In Australia such languages are limited to the extreme north of the Northern Kimberley district and to Laragiya; all other languages are gender languages: Lamalama, Dfirbal, the east coast languages, all the dual classifying languages. 
It 1 s suggested that dual classification represents the earliest stage of the process under study. Beginning as demarking sex of living beings, it subsumes finally all existence under one of the two groups. It is a sort of linguistic dual organisation. Schmidt, following the Culture Circle phllosophy, tried to work out links between such social phenomena and linguistic phenomena. There is no intention here to do such a thing: on the contrary, the areas of dual organisation in soclety and in language do not colnclde. Actually two different discussions have to go on side by side; one is concerned with the principles of classification in a language, the other the formal means by which the classification is made. Multiple classifying languages and dual classifying languages may both be elther prefixing or suffixing.

Masculine and feminine distinctions are the chlef marks of the DC languages, especlally those which suffix. In some cases these are 'natural', 1.e. males are masculine, females are feminine; in others they are 'grammatical' as in Romance languages in Europe. Th1s is another crossing of principles which occurs in apparent irregularity in Australia. Even in DC languages in which classing is grammatical, there is no necessary agreement in the morphemes used for each marker.

Other types of distinctions than $M$ and $F$ seem clearly to have begun by the marking of a non-human/human, rather, perhaps than inanimate/ animate, because the assignment of the non-human animates st1ll presents much varlety in the various languages. The non-human w1ll include the animals. The latter are marked in CY by the determinative min, where as the inanimate marker *may is not only CY but universal wherever such marking takes place at all. Obviously food was a first necessity: *may is the most important concept in Aboriginal - or any IIfe. So the beginnings of a four-class system appear: masculine, feminine, food, remainder. In some cases it was a three-class system that developed: human, animal, remalnder.

Let the remainder first be called 'neuter', without implying that this means 'lifeless'. Neuter might be subclassifled, and in Arnhem Land this took place in a number of ways, varying from region to region. In one area tools were picked out for special mention, as in Forrest River, where $n$ - became the marker for artifacts of human origin and, Indeed, In the case of wana, honey, Insect manufacture, but of high value to man. In another region reference to the earth was picked out for marking, as in Mawng and the Gunwinjgu group, Rose Rlver and Groote Eylandt. All these less common cases are scattered. 
The animal world would probably be classified first according to the sex of the animal. This was usually done by separate words for each, as 1tems in a landscape, not by any theoretical taxonomy. Such taxonomy, when 1t occurred implied contact, knowledge and a certain special 1mportance. In Forrest River a became the sign of the animal class, which was regarded as indeed animate, but not human. In this class the clearly animate spirit world was included for that also is non-human. So a spirit (FR djuwari) came to take the a-concord: djuwari a njinga, this spirit. The same thing happened in some Bantu languages. The prefix a seems to be an abraded form of $R a-$ of the $S E$ languages (Nunggubuyu and Anindilfawgwa).

The chief difficulty that arises in connection with noun class prefixes is not the variety of morphemes, but the variety in the semantic fields which they denote. It is more than possible that the latter varlety arises from the falling together of orlginally separate prefixes into homonyms through phonetic or other types of change during the lifetimes of the languages. One outstanding example of this is the prefix ma-.

This prefix is the only one which occurs in all the languages under consideration, without exception. Reference to the Table (5) will show that it is universal. But its semantic field is not the same in all. Generally it refers to vegetable food, but in parts of Arnhem Land and the north in general it refers to ground or water - in some cases to objects connected with ground or water, in others only to obfects connnected with the water. The former subgroup is exemplified In the Gunwinjgu group, the latter in the Rose River-Groote Eylandt group. The fact that in the Gunwinjgu group the prefix can in certain cases be man- Instead of ma- is also worth noting.

Where ma- refers to foodstuffs, it can be traced to *mayi, vegetable food. But this does apply to cases such as Nungguburu ma-Rajag, canoe (as compared with a-Rajag, tree, wood). It is in these cases that the alternative man- seems to occur, as in Gunwinjgu man-gabo, a creek. There could then be an alternative root *man- to be traced - but for the fact that Gunwinjgu man-me is vegetable food. Harris (1969:17-18) says for Gunbalang that 'ma- occurs before retroflexed ' $C$ ', before ' $C$ ' followed by $u$, $\circ$, also before $w$, y; man-occurs elsewhere, the $n$ conforming to initial nasal ' $C$ ' of stem'. However, her examples are ma-wayag, shadow, and man-dulum, mountain, nelther of which refers to elther food or water! Actually both are atypical references.

In Laycock's Lamalama there is a prefix mun- referring to starch foods such as mun-arem, lizy root. It is interesting that he quotes 
certain of his informants as translating these into English with a maya-prefix to the English word: maya-lizy, etc. Th1s means that they did not distinguish two groups, mun-(or man-) and maya (or mayi-). It would perhaps be possible that water plant and water itself have caused a cross between the two forms and meanings here.

\subsubsection{Syntactic Factors in the Development}

Two types of syntactic influence are seen in the development of the class markers which work by prefixation. The first has already been referred to: an ergative language tends to mark this factor in the changing shape of 1ts prefixes for ergative and sometimes other cases. This means that the determiners now prefixed were once free forms up to the time of the advent of ergativity into the languages. The most notable case of this is seen in Yanjuwa as described above (5.3.1.), for in Yanjuwa a class prefix may take on three forms. Kirton (1971:39) gives the prefix sets, of which three classes exhibit the following forms:

Table 5

\begin{tabular}{|l|l|l|l|}
\hline & Class 5 & Class 6 & Class 7 \\
\hline nuclear & ma- & na- & nạ̣u- \\
referent & mu- & nu- & nuwaṇu- \\
directive/accessory & mungu- & nungu- & nungaṇu- \\
\hline
\end{tabular}

The names of the cases are hers, and their meaning does not matter at the moment. At the same time the nouns themselves take as case affixes $-\phi$, -wu and -li/-la respectively.

That these markers were then free forms preceding the noun is clear. What would they have been? E1ther articles or demonstratives would be likely to occupy such a position. For Australian languages a demonstrative is the more likely cholce. So the theory here accepted is that the present class markers began life in the present prefixing languages as demonstratives preceding the noun. This does not rule out the possibility that they were earlier nouns - determinatives later reduced to demonstrative function. This is precisely what the determinatives in $C Y$ and Daly languages are doing now. As nouns they are secondary, of only general meaning. It has been shown earlier how the process of degradation is suggested by the present-day uses in Djirbal. 
Another syntactic problem, however, arises from the fact that some languages are suffixing. This would suggest that at some stage the embryo class markers - nouns becoming demonstratives - followed the radical noun. Given the orlginally free word order of Australian languages - still preserved in many of them - there is no difficulty in this suggestion. The case of simultaneous prefix and suffix $(p+R+s)$ is a little more difficult, but the suggestion made above that this represents a more or less 'cockney' emphasis being given to the noun by the repetition of the determinative still seems reasonable. A case could be made out for suffixing being earlier than prefixing, and the example given in Djirbal of a hypothetical *bala-m mayi gunbaRa points in this direction. This will account for suffixing (bala-m *bala mayi) and *mayi gununbara for prefixation. The not uncommon linguistic phenomenon of contamination can account for doubling in reverse order. There is the possibility of a demonstrative being repeated after the noun as well as being used before 1t: in Dfirbal terms, *mayi gununbara - mayi, as was mentioned above. It is possible and no decision can be made between the two processes, in view of the absence of diachronic materlal. The double process is commonest in the NK area: Worora and Unggum1 both show Instances of it on a considerable scale.

The resultant arrangement in terms of number of classes per language and their types and remarks on them appears in Table 6. The 'types' referred to are those of the theoretical English example used in 9.2. The added Type 5 consists of the determinatives in the Daly languages.

The preceding section has dealt chlefly with prefixation. But there is also suffixation, and suffixation is the most usual grammatical process in Australian languages. The smaller group of prefixing languages does not seem to represent a genetic subdivision but something developed apart, based finally on syntactic factors. The suffixing class languages seem to belong to another movement of language, from different areas or times - or both. Many of 1ts members have a considerable share of the $C A$ vocabulary and some kind of EA vocabulary too, but the two contents together seem to be small, and much of the word-store of such languages seems to be 1diosyncractic. In general, as remarked at the very beginning of this paper, Australian languages do not distinguish between male and female beings, much less show a division into grammatical masculine and feminine like the Romance languages. Where they do, the feminine is the marked class and the masculine unmarked. 
The base type in Australia is therefore a language in which neither gender nor class is marked and where the oldest pronouns are singular only. Number marking seems to have come later, and there is more agreement about a dual indicator (usually *buladj, two) than about a plural. A trial 1s least uncommon, though not absent.

The first deviation in morphology from this type is the marking of the feminine third person singular pronoun. These have been discussed In (9.3.2.) above. The distinction is not always made in other than the singular number, even at this stage.

Number seems to have been left undefined at first. It w1ll be suggested elsewhere that in Australian languages (as also apparently In Tasmanian), only singular pronouns at first existed - plural, dual and in some places trial (or paucal) were bullt up differently in different areas and at different times. There is a clear dichotomy between languages whlch mark a plural (or dual) by suff1x, like other classes, and those that differentlate number from class by using a suffix for dual and plural number, even though it may be morphologically the same as the class preflx, biri-or -bira, apparently originally *bara.

In nearly every case number indication 1s limited to humans. A noun of the animate class does not mark plural unless 1 t belongs to the subclass anlmate-human: man and woman can be plural1sed but dog ( $1 \mathrm{f}$ in this class) or spear (if $\mathrm{Cl}$. I, as it often is) cannot.

Present day classing seems almost chaot1c, apart from these very broad outlines. It cannot be thought that this has always been the case. Mythology has played a part: generally sun is feminine and moon is masculine because in Aboriginal mythology these are respectively woman and man. There are exceptions to this, e.g. Forrest River, where sun is Cl. VI $\left(n^{-}\right)$like a manufactured article. Association also has played a part; frequently spear is masculine because it is the man's weapon; wommera, spear-thrower is the servant of the spear as woman is of the man, and so 1 t becomes feminine. Remarks by J.R.B. Love in this connection among the Worora are enlightening (Love 1936: $44 \mathrm{ff}$. ); on pp. 44-5 he has an interesting note on the assignment of classes to introduced objects, and the motives that lead to such an assignment. Phonology has also most probably played a part.

The 1dea of concord needs historical explanation also if such can be found. So do the forms of the concord markers, which are not always 1dentical with those of the noun. The 1dea 1tself most likely sprang from an attempt to define references, and there is evidence that at first the markers used in concord were free forms. Th1s is especially 
Table 6: Classes found in Australian Languages

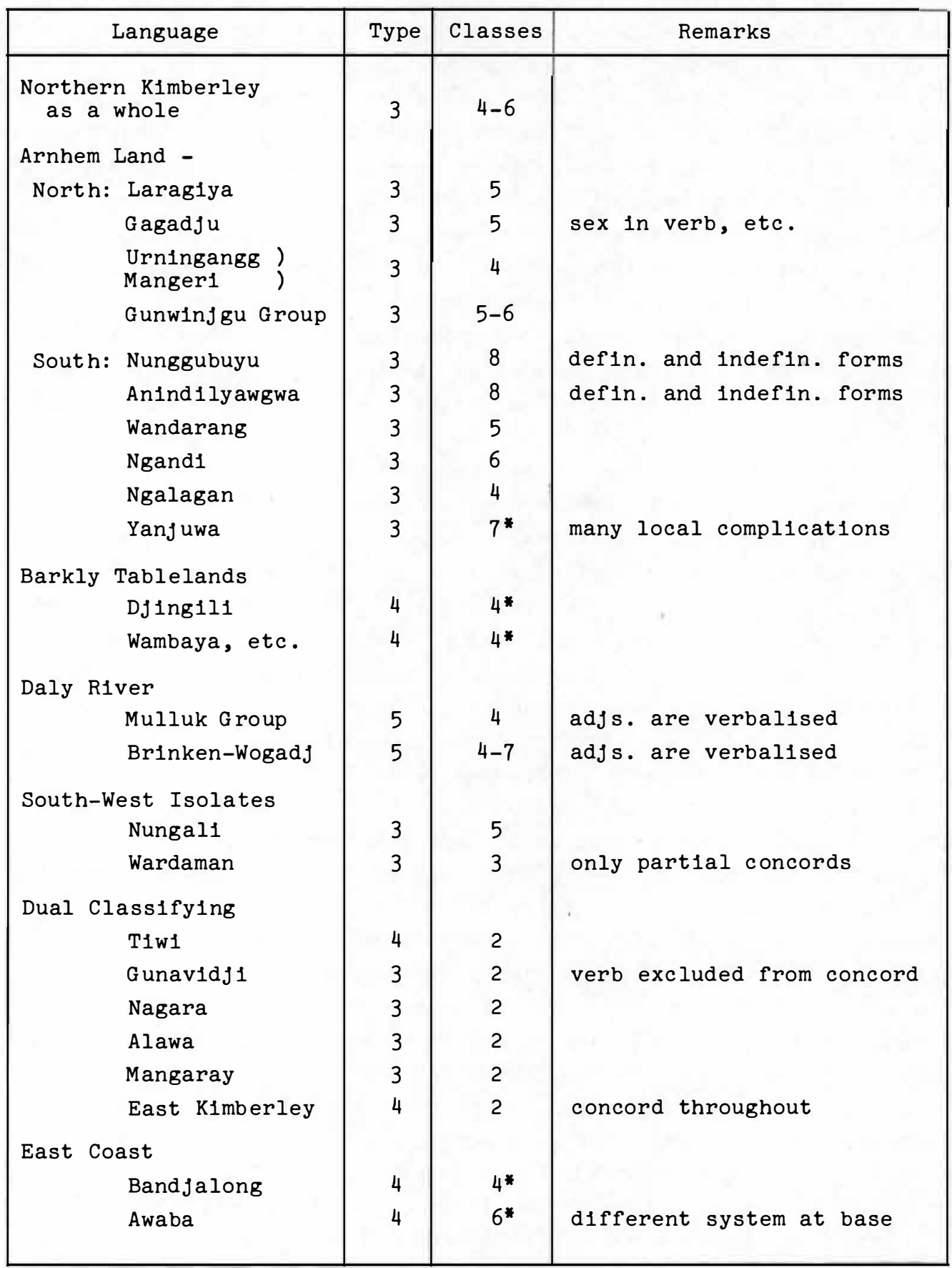

*Languages with this mark are ergative. 
noticeable in Yanjuwa, where the class prefix changes to mark the case of the noun. Incidentally, this serves to suggest that class marking was later than the development of an ergative case, for this case shows itself in the prefixed class marker.

From the grammatical point of view, NCs are syntactic features rather than morphological, and the variation in number of classes and details of concord may be syntactic phenomena as much as semantic. They are attempts to connect in the speaker's mind the 1deas that belong together. They are not elaborations which try to picture increasing details of thought on the speaker's part. Hence it is quite possible that the variations found throughout Australia may be often of - so to speak - local manufacture. This truth would certainly apply to the distinctions of local forms in pronouns and demonstratives: similar processes have taken place in the Scandinavian languages though not in German or English.

For these reasons it may not be possible to do more than fix certain broad outlines of probable development - in the absence of diachronic information - which may show how the existing situations have come about psychologically rather than in terms of historical linguistics. It thus seems very likely that determinatives represent an early manner of gaining clarity of references in Australia, as in the Middle East; but there is no necessary connection between their appearance in the Cape York and about the Daly River. A distinction of two genders can well have developed in more than one area: the diversity of markers suggests this may be so.

Multiple classification is rather different. There are signs of a common origin of this process in the frequent agreement of morphemes marking the classes. But there is no reason to suggest that this was a spread from one centre at one time (more or less), as seems to be the case in the spread of $\mathrm{CA}$ languages, including perhaps the ergative case. Even here some of the ergative suffixes stand apart from the *-lu series and must be historically independent of 1t. The MC languages agree only partially in the distinctions they make. One may suppose transfer of a very few determinatives to the rank of determiners at first - the most outstanding features of landscape and the most Important needs of human life will have affected the development. There would be a distinction between human and non-human; then within the non-human, between animate and inanimate. The relative importance of 1tems of the non-human world will have had an effect - food and water for living, and among foods, animals of chase and other kinds of animal, and non-animal elements of the surroundings. Instruments and 
tools may well be set apart, as they are in some languages. Frequently the non-human groups seem to be regarded primarily from point of origin - earth, water, etc. Body parts are so irregularly classified that they do not seem to belong to early strata, except in rare cases such as Lamalama, where they have their own prefix (-ar), and even then they are not grouped under 1t. In Lamalama, Laycock's 'genital' class seems to be a further refinement of the body parts class - and so on to varying degrees. This applied equally well to the Bandfalong type on the east coast, while the Awaba classing seems to be primarily social and not a classification of nature at all.

\subsection{The East Coast Classifying Languages}

The languages referred to here are Bandjalong and Awaba, and incidentally a number of languages apparently related to these but lacking classificatory systems. These languages are not only historically quite distinct from those of the north and north-west, but they have used different original materials to construct their systems. The main distinctive feature is a masculine classifier-gali, -gal, and a feminine -gali:n. These two are found in the sydney language (generally called Iyora for lack of a true name).

This is an important and interesting early EA word. It is found in 1ts fullest in Victoria, but occurs in Central South Australia (Arabana, etc.). In the form of -gal it forms a widespread ending of tribal names: with phonetic variants such as -wa:l, -bal, it is found in southern New South Wales, a number of regions of Queensland, and in the Northern Kimberley in the name of the Wunambal tribe. It is treated more fully as to its distribution in the general study of Australian languages in another paper of this book. Here the treatment is limited to the part it plays in these eastern central coast languages.

The basic form of the suffix is -*galig. This ending is added to words in the central and western Victorian languages to indicate trial number or a paucal plural. It is one of the characteristics of these languages, and has been the subject of a paper by L.A. Hercus (1966: 335-7). She shows that in Arabana it is st1ll a trial: aniri-gari, we three; aniri, we, limited by the addition of gari<*galig. She then defines it as 'guli or gari meant a group of people sitting together or associated with each other in some way'. People in general in Wembawemba (V1ctoria) is ben, from *ban, a word already discussed frequently in these pages. 
In the east coast classifying languages, this root has become first of all gali, male member of tribe, then in Awaba has taken on the form gali:n, female member of tribe; in the north it has become gan by abbreviation, and so appears in Bandjalong as a feminine marker, there apparently with differentiation into a second form, whereby galigan is female (normal quality) and gan, female (weaker quality). Just what this 1mplies, the Geytenbeeks do not make quite clear; it 1s, however, a local development. In Waga and Gabigabi dialects gan is simply woman, female, as also in Danggad1. It was pointed out in 8.1. that the occurrence of this word in some of the surrounding languages is quite likely a borrowing from the coastal languages, the word gradually working 1 ts way northward. In any case, if this explanation is right, it represents a most unusual case of semantic differentiation in a serles of successive reglons. The orlginal meaning of social group is retained in the languages of Queensland and in the Winambal of the Klmberleys (though there is no accounting for 1ts 1solated appearance in the north-west). It also occurs as a tribal name ending in parts of the western Torres Straits.

Thus a word that began as a trial number marker has gone through some unexpected stages:

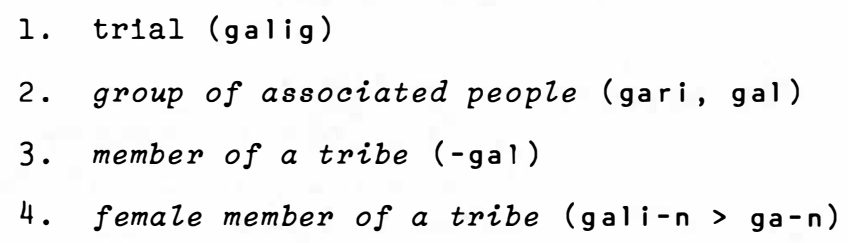

The combination gali-ga-n in Bandjalong is a fourth development of very limited validity and not clearly explained as yet; gan = woman is a local development in the area north of the Bandjalong and to a less degree south of 1 .

In the Bandjalong region there is no appearance of *may as marker for vegetable foods. The 'resldue' class here, called 'neuter' by Geytenbeeks, 'refers to all inanimates other than trees, and to all anlmate belngs other than humans' (Geytenbeek and Geytenbeek 1971:8). It $1 \mathrm{~s}$ marked by a zero ending, and the final - $n$ of Dj1rbal is probably cognate with -gan of Bandjalong. There are other subgroupings in Bandjalong also, such as -gir, the set or class of... (almost in the mathematical usage of set): these are peculiar to the locality. The ending -gay given for neuter reappears in Awaba, where it is applicable to locations and times. 
The Awaba system 18 again peculiar and seems to be of local development. Unfortunately, the more closely related languages are not well enough preserved to make clear whether the system is found in Dharug, Iyora, Guringgay or Darginfung.

The patterning in Awaba has certain connections with that of Bandjalong, sharing the -gal, gali:n, *galig, and also-gay, but in this language the latter is applied to locations or times. The personal marker is -gin- which occurs between noun stem and case ending. No explanation for this offers 1tself as yet. The other difference is that proper nouns and personal pronouns insert -um-, between stem and case ending. The word for eaglehawk, biraban, has a genitive birabangu-ba but, as the name of Threlkeld's tutor, the same case becomes Biraban-um-ba. Similarly, naduwa, $I$, has a genitive emmo-wum-ba, my, and a dative emmo-wu-n, to me, as well as the personal emmowun-gin-gu, to the place where $I$ am, as against the common noun forms biraban-gu and biraban-da-gu and the proper noun forms Bira-ban-(n)un and Biraban-gin-gu. The doubling of $n$ in the personal form seems to be an error based on English use: - um- remains as proper noun and pronoun oblique case marker. R.H. Mathews' notebooks show nothing similar in Darginjung or Dharug, so that the peculiarities look like local developments in Awaba 1tself. 
A. CAPELL

\section{BIBLIOGRAPHY}

BREEN, J.G.

1971 'Aboriginal Languages of Western Queensland'.

Linguistic Communications 5:1-88.

CAPELL, A.

1939 'Mythology in Northern Kimberley, North-West

Australla'. Oceania 9/4:382-404.

1940 The Classification of Languages in North and NorthWest Austral1a'. Oceania 10/3:241-72; 10/4:404-33.

1942 'Languages of Arnhem Land, North Austral1a'.

Oceania $12 / 4: 364-92 ; 13 / 1: 24-50$.

1951 'Bantu and North Australian: A Study in Agglutination'. African Studies 10/2:49-57.

1953 'Notes on the NJigina and Warwa Tribes, North-West Australla'. Mankind 4/11:450-69.

1956 A New Approach to Australian Linguistics. Oceania Linguistic Monographs 1 . University of Sydney. [New edn 1962]

CAPELL, A. and H.E. HINCH

1970 Maung Grammar, Texts and Vocabulary. The Hague: Mouton. 
CHADWICK, $\mathrm{N}$.

1968 'DJing1li (North Austral1a) in a Comparative

Perspective'. Oceania 38/3:220-8.

1971 'Ngarndf1 Wordlist and Phonological Key'.

Papers on the Languages of Australian Aboriginals.

AAS 38, L16:34-45. Canberra: Australian Institute

of Aboriginal Studies.

CURR, E.M.

1886-7 The Australian Race.... 4 vols. Melbourne:

John Ferres, Government Printer; London: Trübner.

DIXON, R.M.W.

1968 'Noun Classes'. Lingua 21:104-28.

1972 The Dyirbal Language of North Queensland.

London: Cambridge University Press.

FRASER, J., ed.

1892 See Threlkeld.

GEYTENBEEK, B. and H. GEYTENBEEK

1971 Gidabal Grammar and Dictionary. AAS 43, L17.

Canberra: Australian Institute of Aboriginal Studies.

HALL, A.H.

1972 A Study of the Thaayorre Language of the Edward River Tribe, Cape York Peninsula, Queensland. Ph.D. thesis, University of Queensland.

HARRIS, J.K.

1969 'Preliminary Grammar of Gunbalang'. Papers in

Australian Linguistics No. 4:1-49. PL, A-17.

Canberra: Pacific Linguistics.

HERCUS, L.A.

1966 'Some Aspects of the Form and Use of the Trial Number in Victorian Languages and in Arabana'. Mankind 6/8:335-7. 


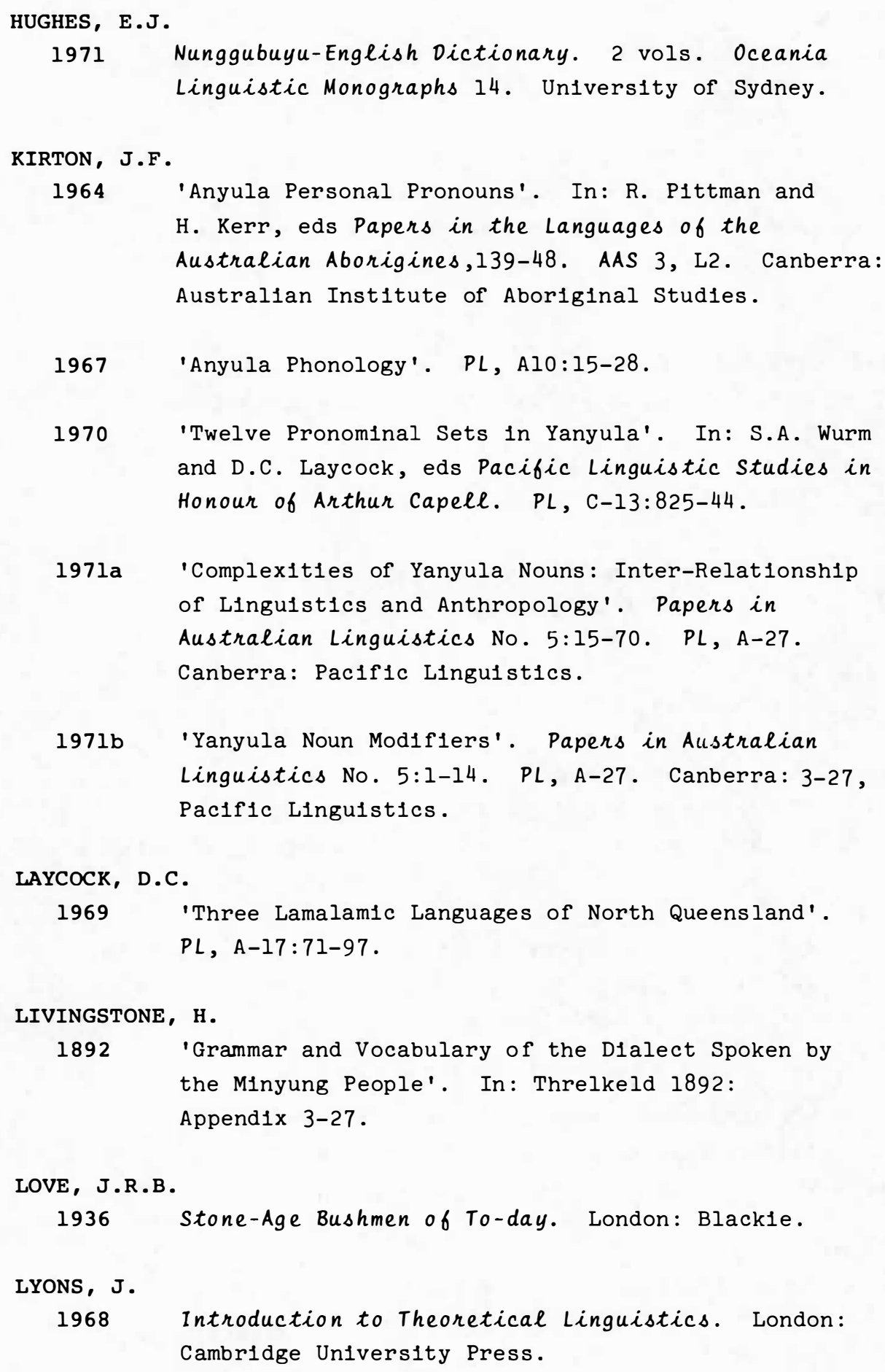


MACDONALD, E.

1964 'Notes on the Noun Classes of Anyula'. In:

R. P1ttman and H. Kerr, eds Papers on the Languages of

of the Australian Aborigines, 151-6. Canberra:

Australian Institute of Aboriginal Studies.

MEINHOF, C.

1948 Grundzüge einer vergleichenden Grammatik der

Bantusprachen. Hamburg: Eckardt and Messtorff.

OATES, W.J. and L.F. OATES

1970 A Revised Linguistic Survey of Australia. AAS 33, L12.

Canberra: Australian Institute of Aboriginal Studies.

OSBORNE, C.R.

1974 The Tiwi Language. AAS 55, L21. Canberra:

Australian Institute of Aboriginal Studies.

RIGSBY, B.

1976 'Possession in Kuku-Thaypan'. In: P. Sutton, ed.

Languages of Cape York, 260-8. Canberra:

Australian Institute of Aboriginal Studies.

SCHMIDT, w.

1919a Die Gliederung der australischen Sprachen.

Vienna: Mechitharisten-Buchdruckere1.

1919b Die Personalpronomina in den Australischen Sprachen.

Vienna: Akademie der Wissenschaften.

SHARPE, M.C.

1969 A Description of the Yugumbir Dialect of Bandjalang.

university of queensland Papers, Faculty of Arts

$1 / 8: 69-122$.

SMYTHE, W.E.

1952 Elementary Grammar of the Gumbáingar Language

(North Coast, N.S.W.). Oceania Monographs 8. Sydney.

SOMMER, B.A.

1969 Kunjen Phonology: Synchronic and Diachronic. PL, B-ll. 
A. CAPELL

THRELKELD, L.E., edited by J. FRASER

1892 An Australian Language as Spoken by the Awabakal, the People of Awaba or Lake Macquarie...

Re-arranged, condensed, and edited, with an appendix, by J. Fraser. Sydney: Government Printer.

TRYON, D.T.

1970 'The Daly Language Famlly: A Structural Survey'.

In: D.C. Laycock, ed. Linguistic Trends in Australia...,

51-7. AAS 23, L9. Canberra: Australian Inst1tute of Aboriginal Studies.

1974 Daly Family Languages, Australia. PL, C-32.

WORSLEY, P.M.

1954 'Noun-Classification in Australian and Bantu:

Formal or Semant1c?' Oceania 24:275-88. 


\title{
CLASSIFICATION OF VERBS IN AUSTRALIAN LANGUAGFS
}

\author{
A. Capell
}

\section{INTRODUCTION}

Noun and verb are the two principal formal categories in Australian languages. Another paper in this volume deals with the classification of nouns. The present paper sets out the various manners in which verbs may be classifled. It is not concerned directly in the expression of person, tense or mood, although mention will be made of these factors in describing the verb classes and how they are reflected in the classificatory systems. The general introduction to the paper on the classification of nouns makes mention of verbal classifications in the most general terms. Detalls are given in the present paper.

From the viewpoint of classification there are three types of verbal system in Australia: 1. Language in which the verbal stem is invarlable for person, tense, mood and volce, the markers of these being indicated by affixes to the root itself. The affixes may be suffixes or prefixes; the majority of languages use suffixation as a confugational process. 2. Languages in which the markers are added, not to the base, but to an auxillary which may vary according to the semantic class of the verb - and in the northern Kimberley according to whether the verb base begins with a vowel or a consonant.

3. Languages in which only tense, mood and volce indicators are added to the stem, while person - and occasionally tense - 1s marked by the affixation of the relevant markers to an invariable particle which does nothing more than act as a carrier. This has been called by the chemical term 'catalyst' because of 1tself it adds nothing to the reaction.

Other divisions of the matter are possible, but these have their place in the general chapter on the nature and development of the Australian languages elsewhere in this volume. 
The systems of classification of verbal stems may be diagrammed as follows :

(a) SIMPLE

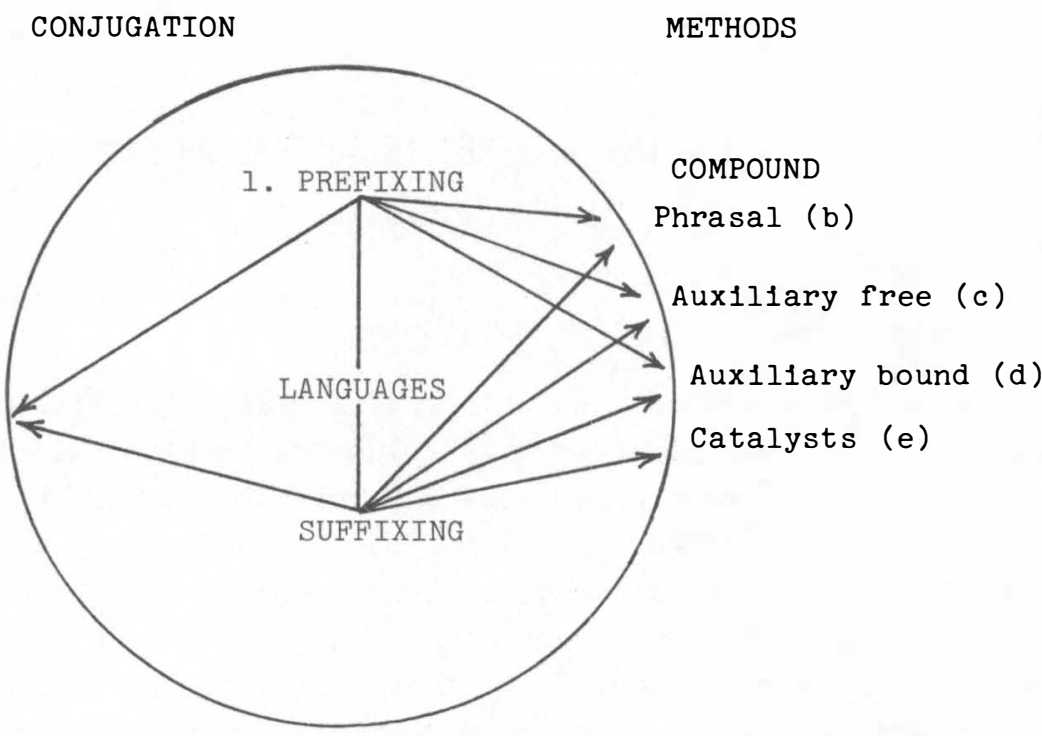

The types are equally divided between prefixing and suffixing languages, except that no prefixing language uses catalysts.

In the western Torres Straits there is no compound confugation. These languages have the simple type, but there are prefixed elements which modify the meanings of stems in a way best described as adverbial. The Map indicates the regions in which the various subgroups occur, and the methods of indicating person and number. In some areas insufficient is known about the confugation systems to enable classification to be made: these are extinct languages that were not recorded while they still existed.

It is not necessary to treat prefixing and suffixing languages separately. The probable origin of prefixation is discussed in the general study elsewhere in this book. The system of person marking has no relevance for this chapter. It is possible that it did have an influence in determining what type of verb classing a language would develop, but that is a minor point at the descriptive level. In this chapter the only indication whether a language is prefixing or suffixing will come to light in the numbering ( 1 or 2) of the actual examples, and if the language does not mark person at all, the matter will not arise.

In European languages the verbal stem is usually confugated by a suffix which indicates person and number of the actor. The Latin 


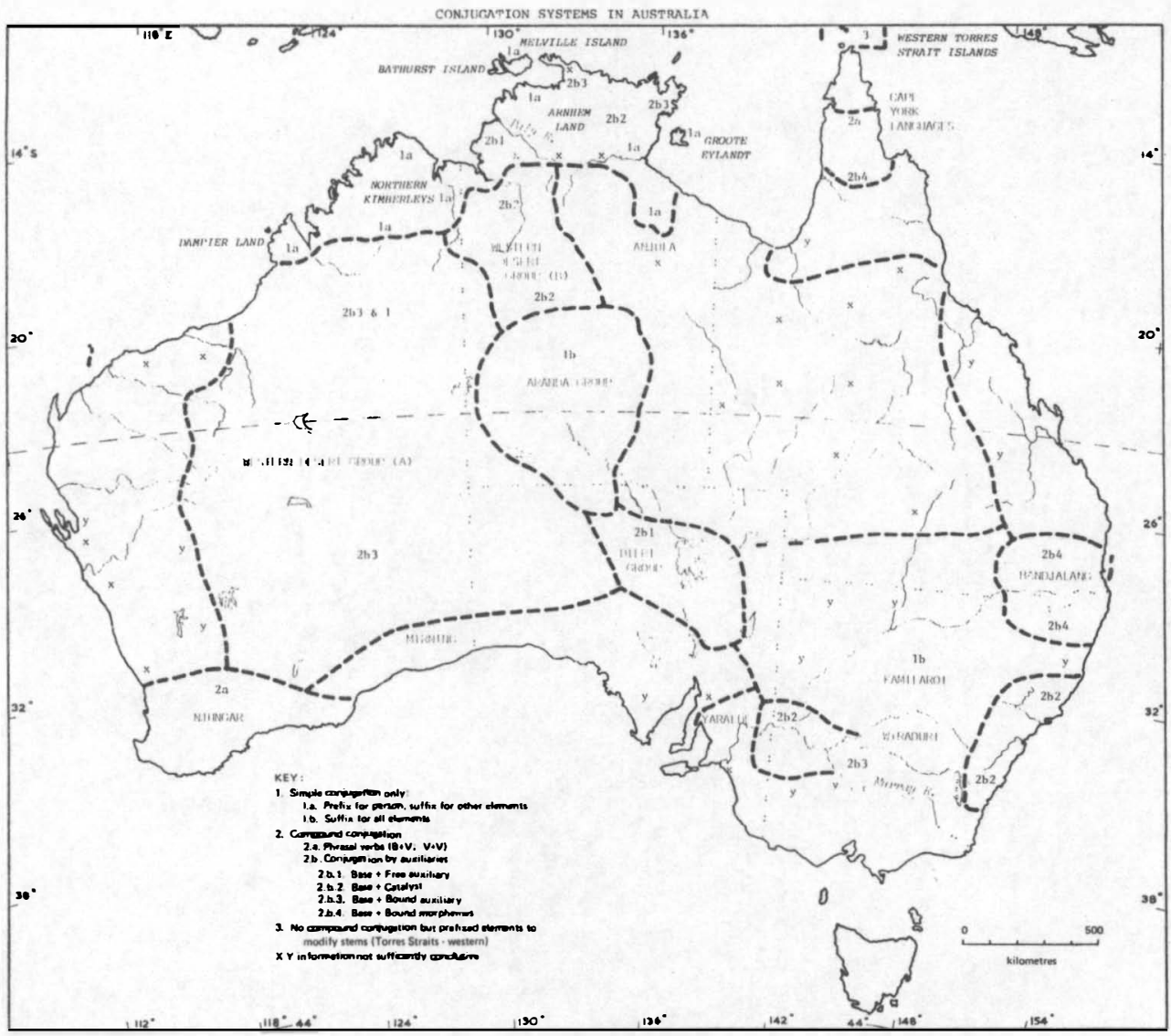



type is represented by such roots as am-o I Zove, habe-o $I$ have, etc. But there is also a Latin type such as gratias ag-o I give thanks. Here is a noun root supported by a verbal stem without which it cannot be confugated. In Australia many languages have such double verbs. In Ngarinfin of the Northern Kimberley, for instance, one says a-n-unulu-n him-I-give-PRES., I give it to him; but one also says wulan n-ama-najga speech $I$-do-to-him, I speak to him. It is impossible

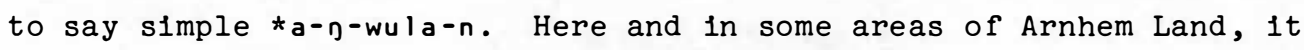
seems that the decision regarding the type of confugation depends on whether the verb stem (for a prefixing language at least) begins with a vowel or a consonant: In the latter case it is treated as a compound verb with some kind of auxiliary. The matter is not really as simple as this, but detall will be given in due place (2. below).

\section{SIMPLE CONJUGATION}

The term 'simple' here means that person and other endings are added directly to the verbal stem, without any use of auxiliaries of any type. These are of the Latin type am-o, and just as in Latin there are different classes of 'conjugations' (am-o, hab-e-o, fac-i-o, aud-i-o, etc.) so there may be different 'conjugations' or classes in Australian languages of the 'simple conjugation' type. This is not what is meant here by verb classification, as will become clearer in the following pages. The 'classification' referred to in Australia means the use of different groupings which are basically semantic.

In Australian languages of type 1 there is usually only one 'confugation', 1.e. one set of markers applicable to all verbs. In probably the majority of cases these markers are added to all verb stems, not to classes in the Latin sense. Such simple confugation is presumably the original system in Australia, and 1ts occurrence is marked on the Map. But compound confugation in 1ts various forms is widespread also. It seems to be concentrated in the north-west and to decrease in frequency from west to east. At least the avallable examples are less common in the latter area.

This type of confugation need be hardly more than mentioned and illustrated in this paper. An example of simple conjugation without person markers is found in Gadhang of the Hunter River region, New South Wales:

$$
\begin{aligned}
& \frac{\text { Danda miRi nja:-njala }}{I \text { dog see -PAST }} \\
& \frac{m i R i-g u \text { baRanan nja:-njala }}{\text { dog-ERG me see-PAST }} \\
& \text { I saw the dog and the dog saw me }
\end{aligned}
$$


No matter what the actor, the verb ending will not change; this must be indicated in the actor - as the language is ergative, this is eas1ly done. While the pronouns do not have an ergative, they have oblique cases built on different stems in a way that is not relevant here.

A second example is taken from DJabugay, in the Rain Forest region of North Queensland:

$$
\begin{gathered}
\frac{\text { Dawuggu numa gali-na }}{I \text { tomorrow go-FUT }} \\
\text { bama-lu minja baga-na } \\
\text { man-ERG meat eat-FUT } \\
I \text { will go tomorrow and the man will eat meat }
\end{gathered}
$$

Beyond this point a number of complications may be found, but the system is still 'simple' even though person, number, etc. may be indicated in the verbal affixes. There seems to have been a series of developmental stages: see Capell (1962; 1972) and part1cularly Wurm (1969).

Information supplied by J.G. Breen (Capell 1976:624) indicates, in h1s own words that 'Western Queensland languages in general have no compound confugation'. One exception is Midhaga (see 2.2.1.7.4).

Most languages however seem to have very few compound verbs, e.g. Bularnu has a few of the form $\mathrm{V}+$ baga meaning to do $V$ while going (baga to go); Bidjara has a couple of what may be compounds with bura to go away, e.g. wagani-bura to run fast (wagani to run); Wagaya (Eastern Northern Territory, not West Queensland) has a few such as budjagajund to run away with (budjaga to run, jund to give); WanggaYudjuru has tarilipirraka to (run and) spear, (tari to spear, pirraka to run). None of the processes involved seem to be productive. There are a few productive formative stems clearly derived from verbs, e.g. Bidabida-yanța to do while going along, cf. kaṇta to go. Andegerbina has compound verbs in -alba-action while going towards the speaker (?), cf. alba to go, e.g. bidjalba- to return (bidja to come). Gnadjalba to bring (goa-to carry, and also verbs that seem to be compounded with la to go, function not clear to me yet. I would not call any of these things compound confugations. Other languages similar to one or other of the above, or with less semblance of compound conjugation are Marganj, Gunja, Gunggar1, Wanggumara, Ngawun/Mayagulan, Warluwara.

Such compound confugation is not treated in the present statement it is really a matter of stem compounding, which does not belong to the classification types under discussion. 
The largest area of Australla completely without compound conJugation appears to be Victoria, and if the thesis that Victoria represents the most archalc area of the country is upheld, then it would seem that the Early Australian level of language had only simple confugation - and other facts support the idea that this stratum had only verbs invariable for person and number. It is possible that the paucity of information on Victorla is leading to a wrong conclusion in this matter. Study of Hercus' The Languages of Victoria (Hercus 1969) serves only to point up this scarcity. Capell (1956 (1962)) showed that the Wudjawuru language of western V1ctoria has the affix-transferring system of the WD languages well developed, although R.H. Mathews' brief paper (1902) does not give the least suggestion that this is so. Even if, as Capell now holds (see the general paper on Australian languages in this volume) affix transference is only a special syntactic event, its occurrence in western Victoria shows influence from the WD languages on a considerable scale. It is possible, therefore, that auxiliarles in some form or other occurred in Victorla more widely than they are documented, but nothing can be built on this to invalidate the statements made above.

Apart from these two fairly continuous areas from which compounding is absent there are others more fragmented. One of these is Tiw1 (Bathurst and Melville Islands), others are Gunavidf1 and Nagara on the north coast of Arnhem Land, Nunggubuyu at Rose River on the east coast, and Groote Eylandt. As well, there are some - but not all languages in Cape York Peninsula which do not compound verbs in the way here discussed. In the north-west of Western Australla also there is a falr sprinkling of such languages, along the margins of the WD languages. The areas can be found on the Map.

\section{COMPOUND CONJUGATION}

Processes similar to those outlined in the Introduction as 'compound confugation' are found in parts of Australia other than those mentioned and mapped in the preceding section. It is the business of this part of the paper to review these processes. As a general definition, that offered by D.T. Tryon is useful: 'Two verbs to translate one action, the first indicating the type of action being performed, and the second specific, indicating exactly which action is being performed within the fleld delimited by the particular verb class. As with the Daly Family, the general verb delimiting the field is bound, while the particularising verb is a free form. Again, as with the Daly languages, only the bound form is required to denote 
certain actions.' (Tryon 1971:10). One example in Wageman is wuri ma na-ma-yi hunt I-go-past, I hunted. In Narinjin and other languages however, there is the complication that the generic part of the verbal compound is often a noun, or perhaps a gerund. In the example below maRa is a $\mathrm{Cl}$. V noun, Zight. (Worora maRa-ma, with $\mathrm{Cl}$. V suffix when used as a noun, but maRa alone when used as the first element of a compound verb). In Worora maRa ga-n-o:-na I see him is literally I hit him (with) light. There is actually structural difference between this type and the Daly type as defined by Tryon, and this needs to be kept in mind in the study of the verbal systems involved. Unfortunately, it is not always possible to isolate and classify the first element of the compound. In Mawng, although the majority of the verbs are simple, some are compounded on a still different system: the confugated verb comes first, not second, and the second element is usually a type of stative noun or gerund, as in yuRan ab he went sit = he sat down; yuRan alja he went forget(ful), he forgot. In other Mawng examples, the verbs to do, take, eat, hit and others are used (Capell and Hinch 1970:69-83). Exchange of auxillaries is not unusual. In Ngarinjin it is possible to start from mindjal mouth and form mindjal ne: I eat (as an action, usually in the continued tense form), mindjal $n$-ama $I$ do eat (a certain kind of food) and mindjal wu-n-o:n $I$ am eating (a certain food now) using three different auxiliaries in varying circumstances, each defining the manner of eating.

The analysis of such compound confugations, in the case of the $\mathrm{NK}$ languages, and those of East Kimberley and Arnhem Land can be best 1llustrated from Ngarinjin of $\mathrm{NK}$, which is entirely typical. The form remains similar throughout, the semantics of the auxiliaries influence the combinations but not the forms. In Ngarinjin, maRa Zight, takes on the form maRa a-n-o:-ni seeing I did to him, I saw him. This implies a simple act of vision, willed or otherwise, but maRa a-n-ela-ni seeing I held him is rather I stared at him, kept him in view. In Ngarinjin there are eleven such auxiliarles, all of which have specifled uses, and the student must learn which one (or ones) are usable with a given verb.

The phrase structure patterns of the two types are as follows: 
1. anuwiljani I speared him

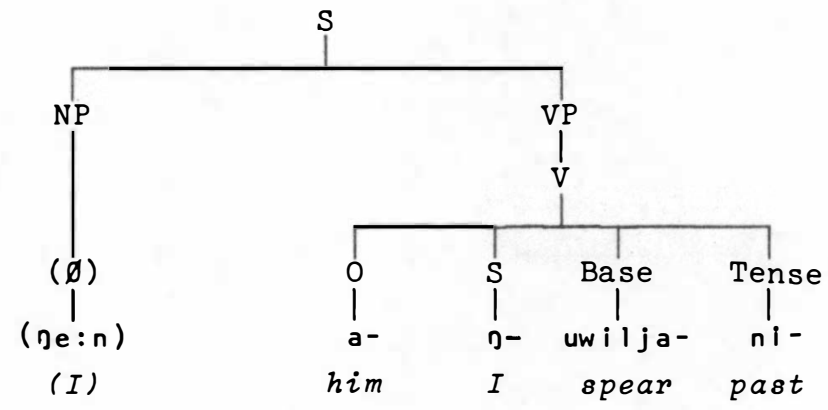

2. maRa agoni I saw him

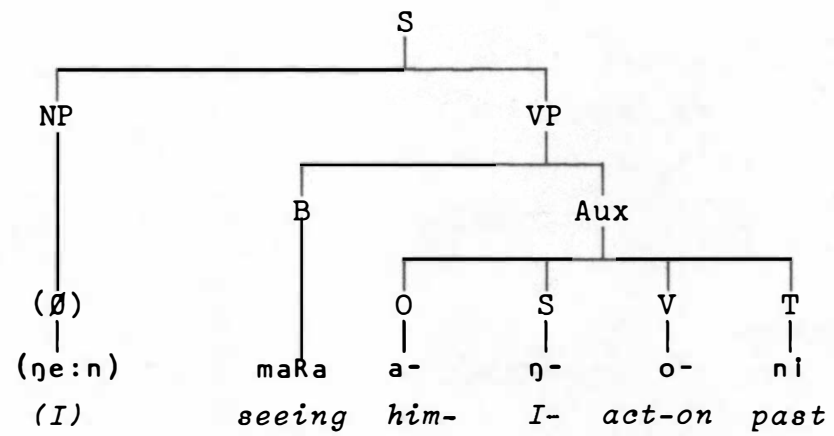

Where a noun-object is involved the pattern is extended:

3. ganangud anuwiljani I speared the dog

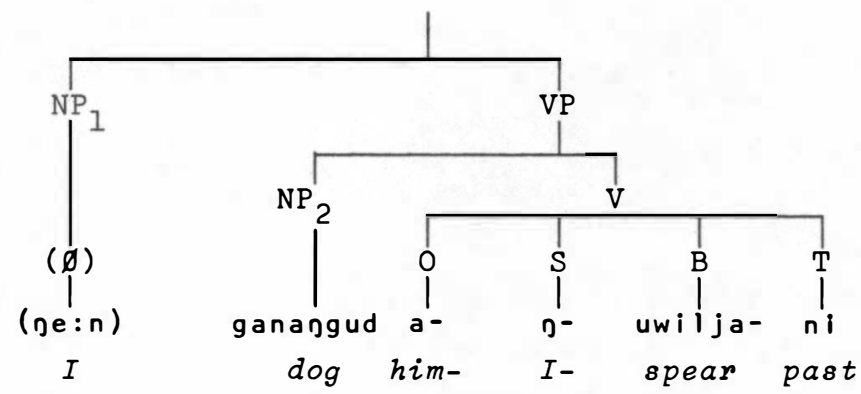


4. ganangud maRa anoni I saw the dog

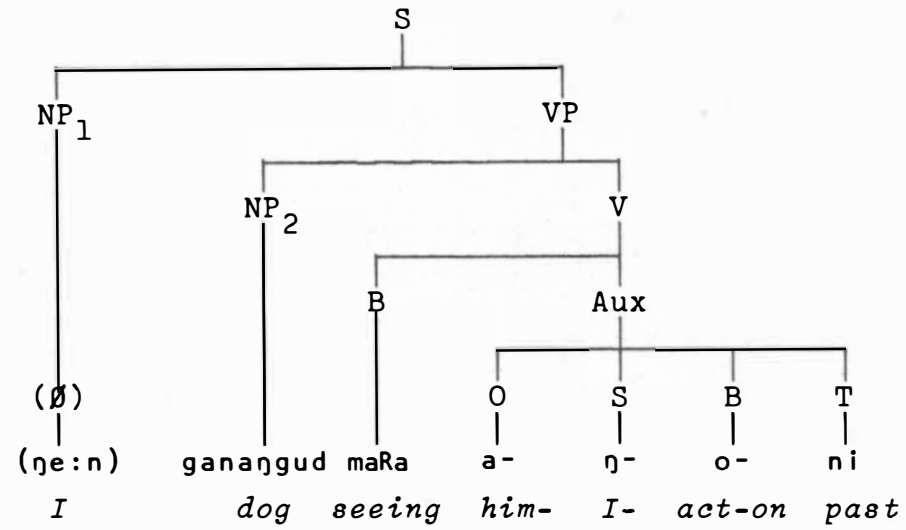

This formal patterning is modified by the auxiliaries in use in a given language, and these are best lllustrated under the various subsection headings which now follow:

TYPE

1. stative

2. action

3. motion

4. reflexive

5. effective

6. continuous effect

7. ejective

8. taking

9. Junctional

10. locating

11. causative
BASE MEANING

be

do

go

fall

strike

hold

throw

take

give

put

make
NGARINJIN STEM

-e -

- ama-

-a -

-awa-

-bu- -o:-

-ela-

-ebi-

- uma -

-uguiu-

-inina-

- and ju -

As stated, the verb base remains unchanged, and the auxiliary takes markers of person, number, tense, etc.

In these languages, noun class is marked in verbs of the third person. In the southern subgroup, to which Ngarinjin belongs, subject marking by class concord is required only in intransitive verbs: maḍa a he is walking, maḍe nja: she is walking. With transitive verbs, 
Ngarinjin does not mark class of subject (though the northern languages, Gambera etc., and in Arnhem Land Laragiya, Mawng and Anindilfawgwa do), the eastern dialect of Ngarinfin does have a common $\mathrm{Cl}$. IV and $\mathrm{Cl}$. V marker; otherwise, only object class is marked. Thus:

\begin{tabular}{|c|c|c|c|}
\hline $\mathrm{Cl}$. & I bring the & kangaroo & íali anumaṇ \\
\hline Cl. II & I bring the & phalanger & langari njanuman \\
\hline Cl. III & I bring the & children & jile:la bunuman \\
\hline IV & I bring the & stone & mandja wunuman \\
\hline V & I bring the & sandstone & banaru munuman \\
\hline
\end{tabular}

In the compound verb a corresponding procedure takes place. A transitive auxiliary carries both subject and object of the action, object preceding subject: jile:la gudu bu-n-oni children striking them-I-do-past, struck the children. If the auxiliary is intransitive, an object required in the compound is shown by suffixing the direct object marker: with the root bu blow with the mouth (homonym of the auxiliary bu striking); o:ndan bu na-ma-nagga paint blowing I-do-it, I blow the paint on to it. Dual or trial objects are shown by suffixes, as in buruRu maRa bu-p-o:n-njiri men seeing them-I-do-two, I see both the men.

Interchange of auxiliaries is frequent but not at will. An example with ada sitting: ada nama rest, I do a resting, I stay or sit; ada a-n-inina-Ra sitting him-I-put-past, I made him sit down. An intransitive auxiliary may recelve transitive powers not only by the addition of an oblique pronoun, as in jara n-awa-n falling I-falz-pres. (Aux. 5) $>$ nara n-awa-n-nagga $I$ fall on him but also by conjugation with transitive prefixes: $n-a$ I go > dambun mu-n-a-n-balu camp it-I-gopres.-directive, I am coming this way to the place. This manner of transitivising an intransitive verb seems to be peculiar to the southwestern section of the NK languages.

With this general introduction it is now possible to pass on to the various subgroups of different kinds of compound conjugation found in varlous parts of Australia. They are set out in terms of the small letters placed beside each in the preceding diagram.

\subsection{Phrasal Verbs}

\subsubsection{Phrasal verb compounding}

This type of compounding is chosen as a beginning because in it the individual verbs of a compound retain most freedom, both of 
transference to other settings and in regard to their own semantics. In languages of this kind, each verb is still able to be used as a full verb apart from its occurrence as an auxiliary. The languages concerned are found mainly in Cape York Peninsula, and the examples here are drawn from Thayorre of Edward River district. The information used is based on the work of A.H. Hall (Hall 1972).

Hall (1972:82ff.) states that 'normally the verb may have one or more auxiliaries before or one after or both these alternatives occur similtaneously.... In order to understand the nature of the verb phrase, it will be necessary to decide which are nuclear tagmemes, what fillers can occupy available slots, and then to 1llustrate these showing how many auxiliaries tend to occur before the verb and how many after and whether any preferences occur for some and not for others'. He then illustrates, first, the nuclear tagmemes, of which he says two are necessary, the head tagmeme plus one tagmeme in either position:

$\begin{array}{lll}\text { (Auxiliary) } & \text { Head } & \text { Auxiliary } \\ \ldots \text { ant } & \text { yu:mp } & \text { okun.... } \\ \text { try } & \text { do (it) } & \text { maybe }\end{array}$

He then proceeds to exemplify eleven different combinations of word classes such as directive + verb or verb + directive, two verbs together, noun + verb or noun + verb, verb + auxiliary, which cannot be illustrated in full here. A few examples must suffice:

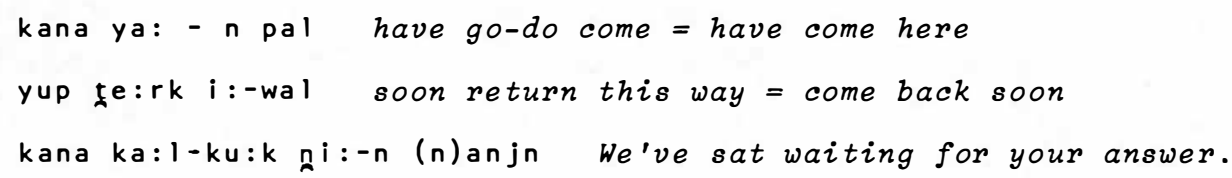

In the third example, ka:l-ku:k take-word is one type of compound, kana is an auxiliary of completion (not in terms of 'auxiliary' as here considered), $n i: n-n$ is sit-imperfective, sitting, so that $k a: l-k u: k-n i: n$ is a double compounding of verb + noun + verb. The whole pattern allows of a good deal of movement and interchange of parts. The system is not rigid, and it will appear in the following sections of this study that a pattern of increasing rigidity is being developed, rather than one of increasing complexity. In Australian linguistic development such has been the case throughout: increasing rigidity of construction has been combined with increasing complexity, the one leading on to the other. If the tendency is for languages to decrease in complexity, as W. Tauli (1958) has tried to show in his 
book on the subject, then the Australian languages have not yet reached the stage of breakdown. It seems falrly clear that IndoEuropean languages with the exception of the Slavonic languages (within limits, as shown by Bulgarian) and the Baltic languages (again with limits shown by Latvian) have withstood the tendency and have retalned their morphological complexity. The Australian languages do not seem to have done this, and as they seem to be surrendering, with varying speeds, to the pressure of English since colonisation, it is unlikely that they will survive long enough to do 1 t.

There is considerable varlety possible in the Thayorre recombinations of free forms into 'bundles' which as a total act as another free form. At the same time there are elements which are bound forms that can be added to make the 'bundles' into usable verbs, as in ninjiR-p-un ready + verbaliser + causative to which again tense indicators etc. may be added, as in Hall's example (p. 138): nul ku:lan najkn kana niniRpun-nam he track your now ready-verbalisercausative-future, He is now going to prepare your path. The basic element of the compound is here an attribute (ready) made into a verb by a bound suffix (-p-) to which a causative (-un-) is linked before the tense marker is added. But, as Hall says later ( .155$)$, 'auxiliaries may fill an obvious gap in the inflectional pattern, syntactically rather than morphologically,' elther before or after the verb base. These modifiers intersect with a perfective-imperfective system.

Verbs may combine, as in law tik snap break, 1.e. break with a snap or break by snapping; tup ke'er swish spear-did. In particular there is one noun stem which combines with (in Hall's list) twenty-three verb bases. This is $t^{a}:(w)$ mouth, and all the actions listed involve the mouth. This process reminds one of formations that will be seen in other parts of this survey, such as Arnhem Land compounds. A very few compounds are built on ko: (w) nose, as ko:mat croak: but Hall's other two examples do not seem to belong to the set except in form. They are ko:pint rescue and ko:-junp show off. The root ne:r eye gives ne:r-mu:nt blink, ne:r-ru:k sharpen and ne:r-ti:k copy. At this stage, as Hall points out, it becomes a matter of 'compound' words. In his later chapter on compounding he quotes among other types which are non-verbal, ka:l-u-je:n remember, me:R-t-pa: $r$ weep; wark-(y)an-t wander round, wut-wun sleep lie, pot-pa:t shiver, tarn-(R)e:k strengthen; magiR-wunp measure, gapaR-(p)iRk rip off. The bracketed elements mark phonetic changes that take place in the process of combination. 


\subsection{Auxiliaries}

When one element of the phrasal verb has reached a subordinate position in the phrase, it is easy for 1t to lose 1ts individual force and be debased into an auxiliary place in which its general or basic meaning remains only as an indicator of the way in which the action of the dominating verb has been carried out. This appears in the Daly River languages as marking action by sitting, standing, etc.; elsewhere in other ways. At this stage the tendency is for only a few verbs to be used in the subordinate position, and these can then be regarded as auxiliarles. They may develop as in English into 'modal' verbs - can, may, should, etc. In the Australian languages they have not in general done this (in a few cases in the NK, for instance, they may have done so: at this length of time it cannot be proved). In Australia there are ways of expressing all these 1deas, and a certain amount of agreement in the forms of the indicators suggests common origins, but there is no evidence that the modal verbs are such debased auxiliaries. At a later stage auxiliaries may lose their semantic identity and become simply means by which person, tense, etc. may be indicated in forms whose roots were perhaps not originally verbs at all. The former usage is here treated as 2.2.1, and the latter as 2.2.2. These two sub-groups are now treated in sequence.

\subsubsection{Free auxiliaries}

\subsubsection{Cape York languages}

The Thayorre system which has just been considered approaches fairly closely to the one now to be consldered, but a type language for this subsection is better supplied by Gog-Nar, a language of the south-western edge of Cape York, treated by Breen (1976a and b).

In this language verbs can be compounded, usually of $\mathrm{N} V$ bases, as in yel yem eye throw, 1.e. look. Subject still has to be Indicated and so do tense and mood: these are not in question here. This does in a way compare with Ngarinjin burgadj a-n-e:bu-n question him-I-throw-pres., I ask him. In English also one can speak of 'casting a glance'. There are also what Breen has called 'formatives', and these are auxiliarles much as in Bidjandjadjara (2.2.2). Their exact status is equally uncertain in both, and something will need to be sald about them because they occur widely in New South Wales as well, and apparently represent a falrly old and widespread development, Including Cape York, New South Wales, Western Desert and South-west 
Austral1a. Breen uses mba as a 'formative', which he defines as a stative; it might possibly be better defined as inchoative. An example is man Ray-mba-n throat got dry < Ray dry. There is an allomorph, ba, and another bada, and the latter may still retain word status - showing that this type is a debasement of the Thayorre type. Breen gives seven such auxiliaries (1976b:252). An 1mportant subdivision is supplied by 'certain verb stems, all with initial /o/ and all very common, have a bound form from which an initial consonant has been deleted and which is used much more frequently than the free form. These include / $\mathrm{hl} / \mathrm{go}$, walk, and homonym / $\mathrm{hl} /$ to spear, kick...' (Breen 1976b:252). His examples show something actually more complicated, in that the dependent phrase is amalgamated with the verb almost in a polysynthetic manner: nand garnging let's go now, glossed as we ( $\mathrm{pl}$. ) now-go-PURP, nu minyalg $I$ will eat some meat which is $I$ meat-eat-PURP: the base for eat is / ga/. There is also an Independent $n$ indo become, seen in bungu nindor got to his knees (bungu knee). The stages involved here are obvious: an independent word, an auxiliary and finally a polysynthetic unit. Breen quotes as examples of the independent stage a phonologically free stem, landabadim is itchy, binwar badim is thinking (person is not marked). He also shows how a causative $b i$ added to the imperfective future tense of an intransitive verb derives from it a causative transitive as in yegi climb > yegi-n-bin lifted or woke (trans.). A similar result may be obtained by using bala leave: added to an $\mathrm{N}$ stem, dugumb deep > dugumba-bala-nga deepen it. Here it is possible to see the development of a compound confugation, lllustrating with some probabllity a process through which such systems could have arisen elsewhere in Australla - and it must be remembered that absence of documentation diachronically makes it necessary never to say more than 'could have' in any of the present studies.

\subsubsection{South-western languages}

Very similar processes have been at work also in South-west Australia, in the Wadjug languages about Perth. Here the modern authority is W.H. Douglas (1968). Douglas presents many examples of $\mathrm{N}+\mathrm{V}, \mathrm{V}+\mathrm{V}$ and other compounds which are similar in principle to those of North Queensland. Douglas states: 'compound stems of two types: free plus bound root; free root plus free root' show the patterns and exemplifies them by mudidj strong, + -b become + aspect > mudidjabinj becoming strong; wang talk + njin sit > wang njin converse; wod throat > wod baRan throat grasp, choke a person, and many other examples scattered through the work. 


\subsubsection{The Dampier Land languages}

The outstanding difference between these languages and those treated earlier is that the Dampler Land languages are prefixal, like those of the Kimberley to the north and Bunaba-Guniyan to the east of them. They comprise the following languages (see Wurm 1972:124, where they are classed as 'Njul-njulan' from the name of one of them). In construction and vocabulary alike they stand largely apart from others, and although there is CA material in them, they provide one of the distinctive 'regional' vocabularies in Australia (Wurm 1972:93-4; Capell 1956/62:103-6). The materlals used here are partly from published sources (Capell 1953:450ff.; Worms 1942:125ff.; Nekes 1938: 139-63), and partly from unpublished fleldwork of Capell. The only published references to Bunaba and Guniyan are in Capell 1940:416ff., where also some Dampler Land material is given in 411-15.

The Dampler Land languages are listed by Wurm (1972:124) as follows:

1. Njulnjul, with an assoclated group of dialects: Bard, DJabirdjabir, Nimanbur, DJaw1, Ngo:mbal, DJugan. These are all located on the Dampler Land Peninsula.

2. Yawur, also spelled Yauor, DJauor, about Broome.

3. Njigina, about Derby, and 4. Warwa, between that region on the area of the Northern Kimberley languages.

In the present setting, the description will be limited to the Njulnjul and Njigina groups: the characteristic features are all included within these.

In all the languages, person marking is by prefix and tense and mood by suffix: this is in keeping with the general patterning of Prefixing Languages in Australia. In both groups there are simple verbs and compound verbs. Worms (1942) using as examples the verb to sme 2 , gives Njulnjul nan-moreran (transitive) $I$ sme $z i t$, and ga-bonyen (= ga-bunjin) (Intransitive). Forms of the same root appear in the other languages, except that in NJigina there is only one root involved: nan-bandjun, with a slight variant nam-bandjun as intransitive.

The pattern in general for compound confugation is a number of auxiliarles which in their Njulnjul form are: (1) gandin $I$ say, (2) Danin I am, (3) nanam I put, (4) nanag I bring, I carry, (5) nandjid $I$ go, (6) nanar $I$ bite. These seem to be very similar to 
those found in the WD languages and some of them may be CA roots, e.g. -am put (*(a)ma); -ag bring (*-ga); nandin I say seems to agree with Gunwinjgu -di (see earlier, but there is change of meaning if this is so). It is difficult to link -ar bite with *bad(j)a, but it may be possible.

Warwa deviates considerably and seems to have been influenced rather deeply by the Northern Kimberley languages (Capell 1953:458ff.). Capell has stated that there has been NK Influence in Warwa not only in forms but such that it 'has thrown it out of order in two ways:

(1) the wrong meanings have become attached to person prefixes, e.g. $n$ - is used in the 3rd sing. and plur. as well as in lst sing. and (2) a totally new type of transitive confugation has been developed, though the general outline of tenses and moods remains as in NJigina'. The auxiliarles used in Warwa are: 1) janganj $I$ am, 2) DaRan $I$ say, 3) Danman take or put, 4) Danangan I hit, janan I stay, put, 5) Danangaweran $I$ folzow, 6) ganangama $I$ give. One example of each w1ll show: wodidjnanganj I dig ground, bindanuna naRan $I$ am sick, liyan janman $I$ like, l1t. put to stomach, or inside, gidar ganangan I pulz (gulin nanajalu I sleep is a Warwa variation for the Nfigina given below), nila ganaggaman $I$ show him.

The Nfigina auxiliarles with corresponding examples are very like these but rather different from Njulnjul:

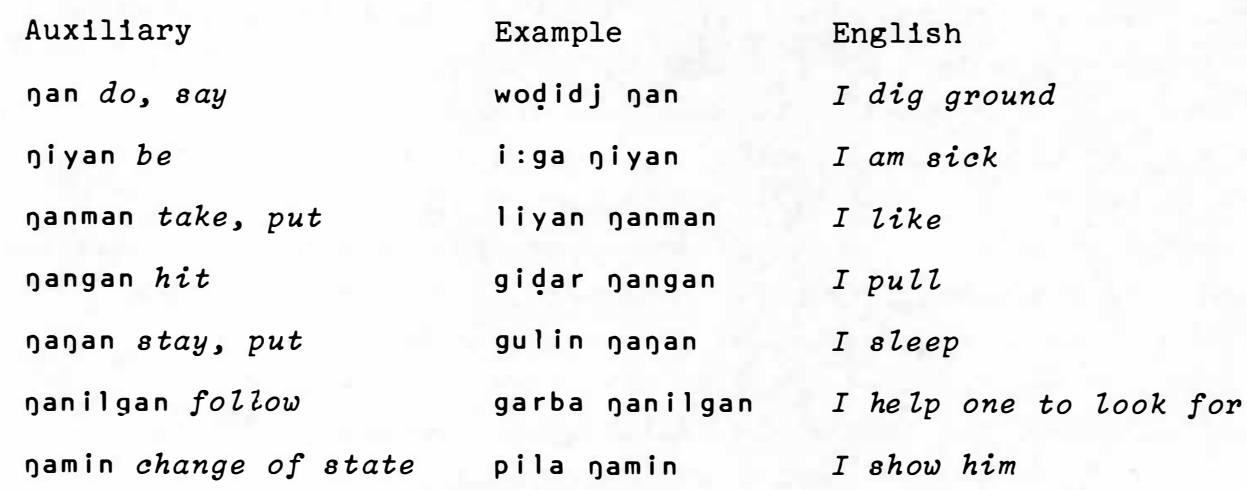

\subsubsection{Daly River languages}

The Daly River languages have a type of verb compounding that is peculiar to them. This is described by Tryon (1974:304) in the followIng terms: 'In all of the languages there are, in general terms, two verbs contained in every verb phrase, one a bound form, used to Indicate the verb class and general type of action; such verbs may be called secondary verbs, for they indicate elther the general action 
type or the physical position in which the action denoted by the primary verb, normally a free form, is performed; the other, the free form verb stem, indicates generally the particular action which is performed within the range delimited by the secondary or bound stem'. A few examples from various languages of the group will make the meaning of this rather complicated explanation plain to those who have had no experlence of the particular set of languages. Reference is made here to Tryon (1970:5lff.), examples being taken from Maranunggu. Firstly, there are twenty-two verb classes in this language - and 1t is typical. The auxillary verbs consist of three parts, tense + person + aspect, the name used by Tryon for the particularising verb stem. So wad ganani $I$ went, which consists of a base verb wad, of golng, and a compound auxillary ga-na-ni past-Imovement. Actually the form here is simple non-future, a definite past Involves adding a past auxillary yi at the end of the phrase (Tryon 1970:18). Another aux1l1ary, -ma-, of standing, y1elds forms such as djinda nala ga-na-ma gay ayi spear for past-I-stand call past, 1.e. I called out for a spear.

A paper by D. Birk on Mulluk-Mulluk (B1rk 1976) deals with what is really the same system. He brings out the fact that 'In the great majority of cases the verb root has the cholce of up to six confugations, of which five have the semantic role of variously defining the manner' of the action. Thus '1t is not the case that each verb root always co-occurs with a particular auxiliary; the cholce is, in principle, multiple, all conjugations being productive'. This is the state of affairs also in Ngarinjin, whose eleven possibilities have been listed earlier, but there is in the NK languages less varlety allowable in practice, whatever the theory may have been. In all the languages, the semantic aspect is primary, and indeed suggests that there has been a coalescence of more than one system.

Some of the languages are more elaborate than Maranunggu:

Nganglgurunggur has twenty-nine auxiliarles among which a cholce can be made. There are also other elements which are invarlable and Indicate the manner of an action, such as du touching, which occurs with four auxillarles, e.g. jarin du $I$ feel for turtles; nudubun du I taste, try the point of a spear; nebem du I grind up and nerim du $I$ awaken somebody. These uses are slightly different from the others. The classification of the auxiliarles given by Hoddinott and Kofod $(1976: 695-6)$ is a double one: (a) semant1c particles which express the verbal meaning, as in yenim fa he screams; wudem fel he dives. These come from a varlety of word classes, mostly adverbs, some 
gerunds; (b) particles largely adverbial and retalning the function. They Indicate how the action was done: da-ba arm, mengin ba wa he picks up by the arm. Markers of tense detall are also free forms such as tye past and gini future. The Maranunggu (a)yi of past t1me is similar.

The exceptional language of the Daly River group is Wadjiginf, where the verbs are still certainly double, as in the rest of the areas, but the verbs of manner and position are not present. Instead, there is a compound verb which is very like those of the Northern Kimberley languages, in which a noun or gerund form is completed by a verb in which subject and object are amalgamated, Just as in the NK group.

The main feature of Wadjlging to be noted here is the transitive verb, In which the object is represented by a marker used with that of the subject prefix. For detalls reference should be made to Tryon (1974:214-5), who says: 'The subject and pronoun object are fused into a combined or portmanteau morpheme, a feature not found elsewhere here in the Daly Famlly. W1th noun objects, then, there are four possible forms for each actor'. The transitive verb phrase is plctured as

$\operatorname{VP}(\operatorname{Trans})=+$ subject/object + predicate (+vb stem + tense). Th1s is again precisely the plcture found in the NK and AL languages, and repeated in Lamalama in N.E. Queensland. In Wadj1ginj, however, there are future and non-future forms as a general rule, not past forms. As in the NK also, object precedes subject in the combination: ya-n-him-I; yi-n him-you, but there are irregularities and Tryon (1974:216) was not quite happy about all deta1ls of the analysis. Th1s, however, is beyond the 1mmediate subject. What is 1mportant here 1 s the system of confugation, which shows that this language stands apart from the rest of the Daly Famlly and seems to have connections with the type that blossomed out chlefly in the languages to the north of 1 .

\subsubsection{Languages along Southern Arnhem Land}

There are some languages spoken along the southern edges of Arnhem Land that have connection with the present section. These are chlefly those of the Roper River area - Wandarang, Mara and Alawa, Mangaray and Yangman. Some of them were noted by Capell (1942) and brief notes given on them. The first three were outlined by M. Sharpe (1976); the last two were noted by Capeli but no materlal on them has yet been 
published. The bulk of the Arnhem Land languages, although they have noun classes, do not compound verb stems; those in N.E. Arnhem Land (the Murngin and Yulngu group) do compound verb stems but have no noun classes, while in the north-west the Gunwinjgu group have both noun classes and verb classes of the kind here considered.

The following notes rest largely on the as yet unpublished paper of Sharpe, and the fleld notes of Capell for the south-western languages.

Wandarang, Mara and Alawa form a subgroup in a number of respects, including the classification of verbs. The systems of classification, however, seem to be rather irregular, and give the feeling - for what It is worth - that they are not basically part of the languages. According to Sharpe, Alawa exhibits \pm thirty auxiliaries, Mara and Wandarang \pm fifteen, whose confugational forms (person, tense, etc.) are often irregular and even suppletive. She deals chlefly with Alawa, where she finds different auxillarles used with roots marking qualities of a thing, transitive sensations, instrumental transitives, change of state, motion, and such ditransitive verbs as give. Present space allows only brief illustrations of the verbs so classed. Firstly, the statement about the irregular and suppletive nature of the forms may be 1llustrated by a few examples from her lists: na sit, gives punctlliar past nagajan $I$ sat, future neyi $I$ shall sit, present neni there are also irrealis f'orms; ma do, has in the same order ma, $m i$ and manjdji, and yura go has ana or ina, djura, lindu or lindiyi. These irregularities in themselves suggest a complicated history that probably cannot be worked out in the absence of diachronic information.

Some of the classifications can be similarly illustrated in outline :

1. Qualitative verbs: gulg $r i$ to be heavy; ruwu gulg neni the tree is heavy; ruwu gulg manjdjawa nda the tree is not heavy.

2. Instrumental qualitative verbs: galur $r i$ be round for a purpose, as In ludjuludju galur neni (or galur mayin) the coolamin is round for water.

3. Transitive sensation verbs: gaya na to hear; njinaya $r i$ to like (with a different auxiliary), shown in dul gulananna nda yargala we found the kangaroo; gaya geneni nda garuReru njuR nembeli hear the dingo howling.

4. Transitive action state: lilmiri gunn ganna nda girimbu man watch he-did-it kangaroo, 1.e. the man watched the kangaroo.

5. Change of state verbs: bun njidi be born; budid winja get up and go, as in $1 \mathrm{ilmi}$ budid nala the man sets out. 
In Mara, Capell's examples show the following situations: gal ilguduliyi I bite you, gal gadjuliyi I bite him; nan nalindu I run; mal nana I climbed (aux. go, past); walanjan nowi? walindu the fish is swimming (here the Murngin dialect Maragulu can reverse the order though using the same construction: gwi:ya mardji gabagar fish goes swimming); dar nalinma I hid (myself); pal namanjdji I speak (doing talk); others appear on the lists but have not been worked out as yet.

There are exactly similar structures in Wandarang, Ngalagan and Ngand that do not call for detalled lllustration in the present survey context. They are not present in Garawa and Yanjuwa to the east. The chain of this language type stretches westward. It is found in Mangaray, on the immediate west of Alawa, but has not yet been analysed. Like Alawa, Mangaray has simple verbs such as jayag I go, nama $I$ hold, and compounds as shown In gabudji duRur bundi jandju blind man I lead; ba:ndi boRan nawu yinji the snake is crawling. Exchange of auxiliaries with consequent semantic change is possible here also: compare the above blind man I am leading with duRur bu drag it: and the simple nayag go with minaba liwu yag $I$ dive into the water.

Farther west, towards Katherine, the Yangman language shows a similar phenomenon, but this again has not been analysed. A few scattered examples from Capell's fleld notes, however, show the presence of such compound verbs as wogba ganimen follow me; if -me $(n)$ represents the common Australian ma take, do root, then the analysis is a following do-to-me. Yangman is one of the few Australian languages that show a strong tonal patterning: here it is wógbà jānímēn. A further example, from a story text, shows ingenba njelma buriya nolgin translated by the informant as another man mustered the people; njelma buriy-a gather he-them-went shows a transitive use of -a or -ya go, as can be found in the Ngarinfin and other NK languages. Some further examples may be quoted, although they cannot be analysed in detall as yet: yingengaR garlo:yi we meet; wiriyi wungumbuRuRi he turned and hit (-bu-) them; la:l yirgugari we were tired (la:l tired, yirgu-we, -ga verb root (be?), -ri past). The nelghbouring language, Wageman, has already been listed with the Daly River languages, to which it is akin, and shows verbal phenomena similar to theirs.

A little to the north, however, Wadaman (Wardaman) does show the compounding phenomena. Among the auxiliarles listed there are

${ }^{1}$ In this example, an acute accent indicates high tone, grave the low tone, and macron the mid or level tone. 
gadjinin I stay, I am, namin $I$ do (the common -ma- root), nawin I fazl (the common -wa- root); najbun $I$ hit him (the common -bu- root), na-gi-n take, place (common -ga-), nawan $I$ give, nanjdja $I$ do. These compare with some of the NK roots, and through them with some form of early Australian, and similar comparison may be made with the suffix -ba, a frequentative in both NK and Wardaman - in the latter, for Instance, bagba jamin I break it with frequent blows (also good Ngarinfin!). In point of fact, comparison can often be made between this language and Ngarinjin, e.g. Wardaman nawa-dari $I$ left them, cf. Ngarinjin djari bununi, also I left them, Wardaman jamin djerin he dug (a hole) compares also with Ngarinjin djari dig though the latter uses a different auxiliary.

\subsubsection{The Northern Arnhem Land languages}

The comparisons made above between Wardaman, near Katherine, and the Northern Kimberley languages allows a turn northwards in the investigation towards the languages of northern Arnhem Land, especially those in the north-west.

\subsection{Laragiya}

The Laragia (Laragiya) language formerly spoken about Darwin patterns in practically the same way as the NK languages. There are simple verbs, and there are also compound verbs. In the compound verbs the first element is gerundial in nature, the second - the auxiliary - carries person, tense and other necessary markers. One of the commonest auxiliaries in the compound verbs is -ia-hit which corresponds to the NK (and $C A$ ) root -bu-, but differs from it formally. It is therefore possible either that the formation by means of hit in the extended sense of 'acting upon', is older than the use of *bu-, but it could be that Laragiya has imitated the common usage with 1ts own equivalent, 1.e. that -ia- is a calque or loan translation. This cannot be historically determined. As in Ngarinjin, the basic meaning of hit is lost: 1t is only in Worora of NK that the basic as well as the extended meaning of the root is retained. Examples in Laraglya are: duidui bilan I knocked, diridj bilan $I$ pinched him. Another frequent auxiliary is -ga-do, say which answers to the $\mathrm{NK}$ and elsewhere -ma-. The fact that in $\mathrm{CA}$ *ga = take, hold may or may not be important. In Laragiya the root sometimes indicates becoming (take on) or belng in a state, as in nirnir jagam I am hot, but note bidbid nagin I waved $i t$, bididjbaw nagin I rolzed it along, girgir nagin I scratched it (*gidi(gidi) tickle, scratch, probably EA), manamana wiwi magin the wind blew. A third is ag to go, 
as In way gaylga $I$ swim, bawRuli gagag $I$ shall lead him, bawudjin naledji I passed by (a supplet1ve form, cf. Mara etc. In 2.2.1.4), njul naledji I dived. This auxiliary may be used transitively or intransitively, e.g. luglug wagag $I$ shall steal it. A further example is - $r$ hold, gugar $I$ will hold $i t$, as in mingil muwar $I$ hop, presumably $I$ hold a hopping position, the $\mathrm{m}$ - class prefix probably referring, as it would in Ngarinjin, to the ground; murg gugar I'zl grab it. St1ll another is $-(w)$ al make, as in gulwa guguwal I'll make a song, I'll sing.

In all these forms the strong typological resemblance of Laragiya to the NK languages is maintained, even when the vocabulary is quite different. Seeing that CA vocabulary is at a lower percentage in Laragiya than in NK, it is open to suggestion that the system in Laragiya is basically common to this and all the NK languages, but that the latter have incorporated $\mathrm{CA}$ material at a later date. When this material is examined from an LS point of view (which cannot be done here) the conclusion is greatly strengthened. It has already been suggested, in another paper in this volume, that noun-classing in the NK is a relatively late formation, the structures of Laragiya and $\mathrm{NK}$ remain as early types, on to which classification patterns have been added later.

\subsection{Other Western Arnhem Land languages}

The lesser known languages - Gagadju, Manger1, Urninggang - do not use compounding. Their verbs are all simple bases to which person and other markers are added as affixes elther before or after the base. The first group that shows compounding, eastward of Laragiya, is the Gunwinjgu group. It must be recalled, however, that some languages such as Warral, are not known structurally at all.

\subsection{Gunwinjgu Group of Lanquages}

Under this heading are subsumed Gunwinfgu 1tself, along with Mawng, Gunbalang, Gundangbon, Mayal1 (a dlalect of Gunwinjgu not of free standing). The Jiwadja language is the nearest relative to Mawng, but has no noun classes (Capell 1962:127-170). In Mawng there is very little compounding of verbs, and in Jiwadja apparently none at all. The Mawng situation has been mentioned already in (2) above. It is not enlarged here; the main stress in on the phenomena in Gunwinjgu.

In Gunwinjgu, noun object incorporation into the verb complex is allowable: I am making a spear may be elther man-gole na-manbu-n or na-gole-manbu-n I am washing my head is normally na-go:dj-djiridjbure-n I head wash. The peculiarities of verb classification in 
Gunwinjgu seem to rest on this capacity; the gerund is incorporated between subject ( \pm object) marker and tense etc. ending. This formation does not seem to have been noticed before, certainly not by the present author in earlier publications, but if it is assumed to be acting, the analysis of the verbal systems becomes much easier. The pattern in the Gunwinfgu compound confugation then becomes uniformly

+ subject \pm object + gerund + tense etc. markers

and in 'tense etc. markers' the reflexive suffixes are contained. The papers put out in the Australian Institute of Aboriginal studies Seminar in 1974 (see Dixon, ed. 1976) did not notice this fact, and therefore both Carroll's paper (Carroll 1976) and Capell's comments on it need to be revised from this new angle. The earlier Gunwinjgu grammar (Oates 1964) also needs to be revised from this point of view.

In all these earlier analyses the compounding of verbs in Gunwinjgu has stood apart from that in other languages as being suffixal, e.g. na-wog-di I spoke as compared with gun-wog a word, speech. A simple verb such as na-bu-n I hit him does not really contrast with the compound in the same way as in the other languages. There are no verbs in Gunwinjgu of the gerund + auxiliary type. But if na-wog-di could be broken up into *wog na-di, the normal pattern would be attained. Owing to the fact that noun incorporation is the rule in Gunwinjgu (though not now compulsory), *wog na-di becomes impossible, and the incorporative type becomes standard. The various 'suffixes' listed by Oates and Carroll then become the stems of verbs preceded by a 'noun' of some type, which often does not exist as a free form. This is true of many of the 'bases' in the NK and other languages; in these the 'bases' are functionally gerunds, followed immediately by the verb; In Gunwinfgu they are still nouns incorporated into the verb but the principle of compounding remains the same.

The interpretations of these forms are not at all clear in many instances. J.T. Platt remarks in another context: 'semantic analyses based on morphology run into all sorts of difficulties... the semantic analyses may, at first, look to be very language specific, but if we look further we may see that there are interesting parallels between the morphological analysis and possible underlying structures for related lexical 1tems in English and other languages' (Platt:1974:119). The same remarks may be made for Gunwinjgu as for Bidjandjadjara, to which Platt's remarks refer. Some of the suffixed auxiliaries in Gunwinjgu are recognisable as elther free forms within the presentday language or related to other forms, elther ${ }^{*} \mathrm{CA}$ or ${ }^{*} \mathrm{EA}$. The 
present summary statement will therefore be divided into two sections, one referring to roots which can be recognised with fair confidence, and the other roots not so recognisable at least nowadays.

What are the bases in Gunwinjgu? In some cases, such as gun-wog, they can appear with a noun-class prefix and function as nouns. In others, they do not function independently, but there are signs that once they did: there is the infix -bo:- of reference to water, combining with-nu-eat or drink, to make na-bo:-nu-n lit. I-watereat, 1.e. I drink. This does not stand alone, but the writer well remembers it as the first call in the Maray in ritual, a prolonged gunbo:, gunbo:, gunbo: by the song leader and master of the rite, and clearly a call to water which is central to the mythology. Another, -bolg-reference to ground does occur alone as gun-bolg ground, earth, camp, and in verbs such as -bolg-ge drop to the ground and in other nominals such as gunRed ga-bolg-neyo earth $i t s$ ground name, the name of the place. If a man in a temper calms down, he ga-pud-me; if a stormy sea calms down 1t ga-bo:-nud-me. These prefixed elements are noun classiflers extended to verb classification, not auxiliaries: the suffixed -me is the auxiliary, usually intransitive, with -ge as the corresponding transitive.

The result turns out to be a plcture not unlike the Daly River Family languages already dealt with. Moreover, some of the markers listed by Oates (Oates 1964:37ff.) do not seem to be Justified, e.g. ginje cook looks to be a simple root and not -gin-je: no suffix -je appears. This applies to quite a number of other allomorphs. The final analysis at present will then be:

1. Recognisable roots:

$$
\begin{aligned}
& \text {-bu hit } \\
& \text {-di stand } \\
& \text {-ga take (hither) } \\
& \text {-ma take (away) } \\
& \text {-na see }
\end{aligned}
$$

2. Not now recognisable roots:

$$
\begin{aligned}
& \text {-ni sit } \\
& \text {-Re go (-m-Re come) } \\
& \text {-we throw } \\
& \text {-wo give } \\
& \text {-yo Zie }
\end{aligned}
$$

$$
\begin{array}{ll}
\text {-do } & \text {-me }(<- \text { ma? }) \\
\text {-ge }(<-g a ?) & -r i \\
& \text {-wa (?) }
\end{array}
$$


The two sets are now briefly exemplified:

(1) -bu hit $\mathrm{CA}$ *bu: most of the examples are in NK languages reduced to 'action on an object': -dulu-bu pierce, -djiridj-bu wash (-djiridj-bu-Ren wash oneself), -maṇbu-make, heal. Th1s is almost as common a formative as in NK languages.

(2) -di stand, na-di I stand, -wog-di talk (standing as a rule) there does not seem to be a corresponding *-wog-ni talk while sitting, -miri?-di be sharp, like a point, standing out.

(3) -ga-take, with basic 1dea of motion towards speaker, bring, -manga- fall down, take a fall (to oneself), -walga hide.

(4) -ma take, motion away from speaker, as in bunja-ma kiss, which must be away from actor towards reclpient, -lalma separate, again in the same manner. The root is used by 1 tself as na-ma-n I do, I say, a double meaning which is very commonly found with this $\mathrm{CA}$ root, e.g. In the NK languages and in Alawa, etc. There seems to be a phonetically variant form In the third root of group 2, -me, as also there is a -ge from -ga; these are discussed below. As an auxiliary the root -ma is Australia wide, being found as far from NK as northern New South Wales.

(5) - na see, also a CA root, but not commonly found as an auxillary in other languages. It is involved with activities which involve the eyes: -wo?na watch, keep watch on, be alive. An interesting case is found in the modern verb to read, -bim-burg-na: -bim is carve, write, -burg is body, and -na: one who sees the form which has been carved or written.

(6) -ni sit, na-ni I sit, dwe 2 , remain. Th1s is the simplest form of an EA root $\star_{n} i$ which appears in CA as $\star_{n i n}(i)$. An example is wayi-ni sing, which is really sit and sing, as is usually done.

(7) -Re go, and with prefix of reversed motion, -m-Re come. This is auxillary for verbs of movement as a whole, whether by the actor or not, e.g. -bo:Re to flow out, issue is built from the water indicator -bo previously mentioned, and -Re, -djargRe assemble uses the plural action prefix-djarg-; -djalg-mi-Re- to tear as cloth, uses the tear -djalg-, and can also be -djalgme- without the direction suffix; some other cases are not so clear, e.g. -bugiru-Re to dream and wuyug-mi-Re to be tired - again a form of -me, plus the 
directional - Re.

(8) -we to throw, related to the NK root wadj: Gunwinjgu na-we-

$I$ throw it away. In Ngarinjin, however, this would be a compound word: wadj anebun throwing $I$-do-to-it, whereas here 1t is a main verb: what is the history of the formation of these compounds? Examples: munge-we to send, mari-we to be in a hurry (sc. to get away), -go-we to tell a lie (1t is thrown at the reclplent:), -bugburi-we to knock over.

(9) -wo give, one of the forms of a CA root that appears as *wu, *yu or *ju. As a full verb it is na-wo:n I give it to him. Oates remarks that 1 acts on varlous speech categorles, e.g. -ba-wo to go away, -bele-wo make clean (clear -bele), -woybug-wo make true, 1.e. belleve a thing, -ware-wo make a mistake (CA root *wari bad), -yag-wo to finish (yag done). The Gunwinjgu word - nu however, is the verb eat, and comes from a different root.

(10) -yo to lie down: na-yo. Th1s does not seem to be a general Australian root of elther stratum. It appears in -ge-yo to sleep, -yiri-yo stretch oneself, -boyboyo lie prone, - lumbari-yo lie supine, -go:dj-bugiri-yo to dream, where $-g o: \mathrm{dj}$ is head.

The second set of formatives is shorter, but not to easy to deal with, particularly in the cases of -ge and -me, which are clearly derived from -ga and -ma respectively. The former is a common transitiviser, the latter an intransitiviser, and the two will often interchange with the one verbal (or gerund1ve) pref1x; Oates' lilustration is juri-boled-ge-men you turn it over and ga-boled-me he turns (himself) over. She adds, however, 'but there are many intransitive verbs ending in -me, and transitive verbs ending in -ge which have no corresponding transitive or intransitive counterpart' (Oates 1964:37). There is no solution offered in the present short space to the matter; 1 would seem that a further suffix - $i$ has been added ( $m a+i=m e ; ~ g a+i=g e)$, but what this would be cannot be sa1d.

The remaining roots are -do, $-r i$ and -wa, the last belng doubtful, since none of the examples in Oates seems to appear also without the -wa, 1.e. 1t would be part of a stem, not a suffix at all.

For - do the evidence is unsatisfactory. It could be that 1 t represents a phonemic varlation of -ro, a verb to throw na-ro, and that -dagendo put or place in a container refers to throwing an 
article into the container. According to Capell's vocabulary there is also-da?gen-di to embark on a canoe, 1.e. to stand in a canoe as a container, thus 1solating the root -dagen- or da?gen-(dialect varlation). Whether -Ro-me to dodge belongs here depends on checking as to ro/Ro. A verb -do-we die could belong to the -do root as well, but the whole matter of these non-separable suffixes is unsatisfactory and 1 s best left so for the moment.

This demonstration of the nature of the Gunwinj gu verb has been given probably an over-great proportion of a work of the present nature, but as 1t represents a type not previously reported for Australia this seemed advisable. As remarked, it does look rather like the Daly River type previously treated more briefly.

The remaining uncertain formative is - $r i$, and here Oates' examples are amb1guous. It is true that -durgmi-ri to work may represent -*durg-me $+* d i-$, as work 1s mostly done standing, and the -di form is used w1th some laxity about position, but -diri play looks like a simple verb, and -benyi-ri listen needs more analysis, since it evidently has connections with -bega-hear and -ben-ga know. The last appears as -bengu in Gundangbon.

For Gunbalang, J. Kinslow Harris states in regard to compound stems, that 'in some of the compound and reduplicative stems each morpheme is semantically 1dentiflable, 1.e. ngayn-has the meaning "actions towards the speaker" and -ka has the meaning go, so that in combination -ngaynka (read -nanjga in present orthography) means to come. However, the majority of these stems are a combination of a non-product1ve morpheme in unique occurrence with a morpheme which may occur elsewhere as a simple root, 1.e. -puyn (=-bu-nj*CA bu $h i t)$ is a simple root which occurs with the non-productive morpheme -mij glving the combined meaning -mijpuyn to meet.' (Harris 1969:6).

In the south-central area the group of dialects known as Buwan, Ngalgbon or Dalabon has a system very much like that of the Gunwinfgu. Reference may be made to Capell (1962:112), where s1x suffixal classiflers, all cognate to Gunwinjgu forms, are set out as follows:

(1) -bu-, action upon an object: gula? skin >-gula?bu- to skin, an anlmal; danj-spear > danjbu to spear; bi:m clay>-bi:mbuto mark with clay, to write, draw.

(2) -ga-, transitiviser, with some exceptions: cf. Gunwinjgu -ge, -ga:boled-ga upset, overturn; -ra?ga- to drop; and among intransitives: -do?ga- be awake. The distinction between -ga and -ge found in Gunwinjgu does not appear here. 
(3) -ma-, Intransitiviser: -wulub dive > -wulub-ma bathe; -wo?ma-be drowned; -dadadj-ma- grow weary, seemingly connected with -dadj-ga cut. There is apparently no connection between -wo?ga- sing and -wo?ma- be drowned.

(4) -mi-, equivalent to Gunwinjgu -me, described by Capell (op. c1t.) as neutral in regard to goal, marking a derived verb, used when other, more specific markers are not called for: -wiyal-mi hiccough; -gunon-mi telz, narrate.

(5) -na-, the root meaning see is largely lost in compounding: -jidj-na hold; -wad-na throw, wo-na hear; -gunwo-na think. There is a compound with -ri- (not otherwise used in Dalabon): non spittle > non wad-na-ri to spit, which Capell there interpreted as a-ri- reflexive, throw for oneself spittle; similarly gunj wadnari to sneeze.

(6) -wo-, root of the verb give: -djanwo- ask, give a question; man-wo make, heal, constructed in Gunwinjgu with -bu- as -man-bu-; -doge?wo- find; -we? bad > -we?wo- to swear.

All these forms in Gunbalang and Dalabon are capable of interpretation as compounds of noun root plus verb auxiliary, preceded by person marking, treating the noun as an incorporated form.

\subsection{Other Arnhem Land 1anguages}

Compounding of verbal stems seems to be absent among the other languages of northern Arnhem Land. It does not appear in Gunavidj1, Nagara or Burera - and those to the east belong to another group of non-classifying languages, which will be mentioned in their place (see 2.2.2.7.5 below). In the south-east, Nunggubuyu and Anindilfawgwa also lack the system. It is found in the Roper River area, where 1t has already been mentioned. The Dalabon type, which belongs to the Gunwinjgu model, has been mentioned in 2.2.1.6.3.

\subsubsection{South Australian languages}

Th1s subgroup comprises the South Australian languages in which compound confugation occurs. It consists of six interrelated languages :

$\begin{array}{ll}\text { Diyar1 } & \text { Midhaga } \\ \text { Dh1rar1 } & \text { Yandruwanda } \\ \text { Ngamin1 } & \text { Yarluyand1 }\end{array}$


occupying an area east of the Lakes district and stretching towards the north-west corner of New South Wales and the south-west corner of Queensland. They are characterised generally by certain common features, apart from vocabulary. They do not mark person in the verb, but require a noun or pronoun subject and object to be expressed. They are ergative languages. They use a small number of auxillarles (elght at the most) which mark tense and mood, whlle the main verb remains unaltered to a very large degree. The auxillary verb 1tself can also function as a main verb.

Diyar1 (Dier1) is the best known of the languages. There is a New Testament translation by Reuther dating from 1896, as well as some published grammatical studies of varying degrees of unsatisfactoriness. The remalning languages have recelved less attention. The information used in the present notes is derived from work by sundry students - published materials on D1yar1, and papers by Breen (1976c,d) and Austin (1976), with reference to a little materlal made avallable by L. Hercus in which Yarluyand1 is mentioned.

\subsection{Diyari}

Dlyarl has no genders or classes in nouns but does mark masculine and feminine in pronouns on a basis of 'natural' gender. The normal sentence type is SOV, and in the verb the pattern is base + auxiliary. The simple base is used alone only in dependent clauses, and the suffix then has a special use. There is a verb to be - wandi - which is one of the auxiliaries but appears in equational and descriptive sentences. In one of Berndt's texts there occurs the sentence nanija nanay widla gurupuru she is woman strong, where the syntax can be fustifled in a way not relevant here. Apart from the present (or aorlst), verb bases can be used only with auxillarles: jada ganay is speaking.

There are six auxiliarles, each having 1ts own basic meaning, and usable under certain conditions as a main verb. They are:

\begin{tabular}{lll} 
Auxiliary & Meaning & \multicolumn{1}{c}{ Use } \\
bara & lie & state just attalned \\
nana & be & permanent state \\
waba & go & entry upon a state \\
wandi & seek & state attained or action done \\
wara & throw & action already done \\
wiri & enter & state recently attained
\end{tabular}


There are aspect endings used with the auxiliarles, as in nawu worga-la wandi, bunani wiri-la he came to enter the house and the imperfective -la also indicates purpose. The detalls of tense and aspect are expressed in various combinations of roots and auxiliaries:

1. With -na perfective: nani jada-na wandi $I$ spoke, nani jada-na waray $I$ have spoken, jani jada-na bara-ya I spoke some time ago; bara suggests $I$ have thrown in my word, and it's all done.

2. With -la Imperfective: Dani jada-la najay $I$ am about to speak, I shall speak, nani jada-la waba-ya I am in the process of speaking, going to speak, nani jada-la wiri I have entered upon speaking, begun to speak.

It is possible for auxiliaries to qualify themselves in a repetitive manner, as in wandina wandi, which occurs twice in Reuther's New Testament translation: Matthew 2:20 were seeking - also John 11:56. On the other hand he uses in Luke 4:33 warana wandi he threw, where Austin quotes warana waray. This may be a stylistic use of Reuther's: it is difficult now to say.

The entire system of auxiliaries here is different from those used in the other languages studied here. It seems to be a matter of expressing first of all by means of an aspect marker whether the act is complete or not, then by an auxillary when 1t was or will be completed, and what sort of activity is involved in the completion.

In terms of phrase analysis the various situations might be set out in something like the following ways:

1.

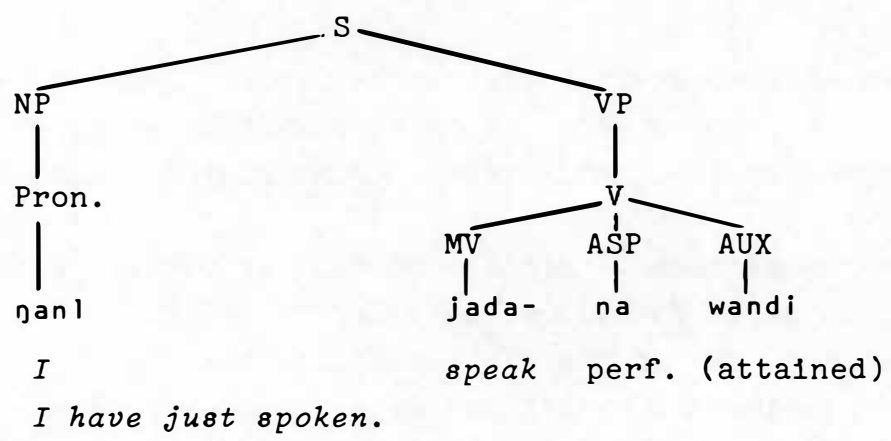




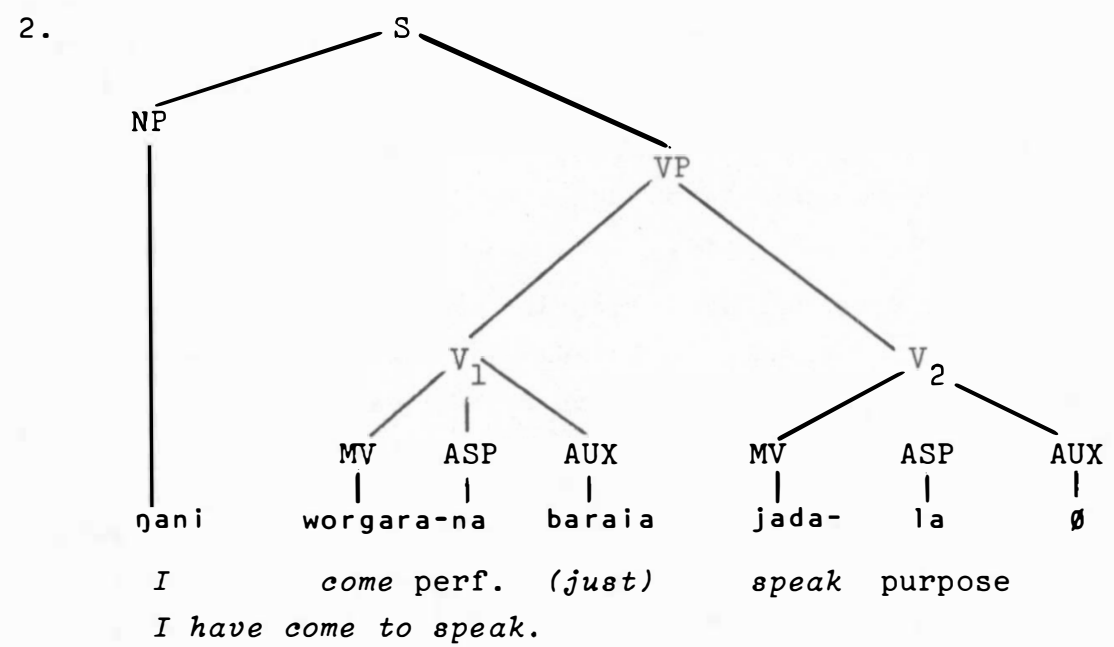

An example of the ergative construction, the locative ending and the sentence medial use of - na aspect is seen in the following:
nu-lu bradjana madjadinda-na nuga-ju-bini mida-ni, he-erg. everything now having-lost that-in-emph. Zand-in,
mawa biṇa bandji-na wandi
hunger great make-perf. past.
When he had lost everything, a great famine happened in that country.

\subsection{Dhirari}

The Dhirari language is a dialect of Diyari, and the notes used in this section rest on a paper by Peter Austin given at the 1974 May meeting of the Australian Institute of Aboriginal Studies, Canberra (Austin 1976).

The general pattern is similar to that of Diyari $i_{\text {with the added }}$ complications of an additional auxiliary verb' (Austin). Austin also finds that some of the Diyari auxiliaries are not functioning in Dhirarl, but (using his spellings) wandiy and waray are regularly found, marking 'distant past' and 'less distant past' respectively. They occur after buri which is not an element of Diyari. This buri is fall and as such appears in Diyarl also: Austin gives nani gaba-ni buri-yadi she fell into the water. This becomes in Dhirari 


$$
\begin{array}{ll}
\text { nani gaba-ni buri-nda buri-yadi } \\
\text { she water-DAT/LOC falz-PART buri-PROB }
\end{array}
$$

according to Austin's analysis.

The buri verb, then, is characteristic of Dhirari; and with the absence of most of the auxillarles used in Diyari, gives 1ts special character to the dialect. Aspect and tense and other endings are added to buri, and the dlalect presents a totally different aspect from that of Diyari however close the two may be in vocabulary. Further reference needs to be made to Austin (1976).

\subsection{Ngamini}

The information on this language is drawn from a paper presented by J.G. Breen at the above-mentioned meeting (Breen 1976c). He links Ngamin1, Midhaga and Yarluyandi in a dialect chaln stretching north-east from Dhirar1-Diyari.

Ngaminl shows elght auxiliarles, which are:

1. barga run, momentary action whlle the actor is moving.

2. diga return, action directed back to where the original action took place.

3. guru motion away - not used as main verb.

4. marga crawl, continuing action while the actor is moving.

5. Dana do - but Breen 1 s uncertain - denotes intention; rare as main verb.

6. waba go, walk, habitual action in past time.

7. wara throw, marks past time.

8. wiri enter, seems to denote arrival, but some uncertainty. There are, however, extra suffixes which Breen calls 'verb stem formatives'; these have suspicious resemblance to some of the WD auxiliaries:

(1) -ba added to intransitive verb stem, makes a causative: from 8. above, wiri-ba to insert.

(2) -ga may be added to an intransitive stem such as waba go to form wabaga take: this certainly looks like the CA root ga- take, carry, hold.

(3) -naga is added to a non-verbal stem to indicate causation: naRi dead, naRinaga kizz. This looks like a form of -ga, but if the 
stem is non-verbal it is hardly likely to be the imperfective marker (which is -na).

(4) -ni turns a noun stem into a verb stem: biṇa big, binaṇi grow. Th1s looks like a form of $\mathrm{CA} n i n(i)$ sit. If these 1dentifications can be accepted, then we have double composition in this language.

Concerning these aux1liarles Breen (1976c:747) writes: 'by far the most frequently used is wara, used in 1 ts present tense form warayi to mark the past tense'. He 1llustrates:

gubanu mada naganamu waraṇa warayi
child-ERG stone me-IO throw- past
The child threw a stone at me.

He proceeds to illustrate the other auxiliarles with examples that are precluded here by considerations of space.

\subsection{Midhaga}

Breen (1976c:749) found data on this language very uncertain, and notes that 'it did have at least two auxillary verbs' - guli sit, wait, and wiri enter. H1s examples are:

$$
\begin{aligned}
& \text { 1. wani nadu yadabanda guli } \\
& \text { song I sing-pres. sit } \\
& \text { I am singing a song. }
\end{aligned}
$$

2. wadananduwara yini daRinda wirindari where-from you come - arrive - past

Where did you come from?

It is also possible to use at least the first one independently and with itself as in gulinda guli sitting.

These few examples show a system that is essentially the same as that of Diyarl 1tself, with again some varlations from pattern.

\subsection{Yandruwanda}

Here again the information is chlefly from Breen (1976d), but Hercus and Wurm have also gathered material in the language. Here such compounding as is found seems to be borrowed, for Breen remarks (1976d:750) that only in the Strzelecki Creek dialect is anything such found, and then only with gana do as an auxiliary. He exemplifies with 


$$
\begin{aligned}
& \text { Danyl dawana nanala } \\
& \text { I go-FUT do-PRES } \\
& \text { I am going to do. }
\end{aligned}
$$

However, he adds: 'It does, however, have a system in which verbs (or certain other words) are compounded with a main verb to perform a wide range of functions, including some similar to those performed by auxiliarles in Ngamini. Thus it forms a link between the auxiliary verb system and the more common system in which verb modification is by affixation or morphemes which exist only in bound forms.' In this 1t seems to be closer to other systems studied in his chapter than to the present subsection as a whole. It also, noticeably, has subdivisions of morning-noon-night tenses, such as appear in Tiwi of Bathurst-Melville Islands and parts of New South Wales.

\subsection{Yariuyandi}

No information is to hand regarding this language; only a mention that it belongs to the present grouping.

Introductory Note on 2.2.2, and 2.2.3.

Preliminary Note on the Western Desert (WD) Languages

The group of languages which has become known in Australian linguistics as 'Western Desert' (WD) is very clearly marked of from all the other languages by certain characteristics. These are a subject for another paper by the same author in the present work as far as more detalled description is concerned, but something needs to be sald about them here to make clear the designations 2.2.2. and 2.2.3. In the present section. They form a whole in that they alone employ as person endings in the singular number sing. 1 -na, sing. 2 - $n$ and sing. $3 \emptyset$. All other languages elther use none at all or have a set of markers of quite different origin. Their vocabulary is that originally designated 'Common Australian' ( $C A)$, in the sense that the highest percentage of $\mathrm{CA}$ words is found in these languages - up to almost $90 \%$ in some of them. It is claimed it was from this region that $C A$ vocabluary moved out south-east, east and south-west - a comparatively small proportion only to the north and north-east, and also to the south-west. Historically these seem to have been the latest developments of language in Australia before European Immigration. Western Desert languages share certain grammatical features which need to be mentioned here: they are 
explained more fully in the other paper. They are divisible into two subgroups on the basis of the behaviour of the verb, and for that reason they are examined in the present setting. The two subdivisions are (1) those that do not mark person in the verb 1tself, but use a 'catalyst' on which the person markers are congregated, and (2) those which add the person markers to the verb stem 1tself. Both, however, have the phenomenon known as 'Affix Transferring' (AT) though each employs it according to its own genius. The nature of this phenomenon and 1ts historical explanation are also included in another paper in this volume, and seeing that it occurs in both, in spite of their structural difference, it would have to be either prior to the division of the WD languages into the two subgroups, or borrowed from one into the other. This question does not concern the present purely descriptive paper, for both subdivisions have the system of auxiliary verbs in common.

It is simpler to take the Catalyst languages first, so that they become 2.2.2, and the other WD type follows as 2.2.3.

\subsubsection{The 'Catalyst' Languages}

These languages are predominantly WD, but are found in parts of eastern Australia - Victoria and New South Wales - as well, to which they seem to have been imported from the WD area. The historical discussion of this claim is featured in the historical paper to which reference has already been made. On the map they appear as 2.2.2. and have been described in outline by Capell (1956/62 and earlier, 1940). The present description will be divided into three area sections: Western Desert and Northern Territory, Victoria and New South Wales.

As described in the earlier account by Capell they were labelled 'Mudbura' type languages because the complication is greatest in this language. They Include

1. Ngard1, about Lew1s' Creek, Northern Territory.

11. Wanayaga, about Tanam1, Northern Territory.

111. DJaru and Nfinin (dialects of one language) with possible addition of Wandfira, to the south of Hall's Creek, Western Australia.

1v. Malngin, Upper Ord River, Western Australia.

v. Ngarinman ( gaRinman), from about Rosewood Station towards Victoria River, Northern Territory.

v1. Mudbura, Wave Hill region, Northern Territory.

v11. Gurindj1 may now be added, east of Mudbura. 
The name 'catalyst' applies to a particle to which markers of person, both subject and - for transitive verbs - objects are added. The particle is monosyllabic, being either ba, na or in 1ts DJaru form nu. It is as a rule meaningless - though there are complications In Mudbura, where a number of particles are used, determined by the tense or mood of the verb. To say ba-na simply means that ' $I$ ' am or do something. It says nothing about time or manner of the action. Th1s 1s made clear in the ending of the verb. A Mudbura example 1s:

$$
\begin{aligned}
& \text { ba-n na-nanari manari ma } \\
& \text { C-you eat-past food? }
\end{aligned}
$$

1.e. have you eaten food? A meaningless, purely functional particle of this kind has therefore been given the name 'catalyst' from 1 ts use in chemistry for a substance which enters into a total reaction and makes it possible, without being affected 1tself.

The 2.2.2. languages are mostly - but not necessar1ly - ergat1ve, and the noun phrase does not enter into the present subject matter; $1 t$ is enough to say that if a cardinal pronoun is used (for emphasis) as well, then 1t precedes the whole phrase and if the phrase is transitive the ergative form will appear, as in Waljb1r1:

$$
\begin{array}{cll}
\text { nadjulu-lu ga-na-ngu wari-ṇi } \\
\text { I-ERG } & \text { C-I-you seek-PRES. }
\end{array}
$$

Here the ergative subject phrase stands outside the construction ent1rely; It is not necessary except to provide emphasis - unless, of course, 1t is a noun subject, when 1 t will appear, but then the $C$ carries no person marker:

$$
\begin{array}{ll}
\text { garga-lu ga-ø-ngu wari-ṇi } \\
\text { man-ERG C-he-you seek-PRES. }
\end{array}
$$

a man is looking for you.

The reason for classing these languages as examples of compound conJugation is that in other parts of Australia the particles - ba especially - occur as bearers of meaning in their own right. This original meaning is in abeyance if not entirely lost in the $C$ languages but it may still influence the particle chosen.

In these languages the princlple of Affix Transference is found in certain cases: negatives and interrogatives tend to remove the person markers from the $C$, eliminate the $C$ and carry the markers as suffixes to the head word of the phrase, e.g. Walfb1r1:

$$
\begin{aligned}
& \text { gula-na-ngu ju-ngu } \\
& \text { not-I-you give-FUT. }
\end{aligned}
$$


I shall not give it to you, or with an interrogative:

$$
\begin{aligned}
& \text { njaRba-la-ngu balga manu } \\
& \text { where-he-you find-PAST? }
\end{aligned}
$$

where did he find you? - balga ma- being a compound verb of the type to be discussed later. AT processes can occur even when the head word carries a case marker of its own. Yulbaridja:

$$
\begin{aligned}
& \text { buli-nga-na dadi-n-ba } \\
& \text { rock-on-I climb-PAST }
\end{aligned}
$$

I climbed on to a rock. Yulbaridja is a 2.2.3. language (not using C constructions) but otherwise works in the same way as 2.2.2.

In most of the $C$ languages, word order is fairly free, and $C$ is not bound immediately to its verb. It may precede or follow it or be disfoined in some other way. DJaru:

$$
\begin{aligned}
& \text { na-ṇa-la nja-nani wuna djadjadji na- } \emptyset \\
& \text { C-I-him see-PAST walk about C-he }
\end{aligned}
$$

I saw him walking about. Again: badai ja-ni na climb go-PAST he, he climbed up, or with extension: na-nalu burungu badai ja-nangu naliwa: C-we early climb go-FUT. we; we shall climb early.

In Mudbura there are complications in the systems, in that while ba is still the basic or indicative particle, there is a form bi for a hypothesis or contingency and $n j a-$ for an emphatic future, and a conditional ba---nja-- with infixed pronouns (Capell 1940:427). Examples of these are: ba-na na-nani manari C-I eat-PAST food, $I$ have eaten food; nja-na juguru C-(fut)-I give-FUT, I shazl give; nja-ṇa-ba ginanguya yali gaRu, ba-ṇa baru-ru If I catch that boy I'll beat him; ba-na-ba wandula, nja-ṇa-ba nja-ngala $I$ would catch him if $I$ saw him. No examples of this complication have been adduced in the other languages.

The mere possession of $\mathrm{C}$ would not qualify these languages to be classed as 'compound confugation' languages, but the examples have been necessary for two reasons (1) because the phenomenon is 1tself different from the situation in other Australian languages, and (2) because they actually do possess compound verbs. The compounding is practically the same as in the languages of 2.2.3. except that in the latter there are no catalysts and the person markers are added directly to the second element of the compound. In 2.2.3. also there are simple verbs as well as compound verbs, and while this is the case also in 2.2.2. languages, in these nelther basic nor auxiliary verb carries the person markers.

The languages of 2.2.2. and the forms of the catalysts are as follows: 


$\begin{array}{ll}\text { Language } & \text { Catalyst(s) } \\ \text { Ngard1 } & \text { nu- } \\ \text { Wanayaga } & \text { n-, nu- } \\ \text { Djaru } & \text { n- } \\ \text { Malngin } & \text { nu- } \\ \text { Ngarinman } & \text { na- } \\ \text { Mudbura } & \text { ba-, nja-, ba...nja... } \\ \text { Gurındj1 } & \text { nu- }\end{array}$

The Walfbirl group of dialects (Including Walmanba) differ from the others in that they have an alternative 2.2.3. type in which the person markers are added directly to the auxiliary verb, ga- to the non-past and ba- to the past, but alternating freely with affixation to the verb stem 1tself, without particle. Walmanba uses ba-but replaces ga-by a-. In Waljbir1, I look for it may be elther wayunu ba-na-la or wayunu-ṇa-la, while Walmanba can say elther wayunu ba-nga-la or wayunu a-na-la for the same phrase. I will look for $i t$ to-morrow is in Walfbirl djugura ga-na-la wayini, In Walmanba djawadi a-ṇa-la waylni (or In the other word order, of course; note also vowel harmony here in the tense changes).

Something must now be sald about the auxiliary verbs that justify the classing of these two subdivisions of WD as 2.2.2. and 2.2.3. respectively. The auxiliarles form a small closed group, and they are historically extremely important for the tracing of linguistic history in Australia, as appeared in the paper referred to several times already. Here 2.2.3. may be introduced first and the two groups treated together subsequently.

\subsubsection{Languages Using Free Auxiliaries}

In a typical language of this group such a structure may be found as see-do-I-shall-I-him = I shall see him; spear throw-FUT-you-us = you will spear us and similar periphrastic arrangements. They differ from those of 2.2.2. In not using a catalyst of the type of C-I-him spear throw-FUT = I shall spear him.

Contrary to the type of the Daly River Family, where all verbs are double, in 2.2.2. some verbs are simple, others double. In all of them simple verbs exist in considerable numbers and in most they are in a great majority. The 2.2.2. languages in general mark tense by suffix, and add a final person suffix, including a second object suffix if the object is a pronoun, giving the pattern $V=R+t+p$,'root followed by tense marker, followed by person marker of both subject and object - 
even in some cases an anticlpatory object'. It 1s, however, possible and this demarcates 2.2.3. as a class - to express by means of an auxiliary a particular shade of meaning or emphasis, e.g. -bu- hit found as free verb, may assume the role of an auxiliary as in Bldjandjadjara gurani do wrong > gura-Ra-bu-nanji do great wrong to. Actually it is not right to conjoin the two roots in speling, as has been done in Bidjandjandjara writing. The -Ra- of guraRa- is the suffix of the sentence medial I form (a type of participle 1mplying that the same actor performs both actions (Trudinger 1943:219).

A transition language appears between 2.2.2. and 2.2.3. In Ngard1 of the Northern Territory, which combines all three confugation types. There 1s the possibility in this language to use

1. direct suffixing of pronouns to a simple verb stem: AT processes with a negative will then produce, e.g. wagura-lu la-ni not-they-two spear-PAST, 1.e. they did not spear;

2. suffixing of pronouns to an auxillary, e.g. dalj ma-ngu-ṇa breaking do-shall-I, 1.e. I shall break;

3. Just a catalyst, e.g. ga-lili djura ja-nani C-they down PAST, 1.e. they descended.

These languages cover the bulk of the Western Desert area, and can be regarded as forming a definite subdivision of Australian languages by themselves. They are not the only languages in which this process occurs, however; there are 1solated groups elsewhere. The Dampler Land languages are contiguous, it is true, but their methods and actual morphemes are quite different, so that they call for separate statement.

Most of the Western Desert 2.2.3. languages are also AT languages. The utterance (or sentence, in this case) consists of a head word to whlch suffixes are added. There are two types, according to whether the head word is the verb stem or not. Two patterns result:

(1) Head word $(H)$ is the verbal stem:

$$
\mathrm{U}=\mathrm{H}+\mathrm{t}+\mathrm{p}_{\mathrm{S}} \pm \mathrm{p}_{\mathrm{O}}
$$

where $t=$ tense marker, $p=$ person marker, elther as subject (s) or object (o).

(2) If $\mathrm{H}$ is a nominal (1ncluding free pronouns, which may be used in such a situation, but the suffixed pronouns must st1ll be added to the verb): 


$$
\mathrm{U}=\left[\mathrm{H}+\mathrm{p}_{\mathrm{S}} \pm \mathrm{p}_{\mathrm{O}}\right]+[\mathrm{V}+\mathrm{t}]
$$

Varlations of detall take place according to the exact nature of $\mathrm{H}$ :

(1) $\mathrm{H}$ is a noun or free pronoun:

$$
\begin{aligned}
& \text { Bidjandjadjara } \frac{\text { Dana-lu-ni bambu-nu? }}{\text { who-ERG-me touch-PAST }} \\
& \text { Who touched me? }
\end{aligned}
$$

(2) $\mathrm{H}$ is a negative:

$$
\text { Waljbir1 gula-na-ngu yu-ngu }
$$

(3) $\mathrm{H}$ is adverbial:

$$
\begin{array}{ll}
\text { Bidjandjadjara } & \frac{n j a: g u-n g u-n \text { bu-nanji? }}{\text { why-8elf-you hit-PRES }} \\
& \text { Why are you hitting yourself? }
\end{array}
$$

These examples are adapted from Capell (1972:5-36) where more detall on the whole subject may be found.

\subsubsection{Western Desert Languages}

Wurm (1972:127) l1sts forty names under 'Western Desert Languages', and these are practically all dialects of one language - differing considerably in vocabulary from area to area but very similar to each other in structure. Also structurally not unlike them is a group of three languages grouped as 'Marngu' - the basic word for man being used as is often done by Australian students to name either a language or a group. These three are Nfangumarda, Garadjari and Mangala. They are sufficiently close to each other to be subsumed under the heading 'Western Desert' for the present purpose. The main features of these WD languages as far as verbal systems are concerned are:

1. A majority of simple verbs to which tense endings are added, followed by subject pronouns and in some also object pronouns, which are not abbreviations of free pronouns. In the paper dealing with the history of Australian languages in this volume, it is suggested that these suffixed pronouns are not related to the free pronouns, but that the latter have been developed from an original suffixed set that provided only for the singular number. In the present paper, however, the synchronic situation is considered: all numbers are provided for, but the non-singular suffixes are bullt up in various ways (Capell 1955:283ff.). In general, dual and plural are present, but some 
languages, such as Bldjandjadjara, do not make full provision for a distinction of inclusive and exclusive in the dual and plural.

2. In a minority of cases, whose number varies from language to language, the verb root remains unchangeable, and confugation is carrled out by means of a set of auxillary verbs, whose number also varies, to which subject and usually object markers are added. Certain elasticity of arrangement is allowed, especially where AT processes occur. In some languages, such verbs are used mainly to provide nuances of meaning (as has been shown already for Bidfandfadfara); In others, the simple stem is either confugated by itself or is not changed at all and auxillarles are used instead. This would rather suggest that the historical development of these systems has been gradual and without uniformity (not from a single centre), but this again is a diachronic matter for which only indirect evidence is available.

The normal patterning in this subgroup is

$$
\mathrm{Vph}=\mathrm{R}+\mathrm{t}+\mathrm{p},
$$

1.e. the verb phrase consists of a root to which tense and person markers are added. In the case of a compound verb, the pattern is

$$
\mathrm{Vph}=\mathrm{R}+[\mathrm{A}+\mathrm{t}+\mathrm{p}]
$$

where $A=$ auxiliary; and again, the order of $R$ and $A$ may change, but that of $t$ and $p$ is fixed.

Example:

Bidjandjadjara baluRu nji-nanji

The child is sitting.

Dana-lu djiduja baladja wadabara-1-gu?
who-ERG dog that chase-LINK-FUT
Who wizl chase that dog?

This is the general usage of all the WD languages, including some of the Waljbiri forms (present tense, optionally). But in Bidfandjadjara and the related dialects it is possible to use auxiliary verbs, of which there are five: bu- hit, marking intensity of action; gadi-continuity of action; ma-do (also say, take); wan- throw, and njin- stative. These roots can all be used as simple verbs as well as serving as auxiliaries. In this latter use, it is unfortunate that the habit of writing them as part of the verbal stem was early adopted; if they are separated out their function becomes clearer: 


$\begin{array}{llll}\text { guraṇl do wrong } & \text { guraRabu- } & \text { do great wrong } \\ \text { baldjuni walk } & \text { baldju! gadi- continue to walk } \\ \text { gulini } & \text { listen } & \text { guliRanjl- be obedient }\end{array}$

There is one feature here that is not shared by most languages: the base verb is participlalised, the ending - Ra being the SM I form - the participle which indicates that the same actor acts in both verbs. These SM forms are themselves rare in Australia, and the Bidjandjadjara usage, more complicated than most, would seem to be a relatively late development. Th1s must not, however, be taken to imply that the whole system is 'late', but only that its use in Bidfandjadjara probably is.

A few fixed auxiliaries in Bidjandjadjara are omitted, such as - (a) ri Inchoative, -gara having, -naRa standing. These are not separable and present a different type that is not germane to the present study.

The only other WD language of this type that can be lllustrated here is Yulbarldja, which has been studied by O'Grady as well as Capell: see O'Grady et al. (1966:150ff.). This language has both simple and compound verbs, and the person endings are typlcal of the languages throughout WD. O'Grady's list of compounding elements (O'Grady et al. 1966:156) contains:

- naRa stand as component of stative verbs: it can also be

a free verb to stand;

-bu hit, which marks transit1vity: wiri-bu-wa throw it!;

-ya go, verbs of movement: galgi yagaya-skulk about;

-nya see, of mental action (cf. English I see!): djala-nja-

forget.

Yulbaridja is an AT language, as the following examples show:

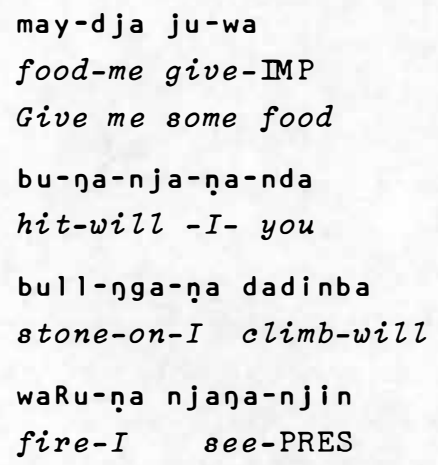


On the northern boundarles of the WD area certain other languages call for mention; these are NJangumarda, Garadjar1, Mangala and Walmadjari.

Nfangumarda shows precisely the same type of structure as those of the WD area as a whole. Concerning the verbal system of this language, O'Grady (1964:66) says: 'verb compounds involve a relatively large number of morphemes as first member, and relatively few as second member.' The morphemes that occur as second member are the following:

1. -ya-go, as a free verb and as the auxillary for motion: wada yanara he went off the road. In this example the verb as spelled in a free form is spelled by O'Grady as a suffix to the main verb; but he says that it can be separated from 1ts referent: yangulumuṇu yuḍgadi wiyara I am going to go fishing.

2. -ga-carry: wada ganyara he took it off the road; gaRir ga-nja-ṇa $I$ slipped.

3. -yi-give ( $\left.\mathrm{CA}{ }^{*} y u-\right)$ : mura yinjanja he cheated me.

4. -yaga- leave, quit: midu yaga-ṇa-ṇa I didn't believe him, 11t. I left faith in him.

5. -baḍi-, meaning not recognised in a free form, only known in a compound: djunara baḍi-ṇi-yalu they encircled him.

6. -gama-call, shout: djuRi gama-la taste it:

7. -badji-bite: djuRi badji-ṇa he tasted it.

8. -Ruwi- hit with a missize: ḍiḍị̣i Ruwi-yiṇi I twisted it.

9. -buri-puzz: dạng̣n buri-li stretch it!

There are further details in the grammar that are not relevant here. What does appear is a large use of auxiliaries to which person markers are added. Unfortunately there is no statement about the category to which the root belongs - 1t apparently is not always. a verb. There are no catalysts in the language and no AT process.

Immediately to the east of NJangumada comes Garadjar1. A grammatical sketch of this language has been given by the present author (Capell 1962:5lff.), from which the following remarks are adapted to clarify the situation. It should be stated, however, that another analysis suggests an appearance of the catalyst ba: reference will be made at the end of the paragraph concerning this matter, which is not certain but a possible interpretation. 
There are three dialects: coastal (Ngadja or Murgud), Ngangu (inland to S.E. of La Grange), and Ngawudu or Baldu, to N.E. near Mangala. These differ considerably, as shown in the lst sg pres of bite: Ngadja badja-ṇa; Ngangu badja-n ba-ṇa; Ngawudu badja-n ba-nan. The point of interest is that two dialects use the catalyst ba- while the third - the farthest west - does not. Examples here are usually eastern, as Capell's work was done mostly with speakers found at Beagle Bay. More recent work done by Fr McKelson is mostly Ngadja, from La Grange Mission. The latter has unfortunately not been published except in xerox form within the Mission itself.

Fr McKelson's work treats all verbs as either single roots or compounds, writing -ba- as part of a single root. He divides verbs into five 'confugations' but does not distinguish the catalyst of the two dialects as a separate element. Nekes and Worms treated ba as come, but this does not seem to be correct; the auxiliary djay-come is the only form with this meaning (Nekes and Worms 1938). Capell's arrangement of auxiliaries treated ba- as come (and this, as stated, is wrong), plus eight others. With adjustment by the omission of ba, the list would now be:

1. -bu-falz: maRu-bu- to dance, as against maRu jin-ba-.

2. -dja-put: galay dja- to finish; jarga dja-conceal.

3. -djay-come: gurga djay-arise; jay djay hunt.

4. -ga-, bina ga-hear; miRa ga- Zook at.

5. ma- do, say: wị̣iri ma- lead; baṇḍi ma-smelz.

6. nja-see, but the meaning implies a homonymous form of which no interpretation is to hand: gundi nja-climb; njaruga nja- Zaugh (Capell 1962:72).

7. wandi-be; jagar wandi float.

The root given as jinba- say has been omitted here; it would break into jin ba- with catalyst. The form in McKelson is regularly indanbaand it forms many compounds, such as garg indanbana .I clear my throat, dinjirb indanbana $I$ sneeze. These in Capell's analysis would be gard jindan ba-ṇa, dinjirb jindan ba-ṇa. Dialect difference appears to lie at the base of this discrepancy, rather than difference of analysis.

Mangala has had effect in the Garadjari area border on the S.E. and something must be said about this language, which lies between Garadjari and Walmadjari (or Wolmeri as 1 t was earlier called). Some material was collected by Capell but remains unpublished; a few notes 
were Included in Nekes and Worms (1938), but the language st1ll awa1ts study in any detall. The language is subject to AT processes: guli-naggu djari angry-I-you become, I'm angry with you; also catalysts are present, as in Rai nana djari I'm afraid; jin ba-nja he speared.

There are both simple and compound verbs; in each case person markers are the same, as also in the nelghbouring languages, e.g. simple: gạ̣idju-ngu-ṇu I shall pinch; jinba-ngu-n you wizl spear him; wiridjangu-na $I$ shall throw it away. Some of the verbs are used both as simple verbs ( $j i n b a$ is one of them) and as compounds (djudu jinbangu-lu he will sing; djari-nja I become; bulga djari-nja I grow big, mature.

The auxiliary verbs evidenced in the material collected include:

1. djari-become (as 1llustrated above); ray nana djari-nja I turn about.

2. bu- strike, hit; djudjud bu-naṇa I spread it out.

3. ga-get, take; garowanj ganana I gather, collect.

4. ma(n)-take; gạ̣i man-na-ṇa I hold; gidar mannana I lead; gawu man-gu-ṇa bani-wura $I$ will call to him.l

A few others are less certain unt1l further analysis is done:

5. yu-give; bo: yu-wa blow it!; muj jin-na-na I move it; juj ji-ngu-ṇu $I$ shall return. ${ }^{2}$

6. Da-, meaning undetermined; wandjan nanana I leave (trs.); gaji-ngu-na budana $I$ wi ll meet (someone).

7. wandu-be; djidanj wandu-lu he is seated; lambu wandu-lu he is asleep.

There are also some doubly compounded verbs: wona-na jan-na $I$ am walking; wona-na janna jab I pass him by. Here also there seems to be an AT effect that is unusual in a compound verb.

One example in the material is intriguing, as it seems to be a Walmadjari formation - which is likely seelng the conditions under which the material was gathered. In the sentence

${ }^{1}$ It would seem that the root ma- do, say, act on, needs to be distinguished from man- take, and there may be confusion in the analysis elsewhere; but in Mangala the distinction seems to be quite clear.

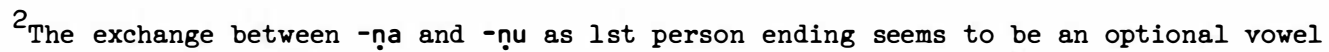
harmony in Mangala. 


\section{$\frac{\text { badja-ni ba-dja gambuRa-lu }}{\text { bite-PAST it-me a flea-ERG }}$}

a flea bit me; the ba is a Walmadjar1 3rd sg. subject marker, and -dja or -dju is a not uncommon WD lst sg. object marker.

Walmadjari, spoken about Fitzroy Crossing, has been studied of recent years chiefly by Joyce Hudson of the Summer Institute of Linguistics, who read a paper on the verbal auxiliarles at the May meeting of the Australian Institute of Aboriginal Studies in Canberra in 1974. Some notes from her as yet unpublished paper make the structure of the language plain. There are some differences in the principles involved. The author states (1976:653) that 'one of the functions of the verbal auxiliary in Walmadjari is to indicate the mood of the sentence... Mood is shown in the verbal auxiliary but morphemes in the verb also play a part... Stems may be simple or compound and are divided into five conjugation classes. There are many compound verb stems and in present data less than 10\% are simple stems (monomorphic).' Again, some auxiliaries can also serve as simple stems, such as bu-ngu mana I shall hit it.

The elements listed by Hudson for Walmadjari are nine in number, mostly those found elsewhere, a few rather unusual. They are:

(1) badjar-bite, chopping, which seems to link somehow with the Australian root bad(j)a bite; (2) bu- strike, hit; (3) djari-become; (4) gar-, undefined; (5) gudji cause; (6) jan-motion; (7) man-do distinguishable from (8) manj-say; (9) wandi-be. Only the less usual will be 11 lustrated here.

Number 1, badjar-biting, chopping, is a simple verb, but compounds as in djun-badjar- to chop: djunbadjar-gu mana mana $I$ wizl chop the tree; gar-does not seem to occur alone, and Hudson says of 1 t 'meaning undefined'; Rugu-gar-gu mana gi!iniri $I$ will block the hole; the rest are falrly parallel to those of other languages.

The person marker mana is of interest - and difficulty. The suffix -na is the lst sg. sign; the root is then ma-. Th1s would look like the auxiliary ma do, cause, but Hudson says that the root is ba- of which the initial becomes $m$ - when the marker following begins with a nasal. The paradigm in the singular would then be: ma-na, ma-n baø. Her examples seem to bear this out. The root is then ba-, which is an early Australian pronoun for 3 rd sg. he, she, it. At the same time there is the catalyst ba already noticed in 2.2.2. Can 1t be that this catalyst is ba-, a pronoun, later degraded? Again, there is a Walmadjarl catalyst na- which occurs 'In interrogative and implied admonitive mood' (Hudson 1976:9). In cases where ba-would occur alone 
It is usually in conversation omitted altogether, but this cannot be done when na- would be used: he...him... becomes nada; contrast nanbayi!u bari-ø binja the man hit the boy and nanbayi nada giranana nura-na is the man sitting in the camp? To the present writer it seems better to suggest that ma- is primary and that ma-na is therefore basic, babeing a substitute 3rd person pronoun within a suppletive system. This, of course, cannot be proved but, as requiring less morphological adaptation or morphological change, is simpler.

\subsubsection{North-east Arnhem Land}

In deciding whether auxiliaries are free or bound it is desirable to use the stress pattern of a language as a criterion. Platt (1974) has so used the inftial stress of Bidjandjadjara: 'It seems appropriate to consider such compound verbs as single lexical items, unless the stress occurs on two or more lexical 1tems as 1t does with some compound verbal groups.' This is what has actually been done in the preceding pages. The WD languages therefore have a majority of compound verbs.

In the so-called Yulngu or Murngin languages of north-east Arnhem Land (NEAL) it is not possible to separate compounding elements out in the way it has been in some of the WD languages. In the course of the preceding study it has been possible to suggest that certain of the languages combine elther catalyst systems or free auxiliary systems. Waljbirl and some of 1ts nelghbours belong to this set. The same thing will appear below in some of the New South Wales languages, where a verb obviously is compounded, but the second element of the compound cannot be isolated within the language, and frequently the base or stem cannot be used alone. Th1s is the basis on wh1ch 2.2.3.2. languages are isolated.

The Yulngu or Murngin languages form one such set. These languages number about forty, and no full study of them has yet appeared. Introductory notes were given by Capell (1940:40ff.), but Schebeck has lengthened the list in papers not fully published since then. These languages contrast with those of the rest of Arnhem Land in that they are suffixing, not prefixing, and have no noun classes. In vocabulary they seem to be offshoots of WD or CA languages, rather than members of the largely unclassifled AL languages as a whole. Between these and the Yulngu languages lie DJinang and DJinba, which are catalyst languages of a somewhat peculiar type, not here treated.

In most of the Yulngu languages, it is difficult to regard the compounding elements as auxiliarles in the sense used above, because 
they do not occur independently as morphemes. When New South Wales is reached it is simply a matter of base + bound morphemes: the morphemes do not occur apart from the base and 1t is only by comparison with other languages that the original semantic independence of the morpheme can be recognised - in fact some cannot be recognised at all.

While there is a general pattern in the Yulngu languages, there is much difference in detall between them. Gubabwiyngu is used as the model because there is most material available in that form of the NEAL languages. The others seem to follow precisely similar patterns.

In Gubabwiyngu it is not easy to decide whether a system of compound confugation is coexistent with one in which bound morphemes occur. It is possible to use certain roots as elements in compounding: CA *bu hit is found in dar bu-ma stab, pierce, where the initial element is apparently to be linked with darba wood, tree. There seems to be no regular system of compounding in the sense with which this paper is concerned, so that it has seemed better to include these languages amongst those having only bound morphemes as the basis of confugation systems. There are certain cases here where some disagreement is possible: the problem might be solved by comparison with other Yulngu dialects, for which the present materials are inadequate. One of these is -maRa-ma, a transitivising suffix. The final -ma appears to be the root *ma, leaving -maRa-, and it is tempting to identify this with CA $*_{m a R a(\eta)}$ hand. The Gubabwiyngu verb take, however, is mara-ma, with a flapped $-r-$. It may still be the same root, with a locally developed distinction of the rhotic consonant, and the addition of the verb class marker -ma, one of nine such markers. The transitivising value of the suffix appears in such contrasts as:

$\begin{array}{lll} & \text { Intransitive } & \text { Transitive } \\ \text { turn over } & \text { bii-yu-n } & \text { bil-maRa-ma } \\ \text { wake up } & \text { binga?yu-n } & \text { binga?-maRa-ma }\end{array}$

Some longer series can be found, such as:

$\begin{array}{ll}\text { slow } & \text { bulna } \\ \text { slow down } & \text { bulna?yu-n } \\ \text { make slow } & \text { bulna-gu-ma } \\ \text { slacken } & \text { bulna-maRa-ma }\end{array}$

In some cases the transitive suffix is added not directly to the stem but to what Miss B. Lowe has called the 'short quaternary form' of the 
verb: dinga-ma die > dinga-na-maRa-ma kizl. The quaternary forms, amongst other values, have that of indicating a purpose, so that the suffix - *naRa-, -na- Indicates purpose and is strengthened by the genitive ending - wa, producing a long form -naRa-wa and a short form -na, to which -maRa-ma is superadded, make to.... There is also another causative, added to the dative ending -gu to form -gu-ma. This form is usually applied to adjectival stems: Ragunj dead > Ragunj-gu-ma kill, lit. die-for-make (cause). There are also numbers of morphophonemic changes which act within the groups listed, and the groups themselves are not here listed in full. The total result is a grammatically complicated language, and the chlef impression is that of a language confugating by one system which is not compounding, but based on the use of bound morphemes of various kinds.

If it is possible to regard the -ga- as the auxiliary *ga take, with the -ma of the 'primary grade' added, then we are left with a transitiviser -du-/-yu whose forms are morphophonemically determined: d after stop or nasal, $y$ after liquid $w$ or another $y$, in each case plus the vowel u: -yu-, -du- etc. according to grade. Semantically, however, the problem is not solved, as verbs with one of these forms may be elther transitive or intransitive: -maRa-ma is always transitive. It may be that -ma is simply a marker of type of conjugation, in which situation -maRa- must be regarded as the basic transitiviser, and $-d-/-y-$ as only a verbaliser. This raises a further theoretical question as to why adjectives should have a special verbaliser based on *gu-ma in order to, as already indicated.

In spite of these uncertainties, the Murngin or Yulngu languages seem as a whole to bridge the gap between languages that definitely use bound auxillarles (as has already appeared in the WD languages) and those in which the original auxillaries have lost all independence and been reduced to confugation mechanisms, as appears in the following section of the paper, 2.2.4., to which a transition may now be made. At the same time, however, we shall meet at least one language in the extreme south of the continent that uses $\{-y u-\}$ as a verbaliser: Murund1, for wh1ch see 3.2.1. below.

\subsubsection{Bases with Bound Morphemes}

The languages to be dealt with here use some of the same auxillarles as are found in the other groups, but they are no longer recognised auxiliaries occurring in their own rights as lexical elements. It has already appeared in 2.2.3. that the recognition of auxiliaries as 
free elements was diminishing as one came eastwards and southwards. In New South Wales and the south-east of Queensland, so far as compounding occurs at all, there is a use rather of 'formatives' than 'auxiliaries'. It is recognised that 'formatives' is an ambiguous and unsatisfactory word: any element that goes to form a word is a 'formative' in a general sense. What is meant here is that an element which can be analysed in another language and assigned a basic meaning as a morpheme, now occurs without such status simply as a means of forming a verb from a noun, or some other similar process. This is particularly the case of $g a$ and ma, which hitherto have definitely been indicators of causality, and still farther west, directionals as well as means of expressing transitivity. In New South Wales, however, they are generalised and help to form verbs from other parts of speech without any very clear indication of a basic direction of the action, or anything that would give them clear lexical value.

The languages concerned are found along the east coast of New South Wales in the main: from roughly the region of present-day Brisbane southwards, and nearly all on the coastal side of the Dividing Range. The large group of Bandfalong dialects will be treated first, then a gradual move southward will bring in a review of Gumbainggar, Dhanggadi, Gadhang, Awaba, Guringgay, Iyora, Dharawal, Dhurga, and so towards eastern Victoria. In the inland languages there is less certainty about 1dentification of the type. In Gamilaray, for instance, ga- take is a lexical 1tem in 1ts own right; the past tense is ga-ne and the 'today' past is ka-je but the vocabularies do not seem to suggest that it helps to form compound verbs of any kind. Some attention will be given to the interior languages of New South Wales and Queensland at the end of this section, but in any case there is insufficient information in many of the languages that might be concerned.

One of the main points of interest is a possible answer to the question: seeing that these formatives do occur in the east of Australia in this way, but, so to speak, not in their prime form, how far can such generalised uses of originally free 'words' as 'formatives' be diagnostic of the historical position of the languages in which they occur? The elements used seem to be all WD morphemes, and in the WD languages they lead an independent existence which is at least much curtailed in the far east of the continent.

Varlous uses of ga- and ma- In the reduced forms of suffixes to a root, not necessarily verbal, are found right from the Brisbane area southwards, unt1l Sydney is reached, when ma- changes 1ts character and becomes a confugational element with the verb stem, marking a 
tense. No exhaustive exploration of these changes can be undertaken here, but examples will be given from the varlous languages in which the particles or suffixes are found. In Durubul (Ridley 1875:77-98) no explicit statements are made regarding ma-, but a number of examples are given both in the vocabulary and in translated Biblical texts (which are not well done, but clear enough to show the structures implied in most cases). A common past tense ending in the language seems to be $-r i$, as yuga:ri made: 1t would seem, then, that the translator whose work Ridley reproduced meant by the ending -murri, a past tense -mari < -ma, the -ur indicating a short a followed by a flapped $r$, as often in the earlier writings in Australian languages. Examples then are given in Ridley's spelling and an attempted phonemicisation, as follows:

\subsubsection{Durubul (Djandawal, Yagarabal, etc.)}

1. ba-become: this is an extra morpheme not found in all the New South Wales languages but common in Ridley's material for this language:

bayim ba- to be sick; murumba bayi he will be (come) good; mil bulbu alive > mil bulbu ba-become alive, arise from the dead; nayi name > nayi ba- to name; num-ba-yi shining; guruga ba- to throng a person; dul ba- to sit up, come to a sitting position.

2. ga- seems to be a transitiviser, not so definite as main 1 ts uses, in fact the difference between the two is not always clear:

yu ga- make (if this is a true compound; the material is insufficient in that *yu does not occur, but mostly yugari made; bul ga-bring (but bul-ga-yi is often come); gun ga-cry out (fetch a cry?); gal ga-cut.

3. ma-, transitiviser, also independent verb ma-ni seized; cf. also maRa hand:

gali ma-punish; bugan sleep > bugan ma-put to sleep; bulgan ma- raise up (cf. bul above; the compound bul ga with a final $-n$ is not clear); gungi:r ma kizl; wu:n ma- lay (in a position); bun ma-separate, pluck up (as flower), draw out; dulupundu ma- to close up; juru ma- hide oneself (make shade for oneself? < juru shade). 
This is a language in which yan go is confugated with ma so that yan ma-walk, go. The same is true of Gabigabl and other nelghbouring languages. It will appear that in Iyora (Sydney) ma-becomes a simple tense marker, and ba- becomes another tense marker). There are unclear cases in the texts, e.g. yungar murumba yuggali is translated they cannot make welz; this should apparently be yungar marumba yuga-li not well make-ga-they. Another serles is : dayi-na he lay (sick); dayi ma-ri lay (something on the ground); dayi duna he lay, ingungi:r dayiduna he lay dead); the root duna as a single word means weep, EA *dunga. The above notes, however, make the salient features of this part of Australia clear; some comparisons might also be made with Gab1gab1 and Waga.

\subsubsection{Bandjalong Dialects}

Of these dialects, bridging the New South Wales-Queensland border, there are nine, listed in another paper in this volume. The chief dialect used here is Gidabal, after Geytenbeek and Geytenbeek (1971), with references to Yugumbir (Cunningham 1969).

According to the former authors some auxiliarles still exist in the various forms, but there is evidence that they are not securely established in the language. Thus, 'most nouns that refer to no1ses may be verbalised with the verb root ba- say; nur ba- growl; yare: n bascream; buru: 0 ba- snore, etc.' The authors add: 'a few other combinations have been recorded involving nouns and verbs, e.g. bu:n gawaroll up (as blanket), l1t. coil-break; girur gaware-slip, l1t. smoothrun. With adjectival phrases ma- is the verbaliser: bugal ma- to do something well; daram ma- to dry something; yingam ma- to make angry' (Geytenbeek and Geytenbeek 1971:40). Further about ma- (p. 23) we read: 'It also conveys a causative meaning when verbalising the nominalised forms of the irregular verbs of Groups A and B. A verb root ma- following a locational phrase means put.' The mention of 'nominalised form' w1ll prove important when Dharawal is discussed, because all roots there involving ma- are nominalised (by means of - 1 ) and it will appear that this -1 is a EA nominaliser frequently combined with the purposive *-gu to form-l-gu 'future action'. Dharawal bul ma-i-a he hit him (from *bu, hit is exactly of this pattern). In Gidabal, ga: ga is bring, from the *ga root, but with a compounding element. On the other hand, such verbs as galga-cut look like gal gaand do fit the pattern found in Durubul (above), though not recognised as compounds by the Geytenbeeks. 
For the Yugumbe: or Yugumbir dialect, Cunningham (1969:88) says: 'Some of the adjectives in the data took various verbalising affixes converting them to verb roots, which could then take normal verbal affixation.... Suffix ma- could be assigned the meaning causative, and may be suffixed to nouns also.' Amongst her second order suffixes are -ba, -ga, -ma, -gira and -i.

\subsubsection{Gumbainggar}

This language impinges on Bandfalong to the south and continues as far south as Nambucca Heads and inland to the Dividing Range. The information is drawn from W.E. Smythe (1948). Unfortunately, Smythe's methods of spelling introduce some complications, especially his use of the diphthongs -ai-, -ei and his habit of working with an 'infinitive' -eigu as a base form of the verb, under the Influence of English grammar. The form seems to be -ay-gu with phonetic fluctuation to -ey-gu, and quite a number of adjustments of his spelling are needed here, so that the relationships may be plainer. A form such as bindaimeigu throw is much plainer if taken as binday may+gu: from which 1t would appear that *ma- in this language becomes -mar. These forms are therefore used in what follows, but 1 must be borne in mind that they are interpretations of Smythe's actual spellings.

After dealing with simple forms of the verb, Smythe has a section (pp. 45-6) on 'modifled forms', and these seem to be the compounds that Gumbainggar has to offer in comparison with the more northerly and for that matter, more southerly - languages, taking as his base (-ei, -i:, ai, i)gu ( $1, e$, in the present spelling - ey, -i y, - ay, - i $+g u)$, he gives:

$$
\text { - }\left(e^{y},-i^{y}\right) g u r e^{y} g u \text { causative or permissive }
$$

and with 'a few verbs' variants replacing - gurey by -mber- or -nder-, -(i):baiji:gu desire to, -(e)rev- 'reciprocal'; -(i)lev- 'action by carrying'; and $-(a, a:)$ rev- 'action in a direction away from some point' (Smythe 1948:45-6). On page 45 also he says: 'In this way the verb behaves very much as though 1t were composed of two parts - an invarlable, or more or less invariable stem, and a serles of attached terminal elements which undergo the various modifications...' This, of course, is what he should have done, and it would then seem that the elements concerned are: ay-be become; -gura-cause or permission (rather like Yugumbir-gira), causatives also mba-, nda-, bayi want to, lay-carrying; ray- 'action away from speaker', which would then be treated in writing as separate words. Actually there are other forms 
not listed in the grammar but found in the vocabulary, e.g. the series:

$$
\begin{aligned}
\text { ju:ıgu bad } & >\mathrm{ju} \text { :ngu mbay-make bad } \\
& >\mathrm{ju} \text { :ıgu way- become bad }
\end{aligned}
$$

The last may well be equivalent to Durubul ba-mentioned above. He does exemplify modern verbs adopted from English (p. 57), such as lo:nimbeigu to Zearn; njoinjimbeigu to know; gi:bimbeigu to keep; bailimbeigu to boiz. There 1 s also here wara:li sorry > wara:li warbecome sorry; and daruwi good > daruwi ay-become good seems to be a variant of this same marker. The ma-form appears in jul may-tell a lie, with what seems to be a phonetic variant in jurun dav- lengthen. This language also has a long serles of prefixes which indicate direction of action, but these are outside the present essay. The English loans referred to above Include lo:ni mby- Zearn; njoinji mbay-know; gi:bi mbay-keep and baili mbay-boiz.

Although the formations are far from clear and really need reexamination (largely thanks to the author's unsatisfactory spellings), it is quite clear that much the same set of compounding elements is found in Gumba1nggar as in the more northerly languages.

\subsubsection{Dhanggadi and Gadhang}

These two languages cover the area from Nambucca Heads to Newcastle and 1ts neighbourhood. The information here rests on the work of Holmer (1966, 1967). In these two languages the whole structure seems to be simpler than in the northern languages, and contrasts with the far more complicated structures of Awaba and Guringgay to the south of Newcastle.

These languages have the ga- and ma- auxiliarles in common, although of course the shapes assumed in the conjugation of them vary. The presence of more than these two auxiliaries seems doubtful and Holmer had difficulty with further analysis. While Holmer's account is not entirely clear, it will supply enough information for the present need. In Holmer (1966:43-4) he writes: 'The verbal derivatives (-ba, -ma or -mba-, -nda, -nja-, -ra-, -baja-, -buja-, -windi- or -windji-) have a more vague function than the above nominal suffixes, but usually they form causative verbs. Th1s, at least, is true of the Dhanggadi $-n j a-$ (also-njara-, that $1 s-n j a-p l u s-r a-$ ), as in: mananja-make go (from $\mathrm{T}$ mana-go), $\mathrm{T}$ bajanja- let go out (from $\mathrm{T}$ baja(ja)-go out), $\mathrm{T}$ balajanja- (bala.nja-) make jump (from $T$ balaja-jump)... Some of these formatives are originally independent verb stems; especially the suffix -windi-(as in T bukawindi-kill, from buka dead) is no doubt 
the same as the verb T winda- (windja-), windjița-do, make, go (about), etc.; - ma- may be connected with the verb stem ma--get, take, etc. (usually expressing action by hand... As for -baja-, it is formally 1dentical with the Dhanggadi verb stem baja(ja)-get out, etc.; cf. T wutubaja-grow up (from T wutu-big).' He goes on to mention -buja, as in maRupbuja feel good < maRun good and mundurbuja to sme $z$ < mundur a smelz. He also mentions, what has appeared in other languages, that the formatives may be combined, and instances for Dhanggadi-nja-ra and ba-ra to extinguish a fire is elther badi-ba, badi-ba-ja or badiba-ra. He finds one instance of the -nda (listed for Gumbainggar) in juwanda-put, leave, but is unable to analyse 1 t.

The formative ga- is shared by both languages, and may combine with noun stems or follow verb stems. The general meaning, Holmer says, is be or become, and this is somewhat different from 1ts uses in other areas - a loss of force, actually. Gadhang garwanga gagil it is becoming fine; baga ga-nji will become mad. W1th nouns he gives Dhanggad1 dimbunj $g$-in became a ghost; junmar g-in it became night. Gadhang dalga ga-njila it became hot; banma gaga keep quiet.

\subsubsection{Awaba and Guringgay}

These two languages were probably dialects of each other, Awaba had 1ts centre about Lake Macquarle and probably extended as far as presentday Newcastle. It is the theme of L.E. Threlkeld's writings now best known through Fraser's edition of the major part of them (Threlkeld, ed. Fraser 1892, but see also Gunson 1974). The Guringgay dialect was also investigated by Threlkeld, but all that remains is a lengthy manuscript in the Mitchell Library, Sydney, which has never been published, but has been noticed by Capell (Capell 1972). The exact relationship between this and Awaba has yet to be made out; there is considerable difference in vocabulary, as is usual in Australia even when geographical distance is small. The grammatical structure in each case is practically the same. The real gulf is between this northern language and the Iyora and Dharug of Sydney district, where similar linguistic elements are used in a rather different way. At the present moment, of course, only the verbal structure is under discussion.

Some study in this was made by Capell (1956-62; especially pp. 6970 of the latter edition), but one correction has to be made to a statement on $p .70$ of the earlier work, and this will be included below. The Awaba verb is extraordinarily complicated as compared with that of the languages to the north which have just been discussed, and 
Threlkeld's explanations are not always easy to follow: his analysis seems to be too thorough, in fact, and to be reduced to meanings of individual phonemes in a way that even Fraser rejected - and rightly so (Threlkeld, ed. Fraser 1892:94).

None of the analyses so far published of Awaba formatives is really clear - whether Threlkeld's or Müller's (Müller 1876), based on these. Nelther, for that matter, was Capell's (1956-62). The root trouble seems to be the involved nature of Threlkeld's explanations, based on a theory of phono-semantics (Threlkeld 1850). Capell stated that there are four indicators which serve to show types of verbal action, v1z. ba, ga, ma and na. The first three are right and will be explored here; the fourth seems to be ruled out by closer study: 1t does do so, but only with certain interrogatives. It is 1tself the stem of nanwho and is used in only a few situations which Threlkeld 1llustrates. In other words, $n a-1$ a pronominal base rather than a verbal marker. This perhaps does not invalidate the connection suggested by Capell between this ga and the homonymic catalyst of the WD languages.

The remaining three hold good, however, and they are used very much as in the other New South Wales languages dealt with already. It seems safe to retain the analyses given by Capell in the earlier work:

$\begin{array}{ll}\text { ba } & \text { action as such } \\ \text { ga } & \text { being as such } \\ \text { ma } & \text { transitivity }\end{array}$

the last including causativity, 1.e. transitivity of an intransitive base. These formatives occur in sundry forms, and ma is the formative mostly found in the formation of transitives. Thus, starting from the base bidal glad, it is possible to form:

bidal ga- be glad: bidal ba-n ga-dan I am glad
bidal ma- make glad: bidal ma-n bon ba-n I make him glad The ba- formative is the basis of personal action, and the person markers in the singular number are added to 1 , as in ba-n $I$ (do). 1

The system, however, is not nearly so simple as these examples suggest. Some verbs use almost entirely a given formative as, so to speak, part of themselves: be: I ma- to mock is not found without the ma-. It would moreover seem that in this language the basic forms

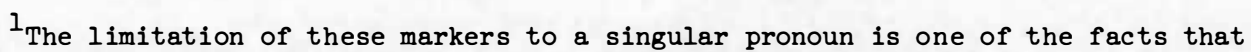
suggests that Australian pronouns provided originally only for singular pronouns dual, trial and plural are all later, composite formations. This is treated in the longer paper already referred to. 
carry a final - $n$ in many instances where this is not part of the original root: *bu hit becomes in the present tense bu-n-dan; mabecomes ma-n in, e.g. ga-ma-n-bin bon ba-n $I$ allow (ma-n) him to be (ga-).

Moreover, the nominalising or gerundial -1 (which is really $* 1$ in EA) plays an important part in Gadhang, Awaba and Dharawal, as well as in other parts of Australia. Th1s, again, is not a subject for discussion here. It sometimes appears with ma-, e.g. nagoya deception $>$ nagoy ma-li-gu in order to deceive, which the writer is inclined to analyse as nagoy + ma(1) + gu deception making-for.

At the same time, not all Awaba verbs are compounded; there are also simple verbs: wiya say > wiya-n ba-n say-PRES ba-I, where basimply serves to show personal action of the type indicated by the root wiya saying. The root *bu gives bu-n-da-n bon ba-n strike-PRES him actor-I. The auxiliaries can be used also by themselves, often in composition with each other: ga-dan ba-n $I$ am, 11t. be-PRES actor-I.

There are also other 'slde' developments of some auxiliaries in Awaba, especially in the uses of ma-. This becomes a 'permissive' in many instances, e.g.

$$
\begin{aligned}
& \text { bu-ma-n- bila bi dia bon } \\
& \text { hit-aZZow IMPERT. you me him }
\end{aligned}
$$

allow me to hit him!

The intransitive marker $g a-$ be can also be used in compounds, e.g. bolo:n ga- set of the sun: bunul bolo:n ga-dan the sun is setting. This also appears to be part of the noun formant seen in wiya speak > wiya-li-gani word, that which is spoken.

The Guringgay forms have not yet been analysed. The sole source of this dialect of Awaba is a manuscript by Threlkeld held in the Mitchell Library and not yet published (see Threlkeld, ed. Fraser 1892). Most of the grammatical forms are 1dentical with those of Awaba, except that ba-nun $I$ do it to you always appears as ba-nu - and it does not look like a mistake on the part of the recorder. As in Awaba, the structure of the VP is

$$
\begin{aligned}
& \mathrm{VP}=\mathrm{V}+\text { tense etc. }+ \text { pronoun }(\mathrm{s}) \text {, e.g. Durun-ala bi? } \\
& \text { here-did you? As in Awaba ba }+y i>b i . l
\end{aligned}
$$

\footnotetext{
${ }^{1}$ As the pronoun you in Awaba is nin-du-wa, and the possessive ni-ro-wumba, it would not be logical to posit ba $+y i$, as here is done, but for the fact that the same recorder (Threlkeld) in his Guringgay manuscript writes your as yiroumba, i.e. yi-ro-wumba < yl rotwun+ba. So it seems that the northern Awaba may have changed an initial $D$ into $y$ in this instance.
} 
The first person form is gurun-ala ba-n as in Awaba. Note that as in the Catalyst languages, tense is marked in the verb, not in the person signs in both Awaba and Guringgay. There is a difference also in the desiderative form: wiya-d-ul ba-nu $I$ want to talk to you (Guringgay) as against Awaba wiya-n-uwil ba-nuwur.

\subsubsection{The Sydney Area}

The area covered by the Awaba dialect group finishes at the northern shore of Sydney Harbour. The language of the Sydney area has no known native name, but has been called Iyora (Iora) after the local word for people, and this is serviceable as a designation. To the immediate west of this, and reaching to the Blue Mountains - definite boundarles again are unknown - was the language recorded by R.H. Mathews (Mathews 1901) as 'Dharruk' (Dharug in the present spelling). This apparently reached to the southern bank of the Hawkesbury River; on the other side, stretching north-westwards, came the related Darginfung language. These seem all to have formed one subgroup by themselves, and are quite distinct from the Awaba group to the north and Dharawal south of Botany Bay. Gandangara, according to Mathews, was hardly more than dialectally different from Dharug.

Information on all these languages is insufficlent for any real analysis of them, and the grammar reputedly written by Lieut. W. Dawes of the Sydney speech has come to light only since about 1970, and no analysis of 1 t has been published yet. ${ }^{1}$ Even Dawes did not give a name for the language, so that Iyora is retalned here.

In these languages there are traces of the auxiliarles found in Awaba and northwards, but their uses are quite different. They now function not as auxiliaries at all, but simply as tense markers, and Capell finds that $1 \mathrm{t}$ is easiest and clearest to treat the Iyora verb as a simple root, conjugated by a separate particle variable for tense, as In English I do come, I did come - I shall come then using a different particle. In Iyora, three separate particles are used for the three simple tenses: one of these is $d j a-$ (which has not appeared in the other languages), and the other two ba and ma. The two latter are future markers, $d j a-$ marks a past, whlle the present (probably an aorist) is marked by change of person endings.

Dawes' manuscript is not perfectly clear as to distinction between ba and ma, so that it seems best at this stage of the study to give simply a few examples of verbs as set out by him. It is worth noting

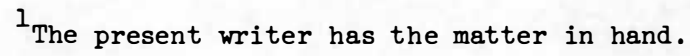


that he is the only writer to supply non-singular verbs, and his account of dual and apparently trial number, is not entirely clear.

However, with Dawes' material, our knowledge of Iyora is now greater than our knowledge of Dharug, especially in regard to the verbal system, for of that Mathews only says that it is similar to Dharawal (which is not true) and that lack of space prevents him from giving examples. His manuscript notes in an exercise book give a better reason than that for omitting 1t. His word list in Dharug is much better than his grammar. In Dharug, and apparently in Iyora as well, the formatives discussed for the more northerly languages do appear and do function, but as consistently as in the north. It may be that the formatives used for tense formations in Iyora and that auxiliaries are accidentally homonyms, but that is inherently unlikely. Before the matter is examined it is best to give some conjugation forms from Iyora according to Dawes' manuscript. It should be remarked first that he does not allow for the distinction of inclusiveexclusive and gives simply 'lst person plural', the ending for which is -jun, but occasional examples of a final -na which looks to be exclusive are found by another writer whose work Dawes included with his own - the two handwritings are quite different. Thus, for Dawes' na: djapun we saw, the second writer has na: djanna: one must suppose therefore that the language - which is an ergative language with AT processes - does make provision for both forms: only the one will be given here because it is Dawes' own writing that is being used.

In Dawes' exposition, the present tense seems to be really an aorist, and is rarely given. For the verb see he has gaya na: only. ${ }^{1}$ The other two tenses given by Dawes are:

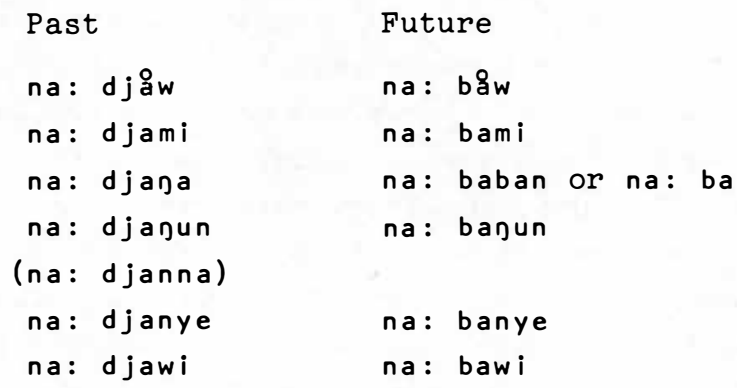

In these examples, it is easy to see that ba has been reduced to a formative, as stated above; after a nasal ending ma- is apparently a ${ }^{1}$ Some other writers use na: instead of na:- for see, and it is of course impossible now to decide; either could be right. The velar nasal form occurs in the second writer in Dawes' manuscript. 
morphophonemic change for 1t: yan ma I shall go, etc.

However, the form ba is also used as a copula in some sentences given by the second writer in the manuscript: $m i$ bo djara? What is its name?, answer: Djegomarani djara ban Its name is Djegomorani. The ending - djapa often given with verbs in 3rd sg. past, looks like an error: bay djana he beat should undoubtedly be he beat me.

For Dharug the documentation is unsatisfactory. In some of Mathews' examples the verb is not marked for person at all, but does carry the -ma suffix, as in

$\begin{array}{ll}\text { naja badi ma } & I \text { eat } \\ \text { njindi badi ma you eat } \\ \text { nanu badi ma he eats } \\ \text { gali badi ma you and I eat }\end{array}$

In others, there is change of final vowel for the persons at least of the singular:

$$
\begin{array}{ll}
\text { naja naliwa-du } & I \text { am sitting } \\
\text { njindi nalawa-di } & \text { you are sitting } \\
\text { nanu galiwa-d } & \text { he is sitting }
\end{array}
$$

In the future tense, -ba becomes the suffix in the following examples: maraga nalaway-bi nali perhaps we two eat, 1.e. let us two eat.

This is also rendered nali-dja nalaway bi, the pronoun being in the ergative case for no obvious reason. The 3 rd person singular remains constant, as in nalawad nunbi she, its. On the amount of information in Mathews' notebooks (material which he never published), it seems impossible to go further.

To pass now to the occurrence of compound verbs in both Dharug and Iyora, many examples occur in both the languages and the two do not always agree in the formation. There are instances in which the Dharug vocabulary of Mathews (1901:157-60) shows a verb ending in ma where the Iyora lists give it without ma and Dawes' confugations show ba (or morphophonemically ma) or $d j a$ as tense markers. Thus: Iyora wida, Dharug wadama drink; Iyora wad ma swim, Dharug wari-na, whlch seems to have a different ending, reminiscent of Awaba -na; Iyora bada, Dharug bada maeat. The -ga ending seems rarer, and in the present state of knowledge it cannot be defined as holding the same position as in Awaba, the words ending in -ga, in the vocabulary do, however, seem to be all intransitive, as Iyora yil-ga Zeap, Dharug gari-ga; but for Zaugh the 
languages disagree slightly: Iyora djanl-bl, Dharug djan-di-ga; Dharug stand (Iyora not given); dunga weep in both languages, is monomorphemic, but there is woin-ga whistle (Dharug) wogawina (Iyora). Tense formation here seems to be involved in Dharug wangi-d, (Dharug) pretend as 3rd sg. of the -ga verb, cf. ma:ni-d takes.

The few examples in Ridley (1875:101) of sentences in the Gwiyagal (George's River) dialect of Iyora (see Capell 1972:25-7) do show a similar structure but they are too sparse for it to be clear. They include: bun-ma kill, man-ma take! This dialect however seems to have a different method of person marking if the analysis of bindwagun I'll give you as bln-dwa-gun give-I-you is right and wuni-djeru-n-bi want-you-PRES, you want bears it out.

\subsubsection{South Coast of New South Wales}

Most of these languages are no longer in use and it is difficult to distinguish boundaries. Examples will be taken here only from Dharawal and Dhurga, which are fairly closely related. They have been studied by Diana Eades (1976). These languages are rather more difficult to analyse than those north of Botany Bay, largely because the material is inadequate and inconsistent. This fact is well brought out by Eades. She, however, has denied entirely that these languages use auxiliaries at all. It is true that so far as the material goes they do not use them as free formatives, such that different auxiliaries can be used with one root, and she denies the present writer's claims that they can be found at all in the languages. The author, nevertheless st1ll feels that this is wrong, and based perhaps in too great a caution in analysing what must be admitted to be faulty material. In both the languages she takes the verbal stem as ending in a consonant and the person markers as beginning with a vowel (Eades 1976:54ff.). Hence Dharawal bulm-aya he struck as against Capell's bu-l ma-y-a. She states that the appended -1 on the root *bu strike is unexplained. She speaks of 'the unexplained link -1 '. However, the link can be explained; it is the gerund-forming -1 that can be assigned to $\mathrm{EA}$ as $*-1$. It is frequent especially in WD languages in a future formed as -1-gu. She is equally sceptical of R.H. Mathews'-gay, as a formant for intransitive verbs derived from adjectives, which the present writer takes as the auxiliary ga already found in the more northerly languages, and as EA *ga of carrying. There is a difficulty in explaining the final consonant, but the usage is so similar to that of other languages that the two can almost certainly be identified. Thus nagun good, nagun-gay-nay $I$ am good, past tense nagun-ga-ya-nay, future 
nagun-gay-naya-nay. It should also be noted that the negative in Dhurga comes between the auxillary stem and the tense or person signs: Dhurgadja ma-namba-ga $I$ do not speak.

To take ma-do, make, cause first: it seems arbitrary to deny the form as an auxiliary once the nature of -1 is realised. It is true that in Wiradjurl and other languages across the Dividing Range -1 is not involved: Wiradjuri bu ma-ra $I$ hit (now) as agalnst Dharawal bu-l ma-y-nay. This may be compared with mi ma-ra detains, and Awaba mi ma-li remain cause-to, detain. Wiradjuri does use ma as a normal auxiliary with transitive verbs, without -1, but nearly all the Wiradjurl tenses except the present include an -1 with the auxiliary, not with the root: ma-l-narin (this morning past), ma-l-nurani (near past), ma-l-guwan (completive morning tense), while with verbs of the yan-go type this does not occur, whlle with those of the bada bite type (simple stems) the gerundial is added directly to the root: bada1-giri ate.

There are other Dharawal verbs in which Eades makes the root or stem end in $-\mathrm{C} m$ in what seems to be an unjustified way, e.g. danm- eat rather than accept dan ma- as a compound verb. Again, some verbs end in - Cg where Capell would interpret $-c+g a$, as in nan ga- sleep, yila ga-rejoice (Eades 1976:54). Most of these are intransitive verbs, as they should be according to the other languages, except babu-g bite (which may be elther transitive or intransitive in English).

Other examples occur which could be reinterpreted, such as mimbkiss, with what would be the ba auxillary treated in Awaba supra: in that language actually the verb to kiss or salute takes ga- according to Threlkeld: bupbun ga-. The Dharawal example pattern is $\mathrm{mim}$ ba-. There is also an apparent form *da which has no relations in other languages; taking Eades' forms, nand-see, yand-go, bind-l bind-give, gandi-hear. These are quite normal Australian forms without the final $-d$, and in some languages without the $-n$ either. With the last mentioned, N.E. Arnhem Land na-ma seems a reasonable cognate: -ma is here the 'infinitive' ending, not the auxiliary. The root for give in Australia varies between gu-, wu- and yu-; bindcould possibly belong here but is outside the present research. Presuming $-n$ to be a final of root at some stage at least of ProtoAustralian language, it still remains to 1dentify the -d, this could represent $-1 /-r$ for -1 a/-ra after a nasal, but there is no means of identification at the moment and the form is best left marked as an auxiliary but uninterpreted. 
In Dhurga there are also numerous examples which come to light in a critical examination of R.H. Mathews' vocabulary. There are simple verb forms to which person and tense endings are added directly, as na:ra-ga $I$ bind; nambadja-ga I catch; ya:wa-ga I talk; wadaluwal-ga $I$ search for - and nja-ga I see, which lacks the final consonant of the corresponding Dharawal verb listed above.

There are examples where a ma auxiliary can be safely identified: dja ma-ga I talk; ju ma-la-ga give did-PAST-I - quite different from Dharawal - dana ma-ga $I$ eat; guwinj ma-r twist it; bulu ma-ga $I$ wash; djinja ma-ga I build $i t$; and quite a number of other examples. A smaller number evidence ba, as in djindju ba-ga $I$ spit; djarum ba-r be quiet! (Interpreting Mathews' spelling djarumbur). There are also a few of the doubtful d-forms as in junda-ga I drink, and nara-ga I hear seems to be a simple verb here. Although Eades does not accept such analyses - and Indeed holds that the avallable materials are inadequate, there is nothing inherently unlikely in what is said here, and both form and sense support the suggestions made here. It may be added in passing to the next section, that Wiradjuri binan ga-ra hear seems to be quite the right interpretation of binanggara, in view of the $C A$ *binan ear compounded in Ngarinman binan + auxiliary to hear, especially as in that language the noun ear has been replaced by lana.

\subsubsection{Languages Inland from the Dividing Range}

A note needs to be added concerning these, because mention has been made of Wiradjur1, where certainly ma and ga are present as bound auxiliaries - and the point is exactly that in all this area the auxiliaries are not only morphologically bound forms (even if it is convenient to write them separately) but bound to certain verbs also.

There is no satisfactory grammar of Wiradjur1, but the notes by Günther in Threlkeld, ed. Fraser 1892: Append1x, 56-120, enable certain things to be sald on the formatives in this language. Ba, ga, ma are among others.

1. ba be, also in form bala is used with pronoun suffixes: bala-du $I \mathrm{am}$.

2. ga be, used only with present tenses, but may also be interrogative, example: wadan-ga- to be angry.

3. ma- Is causative: giway sharp > giway-ma sharpen. It is also used with English loanwords: ring ma- to ring a bezl.

There are also certain others which are not fully explained, e.g. gana burn (Intr.) > gana bi-set on fire; balu die + bu strike> 
balubu-i kill; bana break (Intr.) > bana-narl-break by falling. In point of fact Wiradjuri word formation (not only verbs) in general is rather complicated.

For the Ngunawal language (about Goulburn, New South Wales) most of the information rests on R.H. Mathews (1904:297ff.) and his notebooks (unpublished). His model verb beat is in present tense jubu-ma-nga in his spelling ngubumanga, in which ma- is clearly involved as a formative. This, however, becomes $-r i-$ in past tense and - $n i-$ in future, recalling the abovementioned wiradjuri markers which are limited to a single tense. However, he notes that 'a predicative adjective will become an intransitive verb' and this then involves ma, $r i$ and ni - showing that the basic meanings have been lost: munun ma-nga I am large. A substantive verb 'to be' does not occur in this language: yedan madi nunu good very this, this is very good.

There is thus at least a suggestion that Ngunawal was not entirely without a system of formatives similar to those of Wiradjuri.

To the north of the Wiradjuri there are a number of languages, of wh1ch Gam1lroy (Kamll(a)roy) is the best recorded (R1dley 1875:3-43). The same auxiliaries are found in these languages also, but again reduced to the status of formatives and in some cases changed considerably in form. Communications from Peter Austin (Canberra, Australian National University) have helped considerably in clearing up the situation in Gamilroy and the nelghbouring languages and have been embodied in the present note. Austin in a private letter states that he cannot identify the ga auxiliary in this language, but it seems to the present writer that it is to be recognised in the forms of $\mathrm{gi}$-, given by Ridley $(1875: 13)$ as be, become. In regard to the other auxiliaries, it seems best to embody the information supplied by Austin, who writes: 'The morpheme -ma-l turns up in Gamilaraay [Austin's spelling], Yuwaaliyaay and Yuwaa:araay as an affix on $y$ and D conjugation intransitive verbs, which converts them into 1 conjugation transitive verbs...all these languages have four verb conjugations, $y, 1, \eta$ and $n .^{\prime} 1$ It is also found on English loanwords which are borrowed as verbs, for example gigima-l kick whlch is borrowed from English. Examples of the ma transitiviser include the following taken from the honours thesis of Mrs Corinne Williams (Williams 1976), a grammar of Yuwalaray:

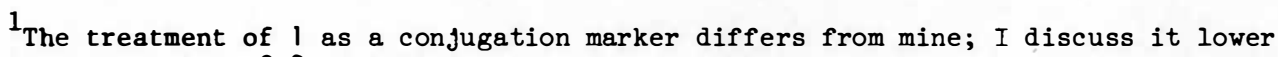
down in section 3.0 of this paper. 
$\frac{\text { gl: ru nama dayindu: I nana bunda:ma:y }}{\text { (statement) that man-dim. lsg.0 fall-me-nonfuture }}$

That man made me fall over

and

gi:ru Dya giya:na Dinuna dandwuwimali
(statement) I be-continuous you sleep-ma-f'uture
I'm going to make you go to sleep

'The same affix is found in Wiradjuri, Wayllwan and Wangaybuwan to the south and west to which the three northerly languages are closely related...As for the intransitivising marker ga I can find no trace of it in any of these languages; ${ }^{l}$ the only affixes affecting the change from transitive to intransitive stems are the reflexive and reciprocal which are not at all connected with ga.'

Austin also remarks that he would expect to find these formatives also in Queensland and quotes their occurrence in Diyari, as has been already mentioned here. Professor Wurm (Wurm 1972), however, does not recognise them in the New South Wales languages between the Darling River and the South Australian border.

\section{THE NATURE AND HISTORY OF THE SYSTEMS}

\subsection{Introduction}

The time has now come to undertake a discussion of the history of the various systems of compound confugation which have been outlined in the preceding sections. It is obvious that $E A$ verbs did not have this dual system of confugation. It would in fact seem that the earliest verbal system was hardly a system at all: this seems - from the few remains that can be interpreted - to have remained the form in Tasmania (Capell 1968). Compound conjugation is Australia developed first of all as a syntactic matter, a device probably for vividness and clarity of expression, certainly not for any grammatical reason.

The stages that will be suggested are as follows:

1. Uses of $\mathrm{V}+\mathrm{V}>\mathrm{V}+$ auxiliary $\mathrm{V}>\mathrm{V}+$ morphemic $\mathrm{V}$.

2. Gradual subdivision of this scheme in different areas in different ways, with involvement of $\mathrm{N}$ as well as $\mathrm{V}$.

It even seems possible that the more elaborate scheme belongs to the relatively modern $C A$ period, which must be dated as later than 10,000 B.P. The frequent use of the gerundial marker -1 is the ground for

${ }^{1}$ See previous footnote. 
making this statement, for -1 certainly appears to belong to the CA stratum, and is most marked in regions where such influence can be suggested on other grounds also. This is, in fact, the main reason for treating the Dharawal verb, e.g. bu-l-ma-y-a he hit him as bul maya, and this seems to have been a borrowing from the Wiradjuri subgroup where the system was developed more highly. In fact, the tendency for the construction to occur with the CA *bu hit root makes it tempting to suggest that something like a 'sprachbund' was operating in the south-east of New South Wales, and perhaps elsewhere.

By way of preliminary, attention may be suggested to rather similar phenomena, of course with different morphemes, found at least in parts of the Indo-European languages. In modern English it is possible to say not only I came but I did come. Such a construction is at first emphatic, then becomes functional on 1ts own merits which, especially for non-English speakers learning the language, are considerable. There is a tendency to simplification visible in language as a whole: the loss of the Latin future-by-inflection and its replacement by $a$ future-by-auxiliary in the Romance languages, is not 1solated, and would probably be found more frequently if the early history of nonliterary languages were known.

The various systems of auxiliarles that have been noticed lend themselves to classification, as in the following diagram:

\begin{tabular}{|c|c|}
\hline Independent & $\begin{array}{l}\text { (a) Syntactic combination, derived from an } \\
\text { original phrasal verb combination. } \\
\text { (b) Syntactic combination derived from an } \\
\text { original }+\mathrm{V} \text { phrase, } \mathrm{N} \text { being object, } \\
\text { or gerund derived from a verb stem by } \\
\text { the addition of }-1 \text {, the CA gerundial } \\
\text { marker. }\end{array}$ \\
\hline Catalyst & $\begin{array}{l}\text { The catalysts were originally independent } \\
\text { verbs, whose independence was lost and } \\
\text { their meaning reduced to verb in general } \\
\text { terms. }\end{array}$ \\
\hline Dependent & $\begin{array}{l}\text { Originally fully meaningful, but the mean- } \\
\text { lng has been largely lost and has assumed a } \\
\text { semantic change in the resulting compounds. }\end{array}$ \\
\hline Bound & $\begin{array}{l}\text { A final stage, in which very little of the } \\
\text { original is retalned, and it is used only } \\
\text { to make the compound phrase possible. }\end{array}$ \\
\hline
\end{tabular}


In the diagram on page 237 some Ngarinfin sentences were transformationally analysed under the general form of

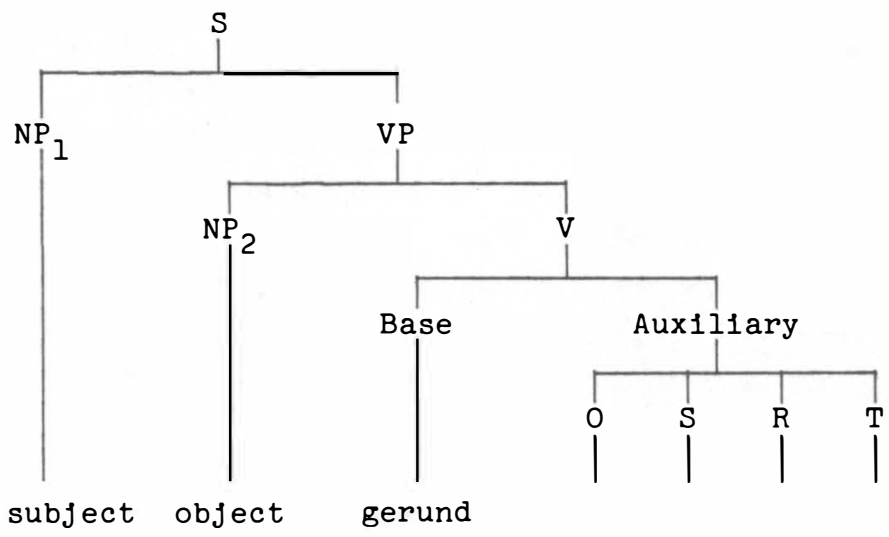

This same general pattern suggests a combination diagram in which the varlous types of Base and Auxiliary can be arranged in forms which allow of typological classification of the phenomenon. This diagram follows as Diagram II. Both $\mathrm{NP}$ and $\mathrm{NP}_{2}$ being optional, the VP phrase only is taken as base. The next diagram therefore takes the form:

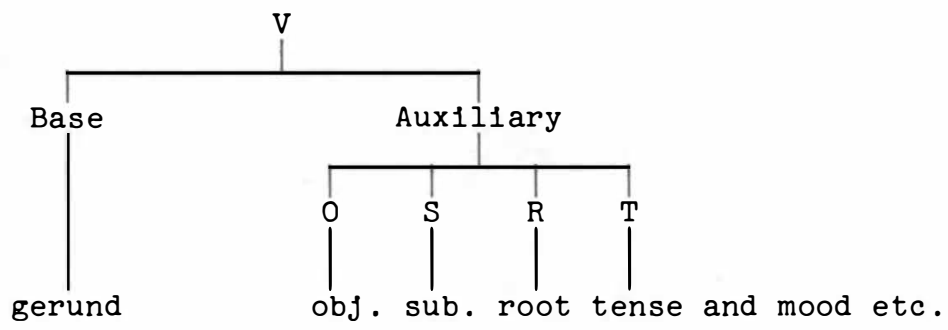

The classification types rest on the morphemic and semantic contents of 'base'; the order of subject and object markers may also be so or os in different types of languages. This last point is diagnostic for the present purposes and needs to be regarded especlally in the analysis of the Gunwinjgu type verbs (2.2.1.6.3.). A re-study of this section will show that 1 is just the order of $O$ and $S$ that has decided this particular type of compounding. As a matter of fact, of course, it is not essentially different from that of Ngarinjin and the Kimberley languages in general, but does lead to different emphases and therefore different orders, as will appear below. 
Regarding the WD languages, K. Hale (1972) writes as follows: 'The process of de-stressing and cliticizing pronouns eventually became an obligatory rule and subsequently independent pronouns were recreated from other sources avallable to the language (sc. Walfbir1), such as oblique forms of pronouns like those found in possessives or in other functions not normally subject to cliticization.' In this essay, Hale regards the Warnman pronouns as re-creations. Wider comparison with languages of Victoria (for instance) leads the author to disagree with Hale in this matter, and to believe that the WD languages (brought to birth from *CA) originally had only suffixes for person - number developed later, as did the distinction between inclusive and exclusive. He has tried to show this in an earlier writing (Capell 1955). In some the inclusive-exclusive distinction has never developed (e.g. Bldjandjadjara) and in others it is limited to certain situations: In Yulbaridja it is found only in suffixed and not in cardinal pronouns. Eastern Australia (representing *EA type languages) quite frequently shows pronouns that are built on a nominal root (Capell 1956-62:2lff.) just as apparently Warnman originally had. Moreover, only singular forms are sometimes present, as seems to be the case in Tasmanian. In the WD languages the suffixes are as a rule only those for lst and 2nd persons singular; 3rd singular is zero, and other numbers are all composite. This is a matter belonging to the historical section in this volume and cannot be enlarged on here, but its conclusions are accepted for the present discussion also.

\subsection{The Phrasal Verb}

The simplest form of phrasal verb is the combination of two bases both verbal by nature; slightly less simple is the phrase in which one element is nominal by nature. Both occur in the Cape York area of Australia. Not only is this the simplest type of compounding, but in fact it is not grammatical compounding at all, nor is 1 t limited to Australian languages. Such compounding as look see is used in Chinese, and snap break is a similar example in Australia (2.1.1.). This process is entirely syntactical, and reappears often as a stage in thought development. For the purposes of this paper it had, of course, to be mentioned and 1llustrated, but it need not be treated as a stage in the historical part of the compounding process, but only as a phenomenon in 1ts own right. As a matter of fact, such compounding is found outside the Cape York area as well. Idlomatic uses of such double verbs is found for instance in the Bandjalong and other regions. 
There are areas of the continent where phrasal verbs are not in use. These are areas in which there is complication in the morphology of the verbal system demanding that each verb be marked for person, tense, etc. Nor is there any historical development from area to area, for phrasal verbs are found both in Cape York in the extreme north-east and Njungar in the extreme south-west.

There is, in fact, a tendency to PV organisation in many languages in Australia in which verb compounding is not developed; examples from Bularnu and other south-west Queensland languages have already appeared in the Introduction to this section. The same process is appearing in English in phrases such as to baby sit.

Where phrasal verbs exist, they may be elther $\mathrm{V}+\mathrm{V}$ or $\mathrm{N}+\mathrm{V}$; on account of the basic SOV typology of Australian languages, there is a bias against $\mathrm{V}+\mathrm{N}$. In a language such as Gog-Nar, such a compound as yel + yem eye throw = look is natural; so also is the NJungar wang + njin talk-sit $=$ sit talking. A language such as Thayorre, however, allowing a serles of verbs together, becomes more complicated. The following examples are culled from Hall (1972); they also show examples of the rarer $\mathrm{V}+\mathrm{N}$ combination

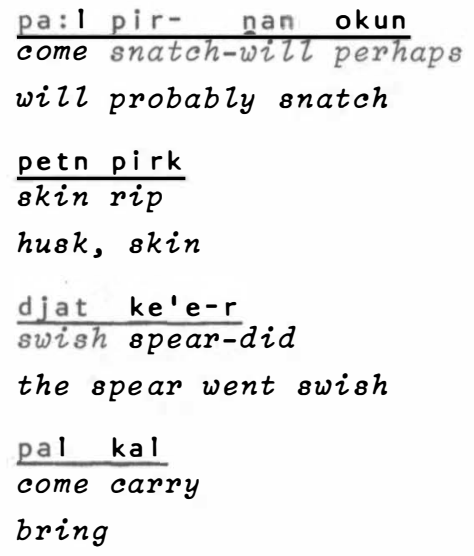

Longer combinations of various degrees of intimacy are possible here: kana ya:-n pal have go-do come = have come here; ant te:Rn-na ka:r-p try kizl-can not-too = won't threaten to kizl. Examples of this type show a maximum of separability within a total limit of order, as appears in:

$$
\begin{aligned}
& \text { kana ka: } 1-k-k u: k \text { ni:n-n (n)andjn } \\
& \text { have back-speech sit-ting we } \\
& \text { We've sat waiting for your answer. }
\end{aligned}
$$


At this stage all that is involved is a sequence of words (plus inflections) each of which can occur separately. In other languages this will harden into a flxed set of elements which can occur only when they do, as in the Gunwinjgu:

Dari-ben-mane-djal- djarg-gole- manbo-yi
we them IO continulty group spear make IMPF.
we used always to yather together and make spears for them

Here no element is free; even spear, to appear in the free state, must take the class prefix and become mangole. The various types of verbal compounding seen in the preceding pages are therefore to be regarded as the growth of a complex system in different parts of Australia differently, and influenced no doubt by many different facts, in each of them. But it seems impossible to doubt that these various systems originated in a simple Phrasal Verb system to which other elements were added under other conditions.

\subsection{Compounding by Auxiliary}

The various systems of compounding by auxiliaries which have been lllustrated here represent complex developments, not all resting on the same foundation, but all agreeing in at least one point; a certain number of basic verbs were chosen out of the whole vocabulary of the language as 'builders' for verbal expressions. The free choice of combination existing in the PV languages became limited when certain basic 1deas were accepted as foundations for compounding. Auxiliary verbs as they appear in the different languages grow fewer and fewer in different regions, until finally it seems to be forgotten that the auxiliarles were ever free forms with full semantic force, and they become simply instruments for expressing verbal caiegorles, even a simple difference between transitive and intransitive - and in so far as roots ma and ga come to do this in some languages, they themselves had so far lost their meaning that it was apparently forgotten that both of them are originally transitive: An auxiliary is a full verb that has been downgraded in certain circumstances. It would also seem that there are occasional homonyms to be reckoned with: the transitiviser ma was originally do, and so cause, bring about an action in most areas, but where it $1 \mathrm{~s}$, as in the Daly River area, the coefficlent of 'standing action', as in ganama gay I (stand and) call, I call from a standing position, this clearly is a different root. 
The appearance of ma in a language does not allow it to be taken for granted that it is always the same ma, although generally it is.

In terms of TG set-out, sentences of the type of the Daly example djinda nala ga-na-ma gay ayi spear for past-I-stand call-past, 1.e. I (stood and)l called for a spear (2.2.1.4.) a tree of the following shape seems to be acceptable:

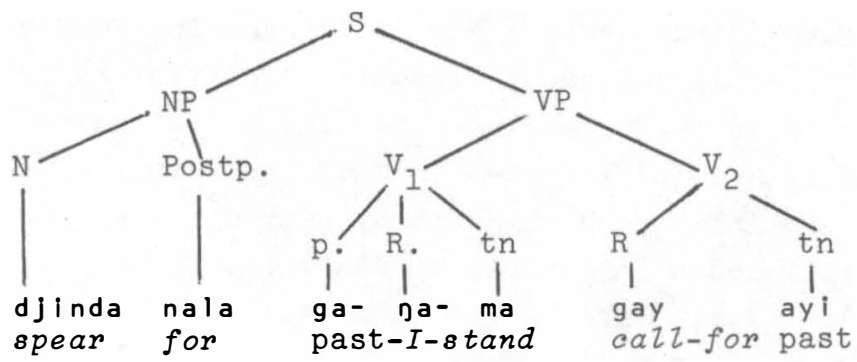

There are stages between the PV verbs and the compounding processes that have been studied in the preceding pages. What is being exhibited first of all is a logical division into types, not a historical account of origins and stages. So far as it is possible, hints concerning this latter will be given in a final section of this paper.

\subsubsection{Free Auxiliaries}

The first stage of development of auxiliaries is probably represented by those languages in which the auxiliary is free, 1.e. leads a semantic as well as a grammatical life of 1ts own. In Ngarinjin, for instance, ne is $I$ am - but it can also help to make a verbal phrase. In some of the languages there is a considerable number of such free verbs used as auxiliarles as well as standing in their own right. They combine with bases that are, so far as distinguishable in grammatical terms, nouns rather than verbs, or sometimes even adverbs. In 2.2.1. comparison was made between Gog-Nar yel gem eye throw, look at and Ngarinfin burgadj anebun question I-throw-him, I ask him. These two are parallel except for the added grammatical features in the Ngarinfin verb. They are both $\mathrm{N}+\mathrm{V}$ structures. In Ngarinfin burgadj does not seem to be used as a noun as it would be in English what is your question?, but that is not important; an Aboriginal speaker would

${ }^{1}$ Stood has no logical part in the sentence as a kind of action; it is simply that calling is done in a standing position, as this language structures the activity. 
certainly prefer the more concrete expression what are you asking me?. The point is that structurally both phrases are the same. In Gog-Nar the combinations of $\mathrm{N}+\mathrm{V}$ are very numerous - and so in other $\mathrm{CY}$ languages as well; in Ngarinfin there are only eleven such combinations, and in other NK languages usually less. The 'phrasal verb' is beginning to be an auxiliary, one of a certain - small - number of helpers which retain their own functions as well as 'helping out'. As other areas of Australla are reached, these 'helpers' are fewer and their work greater, except in so far as more actual verb roots are developed. Free auxillaries certainly seem to be the earliest stages historically as well as logically, but there is no need to lay that principle down at this stage.

In the process of development it is noticeable that $V+V$ tends to disappear and $\mathrm{N}+\mathrm{V}$ remain a lot longer on the historical scene. The Ngarinfin tree patterns have already been set out (section 2.) and need not be repeated. The difference between these and the Gunwinjgu type has also been ment1oned, and it was there suggested (2.2.1.6.3.) that a theoretical difference exists between them and the NK shapes, due to object incorporation as part of the agglutinative picture in Gunwinfgu and 1ts relatives. Some tree diagrams showing the Gunwinfgu analysis may be of help to reinforce this difference. A series of sentences showing the different types produced by the occurrence of inset nouns in these languages is therefore given here.

(1) bininj ga-nud-me the man calms down:

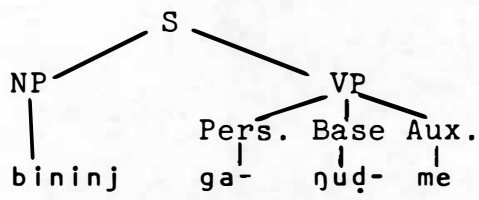

(2) gurula ga-bo-nud-me the sea calms down:

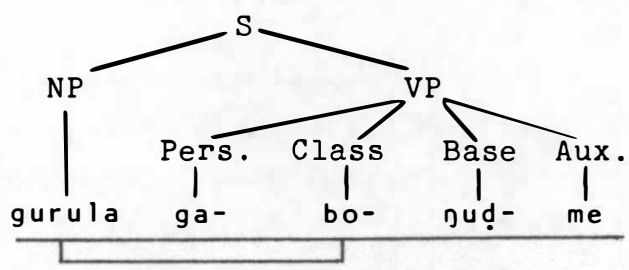


(3) gunRed bolg-neyo camp its name, name of the camp:

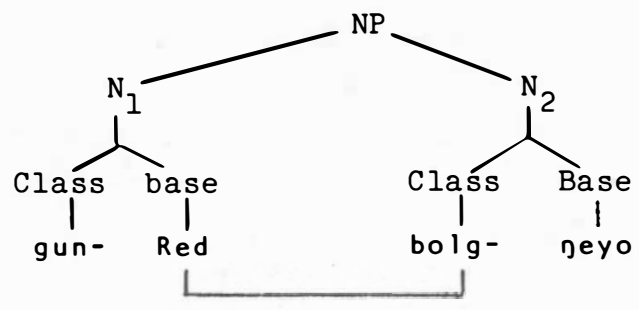

To which is added an example not used above:

$$
\text { na-godj-dji-re-n I wash my head }
$$

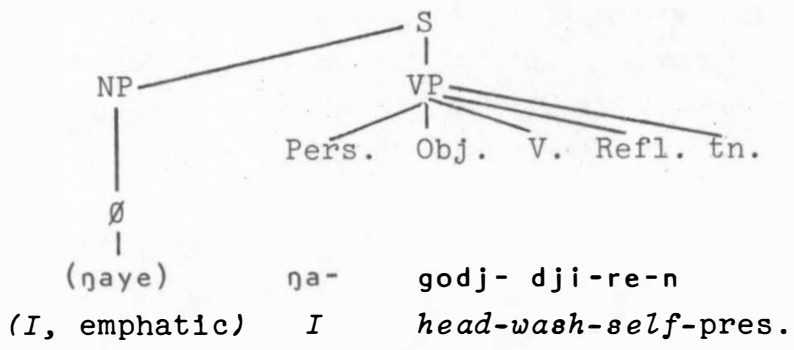

which is exactly parallel to

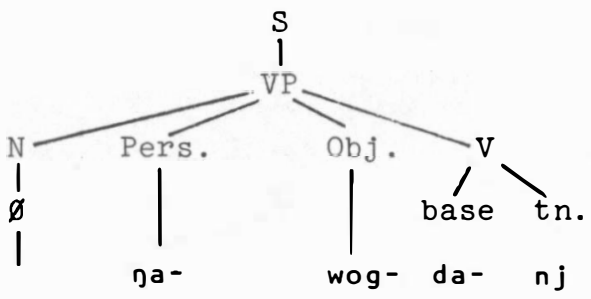

Dawogdanj I spoke, I said a word

on which the assertion was based that the Gunwinfgu subclass rests on its power to inset noun objects before the verb, retaining in the VP the syntactic structure of $\mathrm{S}$.

Very similar patterns can be worked out for the Dampier Land languages. The historical problem in this case is more difficult, in that Dampier Land shows one of the Regional vocabularies which suggest an origin apart from those of the chief body of Australian languages. That question cannot be gone into in this paper. It is worth recalling that here also not all verbs are compounded; as in most of the languages (except Daly River) there are simple verbs also. 
Mention of the fact that all verbs are compounded in Daly River languages brings out the fact that a different principle is at work in these, and this needs to be demonstrated in some deta1l. The fact 1tself has been stated by Tryon, but he has not compared Daly River compound verbs with those of the NK and AL languages.

First of all, although the compounding is still normally in the same order - Base + Aux., this does not need to be so, and Aux. + Base is allowable. The difference lies in the fact that Daly River auxiliaries classify actions in a way similar to noun prefixes classifying nouns. It is a classification by kind of action, so that the same base can sometimes take different auxiliarles in a somewhat different sense. This is true also of the NK languages, as has already been shown in the relevant section of this paper, but the true nature of the auxiliaries is not quite so clear in NK as in Daly River.

Moreover, the order of elements in the auxiliary itself is different:

$$
\mathrm{NK}: \quad \mathrm{O}+\mathrm{S}+\mathrm{B}+\mathrm{T}
$$

(where $\mathrm{T}$ covers mood and volce as well as tense)

$$
\text { Daly: } \quad T+S+B+0
$$

The originally free position (1t would seem) of the pronoun object has caused 1t to be left outside the Daly River compound. In the NK the basic order SOV has led to 1 ts being included in the verb phrase, and not only so, but to 1ts having priority over the subject marker. This latter peculiarity might be accounted for by supposing that the system points back to a preceding free subject, so that VP represents $\left(0+S_{2}\right)$, the second $S$ being incorporated in the VP. The earlier sentence type in NK would then have been

$$
\mathrm{S}+\mathrm{O}+\mathrm{VP}=\mathrm{S}_{1}+0+\left(\mathrm{O}+\mathrm{S}_{2} \mathrm{~V}\right) \text {. }
$$

In the Daly River languages the auxillarles are concerned with manner of action. Tryon's summary (1974:298ff.) speaks of five verb classes in the Mulluk group, but adds 'within the Brinken-Wogady and Djemeri groups, however, in addition to the five verb classes just listed, there are up to twenty further classes,' and they are all concerned with the manner in which an action is done. There is a world of difference, therefore, between the NK type and the more general Australian type to be reviewed below, and those of the Daly River. The latter seem to have developed quite independently of the rest of Australia - and Indeed the cognate count between Daly River and the rest of the continent is also often very small. 


\subsubsection{The Degradation of Auxiliaries}

The subsequent sections of this paper have shown the auxiliarles gradually losing their independence. First they are reduced to indicators of various kinds of action, while still retaining an 1dentity, e.g. as in south-eastern New South Wales, where the negative follows the auxiliary and not the main verb (see the Gandangara and Dhurga examples). Later they become simply grammatical formatives, which are very well treated in writing as part of an entire verbal stem to which tense and other suffixes are added. At this stage there is loss of 1dentity to the extent that it becomes 1mpossible to prophesy which auxillary will appear in a given case and whether it will retain any clear sign of 1ts original meaning. Last of all, a set auxiliary is used with a given verb, with little regard for meaning.

In all this there is no precise geographical link; DJirbal -ba and -ma (as will be shown below) no longer function as anything but markers of intransitive and transitive verbs respectively, and both add an -1 which is in that language a confugation sign and not a gerund (probably not even historically derived from the gerund -1-), and moreover -ba is reduced to $-b i-1$, functioning as such a compound.

Parallel to all these developments, there are languages in which the same functions are carried out by totally different sets of markers, and to these attention must now be turned.

\subsection{Other Systems of Verb Derivation}

It would seem that in the extreme south-west of Australia the various derivational systems here studied, did not hold good. In most cases there is insufficient material for analysis of the verbs in Njungar and the related dialects. The same facts hold good in the extreme south-east - Victoria and even the south of South Australia. Th1s would fit in with the 'areal' linguistics theory. There is no intention of embarking on this type of argument here, but some notes will be given on the south-eastern groups of languages in order to make it clear that the various methods of confugation and derivation that have been studied above are to be connected with the CA languages, and result from the movements of speakers of such languages from their original homes towards the east and south of the continent.

Notes will be given on the verbal systems of Banggala (Parnkalla), Gaurna (Kaurna), Narrinjer1 or Yaralde, and Murund1 from the South Australian languages to bear out what has fust been sa1d. Study of 
Hercus ( 1969 Part I) will show that Victoria is equally innocent of the systems of auxiliaries and formatives that have been studied. A beginning is made with Banggala.

The fact that, although the phenomena just considered belong for the most part to the CA stratum, they are based on analogues in EA w1ll become clearer if a look is taken at the latter types of language. Few, if any, Australian languages are entirely free from CA intrusion, though some are much less influenced than others. This is particularly true of the south-eastern languages (and for that matter the grammar of the south-western languages is largely EA), more markedly perhaps than some of the AL languages not dealt with in detail here.

A preliminary glance at the structures of Banggala and Gaurna (Kaurna), Yaralde and Murund 1 among the South Australian languages, and those of Victorla still farther east, will be taken first. The cltations of words in this section will be largely those of the original grammar writers, except for Yaralde, where later work (Yallop 1975; Grimwade 1975) allows of greater phonological approximation.

In Banggala - see Schürmann (1844) - quite a number of auxiliary verbs are found, but these are actually of the PV type, seen in the CY languages. Schürmann says, 'When the sense admits 1t, the following words are frequently used, where we would employ the auxiliary to be, viz. yuwa-ta to stand; ikka-ta to sit; padna-ta to go; kari-ti to continue; wawi-ti to lie down; as: kutyo yurari yarlanga padna tanna the other men are hunting...' H1s sentences are best analysed to show what is really happening: pallari kangaranga kari tanna the women among the grass tree roots continue, 1.e. are; kutyu yurari yarlanga padna tanna the other men hunting go they, and so forth. The first of these auxiliaries recalls the Daly River system, but unfortunately it is not illustrated by a sentence - nor, of course, can it be sald in the absence of text matter, that these were all the auxiliaries in use. There are interesting uses of padna-ta go, as in ninna yureyappu padnata? are you aware?, lit. you ear-attending go?; ngai kubmanna padnata $I$ am alone, 11t. I one go; karakurtu karkurarkuru ngukatao kauungu the boat goes whizing through the water (very rapidzy), seemingly

$$
\frac{\text { gaRagudu gaRguRaRguRu nuga-da-wu }}{\text { boat }} \frac{\text { gawu-ngu }}{\text { whizaing }}
$$


Other examples culled from the vocabulary include parungu kari tannal yuRari game-for continue men, 1.e. the men are still hunting; kaya ilka padna (tanna) they go spear-having, 1.e. they have spears.

The causative, expressed by the ma auxiliary in the CA languages, is here expressed by +nutu, e.g. birkibirki-nutu to break into many pieces, from birkibirki-rri-ti to crumble (Intr.); ngalaniti grow Zarge > ngalaningutu enlarge; marniti good, be good > marni-ngutu make good. And Schürmann adds that ngutu can be appended only to intransitive verbs, including such as yuwa-ta stand > yuwa-ngutu raise up; worniti fall > worningutu drop something.

This system providing means for deriving one type of verb from another or verbalising another part of speech, obviously works quite differently from those studied above.

In the Gaurna (Kaurna) language of the Adela1de district (Te1chelmann and Schürmann 1840) there are differences agaln, and apparently compounding was not greatly in evidence. For make wapp-e-ndi is given, and it is abbreviated slightly to -app-e-ndi (-e- is a confugation class marker, and -ndi 'Infinitive') as a causative suffix, e.g. wakkina bad, wakkinarndiappendi cause or allow a person to become bad apparently both halves of such a compound could be confugated - the lack of text materlal is here a problem. This suffix seems to have been fully productive; the root would be * $(w)$ app-. On the other hand, -r-e-ndi marks the intransitive or even benefactive; pingya-r-e-ndi to turn, to lighten, to flash, with causative pingya-ri-app-e-ndi turn something round. There 1s, however, a suspicion that ma has come into the language also as formative, for the authors give bakka dry bark> bakka-ndi dig out roots, but bakka-ma-ndi to peel something. However, ma-ndi is glossed as draw, pull, and may be compounded with karra up, high, as karramandi to hand, take, pick up, and this is apparently the root *ma with a local suffix.

In these final examples it is possible - though the possibility is hardly Justified - to see a southern extension of CA influence. Further south, in Yaralde, Murund1 and some V1ctorian languages there does not seem to be any such influence discernible. According to a personal communication from S.A. Wurm, the CA formation does not occur in New South Wales west of the Darling River. The system of auxiliaries, therefore, must be taken as derived ultimately from the CA stratum. Phrasal verbs occur in Cape York and in Banggala, but these

${ }^{1}$ I take it that tanna represents the 3 rd person plural pronoun so common in Australia, and write it separately, though Schürmann makes it part of the verb. 
are not historically diagnostic in any case, as has been already stated. The question of how CA auxiliary formations got into eastern New South Wales has still to be faced.

F1rst, however, the Yaralde and Murundi evidence, negative but no less important, must be assessed.

The Narringerl group of dialects of which Yaralde is one (Taplin 1878, 1880; and Yallop 1975) occupled the lower Murray region between that river and the southern ocean, and Murund1 (Moorhouse 1846) was spoken on the Murray near the southward bend. These are the only two forms of speech from this region at all well recorded.

In Yaralde according to Taplin there are three auxiliarles: -war (which Yallop takes as -uwal/-uwar) and -min-both causative, along w1th -en- of being or dolng, and -el-be, do, intend (Yallop) - the last a most unsatisfactory designation, although certainly it does serve as a copula verb. Among Yallop's examples (orthography here modified):

$$
\frac{\text { Da:bi }(n) \text { e l-un } \text { pa:d j i }}{I \text { be-PRES friend }}
$$

I am a friend shows el taking the tense markers, but just as of ten or more often? - these were added to the maln verb:

$$
\begin{array}{lll}
\text { ya:n-un } & \text { el } & \text { ab } \\
\hline \text { speak-PRES do } & \text { d }
\end{array}
$$

I am speaking, or

$$
\frac{\text { yu:n el idj brag-ani napi }}{\text { soon do it pise-FuT sun }}
$$

the sun will soon rise.

Transit1vity is marked by -uwal/-uwar, but also derived from other parts of speech are similarly marked: wireni bad > wiren-uwar-un act bad-PRES; -min- or -mind-does just the same task: buldamul-min-un tired-make-PRES. There is just the possibility that this may represent *ma, especially in view of the occasional final $n$ in some languages, but it is not convincing. It does not seem possible to fit these suffixal morphemes into any of the patterns hitherto examined, they represent a system sui generis.

Murund 1 as set out by Moorhouse seems even less clear. The -un present tense marker of Yaralde is shared, but the other tense endings differ between the two languages - and for that matter there is in Murngin in N.E. Arnhem Land a class of verbs ending in - un in the present tense, which need to be examined before this section is closed. The Murundi formatives have to be dug out from the vocabulary, and the 
surprising result is that Murundi in its system does seem to show a surprising resemblance to Murngin. Moorhouse's material is not good enough to enable a system to be properly worked out. Examples of verb derivation occur in the vocabulary, but though a number of verb classes can be found, they do not seem to be clearly analysable - nor do those of Murngin, to the degree that any reason for a given verb being in a given class can be suggested. The following are fust some of the discernible subgroups in Murundi. Even the basic EA roots of words are largely missing from Murundi.

Moorhouse's spellings are largely retained because it is often uncertain what they stand for. For hit the root *bu may be hidden in bund- (present tense bund-un) but this is not certain. It would point to an original EA *bund- which nearly everywhere has lost its final consonant, and in any case this chapter is not concerned with reconstruction of $\mathrm{EA}$ or $\mathrm{CA}$ vocabulary. A number of consonant additions to the stem are found: not to the intransitive, as in tap-bury > tap-t-be in the grave; djerub-chase > djerub-ul- run away; woarn(= wuwan-?) come > wuwan-uw-carry, cause to come; kailk-ask > kailk-uwa- ask for, order a thing; and a common intransitive ending -ang- is added to a number of roots, e.g. wir-ang-tremble; bokk-ang burn, blaze > bokaikn-order or arrange the fire; gidl-ang-be angry> gidl-ar-become angry; gir-edl-an-be in Love > gir-b-make love to a woman; parldk- hit > pardlk-udli-ma-beat-cause-make - the sole or nearly sole suggestion of the *ma $_{\text {mat. }}$ root.

In some cases, as noted, there is a suspicious resemblance to the Murngin or Yulngu languages (chiefly Gubabwiyngu will be cited) of N.E. Arnhem Land, where a present tense marker - un may be preceded by a consonant that does seem to be diagnostic. For the previous reference to these languages see 2.2.3.2. above. In the Murundi examples in Moorhouse, the chief linking consonant seems to be $t(=d)$, which is the consonant in Murngin that serves to verbalise a stem ending in a stop, as $y$ verbalises one that ends in a non-stop. In Murundi, the distinctive function of the added consonant is not clear (at least in the avallable material): gab-un and gab-d-un both mean speak, say, but there is also an example or two in which -an is written by Moorhouse, with a difference in meaning: yurrun be afraid, but yurran frighten. In Gubabwiyngu also there is an -an confugation to which attention has been called earlier.

There are unexplained cases such as kudl-un to warm > ku-edl-un to shine > ku-e-dl-emat-un be shining; djab-d-un accompany each other 
(go in a group?) > djab-b-un accompany ${ }^{l}$; de-rri-n stand > de-dd-in cause to stand, raise. While it is not the purpose of this section to suggest analyses for these forms, they do emphasise the great difference between the languages of the area and those of the CA groups, and suggest possible links with north Austral1a - links which are clearly established by comparisons between the Northern Kimberley, Arnhem Land and Western Victorla, as discussed in the general section on the Australian languages.

\subsection{Summary and Probable History}

The establishment of the series

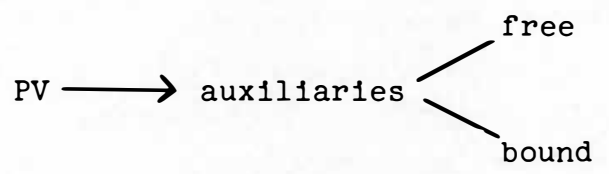

brings the historical element into focus. It does not follow, however, that the development has been in terms of present day distribution of these features, from one point of the compass to some other. Moreover, the system of catalysts does not seem to fit directly into the series at all. There w1ll have been many local developments, especially $1 \mathrm{f}$ the Sprachbund association earlier suggested is at all real.

Classification of nouns in the northern parts of the continent has also caused complication. The Daly River 'coefficient of kind of action' system also does not belong in the series. These languages with such a small percentage of $C A$ are so different in structure from most other Australian languages that they seem to represent a separate movement into the continent, affected by such later movements as EA and CA - probably both.

The possibility of the following stages is therefore suggested with the proviso that it may not be right, certainly not in all details :

1. Systems of 'phrasal verbs' would be quite early. Whether the st1ll extant systems of the CY area represent the early stage of this is open to doubt until the historical position of these languages can be more definitely established in terms of lexical investigation. There

\footnotetext{
${ }^{1}$ My personal inclination is to spell djab-un for accompany so that djab-d-un may be regularly derived from it. Double consonants do not seem to have phonemic value in Moorhouse's spelling. There is also marked vowel harmony in the tense endings in Murundi, which Moorhouse does not mention. But $\mathrm{cf}$. -in and -un endings in his vocabulary.
} 
is certainly much in common between them and the New South Wales coastal languages that lies outside the present paper. While some vocabulary (such as *dunga weep) is common to these and New South Wales (including Sydney area), some of it (Including this same root) is also found in the north-west of Western Australia, as O'Grady's study (1967) shows. These types do represent an early stage of syntactic expression in Australia, but are so widely shared - outside the continent as well as in 1 - that 1t can hardly have the historically diagnostic value one might be inclined to assign to 1 .

2. A small set of auxiliarles - ma-, ga-, ba- and with greater limit na-, seems to hang together all over the continent, from WD to New South Wales. The connection between the presence of these as a series is so constant that they do seem to be established as a related set. The first two have definite semantic content that also seems to be constant. Its activity varies; in some areas these roots can still function as independent verbs, in others rather less so. Another stage can possibly be recognised in the contrast between languages in which confugation is based on an auxiliary ma as one or sole auxiliary, and languages in which ma is a formative, not in any sense a free form with a definite lexical meaning, but without semantic content other than 'transitivity' of which 1t serves as a marker. This group seems to comprise the languages between the Dividing Range and the Darling River in New South Wales (where even some intransitive verbs can have ma). Other auxiliaries, especially ga, may be present here, and 1t seems likely that this represents the breakdown of a system still holding fairly well together on the coast (Dhurga northward to Bandfalong), and that this is itself the remains of a fuller system from WD and Central Australia. If these hypotheses are reasonable, something more may be built upon them. At the same time, ma is still felt to be an auxiliary rather than part of a verb stem in the coastal languages themselves, in that another suffix - such as the negative is interpolated between the root and the ma to which personal endings are added, e.g. Gandangara:

$$
\begin{aligned}
& \text { nala muga ma-nja } \\
& \text { sit not } A U X-I
\end{aligned}
$$

as against Dharawal

$$
\begin{array}{ll}
\text { bu-1 } & \text { ma-mbera-nay } \\
\text { strik-ing } & \text { AUX-Zong-ago-I }
\end{array}
$$

which seems to represent an even earlier pattern in which the verbal noun bu-l strik-ing occuples the 0 position in SOV sentence type 
patterning as

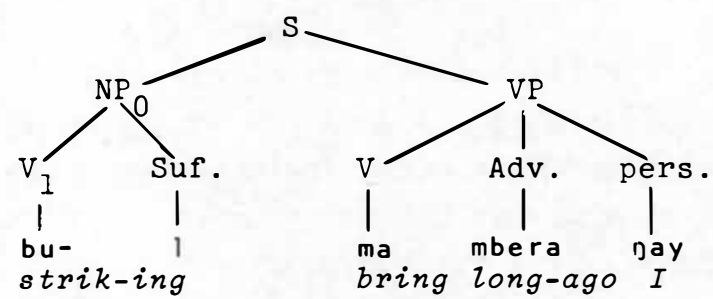

This is an even earlier pattern, for gay is practically the free pronoun jayu $I$. The 1mplications of this occurrence in this area where noun roots + suffix so often = pronoun cannot be brought out here.

From the historical point of view a suggested summary of the foregoing study would be as follows:

1. The ma-, ba- and ga serles of auxiliarles is CA. This statement rests on the wide occurrence of these in the acknowledged CA regions of the continent, and their overwhelming influence where these $\mathrm{CA}$ languages have spread. In the WD area in particular they are of great importance. The ba and ga serles are chlefly manifested as independent elements in the catalyst area, but occur in a somewhat degraded form in the eastern languages also. Their use as formatives will be the latest development, and in many of the eastern languages their original meanings are not always clear, in that ma is liable to occur with intransitive roots, and not only with transitives, as it originally did. In the eastern languages they have come rather as formatives than as free auxiliarles because they were not native to languages which took them over, and so had not discrete conceptual meaning to the speakers, only a general indication of type of action. The pa forms remain somewhat obscure: 1t would seem that these did not spread very widely. Threlkeld in his 'Key' (Threlkeld 1850) in his continual effort to analyse the Awaba formatives psychologically or conceptually, speaks of $\mathrm{h}$ - as a personal marker; $n a-$ as 'actuallty of personal1ty', 'person as actual', and $\eta \mathbf{i}$ - 'Indication of person', a peculiar phrase used when one leaves another to be in place: ji-noa-ki you remain, $I$ go. Under the first heading he refers to ja-n who?, jatoa (jaduwa) it is $I$ who..., and ne:l place of action as in ta-kili-nel (dagiline:l) eating place. This suggested to the writer (Capell 1956/62:70) 'personal action', and the catalyst ou as a local phonetic variation of 1t. However, if there is any truth in this, ja- became a pronominal root rather than a marker of verbal activity. In fact it is the marker of first person pronouns in the bulk of Australian languages, and the situation is still obscure. The possible history of ga- is best left 
unsettled, and the general discussion limited to the other three auxiliaries.

There has been higher development of the auxiliarles in the western desert area, where the original CA group of languages would appear to have taken on 1ts special character. The movement eastward remains to be traced, but this is a matter for the general paper on the languages and not for this special line of study.

2. The PV systems are to be set apart from this development altogether. They would seem to be indigenous to the CY languages and traces of them are st1ll found in areas in which dependence on the CY stratum are located - along the east coast at least as far south as Bandjalong.

3. There are non-CA systems visible also in a number of languages such as those of the far South Australian languages (Yaralde, Murund1, etc.) and other southern areas where CA had less influence.

If 1 is is true that the basic auxiliaries do not occur in New South Wales west of the Darling River, and are absent from the greater part of Queensland, but do occur in eastern New South Wales and southern Queensland, further investigation is required as to how they reached these latter areas. Vocabulary comparisons (which belong to the general paper) Indicate that $C A$ influences cross through northern Victoria into coastal New South Wales, and as suggested here, spread by Sprachbund methods to the interior regions of the Wiradjuri-Gamilaray. It is to be presumed that the use of the auxiliaries ma, ga, and in some cases ba reached New South Wales as part of the 'packet'. What is needed is further information on east coastal Queensland, and this is lacking for the regions south of Dfirbal.

In DJirbal, Dixon (1972:86) shows a formative -bil which forms intransitive verbs from other parts of speech, and -mal which forms transitive verbs from roots of two syllables (1f there are more than two syllables the suffix is -mbal). Amongst his examples are

$$
\begin{aligned}
& \text { bayi yaRa bulgan the man is big } \\
& \text { bayi yaRa bulganbil the man has become big }
\end{aligned}
$$

In these cases the final -1 is a confugation marker, not the gerund marker; the suffixes are -ma and -bi (-ba?). If the last 1dentification is right then two of the auxiliarles are present here, ma and ba, transitive and intransitive respectively. They would seem to be late formations in that they do not strictly follow the original uses and meanings of the suffixes. In Awaba (New South Wales) for instance, they do have much greater sense of function or original meaning, so 
that the southern forms would seem to be earlier and possibly brought in with the CA stratum of language directly.

At the absence of information from Djirbal south to Waga-GabigabiBandjalong is a handicap. There is very little such to hand at present and $1 t$ will be of interest, if further material can still be gathered, to find out what it has to tell about the movements of the CA auxiliaries.

At present the survey seems to end at this point, with the list of suggestions made at the beginning of this section. The commonly shared auxiliarles are of CA orlgin, but have been modifled in both usage and meaning in different ways in various regions. How this has historically come about is part of the questions that belong to a general history of language in Australia. 
A. CAPELL

\section{BIBLIOGRAPHY}

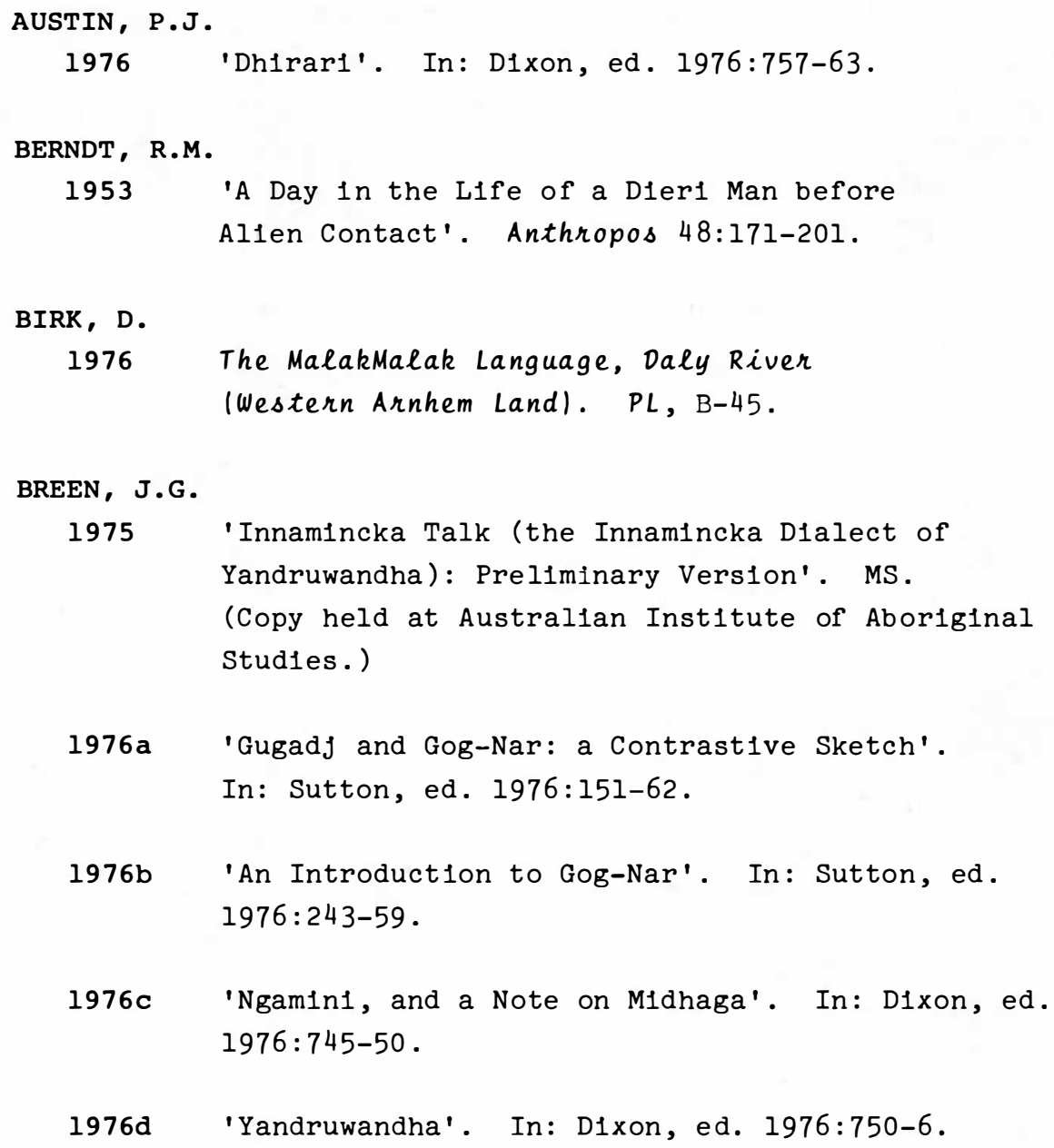


CAPELL, A.

1940

'The Classification of Languages in North and North-west Austral1a'. Oceania 9/4:382-404; 10/3:241-72; 10/4:404-33.

1942 'Languages of Arnhem Land, North Austral1a'. Oceania 12/4:364-92; 13/1:24-50.

1953 'Notes on the Nj1gina and Warwa Tribes, NorthWest Austral1a'. Mankind 4/11:450-69.

1955 'Forchheimer and the Pronoun'. (A review article.) Oceania 25/4:283-91.

A New Approach to Australian Linguistics. Oceania Linguistic Monographs 1. University of Sydney. New edition 1962.

1962 Some Linguistic Types in Australia. Oceania Linguistic Monographs 7 . University of Sydney.

1968 'What Do We Know of Tasmanian Languages?' Launceston, Tasman1a: Records of the Queen Victoria Museum $30: 1-7$.

1970

'Aboriginal Languages in the South Central Coast, New South Wales: Fresh Discoveries'. Oceania 41/1:20-7.

1971 'H1story of Research in Australian and Tasmanian Languages'. Current Trends in Linguistics, vol. $8: 661-720$.

1972

'The Languages of the Northern Kimberley, W.A.: Some Structural Principles'. Oceania 43/1:54-65. Summary'. In: Dixon, ed. 1976:615-25. 
CAPELL, A. and H.E. HINCH

1970 Maung Grammar, Texts and Vocabulary. The Hague:

Mouton.

CARROLL, P.J.

1976 'Gunwinjgu'. In: Dixon, ed. 1976:704-8.

CUNNINGHAM, M.C. (SHARPE)

1969 A Description of the Yugumbir Dialect of Bandjalang. university of queensland Papers, Faculty of Arts $1 / 8: 69-122$.

DAWES, W.

1790 Grammatical Forms of the Languages of New South Wales in the Nelghbourhood of Sydney in the Year 1790.

Notebooks in the Marsden Collection, S.O.A.S. Library, London.

DIXON, R.M.W.

1972 The Dyirbal Language of North queensland. London:

Cambridge University Press.

1977 A Grammar of Vidin. Cambridge Studies in Linguistics

19. Cambridge University Press.

DIXON, R.M.W., ed.

1976 Grammatical Categories in Australian Languages.

AAS, L22. Canberra: Australian Institute of

Aboriginal Studies.

DOUGLAS, W.H.

1968 The Aboriginal Languages of the South-west of

Australia. AAS 14, L4. Canberra: Australian

Institute of Aboriginal Studies.

EADES, D.K.

1976 The Dharawal and Dhurga Languages of the

New South wales South Coast. AAS, RRS 8. Canberra:

Australian Institute of Aboriginal Studies. 


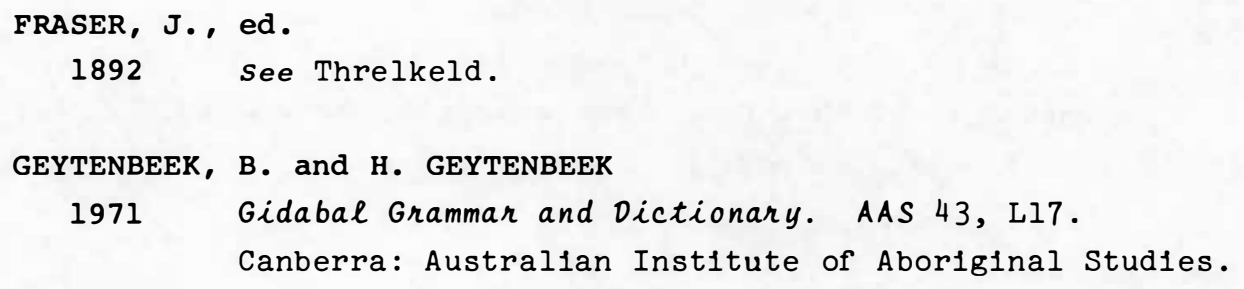

GLASS, A. and D. HACKETT

1969 Pitjantjatjara Texts. AAS 19, L7. Canberra:

Australian Institute of Aboriginal Studies.

1970 Pitjantjatjara Grammar: A Tagmemic View of the Ngaanyatjara (warburton Ranges) Dialect. AAS 34, L13. Canberra: Australian Institute of Aboriginal Studies.

GRIMWADE, G.

1975 Narinjari: an Outline of the Language Studied by George Taplin, with Taplin's Notes and Comparative Table. Part 2. George Taplin and His Work on Aboriginal Languages. Oceania Linguistic Monographs 17 . University of Sydney.

GUNSON, N.

1974 Australian Reminiscenses and Papers of L.E. Threlkeld, Missionary to the Aborigines, 1824-1859. 2 vols. AAS 40, E2. Canberra: Australian Institute of Aboriginal Studies.

GÜNTHER, Archdeacon J.

1892 Grammar and Vocabulary of the Aboriginal Dialect Called the Wirradhur1'. In: Threlkeld; Fraser, ed. $1892: 56-120$.

HALE, K.L.

1973 'Person Marking in Walb1r1'. In: S.R. Anderson and P. K1parsky, eds A Festschrift for Morris Halle. New York: Holt, Rinehart and Winston. 308-44. 
HALL, A.H.

1972 A Study of the Thaayorre Language of the

Edward River Tribe, Cape York Peninsula, Queensland.

Ph.D. thes1s, University of Queensland.

HARRIS, J.K.

1969 'Preliminary Grammar of Gunbalang'. PL, A-17:1-49.

HERCUS, L.A.

1969 The Languages of Victoria: A Late Survey. 2 parts.

AAS 17, L5 and L6. Canberra: Australian Institute of Aboriginal Studies.

HODDINOTT, W.G. and F.M. KOFOD

1976 'Ngang1kurungur'. In: D1xon, ed. 1976:691-8.

HOLMER, N.M.

1966 An Attempt Towards a Comparative Grammar of Two

Australian Languages. Part 1. AAS 5, L3.

Canberra: Australian Institute of Aboriginal Studies.

1967 An Attempt Towards a Comparative Grammar of Two

Australian Languages. Part 2. AAS 5, L3.

Canberra: Australian Institute of Aboriginal Studies.

HUDSON, J.

1976 'Walmadjar1'. In: D1xon, ed. 1976:653-67.

MCKELSON, K.

1974 'Studies in Garadyar1'. La Grange, Western Austral1a. Xeroxed.

1975 'Learn a Language'. La Grange Mission, Western

Australla. Xeroxed; 140pp. +4 cąssettes.

(Garadyar1)

MATHEWS, R.H.

1901 'The Thurrawal Language'. Royal Society of

New South wales Journals and Proceedings 35:127-60.

1902 'The Aboriginal Languages of Victorla'. Royal Society 
of New South wales Journal and Proceedings $36: 71-106$.

1903 'Some Aboriginal Languages of Queensland and Victoria'. Proceedings of the American Philosophical Society 42:179-88.

1904 'The Ngunawal Language'. JRAI 34:294-9.

MOORHOUSE, M.

1846 A Vocabulary and Outline of the Grammatical Structure of the Murray River Language... Adelaide: A. Murray. Public Library of South Austral1a: South Australian Facsimile Editions 41, 1962.

MÜLLER, F .

1876 Grundriss der Sprachwissenschaft. 4 vols. Australian in vol. 2, section 1:1-99.

NEKES, H.

1938 The Pronoun in the Nyol-Nyol (Nyul-Nyul) and Related Dialects'. Oceania Monographs 3:139-63. University of Sydney.

NEKES, H. and E.A. WORMS

1953 Australian Languages. Micro-Bibliotheca Anthropos 10.

OATES, L.F.

1964 A Tentative Description of the Gunwinggu Language. Oceania Linguistic Monographs 10. University of Sydney .

O'GRADY, G.N.

1964 Nyangumata Grammar. Oceania Linguistic Monographs 9. University of Sydney.

O'GRADY, G.N., C.F. VOEGELIN and F.M. VOEGELIN

1966 Languages of the world: Indo-Pacific Fascicle Six. Anthropological Linguistics 8/2. Indiana UnIversity. 
PLATT, J .

1974 'What's Becoming What? A Note on Inchoatives in Pitfantfatjara'. Linguistic Communications 14:110-19. Monash Univers1ty.

REUTHER, J.G.

1896 The New Testament in Diyar1.

RIDLEY, W.

1875 Kámilarói and Other Australian Languages... 2nd edn. Sydney: Government Printer.

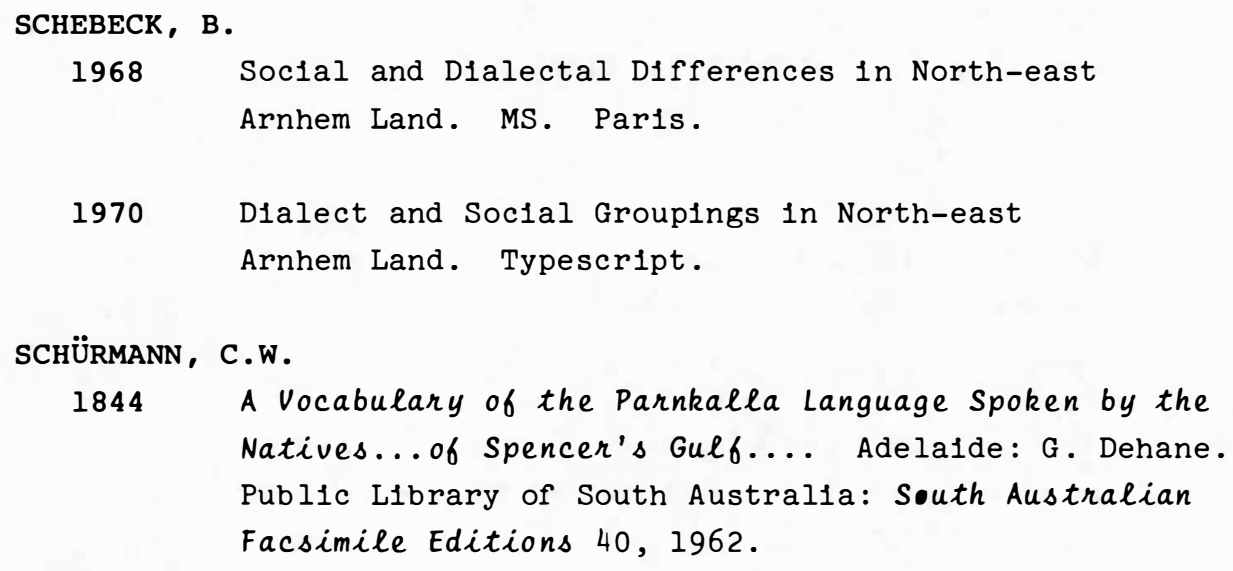

1844 A Vocabulary of the Parnkalla Language Spoken by the Natives... of Spencer's Gulf.... Adela1de: G. Dehane. Public Library of South Australia: South Australian Facsimile Editions 40, 1962.

SHARPE, M.C.

1976 'Alawa, Mara and Warndarang'. In: D1xon, ed. $1976: 708-34$.

SMYTHE, W.E.

1948 Elementary Grammar of the Gumbdingar Language (North Coast, N.S.W.). Oceania Monographs 8. Sydney: Australian National Research Counc1l.

SUTTON, P.J., ed.

1976 Languages of Cape York. AAS, RRS 6. Canberra: Australian Institute of Aboriginal Studies.

TAPLIN, G.

1878 A Grammar of the Narrinyeri Tribe of Australian Aborigines. Adela1de: Government Printer. 
1880 Grammar of the Narrinyeri Tribe. Adela1de.

TAULI, $\mathrm{V}$.

1958 The Structural Tendencies of Languages. I. Helsink1: Suomalainen Tiedeakatemia.

TEICHELMAN, C.G. and C.W. SCHÜRMANN

1840 Outlines of a Grammar, Vocabulary, and Phraseology, of the Aboriginal Language of South Australia.... Adelaide. Public Library of South Australia: South Australian Facsimile Editions 39, 1962.

THRELKELD, L.E.

1834 An Australian Grammar... of the Language, as Spoken by the Aborigines.... of Hunter's River, Lake Macquarie, $\&$ New South wales. Sydney: Stephens and Stokes, Herald office.

1850 A Key to the Structure of the Aboriginal Language.... Sydney: Kemp and Falrfax.

THRELKELD, L.E., edited by J. FRASER

1892 An Australian Language as Spoken by the Awabakal, the People of Awaba on Lake Macquarie.... Re-arranged, condensed, and edited, with an appendix, by John Fraser. Sydney: Government Printer.

TRUDINGER, R.M.

1943 Grammar of the P1tjantjatjara Dialect, Central Austral1a'. Oceania 13/3:205-24.

TRYON, D.T.

1968 'The Daly River Languages: A Survey'. Papers in Australian Linguistics No. 3:21-46. PL, A-14.

1970 An Introduction to Maranungku (Northern Australia). PL, B-15.

1971 'The Wageman Language'. Papers on the Languages of Australian Aborigines: 1-11. AAS 38, L16. Canberra: Australian Inst1tute of Aboriginal Studies. 
1974

Daly Family Languages, Australia. PL, C-32.

WILLIAMS, C.J.

1976

Yuwaaliyaay and Yuwaalaraay Dialects of North-Central N.S.W. B.A. (Hons)

subthesis, Australian National University, Canberra.

WORMS, E.A.

1942 'Sense of Smell of the Australian Aborigines:

A Psychological and Linguist1c Study of the Natives of the Kimberley Division'. Oceania $13 / 2: 107-30$.

WURM, S.A.

1969 'Person Marker Sequences in Australian Languages'. Papers in Australian Linguistics No. 4:51-70. $P L, A-17$.

1972 Languages of Australia and Tasmania. The Hague: Mouton.

YALLOP, C.

1975 Narinjari: An Outline of the Language Studied by George Taplin, with Taplin's Notes and Comparative Table. Part I. The Narinjari Language 1864-1964. Oceania Linguistic Monographs 17 . University of Sydney.

1977 Alyawarra. An Aboriginal Language of Central Australia. AAS, RRS 10. Canberra: Australian Institute of Aboriginal Studies. 


\title{
AUSTRALIAN CASE SYSTEMS \\ SOME TYPOLOGICAL AND HISTORICAL OBSERVATIONS
}

\author{
Barry J. Blake
}

\section{PREFATORY NOTE}

The phonemicisation used in quoting examples in this paper has been regularised to the scheme given below. However, I have retained the volceless symbols ( $p, t$, etc.) or volced symbols ( $b, d$, etc.) as in the sources. The difference between volceless and volced stops is not normally significant in Australian languages.

Lablals: $p, m$; lamino-dentals: $t, n, l$; aplco-alveolars: t, n, i, r (flap); aplco-postalveolars (retroflexes): t, n, !, r (glide); lamino-palatals: $t^{\gamma}, n^{\gamma}, i v, y$; velars: $k, 0, w$; vowels: $i, a, u$. Some languages have a 'trilled $r^{\prime}: r r$; some have a glottal stop: ?.

In general language names have been spelled in accordance with A.I.A.S. conventions.

Examples quoted in the text are numbered consecutively and numbers quoted in the text refer to these examples. Paragraphs are referred to by compound numbers, e.g. 2.1.

The expansion of the abbreviations for Australian states (e.g. Q. for Queensland) is avallable on the map.

\section{ACKNOWLEDGEMENTS}

I would like to thank the following people for reading the first draft and supplying me with a number of helpful comments: Peter Austin (A.N.U.), Gavan Breen (Monash), Bob Dixon (A.N.U.), Ken Hale (M.I.T.), Luise Hercus (A.N.U.), Tasaku Tsunoda (Griffith), and Stefan Wurm (A.N.U.). 


\section{Notes on the Map}

The map does not include Tasmania.

It is uncertain whether the extinct languages of Tasmania were related to those of the mainland. Recent work by the author has tentatively established a tenuous lexical link with the western Kulin languages of western Victoria and hence indirectly with the mainland in general. 


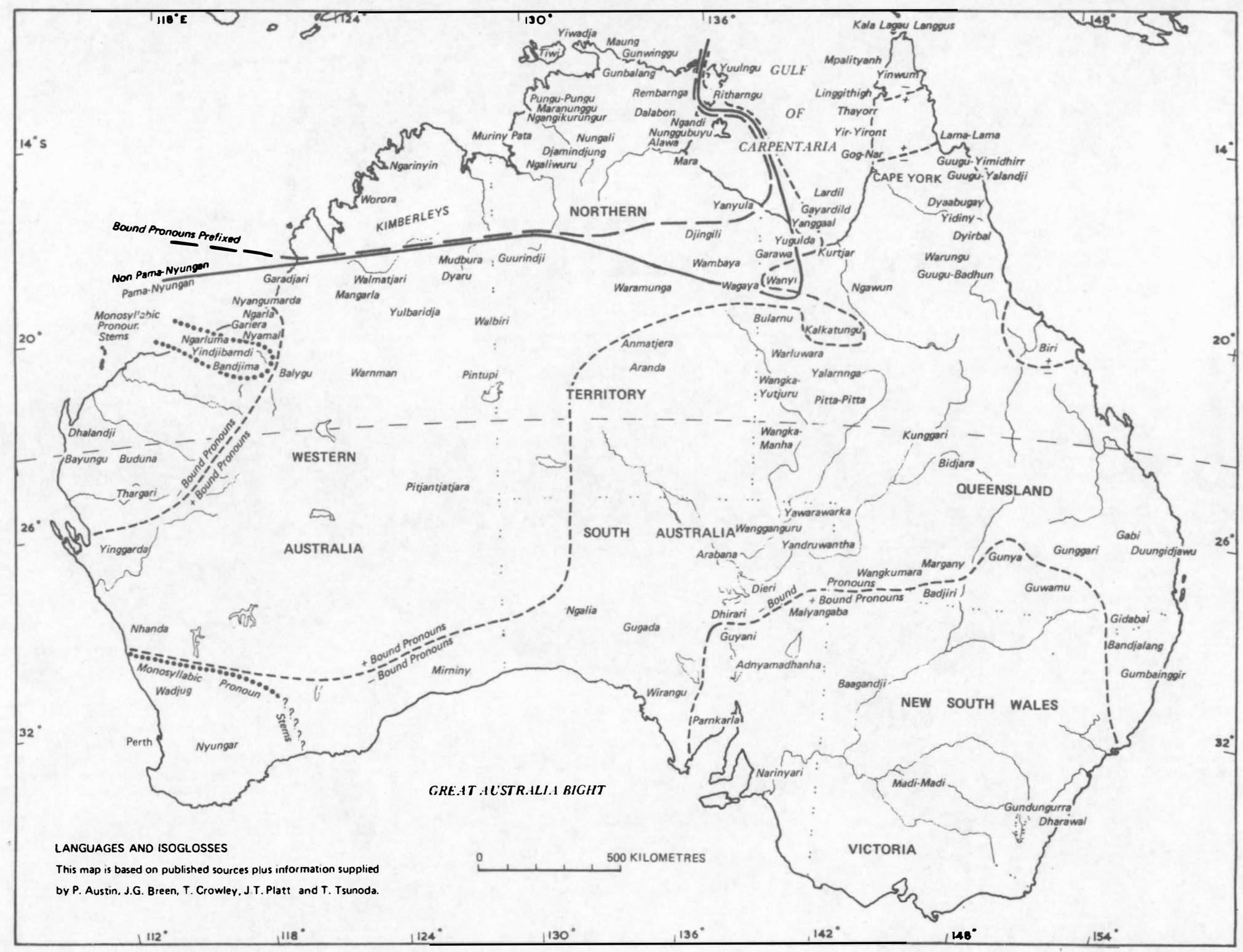





\section{TYPOLOGICAL OUTLINE}

\subsection{The Major Syntactic Case Relations}

In this paper I use the convention of labelling case relations in capitals (DATIVE, INSTRUMENTAL, etc.) and case forms in small letters (dative, instrumental, etc.). The major syntactic case relations are labelled INTRANSITIVE SUBJECT $\left(S_{1}\right)$, AGENT $(A)$, and PATIENT $(P)$. A morphological or syntactic system identifying $S_{1}$ and $A$ is described as 'accusative', a system 1dentifying $S_{1}$ and $P$ is described as 'ergative'.

In describing the systems for marking the major syntactic cases $\left(S_{1}, A\right.$ and $P$ ) to be found in Australian languages, it is convenient to distinguish between the Pama-Nyungan family which covers most of the continent and the non-Pama-Nyungan family which occupy the Kimberleys and the Top End (see map). The classification of Australian languages that recognises Pama-Nyungan, etc. was based on cognate densities between lexical 1tems. However, this classification corresponds broadly to what we would find if we classified according to cognate densities between function morphemes or according to morpho-syntactic systems. The classification in 1ts revised form (Wurm 1972) recognises twentyseven non-Pama-Nyungan families.

Most Pama-Nyungan languages employ an ergative system of case marking for nouns and an accusative system for pronouns. The case marking is in the form of suffixes to the last word in the noun phrase or to all primary constituents of the noun phrase. The ergative is commonly marked by allomorphs such as -lu (after vowels) and -tu (after consonants), the latter assimilating in point of articulation to some or all consonants. In some languages - nku is used with vowel stems of fewer than three syllables and -lu with longer stems. The accusative is usually marked by -na or $n v a$. Many but by no means all the PamaNyungan languages employ cross-referencing bound pronouns. In some languages these are suffixed to the verb, in others to the first word 
of the clause and in others again to a special auxiliary particle. Almost invariably these bound pronouns operate in an accusative system, the identification of $S_{1}$ and $A$ showing up in case marking or via suppletion (as in English she v. her).

The following examples are from Pltjantjatjara (S.A., W.A., Douglas 1964, Glass and Hackett 1970). Pitjantjatjara is a typical Pama-Nyungan language with nouns operating in an ergative paradigm and free pronouns operating in an accusative paradigm. There is also a system of bound pronouns which operate in an accusative paradigm, these bound pronouns generally belng suffixed to the head word of the clause (but see example 7). The cholce between using bound pronouns or free pronouns or both is free at the information level. A number of factors determine which pronouns are used; the bound forms generally represent the unmarked cholce but a free pronoun is used if the referent is to be emphasised. The bound pronouns are potentially cross-referencing, but we do not have the classic cross-referencing system of obligatory bound pronouns that characterises most of the non-Pama-Nyungan languages.

1. wati pika

man sick

The man is sick

(Douglas: 30 )

2. wati-lu tritri pu-nu

man-erg child hit-past

The man hit the child

(Douglas : 30 )

3. nayulu nyarajka nyina-ju

I there sit-past

I sat there

(Douglas: 32 )

4. nayulu papa nya-nu

I dog see-past

I saw a dog

(Douglas : 58)

5. wati-lu nayu-nya nya-nu

man-erg me-acc see-past

The man saw me

(Douglas: 59)

6. nyuntulu-n yina tyukumunu

you-you old man big

you are a very old man

(G \& H: 96)

7. Dayu-nya munta-ni i-n wana-lku

me-acc query-me-you follow-fut

Will you follow me?

(G \& H: 48) 
8. ka-nta-ya pini-lu nya-ku

and-you-they many-erg see-fut

And many people will see you

(G \& H: 48)

Note the appearance of a hierarchical principle of ordering bound pronouns in the last two examples. In general the first person bound pronoun precedes second or third and second precedes third, Irrespective of grammatical function (though $-n$, the second person singular form for $S_{1}$ and $A$, is always sequence-final ( $G$ \& $H$ : 47-48). Hierarchical principles involving person, and to a lesser extent number, are falrly common in Australia, and they usually show up in the relative ordering of bound pronouns.

Typically the non-Pama-Nyungan languages lack case marking for $S_{1}, A$ and $P$ and rely instead on cross-referencing pronouns to mark the major syntactic relations. These cross-referencing systems operate e1ther on an accusative system as in T1w1 (Bathurst and Melville Islands, N.T., Osborne 1974) or in a way that involves sufficient fusion and other sources of 1rregularity as to make the system synchronically unanalysable. In most of the non-Pama-Nyungan languages, the cross-referencing pronouns are preflxed to the verb. The following example is from Gunwinggu /kunwinyku/ (N.T., Oates 1964:108), from the story of Godewele the Giant,

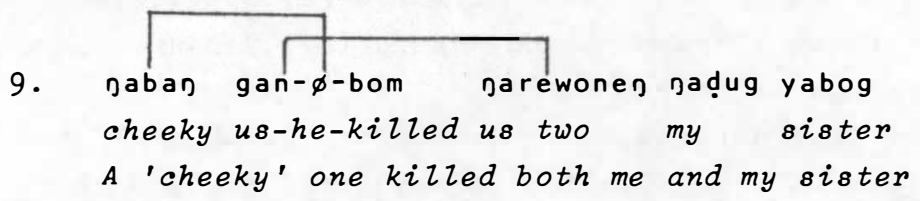
gan is not specifically us. ga- can refer to a first person $P$ of any number acted on by a second person, or a non-singular first person $P$ acted on by a third person. $-n$, if the combination is to be analysed, is an accusative marker, but $I$ am dubious about whether an analysis is a valid reflection of the synchronic organisation of the prefix rather than an exercise in internal reconstruction.

Very broadly we could sum up the case marking systems for the major syntactic relations as follows:

Pama-Nyungan

$\begin{array}{llll} & S_{1} & A & P \\ \text { Nouns } & -\varnothing & -I u^{I} & -\varnothing \\ \text { Pronouns } & -\varnothing & -\varnothing & { }_{N} v_{a^{2}} \\ \text { (Bound Pronouns } & \text { Accusative System) }\end{array}$


Non-Pama-Nyungan

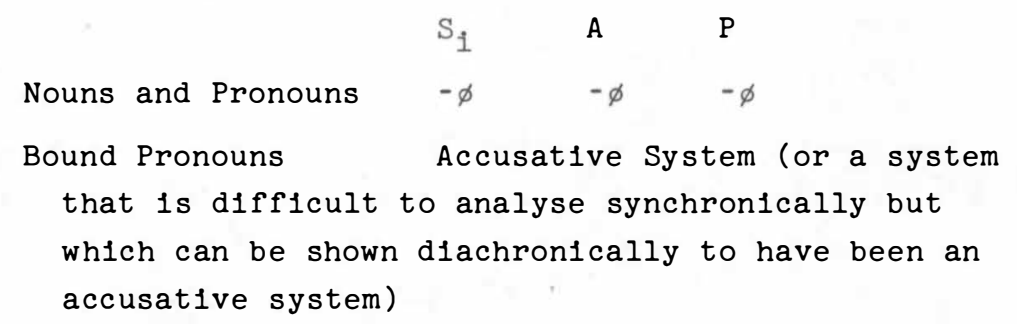

There are numerous exceptions to the broad summary given above; some deta1ls appear in Blake 1977. Among the Pama-Nyungan languages accusative marking often intrudes into the basically ergative system so that in some cases human nouns (e.g., Arabana, S.A., Hercus p.c.) or all animate nouns (e.g., Thargar1, W.A., Kloke1d 1969), or in a few instances all nouns, have accusative as well as ergative marking (e.g., Wangkumara, Q., Breen 1976a). Also in some Pama-Nyungan languages ergative marking often intrudes into the basically accusative pronoun paradigm so that some person/number combinations, especially first and second singular, have ergative as well as accusative marking. For example, the Giramay dialect of Dylrbal has a three-way contrast ( $S_{1}, A$ and $P$ being separately marked) in the first and second singular (D1xon 1972:50) as has Gab1 (Q., Mathew 1910:28, quoted by D1xon 1972:7). Yandruwantha (S.A.) has a three-way contrast for all singular pronouns (Breen 1976c:595) and Aranda (N.T.) has a three-way contrast on first singular only.

Ergative marking is scattered sporadically among the non-PamaNyungan languages with a concentration in the east, e.g., Garawa, Yanyula, Wagaya, Wambaya, DJingll1 and Alawa exh1b1t ergative marking.

It is rare for ergative marking to be found in the bound pronouns. Yugulda (Q., Keen 1972) has an ergative/nominative/accusative distinction in the first and second person and some languages in or near New South Wales, especlally near the ' \pm bound pronoun 1sogloss' (see map), have some ergative bound forms. Yanyula (N.T., Hale p.c.) is unusual among non-Pama-Nyungan languages in having some ergative marking in the bound pronoun system.

\subsection{Dative}

Almost every Australian language has a suffix that could be labelled 'dative'. In very many of these languages the form is -ku or -wu or both; where both varlants occur, -ku normally appears with consonant-final stems, and -wu with vowel-final stems. The range of function may embrace: (a) the adjunct of an intransitive verb or the 
complement of a semi-transitive verb; ${ }^{3}$ (b) the 'indirect object' of transitive verbs, (c) possessor, (d) purpose, (e) beneficlary and in some languages the notion of indirect cause or reason (compare English for in she did it for spite). ${ }^{4}$ However, in a large number of languages there is a separate genitive suffix to make the possessor; in a few languages there is a separate form to mark purpose, and in a very small number of languages there is a separate form to mark beneficlary. The Indirect object of verbs for give is quite often expressed in the same way as $P$ rather than by the dative, but the indirect object of verbs for show, teach and tell is usually in the dative.

In some languages the dative form also expresses to or towards, but more often there is a separate allative form.

In some languages, mostly the Pama-Nyungan languages of Western Australia, the form that expresses the LOCATIVE case relation competes with the dative form in expressing some of the functions listed above. In Pitjantjatjara, for example, the indirect object of the verbs for say to, teach and show appear in an indirect object/locative/ instrumental form.

The dative plays a part in a number of interesting constructions. In some instances 1 ts use is semantically motivated; in others it is syntactically motivated.

A few languages use an intransitive-like construction to express ongoing as opposed to completed activity, and/or attempted as opposed to successfully completed activity and/or indefinite as opposed to definite $P$. In Kalkatungu ${ }^{5}(Q)$, for instance, we find contrasts such as

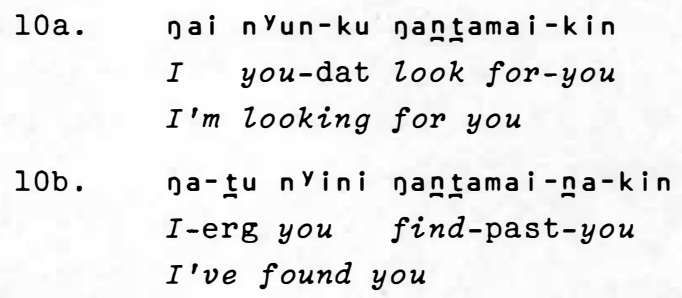

Note that in 10a we have the same case marking as in an intransitive sentence, but note also the presence of the bound pronoun (-kin) for P. This cross-referencing bound pronoun could not be used in a genuinely intransitive sentence such as

$$
\begin{aligned}
& \text { 11. Dai nyun-ku inka } \\
& \text { I'm coming for you }
\end{aligned}
$$

10b represents the normal ergative construction. In Kalkatungu pronouns as well as nouns operate in an ergative system. The use of 
bound pronouns in independent clauses is optional.

Examples of syntactically motivated constructions involving the dative are given in 3.3 and 3.4 . See also 3.6 .1 for further discussion of the construction illustrated in $10 \mathrm{a}$.

\subsection{Concrete Cases}

Australian languages typically exhibit an allative case (to), a locative case ( $a t$, near, etc.) and an ablative case (from).

The INSTRUMENTAL case relation is rarely expressed by a separate case form. Most often it is syncretised with the ergative, in a minority of languages with the locative (e.g., Pitjantjatjara, W.A., Warluwara, Q.). Where it is syncretised with the ergative, the INSTRUMENTAL can usually be distinguished from A on syntactic grounds. If the language has a cross-referencing system, $A$ but not the INSTRUMENTAL is cross-referenced.

The sense of Indirect cause or reason (He died from snakebite) is often expressed by a separate case suffix, the 'causal'. Where there is no separate causal case form, this function is expressed by the ablative, or in some instances by the locative, instrumental or dative.

\subsection{Pama-Nyungan Case Systems}

The following chart is intended to give an overall impression of the Pama-Nyungan case system. It is not the system of any particular language but a generalised version to which the systems of most PamaNyungan languages approximate. The curly brackets indicate common syncret1sms.

It is not possible to display the rather more divergent non-PamaNyungan systems on a chart. The principal difference is that usually they exhibit no case marking for $S_{1}, A$ and $P$ and that the other case relations are expressed by a greater variety of forms. 
12. Pama-Nyungan Case Systems

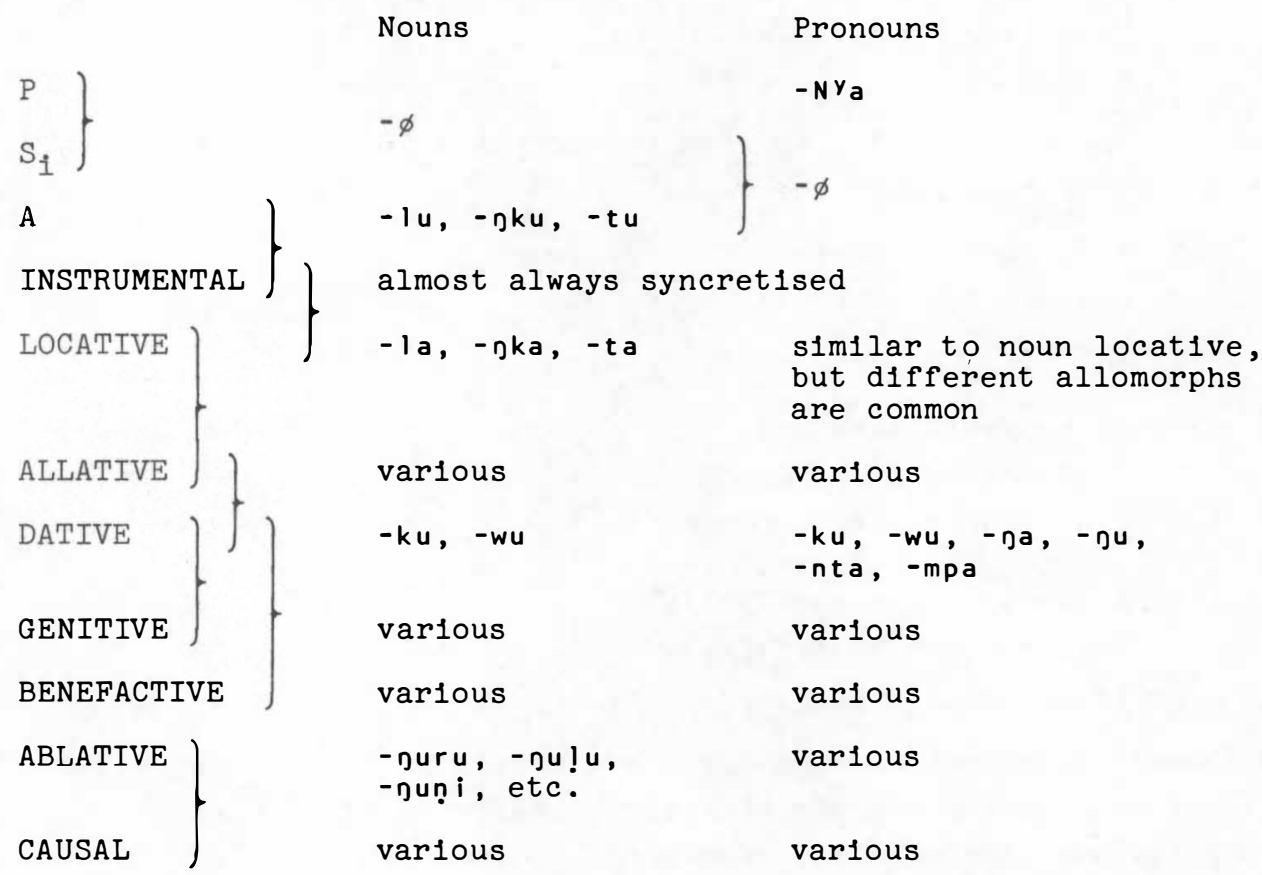

\subsection{Transitivising Mechanisms}

Most if not all Australian languages have a productive suffix to convert intransitive verbs to transitive and some have suffixes for converting transitive verbs to ditransitive.

The most commonly encountered mechanism is a suffix for forming transitive verbs from intransitive ones with the $P$ of the transitive verb corresponding to the $S_{1}$ of the intransitive. In Kalkatungu, for instance, we find,

13a. pila-pila iti

child return

The child goes back

13b. marapai-țu pi la-pi!a iti-nti

woman-erg child return-cause

The woman sends the child back

Kalkatungu also has the non-productive causative -ma and also a

productive causative -puni for nouns and adverbs

14. ma paa yarka

food there far

The food is over there 
15. maa paa yarkapuni $i^{6}$

food there far-cause

He put the food over there

$-n t i$ ( -manti) may also be used to express a LOCATIVE, INSTRUMENTAL or CAUSAL relation through the verb,

16. țuku-yu nu-nti i-na

dog-erg lie-LOC-past

The dog lay on it

17. na-țu kunti wati-nti i

I-erg house clean-INSTR

I cleaned the house with it

18. mațu-yu lai-mantii-kin

mother-erg hit-CAUSAL-you

(Your) mother hit you because of it

However, these constructions are used mostly in subordinate clauses where the noun phrase bearing the case relation is anaphorically deleted and the case marking transferred to the verb,

19. ucan caa anpa-ya maa-tyi țuyi-manti-caya wood here gather-imp food-dat cook-INSTR-purposive Get some wood to cook the food with

Some languages have devices for expressing the DATIVE case relation in the same way as $P$. This enables certain intransitive verbs to be transitivised and certain transitive verbs to become ditransitive. In Pitta-Pitta (Q.) for instance, -la is used to transitivise a verb like tiwa (be jealous of) so that it can be made reciprocal, reciprocal formation applying only to transitive verbs,

20. Danytya muyutyu-ku tiwa-ya

I old woman-dat jealous-pres

I'm jealous of the old woman

21. tiwa-la-mali-ya mana pula-ka

jealous-tr-reclp-pres might they two-unmarked delctic

They might be jealous of one another

It is also used to incorporate the DATIVE in the case frame of the verb of a transitive verb as a 'second object' in examples like the following,

22. nanpaka kaṇța-ka yanțurru-na mari-lina nanyari-ña

she go-past food-acc get-infin me-dat-acc

She went to get food for me 


\section{3. nanpaka kaṇta-ka yanţurru-ña mari-la-lina nanya she go-past food-acc get-tr-infin me-acc \\ She went to get me some food}

\section{MORPHOLOGICAL DEVELOPMENT}

\subsection{Nouns}

\subsubsection{Ergative(-Instrumental)}

The ergative is commonly represented by $-l u,-\eta k u$, and $-T u$, one or more of these forms appearing in a given language. Where all three varlants occur, -lu often occurs with vowel-final stems of more than two syllables, -nku with disyllablc vowel stems (very often there are no monosyllabic stems), and -Tu occurs with consonant stems. T assimllates in point of articulation to the final consonant of the stem.

The relationship between $-1 u$ and $-T u$ is determined by whether we have a hardening or softening environment. -lu, the weaker variant, occurs with vowel stems, 1.e. with the consonant in the intervocalic leniting environment; -Tu occurs in the hardening environment of a consonant. The alternation between -lu and -tu is parallelled in the dative where -wu occurs following vowels and -ku following consonants, and also with the phonological filler -wa -pa (see 2.2.2.1) where -wa occurs with vowels and -pa with consonants. 7

The relationship between - oku and the other variants is explained by Hale (1976e) as follows.

Some Australian languages have a rule that appends a velar nasal to vowel stems. In some dialects of Anmatjera, an Arandic language of Central Australia, the velar nasal is appended to disyllabic noun stems only. If we posit *-lu as the basic, historically underlying form of the ergative, we can account for allomorphs such as - tu with alveolar stems and -țu with retroflex stems by rules of hardening and assimilation. The distribution of possible final consonants in contemporary languages suggests that a greater variety of consonants could once have occurred in word-final position in many languages than is now the case. In particular, labials and velars tended to be eliminated from word-final position. This would mean that stems ending in velar nasals and exhibiting ergatives in $-k u$, would come to display an alternation: nominative in zero, ergative in -oku. If languages ancestral to those that have -nku with disyllabic vowel stems once had the Anmatjera-type rule of adding velar consonants to vowel stems, then they would have had a preponderance of velar nasal stems and, after elimination of word-final velars, a preponderance of ergatives in -nku. -nku could then have been reinterpreted as the allomorph for 
disyllab1c vowel stems and generalised to all such stems. 8

In some languages (e.g. Dyaru, W.A., Tsunoda p.c.) -oku dissimilates to -ku if there is a nasal-plus-stop cluster in the stem (see 37 , cf. Blake forthcoming).

Some languages lack the full set of varlants given above. In some languages (e.g. Yalarnnga, Q.) there are no consonant-final stems and so it is not surprising to find no -tu. However, many languages have generalised $-l u$ or ${ }_{-}^{*} n k u$. In P1tta-Pitta (Q.) $-l u$ is the only variant of the ergative, but - $n u$ from - $n k u$ marks $S_{1}$ and $A$ in the future (see $54,55)$. Warungu uses - tu w1th consonant stems but has generalised - oku with vowel stems to the extent that -lu occurs only with wanyu (who) and as an optional variant with gayana (father) (Tsunoda 1974:84).

The forms given above have been subject to a few phonetic changes in various languages. - $\eta u(<*-\eta k u)$ occurs as the variant for disyllabic stems in Walmatjar1 (W.A., Hudson forthcoming) and In Kunggar1 (Q., Breen field notes) as well as in Pitta-Pitta as noted above. -ku (also <*-jku) occurs in Warluwara (Q., Breen 1971) and several languages of Victoria and New South Wales. -ru $(<*-1 u)$ occurs in Wangka-Manha (Q.) and In Arabana and Wangganguru (both S.A., Hercus p.c.). Vowel harmony, or more particularly harmony involving the high vowels occurs in some languages. Arabana and Wangganguru in fact have the harmonising variant - ri as well as -ru. Loss of final vowels has occurred in Cape York and in the Arandic languages of Central Australia. Thus in Aranda the generalised variant -lu appears as -!. In the south-west corner of the continent metathesis-cum-vowel reduction has produced ak $(<*-k u<*-\eta k u)$ and al $(<-l u)$. Thus in Wadjug -al appears as the generalised variant of the ergative (O'Grady et al. 1966:132) and in Nyungan -ak appears as the ergative marker (Douglas 1976).

The ergative marker occurs in all Pama-Nyungan languages except Lard1l, Yanggaal, and Gayardild (all closely related to one another and located on the Wellesley Islands and adjacent malnland at the bottom of the Gulf of Carpentaria) and Bandjima, Yindjibarnd1, Ngarluma and Garlera in north-west Western Australia. However, reflexes of lu occur marking the INSTRUMENTAL in Bandjima and the INSTRUMENTAL and the $A$ of the passive in Yindjibarndi (O'Grady et al. $1966: 84-103$ ).

In some Pama-Nyungan languages use of the ergative is optional. In these languages it is employed only when it is necessary to disambiguate a sentence. Baagandj1 (N.S.W., Hercus p.c.) is extreme in this respect using its ergative marker, -ru, very sparingly. 
Ngarluma and the other languages referred to above as lacking the ergat1ve marker are in fact accusative languages. The W.A. group (Ngarluma, etc.) seems to have moved from an ergative system to an accusative system by generalising 'surface intransitive' type patterns as 1llustrated in 10a. It is notable that in this group of languages $P$ is marked by $-k u$ (and other varlants) which represents a syncret1sm of $P$ and DATIVE. $-k u$ is very widely distributed in Australia as a dative marker. The following example is from Ngarluma (Hale 1968:14),

24. mankula țalku-na yukuru-ku child strike-past dog-acc/dat The child struck the dog

If this hypothesis is correct, $\mathrm{viz}$. that these languages have become accusative by generalising the 'surface intransitive' pattern, then what would otherwise be a remarkable coincidence, viz. the use of $-k u$ for $P$ as well as DATIVE in fust the accusative languages, is explained.

In Lardil and the other 'Gulf' languages cited above, we find an accusative system rather than an ergative system. In Lardil 1tself the only language of the group on which data has been published (Hale 1965, 1967a, Kloke1d 1976), the accusative is marked by (i)n, perhaps a reflex of the common Australian accusative marker *Nya (see below). However, in the future the accusative is marked by $-k_{u r}^{9} \sim-$ wur $\sim-r$ (see 2.1.4).

I rather think that Lardil has moved from being ergative to accusative, having generalised the 'surface intransitive' type construction in the future tense in the same way as Pitta-Pitta (see 54, 55) and then having extended this construction to the non-future.

There are positive signs of Lardil having been ergative, both in the forms of the first and second person singular pronouns (see discussion in 2.2.2.1) and in what Klokeld calls the cleft construction in which $P$ is in the nominative and $A$ in the genltive (Kloke1d 1976:557-558),

$$
\begin{aligned}
& \text { 25a. țanka kuparikun ti:nin wanalkin } \\
& \text { man make this-acc boomerang-acc } \\
& \text { The man made this boomerang } \\
& \text { 25b. ți:n wanal tanamen kuparițarkun } \\
& \text { this boomerang man-gen make } \\
& \text { It was this boomerang that the man made }
\end{aligned}
$$

The verb form in 25b. Is not passive, but the genitive is used to mark the $A$ of the passive. 
The use of the 'surface intransitive' construction for the future tense probably requires some explanation. The construction involves using the same marking that is used for an intransitive verb and its adjunct for a two-place verb (see 10a). Thus a verb for go will normally be intransitive and the 'goer' will appear in the nominative. The adjunct of such a verb normally appears in a case other than the one used for the $P$ of an unambiguously transitive verb, usually in what we call the dative. This same construction is usually used for some two-place verbs that do not involve impingement on the goal of the verb, e.g. verbs for look for or like. This of ten involves an awkward question of whether these verbs are simply intransitive or a special kind of transitive. If one is lucky, one finds certain formal characteristics of transitive verbs associated with them. In Kalkatungu, for instance, the verb okumai (to look for) takes a distinctively transitive pronoun form in the imperative, but on the other hand it has to be transitivised like any intransitive before it can be made reciprocal. Given this mixture of characteristics it should probably be labelled something like 'semi-transitive'. What is important however is the use of intransitive-like case marking for two-place verbs that do not involve impingement on the goal and the use of this same marking where reference is to uncompleted activity or future action. In each case there is no impingement or at least no completed impingement. The intransitive marking is also used for indefinite goals ( $I^{\prime} m$ cooking tucker), where reference is to the activity indulged in rather than specifically to activity carried out on the goal. It may be relevant to note that indefinite objects are probably more common with verbs in the imperfect or future. Think of characteristic patterns such as we are going to hunt kangaroo(s)/We cooked the kangaroo.

In any event we have a certain kind of 'logic' involved that opposes impingement and non-impingement so that the optional goal of a oneplace verb, the goal of two-place verbs that do not involve impingement because of their inherent semantics, and the goal of any two-place verb in the imperfect or future or an indefinite goal are treated alike in terms of case marking. The 'logic' is somewhat fuzzy and indefinite in Kalkatungu. In Yugulda (Q.), to Judge from Keen 1972, it is more definite but the 'logic' is slightly different in scope in that the use of the negative demands intransitive case marking. Pitta-Pitta (Q.) exhibits another version of the 'logic' (see 3.2). It is interesting to note that these examples are all from north-western Queensland and there is not much evidence of this kind of 
thing reported from other areas.10 Yugulda, interestingly enough, occupled an area on the southern coast of the Gulf across the water from the other accusative languages of the area. It is not surprising then to find that Lardil makes a future versus non-future distinction in its case marking using -kur etc. to mark the future accusative.

Whether I am on the right track in suggesting that Lardil became accusative by generalising the surface intransitive pattern to all future verbs and then generalising the $S_{1} A: P$ schema to the non-future remains to be seen. It is certainly a plausible line of development and it is a line of development for which there is some evidence in the case of P1tta-Pitta (see 3.2).

It is interesting to note the -ku (assuming Lardil -kur contains a reflex of $*-k u$ ) is Involved in the West Australian accusative languages, in the Wellesley Island accusative languages and in P1tta-P1tta, which is an accusative neutral mixture.

Among the non-Pama-Nyungan languages the ergative is not strongly represented. Many of these northern languages lack 1t entirely (e.g. T1w1, Osborne 1974), or use 1t rather sparingly (e.g. Dalabon, N.T., Capell 1962:111). In some languages a marker is used on $S_{1}$ as well as on $A$, and although such a marker is sometimes reported as an ergative, probably because it is common with A, its clalms to being an ergative are dublous. In Nganglkurungur (Daly River, N.T.) Hoddinott and Kofod (1976b:401-405) report the use of $n i n g i$ as an ergative (and instrumental) form, but they note that it is not always used to mark $A$ and that it is sometimes used to mark $\mathrm{S}_{1}$.

Non-Pama-Nyungan languages exhibiting an ergative, whether obligatory, optional or 'dubious', are scattered around and do not occur in a contiguous bloc. Since ergative marking is a minority feature among the world's languages, I interpret this distribution as reflecting remnants of a once ublquitous ergative system. The argument based on the scattered distribution is not conclusive of course, but it is made more plausible when one considers that all nonPama-Nyungan languages employ cross-referencing bound pronouns for the major syntactic cases and therefore there would be some redundancy involved in having case marking on noun phrases. I argue below that these cross-referencing bound pronouns are an innovation (see 2.3).

One weakness in this line of argument might appear to be the varlety of forms marking the ergative in non-Pama-Nyungan languages. Ngand1 (Arnhem Land, Heath forthcoming) appears to be one of the few with a reflex of $*-1 u \sim-t u .^{1 l}$ However, Ngandi has borrowed 1 ts form -tu from the nelghbouring Ritharngu language as Heath (forthcoming: 
chapter III) clearly demonstrates. Ritharngu is a Pama-Nyungan language of the Pama-Nyungan enclave in northeast Arnhem Land (see map). Alawa (N.T., Sharpe 1972) has forms like -ri, tri, -yiri, Rembarnga and Dalabon have yi?, Muriny Pata (Port Keats, N.T., Walsh 1976) has - te and -re. These may or may not turn out to be reflexes of *-lu $\sim *-t u$. A number of languages have forms such as $n v_{i}$ Nungal1 (N.T.), -ni Ngaliwuru and Djamindjung (N.T., Hoddinott and Kofod 1976a:397-401), -ni Wambaya (N.T.) and -ni Djing1l1 (N.T., Chadwick 1975, 1976). Ngangikurungur (N.T., Hoddinott and Kofod 1976b:401) has $n$ ingi as a 'dubious' ergative cum instrumental, and forms such as $n i$ occur in a number of Daly River languages (Tryon 1974) as an instrumental, and forms such as nyini, nyine, nvinta, $n v i n k e$ occur as instrumental forms in the languages of the Kimberleys. It is likely that these forms are cognate and that they have as their origin the provenience suggested by Chadwick (1976) for DJingili. They are likely to reflect a third person pronoun form. ${ }^{12}$ There are a number of possible ways this could have happened. The most likely seems to be from the use of a third person pronoun following an A noun phrase and bearing an ergative inflection. In Pitta-Pitta (Q.) for example, a language in which there are no bound pronouns, noun phrases in $S_{1}$ or $A$ function are normally followed by a third person pronoun.13 In Wangkumara (Q., Breen 1976a:336-339), third person pronouns have become suffixed to nouns as class markers, the non-feminine pronoun becoming a masculine singular marker, the feminine pronoun becoming a non-masculine-singular marker. In fact the forms used in Wangkumara, which are forms common in Queensland, may be cognate with the forms under discussion.

$\begin{array}{lll}\text { 26. } & \text { Masculine } & \text { Feminine } \\ \text { Nom } & \text { nial4 } & \text { nani } \\ \text { Erg } & \text { nulu } & \text { nanrru } \\ \text { Acc } & \text { nina } & \text { nana }\end{array}$

When these forms are used as class markers, in most cases the initial nasal is lost.

This line of argument needs further substantiation of course, but there is a plausible line of development from characteristically placing third person pronouns at the end of phrases to suffixing them and there is some similarity in form between the third person pronouns of Queensland and the 'nasal ergative' forms under discussion. The disyllabic forms that occur such as nvinke may reflect the common 
ergative marker in the second syllable.

\subsubsection{Locative}

The locative is usually represented by one or more forms that match the ergative forms in consonants but have the vowel a instead of $u$. Thus in Dyaru (W.A., Tsunoda p.c.) we find the ergative represented by - jku (for disyllablc vowel stems), -lu (for longer vowel stems) and Tu (for consonant stems), and parallel to this we find the locative represented by - $n k a$ (for disyllabic vowel stems), -la (for longer vowel stems) and Ta for consonant stems.

In some languages there are some discrepancles between the full set of ergative allomorphs and the locative allomorphs, but in general the evidence points to a proto-form that matches the ergative in consonants but has a instead of $u$, 1.e. a proto-form -*la -*ta, with -nka being derived along the same lines as -oku (see above).

The phonetic changes that have affected the ergative naturally affect the locative in the same way. Thus Walmatfari (W.A., Hudson forthcoming, and Malyangaba (S.A./N.S.W., P. Austin p.c.) have a locative allomorph - ja to match the ergative allomorph-ou, and Warluwara (Q., Breen 1971) has locative -ka matching ergative -ku.

Where phonetic changes such as loss or reduction of final vowels have occurred, this has had the effect of syncretising the ergative and locative. As noted in 1.3, the INSTRUMENTAL is normally expressed by the ergative (or better ergative-instrumental) case form, but in a few scattered languages it is expressed by the locative (or locativeinstrumental) form. If loss or reduction of final vowels occurs, a syncret1sm of A, INSTRUMENTAL and LOCATIVE occurs. Th1s has happened In Wagaya (N.T., Breen 1976b:340, the Arandic languages of Central Australla and Kurtjar (Q., Black p.c.) for example.

The generalising of one varlant at the expense of others that was noted above in the discussion of the ergative is not always parallelled in the locative. Since this is not a phonetic change, the different development of the two forms is not surprising. In Pintup1 (N.T., $K$. and L. Hansen forthcoming), $-i u$ has been generalised as the ergative marker and - jka as the locative. In Pitjantjatjara an innovation has occurred in the conditioning of these allomorphs in that - lu (ergative) and -la (locative-1nstrumental) are used with personal proper name vowel stems, but $-\eta k u$ and $-\eta k a$ are used with common noun vowel stems.

Most Pama-Nyungan languages have forms that are falrly obviously derivable from proto $\stackrel{*}{-1 a} \sim^{*}$ ta. Kalkatungu (Q.) has locative 
allomorphs - $t i$ and - pia but these presumably represent an innovation as the expected familiar forms can be found lurking on some irregular high-frequency nouns and on adverbs, e.g. kuu-jka (at the water), utinka (behind, at the back). Pitta-Pitta (Q.) has locative -ina but the famlliar forms can be found with other functions. -na (<*-nka cf. future $S_{1}$, A marker - nu <*-nku) expresses purpose, and -la expresses indirect cause or reason (drunk from rum), a function often covered by the ergative-instrumental or locative-instrumental in languages lacking a separate 'causal' suffix.

The common locative forms are not well represented outside the Pama-Nyungan family. Most non-Pama-Nyungan languages have an exclusively locative suffix, a few exhibit syncretism of the LOCATIVE, INSTRUMENTAL and AGENT (e.g., Alawa, N.T., Sharpe 1972) or LOCATIVE and ALlAtiVE (e.g., Gunwinggu, Arnhem Land, N.T., Carroll 1976).

\subsubsection{Accusative}

The accusative case does not occur much with nouns though it is common with pronouns. It is used with all nominals in Pitta-Pitta (Q.), except in the future tense (see 54, 55), and it is used with all nominals in Wangkumara (Q., Breen 1976a:336-338), but in the latter instance this is the result of suffixing case-marked pronouns to nouns forming a system of class markers (see 26). As noted above, it is used in the accusative language, Lardil, but separate accusative marking is used in the future as opposed to the non-future.

A number of languages exhibit accusative marking on some classes of nominals, usually personal proper names and/or kin terms or these categorles plus human nouns or plus human and animate nouns (see Silverstein 1976).

The form of the accusative is commonly -na or $-n v a$. If we accept Dixon's thesis that both the dental laminal and palatal laminal series of phonemes in Australian languages derive from a common laminal series, then the proto-form will be $\stackrel{*}{N}^{\prime} \mathrm{y}$ a where the capital represents a laminal in a proto-language having only one series of laminals.

I see no evidence in the distribution of accusative marking with nouns to suggest that accusative marking was increasing 1ts territory (1.e., 'spreading' from pronouns) or decreasing 1t. In some special cases 1t probably spread, e.g. Wangkumara, for the rather special reason that pronouns (marked for $A$ and $P$ ) were suffixed to nouns, and perhaps in Lardil as suggested earlier. In any case the distribution of accusative marking as we find it is natural in the sense that it is concentrated at the end of a scale that runs from inanimate through 
animate, to human, to subclasses of human and this accords with patterns of accusative marking in some non-Australian languages, e.g. the use of a for definite, animate PATIENTS in Spanish, pe for human PATIENTS in Roumanian, the use of the genitive for animate PATIENTS in Russian, the accusative -(ii)g in Mongolian for human PATIENTS and the use of -ko for animate PATIENTS in Hindi. 15

There do not seem to be any examples of accusative marking with nouns among the non-Pama-Nyungan languages. This is not too surprising when one considers that they make greatly reduced use of case marking for the major syntactic functions, relying instead on cross-referencing pronouns. There is clear evidence in these cross-referencing pronoun systems of accusative marking, and more particularly reflexes of ${ }^{*} \mathrm{~N} Y a$. This is discussed in section 2.3 .

\subsubsection{Dative}

A form -ku marks the dative in a very large number of languages. Besides occurring in something like ninety per cent of the PamaNyungan languages, it is also fairly well represented among the nonPama-Nyungan languages. Often there is a varlant -wu following vowelfinal stems, with -ku occurring on consonant-final stems.

\subsubsection{Summary}

The following forms then can be reconstructed as belonging to some remote proto language:

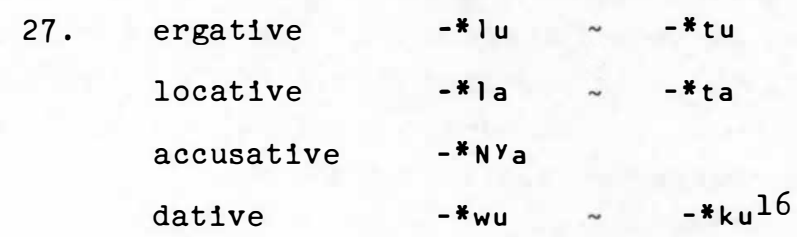

The ergative was probably once more widespread than 1 t is now, and is likely to have been lost from languages like Ngarluma and Lardil and from most of the non-Pama-Nyungan languages.

The accusative may have lost ground in the non-Pama-Nyungan languages as they shifted the burden of syntactic case marking from the use of case suffixes to cross-referencing pronouns.

The dative is likely to have been retalned in form and function from a remote proto-language, but has probably been extended to mark $P$ in Ngarluma, $P$ in the future in Pitta-Pitta, and it has probably been extended to marking purposive on verbs and also future tense (see Blake 1976:421-424). 
The LOCATIVE relation is expressed by a distinct marker over most of Australia. The Pama-Nyungan languages tend to reflect a common proto-form, the others express the relation by a variety of forms.

\subsection{Free Pronouns}

\subsubsection{General}

As indicated in 1.1 free form pronouns in the Pama-Nyungan languages operate in an accusative paradigm whereas in other Australian languages there is usually no case marking for $S_{1}, A$ and $P$, elther with pronouns or with nouns. The accusative is almost always marked by what is clearly a reflex of $-*^{*} \mathrm{Y}$.

In some Pama-Nyungan languages we find:

(a) Ergative as well as accusative marking on third person pronouns, particularly if the forms are demonstrative in origin. This is fairly common.

(b) Ergative as well as accusative marking on an odd person/ number combination or two. In a few instances this occurs with first or second person singular.

(c) Ergative as well as accusative marking on all pronouns.

(d) Ergative marking rather than accusative marking on all pronouns.

Major syntactic relations apart, the rest of the pronoun paradigm is similar to the noun paradigm in most languages but rarely exactly the same. There are usually some differences in the number of case forms and in their actual shape or phonemic form. For one thing, pronouns, certalnly first and second person pronouns, are typically human and the semantic category of locative is not much required though comitative needs to be expressed.

In the area possessive-indirect object-purposive-benefactive the pronoun paradigm often shows a different number of distinctions from the noun paradigm of the same language but it is difficult to generalise. Also we find that besides -ku $\sim-$ wu, forms such as -na, - ju, -nta, -ta, -mpa are common. Usually the first and second person singular have a different inflection in the dative (and genitive or benefactive) from the other person/number combinations. Thus in Warluwara (Q., Breen 1971) the first and second singular forms of the dative are nata and yinda, but all the other person/number combinations consist of the nominative plus - pa. It is falrly common for the oblique cases of pronouns to be bullt on a stem other than the 
nominative. In Gumbainggir (N.S.W., Smythe 1948), the dat1ve paradigm runs: Is ja:nvun, 2s $\eta \mathbf{i} n n u$ with the other first and second person forms suffixed by -mba, e.g. nali-mba. Other oblique cases (except for the accusative) are then bullt on this stem, e.g. nali-mba-la (we two (inclusive) locative).

Some of the forms used to mark the dative (or genitive or benefactive) with pronouns (and in some instances nouns) look like locative allomorphs (e.g., -nta, -ta, -mpa) and Indeed this is likely to be their source. These forms do in fact occur as locatives with nouns and pronouns in some languages, e.g. Warungu (Q., Tsunoda 1974: 180-181) nali-nu-nda, the locative of we two (-ou is the genitive). Quite independently of the forms under discussion, the locative in a number of Australian languages covers indirect object and allative functions and when one considers the fact that locatives are not going to be required very frequently with human referents it is not surprising if locative allomorphs assume dative and simllar functions. - nu, though not clearly related to $-^{*} \eta k a \sim *-1 a$ (see 2.1) is attested as a locative in a number of Cape York languages and is the locative for pronouns in Kalkatungu (Q.). - ga is found in very many languages Including a number of non-Pama-Nyungan languages as a dative or purposive.

\subsubsection{Major Syntactic Relations}

\subsubsection{Pronoun Augmentation}

The main feature of interest in the pronoun paradigm is the distribution of nominative, ergative and accusative marking, especially the distribution of the case forms with pronouns vis-d-vis their distribution with nouns.

Before discussing the free pronouns, let us look at a typical PamaNyungan pronoun paradigm. This example is from Warungu (Q., Tsunoda 1974:180-181). Only the nominative and accusative are shown, but there are also two dative case forms, a locative, a comitative and an ablative. 
28. Warungu Pronouns

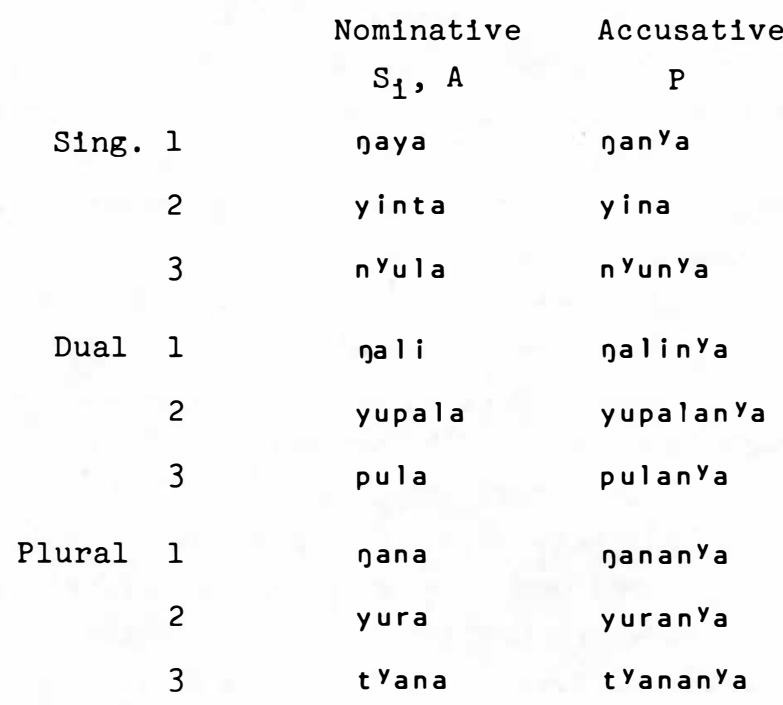

It will be noted that while in the non-singular the accusative is added to the nominative, in the singular the accusative contrasts with a nominative suffix added to a monosyllabic stem. If one examines these nominative suffixes to singular pronouns in a range of languages one finds that they seem to consist of

(a) a syllable resembling an ergative marker;

(b) a syllable -pa or -wa;

(c) a syllable resembling an accusative marker.

Warungu probably falls into category (a) although this is not immediately obvious. In many languages however the nominative consists of a form such as jatu, or in a smaller number of languages, naypa or janya.

In a recent paper Dixon (1977) suggests that at an earlier stage Australian languages allowed monosyllabic words but then at a later stage they ceased to tolerate them - this is the situation in a majority of contemporary languages. He suggests that at an earlier stage the singular pronouns operated with ergative and accusative marking and that when monosyllabic words became proscribed the $s_{1}$ forms were augmented by extending the ergative form to cover $S_{1}$ as well as $A$ or by augmenting with a syllable -pa (widely used in Australia as a phonological filler) as suggested earlier by Hale. In this way he seeks to account for the appearance of an 'ergative looking' marker 
on the $S_{1}$ form of pronouns. If the ergative form was extended to embrace $S_{1}$, an accusative system resulted; if -pa was added, a threeway system of marking resulted.

There seems to be no doubt that the singular pronouns have been augmented. Dixon's argument concerns only first and second person where the proto-forms are reflected almost ublquitously, but I think that the argument can be applied to the falrly widespread third person singular forms (see examples in 34. below). Moreover, I think that $-\mathrm{N}$ Ya can be added to the list of morphemes used as augments (see below). However, I wonder if an early proto-language had ergative as well as accusative marking for first and second person singular. This seems to involve positing a rather unusual proto-language. It may be that in some instances the ergative form of nouns was simply extended to cover both $S_{1}$ and $A$ with pronouns. There is some evidence to support Dixon's position. In some languages that have retained the use of monosyllabic words, we find a system nearly identical to that posited by Dixon for the proto-language. For example, in Gabi (SE. Q., Mathew 1910:208, quoted by Dixon 1972:7) we find,

29. Gab1

$\begin{array}{ccc} & \text { first singular } & \text { second singular } \\ \mathrm{S}_{1} & \text { Day } & \text { Din } \\ \text { A } & \text { Daydyu } & \text { Dindu } \\ \mathrm{P} & \text { Dana } & \text { Dina }\end{array}$

Also in the related language, Duungidjawu (SE. Q., Wurm 1976) we find much the same thing,

30. Duungidjawu

$\begin{array}{ccc} & \text { first singular } & \text { second singular } \\ \mathrm{S}_{1} & \text { nai } & \text { Din } \\ \mathrm{A} & \text { gadyu } & (\text { o) indu } \\ \mathrm{P} & \text { ganya } & (\text { D) ina }\end{array}$

No language seems to have a form of ergative provenience marking $S_{1}$ but not $A$. However, whether the ergative once functioned with singular pronouns or was extended from nouns to cover $S_{1}$ and $A$, the same distribution would result. It would not normally happen that a language would extend an ergative from nouns to $S_{1}$ pronouns without embracing A pronouns. 
Almost without exception bound pronoun systems operate accusatively for all person/number combinations and they presumably reflect the earlier system operating with free pronouns. Th1s would argue against Dixon's suggestion that the free singular pronouns had a distinct $A$ form.

Dixon's list of augments can probably be extended to include -*Nra. Consider the following forms from Nyungar(SW. W.A., O'Grady et al. 1966:131) and Kunggar1 (Blackall, Q. - not to be confused w1th Gunggar1, Roma, Q., Breen field notes).

31. Nyungar

$\begin{array}{ccc} & \text { first singular } & \text { second singular } \\ \mathrm{S}_{1} & \text { ganva } & n v i n i \\ \mathrm{~A} & \text { natyu } & n v u n t u \\ \mathrm{P} & \text { ganva } & n v i n i\end{array}$

32. Kunggar1

$\begin{array}{ccc} & \text { first singular } & \text { second singular } \\ \mathrm{S}_{1} & \text { gana } & \text { yina } \\ \mathrm{A} & \text { gațu } & \text { yinti } \\ \mathrm{P} & \text { gana } & \text { yina }\end{array}$

Perhaps the ergative systems that have resulted in these cases (at least with first and second singular) could be taken as supporting Dixon's putative proto-system. The 'accusative looking' form for $S_{1}$ would be seen as an extension of the accusative for the phonological reasons, the ergative would be seen as 'original'.

How common the use is of * $^{*} \mathrm{Va}$ as an augment can only be answered after some problems of historical phonology are solved. A number of languages in south-west Queensland have forms such as nanyi (first person $S_{1}$ ), ( $y$ )ini (second person $S_{1}$ ) and since some have gani for first person plural where other languages have jana, it is likely that nanyi derives from nanya by regular sound change.

There are a number of phonological problems involved in deriving some attested forms from the proto-forms. Dixon suggests pay $+\mathrm{tu} 17$ as the proto-sequence for the first person and $n$ vun or gin + tu for the second. These allow the stralghtforward derivation of forms such as paytyu, gatyu or jațu and nyuntu or pintu. Certainly lenition of $N Y$ to $y$ has occurred in some languages; see for Instance the Warungu 
second person singular, dual and plural forms in 28. Similarly vowel reduction has occurred producing forms such as Warungu yinta from *NYintu and yupala from *Nyumpalu. However, although a form such as nayu in Garawa (Q., Furby 1972) probably derives from nay + tu via natyu, a form such as Warungu naya could derive from nay $+t u$ via gaTyu > nayu > naya (cf. yinta) or by simply repeating the vowel of nay. This is a common augmenting principle among the world's languages and is attested in Australia, e.g. assimilating English words to vernacular phonemotactic patterns. A simllar doubt arises with a not uncommon form for the second person, viz. nyini. Is the $i$ an assimllated a, $n{ }^{y i n i}$ reflecting ${ }^{*} N{ }^{Y} i n+N y a$, or is $n y i n i$ derived from $n y i n$ by repeating the vowel? There are also problems in sorting out some of the stems. Is the second person Nyin, Nyun, Din or gun? What is the significance of $y$ in nay, an element which does not appear in the dual or plural? What is the significance of $-n$ in $N y_{i n}$ etc., another element that does not appear in the dual or plural? However, the problem of the stems is not directly relevant to the question of the development of the case marking.

If we accept that forms like natyu, $n y i n t i$ etc. reflect ergative morphemes in their second syllables, this has important consequences for the non-Pama-Nyungan languages. Since these lack case marking in most instances for the major syntactic functions, the question of the relationship between this system and the Pama-Nyungan system arises. As we noted in 2.1.1, a scattered minority of non-Pama-Nyungan languages exhibit ergative marking on nouns and pronouns and this scattering probably represents the relics of a widespread if not ubiquitous system. Further evidence of former ergativity can be found in the pronoun forms for the singular in some of these northern languages. Consider the following,

33.

\section{First Person Second Person}

$\begin{array}{lll}\text { T1w1 } & \text { Dia } & \text { Dinta } \\ \text { Gunbalang } & \text { Dayi } & \text { Duta } \\ \text { Y1wadja } & \text { Dabi } & \text { Duyi } \\ \text { Djing1l1 } & \text { Daya } & \text { nyama } \\ \text { Worora } & \text { Dayu } & \text { Dunydu } \\ \text { Gunwinggu } & \text { Daye } & \text { Duda } \\ \text { Maranunggu (Daly R.) } & \text { Dany } & \text { nina } \\ \text { Pungu-Pungu (Daly R.) } & \text { getye } & \text { kene }\end{array}$


These examples have been chosen more or less at random. It would have been possible to select a sample specifically to bring out the number of 'ergative looking' forms to be found among the non-PamaNyungan languages, but as 1 t is one can see a sprinkling of forms that probably reflect the ergative marker. There is no suggestion that these reflect an ergative system however, only that they reflect an ergative marker. They could well reflect a marker that had been generalised to $S_{1}$ from $A$ or from the noun paradigm.

In 2.1.1 I suggested that Lard11 may have moved from being ergative to accusative. It is worth recording that the $S_{1}$, A pronouns for first and second singular are gata and gyinki respectively. These seem likely to reflect the ergative marker in the second syllable.

The following table gives examples of singular pronouns in $S_{1}, A$ and $P$ forms for a number of Pama-Nyungan languages. The first dual is given also as an example of a disyllabic stem where the putative augmentation did not take place.

The suggested lines of development outlined above account for most of the forms that appear. Dyaabugay 1llustrates another feature not mentioned above, namely the use of the plural stem nyura for the singular stem, a change reminiscent of the replacement of thou by you In English and a change that occurs sporadically over the continent.

The table has an eastern Australian bias but the deficiency is made good in example 40 where a number of Western Australian forms are quoted. In some of the Western Australian languages augmentation has occurred more than once as can be seen by inspecting Table 40. Th1s additional augmentation is discussed in the text following 40. 34.

\begin{tabular}{|c|c|c|c|c|c|}
\hline \multirow{3}{*}{$\begin{array}{l}\text { Warluwara } \\
\text { Q. }\end{array}$} & & Is & $2 s$ & $3 s$ & $1 d u$ \\
\hline & $S_{1}$ & Daṇa & yipa & yiwa & Dali (Inc) \\
\hline & A & Daṇa & yipa & yiwa & jali \\
\hline \multirow{3}{*}{$\begin{array}{l}\text { P1tta-P1tta } \\
\text { Q. }\end{array}$} & $\mathrm{P}$ & Dana & yina & yinya & gal inga \\
\hline & $s_{1}$ & $\operatorname{gan} y t^{y} a$ & $(y)$ inpa & nuwa - & gali \\
\hline & A & Dațu & $(y)$ intu & nulu- & Dalilu \\
\hline \multirow{4}{*}{$\begin{array}{l}\text { Bidjara } \\
\text { Q. }\end{array}$} & $\mathrm{P}$ & Dana & $(y)$ ina & $(y)$ ina- & galina \\
\hline & $s_{1}$ & Daya & yinda & nula & Dali \\
\hline & A & Daya & yinda & nula & Dali \\
\hline & $\mathrm{P}$ & Dadyuna & yuna & nupuna & Dalinyana \\
\hline
\end{tabular}




\begin{tabular}{|c|c|c|c|c|c|}
\hline & & ls & $2 \mathrm{~s}$ & $3 s$ & $1 d u$ \\
\hline \multirow{3}{*}{$\begin{array}{c}\text { Garawa } \\
\text { Q. }\end{array}$} & $\mathrm{S}_{1}$ & Dayu & $n i n y_{d} y_{i}$ & $n y u l u$ & pa $1 \mathbf{i}$ \\
\hline & A & nayu & $n i n y d y i$ & $n y u l u$ & Da $\mathbf{i}$ \\
\hline & $\mathrm{P}$ & Dana & nina & $\varnothing$ & gal inya \\
\hline \multirow{3}{*}{$\begin{array}{l}\text { Yalarnnga } \\
\text { Q. }\end{array}$} & $S_{1}$ & Dia & nawa & & Da! i \\
\hline & A & Datu & nulu & & Da lu \\
\hline & $\mathrm{P}$ & Dia & nawa & & $D a ! i$ \\
\hline \multirow{3}{*}{$\begin{array}{l}\text { Kalkatungu } \\
\text { Q. }\end{array}$} & $S_{1}$ & Dai & $n y i n i$ & & pa 1 i \\
\hline & A & Datu & nyinti & & Daliyi \\
\hline & $\mathrm{P}$ & pa i & $n y i n i$ & & Dali \\
\hline \multirow{3}{*}{$\begin{array}{c}\text { Ngawun } \\
\text { Q. }\end{array}$} & $S_{1}$ & Dayu & yuntu & & Dali \\
\hline & A & Dayu & yuntu & & Dali \\
\hline & $\mathrm{P}$ & Dana & yira & & na linta \\
\hline \multirow[t]{3}{*}{$\begin{array}{l}\text { Dy aabugay } \\
\text { Q. }\end{array}$} & $s_{1}$ & Dawu ( oku) & nyura & & $\begin{array}{l}\operatorname{Dan} y_{t} y_{i} \\
(\text { non } s g)\end{array}$ \\
\hline & A & nawu ( Dku) & nvura & & Dan $y_{t} y_{i}$ \\
\hline & $P$ & Danya & nyurany & & $\operatorname{Dan} y t y_{i n} y$ \\
\hline \multirow{3}{*}{$\begin{array}{l}\text { Duungidjawu } \\
\text { Q. }\end{array}$} & $s_{1}$ & Dai & nin & yo: $(r u)$ & Da:m \\
\hline & A & gadyu & ( $(0)$ indu & yo: $(r u) n d u$ & Da:mbu \\
\hline & $P$ & nanya & ( $)$ ina & yo: na & Da:mma \\
\hline \multirow{3}{*}{$\begin{array}{l}\text { Warungu } \\
\text { Q. }\end{array}$} & $S_{1}$ & Daya & yinda & nyula & Dali \\
\hline & A & Daya & yinda & $n y u l a$ & Dali \\
\hline & $P$ & nanya & yina & nyunya & Dalinaya \\
\hline \multirow[t]{3}{*}{$\begin{array}{l}\text { Dharawal } \\
\text { NSW }\end{array}$} & $S_{1}$ & Dayagan & nyindigan & & Dalgan (1nc) \\
\hline & A & Dayaganga & $n^{y}$ indiganga & & Dalganga \\
\hline & $P$ & nayagan & nyindigan & & nalgan \\
\hline \multirow[t]{3}{*}{$\begin{array}{l}\text { Mad1-Mad1 } \\
\text { V1c. }\end{array}$} & $S_{1}$ & $y i d i$ & Dindi & & ga $1 \mathrm{i}$ \\
\hline & A & $y i d i$ & Dindi & & Dali \\
\hline & $\mathrm{P}$ & yinan & Dinan & & nalin \\
\hline
\end{tabular}




\begin{tabular}{|c|c|c|c|c|c|}
\hline \multirow{3}{*}{$\begin{array}{l}\text { Narlnyari } \\
\text { SA }\end{array}$} & & Is & $2 s$ & $3 s$ & $I d u$ \\
\hline & $S_{1}$ & Dapi & bint $i$ & $k i t{ }^{y}$ & De 1 \\
\hline & A & ga $t i$ & Dinti & $k i l i$ & De 1 \\
\hline & $P$ & & & kin & \\
\hline
\end{tabular}

\subsubsection{Free Pronouns in an Ergative Paradigm}

As noted earlier the free pronouns in some languages operate in an ergative paradigm. The set of languages exhibiting this feature is as follows:

(a) Warnman, Dyaru, Yulbaridja, Walmatjar1, Walb1r1, P1ntup1 (a roughly contiguous set extending over an area in the northern W.A. and into N.T.).

(b) Dharawal and some related languages as in Eades 1976 (south coast of N.S.W.).

(c) Rembarnga, Ngand1 (Arnhem Land N.T.), Muriny Pata (Port Keats N.T.).

(d) Kalkatungu, Yalarnnga, (Kunggar1?) (western Q.).

In some instances at least it is possible to find evidence to suggest that the ergative pronoun paradigm is an innovation. Warnman (W.A., O'Grady et al. 1966:136-7) has a set of free form pronouns that consist of a stem para to which forms marking person and number are suffixed,

35.

$\begin{array}{lll} & \text { lst Person } & \text { 2nd Person } \\ \text { Sing } & \text { para- } \varnothing & \text { para-ıku } \\ \text { Dual } & \text { para- } \phi-k u t y a r a & \text { para-ıku-kutyara } \\ \text { Plural } & \text { para- } \phi-w a t ̦ a & \text { para-ıku-wața }\end{array}$

Th1s system seems to have derived from an earlier auxiliary or catalyst particle plus a bound pronoun. Catalyst particles to which bound pronouns are attached are a feature of the area and - jku is not only synchronically the second person $S_{1}$, $A$ bound pronoun in Warnman, it is the $S_{1}$, A bound pronoun in a number of Western Desert languages. It seems fairly clear that a combination of catalyst particle plus bound pronoun has usurped the position of an earlier free pronoun. If this is so, it is not surprising to find that the new forms operate in an 
ergative paradigm since this would have been the only paradigm avallable as a model when the earlier free pronouns fell into disuse.

The following example lllustrates the use of the 'new' free pronouns and the cross-referencing pronouns. The free pronouns are optional.

$$
\begin{aligned}
& \text { 36. para- } \phi-1 u-n g a-n k u \text { paralyi tyinka-ṇa para-nku-ku } \\
& \text { pronoun-I-erg- } I(\mathrm{~S})-y o u(\mathrm{P}) \text { boomerang make-past pro-you-dat } \\
& \text { I made a boomerang for you. }
\end{aligned}
$$

In other languages in the area that have ergative pronoun paradigms, there is evidence that the free pronouns for the major syntactic functions have been recreated probably on the basis of oblique forms. This is in fact Hale's suggestion regarding Walbir1 (Hale 1973b:340),

'The process of destressing and cliticising pronouns eventually became an obligatory rule and, subsequently, Independent pronouns were re-created from other sources avallable to the language, such as oblique forms of pronouns like those found in possessives or in other functions not normally subject to cliticization.'

The evidence is largely the discrepancy between the actual shapes of the bound forms and the shapes of the free forms (as pointed out by Hale), plus the regularity of the ergative affixation. Consider the following forms from Dyaru (W.A., Tsunoda p.c.) where both these features are evident, 
37. Dyaru Pronouns

(a) Free Forms

\begin{tabular}{|c|c|c|c|c|}
\hline & & & $S_{1}, P$ & A \\
\hline Sing. & 1 & & gat $y_{u}$ & na ty $u-\eta k u$ \\
\hline & 2 & & ny untu & $n y u n t u-k u$ \\
\hline & 3 & & nyantu & $n y a n t u-k u$ \\
\hline Dual & $1:$ & Inc & gali & $\eta a l i-n k u$ \\
\hline & & ex & Datyara & Dat Yara-lu \\
\hline & 2 & & nyunpula & nyunpula-lu \\
\hline & 3 & & nYanpula & nYanpula-lu \\
\hline Plural & 1 & Inc & palipa & galipa-lu \\
\hline & 1 & ex & Danampa Danimpa & Danampa-lu $\sim$ ganimpa-lu \\
\hline & 2 & & nyuraa nyurara & nyuraa-lu $\sim$ nyuraca-lu \\
\hline & 3 & & nyantu & $n y a n t u-k u$ \\
\hline & (b) & Bound & Forms & \\
\hline & & & S & $\mathrm{P}$ \\
\hline Sing. & 1 & & $-n a$ & $-y i$ \\
\hline & 2 & & $-n$ & $-\eta k u$ \\
\hline & 3 & & $-\varnothing$ & $-\phi$ \\
\hline Dual & 1 & Inc & $-1 \mathbf{i}$ & $-a \operatorname{lin} y$ \\
\hline & & ex & -1 iуа $(r)$ & -yiran -yaran \\
\hline & & & -npula & - okuwuka \\
\hline & & & -wula & -wula (y)anu $\sim-$ wulany \\
\hline Plural & 1 & Inc & $-1 i w a$ & -alinypa - nalipa \\
\hline & & & - ṇa lu & - (n)animpa ( $(n)$ anampa \\
\hline & & & $-n t a(l u)$ & -nyura \\
\hline & & & $-1 u$ & $-(y) a n u$ \\
\hline
\end{tabular}


The discrepancy between the bound forms and the free forms can be gathered from an inspection of the table. Note that some of the accusative bound forms are marked by $-n y(-)$, clearly a reflex of the accusative marker that is found over most of Austral1a. The allomorphs of the ergative marker on the free pronouns are distributed according to the principle operating with nouns: - jku occurs with disyllabic stems (dissimilating to -ku if there is a nasal stop cluster in the stem) and $-1 \mathrm{u}$ occurs with longer stems.

Dyaru then seems to have formed a new serles of free forms for $S_{1}, A$ and $P$ and to have modelled them on the noun paradigm w1th one form for $A$ and another for $S_{1} / P$. The same line of argument can be followed with the other languages listed under (a) above.

of the languages noted under (b), namely those languages of the south coast of N.S.W. treated by Eades (1976), it is generally true that the free pronouns exh1b1t ergative allomorphs distributed as for nouns, at least insofar as there is evidence avallable. There are also systems of bound pronouns in use, and all in all it seems as if the suggestion made about Dyaru could be repeated in the case of these languages.

In one language of this area, Gundungurra, we find a system the same as that described above for Warnman. The free pronouns consist of a base gula- to which bound pronouns are suffixed,

$\begin{array}{lll}\text { 38. Sing. } & \text { gula-nga } \\ & 2 & \\ & \text { gula-nydyi } \\ \text { Dual linc } & \text { gula-na } \\ & \text { gex } & \text { gula-ggulan } \\ 2 & \text { gula-mbu } \\ \text { Plural l inc } & \text { gula-mbanyan } \\ & \text { gula-mbanyila } \\ 2 & \text { gula-mbandu }\end{array}$

The bound pronouns exist independently of thelr use with -gula. Presumably this system has the same genesis as that proposed for the Warnman system.

of the non-Pama-Nyungan languages exhibiting an ergative pronoun parad1gm, Rembarnga, Ngand1 and Muriny Pata, Ngand1 can eas1ly be accounted for. Heath (forthcoming b) demonstrates convincingly that 
Ngand1 has borrowed 1ts ergative marker from the nelghbouring PamaNyungan language, Ritharngu. The use of this ergative marker with pronouns reflects a situation in which an introduced functional morpheme is generalised to all nominals.

In the case of Rembarnga (McKay 1975) and Murlny Pata the only evidence of possible innovation lies in the fact that the bound pronouns operate in an accusative system and this presumably would reflect the earlier free pronoun paradigm.

As for the remaining languages, Kalkatungu exhibits a discrepancy between the shape of 1 ts bound pronouns and its free ones, so one would expect that the free forms represent a relative innovation. Yalarnnga has virtually no bound pronouns. Kunggari may or may not exhibit an ergative pronoun paradigm. It certainly does in the first and second singular (see 32) but the information avallable on the other person/number combinations is incomplete.

On balance then one could say that since bound pronoun paradigms probably reflect an earlier system and since bound pronouns operate in an accusative system, the free pronoun paradigms were once accusative. We have also seen that in the case of some of the languages with ergative pronoun paradigms, there are additional reasons for belleving the ergative system to be a comparative innovation.

\subsection{Bound Pronouns}

If we consider bound pronouns in Australian languages, we can classify languages into four types along a seriation scale thus:

(a) languages with no bound pronouns

(b) languages with bound pronouns that are transparently abbreviated forms of the free pronouns

(c) languages with bound pronouns that are not simply abbreviated forms of the free pronouns

(d) languages with bound pronouns that exhibit fusion and various irregularities in transitive clauses (where the bound pronouns for $A$ and $P$ are Juxtaposed)

\subsubsection{Languages with no Bound Pronouns or 'Abbreviated' Free Pronouns}

It is interesting to note that most of the languages lacking bound pronouns are to be found in a contiguous area running from the Great Australian Bight in South Australia to the Gulf of Carpentaria in Queensland (see map). This suggests that the process of developing 
bound pronouns or dropping them is subject to diffusional pressure, but leaves the question of whether the 'boundless' languages are ones whlch have not developed bound pronouns or whether they are ones which have lost them. One cannot apply stratigraphical arguments to the distribution of 'bound' and 'boundless' languages in the way one can with the distribution of lexical 1tems. Since the form of lexical 1tems 1s, in almost all cases, arbitrary, a discontinuous distribution as opposed to a continuous one must normally be interpreted in terms of the continuous area representing an innovation and the discontinuous one representing a conservative form. However, with the cholce between 'bound' and 'boundless' languages we are not dealing with an arbitrary expression-content relationship, rather 1 t is the case that a language can develop bound pronouns from free ones (where else could they come from?) and 1t can also lose bound pronouns, as has been the case in Europe, for Instance. In any case, the stratigraphical evidence is amblguous since there are discontinuous 'boundless' areas (NW. W.A., t1p of Cape York) as well as discontinuous 'bound' areas.

Gavan Breen points out that if the boundless languages had lost bound pronouns, one would expect to find vestiglal evidence of this and in fact there seems to be practically none (but see below). There are one or two instances of 1solated bound pronouns, e.g. Yalarnnga - nu marking the $S_{1}$ or $A$ of 1mperatives, but often, as in this case, their transparent relation with free forms suggests innovation.

One can see the force of this argument if one considers developments In Europe. Pronouns functioning as $S_{1}$ and $A$ (subject pronouns) were suffixed to verbs, became unstressable, and in many cases monophonemic, and were supported by optional free forms for the purposes of emphasis, contrastive stressing and the like. Thus in Latin the first person singular (at least in some active tenses) was represented by - $m$ as in amabam ( $I$ used to Zove), w1th ego avallable when the first person singular was to be stressed. In French, ego appears as a proclitic / $/ 30 /$, whlch has become unstressable, so that the disfunctive mo $i$ has to be introduced to allow the first person singular to be emphaslzed, moi, je t'aime ( $I$ love you). In general an older layer of bound pronouns shows up as a set of verb inflections, and even in English, the European language to have lost most of 1 ts inflections, a third person singular form is retalned in he comes, etc. where -s reflects a pronoun, ultimately a demonstrative (belng an Anglian form

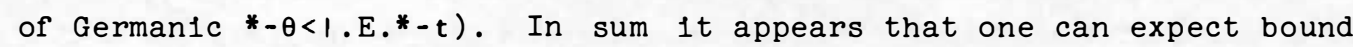
pronouns, if they are lost at the expense of a set of free forms, to disappear gradually, leaving vestiges on the verb or wherever they were affixed. 
On the other hand one cannot dismiss entirely the possibility of a kind of pidginisation involving the sudden and complete loss of bound pronouns. In Kalkatungu, for instance, where bound pronouns are optional in non-dependent clauses (at least with most tense/aspect markers), informants will normally omit them for the benefit of a struggling European linguist. One can 1magine clrcumstances involving inter-tribe bilingualism in which a pldginised form of the language ousted an earlier, morphologically irregular paradigm, a process which can be observed in a number of present day Aboriginal communities where the natural transmission of the language to the younger generation is suffering from competition with English.

However, when one considers that those languages bordering on the boundless area for the most part exhibit bound pronouns that are patently abbreviated free forms, 1t supports the contention that the development is largely, if not entirely, a one-way development from 'boundless' to 'bound'.

Breen (p.c.) claims specifically in the case of Badjir1 (Q.) that 1t borrowed the system of bound pronouns but not the forms from the nelghbouring Gunya (Q.). Similarly, Heath (forthcoming) demonstrates that Ritharngu, a Pama-Nyungan language of the Pama-Nyungan enclave in north-east Arnhem Land, developed bound pronouns under the influence of Ngand1, a nelghbouring non-Pama-Nyungan language which makes extensive use of cross-referencing bound pronouns. Ritharngu developed the bound pronouns from 1ts own free pronouns and is the only Pama-Nyungan language of the Arnhem Land enclave to have developed such forms.

One area where there does appear to have been a kind of loss of bound pronouns is northern Cape York where the former bound forms are suffixed to the free forms obligatorily and hence no longer function as bound pronouns. In Mpalityanh, for example, the first person singular $S_{1}$, A form is ayu-n. - $n$ is a reflex of a bound form of the pronoun. Independently of this the initial velar nasal of the stem * nayu has been lost as part of a general 'initial dropping' change. Similarly in Yinwum, first dual inclusive is le-1, where le reflects * gali with loss of the inftial syllable and - l ultimately reflects the same stem having been used as a bound form (Hale 1976b:30). In Yinggarda (W.A., O'Grady et al. 1966:118) the first person $\mathrm{S}_{1}$, A bound pronoun has become permanently suffixed to the free form. -na remains as a means of indicating first singular, but the free form is no longer *nața but națaṇa. 
To clarify the preceding generalities the following examples are presented. The first is from Narinyar1 (S.A., Yallop 1975:40) and lllustrates a language in which the bound pronouns are patently reduced forms of the free ones.

\begin{tabular}{|c|c|c|c|}
\hline & $\begin{array}{l}\text { Ist Person } \\
\text { free/bound }\end{array}$ & $\begin{array}{l}\text { 2nd Person } \\
\text { free/bound }\end{array}$ & $\begin{array}{l}\text { 3rd Person } \\
\text { free/bound }\end{array}$ \\
\hline ing. & papi/-api & Dint $i /-i n t i$ & $k i t y_{i} /-i t y_{i}$ \\
\hline Dua & nel/-anel & jurl/-upurl & $k e \eta k /-e j k$ \\
\hline cal & $u r n /-a r n$ & jun $i /$ - upun & $r /-a r$ \\
\hline
\end{tabular}

Narinyarl is one of the few languages in which ergative forms appear, thus

$\begin{array}{lll} & \begin{array}{l}\text { Nominative } \\ \text { free/bound }\end{array} & \begin{array}{l}\text { Ergative } \\ \text { free/bound }\end{array} \\ \text { 1 Sing. } & \text { napi/-api } & \text { nati/-ati } \\ 3 \text { Sing. } & k i t y i /-i t y i & k i l i /-i l i \\ 3 \text { Dual } & \text { kejk/-ejk } & \text { kejkul/ejkul }\end{array}$

The few examples of ergative bound forms occur in eastern Pama-Nyungan and where they occur in general they reflect the comparatively recent derivation of the bound forms from the free forms.

In general, bound pronouns in eastern Pama-Nyungan languages bear a transparent relation to their free counterparts. Capell gives a number of examples from New South wales languages in his New Approaches (Capel1 1956:16-17).

\subsubsection{Languages with Bound Pronouns Distinctly Different from the Free Pronouns}

The following table is presented mainly to illustrate languages in which there is some discrepancy between the shape of the bound pronouns and the shape of the corresponding free ones. However, it has been extended to cover most of the Pama-Nyungan languages of Western Australia and of the adjacent parts of the Northern Territory and South Australia, since a number of interesting factors can be found within this range. Only the first and second person singular has been shown. In general there is a closer correspondence between free forms and bound forms in the other person/numbers. 
40. Western Pama-Nyungan Pronouns

\begin{tabular}{|c|c|c|c|c|c|c|c|c|}
\hline & & & & & & & & \\
\hline & & $S_{1}$ & A & $\mathrm{P}$ & DAT & $S_{1}, A$ & $\mathrm{P}$ & D \\
\hline Ngarla & ls & Daya, nayi & & & & & & \\
\hline & $2 s$ & nyinpa & & & & & & \\
\hline Nyamal & 1s & Datya & & & nat yuku & $-n a$ & & \\
\hline & $2 s$ & nyunta & & & & & & \\
\hline Ba1lko & 1s & Dața & Datalu & & & - nga & $-t^{y a}$ & $-t^{y_{u}}$ \\
\hline & $2 s$ & nyinta & & & & -npa & & \\
\hline Bandj Ima & Is & Dața & Dața & Dat yu & Dat $y_{u}$ & & & \\
\hline & $2 s$ & nyinta & nyinta & $n y i n k u$ & $n y i n k u$ & & & \\
\hline Y1ndf 1barnd1 & Is & Dayi & Dayi & Dayu & Dayu & & & \\
\hline & $2 s$ & nyinta & nyinta & $n y i n k u$ & $n y i n k u$ & & & \\
\hline Ngarluma & ls & Dayi & Dayi & gat $y_{u}$ & Dat $y_{u}$ & & & \\
\hline & $2 s$ & nyinta & $n y i n t a$ & $n y i n k u$ & $n y i n k u$ & & & \\
\hline Dhalandf1 & is & Data & Data & gațana & $t y u t ̦ i$ & & & \\
\hline & $2 s$ & nyinta & nyinta & nyintana & nyintama & & & \\
\hline Buduna & ls & Daya & & & & & & \\
\hline & $2 s$ & ni. & & & & & & \\
\hline
\end{tabular}




\begin{tabular}{|c|c|c|c|c|c|c|c|c|}
\hline & & $s_{1}$ & A & $\mathrm{P}$ & DAT & $S_{1}, A$ & $\mathrm{P}$ & D \\
\hline \multirow[t]{2}{*}{ Bayungu } & Is & Dața & Dața & Dațana & Datganu & & & \\
\hline & $2 \mathrm{~s}$ & nyinta & nyintalu & & nyintanu & & & \\
\hline \multirow[t]{2}{*}{ Thargar1 } & Is & クаðа & раба & Daðaña & Danay $i$ & & & \\
\hline & $2 s$ & nura & nura & nurana & nuraba & & & \\
\hline \multirow[t]{2}{*}{ Yinggarda } & 1s & Dațaṇa & Dațaṇa & $D a t a$ & & $-n a$ & & \\
\hline & $2 s$ & nyinta & nyintalu & nyintana & nyintanu & -npa & $-n t a$ & $-g u$ \\
\hline \multirow[t]{2}{*}{ Nhanda } & is & Dayi & Dayi & Dayina & Dayu. & $-w a$ & $-\underline{n} a$ & $-\underline{t} v$ \\
\hline & $2 s$ & $n y i n i$ & $n y i n i$ & nyininga & nyiniyu & $-n y t y v,-n y a$ & $-n t a$ & $-n y_{k u}$ \\
\hline \multirow[t]{2}{*}{ Wadjug } & is & Danya & Dat $y_{u}$ & Danya & & & & \\
\hline & $2 s$ & $n y i n i$ & nyuntu & $n y i n i$ & & & & \\
\hline \multirow[t]{3}{*}{ Nyungar } & Is & nany, nety & $\operatorname{Dan} y$, Det $y$ & (D) any & (n) any & & & \\
\hline & $2 \mathrm{~s}$ & nyintak & nyintak & $n y i n i n y$ & nyinak & & & \\
\hline & & nyunak & nyunak & nyunany & nyunan & & & \\
\hline \multirow[t]{2}{*}{ East Mirniny } & Is & Dațu & Datu & gaṇaña & gaṇiya & & & \\
\hline & $2 s$ & gunțu & & & gunțiya & & & \\
\hline \multirow[t]{2}{*}{ Gugada } & ls & Dayulu & Dayulu & Dayunya & Dayugu & & & \\
\hline & $2 s$ & nyura & nyura & nyuranya & nyuramba & & & \\
\hline
\end{tabular}




\begin{tabular}{|c|c|c|c|c|c|c|c|c|}
\hline & & \multicolumn{3}{|c|}{ Free } & \multicolumn{4}{|c|}{ Bound } \\
\hline & & $s_{1}$ & A & $\mathrm{P}$ & DAT & $S_{1}, A$ & $P$ & $\mathrm{D}$ \\
\hline \multirow{2}{*}{$\begin{array}{l}\text { Ooldean } \\
\text { (Ngalia) }\end{array}$} & ls & gayulu & Dayulu & Dayunya & Dayuku & $(-n a)$ & & \\
\hline & $2 \mathrm{~s}$ & nyura & nyura & nyuranya & nYurampa & & & \\
\hline \multirow[t]{2}{*}{ Pitjantjatjara } & Is & Dayulu & gayulu & Dayunya & gayuku & $-n a$ & $-n i$ & $-t^{y} u$ \\
\hline & $2 \mathrm{~s}$ & nyuntulu & nyuntulu & nyuntunya & nyuntuku & $-n$ & $-n t a$ & $-n k u$ \\
\hline \multirow[t]{2}{*}{ Pintupi } & is & Dayunya & Dayulu & Dayunya & Dayuku & $-n a$ & ا & $-t^{y} u$ \\
\hline & $2 \mathrm{~s}$ & nyuranya & nyuralu & nyuranya & nyuraku & $-n$ & $-n t a$ & $-\eta k u$ \\
\hline \multirow[t]{2}{*}{ Yulbaridja } & is & Dayu & Dayulu & Dayu & Dayuku & $-n a$ & $-t \times a$ & $-t y_{u}$ \\
\hline & $2 s$ & nyuntu & nyuntulu & nyuntu & & $-n$ & $-n t a$ & $-\eta k u$ \\
\hline \multirow[t]{2}{*}{ Nyangumarda } & is & Datyu & Dat Yulu & & Datyuku & $-n V$ & $-n y_{i},-n y_{a}$ & $-t^{y} i,-t y_{u}$ \\
\hline & $2 s$ & nyuntu & & & & $-n$ & $-n t V$ & $-g u$ \\
\hline \multirow[t]{2}{*}{ Garadjarı } & is & Dat $y_{u}$ & Dat Yulu & & Datyuku & - nga & $-n y a$ & $-t^{y} a$ \\
\hline & $2 s$ & nyuntu & nyuntulu & & & $-n$ & $-n t a-n g u$ & $-n g u$ \\
\hline \multirow[t]{2}{*}{ Mangarla } & is & Dayu & nayunku & gayu & Dayuku & $-n a$ & $-n y_{a}$ & $-t y a$ \\
\hline & $2 s$ & nyuntu & nyuntunku & nyuntu & nyuntuku & $-n$ & $-n a$ & $-\eta k a$ \\
\hline \multirow[t]{2}{*}{ Walbirs } & 1s & Dat $y u(I u)$ & Dat $y_{u}(1 u(! u))$ & gat $y_{u}(1 u)$ & Dat Yuku & - ṇa & $-t^{y} u$ & $-t^{y} u$ \\
\hline & $2 s$ & nyuntu( $1 u)$ & nyuntu( $(\mathrm{u}(!) u))$ & $n$ yuntu( $1 u)$ & nyuntuku & $-n p a$ & $-\eta k u$ & $-n k u$ \\
\hline
\end{tabular}




\begin{tabular}{|c|c|c|c|c|c|c|c|c|}
\hline & & \multicolumn{4}{|c|}{ Free } & \multicolumn{3}{|c|}{ Bound } \\
\hline & & $s_{1}$ & A & $P$ & DAT & $S_{1}, A$ & $\mathrm{P}$ & $\mathrm{D}$ \\
\hline \multirow[t]{2}{*}{ Mudbura } & Is & Dayi & Dayi & Dayinya & & -ṇa & $-y i$ & \\
\hline & $2 s$ & nyuntu & nyuntu & nyununya & & $-n$ & $-\eta k u$ & \\
\hline \multirow[t]{2}{*}{ Guurindji } & Is & Dayu & Dayu & Dayiny & & - ṇa & $-y i$ & \\
\hline & $2 \mathrm{~s}$ & nyuntu & nyuntu & nyuntu & & $-n$ & $-\eta k u$ & \\
\hline \multirow[t]{2}{*}{ Dyaru } & Is & Dat $y_{u}$ & Dat Yunku & na $t^{y} u$ & & - ṇa & $-y i$ & \\
\hline & $2 s$ & nyuntu & nyuntuku & nyuntu & & $-n$ & $-\eta k u$ & \\
\hline \multirow[t]{2}{*}{ Walmatjar1 } & Is & Dat $y_{u}$ & Dat Yupu & Dat $y_{u}$ & Dat Yuwu & - na & $-t^{y} a$ & $-t y i$ \\
\hline & $2 s$ & nyuntu & nyuntugu & nyuntu & nyuntuwu & $-n$ & $-n t a$ & $-g u$ \\
\hline
\end{tabular}


It is interesting to note that of the languages illustrated, only Bandj1ma, Yindjibarnd1, Ngarluma, Wadjug, Nyungar and Mirniny have pronoun systems in which the oblique case marking is suffixed to a monosyllabic stem in the first and second singular, 1.e. only these languages pattern like the Pama-Nyungan languages of eastern Australia as described in 2.2.2.1. All the rest have disyllabic stems. Contrast the $A$ and $P$ forms in Nhanda and Wadjug,

A P

$\begin{array}{lll}\text { Nhanda (disyllablc) } & \text { gayi } & \text { gayi-na } \\ \text { Wadjug (monosyllab1c) } & \text { ga-tyu } & \text { ga-nya }\end{array}$

Note in particular the distribution of the 'monosyllabic stems' on the map. They are all peripheral. Note too the distribution of languages with bound pronouns and those without bound pronouns and see the correlation between monosyllabic stems and lack of bound pronouns. No language in the area covered has bound pronouns and monosyllabic stems (though some have disyllabic stems and no bound pronouns):

disyllab1c stems

bound pronouns

\begin{tabular}{|c|c|c|c|}
\multicolumn{1}{c}{} & \multicolumn{1}{c}{ d } & \multicolumn{1}{c|}{$x$} \\
\hline+ & + & - & - \\
\hline- & + & - & + \\
\hline
\end{tabular}

The first person disyllabic stems involved are natyv-, nata-, payi-, nayu- and gatyu-. It is falrly clear that these are ergative in origin. The possibility that they derive from a dative and locative source (unlikely on semantic/syntactic grounds), a possibility raised by the similarity of some of the forms with some dative and locative forms, is ruled out by the clearly ergative shape of the second person nyuntu (nyunta being the only other variant).

What appears to have happened is that analogy has operated on the first and second singular to bring them into line with the other person/number combinations of the pronoun paradigm and indeed into line with all other nominals. With other nominals the case suffixes would have been attached to the nominative, as they still are, whereas in the first and second singular there would have been an actual nominative suffix so the other case suffixes would have been attached to a stem. 
41a. Putative earlier system

$\begin{array}{lll} & S_{i}, A & P \text { (standing for rest of } \\ \text { first singular } & \text { pa-tyu } & \text { na-nya pradigm) } \\ \text { first dual } & \text { gali- } \phi & \text { nali-nva }\end{array}$

41b. System after assumed reshaping

$\begin{array}{lll} & S_{1}, A & P \\ \text { first singular } & \text { natyu- } y & \text { jat } y_{u-n} y_{a} \\ \text { first dual } & \text { nali- } \phi & \text { nali-nya }\end{array}$

I doubt whether this represents an innovation made at a stage that we might think of as proto-western-Pama-Nyungan but rather an innovation that diffused from a non-peripheral area. The peripheral languages with monosyllablc pronoun stems are quite similar overall to the languages with disyllablc pronoun stems, certainly not a significantly different substratum (though that is not to say that they lack substratum features entirely). In the case of the other feature that is distributed geographiclly in much the same way as disyllabic stems, viz. bound pronouns, we find that similar languages sometimes fall to share the feature. Ooldean (Ngal1a), Gugada and P1tjantjatjara are quite similar, but only Pitfantfatjara has bound pronouns. Ooldean does exhibit some instances of -na (first person singular). As I stated earlier, I belleve that the bound pronoun princlple was probably spreading rather than receding, but the considerable discrepancy between the bound and free forms is disturbing.

A number of other developments must have followed the introduction of disyllabic stems in the singular. As noted in 2.2.2.2, a number of the northern languages under consideration developed an ergative system of pronouns. On the evidence avallable to me 1 t is not clear whether Nyangumarda, Garadjarl and Mangarla have completely ergative paradigms; Mangarla appears to have mostly a three-way system.

Pintup1 has developed an ergative system w1th - nva generalised to $S_{1}$. A number of languages in the area have generalised - nva to $S_{1}$ with some classes of nominals. This development is not 1solated. Pitfantfatjara and some adjacent languages have transferred -lu from the noun paradigm to the pronoun paradigm, extending it from $A$ to $S_{1}$ and $A$, an interestIng development in light of the putative augmentation discussed in 2.2.2.1.

However, the main reason Table 40 was presented was to 1llustrate 
the discrepancy between the shape of the bound pronouns and the free pronouns. In almost all the languages in the area that have bound pronouns, the first person singular $S_{1}$, A bound form is -na. There is virtually no possibility of relating this to na via sound changes. Warluwara (Q., Breen 1971), a Pama-Nyungan language that does not employ bound pronouns, has nana as 1ts first person singular $S_{1}$, A free form, and so does Yanyula (N.T., K1rton 1964), a non-PamaNyungan language on the southern coast of the Gulf of Carpentarla. These languages may retaln a relic of the free form from wh1ch -na 1 s derlved. Warluwara is not far from the perlphery of the languages under discussion and Indeed is cont1guous with Kalkatungu which can be shown to be an outlier of western Pama-Nyungan. Yanyula is some distance to the north but Yanyula and Warluwara share strikingly simllar pronoun paradigms (Breen p.c.) though geographically separated and typologically quite different. 18 As can be seen from the table, Mirniny has nana-na as the free $P$ form for first person. Th1s too looks like a relic of the form from whlch nana must have been derived. There 1s no need to posit nana as having occurred in proto-westernPama-Nyungan nor indeed directly in the history of any one language in which it is now found. All that needs to be posited is a form * nana in a language in which bound pronouns developed. Loss of the first syllable of a disyllabic stem and retention of the second syllable is very common in the formation of bound pronouns from free ones. It must be remembered that nana 1s disyllab1c. In explaining the development of disyllabic stems in western-Pama-Nyungan, earlier monosyllab1c stems were posited. We need to posit *nana as a source of na and *nay+lu as a source of the disyllablc (and monosyllab1c) stems. The continuous distribution of both these features is strongly suggestive of diffusion. There is no theoretical difficulty in positing these as sources occurring independently at some stage of the history of the area.

The flrst person bound form for $P$ is represented by $-t y a,-n i$, $-n y a,-t y u$ and -yi. -nya is simply a reflex of the accusative marker (see Capell 1962:80 re Garadjar1). - tyu is a dative in origin. Note that 1t is distinctively so in Yulbaridja for instance and represents a syncretism of $P$ and DATIVE in Walbirl. Its ultimate origin is plausibly -*ku(*nay $+k u>$ patyu). Compare the corresponding second person forms. -yi is a dative form also and occurs only in some of the languages where $P$ and DATIVE are syncretised in the bound forms. The evidence is the parallel appearance of -ku with the other person/ number combinations and the parallel vowel shift and lenition of the 
$S_{1}$, A form (*natyu $>$ natyl > nayi) at least in Mudbura. 19 -tya In form is plausibly a locative; compare the parallel form -ta with the second person. If this assumption is correct, it suggests a system in which $P$ was marked by a locative in the first and second singular. - ni is even more difficult to explain but the Mirniny free form dative naniya (alongside accusative naṇana) is suggestive. Where it occurs, 1t is parallelled by -ta in the second person.

of the second person forms, $-n$ for $s_{1}$, A is a not unexpected reflex of * $N Y V n$, and -npa is simply - $n$ plus -pa, a phonological filler added in some languages that do not allow final consonants (cf. Hale 1973b). The $P$ form - $n$ ta is interesting in that it looks as if it might reflect the locat1ve*-la (cf. 2.1.2, 2.2.1). -jku occurs only where there is a syncretism of $\mathrm{P}$ and DATIVE, but note that - $n$ ta and the corresponding first person forms contrast with dative forms in a number of languages.

\subsubsection{Languages with Fused, etc. Bound Pronouns}

The final stage of the development of bound pronouns can be 1llustrated from a number of non-Pama-Nyungan languages particularly in Arnhem Land. In a majorlty of these northern languages the bound pronouns are prefixed to the verb or to the auxiliary verb. In transitive clauses the pronouns representing $A$ and $P$ are usually contiguous.

In Maung (Goulburn Is. N.T., Capell and H1nch 1970:73-76) the $S_{1}$ forms for first and second singular are na and an respectively, but in a clause where first singular is $A$ and second $P$ or vice versa we do not find these two morphemes. Instead for $1 \mathrm{~s} \rightarrow 2 \mathrm{~s}$ (where $\rightarrow=$ 'acting on') we find gun and for $2 s \rightarrow$ ls we find gan. Dan is not na + an since the $-n$ upon closer inspection turns out to be a marker of $P$ function for first and second person, 1.e. It is an accusative marker presumably reflecting * $-\mathrm{N}^{\mathrm{V}}$. Maung exhibits a number of principles in the formation of 1 ts bound pronoun complications. Where $A$ and $P$ are both first or second person, the person of $P$ only 1s marked. This is true of the example just quoted. gu- is to be glossed as second person in $P$ function. Where $A$ and $P$ are third person, $P$ precedes $A$ but if a first or second person actant is involved that person precedes a third person. There are a number of neutralisations, e.g. Janin or na+ni+n consists of a first person marker, or plural marker and $-n$, the accusative marker, but it is used not only for $2 \mathrm{pl} \rightarrow 1 \mathrm{pl}$ but also for $2 \mathrm{pl} \rightarrow 1 \mathrm{~s}$. Moreover, there are a number of phonological constraints operating that force a number of morphophonemic changes. The total effect of the person hierarchy, suppletion, neutralisation, morphophonemic changes, and 
the constraint on specifying the person of $A$ in combinations involving first and second person is to render the system synchronically unanalysable. The only reasonable synchronic analysis is to assume that a speaker of a language like this learns off by heart the finite set of forms involved. On the other hand an internal reconstruction of the system can easily be carried out.

I will not present the Maung data in full. The reader is referred to Capell and Hinch or to Blake 1977 where data in Maung, Y1wadja, Rembarnga and Gunwinggu is displayed and partially analysed.

There is no doubt that in these languages and in some other languages of Arnhem Land, e.g. Nunggubuyu and Ngand1, the representation of combinations of $A$ and $P$ by bound pronouns is quite opaque and represents the end of a line of development from the exclusive use of free forms via transparently abbreviated bound pronouns.

It is important for the overall argument presented here to note that in most of the non-Pama-Nyungan languages one finds clear reflexes of * $\mathrm{NYa}$. Ngandi is an exception in that -ku has been generalised at the expense of ${ }^{*}-N^{Y}$ (see Heath forthcoming:section $3.6)$.

Some non-Pama-Nyungan languages are not opaque in the way I have described above. In some of the Daly River languages, for example (Tryon 1974), the $S_{1}$, A pronoun is prefixed to the auxiliary verb and the $P$ pronoun suffixed. Usually there is some fusion of the $S_{1}, A$ pronoun and the auxiliary and discrepancles between the shape of free forms and their bound counterparts.

\subsubsection{Summary}

The evidence suggests that with few exceptions there has been a development from having independent pronouns only to using obligatory cross-referencing bound pronouns with free forms being used only for emphasis. The languages lacking bound pronouns are almost all to be found in a swath running from the Great Australian Bight in South Australla to Cape York. This represents the most conservative area typologically. This area is flanked, particularly to the east (most especially in and near to New South Wales) by languages exhibiting bound pronouns that show a clear relationship with the free forms. Most of the Pama-Nyungan languages of Western Australia have a bound pronoun system that is not clearly related to the system of free forms especially in the first and second singular. The non-Pama-Nyungan languages often have complicated systems of obligatory crossreferencing bound pronouns, complicated in that there is no clear 
relationship between the $A$ and $P$ bound forms and the $S_{1}$ bound forms and between the free $\left(S_{1}, A, P\right)$ forms. Where this relationship has been obscured by morphophonemic constraints, hierarchical rules, person or number neutralisation rules, etc., it is possible in every reported case to demonstrate that an accusative system underlies the irregularities.

\section{SYNTAX}

The presence of ergative morphology raises a number of interesting syntactic questions. Since in an ergative system of marking it is $P$ that is 1dentified with $S_{1}$ one wonders if $P$ is identified with $S_{1}$ in syntactic rules. One wonders if $P$ is in some sense more closely tied to the verb than $A$, the latter being a peripheral constituent like the $A$ in a passive construction. And one wonders if there is an active/passive distinction in these ergative languages.

Because of lack of data it is not possible to pursue this question in detall covering a wide number of languages. I will confine myself to a few selected examples.

\subsection{Walbiri}

Walb1r1 (N.T.) a western Pama-Nyungan language 1llustrated in a number of papers by Hale, seems not to be syntactically ergative though it has a fully ergative case marking system operating with both nouns and pronouns (see example 40). In fact Walb1r1 seems to have rules that 1dentify $A$ with $S_{1}$ and rules that make no exclusive identification of either $A$ or $P$ with $S_{1}$.

For example, in indirect commands it is $S_{1}$ and $A$ that must be supplied as covert constituents of the subordinate clause (Hale 1968: 36-37),

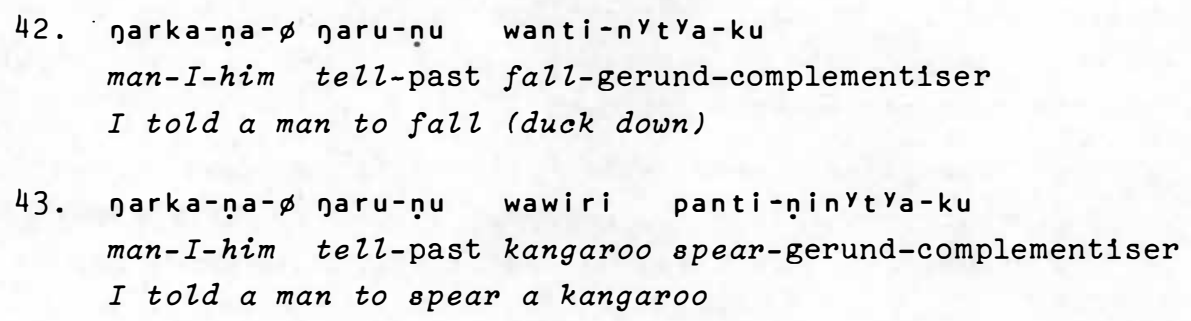

Similarly with the following constructions, it is $S_{1}$ and $A$ that must be understood as covert constituents of the subordinate clause under identity with the $P$ of the main clause (Hale 1968, and p.c.). 
44. Darka-nku wạna pantu-ṇu pạ̣ka-nvtya-kura man-erg snake spear-past run-gerund-complementiser The man speared the snake as it was moving quickly

45. Darka-nku wạna pantu-ṇu kuḍa ya!ki-ṇinytya-kura man-erg snake spear-past child bite-gerund-complementiser The man speared the snake as it was biting the child

Walbirl does not have anything like a passive construction. In English rules for the well-formedness of complex sentences often make reference to the notion of grammatical (1.e. derived or surface) subject. The grammatical subject is $S_{1}$ or $A$ in the unmarked case, but it can embrace $P$ if the passive construction is used. The constructions 1llustrated above operate strictly with reference to $S_{1}$ and $A$, more particularly, with reference to the identity of $S_{1}$ and $A$ in the subordinate clause and $P$ in the main clause. If one wants to say something like The man speared the kangaroo that was being followed by the dogs then another construction must be used,

46. Darka-nku wawiri pantu-ṇu kutya-lpa maliki-li pura-tya man-erg kangaroo spear-past comp-aux dog-erg folzow-past The man speared the kangaroo as it was being followed by the $\operatorname{dog} s$

This latter structure is exemplified in Hale 1976 (d) and he refers to it as the 'adjoined relative clause'. It appears to be a construction in which there might be no actant common to the main and subordinate clauses (In which case 1t corresponds to English sentences of the type $X$ did $Y$ while $W$ did $Z$ ) or 1t might involve 1dentity of reference between any of the actants of the main clause and any of the actants of the subordinate clause. Where there is this co-reference, the co-referent noun phrase in one clause or the other is anaphorically deleted or represented by a pronoun:

47. Datyulu-!̣-ṇa yankiri pantu-ṇu. kutya-lpa napa na-ngu I-erg-I emu spear-past comp-aux water drink-past I speared the emu which was/while it was drinking water

48. yankiri-!l kutya-lpa napa na-ṇu, gula-ṇa pantu-ṇu emu-erg comp-aux water drink-past that-one-I spear-past nat $y u l u-l u$ $I$-erg The emu which was drinking water, that one I speared 
This construction does not seem to be orlented either accusatively or ergatively.

\subsection{Pitta-Pitta}

In the non-future Pltta-Pitta (W.Q.) employs ergative and accusative marking for all nominals. In the future, a single form represents $S_{1}$ and $A$, while $P$ is represented by a dative (-ku) or the accusative (-na). Roth (1897) records $-k u$, but the main informant consulted by Breen and myself uses $-k u$ or na.

$$
\begin{aligned}
& \text { 49. palku nu-wa-ka kaṇța-ya-gu } \\
& \text { man he-nom-delctic go-pres-hither } \\
& \text { The man comes } \\
& \text { 50. piți-ka palku-lu nu-lu-ka kulparri-naa } \\
& \text { kill-past man-erg he-erg-delc emu-acc } \\
& \text { The man kilzed the emu } \\
& \text { 51. palku-ju ñu-ju-ka kaṇța- } \\
& \text { man-fut he-fut-delc go-fut } \\
& \text { The man will go }
\end{aligned}
$$

These examples 1llustrate the system for marking $S_{1}$, $A$ and $P$ in the non-future and future. The word order is falrly flexible, but a preferred order $1 \mathrm{~s} \mathrm{VS}_{1}$ and $\mathrm{VAP}$, especially if the actants are represented by pronouns. The use of a third person pronoun crossreferencing $S_{1}$ and $A$ is practically obligatory, and a third person pronoun cross-referencing $P$ is employed occasionally (see bracketed 1tem in 52 above) if $P$ is definite.

Clearly the case marking system in the non-future is neutral rather than ergative or accusative, while in the future it is, at least in terms of 1dentification of $S_{1}$ and $A$, an accusative system. It is not too surprising then to find that the syntax is neutral.

Consider for example the following sentences: 
53. mamakaya-ka na-țu plyawa!l l-na ț lnpa-ma-ka-na grab-past $I$-erg dog-acc run-around-past-acc I grabbed the dog $\left\{\begin{array}{l}a s \text { he } \\ \text { who }\end{array}\right\}$ ran around

54. mamakaya-ka ga-țu kați-na piyawa!i-lu țatyi-ka-nal(-)wat y $\mathbf{i}$ grab-past I-erg meat-acc dog-erg eat-past-acc-before I grabbed the meat before the dog ate it

55. mamakaya-ka na-țu piyawa! i-na kați-ña țatyi-ka-na grab-past I-erg dog-acc meat-acc eat-past-acc I grabbed the dog $\left\{\begin{array}{l}\text { as he } \\ \text { who }\end{array}\right\}$ ate the meat

In each sentence an actant of the main clause is co-referent with an actant of the subordinate clause; more specifically $P$ of the main clause is co-referent with $S_{1}, P$ and $A$ in 53, 54, 55 respectively. In a transformational model one would describe the formation of these sentences in terms of deletion of an actant from the subordinate clause under co-reference with an actant of the main clause. Note that no exclusive identification of $S_{1}$ with $P$ or of $S_{1}$ or $A$ with $P$ is required; an identification of any actant in a major syntactic relation in the subordinate clause with $P$ in the main clause makes for the formation of a well-formed sentence. This holds true for other constructions. In general the syntax seems to be neutral, 1dentifying neither A nor $P$ with $S_{1}$, the neutrality of the syntax reflecting the neutrality of the case marking.

\subsection{Kalkatungu}

Kalkatungu (W.Q.) has a morphological system similar to that of Walbirl (nouns and free pronouns operate ergatively, but bound pronouns accusatively) but differs from 1t syntactically in that it does have a passive-like case-switching rule.

Let us consider first of all constructions involving - nyin ( -tyin). - nyin occurs on the verb of subordinate clauses that translate English adverblal phrases and clauses of time (while working, as he was patting the dog) or relative clauses (who was ...). It seems to be a nominalising suffix to which noun case marking may be added; I refer to 1 t as a part(1ciple). 


$$
\begin{aligned}
& \text { 56. na-tu lai-na pl!a-pila inka-trin } \\
& \text { I-erg hit-past child go-particlple } \\
& \text { I hit the child as he was walking along }
\end{aligned}
$$

57. Da-țu lai-na pila-pila kanḳari-i nita-i-nvin

I-erg hit-past child knife-dat steal-a/p-part

I hit the child for stealing the knife

58. Da-țu wațintii-na pila-pila țuku-yu itya-nvin

I-erg carry-past child dog-erg bite-part

I carried the child who got bitten by the dog

In 58 pila-pila represents the $P$ of the main clause and the $P$ of the subordinate clause. In 57 pila-pila represents the $P$ of the main clause and the $A$ of the subordinate clause. Note that in 57 , the verb is marked by a suffix $-i$, which I have glossed as $a / p$ for ant1passive. In the ant1-passive construction $A$ is marked by the nominative and $P$ by the dative. The term 'anti-passive' (see S1lverstein 1976) captures the analogy with passive constructions. In both, the case relation occupying the nominative case form is demoted to a more peripheral case slot and a case relation previously occupying a non-nominative slot is promoted to the nominative slot. This construction is used in Kalkatungu in - nvin clauses, and in a number of other types of subordinate clause, whenever the $A$ of the subordinate clause is co-referent with an actant of the main clause. It can be considered a device to facilitate deletion, since the use of this construction enables the case relations of anaphorically deleted actants to be recovered. If one considers 57 then it might seem that the ant1-passive is a device for ensuring that only actants in the nominative are deleted. Indeed 1 t may well have been motivated originally by such a consideration, but in 57 , the case relations can be determined from the case marking of the overt actant. If there were no ant1-passive in the language, then a nominative noun phrase in the complement would indicate a deleted A. And of course 1t must be remembered that many Australian languages work quite happlly w1thout an ant1-passive. The fact that there is a cholce between the unmarked construction and the ant1-passive, means that a subordinate clause with no overt actants can be uniquely interpreted, for Instance:

$$
\begin{aligned}
& \text { 59. Da-țu lai-na pila-pila nanvi-i-nvin } \\
& \text { I-erg hit-past child see-a/p-part } \\
& \text { I hit the child for looking }
\end{aligned}
$$




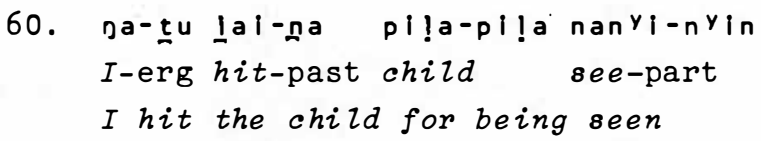

Languages without the ant1-passive elther allow ambiguous structures ranging over the two possibilities or they provide entirely separate constructions for the two possibilities.

Before going any further I should point out that the ant1-passive marker is permanently affixed (and therefore non-functional) to independent verbs in Kalkatungu. This point is taken up again in 3.6.1.

From a consideration of the $-n y i n$ construction, Kalkatungu appears to be a mirror 1mage of English. $S_{1}$ and $P$ are 1dentified in the unmarked construction $(56,58)$ and $A$ is treated specially as it is in the case marking. However, if we consider the favourite construction, further complications arise. This construction, so termed because of its high functional load and high frequency, is usedprincipally to express purpose and indirect commands, but also to provide complements for noun phrases. It differs from the $-n y i n$ construction principally in that the subordinate clause contains at least one bound pronoun suffixed to a particle which I will call the complementiser. A typical purposive example would be,

$$
\begin{aligned}
& \text { 61. inka-na nyini ucan-ku a-ni anpa-i? } \\
& \text { go-past you wood-dat comp-you gather-a/p } \\
& \text { Did you go to collect firewood? }
\end{aligned}
$$

- $n i$ is a bound pronoun representing second person singular and it co-references $n \times i n i$ in the main clause. The $-i$ on the verb is the ant1-passive marker. The case marking in the dependent clause is in accordance with the ant1-passive construction, $-n i$ being the $A$ and appearing in the nominative, while ucan, which is the $P$, is marked by the dative. Note however that the bound pronouns operate in an accusative paradigm only. - $n i$ represents $S_{1}$ and $A$ and is opposed to -kin the form for $P$.

For the most part, only one actant can appear as a bound pronoun in the complement clause of the favourite construction. The actant to be chosen for representation as a bound pronoun in the case of a transitive complement is determined by a person hierarchy rule, first person taking precedence over second and third, and second taking precedence over third. If both actants are third person, A takes precedence over $P$. If one actant is first singular and the other 
third plural, then both may appear as bound pronouns suffixed to the complementiser.

For example, a sentence such as He came here to hit me would be translated Into Kalkatungu as

$$
\begin{aligned}
& \text { 62. nauna inka-na a-ni(-) la } a^{20} \\
& \text { hither go-past comp-me-hit } \\
& \text { He came here to hit me }
\end{aligned}
$$

whereas we went there to hit them would be translated as

$$
\begin{aligned}
& \text { 63. pauna inka-na nata tina-a a-ti la-i } \\
& \text { thither go-past we they-dat comp-we hit-a/p } \\
& \text { we went there to hit them }
\end{aligned}
$$

The ant1-passive construction is used in the subordinate clause where $A$ and only $A$ is represented by a bound pronoun and where it co-references $S_{1}$ or $P$ in the main clause. Thus it is used in 61 $\left(S_{1}=A\right)$ and $63\left(S_{1}=A\right)$ but not in 62 where the bound pronoun represents $P$. The following sentence lllustrates 1 ts use where the A pronoun co-references $P(P=A)$,

$$
\begin{aligned}
& \text { 64. nyini gkai-na ucan-ku a-ni anpa-i? } \\
& \text { you send-past wood-dat comp-you gather-a/p } \\
& \text { Did he send you to collect firewood? }
\end{aligned}
$$

So far everything appears to operate on an ergative princlple, but since in the case where we are dealing with third person actants, it is $A$ rather than $P$ that must be represented by a bound pronoun in a transitive complement, $A$ rather than $P$ is being identified with $S_{1}$.

In sum, Kalkatungu appears to have:

(a) an active/passive-like distinction that involves identifying $S_{1}$ and $P$ in the unmarked case;

(b) a principle that operates on the basis of grammatical subject. In the $-n y i n$ and certain other constructions $P$ of a main clause can be co-referent with $S_{1}, P$ or $A$, but if with $A$, the ant1passive must be used (57);

(c) a principle that operates on the basis of an underlying subject $\left(S_{1}\right.$ and $\left.P\right), v 1 z$. the princlple that determines whether the anti-passive is to be used in the favourite construction and the 'lest' construction (not 1llustrated);

(d) a principle that identifies $S_{1}$ and $A, v i z$. the principle that requires that these actants be represented by bound pronouns in the 
favourite construction and the 'lest' construction (subject to the person hierarchy).

\subsection{Dyirbal}

Dylrbal (NE.Q.), the only Australian language which has been described in any syntactic detall (Dixon 1972), appears to be ergatively orlented in its syntax.

In Dyirbal, nouns operate in an ergative paradigm and first and second person pronouns operate in an accusative paradigm. Dixon characterises the language as one in which the syntax operates consistently on an ergative principle, even though the morphological case marking is partly ergative and partly accusative (1972:128-130).

Dixon presents sentences such as (1972:130),

65. bayi yara baninyu bangun dyugumbiru balgan the man come-past the-erg woman-erg hit-past The man came and was hit by the woman

66. bayi yara baninyu bagun dyugumbilgu balgalganyu the man come-past the-dat woman-dat hit-a/p-past The man came and hit the woman

In 65 a complex sentence is formed on the basis of the actant common to the two clauses (bayi yara) being $S_{1}$ in the first clause and $P$ (deleted or covert) in the second. In 66 a complex sentence is formed on the basis of the common actant being $S_{1}$ in the first clause and $A$ in the second. Note however that in 66, an anti-passive construction must be used in which $A$ is in the nominative (but deleted in our example) and $P$ in the dative, with the verb being marked by the ant1-passive marker - nay.

The general principle is that where $A$ is co-referent with a major actant of another clause in the same sentence, the clause (or clauses) with a co-referent A must be ant1-passivised (see Heath forthcoming a). Dyirbal is ergative in its syntax in that $A$ is specially treated. It operates largely in terms of $S_{1}$ and $P$ being treated as a grammatical subject with A being promoted to that syntactic slot under certain co-reference conditions. One could compare English sentences such as I persuaded him to go, I persuaded him to eat the cake and I persuaded him to be fumigated by a health officer. Where $S_{1}$ and $A$ in the infinitival complement are co-referential with the 'persuadee', the unmarked active construction is used in the complement. Where $P$ is 
co-referent with the 'persuadee', the passive must be used in the complement to promote $P$ to the grammatical subject position.

\subsection{Summary}

As stated at the beginning of the syntax section of this paper, it is not possible to say much about the syntax of Australian languages in general. The type represented by Walbir1, 1.e. a type in which there is nothing akin to a passive rule and where there are syntactic rules based on $S_{1}$ and $A$ and neutral syntactic rules is probably widespread. Languages with an ant1-passive are not too widespread. Y1diny, DJaabugay and Warungu, three languages whose territory was contiguous with or close to Dyirbal territory exhibit anti-passive constructions though they are not closely related to Dyirbal. Ant1passive constructions also appear to be a feature of Bandjalang (N.S.W., Q., Crowley p.c.), Yalarnnga (Q., author's and Breen's fleld notes), Kala Lagau Langgus (Torres Stra1t Q., Ban1 and Kloke1d 1976), and probably, or at least possibly, Guugu-Yalandf1 (Q., R. Hershberger 1964). P1tta-Pitta does have an ant1-passive in independent sentences, see 3.6 .2 .

The accusative Pama-Nyungan languages both Lardil and the other 'Gulf' accusative languages and Ngarluma and the other accusative languages of $\mathrm{NW}$. Western Australia have passive constructions. Ngarinyin and some other non-Pama-Nyungan langauges of the Kimberleys also have a passive construction.

\subsection{Some Suggested Historical Developments}

It is interesting to speculate whether the ergative elements represent an older layer in these systems or whether the accusative elements represent an older layer or whether there is movement in both directions, from ergative to accusative, or from accusative to ergative. There is also the possibility that there is movement to or from a neutrally orlented system.

In two cases it is possible to detect the direction of change. In Kalkatungu the ant1-passive has been generalised in non-dependent clauses and in Pitta-P1tta it has been generalised in at least one type of dependent clause.

\subsubsection{Kalkatungu}

In Kalkatungu the $-\boldsymbol{i}$ that features in examples such as $57,59,61$, 63 and 64 as an ant1-passive marker occurs regularly on non-dependent verbs in the present and past tense. 


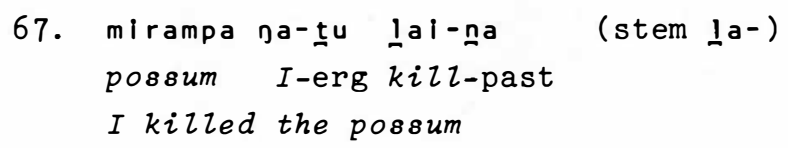

Kalkatungu does employ a construction in which A appears in the nominative and $P$ in the dative. This is used to indicate uncompleted act1vity (see 10) and 1 t 1 s also used where there is a predictable Indefinite $P$ and in drink water, cook tucker, etc. However, - $\mathbf{i}$ appears regularly on the verb in this construction also. Since - $i$ does not have any function with independent verbs, I have interpreted the ant1-passive function with dependent verbs as representing the older usage. There is one very plausible reason why the ant1-passive marker might have been general1sed. In the nature of things - $i$ w1ll appear on over ninety per cent of dependent verb tokens. One often has occasion to use patterns such as: $X$ went to do such-and-such, $X$ told $Y$ to do such-and-such, but rarely does one need to use patterns such as: $X$ went to be verbed by $Y$, or $X$ told $Y$ to be verbed by $Z$. Remember that the anti-passive is used when $A$ in a dependent clause co-references $S_{1}$ or $P$ in a governing clause. Under these circumstances the verb forms in - $i$ must have been very common and so 1 t is not too surprising that they were generalised to main verbs as the regular form. This may not be a correct explanation, 1t may be that there was a usage of the ant1-passive in main clauses and that the $-i$ was generalised from this construction. It is to be expected that $-\mathbf{i}$ would have been used in the construction in which A is marked by the nominative and $P$ by the dative. One way or another the unmotivated use of $-i$ with independent verbs must represent a relative innovation.

It is worth noting in passing that proto-Kalkatungu *1 developed to $* y$ so that $-y \mathbf{i}$ or $-i^{21}$ can plauslbly be derlved from $*-1 \mathbf{i},-1 \mathbf{i}$ belng a common reflexive or reflexive/reclprocal marker in Pama-Nyungan languages and the ant1-passive in the adfacent language Yalarnnga and In P1tta-P1tta, 1mmediately to the south of Yalarnnga.

Kalkatungu uses some dependent verb forms as independent verbs. For example, - $n y$ tyaya the infinitive or purposive form, can occur as a dependent verb as in

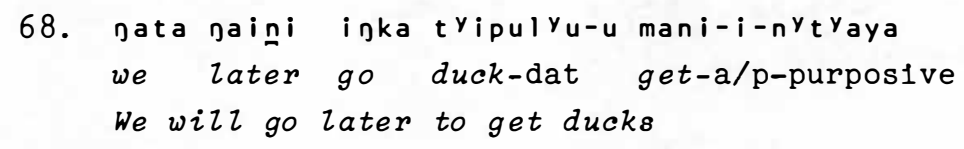

or as an independent verb as in 
69. mirampa caa na-țu waku la-nytyaya possum here I-erg skin hit-future I'm going to skin the possum

When it is used as a dependent verb the ant1-passive principle operates, however when $1 \mathrm{t}$ is used as an independent verb, there is no alternation between passive and unmarked forms. The unmarked form is the only form that is used. This would be the form required if it were dependent with its A co-referencing a governing A.

The favourite construction $1 \mathrm{~s}$ also used as a non-dependent verb form and it is always the non-ant1-passive form that is employed,

$$
\begin{aligned}
& \text { 70. nata-i kuțu a-ti itya } \\
& \text { we-erg egg (comp) } 22 \text { we eat } \\
& \text { we wizl eat the eggs }
\end{aligned}
$$

In sum there is no cholce between having - $i$ or not having it in Independent clauses. Where dependent verb forms are used as Independent verbs, $-i$ is not used. W1th ordinary independent verbs, $-i$ is almost always used. 23

The construction 1llustrated in 70 is interesting that the bound pronouns assume a cross-referencing rather than a co-referencing potent1al.

\subsubsection{Pitta-Pitta}

In P1tta-P1tta $-1 \mathbf{i}$ is suffixed to the verb to indicate activity that is potentially rather than actually directed towards $P$. In the '- $1 \mathbf{i}$ construction' $A$ is in the nominative and $P$ is marked by $-k u$, which I will gloss as dative, or alternatively by the accusative -na. $-k u$, besides marking $P$ in the ' $-1 i$ construction' marks the complement of certain verbs such as yata- (to like) and manuwanytyi- (to be wild with). There is also a suffix - na covering the possessive and purposive functions.

In Roth (1897) $-1 \mathbf{i}$ is 1llustrated as providing a means of expressIng a transitive verb in the absolute sense, 1.e. with no $P$ (op. c1t. 23, author's phonemicisation),

$$
\begin{aligned}
& \text { 71. tatyi-li-ya nanytya } \\
& \text { eat-a/p-pres I } \\
& \text { 'I am at-eating, at dinner, etc.' }
\end{aligned}
$$

This usage 1s confirmed by the best avallable informant, but she also produces sentences such as: 


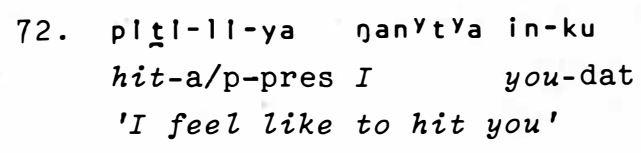
73. patya-li-ka nuwaka in-ku
bite-a/p-past he you-dative
He was very wild with you

In purposive complement clauses, the verb is always suffixed by $-1 \mathbf{i}$ and then further suffixed by - ga the suffix used to express purpose (or possession) with nouns. Consider the following sentences,

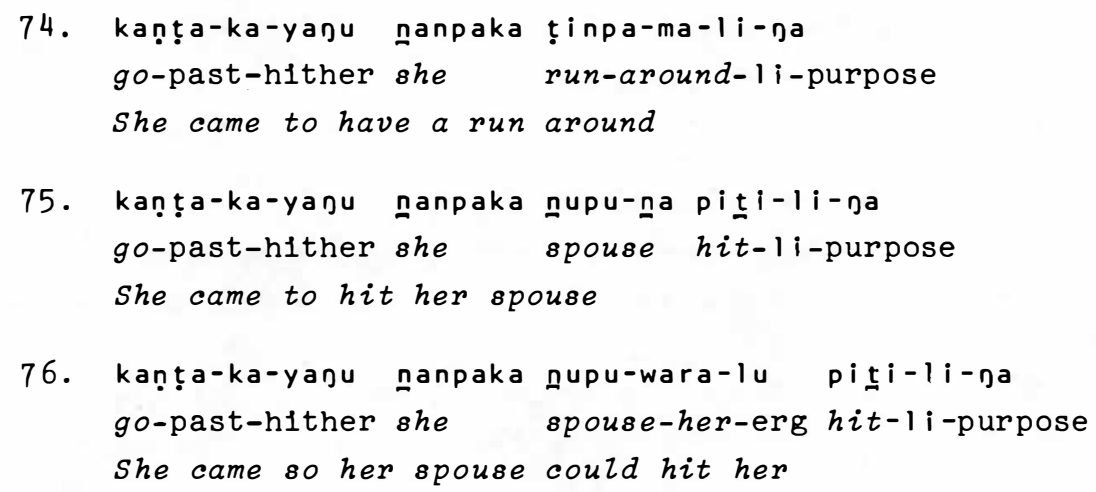

Note in particular that $-1 \mathbf{i}$ occurs in 75 where we would expect a syntactically motivated anti-passive in a language with such a feature, and also in 74 and 76 where we would not expect an ant1-passive.

Since the use of $-1 i$ is significant with non-dependent verbs but not significant with dependent verbs, it seems that the usage with nondependent verbs is older. If we note also that the form involved is $-1 \mathbf{i}$, which is the reflexive-reciprocal marker in a number of PamaNyungan languages, and if we consider that the ant1-passive marker is the same as the reflexive-reciprocal in a number of Australian languages, then there is reason to believe that here we are dealing with an ant1-passive marker that has been generalised. As we observed above in the case of Kalkatungu a syntactically motivated ant1-passive is in the nature of things likely to be used in an overwhelmingly large number of subordinate clause tokens. It would be subject to considerable pressure from each new generation of language learners to extend it at least to all transitive verb tokens in dependent clauses.

The ant1-passive marker in Yalarnnga, the language 1mmediately to the north of Pitta-Pitta, is $-1 \mathbf{i}$. The present reflexive-reciprocal 
marker in Pitta-Pitta is mali, doubtless from matli, ma being a common 'verb morpheme' in Australian languages, appearing as a transitiviser in some languages and as an intransitiviser in others. The $-1 i$ of P1tta-P1tta, the $-1 i$ of Yalarnnga, the -yi $(<-1 i)$ of Kalkatungu and the reflexive-reciprocal $-1 \mathbf{i}$ of a number of other Pama-Nyungan languages undoubtedly reflect a proto-form *-li, though that does not rule out the possibility of 1ts being borrowed from language to language in one function or another. It is likely that the reflexive and/or reciprocal function antedates the anti-passive function. It is interesting to compare the development of passives in Europe from reflexive constructions, in Latin for example, and independently in Romance and Scandinavian.

\section{GENERAL SUMMARY}

If one accepts the serles of suggestions put forward in this paper, and it must be remembered that some of them are rather speculative and intuitive and not based on rigorous reconstruction, then the following plcture emerges.

First of all we have a language in which nouns operate in an ergative paradigm and pronouns in an accusative paradigm. Then crossreferencing bound pronouns are introduced and finally the case marking for the major syntactic functions is lost in favour of the bound pronouns.

$\begin{array}{llll} & \text { Nouns } & \text { Pronouns } & \text { Bound Pronouns } \\ \text { Stage } 1 & \text { ergative } & \text { accusative } & \\ \text { Stage } 2 & \text { ergative } & \text { accusative } & \text { accusative } \\ \text { Stage } 3 & & & \text { accusative }\end{array}$

A fourth stage could be added in which the bound pronouns become unanalysable.

The first stage is represented by languages in a swath running from the Bight to the Gulf and probably embracing the area from the Bight to Perth (see map). The next stage is represented by the eastern Pama-Nyungan languages that have bound pronouns. A slightly more advanced stage is represented by the western Pama-Nyungan languages that have bound pronouns. The most advanced stage is represented by the non-Pama-Nyungan languages, most of which have lost their case marking.

The fact that the cross-referencing pronouns operate in an accusative paradigm is taken to be simply a reflection of the fact that the bound pronouns are derived from free pronouns which operated 
in an accusative paradigm. The free pronouns that operate in an ergative paradigm are interpreted as having developed an ergative paradigm after the bound pronouns were derived.

Ant1-passive constructions, which signify a type of ergative syntactic system, 1.e. one that is ergative in the sense that English is accusative, are concentrated among the languages lacking bound pronouns. This may be because languages with co-referencing bound pronouns would place a smaller functional load on the ergative/antipassive distinction and render the anti-passive more liable to succomb to the pressures described with reference to Kalkatungu and P1tta-P1tta $(3.6 .1,3.6 .2)$.

It is interesting to note that Pama-Nyungan, the family that covers most of the continent, appears to be the most conservative family. Naturally since this family covers such a vast area compared to the other families in the north, it represents the area of lowest diversification. This means that the area of lowest diversity is typologically the most conservative. It has been suggested that Pama-Nyungan spread over its present area comparatively recently. Glottochronology, for what it is worth, ylelds a time depth of 5,000 years (Wurm 1970:18). A comparison of morpho-syntactic diversification In Pama-Nyungan and Indo-European suggests that if Indo-European provides any kind of measuring stick, then a figure of 5,000 or a little less is about right for Pama-Nyungan. One way or another Pama-Nyungan must be of an age considerably less than the period of time Man has been in Australia $(+40,000$ years) and certainly less than proto-non-Pama-Nyungan. Thus we are left with a mystery. If PamaNyungan was part of a language pattern showing the diversity of present day non-Pama-Nyungan less the effects of 5,000 years, how is It that this relatively conservative member happened to be the one that was spread? Or did it undergo some kind of pidginisation in the course of 1 ts spreading, which presumably must have been at the expense of other languages? Or again, is this line of thought quite wrong? Does Pama-Nyungan represent the pattern that was once ubiquitous, and is it that the non-Pama-Nyungan languages for reasons unknown have been subject to relatively accelerated typological change? 


\section{NOTES}

1. I represent the ergative as being basically -lu on the suggested reconstruction of Hale's (1976d:414). See also 2.1.1.

2. I represent the accusative as deriving from $-\mathrm{N} Y a$ on the suggestion of Dixon's (1970) that $n$ and ny derlve from a single proto-laminal.

3. I describe verbs which require only $S_{1}$ as 'intransitive' and any actant that occurs optionally as in English He waits for her is described as an adjunct. Some verbs take two actants but differ from transitive verbs in that they take the same case marking as an intransitive verb with $S_{1}$ and an adjunct. I describe these as 'sem1transitive with $S_{1}$ and a complement'.

4. The functions listed here are categorised semantically. In writing a general paper it is not possible to determine which distinctions are made syntactically. Where the term DATIVE is used 1t refers broadly to these functions lumped together.

5. Examples from Kalkatungu, Yalarnnga, Wangka-Manha or P1tta-P1tta, unless otherwise ascribed, are from my fleld notes.

6. The extra - $i$ which appears unglossed on puni and on $n t i$ in examples 16, 17 and 18 appears on virtually all independent transitive verbs in Kalkatungu. It is discussed in 3.6.1. It appears to be an orlginal ant1-passive marker that has been generalised. In dependent clauses, it functions as an ant1-passive and hence may appear or not in accordance with the conditions described in 3.3 .

7. An example of the -wa -pa alternation can be observed in examples 73 and 74 where the P1tta-P1tta forms for he and she occur

$$
\begin{array}{ll}
\text { he nu-wa-ka } & \text { nhe nan-pa-ka }
\end{array}
$$

$-k a$ is the unmarked member of a set of three delctic suffixes. These forms are left unanalysed in the glosses of P1tta-P1tta sentences for the sake of simplicity.

8. Hale labels his hypothesis as 'highly speculative' and Indeed there are a number of points that still require explanation. In commenting 
on this section of the draft, Hale drew my attention to the fact that in Nyangumarda (W.A.), $-t v_{u}$ is used with consonant stems. The same is true of Yulbaridja (W.A.). In Kalkatungu (Q.), - tu is used after vowel stems. The origin of these variants is one matter still requiring explanation.

9. -kur etc. derive historically from -*kuru (Hale p.c.).

10. The 'surface instransitive' pattern is used in Baagandj1 (N.S.W., Luise Hercus p.c.) and in Pitjantjatjara (S.A., W.A., Platt 1976).

11. Yanyula (N.T.) has ergative forms that reflect -*lu (Hale p.c. See also Kirton 1977).

12. Heath (forthcoming $b: 3.3$ ) suggests that in Mara an old masculine noun-class prefix - na has been speclalised as an ergative-instrumental. Mara is a non-Pama-Nyungan language of the Northern Territory (see map).

13. The third person pronouns in Pitta-Pitta obligatorily incorporate a delctic marker. Third person pronouns incorporating the unmarked delctic -ka are very commonly used with $S_{1}$ and $A$ and sometimes with $P$ if $P$ is definite.

14. A number of Queensland languages exhib1t a masculine (strictly:

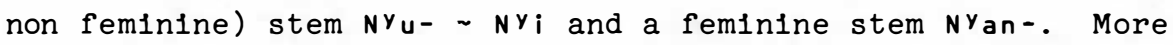
commonly NYu- occurs for third person in general. The vowel alternation of ni-, nu- is difficult to explain. On the evidence here It looks like vowel harmony $i>u$ I_c。u or assimilation to laminal consonants $(u>i)$, perhaps dependent on the presence of two laminals, *NYiya, *NYINYa.

However, over a range of languages we find forms such as nu, $n v_{u}$, ni. nyi, ni. nu, ni. nu as third person pronoun roots, as class markers in classifying languages and as ergative markers. Some rigorous reconstruction is required to demonstrate if some or all of them are cognate. Vowel harmony involving the high vowels is common in Australia and independently of the forms under discussion there are cognates involving apical:laminal correspondences.

15. See Comrie 1976 from which some of the examples are taken. 
16. -ku is probably the original form. There are some languages that have $-k u$ with both $C$ and $V$ stems.

17. Dixon uses the volced symbols: b, d, etc.

18. The pronoun paradigms for Warluwara and Yanyula respect1vely are as follows:

$$
\begin{array}{cc}
\text { Warluwara } & \text { Yanyula } \\
\text { (Breen 1971:182) } & \text { (K1rton 1964:140) }
\end{array}
$$

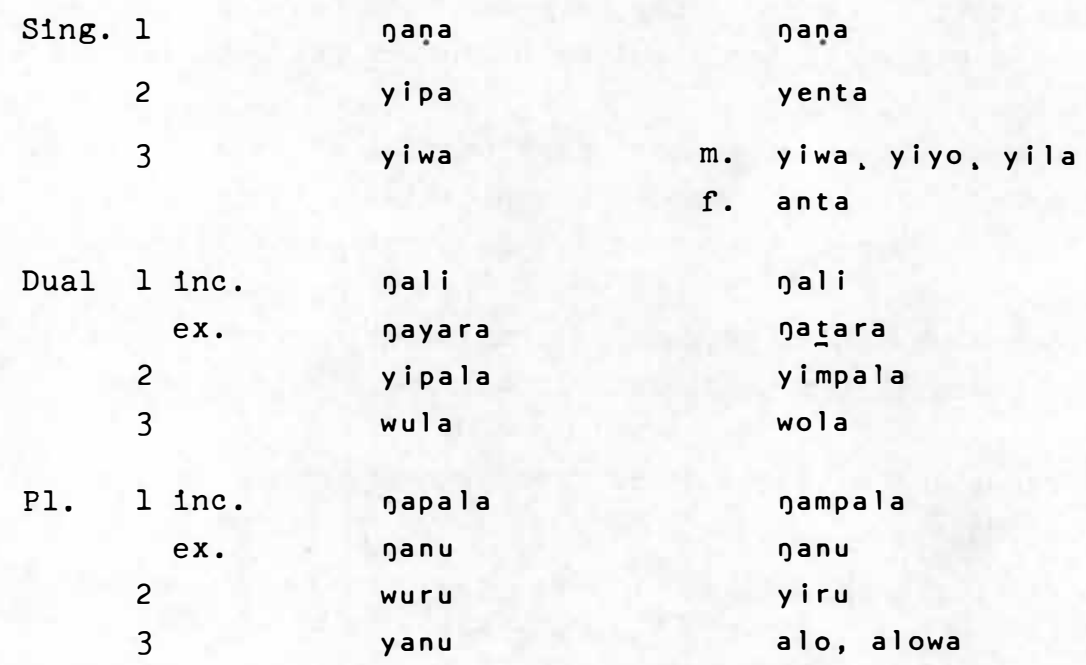

In both languages, jạna is dimorphem1c:

Warluwara Yanyula

$\begin{array}{lll}\text { Nom. } & \text { Daña } & \text { naṇa } \\ \text { Dat. } & \text { nața } & \text { nața } \\ \text { Acc. } & \text { nana } & \end{array}$

In Yanyula, -na serves as the bound form for first person. The similarities between Warluwara and Yanyula extend to the pronoun inflections:

F1rst Dual Inclusive

Warluwara Yanyula

Nom. gali gali

Dat. galina gallna

All. galika!u galiwalu 
19. Hale (p.c.) points out that in Ngarluma, for instance, there certainly seems to have been a development from *nayku to gat $v_{u}$ since the accusative/dative of the first singular is gat $y u$ while -ku is the accusative/dative suffix for polysyllabics and consonant-final stems.

20. Kalkatungu does not allow words of one syllable (or one mora). la, the root for hit or kizl is monosyllab1c. When 1 t is not suffixed, it must be augmented to laa [ $1 \mathrm{a}:]$. However, when it follows a combination of complementiser and bound pronoun, it may be cliticised to the combination. a-ni la may be pronounced [aji lá:] or [ánila]. The bracketed hyphen in the notation indicates optional cliticisation.

21. The anti-passive suffix can be written as $-i$ or -yi according to one's views of phonology. Morphophonemically it is -yi however one writes it and I suggest that this $-y-1$ is a reflex of *1 rather than*y.

22. Since a does not function as a complementiser here, it needs to be glossed as auxiliary particle or something similar.

23. One exception would be interrogative sentences. In these $-i$ is often omitted, e.g.

\author{
naka-ti nin-ti laa \\ what-loc you-erg hit \\ What did you hit him for?
}




\section{BIBLIOGRAPHY}

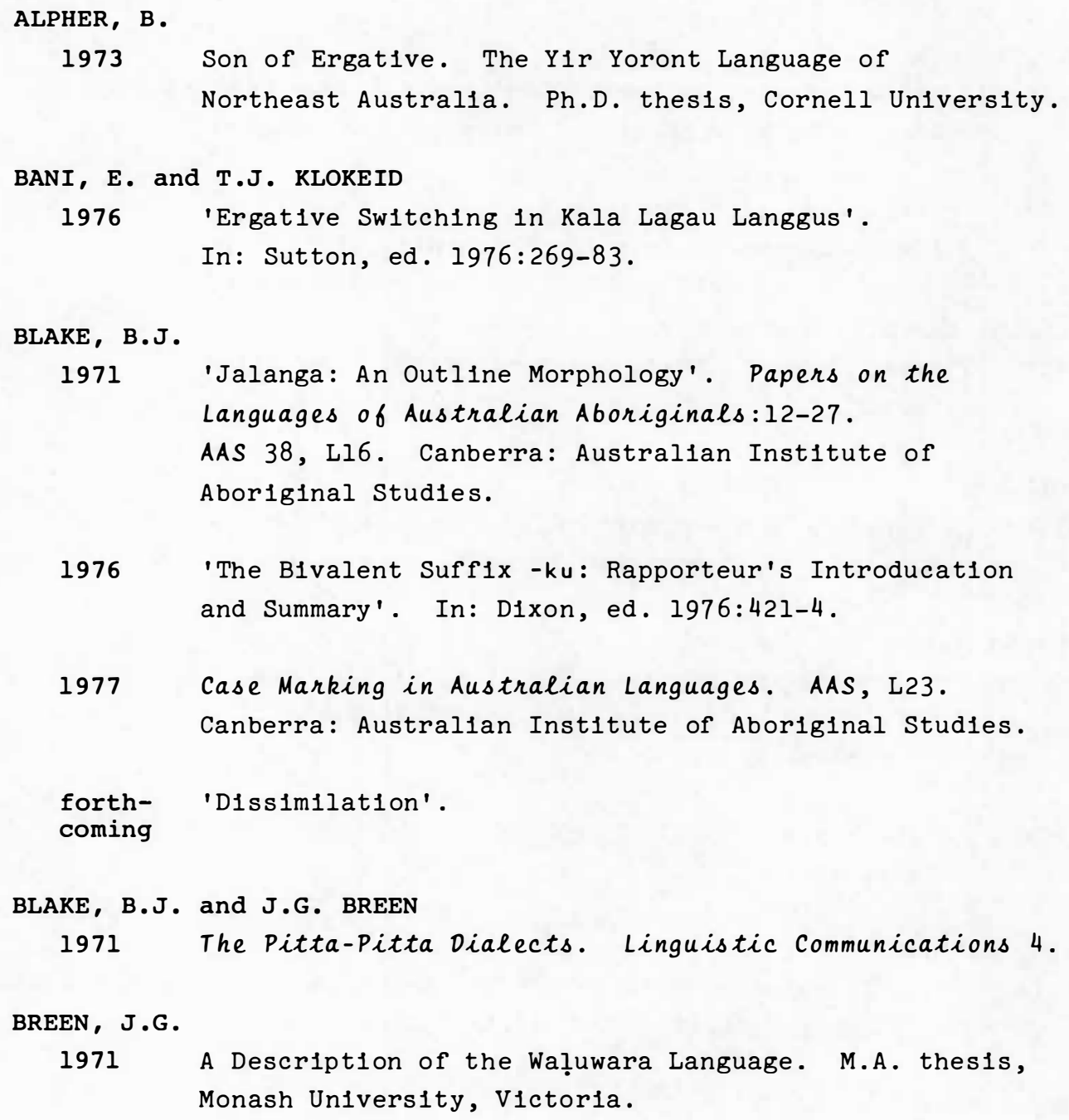


1973 'B1dyara and Gungabula: Grammar and Vocabulary'. Linguistic Communications 8 .

1976a 'Wangkumara'. In: Dixon, ed. 1976:336-9.

1976b 'Wagaya'. In: Dixon, ed. 1976:340-2.

1976c 'Yandruwandha'. In: Dixon, ed. 1976:594-7.

CAPELL, A.

1956 A New Approach to Australian Linguistics. Oceania Linguistic Monographs 1. University of Sydney.

1962 Some Linguistic Types in Australia. Oceania Linguistic Monographs 7 . University of Sydney.

CAPELL, A. and H.E. HINCH

1970 Maung Grammar, Texts and Vocabulary. The Hague: Mouton.

CARROLL, P.J.

1976 'Kunwinjku, a Language of Western Arnhem Land'. M.A. thesis, Australian National University, Canberra.

CHADWICK, N.

1975 A Descriptive Study of the Djingili Language. AAS, RRS 2. Canberra: Australian Int1tute of Aboriginal Studies.

1976 'The Western Barkly Languages'. In: Dixon, ed. 1976:390-6.

COMRIE, B.

1976 "Definite" and "Animate": a Natural Class?

Typescript. Cambridge: King's College.

DIXON, R.M.W.

1970 'Proto-Australian Laminals'. Oceanic Linguistics 9/2:79-103. 
Studies in Linguistics 9 . Cambridge University Press.

1977 'The Syntact1c Development of Australian Languages'.

In: C.N. L1, ed. Mechanisms of Syntactic Change, 365-415. Austin: Univers1ty of Texas Press.

DIXON, R.M.W., ed.

1976 Grammatical Categories in Australian Languages.

AAS, L22. Canberra: Australian Institute of Aboriginal

Studies; New Jersey: Humanit1es Press.

DIXON, R.M.W. and B.J. BLAKE, eds

forth- The Handbook of Australian Languages. Canberra:

coming Australian National University Press.

DOUGLAS, W.H.

1964 An Introduction to the Western Desert Language. Oceania Linguistic Monographs 4. University of Sydney.

1976 The Aboriginal Languages of the South-west of

Australia. AAS, RRS 9. (2nd edn; lst edn 1968.)

Canberra: Australian Institute of Aboriginal Studies.

EADES, D.K.

1976 The Dharawal and Dhurga Languages of the New South

wales South Coast. AAS, RRS 8. Canberra:

Australian Institute of Aboriginal Studies.

FURBY, C.E.

1972 'The Pronominal System of Garawa'. Oceanic Linguistics $11 / 1: 1-31$.

GLASS, A. and D. HACKETT

1970 Pitjantjatjara Grammar: A Tagmemic View of the Ngaanyatjara (warburton Ranges) Dialect. AAS 34 , L13. Canberra: Australian Institute of Aboriginal studies. 
HALE, K.L.

1965 'Australian Languages and Transformational Grammar'. Linguistics $16: 32-41$.

1967 'Some Productive Rules in Lardil (Mornington Island) Syntax'. PL, A-11:63-73.

1968 Preliminary Remarks on Walbirl Grammar: II. Massachusetts Institute of Technology. M1meo.

1973a 'Deep-surface Canonical Disparities in Relation to Analysis and Change: An Australian Example'. In: T. Sebeok, ed. Current Trends in Linguistics, vol. II. The Hague: Mouton. 401-58.

1973b 'Person Marking in Walb1r1'. In: S.R. Anderson and P. Kiparsky, eds A Festschrift for Morris Halle, 308-34. New York: Holt, Rinehart and Winston.

1976a 'Tra.pukay (DJaabugay)'. In: Sutton, ed. 1976:236-42.

1976b 'Phonological Developments in Particular Northern Paman Languages'. In: Sutton, ed. 1976:7-40.

1976c 'The Adjolned Relative Clause in Austral1a'. In: Dixon, ed. 1976:78-105.

1976d 'DJa:bugay'. In: Dixon, ed. 1976:321-6.

1976e IOn Ergative and Locative Suffixial Alternations in Australian Languages'. In: Dixon, ed. 1976:414-17.

HANSEN, K.C. and L.E. HANSEN

forth- 'The Core of Pintup1 Grammar'. coming

HEATH, J .

1978 Linguistic Diffusion in Arnhem Land. AAS, RRS 13. Canberra: Australian Institute of Aboriginal Studies. (References in text are to the 'prefinal' version.) 
to appear 'Is Dy1rbal Ergat1ve?'. In: B. Rigsby and P. Sutton, eds Papers in Linguistics from the 1976 Biennial Meeting of the A.I.A.S. Canberra: Australian Institute of Aboriginal Studies. To appear.

HERCUS, L.A.

1969 The Languages of Victoria: A Late Survey. AAS 17, L5 and L6. Canberra: Australian Institute of Aboriginal Studies.

HERSHBERGER, R.

1964 'Notes on Gugu-Yalanj1 Verbs'. In: P1ttman and Kerr, eds 1964:33-54.

HODDINOTT, W.G. and F.M. KOFOD

1976a 'Djamindjungan'. In: Dixon, ed. 1976:397-401.

1976b 'Ngang1kurungur'. In: D1xon, ed. 1976:401-5.

HUDSON, J.

forth- 'The Core of Walmatjarl Grammar'.

coming

KEEN, S.L.

1972 A Description of the Yukulta Language - an Australian Aboriginal Language of North-west Queensland. M.A. thes1s, Monash University.

KIRTON, J.F.

1964 'Anyula Personal Pronouns'. In: P1ttman and Kerr, eds 1964 .

1976 'Yanyuwa Nominative and Ergative-Allative Cases'. Papers in Australian Linguistics No. 10:1-12. PL, A-47. Canberra: Pac1fic Linguistics.

KLOKEID, T.J.

1969 Thargari Phonology and Morphology. PL, B-12.

1976 'Lard1l'. In: D1xon, ed. 1976:550-84. 
MCCONVELL, P.

1976 'Pronominal Clitic Attachment in the Eastern Ngumbin Languages'. Paper presented to Australian Institute of Aboriginal Studies Linguistics Meeting, May 1976.

MCKAY, G.R.

1975 'Rembarnga: A Language of Central Arnhem Land'.

Ph.D. thesis, Australian National University, Canberra.

MCKELSON , K.

1974 'Studies In Mañala'. La Grange, Western Australı.

Typescript.

MATHEW, J.

1910 Two Representative Tribes of Queensland. London.

OATES, L.F.

1964 A Tentative Description of the Gunwinggu Language. Oceania Linguistic Monographs 10. University of Sydney .

O'GRADY, G.N.

1964 Nyangumata Grammar. Oceania Linguistic Monographs 9. University of Sydney.

O'GRADY, G.N., C.F. VOEGELIN and F.M. VOEGELIN

1966 Languages of the world: Indo-Pacific Fascicle Six. Anthropological Linguistics. 8/2.

OSBORNE, C.R.

1974 The Tiwi Language. AAS 55, L21. Canberra: Australian Institute of Aboriginal Studies.

PITTMAN, R. and H. KERR, eds

1964 Papers on the Languages of the Australian Aborigines. AAS 3, L2. Canberra: Australian Institute of Aboriginal Studies.

PLATT, J.T.

1972 An Outline Grammar of the Gugada Dialect: South Australia. 
AAS 48, L20. Canberra: Australian Inst1tute of Aboriginal Studies.

1976

'P1tjantjatjara'. In: D1xon, ed. 1976:427-31.

ROTH, W.E.

1897 Ethnological Studies Among the North-west-central

queensland Aborigines. Brisbane.

SHARPE, M.C.

1972 Alawa Phonology and Grammar. AAS 37, L15.

Canberra: Australian Institute of Aboriginal Studies.

SILVERSTEIN, M.

1976 'H1erarchy of Features and Ergativity'. In:

D1xon, ed. 1976:112-71.

SMYTHE, W.E.

1948 Elementary Grammar of the Gumbainggar Language

(North Coast, N.S.W.). Oceania Monograph 8.

Sydney: Australian National Research Counc1l.

SUTTON, P., ed.

1976 Languages of Cape York. AAS, RRS 6. Canberra:

Australian Institute of Aboriginal Studies.

TRYON, D.T.

1974 Daly Family Languages, Australia. PL, C-32.

TSUNODA, T.

1974 A Grammar of the Warungu Language, North Queensland.

M.A. thesis, Monash University (3 vols).

WALSH, M.J.

1976 The Murinypata Language of North-West Australia.

Ph.D. thesis, Australian National University, Canberra.

WURM, S.A.

1970 'Linguistic Classification and the Prehistory of

Australia'. In: D.C. Laycock, ed. Linguistic Trends

in Australia, 7-25. AAS 23, L9. Canberra: 
Australian Institute of Aboriginal Studies.

1972 Languages of Australia and Tasmania. The Hague: Mouton.

1976 'Accusative Marking in Duungidjawu (Waga-Waga)'. In: Dixon, ed. 1976:106-11.

YALLOP, C. 1975

Narinjari: An Outline of the Language Studied by George Taplin. Oceania Linguistic Monographs 17. University of Sydney. 


\title{
DIFFUSIONAL LINGUISTICS IN AUSTRALIA: PROBLEMS AND PROSPECTS
}

\author{
Jeffrey Heath
}

1. INTRODUCTION ${ }^{1}$

There are several motives for doing research on diffusional linguistics. Firstly, there is the possibility of correlating the results of the research with archeological, historical, and ethnological studies bearing on past migrations and associations of tribal or linguistic groups. Secondly, diffusional linguistics can function as an occasional adjunct to historical linguistic research of the usual type based primarily on genetic reconstruction. Thirdly, diffusional linguistics can be taken as a subject worthy of theoretical study in 1 ts own right.

In Australia it would appear that the first line of research mentioned above has been unproductive, simply because of the rarity of contacts between Aboriginals and Melanesian or other peoples to the north. In Arnhem Land, Macassan (Indonesian) contact for several centuries prior to about 1920 has been well-documented, and Capell (1965) among others has mentioned the Macassan loanwords in some coastal Aboriginal languages. von Brandenstein (1970) has suspected Portuguese loanwords in the northwestern part of the continent.

Perhaps the greatest potential for such diffusional studies has been in Cape York peninsula and the Torres Stra1ts. It is known that in the Torres Stra1t Islands are found two languages, one of Australian stock and the other of Papuan. Moreover, on the Cape York ma1nland itself many rather bizarre phonological developments have transformed ordinary Australian-type proto-languages into superficially un-Australian languages, and it has been suspected for some time that Papuan interference may have helped encourage these developments. 
However, whereas a strong case can be made for Papuan Influence on Mabluag (in the Torres Strait Islands themselves), there is no persuasive evidence of specific Papuan influence on specific Cape York sound changes (Wurm 1972, Capell 1967:93).

Within Australia 1tself, diffusional studies have been far less important than standard genetic reconstruction in 1dentifying past migrations. For example, conventional reconstruction shows that the Yuulngu languages of northeastern Arnhem Land, though surrounded to the south and west by languages which are only distantly related to them, are closely related to Pama-Nyungan languages spoken in the southern portion of the Northern Territory. Thus diffusional studies are only a minor adjunct in this respect; they are most useful in establishing the duration and closeness of contact among groups in very recent times, while the genetic studies are useful for time perspectives going back several thousand years.

The principal motivations for diffusional studies in Australia, then, are their potential in complementing genetic studies and as constituting an interesting subject matter in themselves. It has long been recognised that the complete classification of Australian languages involves recognition of areal as well as genetic groupings (Capell 1962), particularly when the focus is on vocabulary. However, instead of developing methodological tools for differentiating genetic from areal (diffusional) relationships, Australian linguists have unt1l recently retreated into typological classifications which have left open the relative significance of the two explanations for cognates and morphological sharings.

In a sense, this was wise as a temporary expedient. In such wideranging and ploneering classificatory efforts as Capell (1962), by sticking to relatively straightforward typological classifications it was possible to avold taking strong positions on the extent of genetic vs. diffusional responsibility for sharings - had strong positions been taken at that early stage they would now be highly vulnerable to assaults from regional specialists.

However, in the long run $1 \mathrm{t}$ will be necessary to shift from simplistic typological classification to detalled historical studies of particular subgroups, considering both diffusional interaction and the usual 'internal' analogical and other processes studied by the comparative (genet1c) method. Because of the particular demographic factors characteristic of Aboriginal groups, diffusion has been much greater in Australia than in almost any other part of the world. Therefore diffusional studies will have to go beyond functioning as 
mere occasional adjuncts to genetic historical studies, clearing up the odd difficulty. Diffusional linguistics must develop as a fullfledged component of a broadly-based historical framework, including the traditional methods of comparative method as well. To some extent this means that historical linguistics in Australia will be more difficult than elsewhere, since virtually every change (phonological or other) will have to be examined to see whether 1 t has been motivated by internal analogical or functional/structural considerations, by diffusional forces, or by a complex mixture of the two. On the other hand, if this challenge can be successfully met, Australian linguistics will be in the enviable position of being able to provide theoretical models of historical change quite different from (though complementary to) those derived from such different language families as Indo-European and Malayo-Polynesian.

\section{DIFFUSIONAL VS. AREAL LINGUISTICS}

It is desirable to make a distinction between diffusional and areal linguistics, although these terms are often used as synonyms. The first is the study of actual historical forces and processes brought about by contact among language or dialect groups. It involves the examination of the (reconstructed) structures of the source and target languages, and describes the actual innovations in the latter in this context. Ideally, the relevant aspects of the soclocultural and demographic environment are also considered.

By areal linguistics I mean (in this particular paper) the study of the synchronic distribution of shared features (isoglosses); 1t may also lead to correlations with the distribution of various nonlinguistic shared features.

Consequently, areal linguistics is a static approach concerned with distributional patterns rather than the discovery of the historical dynamics responsible for them. Clearly, it is desirable that we move from 1t to the more challenging but more fruitful approach of diffusional linguistics as our general knowledge of the history of Australian languages improves. The identification of areal patterns is a useful first step which may suggest productive lines of diffusional linguistic research at a later stage, but the latter must be clearly recognised as the final goal.

It is appreclated that serious diffusional linguistic studies are more feasible in certain regions and at certain levels of inclusion than at others. It is unlikely that studies attempting to encompass the whole sweep of Australian languages across the continent can lead 
in the near future to satisfactory results. In order to gain a valid appreciation of the nature of diffusional interaction, and also to sharpen our methodological tools, it will be necessary to conduct intensive comparative/diffusional investigations of small groups of languages in particular regions.

Some of these areas are going to be more amenable to these projects than others. It turns out that the area where I worked in southeastern Arnhem Land is an almost 1deal site for such a study; for the results see Heath (1978).

The advantage of this region is that, as noted earlier, we find the Yuulngu group (a division of the vast Pama-Nyungan family) trapped in the northeastern corner of the peninsula, and in contact over a broad area with languages of the prefixing group (a loose collection of several families, all ultimately related to each other genetically). The Yuulngu and prefixing languages are genetically related, but only at an extremely distant level, and at the time when they came into contact they were apparently so different in structure and vocabulary that they might as well have been genetically unrelated. See Map.

As the result of this, we find a number of pairs of languages which have been in contact for a considerable period but which prior to the initiation of this contact had little in common with each other. Moreover, since there are at least ten Yuulngu languages, and even more prefixing languages in the near vicinity, it is possible to do conventional genetic reconstruction within close subgroups. We are therefore in an excellent position to 1dentify diffusional (as opposed to internal analogical or structural/functional) developments in the history of each relevant language over the last millenium or so.

For example, Ngandi is a prefixing language whose closest sister language in genetic terms is Nunggubuyu. However, in recent times the Ngandi have been interacting socially with the Ritharngu (a group speaking a Yuulngu language) to the north to a greater extent than with the Nunggubuyu. The latter have come to be closely intertwined socially with the Warndarang, the most northerly of a rather different prefixing group to the south.

Much of the proto-language underlying Ngandi and Nunggubuyu (Proto$\mathrm{NgNu}$ ) can be reconstructed by conventional means, also taking into account broader reconstructions for the whole prefixing group. Similarly, much of Proto-Yuulngu and of the proto-language underlying Warndarang, Mara, and Alawa (Proto-MaWaAl) can be reconstructed.

Having done this, it is not especially difficult to determine the set of historical changes which convert Proto-NgNu into attested Ngandi 


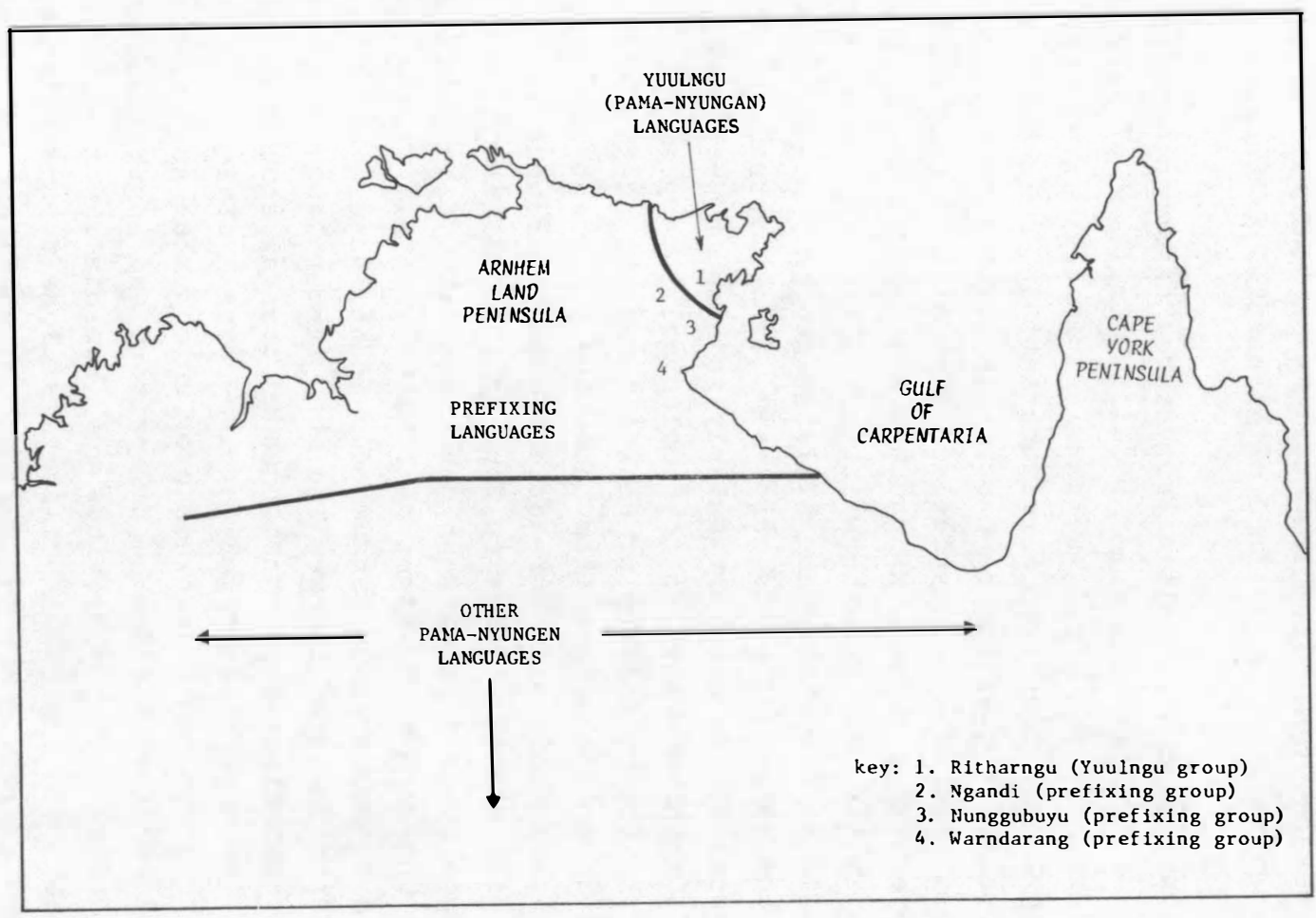

LANGUAGE SITUATION IN A PART OF NORTHERN AUSTRALIA 
and Nunggubuyu, and so forth. We can then judge to what extent diffusional pressures (of R1tharngu on Ngand1, and of Warndarang on Nunggubuyu) are responsible for the historical changes. Similarly, we can evaluate the influence of Ngand1 on the development of Ritharngu, and of Nunggubuyu on the development of Warndarang. In all of these cases, significant diffusional interaction can be demonstrated. Diffusional changes range from the outright borrowing of words and bound morphemes to more subtle (and often partial) structural realignments.

Having established that initial structural divergences have not proved to be a significant barrier to diffusion (even of large numbers of bound affixes and the like), we can legitimately infer that diffusion might have been even more substantial (or at least quicker) had the languages in question been more similar inftially. The southeastern Arnhem Land area is atypical of Australia in that genet1c distances (even, say, between Nunggubuyu and Ngand1) are much greater than is usually the case elsewhere in Australia. Thus a more typical situation would be one where several languages in contact are already closely related genetically and quite similar structurally. Assuming that diffusional forces are particularly intense in such areas, we may reach the situation where it is methodologically very difficult to disentangle the recent history of each language by distinguishing sharings due to common origin from those due to recent diffusion.

Perhaps a reasonable plan for action would be to undertake comparative/diffusional studies in four or five different parts of Australia, each study involving no more than about five languages to begin with. One such study might deal with Warlb1ri, Warramunga, DJing1l1, and nearby Arandic languages. In this area (1n largely arid regions of Central Australia) we find much larger language groups and much less intermarriage among them than in coastal southeastern Arnhem Land. Another study might involve several dialects in the Western Desert group, which extends over an enormous area in Western Australia and parts of the Northern Territory and South Australia. Th1s group differs from the previous one (Warlb1r1, etc.) in that 1t is a chain whereby each dialect is relatively close to the adjacent ones, yet again each dialect group is substantially endogamous. Because it should certainly be possible to reconstruct the proto-language, it should also be possible to determine to what extent the fringe dialects have been influenced by non-Western Desert dialects adjolning them. There should certainly also be a comparative/diffusional study somewhere In Cape York. 
These specific suggestions can be modified or abandoned at the pleasure of the researchers involved; I have done no substantial reconnalsance or feasibility studies involving these regions, most of which I am not directly familiar with. What is important, though, is that at least a few serious comparative/diffusional studies are done in a representative set of areas with different demographic and soc1ocultural characteristics.

\section{DEMOGRAPHIC AND CULTURAL FACTORS}

By 'demograph1c' factors we mean, in this context, the complex of environmental and soclal-structural phenomena which influence the frequency of direct contacts between persons belonging to different language groups. Qu1te obviously, there are going to be cases where two adfacent language groups have little contact, and others where contact is intimate and frequent. Environmental features such as mountaln ranges, bodles of water, and (especlally) areas w1thout water or adequate food supplies can inhlbit contact. A language group of a thousand individuals occupying a large and ecologically diverse territory is likely to be relatively self-contained; a language group of fifty occupying a small coastal area is likely to be predominantly exogamous for several reasons, including the need to maintain military alliances with nelghboring groups and the usual vicissitudes in the relative number of men and women of a particular age avallable for marriage.

For the purposes of diffusional linguistic studies, it is not of cruclal importance to analyse the factors affecting the extent of social contact (including intermarriage) among the relevant groups, but it is important to determine how extensive the contact was. Since we are usually interested in linquistic reconstruction going back at least a few centuries, this means reconstructing the basic demographic patterns of the immediate precontact period where this is feasible. It will normally be very difficult to do this in absolute quantitative fashion, but in discussing a particular region it should be possible to at least determine which groups were most closely in contact with which others. For example, in the area in which my fieldwork was conducted it was possible, by means of collecting texts from old men and so forth, to establish that the Ngand1 were closely assoclated w1th the Ritharngu, while the Nunggubuyu were closely involved with the Warndarang. Such associations do not follow automatically from locating the language groups on a map; Indeed, on the map it appears that the Ngand1 and Nunggubuyu (for example) were in very close contact whereas 
in fact this would be an exaggeration.

Such a demographic investigation provides a rough background for the diffusional study. But there are also nondemographic cultural factors which, in at least some situations, can greatly affect the extent and type of linguistic diffusion observed. Although we cannot provide even a minimal account of these cultural processes here, we may observe simply that there is often an interesting dialectical (not dialectal!) relationship between the system of language/dialect divisions and the system of (nonlinguistic) social divisions such as moleties and clans in a particular area.

By establishing a particular demographic background we can get some 1dea of how frequently speakers of one language entered into communication with speakers of another. Obviously, substantial contact between the two groups is likely to lead to considerable linguistic diffusion by unconscious, relatively automatic interference. However, since in most Aboriginal socleties there is also a nonlinguistic social grid involving molety, clan, and possibly 'tribal' divisions, we have the possibility that these 'automatic' diffusional changes may have been artificially blocked, accelerated, or selectively channeled. In certain instances where two groups have sociocultural motives for overtly manifesting their solidarity or their structural equivalence, we might find strong assimilatory pressures which cause their languages/ dialects to converge at an accelerated rate. Perhaps more of ten, we find dissimilatory pressures by which languages/dialects are not permitted to succumb to demographic factors favoring convergence, or by which the languages/dialects are forced to diverge further than they would normally have done.

This crude dichotomy of assimilatory vs. dissimilatory forces (both of which are diffusional, at least in a broad sense of this term) conceals a whole series of varieties. To begin with, given that there are such nondemographic diffusional pressures, we have to ask what aspects of linguistic structure are most greatly affected. That is, what are the precise linguistic features which the speakers manipulate as indices of their social identities, and what features are relatively inert in this respect? In one area pronunciation might be crucial, in another vocabulary might play the central role.

We must distinguish at least two levels of analysis. There is the etic level - the linguist records actual speech in the relevant languages/dialects and determines the nature and type of the linguistic differences among them. Then there is the meta-level of consclous native awareness of the relationship between linguistic/dialectal 
divisions and social categorles. In some cases we may find considerable etic correlation of the linguistic and social divisions, suggesting that speech differences indeed function as social indices in speech events; in this case there may or may not be an explicit native recognition of this at the conscious, ethnodialectological level. On the other hand, there may be a native theory that linguistic/dialectal divisions do (or ought to) correspond to social divisions, but the linguist may find that in actual speech events there are no systematic linguistic/dialectal divisions.

In this writer's fieldwork area there is considerable variation along these lines. Among the Nunggubuyu, Ngand1, and in general almost all of the prefixing languages investigated, there is no consclous theory that clan or molety divisions are associated with speech differences of any sort. There is also no substantial evidence for actual dialectal differences within language groups, though those cover two moleties and five or six clan groups. Even at the languagegroup level there is no strong normative assoclation between linguistic and social divisions; Indeed, the language group is not corporate politically, ritually, or as a land-owning unit and thus is not really a nonlinguistic social group at all.

On the other hand, the fact that small language groups averaging little more than one hundred persons or so, and in very close geographical and social contact with each other, have maintained quite separate languages for many centurles suggests that there has been some dissimilatory pressure at the language-group level. If demographic factors alone were operative, we would think that such small and interrelated language groups would have merged into larger groups speaking a single language.

The situation among the Yuulngu languages is much different. Th1s block contains somewhere between fifty and seventy 'clans' which are concelved of in large part as dialectal (as well as ritual-owning) units. That 1s, one inherits a dialect as an essential part of one's social 1dent1ty (one also has secondary rights over the mother's clan's dialect and rituals). This situation is 'chartered' by myths which recount how ritual responsibilities, songs, dialects, etc. were distributed among the clans by the creator beings who shaped the social and topographic landscape.

Th1s is the native theory. In practice, the 'dialects' can be grouped into about ten languages from the linguist's point of view; in most cases boundaries between languages are sharp but there is substantial and roughly continuous variation among dialects of a single 
language. The Aborigines recognise this tenfold division at one level of their ethnodialectological theory, but assign it little social significance except when a language group (subsuming several clans) is entirely included within one of the patrimoleties. In part of the Yuulngu area we find that the language groups do tend to line up with molety divisions; the Dhuwal language includes about five large clans in one molety, and two or three other language groups belong predominantly to the other molety.

At the level of clan-dialects, in parts of the Yuulngu area it appears that there are structural features (e.g., choice of futuretense particle) which correlate at least roughly with clan divisions. However, in the Ritharngu language group no systematic differences were found among the dialects, even those belonging to different moleties. These people adhere to the native theory that each clan has its dialect, but at the etic level this is not borne out.

When asked to provide concrete examples of dialectal differences, Ritharngu speakers are at a loss. The differences exist at the metalevel only, and clan identity is not actually indexed by linguistic variables. This does not perturb the speakers when pointed out to them by the linguist, since they do not claim that particular variables accomplish thisindexical function. They simply claim that, at some vague level, there are speech differences of some sort among the clan groups.

Among the Ngalkbon-Dalabon (a prefixing group west of the Yuulngu), there is an explicit theory that speakers from one molety speak 'fast', while the other molety speaks 'slow'. Note that this unlikely theory is focussed on a subjective suprasegmental varlable and thus has the advantage that 1 cannot be readily shown to be false. Cf. Dixon (1976:214-218).

This discussion has not mentioned the many other sociocultural factors affecting linguistic change, including differentiation among generations, between sexes, among individuals as part of personality expression, etc. However, the factors dealt with here - involving one's 1dentity as part of a clan, molety, or language group - are the most vital in the kinds of diffusional research which can be expected in Australia.

\section{DIFFUSION OF VOCABULARY}

It has long been recognised, for example in Indo-European linguistics, that at least certain kinds of vocabulary are relatively susceptible to being diffused from one language to another. Because 
overall diffusion in Australla has been greater than in Indo-European and most other well-known language famllies, we must expect that vocabulary diffusion has been extremely extensive here.

In the southeastern Arnhem Land study 1 t was found that Ngand1 and Ritharngu share nearly $50 \%$ of nominal and verbal stems. Only a handful of shared 1tems can be attributed to independent retention of Proto-Australlan 1tems (e.g., *-bu- to hit, to kill). Consequently, Ngand1 shares more vocabulary w1th R1tharngu than 1 does with 1 ts s1ster language, Nunggubuyu, despite its incomparably closer genetic relationship to the latter.

Diffused lexical 1tems now shared by Ngand1 and R1tharngu 1nclude such basic vocabulary as fingernail, scrotum, mouth, meat, skin, bone, saliva, be afraid, always, ashes, because, to blow, to break, dry country, charcoal, to chop, circumcised man, cloud, country, to cut (two 1tems), to dig, to close off, dreaming (totem), to stand (something) up, bush fire, to operate fire-stick, firewood, to fly, to fly around, to follow, to cross, to bathe, to go past, to go up, honey, to hook up spear onto woomera, to be hungry, to hunt (with dogs), to jump, jungle, later, leaf, to lick, to tell a lie, to light (fire), to look around, to make string, man, mud, to be dark, north (and the other compass points), old man, old woman, one, to be open, other, stone oven, paperbark, person, to feel sorry for, to pull along, rain, sand, to scorch, to scratch, to send, (sun) to set, shell, short, shortcut, to be sick, side, sore (wound), (water) spring, star, story (word), straight, string, sun, to pull out (take away), uncircumcised boy, to want, (water) well, wet, whirlwind, wind, woman, and so forth. In almost all of these cases the 1tems are the basic words for these senses in both languages (not, e.g., Infrequent synonyms). Other doma1ns not mentioned here, such as kinship terminology and florafauna terminology, are also full of diffused terms.

It w1ll be noticed that the above list contains many verbs as well as nouns. Moreover, there are a number of h1gh-frequency verb roots (often monosyllab1c) not mentioned above which occur in both languages. Examples: to hit, to kizl, to see, to hear, to carry, to sit, to stand, to get. Some of these are probably survivals from the remote common proto-language, but one or two (e.g., to hear) are probably borrowings, and at any rate there is no evidence that such high-frequency verbs systematically resist diffusion. In cases where the sharing is retentionist rather than diffusional, we can simply point out that no diffusion was necessary or possible since the 1 tems were already ldentical (or nearly so). 
It should be clear that Australia is not going to be a glottochronologist's paradise, and that genetic classifications based primarliy on quantification of lexical (or other) synchronic sharings are unlikely to bear fruit.

However, even in the Ngandi-Ritharngu case lexical diffusion has not been totally unconstrained. Aslde from the fact that some key 1tems (e.g., stone) have not been diffused, we find that there are some structural considerations which have channeled diffusion into some areas and away from others. However, these considerations are not primarily semantic, so 1t is not a question of particular, semantically-definable domains being especially susceptible or resistant to diffusion.

Whereas noun stems (aside from kin terms) share a substantially similar morphology in both languages, and can occur in 'naked' form without affixes in some instances, for verbs we have to distinguish several different inflectional classes. Moreover, the largest and most productive class in both languages has, in addition to thematised inflectable forms, a naked 'root form' used as a kind of abbreviation for a fuller verb form (or clause), hence Ritharngu thematised stem bangu!?-yu- to return (e.g., past bangu!?-yu-na) and root form bangu!?. The majority of the verb stems which have been diffused between the two languages belong to this class, and we strongly suspect that the occurrence of such roots in an unencumbered root form has facllitated diffusion. The rate of diffusion in the other classes (where the morphological boundary between root and suffix is less clear-cut) has been significantly lower, though some verbs in these classes have been diffused.

If we look at the Nunggubuyu-Warndarang pair a bit further south and east, we find that lexical diffusion has been quite a bit less substantial, and has been almost nonexistent for verbs in particular. This is because the two languages have totally different verbal systems; Nunggubuyu directly inflects 1 ts verb roots with pronominal prefixes and tense-aspect suffixes, whlle Warndarang has an auxillary structure with a verb-particle (often a CVC syllable) followed by one of a small number of specialised auxillaries (which have prefixes and suffixes like ordinary Nunggubuyu verbs). Thus the set of verbs in Warndarang which corresponds structurally to ordinary Nunggubuyu verbs, namely the auxiliaries, constitute an essentially unproductive and closed set which does not easily recelve new members, and Nunggubuyu has no parallel at all to the Warndarang verb-particles. The structural inhibitions on borrowing noun stems in these languages are 
less severe and a falr amount of nominal diffusion has occurred.

In the southeastern Arnhem Land case, then, structural factors rather than semantic ones seem to have been the most effective barriers to lexical diffusion.

There are also a variety of soclocultural factors to consider, however. These include the possibility of artificial exaggeration or diminution of lexical divergence for the purpose of indexing the mutual identification or differentiation of social groups, and also the role played by lexical taboos in encouraging lexical turnover (hence vocabulary borrowings to replace tabooed 1tems).

In the Arnhem Land case, it is difficult to find evidence that soclal-group indexing has played a particularly significant role in determining the rate of lexical diffusion. As we have seen, speakers of most prefixing languages (e.g., Ngand1) have no elaborated native theory by which language/dialect differences are correlated with nonlinguistic social divisions. Among the Ritharngu (and other Yuulngu groups) such a theory exists, but at least in the southern area the theory is not confirmed by etic analysis and there is no evidence that individual lexical items play much role in indexing. Ngandi and Ritharngu are so different from each other in morphology and so forth that it is simply unnecessary to code differences between them by lexical distinctions; the latter might be more significant in a dialect chain where the basic morpological structures were almost 1dentical. In other words, social indexing is more likely to be significant in cases where dialects/languages are splitting away from each other than in cases where two dissimilar languages are in contact and converging to some extent.

The existence of 'special' languages can play an important role in lexical diffusion under certain conditions. The best examples of this are cases where a group has, in addition to the ordinary language, a special avoldance (respect) language used in the presence of certain affines. In the most dramatic cases the avoldance language has a completely different lexical stock from that found in the ordinary language.

As Dixon (1972) has shown, in the Dyirbal group of languages (each of which has ordinary and avoldance languages), it is often the case that an avoldance word in one language is identical to an ordinary word in an adjacent language, and presumably has been borrowed from this source. Hence the situation shown in Figure 1. 


\section{FIGURE 1}

\section{Language $\mathrm{L}_{1} \quad$ Language $\mathrm{L}_{2}$}

ordinary term

avoldance term

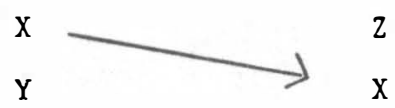

$\mathrm{X}$

Since the avoldance language is used only in restricted social environments, and is generally much poorer in lexical stock than the ordinary language, it is likely that its lexical 1tems are subject to much fluctuation over time. As certain of 1 ts terms go out of use or are forgotten, 1t requires replenishment, and the obvious source for a substitute term is the common term in some nearby language. Hence what is originally an ordinary term in $\mathrm{L}_{1}$ is borrowed into $\mathrm{L}_{2}$ as the avoldance term in the diagram. (Speakers of $L_{2}$ will of ten have only poor fluency in the avoldance version of the nelghboring language $\mathrm{L}_{1}$, so the latter's ordinary rather than avoldance form w1ll be the usual source for replenishing the avoldance vocabulary of $\mathrm{L}_{2} \cdot$ )

However, because the lexical stocks of ordinary and avoldance versions of $\mathrm{L}_{2}$ must be kept totally distinct (to maximise the socialindexing value of the avoldance language), we have the ironic result that the borrowing of $\mathrm{X}$ from ordinary $\mathrm{L}_{1}$ into avoldance $\mathrm{L}_{2}$ actually inhibits the borrowing of $\mathrm{X}$ from ordinary $\mathrm{L}_{1}$ into ordinary $\mathrm{L}_{2}$. In the figure, it is now essential to maintain the opposition between $z$ and $X$, and consequently $Z$ cannot be replaced by $X$ (borrowed from $L_{1}$ ). Since $\mathrm{L}_{2}$ is unlikely to borrow $\mathrm{Y}$ from avoldance $\mathrm{L}_{1}$, diffusion between $\mathrm{L}_{1}$ and ordinary $\mathrm{L}_{2}$ may be held to a relatively low rate because of such factors. To my knowledge, a quantitative study of these phonomena has not been undertaken.

It is worth stressing that only a few areas in Australla have fully developed avoldance languages, though there are many languages with a small number of avoldance terms. Most languages, however, do have analogous phenomena in the relationship between ordinary and song (or more generally ritual) languages. It would be interesting to explore this matter further, but I will content myself here with observing that song languages seem to have played only a small role in lexical diffusion among the ordinary languages in the Arnhem Land case. The song languages themselves have, as might be expected, borrowed extensively from nelghboring ordinary and song languages in replenishing their own lexical stock, but this has not greatly interfered with diffusion among the ordinary languages themselves. Song languages have 
not been the princlpal media through which Ngandi and Ritharngu ordinary languages have borrowed from each other, nor have they deterred such borrowing in the manner suggested above for the avoldance languages.

Before leaving the subject of lexical diffusion, it is necessary to deal briefly with the role of taboos. It has been noted from time to time that upon the death of a person, people in his kindred or some larger group may refrain from pronouncing his name for a number of years. If the name happens to be 1dentical with a word used in the ordinary language, this word may become taboo, possibly for a period of years. Moreover, a word which has the misfortune of being phonologically similar to the deceased's name may also be tabooed. It has been suggested that the high rate of lexical diffusion in Australia is largely due to the operation of the taboo, since it creates a need for lexical replenishment and since the vocabulary stock of a nearby language is the logical place to look for a replacement for the tabooed word.

It is unlikely, however, that the taboo has played a cruclal role in influencing rates of diffusion, except perhaps in certain regions in Austral1a. In the Ngand1-Ritharngu situation, for example, we have documented a remarkably high rate of lexical diffusion, yet among the Ngand1 (who have done most of the borrowing) the death taboo is not especlally strong or long-lasting. Most personal names are obscure song eplthets and the like whlch are unlikely to affect ordinary vocabulary. If the death taboo were so important, we would expect lexical turnover to be far greater in such semantic domains as florafauna, with which many of the personal names are assoclated - yet we find very high rates of diffusion in other areas as well, such as compass-point adverbs and kin terms (not to mention verbs, logical confunctions, etc.). On top of this, diffusion between Ngandi and Ritharngu has also affected many semi-frozen, bound affixes such as case suffixes and the like, and no-one would serlously suggest that an ablative suffix or a comitative prefix is likely to become too hot to handle because of taboos.

This is not to deny that there might be regions in Australla where the death taboo is stronger and has indeed played a moderately important role in stimulating diffusion. Probably the best symptom for such a situation would be that each language in the area has a supply of apparently superfluous synonyms for many common nouns and verbs. In Arnhem Land, for example, the Yuulngu languages (particularly those north of the ones I worked on) are noted for their extravagant 
stock of synonyms. I have elicited body-part terms for one such language (Dhay?y1), and often got five or six synonyms whereas a language like Nunggubuyu only infrequently had more than one. I understand that the death taboo is falrly strong among the northern Yuulngu, and we can infer that the large supply of synonyms is a response to this situation.

What has not been established, however, is how frequently a word which becomes tabooed after a death is permanently exorcised from the language. In many cases it appears that the word is avolded for a decent perlod, ranging from two to perhaps ten years (less for more distant relatives), and is then reintroduced as the common word in 1 ts former sense. Indeed, the personal names themselves are usually recycled (to descendents of the deceased two generations below h1m). Consequently, although we have well-documented cases where a shortterm death taboo has operated, we have little information about the ultimate fate of the tabooed terms, and are thus in a poor position to estimate even crudely the quantitative role of the taboo in lexical turnover.

\section{DIFFUSION OF PHONOLOGY}

It has long been remarked that Australian languages share a substantially unfform phonological system, despite the large geographic distances involved and despite substantial time depth separating one region from another. Moreover, in cases where special phonological features occur, these often have spread throughout a particular region. That 1s, we find few cases where geographically contiguous languages have sharply different phonological systems.

In Arnhem Land, we find a clear boundary between a group of languages with two series of stops (fortis vs. lenis) and with a syllable-final glottal stop, and another group with only one stop serles and without a phonemic glottal stop. This boundary does not correlate with genetic divisions. The first group includes the Yuulngu languages and a number of adjacent prefixing languages to the southwest and south, including Ngand1. The second group includes the prefixing languages further south, including Nunggubuyu (which is genetically closest to Ngand1) and Warndarang. It can be shown that Nunggubuyu, under the Influence of Warndarang, has undergone a serles of consonant shifts converting a Ngandi-like protosystem into the attested Warndarang-like system.

It is likely that diffusion at an earlier stage is responsible for the near-1dent1ty of the consonant systems of the Yuulngu languages 
with those of the adjacent prefixing languages like Ngand1. Certainly the diffusion of large quantities of stems and other morphemes has played a central role in this. However, both in the Yuulngu and prefixing languages we find fortis/lenis oppositions, and glottal stops, in inherited as well as borrowed morphemes. It must therefore be recognised that phonological diffusion in this case has been accomplished not only by direct lexical diffusion, but also by indirect processes whereby speakers of different languages developed regional pronunciation patterns and applied them to their own lexical material. Indeed, in the assimilation of Nunggubuyu phonology to that of Warndarang, direct lexical borrowing (which has been limited) has certainly not been the primary mechanism.

Unfortunately, it is not yet clear whether the Yuulngu or prefixing languages first developed the more complex system with two stop series and with the glottal stop. It is therefore not possible to reconstruct the actual historical developments responsible for the present affinities between the two groups.

This is also the case with another important regional feature of this area, the occurrence of interdental consonants (but only before vowels). Most Yuulngu languages (but not Djlnang, at the northwestern extreme of the group) have $d$ and (fort1s) $t$ in a large number of stems and bound morphemes, and a small number of important affixes and pronominal or demonstrative stems with $\mathrm{n}$. In Dfinang, the laminoalveolars $\mathbf{j}$, č, and $\tilde{n}$ correspond to interdentals as well as to laminoalveolars in the other Yuulngu languages. As for the prefixing languages, many to the west of the Yuulngu group lack interdentals, but $d$ and 5 are common in Ngand1, and $d\left({ }^{*} t\right)$ and $l\left({ }^{*} d\right)$ are common in Nunggubuyu. One suspects that the interdentals originated in the Yuulngu group (having split off, perhaps, from laminoalveolars), and that Ngand1 and Nunggubuyu (or rather Proto-NgNu) borrowed them from this source, while one or two northwestern Yuulngu languages like DJinang have merged interdentals with laminoalveolars under the influence of prefixing languages in that area. If so, the deta1ls must have been complex since the opposition between interdentals and laminoalveolars in Ngandi and Nunggubuyu applies to inherited as well as borrowed vocabulary. The hypothesis presented here cannot be considered established unt1l a more detalled investigation has been carried out.

One of the few studies of phonological diffusion in other parts of Australia (aside from the Torres Strait Islands case mentioned at the beginning of the paper) involves Cape York Peninsula. Alpher (1976) has demonstrated that the dropping of initial consonants in a number of 
essentially contiguous languages has probably occurred subsequent to the splitting of $f$ of these languages from their immediate common ancestor. It is thus probable that diffusional interaction has played a significant role.

However, it is likely that the primary thrust of diffusional forces in Australian phonological systems has been conservative impeding major sound changes rather than ensuring their wide distribution. Although the attested continent-wide similarities may go back to the proto-language, innate lethargy is not a satisfactory explanation for their perpetuation. It is likely that the rarity of major demographic shifts (1.e., migrations), and the near-absence of contact with Melanesian or other forelgn languages, has contributed to a situation where most Australian languages have been surrounded by languages sharing the same basic phonological features. Consequently, the effect of diffusion has been mutual relnforcement, rather than inducement to radical alterations. We have noted some instances where diffusion has played a role in propagating local innovations, but this has been subordinated overall to the conservative effects of diffusional pressures.

\section{DIFFUSION OF MORPHOLOGY AND SYNTAX}

Undoubtedly the most striking result of the Arnhem Land study has been the recognition of large numbers of bound morphemes (mainly preflxes and suffixes) which have been directly diffused across wellestablished language boundarles, e.g., from Ritharngu into Ngandi or vice versa. The examples include case suffixes, derivational verbalising suffixes, a system for thematising verbal root forms (mentioned above) Including the actual suffixes involved, negative suffixes, comltative prefixes, and the like. Simllarly, Warndarang has borrowed from Nunggubuyu (perhaps with some assistance from Ngand1) some case suffixes along with a system of nonhuman noun-class prefixes.

The sheer number of such examples which can be documented, even restricting ourselves to the four languages shown in the map (cf. above), has permitted at least a partial analysis of the factors favoring or lmpeding direct diffusion of bound morphemes; see Heath (1978). The question turned out to be what kinds of morphemes have not been diffused, rather than what kinds have been.

In addition to such blatantly direct diffusion, however, there are also strong indications of indirect morphosyntactic diffusion - the rearrangement or restructuring of inherited morphology and syntactic 
patterns to conform to those of a nearby language. Such indirect diffusion has often resulted in partial assimilation only.

For example, the Yuulngu languages generally have fully independent personal pronouns which can occur anywhere in the sentence (as nouns can), and are generally omitted when a full noun-phrase is present. On the other hand, the prefixing languages in this area have bound pronominal prefixes specifying the category of subject (and, for transitives, object). Consequently, fully independent pronouns though they exist - are generally not used in these case categories, and usually have emphatic or contrastive function when they are used. The prefixes are used whether or not independent noun-phrases for these cases are also present in the sentence. Thus The man hit the woman would have the following surface structures (with word-order free) in the Yuulngu and prefixing languages, respectively:

Yuulngu: man-Ergative hit-Past woman-Accusative
prefixing: man-Ergative he/her-hit-Past woman-Accusative

(Actually, most prefixing languages would use the zero Nominative case for direct object, and some would also use it for subject, but we disregard this problem here.)

The pronominalised versions would be these:

$$
\begin{array}{ll}
\text { Yuulngu: he-Ergative hit-Past her-Accusative } \\
\text { prefixing: he/her-hit-Past }
\end{array}
$$

(Again, the case-marking in the Yuulngu example would actually have Nominative instead of Ergative, but we disregard this.)

Ritharngu, however, diverges from the pattern set by the other Yuulngu languages. It has developed a serles of enclitic subjectand object-marking pronominals, which along with some other optional elements form an enclitic cluster which follows the first constituent in the sentence. If + is the boundary just before an enclitic, the two Yuulngu sentences shown above become these in Ritharngu:

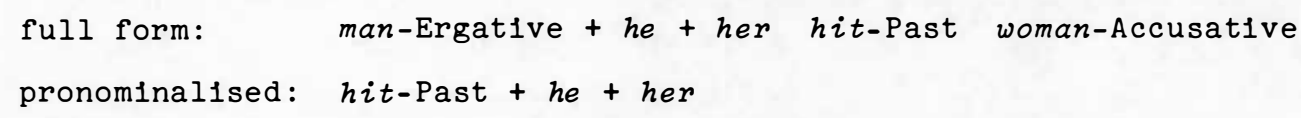

The enclitic pronouns are simply reduced forms of the Yuulngu Independent pronouns (e.g., 3Sg Accusat1ve ña from*ni-ña), and the full forms are sometimes used in Ritharngu as emphatic pronouns in sentence-initial position.

Note that in the full form of the Ritharngu sentence, the enclitics are used although the sentence includes full NP's specifying the 
subject and object. Thus Ritharngu has assimilated partly to the system found in prefixing languages, since it has developed a system of obligatory bound pronominals for subject and object, and uses independent pronouns in these case categories as sentence-initial emphat1c pronouns. However, the mechanical detalls of the Ritharngu system (enclitics following first constituent in the sentence) differ substantially from those of the prefixing systems (prefix-complex fused to verb).

In the northwestern portion of the Yuulngu group, DJ1nang appears to have gone even further and has developed a system of pronominal prefixes (or at least proclitics) marking the category of subject and object. The prefixes are, historically, reduced or otherwise thinly disguised forms of the old Yuulngu independent pronouns in most cases. However, the system of pronominal prefixes is not quite as wellestablished as it is in the prefixing languages themselves, and it appears from the limited data I have collected that the 1Sg prefix er(*nara), for example, is omltted in some tenses (hence the independent pronoun gare must be used).

Unfortunately, at present we know very little about DJinang and the immediately adfacent prefixing and Yuulngu languages. This is likely to be at least as interesting an area for diffusional linguistics as the area further south where I have worked extensively.

\section{THE FUTURE}

It is unfortunate that the southeastern Arnhem Land case study has been so salient in this report. It is to be hoped that within a few years we will have a number of diffusional studies by other Australianists who have specialised in different regions, so that we will be in a stronger position to generalise concerning the nature of linguistic diffusion (and of historical linguistic processes generally) in this continent. At that point the full significance of Australia for diffusion theory will become clear.

It is already apparent, however, that Australla will have much to say about the future of diffusion theory. The latter can only develop properly in the context of a broader historical theory which includes the traditional comparative method for genetic reconstruction. In Australla the comparative method holds great promise, for reconstruction within small subgroups and also (notwithstanding frequentlyheard disclaimers) at the Proto-Australian level. Th1s is also true of several other language families, but in addition to this Australia 
1s almost unique in the extent of diffusion 1t has permitted across well-established language boundarles. Th1s is probably due to 1 ts nearly unique demographic patterns, but whatever the reason Australia w1ll be an 1mportant laboratory for investigating historical dynamics. 


\section{J. HEATH}

\section{NOTE}

1. The author is thankful to S.A. Wurm and P. Sutton for comments on the first draft. The author's fleldwork in Australia has been funded by the Australian Institute of Aboriginal Studies. 


\section{BIBLIOGRAPHY}

ALPHER, B.

1976 'Some Linguistic Innovations in Cape York and

thelr Soclocultural Correlates'. In: P. Sutton, ed.

Languages of Cape York, 84-101. AAS, RRS 6 .

Canberra: Australian Inst1tute of Aboriginal Studies.

BRANDENSTEIN, C.G. von

1970 'Portuguese Loan-words in Aboriginal Languages of North-western Australia (A Problem of Indo-European and Finno-Ugrian Comparative Linguistics)'. In:

S.A. Wurm and D.C. Laycock, eds Pacific studies in Honour of Arthur capell. PL, C-13:617-50.

CAPELL, A.

1956 A New Approach to Australian Linguistics.

Oceania Linguistic Monographs 1. Un1vers1ty of Sydney.

1965 'Early Indonesian Contacts w1th North Austral1a'.

Journal of the Oriental Society of Australia

$3: 67-75$.

1967 'Sound Systems in Austral1a'. Phonetica 16:85-110.

DIXON, R.M.W.

1972 The Dyirbal Language of North Queensland. Cambridge Un1vers1ty Press.

1976 'Tribes, Languages, and Other Boundarles in Northeast Queensland'. In: N. Peterson, ed. Tribes and 
Boundaries in Australia, 207-38, SA 10. Canberra: Australian Institute of Aboriginal Studies.

HEATH, J .

1976

Linguistic Diffusion in Arnhem Land. Ph.D. thesis, University of Chicago. (Published by Australian Inst1tute of Aboriginal Studies as Heath 1978c.)

WURM, S.A.

1972 'Torres Stra1t - a Linguist1c Barrier?' In:

D. Walker, ed. Bridge and Barrier: the Natural and Cultural History of Torres Strait. 345-66. Canberra: Department of Blogeography and Geomorphology, School of Pacific Studies, Australian National University. Publication $B / G 3$. 


\title{
THE HISTORY OF AUSTRALIAN LANGUAGES: A FIRST APPROACH
}

\author{
A. Capell
}

\section{INTRODUCTION}

\subsection{Preliminary Note}

The situation regarding the origin and history of language in Australia is closely linked with the origin and history of the Aboriginal people themselves, and in any detail it is probably just as insoluble. It may indeed be more so, because language does not leave the same sort of tanglble traces as cultural objects and skeletal remains. The purpose of this paper is to make suggestions as to what happened linguistically during the forty thousand or so years that the Aborigines have been in Australia. This period is much longer than the known history of human speech anywhere in the world. If linguistics as a historical science depends on documentation, then the situation for Australia is serlous because there is no documentation prior to the arrival of white men, and much of what there is from the earlier stages of colonisation is very poor and quite useless for historical purposes.

A paragraph of O'Grady's contribution to this volume probably summarises truly the situation regarding the linguistic problem. There he says: The linguistic situation in Australia 15,000 years ago can presumably in no way ever be recovered. Whether there were fifty languages spoken at that time or five hundred, none of us living can ever know.' There may have been five hundred languages, more or less, spoken when Captain Cook first caught sight of the continent. Many have since disappeared, and hardly any of them was recorded before they disappeared, at least in a way that would satisfy the modern linguist. One thing, however, is certain: there was great variety among them. Do they represent one famlly or more? That is the question which this paper seeks to investigate, although only in mere 
outline. The answer would appear to be 'No'. The question then remains: 'What are the relations between the languages?' That is the purpose of this paper: to give such an answer as the known facts indicate.

Quite early in European acquaintance with Australian languages it became clear that there was much diversity among them. Moorhouse in his study of Murund1, published in 1846, began to point out common structural elements among them, including ten common points:

(1) suffixes or particles added to the terminal parts of words to express relations; (2) dual forms of substantives, adjectives and pronouns; (3) limited terms - only five - for time, distance and number; (4) no sibilant consonants; (5) no articles; (6) no auxiliary verb - by which he meant the verb 'to be'; (7) no relative pronouns; (8) no prepositions; (9) no distinctions of gender; (10) no distinct forms of the verb to express the passive volce. Subsequent study has disproved some of these points, such as the absence of gender, but the bulk of them are correct. The typological study of Australian languages thus began quite early after contact. Although wider study modifled Moorhouse's 11st, for 1846 it was an unexpectedly good attempt to relate the languages then known - those from 'Swan R1ver, Port Lincoln, Adela1de, Murray River, Encounter Bay, and New South Wales (Awaba)'.

During the remainder of the nineteenth century, a number of views were put forward as to the origin of the Australian languages, always on the assumption that, in spite of the obviously great variations between them, they did form a unity. These views were briefly but adequately summarlsed by S.H. Ray (Ray 1907a:512-16). There are four of them: (1) the African theory; (2) the Andaman theory; (3) the Dravidian theory; and (4) the Papuo-Dravidian-Malay theory. There is no longer any value in outlining these theorles except for antiquarian purposes. Each quite unsclentifically compared a few features, either of vocabulary, structure or typology, but produced no evidence of regular morphological correspondence. Typological resemblances between the prefixing languages of the Northern Territory and Northern Kimberley and those of the Bantu languages of Africa were pointed out by Capell (Capell 1951) but he did not suggest that there was any genetic connection. After all the discussions, the Australian languages st1ll stand apart as a separate family, not connected, it would seem, with any other, unless New Guinea has anything to offer, and this has not been shown. There are extraordinarily close structural features and occasional morphemic agreements between the 
Northern K1mberley languages and those of Burushask1 of North-west India, but again, apparently nothing which can be bullt on.

Quite apart from the usual technical questions of what constitutes a relationship between languages, there is a problem peculiar to Austral1a, which was ralsed by Dixon (D1xon 1970a:653ff.) and elaborated by Wurm (Wurm 1970:9ff.). Both authors have shown why a special criterion of judgement needs to be raised for Australian languages. This criterion modifies the term 'language family' to 'famlly-like languages', and introduces the term 'phylum-like languages' in place of 'phylum'. Dixon discussed special difficulties in regard to tribal 'splits', and this must be taken as the background thinking in the present consideration. Suggestions made by Elkin (Elkin 1970) must also be taken into account.

Dixon's axioms are best summed up in the present setting. In general, the relationship between languages is to be sought along the established lines of historical comparative linguistics. However, where, as in Australia, there is no diachronic evidence, it seems necessary, in part at least, to follow other princlples. What suggests the original unity of Australian languages is their remarkable agreement in phonology - of which more later - and a certain amount of agreement in structure and vocabulary. The last factor, however, varies immensely even over short distances, whereas words can be compared from one side of the continent to the other, almost like the remains from a lexical bomb explosion.

Vocabulary always supplies certain dangers, and in tracing 1ts evolution there is always the danger of jumping to false conclusions because of 'obvious' resemblances. It is especially necessary to guard against this when material is insufficient, diachronic information is absent and time depths are great. By way of 1llustration, one comparison that first tempted the writer is worth mentioning. Certain linguistic groupings in north-eastern Arnhem Land are known as mada (R.M. and C.H. Berndt 1964/8:63 and passim). In south-western Australla two moleties existed, named Manatjmat and Wațangmaț. The suffix -mat naturally tempted 1dentification with mada. In north-eastern Arnhem Land (NEAL) mada is tongue both as organ and as language. Th1s is one of the rare fallures of $C A \star d a l a n j$ to penetrate, though 1t could, of course, have been lost in modern times through word taboo. But in

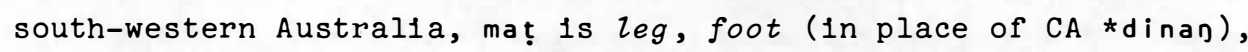
extended to way, path as a totemic mark. Hence the two names are different and, semantically, the south-western word corresponds better to NEAL mala, group, clan. Unless a correspondence could be 
established between south-western $t$ and NEAL 1 , there could be no connection; the fact that this error was not made is due to timely enquiry and the guidance of Mr W.H. Douglas.

Th1s is a type of danger that will always be particularly close at hand in the pursuit of the linguistic history of Australia. Of course, the 1deal way to trace linguistic history is by pair-by-pair comparison of languages. Over the whole of Australla this method presents enormous difficulties, and e1ther the whole effort to trace the history must be abandoned or risks must be taken.

There is another feature in Australia which also makes the application of the procedures of Indo-European linguistics difficult and, in some features, 1mpossible. This is the fact that relationships among languages depend far more on structure than on vocabulary, for reasons which can best be set out in the words of Dixon and Crowley (1979):

'If the speech of two tribes is so similar that it is most economic to write a single overall grammar, with notes on grammatical differences then we may say that the two tribes speak dialects of a single language. If, on the other hand, the grammars differ so much that it seems simpler to write two separate descriptions, then we say that there are two different languages involved.

'It has been shown that the methods of lexicostatistics (which assume a very low rate of borrowing in the case of 'core' vocabulary) do not apply in Australia; Australian languages appear to borrow all types of words with equal facllity. If two rather different languages come into contigulty, they will borrow back and forth unt1l the common vocabulary makes up about 50\% (In pract1ce, say 40-60\%) of each other's total vocabulary. If one tribe splits into two new tribes, each will taboo and replace words independently of the other, and the percentage of common vocabulary will steadily drop, unt1l it reaches the 50\% 'equilibrium' level. We assume that the considerations also apply to Tasmania...

'The only sure criterion for telling whether two tribal 'dialects' do belong to one language is morphological and syntactic similarity. It 1s, however, possible to draw some tentative inferences concerning language groupings from consideration of percentages of common vocabulary between two dialects: (1) If two contiguous dialects have more than $60 \%$ vocabulary in common, they are likely to be genetically closely related. In these cases the grammars of the two dialects will 
be very similar. 1 (2) If two contiguous dialects have less than about 40\% vocabulary in common, then it is probable that they are not closely related genetically, but are dialects that have recently come into contiguity and are currently bullding up their common vocabulary by mutual borrowing. We would in this case expect the grammars of the two dialects to be markedly different. (3) If two non-contiguous dialects have more than $40 \%$ vocabulary in common (a smaller figure would be significant if they were separated by a number of other dialects), then they are likely to be genetically closely related. Again, we should expect their grammars to be rather simliar.

'It should be noted that, in all these cases, lexical comparison can only supply hypotheses of relationsh1p, which must then be checked by detailed grammatical comparison. We cannot make any firm inference concerning dialect relationships from lexical data alone.'

\subsection{Characteristics of the Languages}

The modern Australian languages have the following characteristics:

1. A common phonemic basis. In passing it is only necessary to remark that this feature can hardly be explained from any idea except that of a common origin. There is just the possibility that it may result from a sort of common denominator reached by speakers of originally divergent languages, but this is unlikely. In the field of Amerindian linguistics, Mary Haas has demonstrated the possibilities of such a 'long term' derivation of languages (Haas 1969).

2. Structurally the morphologies are of two chlef types: (1) suffixation only, and (11) prefixation, with retention of suffixes for some features. Th1s dichotomy is noticeable chiefly in the verbal systems. Prefixing languages mark subject and usually object pronouns by prefix, but tense, mood and volce by suffixes. In this group are included the noun classing languages and most of these use prefixes to mark the class of the noun; if number is marked at all, it may be done by prefix or suffixes according to the language. 2 There is also another

${ }^{1}$ In Australia itself this does not necessarily hold. There are several examples of neighbouring languages closely alike in vocabulary, but one of them has noun classes, with the concomitant grammatical markers, while the other does not. In Arnhem Land, Jiwadja-Mawng, Jilngali-Nungali, Ridarngu-Ngandi are three sets of such languages. A. Capell

${ }^{2}$ Reference should be made to the paper on noun classification in Australia, in this volume. 
kind of subgrouping possible - that between languages which use auxillary verbs and those which mark all the features otherwise supplied through auxiliarles by means of the direct verbal stem inflection or the use of adjuncts to the verb. The classification of verbs in Australian languages is discussed in another paper in this volume. The two subgroupings cross each other, and each was presumably developed within the continent rather than brought in by different movements of peoples.

3. Syntactic arrangements are not critical for Australian language subgrouping. From a primitive freedom of arrangement the tendency has been towards fixation and, especially, to a subjectObject-Verb (SOV) structure.

4. Vocabulary varies widely from language to language. There are certain words which appear to be continent-wide. One group of these has been classed as CA. Others are now appearing in varlous regions - regional vocabularies, such as those of Dampler Land - and some of these are found in far separated areas of the continent, such as Kimberley-Arnhem Land and western V1ctorla. These seem to belong to an EA stratum and to have been scattered by later movements of $C A$ speakers: more will be sald of this in the discussion of vocabulary later in this paper. Difficulties in tracing vocabulary in Australia were discussed in the previous sections; another arises from word taboo, by which words resembling names of the dead are avolded at least one instance of avoldance of the pronoun for me has been discovered operating since the early 1950s (O'Grady and Voegelin 1966:142). The fact that there is no definite system for replacing such lost words makes linguistic development harder to trace. There are also kinship vocabularies, such as the commonly-called 'Mother-in-law' vocabulary; in the past also there were secret languages used during the inftiation period, and there are still song languages which are far from fully known or analysed.

Within the feature of structure, two important 1tems need to be contrasted. Some languages do not mark the subject of a transitive verb but they do mark the object, especially if it is a pronoun. Other languages leave the object unmarked, but mark the transitive subject by a suffix, producing what is usualiy called the 'ergative' case. These languages are called 'ergat1ve languages', and they embrace the vast majority of Australian languages. The 'nominative' or 'non-ergative' languages occupy a region which stretches along the north coast of Western Australia, through the Northern Kimberley districts, over most of Arnhem Land, and the 1slands in the Gulf of 
Carpentaria. It has usually been thought that ergativity is a mark of the CA languages, borrowed into the other type languages thus reducing their number greatly. Th1s proposition now seems somewhat unsatisfactory, if only because ergativity is not a feature that is likely to tempt borrowing: 1t means the complete reconstruction of the verbal system of a language, including the abolition of a passive volce. The subject will be discussed below in 4.1 .

Another type of classification used by the present writer (Capell 1965) Is the one he has called 'A Typology of Concept Domination'. As applied to Australia, this has been outlined by Wurm (1971:746ff.). It is based on entire utterance pattern. Instead of breaking down the utterance into two sections under the names of subject and predicate, it is looked upon from the viewpolnt of deep structure. Here it is possible to think of a linguistic entity as consisting of something spoken about - 1ts condition or nature - and some state or activity in which it is involved. Thus:

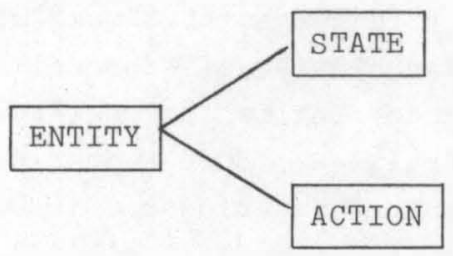

Deep structure (DS) may ultimately be no more complicated than this, which is a functional sentence perspective (FSP). Expansion of each rectangle produces surface structures (SS) which vary from language to language according to the kind and nature of the expansion. It is at this stage that languages actualise DS in different ways, placing the emphasis on one rectangle or the other. The ways in which these different emphases are placed then determine the nature of the language. The following are the three obvious ways:

(a) Some languages develop the S/A rectangles, leaving $E$ relatively undetermined. Such languages may be regarded as 'event-dominated' and the process is then 'event domination' (ED).

(b) Some languages develop the E rectangle and leave the S/A rectangle largely undeveloped. Such languages are 'object-dominated' and the process is called 'object domination' (OD).

(c) Some languages develop all or most of the implications of each rectangle more or less equally, and such languages are 'doubly dominated'. This process is called 'double domination' (DD). 
In the (a) group, state/action becomes refined in terms of volce, aspect, mood, tense, etc. though no precise order of historical development can be la1d down. In fact, languages may change group in the course of their history.

In the (b) group, the 'ent1ty' becomes defined progressively in terms of distinctions such as animate-inanimate, masculine-feminineneuter, noun classification. Again no logical or historical order of development can be la1d down: languages differ.

The formal interaction of part with part, commonly known as 'concord', is an attempt to classify the role of each part of the utterance - what refers to what w1thin 1t - and again, languages differ as to the demands they make on the formal distinction of such roles. Concord may have wide effects not only on the morphological level but also on the discourse level, and may reach any degree of complexity or explicitness on any one of these, using the phonological level as the instrument by which the end is brought about.

(d) Moreover, there are languages that make only the minimum differentiation necessary for clarity of expression on both the $E$ and the S/A sides of the utterance: English is one such language, and here 'domination' is almost neutralised. Such a process can be called 'neutral domination' (ND) and 1t is evidenced in Chinese and other 'Isolating' languages.

All four types of language are found in Australla, and all the evidence to date suggests that there has been a kind of ascending complication from ND to DD in this continent. The following Table summarises areas in which each type of domination obtains:

A. NEUTRAL DOMINATION

No elaboration of morphological features; no noun classes; no Indication of person or number in verbs; on the level of syntax, seek development of subordinate clauses. Type languages: Gadhang, Galgadungu, and the W1k- and Gugu- languages as a whole (w1th some Individual modification of degree).

\section{B. EVENT DOMINATION}

The chlef elaboration is in the verb, where tense forms may be numerous and pronominalisation begins to appear. There are numerous subtypes of this group wh1ch may be set out as follows:

B. 1 Tense and number are indicated in the verb but person is not marked within the tense. Type language: Aranda. 
B. 11 Person is marked in addition to tense and number. Type languages: Ngunawal (NSW), Woywurung (V1ctoria).

B. 111 Person markers used with verbs are also used with other categories, chiefly as possessives with nouns. Type languages occur in Victoria, but there are also influences from B. v.

B. 1v Subject and object pronouns are incorporated into the verb complex. Type language: Wardaman.

B. $\mathbf{v}$ Languages are rather heavily pronominalised; their chief characteristic is the transference of verb suffixes of person and number (subject and object) to the head word of the clause. Subdivisions within B. v are:

B. v (a) Pronoun subjects and objects are free forms but syntactically conjolned with each other. Type language: Narrinjer1 (Yaralde). B. v (b) Transfer of subject and object suffixes takes place regularly. Type language: Bldjandjadjara. There may also be sentence medial as well as sentence final forms within the verbs.

B. v (c) Transfer is made only if the tense is non-past, but sentence medial and sentence final forms occur. Type language: Waljbir1.

B. v (d) Catalytic particles are used to carry the markers instead of their being transferred to the end of the clause. Type language: Mudbura.

\section{OBJECT DOMINATION}

There is more elaboration of nouns than in Groups A or B. Noun classes may occur, leading finally to class forms within the verb as well as within the noun phrase. Subgroups are:

C. 1 Nominal systems are more highly developed than verbal systems; neither is morphologically complex. Type language: Diyar1 (Dier1). 
C. 11 Further object domination is exhibited in nouns and pronouns. Type language: Gubabwiyngu.

C. 11 Noun classes are usually two only, w1th object incorporation (pronoun) in the verb. Type language: Gidja.

\section{DOUBLE DOMINATION}

Noun classes are present in most of these languages, and they are marked also within the verb complex. They are mostly prefixing languages. The subgroups are:

D. 1 Noun classes are present, marked by suffixes, and there is concord with all words in the NP, but not yet in the verbal object. Type language: Wagaya.

D. 11 Noun classes are marked by prefixes; although concord is present, noun class affects object but not subject of verb. Type language: Ngarinjin.

D. 11 The prefixes of noun classes, w1th concord, reappear in both subject and object of the transitive verb (as in Bantu languages). Type language: Mawng.

D. Iv Similar to D. 111, but crossed by a system in which sex of the actor or goal is additionally Indicated as a suffix to the verb complex. Type language: Gagadju.

D. v No noun classes but the tense of the verb (past vs. non-past) exercises control over noun and pronoun subject, and in one case, object also. Type language: B1dabida (P1ttap1tta).

In the present issue, the treatment of the languages w1ll not be based on this analysis for practical reasons regarding historical research, but it is hoped that in a subsequent work this approach may be developed in greater detall.

As a rule, Australian languages do not mark gender. A few have developed pronouns of the third person singular in which masculine and feminine are distinguished. The suffixing languages as a whole, however, pay little or no attention to gender, but the prefixing languages distinguish noun classes, usually between two and $\mathrm{s} 1 \mathrm{x}$ of them; these are 'grammatical' rather than 'natural'. They would seem to have begun by grouping nouns under certain class headings, and 
marking the class by a free morpheme. Th1s happens in some of the present-day Cape York (CY) languages, in a form rather like the classifications made by modern naturalists for plants and animals, and 1 t shows that the principle of classification was developed within Australia, however much it may resemble those of Burushaski or the Bantu languages. Deta1ls of this aspect of Australian languages are given in 'Grammatical Classification in Australia' in this volume.

True prefixing languages are 1llustrated most fully in those of the Northern Kimberley Division of West Austral1a, where (1) a noun belongs to one class and (11) a system of concord is involved throughout the clause and any dependent clauses. The elaboration may vary to almost any degree. One example from Ngarinfin in this subgroup will 1llustrate the principle:

$\frac{\text { ma-rolale m-inda m-aner wo: }}{\text { river }}$ this big flowing it-do-CONT-which seeing
$\frac{m u-\eta-o:-n i}{i t-I-d o-P A S T}$

The class marker is $\mathrm{m}(\mathrm{a})$ - and the whole sentence means $I$ saw this big river which is flowing. They are geographically scattered and numerically a minority, so that it can hardly be claimed that they represent a genetically related group within Australia.

Yet the principle of noun classification is not limited to these and the $C Y$ languages. A few such languages are found about the Atherton Tablelands in North Queensland, and others on the Barkly Tablelands in the Northern Territory and Western Queensland - in fact that it is noticeable that they tend to occur in high areas, though this may or may not mean anything historically.

The majority of the languages are suffixing, and occur throughout the Continent. They fall into a number of subgroups and a great varlety of types. The types which occur in some parts of Australia are set out in Table 1 . This table is based on a formula for the sentence, as defined by Hockett: 'A sentence is a grammatical form which is not in construction with any other grammatical form' (Hockett 1958:199). As there is no theoretical need here for any particular analysis, the common shape is taken for granted, 1.e. a sentence may be pictured as

$$
\pm \text { subject }+ \text { predicate } \pm \text { object. }
$$

In the intransitive sentence the object 1s not present; in many Australian languages also there may not be a separately expressed subject, so that $+\mathrm{P}$ becomes the only necessary element of a sentence. 
Table 1: Types of Sentence Structure in Australian Languages ${ }^{1}$
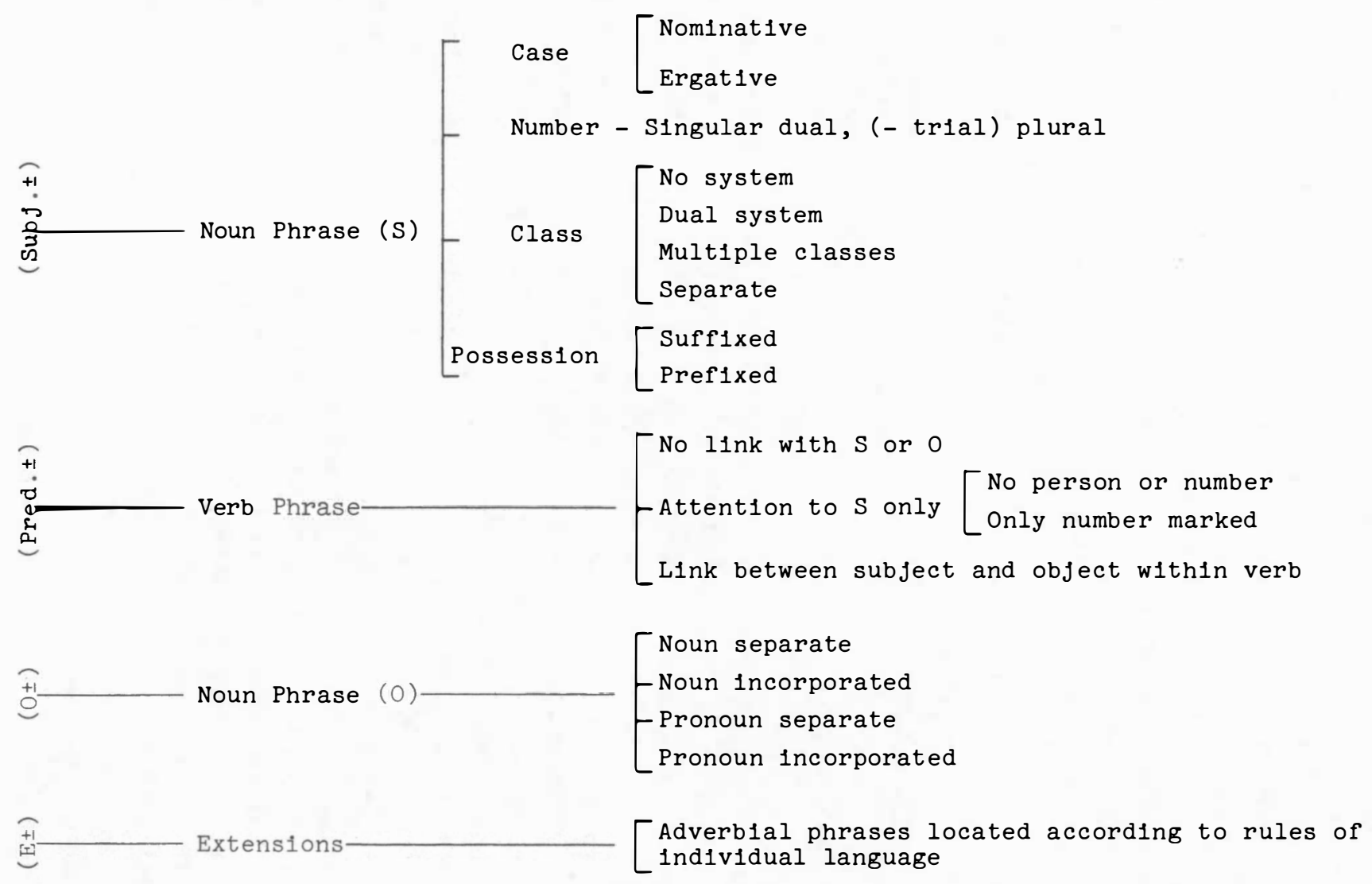

${ }^{1}$ Note: This does not imply Svo order. Such may occur, but Sov appears to be basic to these languages. 


\subsection{Structural Development of Australian Languages}

Detalled analysis of the modern Australian languages, such as that which lies behind the present study, makes it possible to suggest certain stages of morphological and syntactic development through the millennia, though the order in which it is suggested that these took place may need adjustment.

Everything points to a structurally simple proto-language, and this may be sald without deciding the question already raised about the unity or plurality of the language or languages classed here as EA. $E A$ is a sort of legal fiction, in view of the historical situation which confronts the investigator. In fact, more than one 'original' language may have reached Australia at approximately the same time. There is no contradiction in such a suggestion, seeing how little is known of human speech as far back in time as the view of Australian archaeology requires. The view that language was originally holophrastic and has been simplified into analytical types has no historical facts to back 1t. It is here assumed that language began in a simple form, gradually grew more complicated, in different areas and at different times, and that within historical times there have been tendencies to structural simplification in languages, such as Indo-European. In Australia there is no positive evidence (see Taul1 1958, passim).

Assuming, then, that at the stage represented by 'proto-Australian' structure was simple, it may well follow that there was considerable freedom in syntax. In fact, in quite a number of languages such is still the case. A sentence of $s 1 x$ words can be arranged in $s 1 x$ ways. There would be difference in emphasis, no doubt, in each case. There could be difference in meaning also: a subject might well be taken as object, and in this situation a means of distinguishing the two would be developed. Syntactic clarity might well need morphological complication. Once this set in, there could be development in any direction at all, and this would seem to be roughly what happened. How far it can be traced at present remains to be investigated. First, however, must come an investigation of the processes of sound change, as far as these can be traced.

\section{HISTORICAL PHONOLOGY}

\subsection{Preliminaries}

This paper will deal as briefly as possible with the nature of Australian consonant and vowel sounds. The present study is not a 


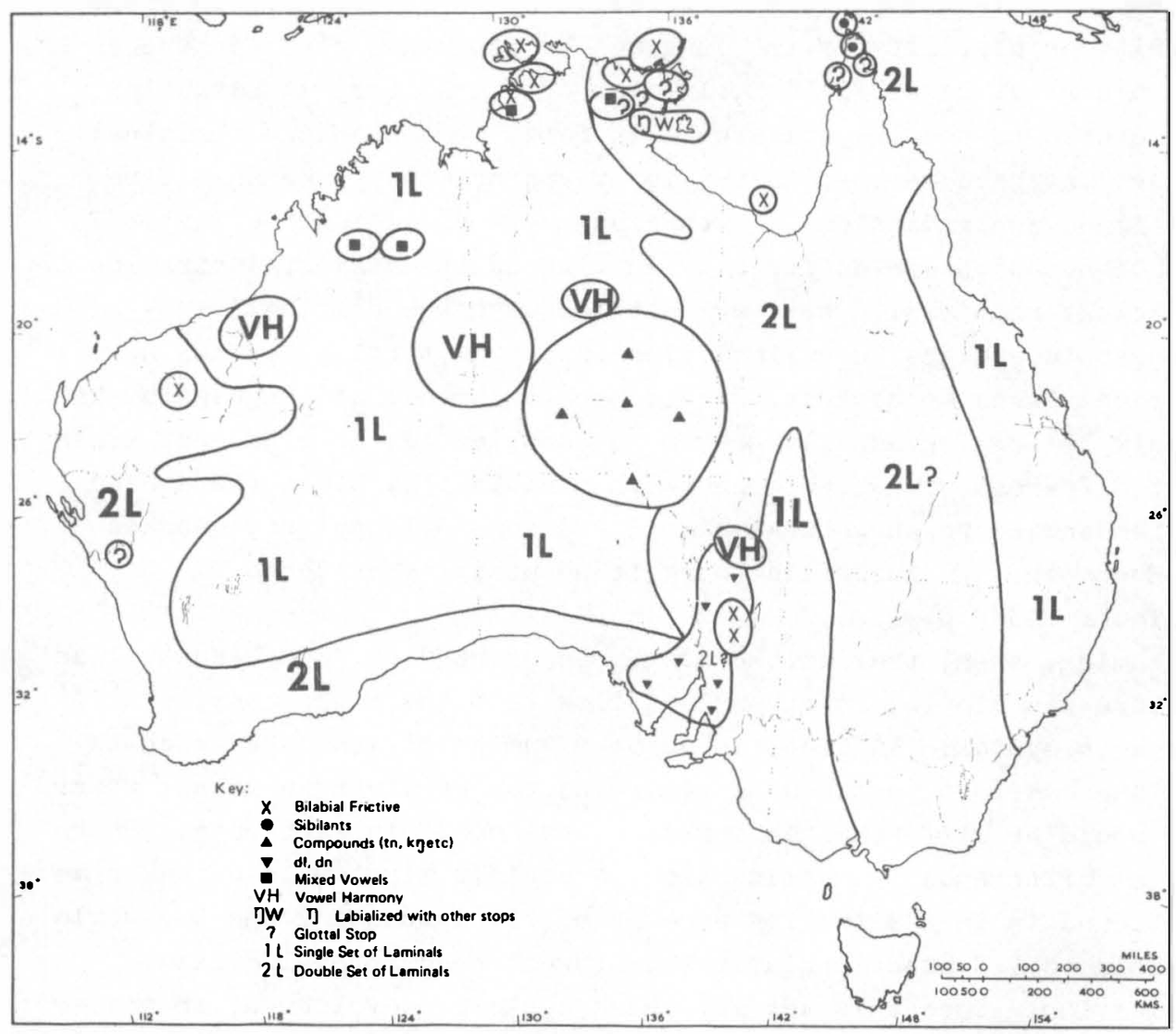

Map I: Phonological Traits, Occurrerice of Less Common Phonemes (after Dixon, 1970) 
'practical introduction to Australian phonetics', but a theoretical study of the origins and development of the languages as a whole. It is not necessary to say much about the phonetic level at all. The normal subdivision of sounds into consonant, semivowel and vowel obtains here as in other forms of human speech. So far as the historical study is concerned, a warning is needed: in tracing the history of language in Australia it is not possible to follow the strict method of demonstration that has been possible in reconstructing proto-Indo-European (PIE), nor even the degree of strictness that has been possible in some reconstructions of proto-Amerindian languages. In America, as in Australia, there are no earlier stages of language avallable for comparison as stepping stones, but in Australia there is the added difficulty of the time depth. Since demonstration as clearly as in PIE is impossible, impression or intuition must at times be allowed a volce, even if this is not strictly scientific.

Even so there are difficulties. 'The Neogrammarian's absolute regularity of sound change is untenable, and this has always been recognised in practice by most investigators. The French phoneticians and the Finno-Ugrian linguists have, in fact, suggested that the notion of the sound 'law' has to be downgraded to a 'tendency' only. In any case, it is the regular aspect of sound change that gives backbone to general linguistics, no matter how much the slipped discs of sporadic change may annoy the linguists' (Antt1la 1972:85).

Not only is there difficulty in determining the primal sounds at this length of time, but semantic problems arise also as regards identification of words. In PIE reconstruction, some elasticity of semantic identification is accepted. In the original lexicostatistics of Swadesh, 1dentity of meaning as well as comparability of form was insisted on. English dog and German Hund are abviously not cognates, yet the existence of English hound and German Dogge, 'mastiff' was not allowed for comparison: hound $-\rightarrow$ Hund and dog $\rightarrow-\rightarrow$ Dogge were rejected and the percentage of cognation was to that extent falsified.

In classical philology this principle of 1dentity of meaning was not accepted as a criterion of cognation. If 1 t had been, such counts would often have been substantlally lowered. Of course, meaning is more static than form, but allowance must be made for meaning changes where origins can be traced and the processes of semantic change understood. In Australla many words exist that are obviously related while thelr meanings diverge greatly from language to language. Alternatively, a large number of homonyms must be accepted, but this 
1s to be avolded as far as possible. Thus, what is clearly the same root - *gadja - appears not only as elder brother but as mother (*ga:dja In proto-Paman [Hale]) and as father (gadja In Gugu-Badhun [Sutton]). The relation between this and *gaga, mother's brother in Garadjarl and other languages, also requires some untangling. Again, Ngayarda *balgara, clear space (O'Grady) may link with balgaRa, smooth, bald and/or palaRa, clear space in Gugu-Badhun. How far semantic difference is to be accepted without invalidating an identification is sometimes a difficult question to answer.

The allowable limits of phonetic change also require consideration In languages which, like the Australian, have no diachronic documentation. Thus *wali, bad (O'Grady) appears in Cape York areas as walwa (Gugu-Badhun) and *wara (Hale, proto-Paman). Changes of final vowel between EA and the modern languages often seem considerable In fact, it has been sald for Australian: 'take care of the consonants and the vowels will take care of themselves' - but the insertion of -w- ralses difficulty. Yet in the Northern Kimberley, Ngarinjin has -alwa, bad, to whlch noun class prefixes may be added and the result Is w-alwa for the Class IV form in that language: ${ }^{1}$

These few considerations light up the nature of the general problem of sound correspondences. The nature of the sounds themselves in these languages must now be consldered.

\subsection{The Australian Sound Systems}

\subsubsection{The Consonants}

Australian languages share almost 1dentical sound systems everywhere on the continent, both in the sounds present and those that are lack1ng. Sibllants are lacking, fricatives are few, and of ten only allophones of plosives. The first problem is found in the nature of the plosives themselves, no matter what their position along the line of formations within the mouth.

As stated by Dixon, it is probably enough to say that 'volcing is not normally phonologically significant' (D1xon 1972:2). The plosive sounds belong, that is to say, to the group that has earlier been called 'devolced' and later 'volced lenis'. It is this that led the present author to use the symbols $b, d$, and $g$ for the three chlef members of the serles; others have preferred to use $p, t$, and $k$. The latter set is satisfactory in languages where there is no distinct

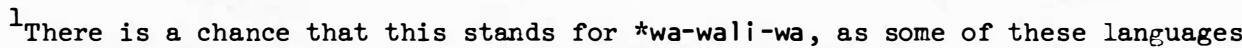
have class marking by simultaneous prefix and suffix. 
volceless set, but the former have been retalned here; these seem to allow for a more simple transition to volced sounds in such combinations as nasal + plosive: $m b$ rather than $m+p>m b$. In a number of languages there seem to be two sets of plosives, but there 1s, as yet, no agreement as to whether or not it is really a contrast between volceless and volced, nor does it seem to have importance for historical research. It would seem that Australian plosives were originally volceless, or perhaps they were actually of that acoustically intermediate type that was noticed even by the untrained first settlers at Sydney in the 1790s.

The places of articulation of plosives also vary in different languages. O'Grady set out as the maximum series six places of articulation for plosives, with nasals corresponding to each.

\begin{tabular}{|cc|c|c|c|c|c|}
\hline & B1labial & $\begin{array}{l}\text { Lamino- } \\
\text { dental }\end{array}$ & $\begin{array}{l}\text { Lamino- } \\
\text { palatal/ } \\
\text { alveolar }\end{array}$ & $\begin{array}{l}\text { Ap1co- } \\
\text { alveolar }\end{array}$ & $\begin{array}{l}\text { Aplco- } \\
\text { domal } \\
\text { (retro- } \\
\text { flex) }\end{array}$ & $\begin{array}{l}\text { Dorso- } \\
\text { velar }\end{array}$ \\
\hline Oral & b & $\underline{d}$ & $d^{\prime}$ & $d$ & $d$ & g \\
Nasal & $m$ & $n$ & $n^{\prime}$ & $n$ & $n$ & $n^{\prime}$ \\
\hline
\end{tabular}

The series is often labelled bllablal, interdental, alveolar, palatal; retroflex, velar (in the order $b, d, d^{\prime}, d, d, g$ ). For $\underline{d}$ the digraph $d j$ is frequently used for ease of printing (and this is done here). No argument as to the exact phonetic realities of the plosive series is needed; the question is unsettled, and for historical purposes 1t does not have to be solved. It w1ll appear that there has been a process of amplification in the series of sounds; that EA probably had only bllablal, alveolar, palatal and velar sets. Modern languages have 4, 5, or 6 places of articulations, and in some areas a serles with nasal release (e.g. Aranda bmaRa, camp or pmaRa if the other orthography is preferred. These releases are sometimes written as capitals (BaRa)). The modern Western Desert languages show considerable interchange between interdental, alveolar and palatal within the same word - not confusion: it is local variation - and simliar uncertainty in other areas suggests that these distinctions were not originally phonemic and probably not made. ${ }^{1}$

${ }^{I_{A}}$ detailed study of Australian laminal consonants is to be found in Dixon 1970b, and this highlights the difficulties surrounding the study of these non-peripheral sounds. Perhaps the fact that they are non-peripheral helps to account for their 
The orders of consonants in Australlan languages generally are plosives, nasals, liquids ( 1 and $r$ sounds, sometimes referred to as laterals and vibrants or rhot1cs) and sem1-vowels. The latter are reductions of the vowels /u/ and / $/$ /.

The suggestion for a PA consonant table (presumably EA: CA seems to have set the complications going) would then be:

\begin{tabular}{|l|ccc|}
\hline & Bllablal & Alveolar & Velar \\
\cline { 2 - 4 } Plosive & $\mathrm{b}$ & $\mathbf{d}$ & $\mathrm{g}$ \\
Nasal & $\mathrm{m}$ & $\mathrm{n}$ & $\mathrm{D}$ \\
Lateral & & $\mathrm{l}, \mathrm{r}$ & \\
Semivowel & $\mathrm{w}$ & $\mathrm{R}, \mathbf{j}$ & $(\mathrm{w})$ \\
\hline
\end{tabular}

The double inclusion of $w$ reports the phonetic fact that it involves lip-rounding as well as similar back of tongue ralsing. The symbol /j/ answers to English 'y'; the capital /R/ 1s the untrilled continuant ' $r$ ' of southern English run, somewhat retroflexed. Th1s sound is so common - and phonemic - In Australian languages as to justify reckoning among primitive sounds.

If a general alveolar series is accepted as PA, the question of the development of the present more complicated sets of sounds has to be faced. The laminal series is the most complicated. Of these, Dixon (1970b:92) declded that the orlginal phonological system contained a single set of laminals: 'although allophones may have been redistributed....Modern double laminal languages have generalised on the proto-Australian patterns'. Lamino-palatal sounds have been introduced before $i$ and lamino-dentals before a or $u$, in his opinion. There 1s, however, a more natural tendency to introduce laminals into palatal sounds before a high front vowel, as happens, for instance, in most Slavonic languages. At what stage retroflexion took place it is difficult to say. O'Grady (1966) shows in the Ngayardic languages a contrast of /panti/, sit with /panti/, smell something. The former

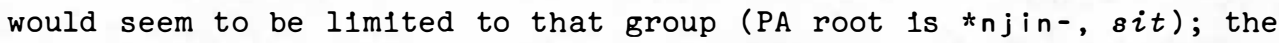
latter is found also in Dampler Land, Yugulda and Ngamin1, the first being near Broome, Western Australla, the second near the Gulf of Carpentarla in Queensland, and the third in east Central Australia. O'Grady has also *pana-L-, shine, of moon, Warnman and Julbaridja 
banjal, as against *baṇa, head, Njangumarda baṇanj, reef - though the semantic change makes some difficulty here. There is the possibility that the complication of the series may be ascribed to the CA stage but at present no assertion is being made about 1t. The question of $/ \mathrm{nj} /$ as a member of the original pattern has also to be considered. The stage then might be:

\begin{tabular}{|c|c|c|c|}
\hline 1 & $d$ & $d$ & $n j$ \\
2 & $\underline{d}, d$ & $\underline{n}, n$ & \\
3 & $\underline{s}, d$ & $\underline{n}, n$ & $n j$ \\
\hline
\end{tabular}

with change of class of / $\mathbf{n j} /$ as other palatals developed; a series of retroflexes developed pari passu, but in which stage remains uncertain.

The possibility cannot be dismissed that retroflexes do represent a development of an $\mathrm{rC}$ and RC cluster. Th1s has been argued (e.g. Oates 1967) and Osborne (1974:10) is able to show cases in T1w1 where $R+V$ becomes $c$ when the vowel is replaced inflectionally by a consonant, e.g. mwarina, daughter / mwadi, son. To make these instances into a general historical law would require more study than has been done.

For the purposes of the present study it is easier to use an arrangement of the phonemes differing from that used in the previous Table, viz. that originally suggested by Jakobson and Halle, according to which consonants are divided into peripheral and non-peripheral categorles, or 'central' as the non-peripheral will be called here. Sufficlently detalled arrangement can be gained without using the acute/grave distinctions. The resulting Table of sounds will then look as in Table 2, wh1ch I owe to conversation with Dr C.L. Yallop of Macquarie Un1vers1ty, New South Wales, Austral1a. It was applied by him to Alfawara of the Arand1c Group: see also Harms (1968:31,37).

Table 2: Australian Consonants as Peripherals and Centrals

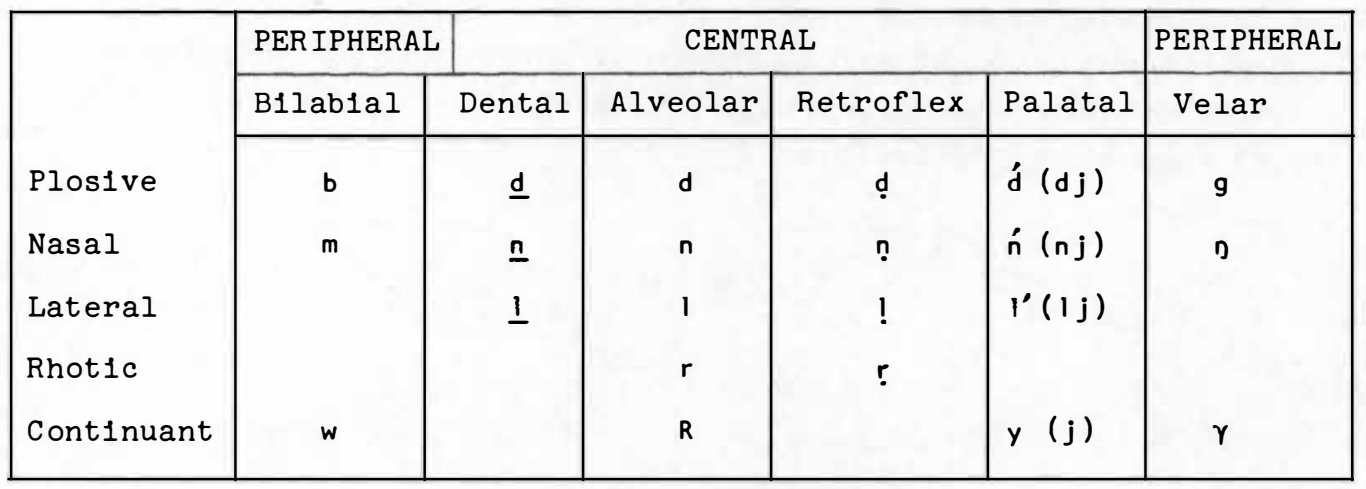


Table 2 allows for the full development of the laminal series as discussed above. So far as PA is concerned, the nasally released series can be overlooked: 1t is more circumscribed than the laminal expansions. Table 3 shows a three-dimensional arrangement of Australian sounds.

The particular advantage of this arrangement is that it allows the rather peculiar historical serles of sound changes (to be discussed later) to be easlly tabulated. These three methods then supply a likely historical commentary in diagram form on the complication of sound systems within Australia, applying to all groups of languages. For further discussion see Capell 1956/1962:6-7.

Table 3: Three Dimensional Table of Relationship between Members of the Australian Consonant System

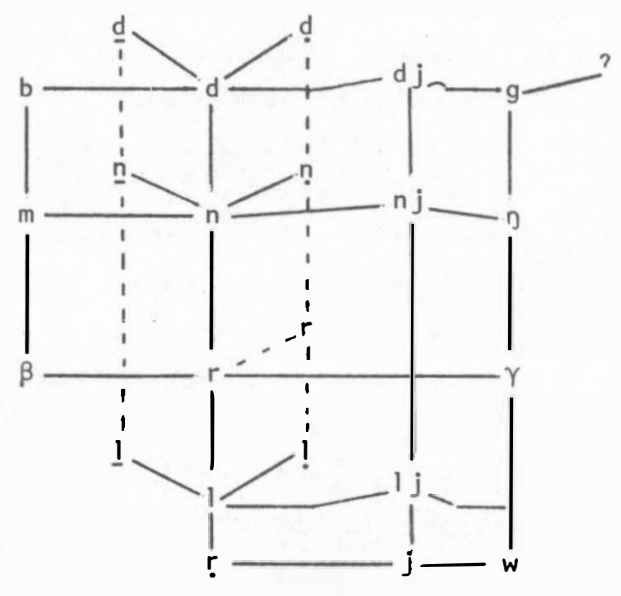

\subsubsection{The Vowels}

The matter of Australian vowels is more complex than the consonants, chiefly by reason of the distribution of two kinds of vowel systems in the present-day languages - one working on a basis of four or five phonemic vowels, the other on a basis of three; In each case there are a number of allophones involved. The two types of consonant system may be schematised as follows:

1.

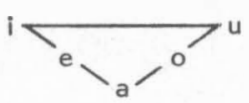

2 .

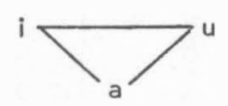


The distribution of the allophones differs in each case, partly from language to language, partly from system to system. In addition, it is sometimes difficult to decide whether a given vowel is phonemic or not. Occurrence of schwa ( $(0)$ and (o) are particularly hard to place. Fortunately, the present study does not involve decisions concerning the allophonic types to any great degree.

The question that is 1mportant here 1s: which of the two systems is the earlier? Th1s is perhaps ambiguous as a method of framing the question. It could also be framed in the form: does the three-vowel system derive from the five-vowel system, or vice versa, or is each historically independent of the other? It is a specially important question because there is no corresponding dichotomy of languages on the basis of consonants. The consonant system is practically the same everywhere, but the vowel system is not so. The consonant system seems to have expanded over the millenla: might not the vowel system have done the same? In which case, the five-vowel system would be the result of an expansion of the three-vowel system. There are languages In which $/ 0 /$ does not occur, at least as a phoneme, 1.e. there are phonemically four-vowel languages. This is so in parts of Victoria, and in Dampler Land, Bard seems to show /o/. In Central Australia, Aranda has $/ \varepsilon /$ as a phoneme and $/ o /$ is subphonemic, but in these languages there may be limitations on the occurrence of the vowels. In Aljawara, $/ \varepsilon /$ appears between a palatal consonant and a following $/ \mathrm{r} /$ or before / $\mathrm{r} /$, whlle /o/ precedes the lablalised velar /gw/. The distribution of the five-vowel languages is as follows:

1. Extreme south-west: Njungar, about Perth.

2. South: In South Australia from Banggala eastwards including Adelaide and the Murray Basin.

3. In V1ctorla: very generally, both east and west, including Gippsland, though $/ \mathrm{o} /$ is sometimes not present as more than an allophone of /u/.

4. New South Wales right to the Queensland border: coastally and inland, including practically all the languages east of the Darling River.

5. North Queensland (Cape York): Thayorre, Mungkan, and some other languages.

6. Throughout Arnhem Land and the Northern Kimberley: only the north-eastern 'Yulngu' group has three vowels.

7. The Torres Straits languages, both Australian (west) and Papuan (east).

8. Central Australia: the Aranda languages. 
When these areas are plotted against certain grammatical and vocabulary features, the whole appears to agree quite well with the archaeological chart of the oldest finds in Australia (Jones 1973:278). They present a somewhat marginal appearance in the sense of the Bartoll School of Areal Linguistics. The bulk of the languages will be shown to present archalc features and the total impression is that the flve-vowel languages belong to the EA rather than the CA groups. The considerable range of allophones in the modern languages could have resulted from the adaptation of three-vowel languages to a fivevowel system which preceded them in a given area. In a language such as Alfawara, this type of incompatibility is especially noticeable. Certain features in syllable structure, to be mentioned below, seem to belong in this setting as well.

Allophonic variations of the five vowel systems may be set out in general terms in the following diagram. The conditions under which an allophone occurs vary somewhat among the languages, and do not concern the present account.

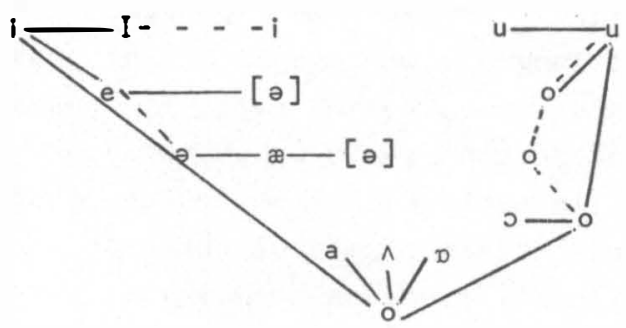

Detalls may be seen in such works as those of Strehlow (1944) for Aranda and Hercus (1969:32-40) for Wembawemba of V1ctoria, or Oates (1964:12-13) for Gunwinjgu in Arnhem Land. Consonant combinations are dealt with also in each of these works.

The allophonic varlations in three-vowel languages are extracted from Capell (1967b:95ff.), where another type of dlagram was used:

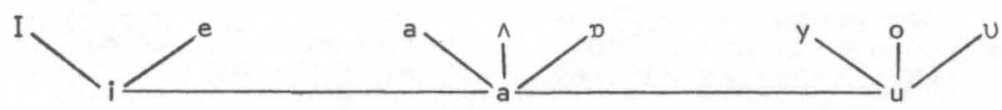

For the study of other phonological traits of Australian languages, general reference may be made to the same article and the attached bibliography. The diagram here differs from that of 1967 , when 1t had not yet been recognised that the occurrence of $/ \varepsilon /$ and $/ \mathrm{J} /$ had historical importance and those varieties of $/ e /$ and $/ o /$ were not included in the printed diagram. 
Questions of stress and intonation are outside the present study, but a word should be sald about vowel harmony, which plays a considerable part in some of the three-vowel languages, particularly in the Western Desert and nelghbouring parts of the Northern Territory. This follows in 2.2.3.

\subsubsection{Other Phonological Features}

Most of the other phonological features of importance in the description of a single language are language-bound and do not enter into the present study. Two, however, are germane to 1t; these are (a) Initial vowel, and (b) vowel harmony.

(a) Some languages do not permit initial vowels, others do. In some cases, initial vowels arise from loss of original initial consonants. This is especially so in some of the Cape York languages and in the Aranda group. Thus, *nali, you and $I$, may become ali. It may be that in some cases where initial vowels are found, such a loss has produced them, but the fact remains that in Australia only a minority of languages permit initial vowels, and it would seem that the earlier Australian did not. Reference may be made to the detalled study of Olgolo by Dixon (1970c).

The question is of Importance in the case of $/ i /$ and $/ u /$ as initials. In most instances, the phonetic structure of these vowels when word-initial is $j_{i}$ and $w_{u}$ respectively. In the three-vowel languages, this could suggest that initial /a/ might have arisen through loss of a consonant such as /3/, but no opinion can be expressed on the subject at this point. In many vocabularies $i$ - and $u$ - are found written initially, but the on-glide must be taken for granted. In a few instances it is definitely not there. In the present work, $\mathbf{j i -}$ - and wu- are written where such an on-glide is intended. The writer's feeling is that, in the early stages, initial vowel was not acceptable, as in Semitic, and some other languages. This is another feature that supports the 1dea of one original Australian - as Indeed the whole phonological structure of the languages does, even while the divergences in vocabulary fight against it.

(b) Certain languages possess the phenomenon of vowel harmony. This is a mark of the Alta1c and Ugrian languages in As1a, but the Australian system is different, as was pointed out in an earlier paper (Capell 1967:99ff.). In the Asian instances, vowels are divided into two groups occurring together in certain sets. In Australia, vowel harmony applies to suffixes, as it does in Asia, though not to the vocalisation of the stem, as in some Altalc and Finno-Ugrian languages. 
In Waramunga, gambadju-guna, of the father, but namini-gina, of the cousin, and mina-gana, at evening. It is the final vowel of the base that determines the first vowel of the suffix. In Walfbiri there is ja-ni-lgi, and then goes, but ja-nu-lgu, and then went (Capell 1962:19). A most exceptional system is that of Dfingili, where the vowel of the suffix determines that of the root, as in nadja-na-dju, I see her, but gidji-ninj-i-dju, we two see her, and gidji-nir-i-dju, we see her (Chadwick 1968:227).

The languages that exhibit vowel harmony are nearly all spoken in the Northern Territory, and they are all three-vowel languages. The phenomenon is not found in five-vowel languages as so far recorded, and seems to belong to the heredity of the three-vowel systems.

In regard to the consonant structure of roots, there are certain other phonological matters that need to be considered. Briefly, these are as follows:

(a) The final consonants in Australian languages depend on laws proper to each language, not to the famlly as a whole. Some languages do not permit final consonants, others delimit which finals are permissible. Consonant clustering is not permitted initially, and in some languages also not finally, but in practically all they can occur internally. The most complicated final clusters are found in the languages of Arnhem Land and Victoria, and the general impression they raise is one of antiquity. Both these groups also are five-vowel languages. These languages appear to be archaic in other features also, and are classed here as EA. Most of the CA languages are phonologically simpler. Some languages which, on the evidence of vocabulary, appear to be basically EA are phonologically simpler and would seem to have been influenced by $C A$ languages to the west of them. These facts will come out in the treatment of the word-store. Schmidt in his Gliederung (1919) paid considerable attention to the phonological patterns of words and, in each subdivision, set out what patterns occur in the languages concerned. Like his subgroupings themselves, however, these are only partially successful. Thus inftial vowels do not appear in his South Central group, and only rarely along the Murray River. Final vowels are allowed in the South Central group except for Badfiri. Actually, if the subgroups are historically valuable at all, there is a broad division into

(1) languages allowing only $-V$, and

(2) languages allowing $-C$, but these can again be subdivided into 
(2a) almost any consonant 1s permitted as final: this Includes Arnhem Land and Northern K1mberley, Yaralde, Victorla in general and the Yuwin group in New South Wales, and

(2b) those that allow central consonants only - nasal, lateral and rhotic.

Here, however, some tend to lose $-V$, so that stops are allowed to be finals, as in the Perth area for example, and some others have $-M$ by loss of final vowel. It therefore remains doubtful whether word structure has any real historical value in this sense, and the matter w1ll not be expanded here.

(b) The flve- and three-vowel systems, however, do seem to be of historical 1mportance. In this matter, Australian languages present a neat contrast to the Semitic, in which scholars posit an original three-vowel system, later expanded to four, five or six vowels in different areas. In Australia, the dichotomy is clearly between the two types, and vocabulary distinction seems to correspond.

It is in the five-vowel languages that the more complex phonologies are found, together with the free use of initial vowels and final clusters of the types $-r b,-1 g$, etc. These are quite impossible in the WD and other CA Influenced areas. It seems, therefore, that the occurrence of these complex phonologies serves to mark of the $E A$ languages in the continent. This does not, of course, mean that there is no CA Influence in other areas of the west; in fact there usually 1s. To demarcate the two is one of the present problems.

\subsection{Processes of Sound Change}

If the phonology postulated as original to Australla is anywhere near correct, a process of elaboration has gone on during the earlier perlods, and indeed 1s still in progress in certain areas such as the south WD. Th1s is contrary to the general 1dea that languages tend to simplify. The 1dea is true indeed as regards structure, but not necessar1ly so as regards phonologies, and in Australia elaboration seems to have been the process. This needs to be looked at on the bas1s of reconstructed forms: what sounds are required to reconstruct forms that could easily have developed into those that are found today? of course, this inductive establishment of a sound system must be worked out in reverse, given the fact that no diachronic information is to hand - a fact that obtrudes 1tself endlessly in Australla.

In these languages, transformations of consonants are easier to deal w1th than those of vowels - and more 1mportant as 1 t happens - because 
they are regular; even today there is considerable vowel varlation at the phonetic level, especlally where vowel harmony has come to play a part.

Consonants seem to interchange from language to language on the basis of their position in the scheme as peripheral or central. Perlpherals tend to interchange w1th peripherals but not with centrals: /b/ w1ll interchange w1th /g/ but not, for example, w1th /d/. Centrals tend to interchange with centrals, but not with peripherals. A glance at the wordlists given in other parts of this study will show many cases where such serles of changes have taken place.

These may be regarded as the most common and regular sound changes. There are others, however, which are more restricted, in fact really determined. Such changes are not only interesting in themselves, but seem to have historical connections useful for the present purpose. Some have been studled by present-day lingulsts, and these need only be summarised here.

The most outstanding areas of the less common sound changes appear In the languages of Cape York Peninsula, and the Aranda Group. Some linguists, in fact, have suggested a closer relationship between these two areas, though 1t could, of course, be a case of parallel development.

One of the developments found in certain non-contiguous regions is the apparent development of two sets of stops. Th1s could be of historical importance in Australia, but unfortunately there has been much argument as to the nature of the second set of sounds. It is not certain that the sounds in question exhibit the volceless-volced contrast. It has been suggested that the difference is one of tenseness rather than of volcing. Thus Sommer (1969:60) proposes a set $p, t, k$ and another tenser set $P, T, K$ to indicate the difference. Th1s may well be right. The present author's experlence in regard to Gubabwiyngu inclines him to this feeling. In this case, comparison of two sets of words in Gubabwlyngu and the closely related Gumady of Y1rrkala, showed that whlle one type of /g/ became /w/ in Gumadj, the other remalned $/ g /$. As remarked already, a change of perlpherals $b>g$ is not uncommon in Australia, and $g>w$ is also common; exceptions appear to point to the second type of plosive. These two sets have been recorded in parts of Arnhem Land, including DJinang, but not only In the north-east, South Australia (Adnjamadhana) and Cape York (Gundjen and others). In each case they would seem to be local developments, as there is no contigulty factor present. 


\subsubsection{The Cape York Languages}

Scholars have long regarded CY languages as standing well apart from those to the south of the Peninsula. At first sight, they look Indeed, hardly Austral1a. It has been shown by K.L. Hale (1966), however, that given certain decldedly drastic sound changes, these languages can be fitted into the general picture. This section will summarise his findings and suggestions, and seek to fit them into the general historical pattern. Hale spoke first of a northern and southern subgroupling which he called the 'Paman' languages - a name based on pama (bama), man as a common root. Elsewhere in the present work 1 will be shown that the root here is *ban, reduplicated as *banbay and then becoming *bamba( $n$ ) which appears not only as bama in this part of Australia, but also as wamba, wamb, amba, amb in the Dampler Land region of the Northern Kimberley Division. It is thus much more widespread than appears at first sight. It should be noted in passing that Aranda does not belong to this group, but shares a form adua, man < *badun wh1ch may or may not ultimately link with *ban.

\subsubsection{Northern CY Languages (Northern Paman or NP)}

According to Hale (1966), these languages belong to the three-vowel group, and the theoretical word pattern is usually*CV(:)CV(C), with severe limitations on the structure of each segment. Initial $C$ is not limited; the vowel following 1t may be long or short, the final consonant is, as a rule, resonant if 1 t occurs at all, but in many cases 1t has been lost. The first great change was a shift of stress to the second syllable, whereby the first syllable was usually lost, but 1 t has left traces of 1 tself in the nature of the second syllable (Hale 1966:168ff.).

These changes point back to times when a root already had a fixed pattern, but the patterns are those which have already been recognised as PA in some form or other (1.e. before any distinction between EA and $\mathrm{CA}$ can be recognised). In Y1nwum $n \mathrm{jdj} \mathbf{i}, \boldsymbol{s e e}$, for Instance, it is possible to recognise *nadji, the nasal leaving 1 ts effect in the Initlal compound $n j d j-$. But the commonest EA form is *na- or *nja-, without a second syllable. Y1nwum $n j d j i$ therefore has been developed from a later b1-syllablc root, in which an ending has been added to *na. That is to say, these NP languages would seem to be quite 'late' In their development: the second syllable of the root for see has already a history. As Hale puts 1t: '1t is clear from this example that the technical exposition of NP historical phonology must allow 
for relative ordering of events' (Hale 1966:169).

In dealing with these languages, Hale has introduced the term 'lenition' for a process by which long V: has affected the inftial stops (*S) and clusters of nasal and stop (*NS) 1mmediately following, usually producing volced fricatives. To this extent the usage is sufficlently like the better known usage of 'lention' in Celtic languages for 1 t to be retalned. So $* / b+m b />/ \beta / ; * / d j+n j d j />$ /ð/ and $* / g+n g />/ Y /$.

\subsubsection{The Southern CY Languages}

The gugu- languages do not share the reductions evident in the north, west and south-west $C Y$ languages. Th1s appears in an unpublished list of Gugu-Badhun words complled by P.J. Sutton, but -C loss is found at times in the Flinders Island language: olbu, old man answers to Gugu-Ya'o djilbu, but durgal, straight is the same in both Flinders Island and Ngayarda. However, another paper by Sutton (1976) on Mbara (M1djamba) on the Woolgar and Stawell Rivers, in the extreme south of the CY area, does show the inftlal syllable losses (e.g. *nali, we two $>1 i$ ) and most of the other characteristics. Th1s whole area 1s poorly recorded (almost lost) but 1t shows great linguistic complication.

If phonemic innovations count towards classification, the CY languages are definitely a separate group: that they should be called Paman is not so certaln, in view of the Dampler Land and Victorian languages sharing with them the very word after which they have been named. This root is discussed in the final section of this paper; but 1t is of use to reproduce the diagram here that will be used there. Th1s rests on a root *ban, which appears in southern Australla uncompounded as person, or father, largely in Victoria and coastal New South Wales. The root may be reduplicated and, if the final velar nasal is replaced by an undefined nasal $N$, it takes the form *baNbaN, and shows the following distributions in its phonetic varlations:

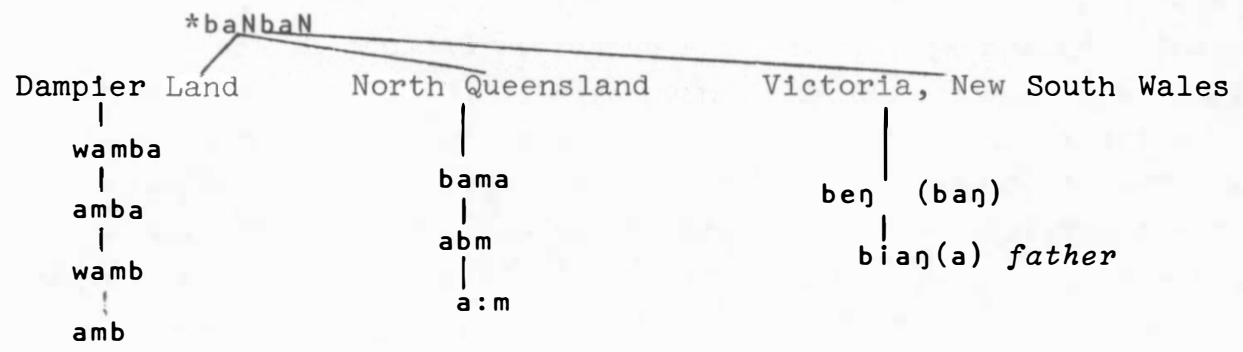


It 1s, of course, possible that *ban may represent *badun but positive evidence is lacking.

At this point the exact locations need not be specified. There is some change of meaning, but not beyond an acceptable degree, especially in view of the wide semantic changes in the application of kinship terms in Australian languages. On this basis, however, if CY languages are to be labelled 'Paman', so should those of Dampler Land and Victoria-New South Wales. Th1s will be discussed in 3.3.3. below.

\subsubsection{Central Australian Languages}

The relationship of $C Y$ to the Aranda group has been suggested as something closer than might be expected because of their sharing a number of sound changes between them, such as the loss of initial consonants or syllables. The languages involved are Aranda itself (In a number of dialects) Aljawara, Andegerebina, Yarowinga and Gajdidf.

Comparison of the Arandic group with $\mathrm{CA}$ and other widespread words shows changes often as drastic as those of $C Y$. They are outlined for Aranda itself in NAAL 2, p. $100 \mathrm{ff}$. Aljawara has similar but of ten st1ll more drastic changes, e.g. w- is usually kept in Aranda but lost in Alfawara. Gajdidy is very similarly patterned. The first demonstration of the facts for this group was made by K.L. Hale (1962: l7lff.), though he did not tabulate the sound correlations.

Some of the transformations, especially of $\mathrm{CA}$ forms in the Arandic group can be summarised here from the material in NAAL, with additions from Alfawara and Andegerebina:

1. C- kept: this applies clearly to sem1-vowels in Aranda roots such as WD wan-, blow, of wind > Aranda wana-; bo-, blow with mouth > Aranda bo-; ya(n)-, go > Aranda yana-, send. But in these cases Aljawara mostly loses the consonant ang-, speak (< *wanga), Gajdidj aknga.

2. C- lost: D- In Aranda, Aljawara uRa, fire < *nuRa (but Gajdidf warra); Aranda and Aljawara ala, nose (Gajdidf $i l a)<\star_{m u l a}$; Aranda and Aljawara ada, $I$ (erg) (Gajdidj ajin) < * $a(d j a)$; Aranda and Aljawara unda, you (erg) < *nundu; $g$ - In Aranda, Yarowinga and Gajdidj ana (Aljawara, Andegerebina adna) excrement < *gunan and some WD roots such as gunga, raw > Aranda anga; wildja, shade > ildja, hut. 
3. Inftial syllable lost: ra, you, pl. < *njura; Aranda linja, Gajdidj alinji, Alyawara alinja, tongue < *dalan; WD gudjara, two > Aranda dara, Gajd1dj, Alyawara adira; WD nju-mbala, you two $>$ Aranda mbala, Alyawara ambula; Aranda bulja, soft, cf. Nfangumada gabulju.

There has clearly been quite early borrowing from WD, while the phonetic changes were still active. The example of njumbala, you two $>$ mbala is instructive, for 1t is njundu, you (sing.) + bala, he in Aranda but njundu + bula, two (EA *buladj) in Alyawara. Each root, *buladj (EA) and *gudjara (CA) has 1ts area of occurrence in WD languages (Capell 1955:285ff.). Aranda llina, Alyawara aylina, we (excl.) Is *nali, you and $I$ with -na (exclusive suffix) as also in Aranda anuna, Alyawara anuningira, we (excl.). In some cases Alyawara seems to reject more than one syllable, if $\mathrm{Ra}$, he is to be paralleled with WD balaRa.

Thus the Central Australian languages of the Arandic Group share a set of rather simliar phonetic innovations, but this does not make them Paman, because thelr corresponding word for man is a form of *badun with a set of phonetic changes peculiar to themselves: *adua. The nearest to this is, in fact, the *aru of Northern K1mberley and bilu-va of Laragla. The CY forms, from a reduplicated *baN, are quite distinct, though 1 t is possible to regard them as based on an abbreviation of $* b a(d u) n$.

Each set of tantalisingly similar innovations is best regarded as developing in 1oco. The resulting language will then have developed further 1nto a set of related languages within 1ts present territory.

In spite of the agreement between $C Y$ languages and the Aranda group as regards types of phonet1c change, the general evidence points to the development of the CY changes locally and at a comparatively recent date. As far as words are concerned, the proportion of CA in the CYPen languages is falrly high, but at the same time the CA words seem to have come into the languages in an already changed form. The evidence for this statement rests in part at least on some unpublished work by L.F. Oates in Murawar1. In the languages of the 'Kana'-group of which this one is typlcal, the CA forms are broken down to the extent that many of them have lost the final consonants, but the inftial losses and other characteristics of CYPen are not present. Compare the following list: 


$\begin{array}{llll}\text { Original } & \text { CYPen } & \text { Murawarl } & \text { English } \\ \text { *guyan } & \text { *guya } & \text { guya } & \text { fish } \\ \text { *gunan } & \text { *guna } & \text { guna } & \text { excrement } \\ \text { *maRan } & \text { *maRa } & \text { maRa } & \text { hand } \\ \text { *miyil } & \text { *miyil } & \text { mi: } & \text { eye } \\ \text { *gaman } & \text { *gama } & \text { gama } & \text { breast } \\ \text { *binan } & \text { *bina } & \text { bina } & \text { ear } \\ \text { *buladj } & \text { *bula } & \text { bula } & \text { two; they two } \\ \text { *minjan } & \text { *minja } & \text { minjan } & \text { what }\end{array}$

Here 1t should be noted that the CY list 1s starred, to represent forms which came into that region and were modifled locally. On the other hand, the last word shows that Murawarl carried the memory at least of a final consonant even though that was changed before being lost in the more northerly languages.

From examples such as these it is natural to conclude that there has been a south to north movement of the vocabulary c1ted, with subsequent 1solation in Cape York and further drastic modification there. These words are all CA; where they occur with equally drastic modification in the Aranda group the latter must be independent parellel changes.

Changes once made cannot be unmade later. It is therefore a more economic conclusion to link the words with CY languages and with the Aranda by the 1dea of two separate departures from the original, rather than a move backwards from CY. Mrs Oates also points to some optional losses of C- In Murawar1, such as (d)anga, to fly, for which there seems to be no CA root. Moreover, Murawarl does admit final consonants, as in milindj, mud. Final consonants are therefore not rejected, and any such loss must have occurred before the $C A$ words in question reached Murawar1, much less CY. Some of the Murawar1 vocabulary is certainly EA, such as da:m(b) 'subsection', which offers 1tself for comparison with Ngarinfin (NK) dambu( $n)$, country, camp, tribal countryalso found in Juwinbara djambu - and in Ngarinjin this word changes noun class according as it is used generally or specifically.

In south eastern Australia it is not so much a matter of sound changes which determine grouplngs. Sound systems are almost monotonously uniform in Victorla and New South Wales. It is a matter of complete lexical differences and, to a degree, also morphological differences 
between languages. This fact is puzzling when the types of sound Innovations within obviously 1solated sets of languages such as those of Central Australia and CY are considered. What is the difference in the history beh1nd each? Do the facts 1mply that the south-eastern languages are not ultimately one at all? Th1s seems to have been so In the Aslan Middle East, and there 1t was no doubt a matter of numerous crossing Invasions.

\subsubsection{The Western Desert (WD) Languages}

In phonological structure these are rather like the Romance as compared with the Germanlc languages: thelr structures are generally much simpler and they sound - as they are - less heavily consonantal than the languages of Victorla and the south-east in general, on the one slde, and the Aranda group on the other. They are three-vowel languages, although of course the normal range of allophones are present, governed by their environments. In most of them it is allowed to commence a word with a vowel, and /a.i.u/ may therefore all be inftial. Syllable structure is VC, CV or CVC, but they are not monosyllab1c, these structures will comblne within the one word. However, the rules of consonant combination within the body of a word - the nature of the phonological word - may be rather strictly governed by a number of rules which cannot be given in detall here. One feature that is pecullar to these languages is that only certain consonants may be wordfinal; any consonant which is not permitted in final position is strengthened by a final syllable -ba. Thus in Bindub1, mangur, three is not permitted, and so becomes mangurba. The CA root dalan, tongue, here becomes dja!inba; thigh is yangalba. It 1s tempting to regard this -ba as not a meaningless syllable, designed simply to make an acceptable word-form, but as the third singular ba, he, she, it, In whlch case the sentence structure would be like that of P1dgin English, man $\mathbf{i}$ kam, the man comes. The difficulty about the explanation 1 s that 1t is not limited to third singular subject position. Hansen and Hansen (1969) quote gandjilj-banma garinu, he put the ribs down; wadi mangur-ba-la galbagadi-gu, we three men climbed; if the explanation is to hold then the pronoun suffix must be regarded as devold of meaning in the modern language and therefore also in 1 ts use. Th1s is possible, but cannot at the moment be put forward as more than a suggestion. The position remains, then, that in WD languages some finals are permitted and others are not. It must also be added that some WD languages do not permit finals at all, or only a final $-n,-1$ or $-r$. The whole system remains as something historically late and highly developed in 1 ts deta1ls. 
Another suggestion that these languages represent a late stage of evolution is the fact that the laminal series (2.4.1. below) is fully developed in them: Dixon's map (1970b:81) shows this fact. They are at once developed and simplified, and this suggests a long period of evolution for the languages. This development will have taken place within the area occupied by the languages at present. Following sections will show that the outliers of the group in north-eastern Arnhem Land have developed again their own peculiarities, and that both differ greatly from the more archaic type of the five-vowel languages of Victoria and the south-east in general. In spite of the vocabulary agreements that will appear between these latter and the Arnhem Land and Northern Kimberley languages (also five-vowel and quite clearly connected with those of the south-east). Even here, too, the Northern Kimberley languages present a somewhat simpler phonetic type than those of the south-east.

The WD languages present a phonetic type sui generis, which could never be confused with those of other areas, whether Cape York, Victoria, Arnhem Land or Central Australia. There is a clear division on this level between Aranda and Waljbiri: Alfawara is a little closer to Walfbiri perhaps, but still noticeably Arandic.

Mention may be made here of the so-called Murngin and Yulngu languages of north-east Arnhem Land. In many points of structure they seem to be an intrusion from Central Australia, and hence can be treated for the present purposes as part of the WD languages. Yet their phonemic structure is peculiar to themselves. They are fivevowel languages, but allow consonant clusters that are difficult to think of in WD languages. Moreover, they have a variety of final consonant clusters which are not part of WD structure. In all this they seem to rest on a non-WD basis, presumably that of Arnhem Land languages which they have displaced or with which they have combined during centuries of coexistence. Moreover, they have developed a second set of plosives, which have already been mentioned.

For general notes on WD phonologies reference may be made to Hansen and Hansen, James Marsh, and Joyce Hudson and Eirlys Richards, all in the same issue of Oceanic Linguistics (8/2, 1969), and for a typical Yulngu language, to Ray Wood (1977). In each case other references will be found in addition.

In a sentence, the WD languages present a type of phonology as different from those of the other languages as are their structures, while the languages of north-east Arnhem Land look quite clearly like 
developments of west Arnhem Land languages under WD Influence, their bas1c structures belng archa1c, but overla1d by more modern forms of speech.

\subsubsection{The Archaic Languages of the South-East and Extreme North}

The title of this subsection in 1 ts wording seems rather to beg the entire question, and this is admitted; but 1 t is hoped to show later that the languages here treated are what the title claims and that vocabulary study will strengthen the connection in due course.

In actual fact, the languages of the Murray Basin, Victoria and coastal New South Wales, which form the group here under Investigation, differ quite a deal in vocabulary from other parts of Australia, and the $\mathrm{CA}$ element has every appearance of belng introduced. Some of the words are found in Arnhem Land and the Northern K1mberley, of ten in varled meanings.

While, of course, all the languages are not provided with 1dentical sound systems, yet they do f1t the general Australian pattern; the real difference lies in the syllable structure rather than in the individual sounds: the northern and southern languages are quite different from the others already mentioned. In what follows, the north is represented by Mawng, of Goulburn Islands, and materlal from Capell and Hinch (1970) is used to 1llustrate the languages.

The consonant system of Mawng is exhibited below:

Table 4: Vowels and Consonants of Mawng, Arnhem Land (From A. Capell and H.E. Hinch, Maung Grammar, Texts and Vocabulary.)

\begin{tabular}{|c|c|c|c|c|c|}
\hline \multirow{6}{*}{$\begin{array}{l}\text { Stops } \\
\text { Nasals } \\
\text { Laterals } \\
\text { Rhotics } \\
\text { Fricatives }\end{array}$} & Bllablal & Alveolar & Retroflex & Palatodental & Velar \\
\hline & b & d & $\underline{d}$ & $d j$ & g \\
\hline & $\mathrm{m}$ & $n$ & ? & $n j$ & D \\
\hline & & 1 & $!$ & & \\
\hline & & $r$ & r & & \\
\hline & $w$ & $\mathbf{R}$ & & j & \\
\hline \multirow{4}{*}{$\begin{array}{l}\text { H1gh } \\
\text { M1d } \\
\text { Low }\end{array}$} & Front & & Central & & Back \\
\hline & $\mathbf{i}$ & \multirow{3}{*}{$\varepsilon$} & & \multirow{3}{*}{0} & \multirow[t]{3}{*}{ u } \\
\hline & & & & & \\
\hline & & & a & & \\
\hline
\end{tabular}


Detalls of the vowel system of the same language follow in the next dlagram, from the same source:

Table 5: Vowels of Mawng on the Phonet1c Level

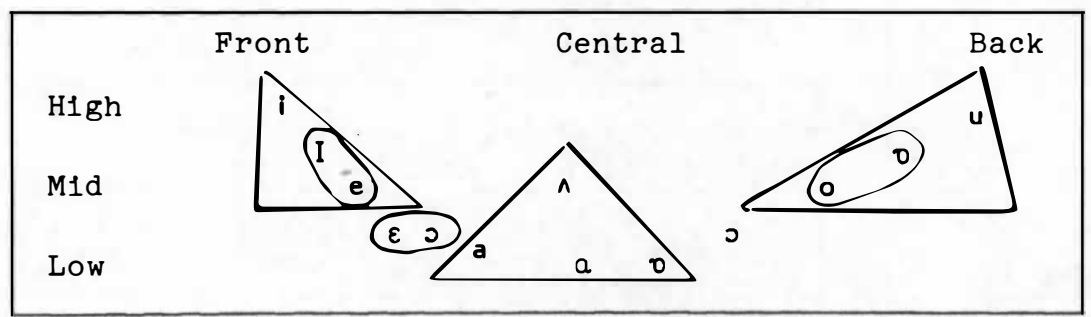

The1r sounds are those of normal Australlan languages in most parts of the continent, plus or minus one or two, princlpally consonants. It is in the consonant clusters, however, that the northern and extreme southern languages differ markedly. The following Table, taken again from the same source, sets out the consonant clusters of Mawng, first the CC and then the CCC clusters. There are conslderable morphophonemic changes when consonants meet in the processes of inflection, and these are to be seen in Capell and H1nch (1970:36). For the present purposes they are 1rrelevant. The possible Mawng clusters are as follows: 
Table 6: Consonant Clusters in Mawng

Word-Medial Consonant Clusters (CC)

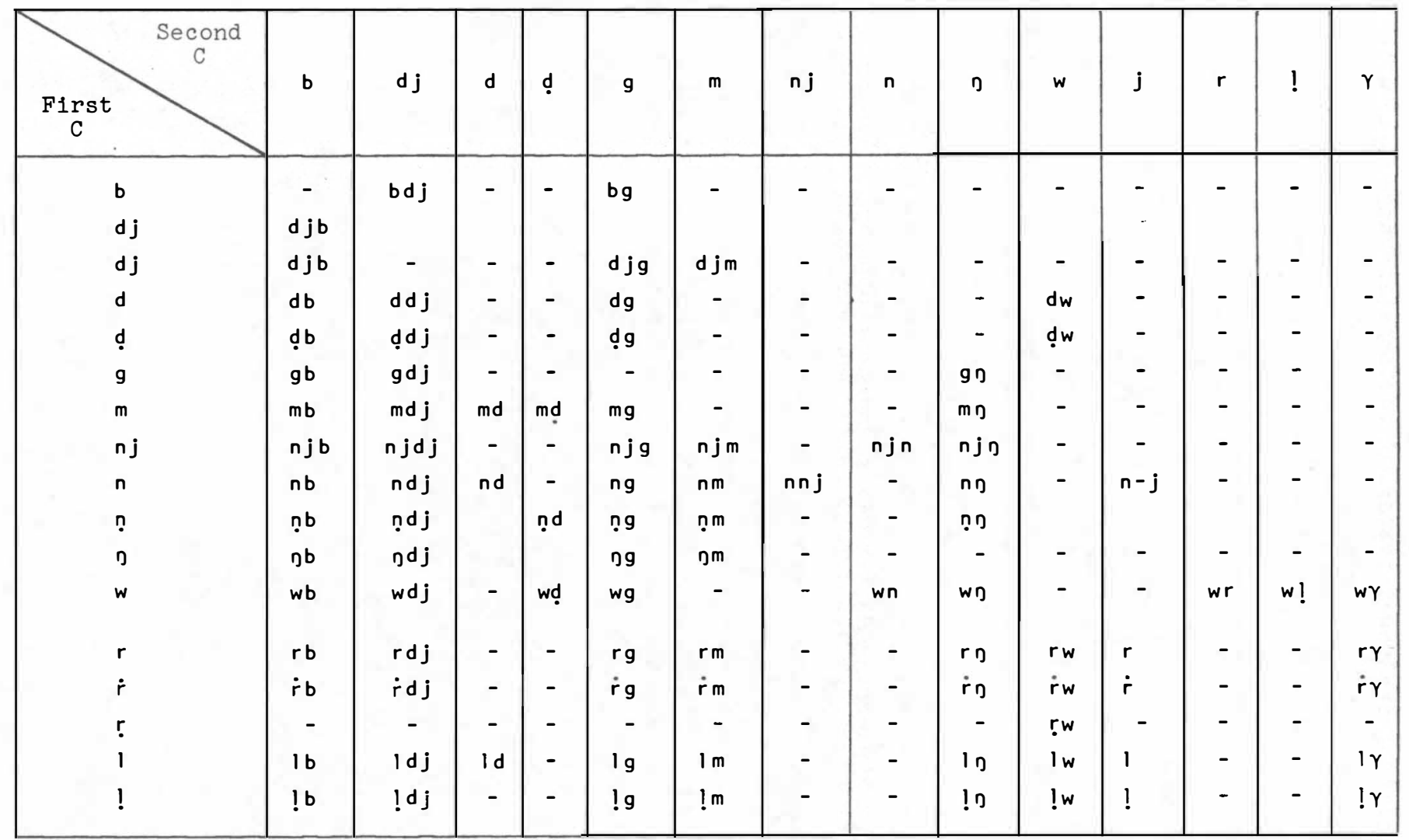


Word-Medlal Consonant Clusters (CCC)

\begin{tabular}{|c|c|c|c|c|c|}
\hline lgb & !gdj & b & - & - & - \\
\hline $\mathrm{lgb}$ & $\operatorname{lgdj}$ & $I n b$ & - & ووا & - \\
\hline igb & $\dot{r g d j}$ & - & - & - & - \\
\hline $\mathrm{rgb}$ & rgdj & - & - & rng & - \\
\hline jgb & - & - & jodj & وص j & - \\
\hline$w g b$ & - & - & wodj & wמg & wndj \\
\hline
\end{tabular}


These clusters differ in complexity and sometimes also in actual shape and content from those allowable in the central parts of the continent, and of course the complex historlcal changes which mark the CY languages have not taken place in these other areas of the continent. Comparison with Victorla and New South Wales can now be instructive, but unfortunately the fact that most of these languages are extinct or almost extinct makes morphophonemic comparison less satisfactory.

The remalning Victorlan languages have been studied by Hercus (1969, 2 vols), and her very careful study of sound systems as they are heard in the surviving languages produces effects highly comparable to those of the far north. Her outline of Wembawemba phonetics reads almost like that of Mawng, except for the less complicated morphophonem1c changes. Of the interdentals only $\underline{d}$ is recorded, not $\underline{n}$ or $\underline{1}$ : this may be modern degradation of richer system. The following are the internal consonant clusters: 1 t will be noted that br- is admitted, but this may be ber- (as In Gwinl of Forrest River, Northern K1mberley): gw- seems to have been a PA combination, e.g. EA *gwijan, fish. It is probably to be regarded as a $g$ with $11 p$-rounding rather than as a combination. Hercus' Table (p. 15) appears as follows and recalls Mawng very clearly: 
Table 7: Combinations of Consonants in Wembawemba

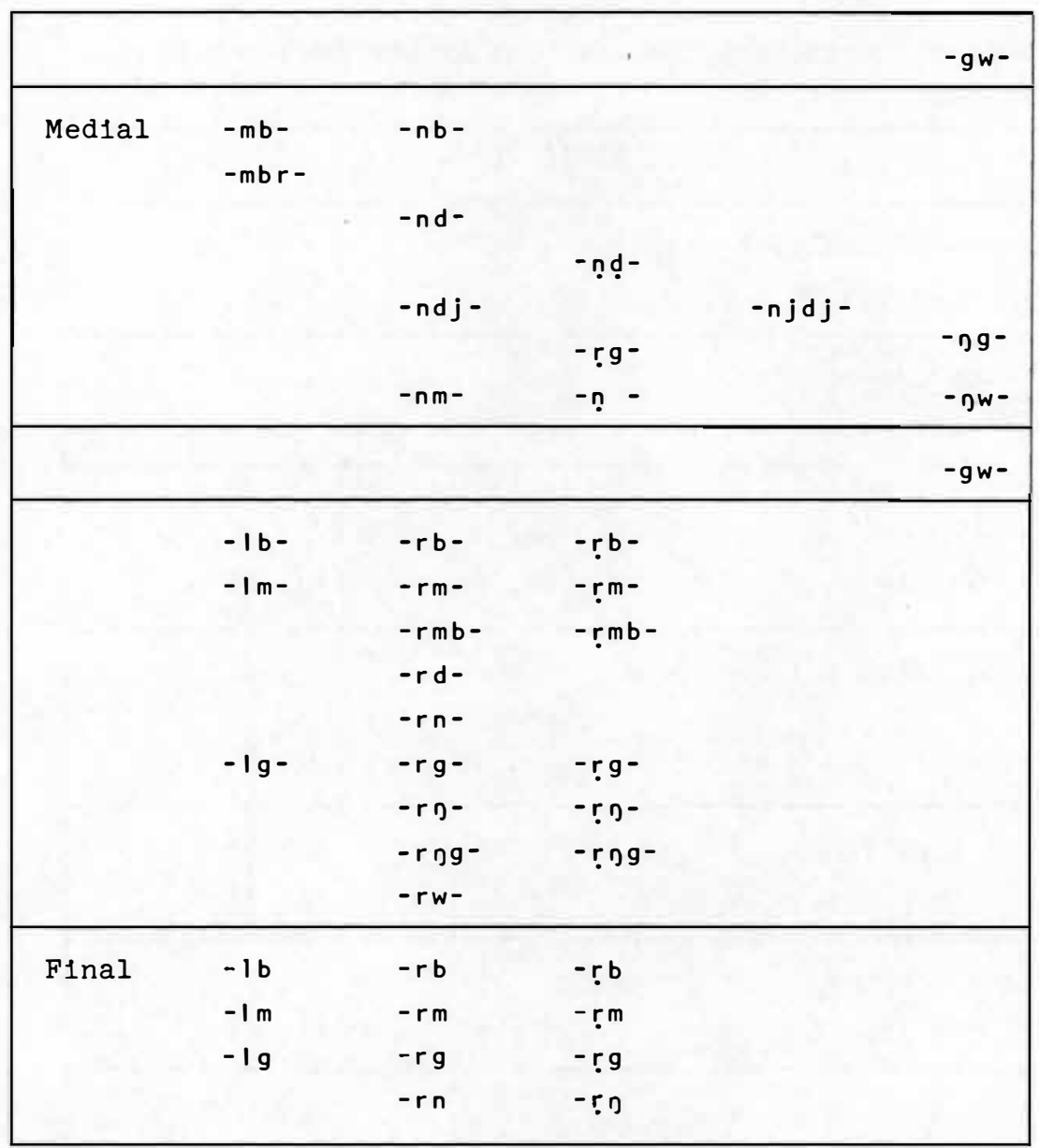

As w1ll appear later, there is a clear line of demarcation between the languages of Gippsland and the rest of V1ctorla, in spite of which Hercus ( $p$. 197) can write: 'Nevertheless, there seem to be some definlte links between the Jaralde group of languages, Jodajoda and Gana1. In grammar Jaralde stands to some extent apart, though there are some resemblances with Jodajoda, such as for Instance the use of a special infunctive or prohibitive particle'. She remarks on the absence of fricatives from Garnay and a special pronunciation of d.

In eastern New South Wales the phonetic evidence 1s largely lacking on account of extinction of languages. Eades in her grammar of Dharawal and Dhurga (Eades 1976:40) after much discussion, produces 
what she regards as likely consonant clusters in the following Table:

Table 8: Consonant Combinations in Dharawal and Dhurga

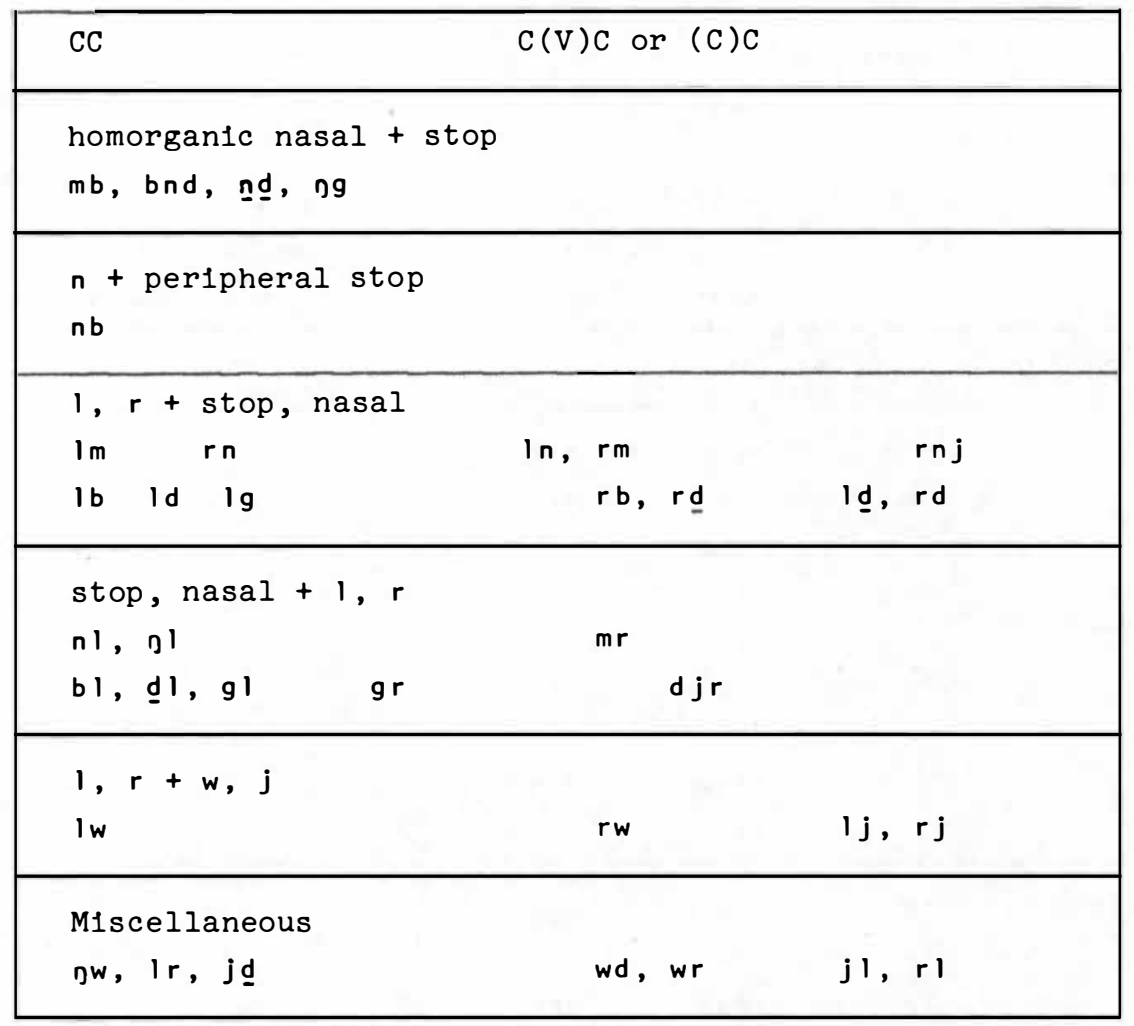

There 1s much in this work that to the present writer 1t seems necessary to reject as incorrect, but the above Table seems to present a possibility for the languages of the south-eastern coast of New South Wales, and here again there is definite resemblance to the more complicated languages of north Australia. If it can be thought that peoples originally related to each other separated at some distant point of time, and whereas some remalned in the north while others finally moved right across the continent, such variation - especially simplification - seems very natural in the linguistic history of the tribes. ${ }^{1}$

${ }^{1}$ Eades rules out CCC on grounds that seem - like much of her book - to the present writer quite uncertain and unsatisfactory. The general style of these languages suggests that CCC may have occurred. 
One consonant exists in Australian languages wh1ch has not been included in the tables nor mentioned hitherto and that is the glottal stop. There are two types of areas of occurrence of this and two different functions. It does not seem to occur inftially anywhere except perhaps (1f O'Grady is right - see O'Grady 1976:61) In Ump1la but it does occur finally in the Yulngu languages and others in Arnhem Land. In the latter group, however, 1t does not occur inftially at all, but only in the final position, and most of ten as syllable final before another consonant. In Ranjbarngu, for instance, the future tense of a verb is formed by means of a repetition of final consonant with a glottal stop interposed, e.g. Dawar?ra, I shall throw it away (Capell 1942:37). The two types of occurrence are obvlously different. In the one case the glottal stop is a phoneme, and occurs as such between vowels in Gandju of Lockhardt River: gu?a:ga, dog, or after a consonant: nal?a, fish. In Arnhem Land there has been much discussion of the function of the glottal stop. It is held to be not a true phoneme, and not to be included in the list of phonemes. In Gandju it seems to replace an earlier * $R$, as in ma? $a$, hand < *maRan but in Arnhem Land (Buwan, Dalabon, Ranjbarngu and the Yulngu languages, as well as Gunwinjgu) there is as yet no final decision as to 1 ts function and place in the languages. Schebeck (1972 and elsewhere) interprets it as a syllable 'accent' Involving a 'glottal rhythm': McKay In an unpublished thesis (1975) treats 1t as a syllablic feature having certain resemblances to the Danish stod and the glottal ending in Finnish. It will not be further discussed here.

\subsection{Historical Phonological Change in Detail}

Th1s section w1ll summarlse chlefly consonantal changes indicated by vocabulary comparisons of present-day languages: how far such changes can be read into the past cannot be defined. The greater t1me depth makes anything like the assurance that accompanies ProtoIndo-European studies unattainable in Australia. In the morphological field it is impossible to restore a feature that has disappeared in al1 the daughter languages of a famlly - the well-known loss of the inflected Latin future in all the Romance languages is a case in point, for if Latin were unknown such a formation could never be guessed. So there may well have been both morphological and phonological changes in Australia that can never be rediscovered. What is offered here is therefore controvertible and no defence can be made.

Three positions of a consonant must be accounted for: initial, medial and final. The occurrence of $-C$ and 1 ts nature 1 s at present 
language-limited and may always have been so. Hence there w1ll be only incidental discussion of this position. The most important example is the occurrence of final $-\eta$ wh1ch is generally retalned where at least one language shows 1t, and in some cases where none do. In many instances it has been lost because most modern languages reject all final consonants or allow only a limited set. Final-dj is rare, but is still found in some areas: *buladj, two, is a clear EA example occurring only in south eastern Australla - elsewhere $1 t$ is always bula, and such a root would have been restored except for the south eastern languages. But there is no reason to suggest that *buladj is a later form in south eastern Australia, for 1t would be unmotivated. Similarly, the pronoun Individuailsing suffix -wa appears as -wadj in Nuggubuyu, but *-badj is taken to be the original form of 1t. The fact that $1 t$ is added to an ergative form (na-ju-) only indicates that in the given language the pronoun *gaju, $I$, was recelved 'ready made' in an ergative form, without ergative meaning necessarily following. It may even be desirable to write this -wa as a separate enclitic word. See further in 3.3.3.

Few examples of the changes postulated here will be presented in the text: they belong to the vocabulary. As for vowel changes, it would seem that Australla is a place where one may indeed look after the consonants and leave the vowels largely to look after themselves: in short, the history of vowel change in Australla remains much less complete than that of consonants and does not seem to be so regular.

\subsubsection{Consonants}

From what has been sald already, the Australian consonantal system 1s to be traced chlefly from EA: what differences there are to be accounted from CA must st1ll be worked out. The consonantal alphabet assigned to EA here lacks the subdivisions of the laminal serles and a number of other later developments as already indicated.

In the following pages, just a few of the more obvious consonant changes between languages in Australla are dealt with: 1t is impossible to do more within the limits avallable. Where a large number of languages are involved and a conslderable time-depth which is undocumented, only general indications can be given. A fuller study would belong to the lexicon of an Australian H1storlcal Dictionary, which is beyond the possibility of compllation at this stage.

All this being granted, a brlef survey of a few outstanding facts is all that can be given - and even then consonant change is easier to deal with than vowel change. Not all consonants are 1llustrated here. 


\section{CONSONANTS}

\section{(a) Plosives:}

$/ b /$. Examples occur of $b$ - kept; or changed to $w$ or $g$ or $m$ or lost entirely. Final -b can also become - $m$ in Victorla, as W. Bungandidj gedubgedub, boomerang; N.W. gadimgadim. ${ }^{1}$

Medial -b- may have another origin. The NK has a root *malara, forehead; Laragiya madbarma $=\star_{m a+m}(a) l a r(a)+m a$, the same root with the $\mathrm{Cl.V}$ marker ma prefixed and suffixed simultaneously. Reduction of $1+r$ has then produced $d+b$, a not uncommon combination in this area.

(b) Laminals:

Sounds classed as laminals may be elther stops or nasals. In Australla the sets usually found are:

\begin{tabular}{|c|c|}
\hline dental & alveolar \\
\hline$\underline{\mathbf{d}}$ & dj \\
$\underline{\mathbf{n}}$ & $\underline{\mathbf{n j}}$ \\
\hline
\end{tabular}

In Australian languages these interact very largely with the apical series:

\begin{tabular}{|c|c|}
\hline dental & domal \\
\hline d & $d$ \\
\hline
\end{tabular}

Th1s may then produce four serles of stops and nasals:

\begin{tabular}{|c|c|c|c|}
\hline \multicolumn{2}{|c|}{ lamino- } & \multicolumn{2}{c|}{ ap1co- } \\
\hline dental & alveolar & dental & domal \\
\hline $\mathbf{d}$ & $\mathbf{d j}$ & $\mathbf{d}$ & $\mathbf{d}$ \\
$\mathbf{n}$ & $\mathbf{n j}$ & $\mathbf{n}$ & $\mathbf{n}$ \\
\hline
\end{tabular}

${ }^{1}$ Apart from the fact that this is a reduplication and that nothing is known of *gedub or *gadim as a simple root, it is difficult to say which was the earlier; but occurrences in other parts of Australia suggest that plosive to nasal is the commoner change. 
Interchanges within these sets have been studied in detall by Dixon (1970b). There 1s usually laminal contrast within a language, and Dixon's summary is as follows: (1) domal (retroflexed) consonants are missing over a considerable area of the north-east; (11) some languages have only one laminal serles, and in this case the major allophone is usually palatal. Phonetic detall given by Dixon is 1rrelevant from the viewpolnt of historical linguistics, as there is no intention here of trying to trace out detalls of possible development in the languages. He then concludes that four types of stopnasal system are found in Australia:

1. With retroflexes and two laminal series

$$
\begin{array}{llllll}
b & d & d j & d & d & g \\
m & n & n j & n & \underline{n} & 0
\end{array}
$$

2. With two laminal series but no retroflex

$$
\begin{array}{lllll}
b & d & d j & d & g \\
m & \underline{n} & n j & n & n
\end{array}
$$

3. With retroflexes but only one laminal series

$$
\begin{array}{lllll}
b & d & d & d j & g \\
m & n & n & n j & 0
\end{array}
$$

4. Without retroflexes but with only one laminal serles

$$
\begin{array}{llll}
b & d j & d & g \\
m & n j & n & n
\end{array}
$$

The distribution of these types is shown in D1xon's map (1970b:81) and It 1 s so 1rregular that there can be no doubt that all the variations from the (4) system have been developed locally and presumably at different stages. For the local historles of language groups the historical order of these developments may well be 1mportant, in fact cruclal, but for the establishment of original Australian series there can be no question: early Australian languages did not have elther the lamino-dental (Interdental) nor the laminopalatal/alveolar (palatal) serles of elther stops or nasals. Dixon's conclusion about the reasons for the developments and the processes of them have been mentioned earlier.

In dealing with sound changes within this serles, therefore, it will be taken that there 1 s one dent1-alveolar set to be considered, and 
this will be 1ndicated here by /ḍ/. The changes found in the modern languages are the following, taking as examples the root *badun, man, for those languages in which the root occurs:

d-kept: Lurldja (badu); WD generally (wadi). Th1s is independently of the phonetic realisation as advanced to interdental or backed to palatal. The retroflex realisation is found In Bldjara (mạ̣i), Ungguml (ạ̣i), Aranda group (ậya < badun + a).

$d->/ r /$ flapped: Central Queensland (mari). It should be noted that in Arnhem Land there is also a true retroflexed flap ( $r$ ) as in the clan name Mararba in the N.E. AL dialects. In NK there is aRu, man in Ngarinjin, which is to be distinguished from the flapped $r$ in aru, snake.

-d- > - w- seems possible in the same root *badun allowing the acceptance of Ngarimawuru (Yodayoda) bawu, Bangeranj bawa. That the realisation is acceptable is suggested by languages of the Upper Murray region whlch show bawan < *badun.

(c) Velars:

g- raises some problems in certain languages. As a rule it seems to be very stable. Roots *gamba, burn, cook, and *gumbu, urine are found widely over Australla and almost always with the inftial consonant kept. Inftlal $g$ - is lost only in the Aranda group and Cape York. In the former, Andegerebina mbwa = (u)mb-u, urine < *gumbu, with the additional final -a that is found also in Aranda group adya, man < *badur, and the mutation of the first vowel is found also In some CY languages. Similarly, from *gunan, excrement, Bularnu gudna, Bldabida guna. The root *gamba is very tenaclous, yet again Aranda mba-. In the case of the root *guyan, fish, $g$ - never disappears, but it is doubtful whether the root 1tself is *guyan or gwiyan. In terms of distribution elther seems possible.

(d) Nasals:

The nasals also are generally preserved, especially as initials. As internals they are not quite so invariable, and as finals, often refected: 1t depends on whether the language allows final consonants, and if so, whether these include nasals. In general some languages that keep final nasals do not allow non-nasal terminals. It is characterist1c of the WD languages that they allow final /-n/ but not $/-\eta /$. Where final /-nj/ is found, this may replace original/-n/. Individual nasals call for specific definition. 
/m/ appears to be extremely stable. Such roots as *naman, breast, or *maRan, hand, and the probably related *ma-, take, retain initial $m$ - even in CY and Aranda languages.

\subsubsection{The Puzzle of Root Establishment}

In many instances such rules for sound development as are given in the preceding sections do not seem to work, and this means e1ther that there are mistakes in the formulation or cross-influences in the application. There is frequently much difficulty in establishing a consistent orlginal form for a word. Of course the length of time involved and the lack of historical information may help to account for these difficulties. In Australian languages in particular there are many cases in which elther the inftial or the final consonant seems to be doubtful. In Sommer's list, based on Hale (Sommer 1969) the device of Indicating a doubtful consonant by the use of $\mathrm{C}-$, meaning some undefined consonant, is used and gives recognition to the difficulty. In such a case it can be taken that the true original consonant is elusive. The given materlal presents varlants that do not seem to sult any regular pattern of sound change that might be expected. One is sometimes constrained not to accept an instance because it does not fit expectation.

The expectation that underlies restoration is that EA is older than $\mathrm{CA}$, and that the former is chlefly eastern, while the latter is basically a western form of an orlginal language. This subject is discussed principally in section 6 , but cannot be avolded at certain earlier stages. Judging by the general fact that final consonants, especlally - $n$ need to be posited in EA but apparently did not occur in the CA stage, CA appears to be a later form of the same basic language as EA, but combined with elements of other origins. This statement rests not only on the study of Kroeber's maps (Kroeber 1923) but also on the mapping out of parts of Curr, volume IV, kindly done for the present writer by $\mathrm{Mr}$ Peter Newton, an honours student at Macquarle Unlversity, New South Wales. In some cases there 1s little or no common material at all to be plcked out of Curr's lists, which consist of 63 words in 196 languages avallable at the time of his writing: allowance has to be made for inadequate phonology, but that can be done.

One such example is provided by a word for mouth, which is presumably da- often plus a second syllable whlch varles from area to area. It is found in Queensland and parts of Victorla, and in the south-west of the continent (which often has these prevalingly 
eastern words; even such a word as *bura, kangaroo, wh1ch appears largely in Queensland, has cognates in the south-west).

An instance of what is being discussed is provided by the word for eye, which was established by Capell as EA *mirin. It could be *milin, but at the moment 1 t 1 s the inftial, not the medial consonant which is critical. In Queensland the word is widely dili. A change of $\mathrm{m}$ - to d- Is unacceptable, because as a rule a peripheral consonant does not interchange with a central consonant. But 1t is hard to say more than 'as a rule' at the present stage. Moreover, there are instances found which polnt to *mijilin as a possible original, but this is a different question. The change of *badun, man to mari in Queensland is acceptable because 1t is only nasalisation of a perlpheral consonant, but *dili( $(0)$ Involves a different principle of change. At the same time the occurrence of two such similar forms with the same meaning is not impossible: this is what is meant by the heading 'The Puzzle of Root Establishment'. Words for egg present a similar and more complicated problem. Capell restored $1 \mathrm{t}$ for $\mathrm{CA}$ as *gambu( $(\mathrm{)})$. The following, however, all appear to be forms of the same root: Walmadjarl gambinj, Baljgu djambu, Mandj1ldjara nambu ( $a l l$ WD and therefore presumably CA forms) found in CY as *gambu (Sommer 1969, after Hale). But the following also would seem to be forms of 1t: ba:m (Gab1gab1), bambu (Jandruwanda), babu (Arabana), gabu (Waljwan), gabu-ga (northern Wiradjur1), bambu (Dj1rbal and Bldab1da), Murawarl gabun preserving the final consonant, so that although *gambun, the initial consonant remains completely uncertain and one is constrained to posit *cambun, the c-1ndicating an uncertain consonant. There are quite a number of these in Hale's restorations for Cape York, but they are not sat1sfactory. Even then there is a remainder including maga (Gaurna, Narangga) which does not seem to belong, and in western coast areas of Western Australia wala which seems even less sultable as a derivative. What then 1 s the final establishment in such a case? Local endings also may be added: Wiradjurl gaba-ga contalns the same suffix found frequently in Ngunawal as -gan, as in Ngunawal miri-gan, dog (*miri widely in this region), and even found in pronouns such as Dharawal ga-ja-gan, $I$, where it is superadded to the ergative ending - ja.

Roots for water present even greater varlety, and 1t is interesting that Kroeber thought the foliowing might all finally represent one root, water belng such a universal necessity, especially to early man, that a single root for $1 t$ is concelvable. Kroeber gives the following list: 
1. gada, gala, gana, kun, gon, galan, gadinl, gadja, gwadja - found in the north and centre, western V1ctorla, Inland New South Wales and south coastal Queensland.

2. gama, gamu, gomo, gam, gumum, mostly in central and western Queensland.

3. gaba, gabi, gawi, gawara - WD, south-western Austral1a, Adela1de area.

4. Daba, naba, nogo, nogo, mugu - western New South Wales, south-western Queensland and north-eastern South Australia.

5. nadjun - New South Wales south-east coast.

6. baba north-west Western Australia, Including Ngayarda areas.

7. baro, bari - southern V1ctorla, southern Cape York.

8. wara - G1ppsland.

These seem to be too varled to be covered by any processes of change, yet almost any two of them can be plctured as arising from each other, given time and lack of communication. Nevertheless, no one theoretical orlginal seems to be constructable, to cover all the presumed developments. The case must rest at present undecided.

A further point may be mentioned here: most established roots are bisyllabic, but a few such as ima, take, seem everywhere to be monosyllab1c. Th1s could belong to *maRan, hand, but there is no noun corresponding to *ga, hold, so again no decision can as yet be made. A few other roots can perhaps be trisyllablc: *mir/l/in, eye appears In some areas in a form that would presuppose $\star_{m} i j i l i n$ : for $C Y$ languages *mijil is suggested. Th1s, too, must be 'held over' pending further study, and there are no doubt more than one other 'puzzle' of establishment.

\section{STRUCTURE OF AUSTRALIAN LANGUAGES}

\subsection{Establishing Historical Stages}

In this study, the unusual step has been taken of beginning an inquiry into Australian linguistic history with the pronoun and the pronominal system in general. The reason for this lies in the fact that pronominal roots as a rule belong to the oldest stratum in a 
language. For Australla - as quite generally - this statement applies to the first and second person and, for speclal reasons, to the singular number and, apparently, the first person dual inclusive. In Australia, as in many other areas, the third person markers are not true pronouns but demonstratives and, in many cases, they express the relative position of the person or object referred to in regard to the position of the speaker. At the same time, there is often the difficulty that the pronoun, being so frequently in use, changes historically more than the noun and is therefore harder to use as historical evidence. It becomes abraded and more subject to 1rregular1ty, like the verb 'to be' in Indo-European languages. In the present instance, these factors are not so welghty, for the emphasis will be on the differences in princlple between the pronominal systems rather than difference in morphological forms. Syntact1c differences will enter only in regard to the part played by ergativity in Australian languages, and that is something which is more general than particular.

The 1mportance of a study of the pronouns was realised especially by W. Schmldt when he wrote Die Personalpronomina (Schmidt 1919b); but detalled as that study was, 1t lacked 1mportant elements because the languages were not as well known in 1919 as they are today - some of the most important facts had yet to be discovered. One of these and the beginning of the present study - Is the fact that not all Australian languages contain true pronouns. In a few languages, 'pronouns' are baslcally nouns and are treated as such in the grammar. Person 1s marked by the addition of a personal suffix, plus or minus a case marker, to a noun stem whose original meaning is not usually now to be discovered. It was probably self, body or some such more concrete meaning. It is sometimes difficult to recognise such an orlgin. An instance is found in south-eastern Papua, where certa1n of the languages have pronouns based on an Austronesian root *awak, body (Capell 1943:2l0ff.). Moreover, 1t is at least doubtful whether EA distinguished number in pronouns, and the distinction between inclusion and exclusion of the person spoken to is not universal in Australia even now. The facts that are to be demonstrated in this section of the work are that

(a) the earliest pronouns were derivatives of noun roots;

(b) number was not part of the early pronominal system; and

(c) the inclusive-exclusive distinction was not original. These facts are all of 1mportance in the linguistic history of Australla. 


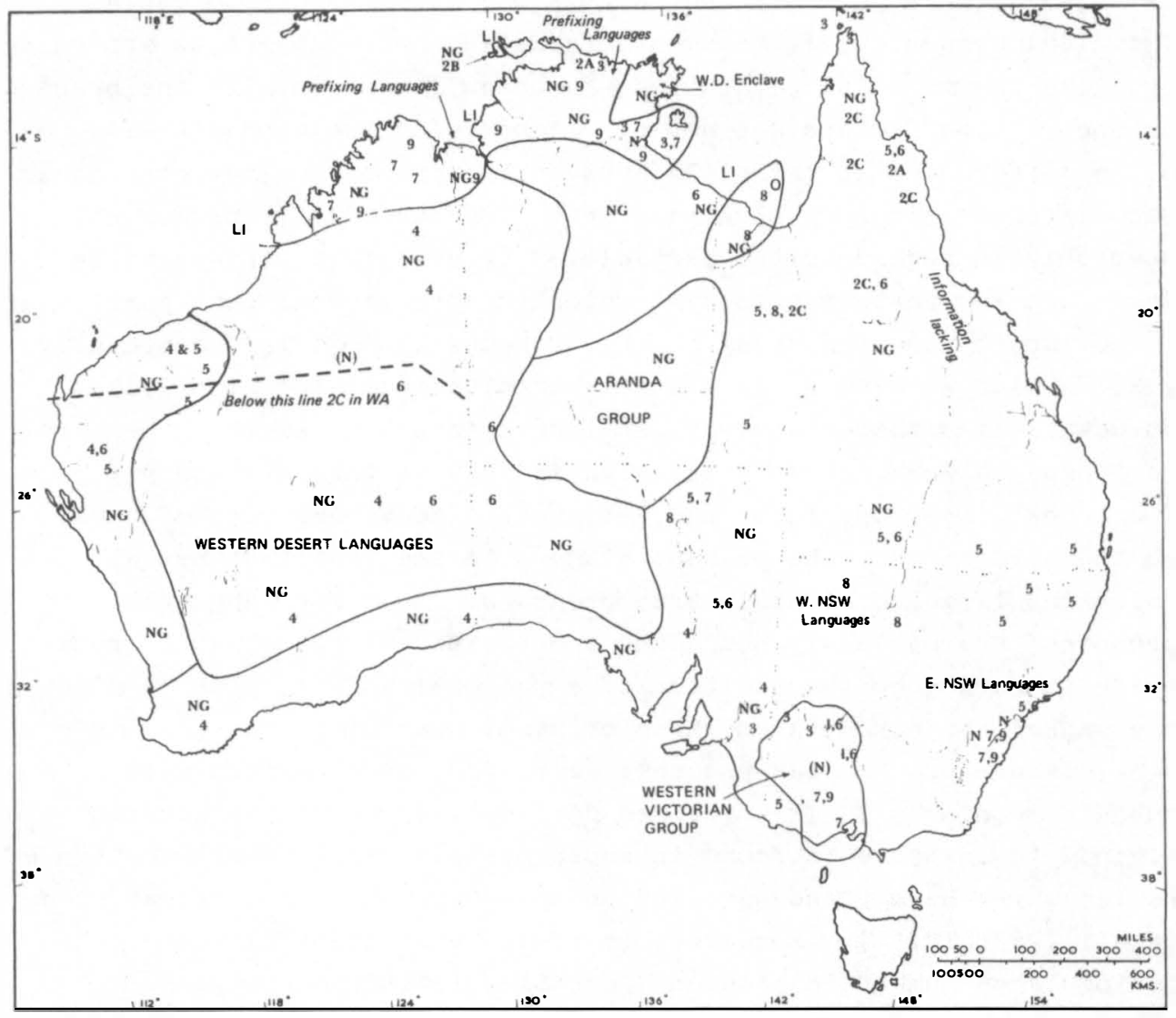

Map 2: Distribution of Pronoun Forms in Australia 
LEGEND TO MAP 2:

DISTRIBUTION OF PRONOUN FORMS IN AUSTRALIA

Maln distinction: LI Language 1solates

$\mathrm{N}$ Nominal basis of pronoun root

NG Common series na-/njin-

The NG sets are borrowed into LI languages, and numbers placed Inside LI areas therefore refer to the same facts as they would in NG areas. The NG sets are subdivisible as follows:

1. Simple forms.

2. Incomplete sets: $2 a$ No dual forms.

$2 \mathrm{~b}$ lst dual inclusive nali $\mathrm{i}$ you and $I$ but no other dual persons.

2c No Inclusive-exclusive distinction in dual or plural.

3. Suffix *-badj added to nominat1ve or ergative base (not distinguished here).

4. Third person singular based on *ba: in some languages other numbers are also so based or instead of singular.

5. Third person singular based on *nu.

6. Third person plural based on *dana.

7. A trial number is present.

8. Tense is marked in pronoun as well as in verb.

9. Syntactic combination of subject and object. 
A similar development, or perhaps combination of originally disparate sources of the languages, is to be seen in the verbal system of EA languages: If there was no inclusive-exclusive distinction in the pronoun, nelther was there (nor is there yet in some cases) any such distinction in the verb. Moreover, the verb did not originally mark person, and some st1ll do not. It would seem also that number marking came before person marking. Th1s is in keeping with the general fact that in Australia there has been continual complication rather than simplification in both phonology and grammar, unlike developments in some other parts of the world (see Taul1 1958).

This complication of verbal structure in Australia can be seen in remarks made by Capell (1972:8-10) on the three types of verb, although there is no parallel mention of pronouns in that paper. Moreover, these different formations are geographically scattered at the present day: verb uninflected for person and number is found in coastal New South Wales (Gadhang), the Lakes districts of South Australla (D1yar1) and numerous other areas. Number without person Indication 1s found in Central Australia (Aranda) and may be a local development; number and person differentiation is the commonest type in modern times. The special feature of the $W D$ and some other languages that has been called 'Affix Transference' (AT), must also be studied and that too has historical significance.

\subsection{Languages Lacking True Pronouns}

The phrase 'true pronouns' 1 s used in the sense of words that serve no other lexical purpose than to indicate speaker or person addressed. They are formed from a common base by the addition of suffixes marking person; these sometimes, but not necessarily, are used also to mark possession with nouns and person with verbs. Such roots can rightly be regarded as nouns, even though their orlginal meaning is not known.

The first example is that of Ngunawal, New South Wales, a language spoken in the district now occupled by the c1ty of Goulburn, and 1ts northern nelghbour Gandangara. These are listed amongst Schm1dt's Yu1n languages, spec1f1cally northern Yu1n, and Kurl respect1vely. In this language, $I$ is gula-nga, you is gula-ndji. The root *gulan, skin, has already been given in section 2 as an EA word for skin; 1t has conslderable spread, from Arnhem Land across Central Australia and Into Victorla and New South Wales, as well as to parts of Cape York Peninsula. It seems to be a typlcal word of the 'central stream'. In some languages it is also the bark of a tree, and in Yidinf 
the human body. The root varles between *gulan and *julan. In Ngunawal and Gandangara 1 t has been narrowed down to become the Index of personality, 1.e. a noun stem carrying possessive markers to indicate the referent. Schmldt (1919a:101) also points out that in northern Kurl languages the differentiation of Inclusive and exclusive in dual and plural is not found, and suggests that R.H. Mathews Included 1t by Induction without evidence in Darginfung - this may or may not be true.

The full set of pronouns in Ngunawal stands as follows:

\begin{tabular}{|l|l|l|c|}
\hline Person & Singular & Dual & Plural \\
\hline 1. Incl. & - & gula-na & gula-n-banji \\
1. excl. & gula-gga & gula-galu & gula-m-banji-li \\
2. excl. & gula-n-dji & gula-m-bu & gula-ngu \\
3. excl. & dana & dana-djula & dana-djimalinj \\
\hline
\end{tabular}

It will be seen that this set includes both dual and plural number and the inclusive-exclusive distinction. This development will only have taken place in eastern Australia, for the CA languages occurring In the central and western parts of Australla wlll show cases in which inclusive-exclusive distinction 1s lacking, and in which we two is I-two, using for two not the EA root *buladj but the CA *gudara. It was method, not form, whlch the CA languages copled at a later date. The bulk of the development must therefore be sought in eastern Australla and in those parts of the west in which CA Influence is least.

The Ngunawal pronouns of the third person are also of interest. As is so common in Australia, only the first and second persons rest on a truly pronominal base - and even these do not always do so, as is apparent in the Warnman and Ngunawal examples - whereas the third persons are mostly demonstratives, usable with or in place of nouns. The special point of interest is that the root *dana is an EA root meaning they, which is usually limited to third person plural. Here it has been used as a third person without reference to number; 1t becomes a singular, to which dual or plural indicators are attached. Th1s again polnts to an earlier lack of discrimination of number.

The above type of construction is found also in western Victoria as well as in New South Wales. In a considerable area of western V1ctorla 
such pronounless languages are found, Including Djadjala, DJabwaru, Dagwuru and some others. Here the systems are simllar: a noun base with a possessive suffix is presumed; however, the noun is not a common noun such as *gulan, skin but varles from language to language, and the whole system is more involved. The following set shows the pronominal forms of Djadjala:

\begin{tabular}{|c|c|c|c|}
\hline \multicolumn{2}{|c|}{ Person } & Verb Markers & Non-verb Markers ${ }^{1}$ \\
\hline \multirow[t]{4}{*}{ Sing. } & 1. Incl. & - & - \\
\hline & 1. excl. & $-n$ & $-\mathbf{e g}$ \\
\hline & 2. excl. & $-r$ & $-i n$ \\
\hline & 3. excl. & $-\phi$ & $-a g$ \\
\hline \multirow[t]{4}{*}{ Dual } & 1. Incl. & $-(n)$ al & $-(0)$ al \\
\hline & 1. excl. & - nalan & $-(n)$ a lag \\
\hline & 2. excl. & -wul & -wula \\
\hline & 3. excl. & -bulan & -wulan \\
\hline
\end{tabular}

At this stage in the development of Australian languages therefore we find a lack of true pronominal forms. They are replaced by noun roots wh1ch have person reference added as suffixes. These references are made to first and second person only. The question of an inclusive-exclusive distinction is not discussed at this point for, in all the instances given here, such a distinction is elther secondary or lacklng. This would seem to be the remalns of a very early stage of the languages. The varlety of the forms given suggests that a pattern was present but not such common roots as would suggest a common protolanguage. It is therefore likely that Australla will provide, not a proto-language, but rather a serles of coeval but unconnected serles of EA languages.

Moreover, even a dual number is not universal: T1w1 and Dampler Land present only first dual inclusive, you and $I$, though in Dampler Land later forms completing the dual have been involved. With these thoughts

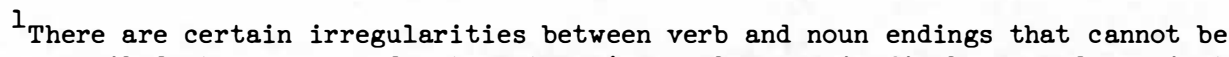
reconciled: they may be due to Mathews' examples, as in final -an and -ag in the dual, and -wul, -wula, -bulan and possibly -bulag in the third dual. These are left unaltered: there is no call for final definition here. See Mathews 1902:71ff. 
In mind, therefore, it is possible to consider some of the other identified non-CA groups of languages. As O'Grady suggests in this volume, it is almost certainly the fact that many early forms of language in Australia have perished without a trace except perhaps in odd words which it is no longer possible to identify as such inheritances. To these are added another set of suffixes covering trial and plural numbers (Mathews 1902:79ff.). Such markers are added directly to the verb, whereas the non-verbs to which they apply are nouns, possessives and object pronouns. The pronominal root is jurw- > jurw-eg, I, jur-win, you etc.; the possessive jurw-an-eg, mine; jurw-an-in, yours, and the objects njan-eg, me, njan-in, you. In all these, the independent pronoun based on jurw- is something quite different from the normal Australian pronoun, but parallel to Warnman bara-.

An example of a language in which a similar system is used but with another root is Djabwuru ban-eg, I, and Dagwuru wa-n, I, probably belongs here also: the EA root *baN, person has already been discussed in the preceding section. In DJabwuru ban- takes the noun person suffixes ban-eg, ban-in, ban-ug, etc., but in Dagwuru wa-, which could be the same root, takes the verbal set, and the third person is given by another root munji. In none of the languages is gender involved in the third person. The set of forms in Dagwuru is as follows:

\begin{tabular}{|l|c|l|c|}
\hline Person & Singular & Dual & Plural \\
\hline l. Incl. & - & way-al & wa-gaganjin \\
l. excl. & wa-n & wa-gan & wa-ganjinju \\
2. excl. & wa-r & wa-bu:l & wa-dgurabil \\
3. excl. & munji & munjibulabil & munji-gadan \\
\hline
\end{tabular}

It should be added that there is also a trial number, formed by the addition of *-galig of which there is discussion elsewhere (3.4). Such a trial is almost limited to western Victoria although there are a few examples in the far north and north-west of the continent, in the regions that usually show kinship to this south-eastern part of Australia. The trial marker is usually the final element of the compound: Djadjala jurwe-nura-galig and Djabwuru ba-nadu-galig, we (incl) three; the corresponding plurals are Djadjala jurwe-nur-ag and Djabwuru ba-nadu-ag. The trial is thus not really a pronominal 
formation, and *galig is simply 'a related group, small in number'. The absence of pronouns ( 1 the above sense) is not limited to eastern Australia; this is a fact that suggests the existence of an early stage of Australian language (perhaps $\mathrm{EA}_{1}$ ). The example to be called is Warman, a language geographically on the northern fringe of the Western Desert. Here the noun root is bara-, wh1ch serves in the first person singular for $I$, but carries suffixes for other persons and numbers:

\begin{tabular}{|c|l|c|c|}
\hline Person & Singular & Dual & Plural \\
\hline 1. & bara & bara gudjara & bara waḍa \\
2. & bara-ngu & bara-ggu gudjara & bara-ggu waḍa \\
\hline
\end{tabular}

There is no third person - a demonstrative balawanin 1s used, with dual balawanin gudjara, and plural balawanin wada. Although, in the present state of knowledge, it is 1mpossible to assign a meaning to bara, the construction by means of number markers, avallable also for other uses, is quite clear.

The bulk of Warnman grammar, however, has been 'taken over' completely by W.D. forms and grammatical elements - in fact it has been swamped by them. On the other hand, Warnman vocabulary stands quite apart from WD vocabulary except for a limlted number of loanwords, examples can be seen in O'Grady 1956. Th1s is clearly an example of an 'early' language which has almost given way before more influential later comers, as British gave way before Anglo-Saxon, and the western Celtic Manx has done and Gaelic is dolng before English. So in Warnman we see the process of domination by a language of another type. In passing, the absence of a bara- third person corresponds to absence of a third person in the other early Australian languages. More will be sald of th1s when the na-/njin $\left(E A_{2}\right)$ base language is treated infra.

\subsection{Other Non-CA Groups of Languages}

Unt1l a language-by-language analysis is made, it is 1mpossible to say just what Australian languages are EA, or to 1dentify any level of EA - which is ultimately a matter of lexicon - but some pronoun systems can probably be diagnost1c, especlally those in Arnhem Land. Mention must be made of certain groups which obviously do not fit the patterns of $\mathrm{EA}$ or $\mathrm{CA}$; these include the languages of the Daly River (DR) region, 
those of Bathurst and Melville Islands (BM), and probably others which can only be worked out later, but certainly not in the present space.

\subsubsection{Languages of the Daly River Area}

The standard study of these at present is that of D.T. Tryon (1974), from which the materlal and some of the general remarks here are taken. Certain features may be listed whlch serve to establish the DR languages as a group in their own right.

Pronoun systems are quite different from those of the EA languages just discussed. For Instance, those of Marldhiel can be shown as follows:

\begin{tabular}{|c|c|c|c|}
\hline Person & Singular & Dual & Plural \\
\hline 1. Incl. & & Dangi & nanginim \\
\hline 1. excl. & jigin & & gaḍ $i$ \\
\hline 2. excl. & nanj & plural & $\operatorname{nad} i$ \\
\hline 3. excl. masc./fem. & nan & bini & wad $i$ \\
\hline
\end{tabular}

Here there are certalnly strange forms, compared with those hitherto quoted, and quite distinct again from the set quoted as EAl. The existence of a set of plural pronouns is noticeable, as is the fact that there is a first person dual inclusive but, if other duals are required, they are bullt from the plural - making this earlier in time - by the addition of a dualiser (bini) which is quite different from the numeral two (djidjiguni). Although the language has noun classification, there is only one third person pronoun, and the plural non-first person carries a marker -di. Tryon (1974:296) remarks: 'There are exceptions, notably in the Tyemerl group, where separate plural and dual forms exist in all persons. In this case also, it does appear that the dual serles is derivable from the plural. Marengar is the only language within the Daly family which has truly separate dual and plural forms for all persons'.

At least, therefore, the 'Brinken' group is something apart from the others, even within this limited region. It would appear also that the occurrence of only one dual pronoun - first inclusive - marks the BM group also, and seems at least a likely situation in the 
Dampier Land languages (3.3.3.). Yet in spite of all this, there appear to be EA forms in the direct object pronoun suffixes (Tryon 1974). These, however, are phrase-final suffixes in VP, where the plural nanginim can be broken up into nangi-nim, and the dualiser -bini superadded, as in Maridhiel:

$$
\begin{aligned}
& \text { kirinki- - }- \text {-tim-pini-ya tyuwunanan } \\
& \text { we/excl/hands-him-bury-dual-past yesterday } \\
& \text { We two buried him yesterday. }
\end{aligned}
$$

(Tryon 1974:77). This is in some ways comparable with Tiwi usages, but not with that of the rest of Australia.

Amongst the pronominals, there are five different dualisers, having no agreement among themselves or with EA or CA. Verbal systems in these languages have very little in common with the rest of Australia, but seem to be sui generis. See the paper in this volume on verb classification in Australia. As remarked above, these languages are also noun-classifying, but again their systems differ widely from those of other north Australian languages: see the corresponding paper on this subject, and Tryon (1970).

On the level of vocabulary also there is wide divergence from the rest of Australia, to a degree that still awaits analysis.

In the summing up, structural features unite to make these languages a distinct group. Tryon (1974:286) says of them: 'While the DR languages may appear to constitute a fairly loose-knit unit when viewed in terms of percentages of shared cognates, a comparison of phonological and morphosyntactic features reveals many important characteristics common to all of the member languages of the Family. Several of these characteristics, especially those involving verb morphology, appear to be restricted to the Daly Family, within the north Australian area'.

\subsubsection{The Tiwi Language of Bathurst and Melville Is lands}

Tiwi very obviously stands apart from the majority of Australian languages, whether geographically close or not. In vocabulary the proportion of $\mathrm{CA}$ is very low - about $8 \%$. Non-CA vocabulary makes no better showing amongst the other languages of northern Australia, in which CA is still very small, but in excess of the Tiwi percentage. There are also Malay components such as kumis, beard, Tiwi kumuti. The general impression was pointed out by Capell (1940 and 1941) and also by Osborne (1974) in his fuller study. In this he speaks of the extraordinary complication of the morphosyntactic level, and writes: 
'The Tiwl verb is a sentence in minlature', and 'nothing quite like it is found anywhere else in the Continent or on the Australian 1slands' (Osborne 1974:2-3). Apart from the remarkable agglutinating processes, 'most striking of all (for an Australian language) is the capacity which Tiw has for incorporating noun-like forms into the structure of the verb, principally as direct object'. These structures may indeed be 'sentences in miniature', and they follow an sov pattern, but still remain unique for the continent. If they represent a straight development from a primitive Australian pattern, it is still something local, not common. Osborne then goes on to make 1 t clear that Tiwi is still an Australian language, however unique, but he is unable to 'place' it among others; it is also clear that lexical comparison is unable to establish Tiwi's genetic relationship (see Osborne 1974:3), especially the rapid replacement of vocabulary for soclological reasons. It remains to be seen whether his pessimism that 'Tiwl's genetic relationships will never be established through lexical comparison but only through structural comparisons' yet to be undertaken, is Justified. On Tiw1 vocabulary see 6.3.1. below.

Nevertheless, certain things do stand out. First is the fact that the dual number is marked only in the first person: muwa, you and $I$. Secondly, there are plural pronouns, and a third person with masculine and feminine distinction. This recalls Daly River and Dampler Land (except for gender distinction which is absent from the latter).

The Tiwi pronouns are:

\begin{tabular}{|l|c|c|c|}
\hline \multicolumn{1}{|c|}{ Person } & Singular & Dual & Plural \\
\hline 1. Incl. & - & muwa & nara \\
1. excl. & nija & & nawa \\
2. excl. & ninda & & nuwa \\
3. excl. masc. & nara & & wuta \\
3. excl. fem. & nira & & wata \\
\hline
\end{tabular}

The crucial first and second person singular are obviously EA forms, and the second person plural also may be fitted into the scheme, but the remainder cannot; moreover, the prefixed person markers, which may be older than the cardinal pronouns, are different, except for first person singular $\mathrm{n-}$, and these vary for tense (Osborne 1974:38ff.). 
They therefore have a non-Australlan background, or at least one that differs from the domonating EA.

Without therefore expanding the treatment at this stage, it is probable that this represents st1ll another type of EA, of limited local occurrence. That any further delineation is possible, granted that the amount of vocabulary change has been as Osborne suggests, seems unlikely - although, of course, further vocabulary study may change the outlook.

\subsubsection{Dampier Land Languages}

It has long ago been shown that Dampler Land (DL) languages stand apart from their nelghbour (Capell 1956/1962) in having a regional vocabulary and considerable grammatical pecullarity. For Nfigina and Warwa, more detalls are given in Capell 1953. In Warwa, there is conslderable influence from the NK languages. Structurally, these languages are largely prefixing: the person of the verb is marked by short pronouns prefixed to the verb stem and varying for tense.

Although the pronouns themselves (see Capell 1953:453) are partly $E A$, based on *na- serles, they have the peculiarity that the dual contains only the first person inclusive you and $I$ - thereby agreeing with T1w1 and some other languages. Such a characteristic may be classed as EA - the earliest forms, treated above, though primitive in beling noun stems, are later in adding suffixes for all dual persons. This development has been plain in Victoria, where even a trial number developed.

The following set shows DL pronoun roots, as theoretically reconstructed from Njulnjul and the other Peninsular languages, Bard, DJaw1, Nj1gina, Warwa and Yawur.

\begin{tabular}{|c|l|c|c|}
\hline Person & Singular & Dual & Plural \\
\hline 1 & gaju & jawu, jaju & jadiri,jarada \\
2 & djuwa & & gurer,gura \\
3 & ginjigg(a) & & jir(ga) \\
\hline
\end{tabular}

These forms are 1d1osyncrat1c, except for the first person singular, which belongs to the *na- serles of EA pronouns, to be treated below (3.4.). Unexpectedly enough, it is the third person singular that is of Interest here: ginjing(a) has been linked by D1xon (1972:258) with 
a root *ginja, found not only in DJirbal and Wembawemba (western V1ctorla) but also in Njlgina. He has pointed out a few other eastwest resemblances also, e.g. DL - jaru, like, gi, near, linking with Lard1l gin and Mbararam nini, there.

It may be remarked in passing that the vocabulary contains much that is peculiar, whereas a $C A$ content is difficult to recognise as anything more than a 'contact borrowing'. From the 100-word 11st used to calculate such content only a half-dozen words were accepted, and some of these only in some of the languages. Aspects of this vocabulary are discussed below in 6.3.3.

\subsubsection{Other Areas}

Not only such areas as Dampler Land but all over Australia there are more or less divergent types whlch cannot be dealt with here in deta11. The1r present-day forms suggest that they began as forms of $E A$ and had recelved materlal from surrounding languages or, in some cases, even distant languages. Such a statement suggests that there have been widespread movements within the continent of which there is no evidence at the present time. Indeed, such events are very likely seelng that the Aborlgines of Australla were moblle unt1l white 1mmigration stopped them. It cannot be known when language areas or tribal territorles became flxed. In some cases such changes of location are probably very modern. One clear example of this sort of replacement of language in a given area is that of western Arnhem Land, where J.K. Harris was able to produce maps showing earlier and present linguistic situations (Harris 1969:maps I and II). Another is the P1lbara region of Western Austral1a, for wh1ch von Brandenstein (1967: 20aff.) produced seven maps of tribal movements - all of them modern enough to be still known, yet indicative of movements that must have gone on in more anclent times on a larger scale. The present-day linguist is at a disadvantage in regard to all this, and can only try to restore such movements by comparison of the existing languages with each other.

Nor are all the languages pronounless, like those discussed earlier. In addition to the language mentioned above, there are some which have taken over, at least as subjects and sometimes with suffixes in the oblique cases - pronouns of the EA serles (na-, njin-), retain strange vocabulary and strange forms of suffixed pronouns, and seem to retain old grammatical structures, especially in their verbal systems. The latter are extremely divergent from the languages used 


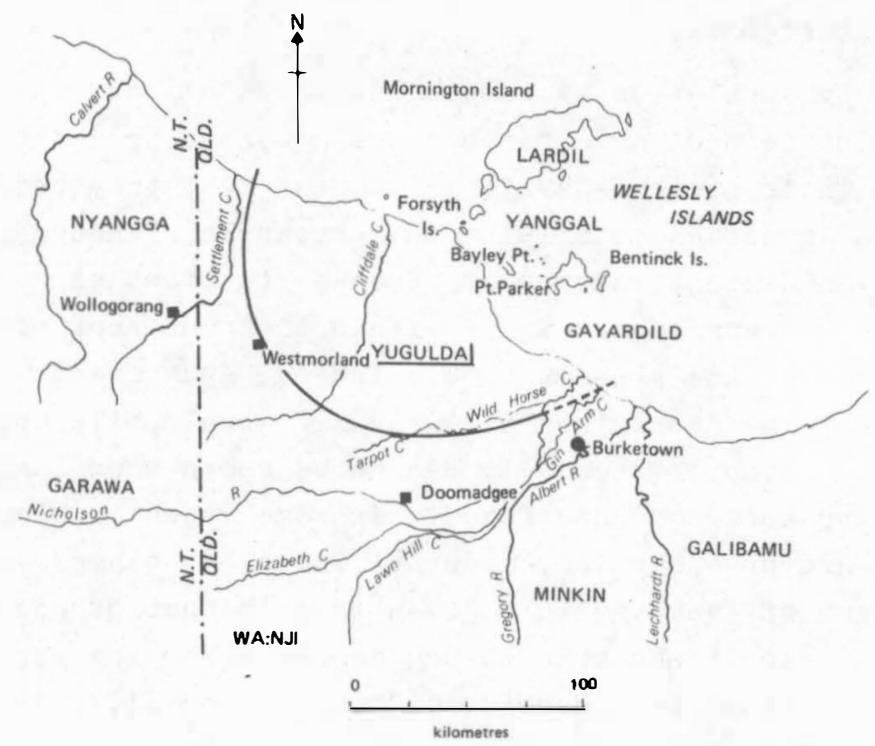

Map 3: The Yugulda Language - Gulf of Carpentaria - in relation to its neighbours (efter Sandra Keen, 1972) 
In other parts of Australia, not only in the morphemes used for the grammatical features, but also in the underlying principles. Examples of these will be found in Yugulda, Garawa and Galgadungu of the Gulf district of Queensland.

\subsubsection{Yugulda, Garawa and Galgadungu}

In each case, the pronouns can be fitted into the more widespread Australlan, even though they have strange components:

1. Yugulda

\begin{tabular}{|l|c|l|l|}
\hline Person & Singular & Dual & Plural \\
\hline 1. Incl. & - & gagura & gagulda \\
1. excl. & gada & Jara & galda \\
2. excl. & njigga & gira & gilda \\
3. excl. & niya & bira & bilda \\
\hline
\end{tabular}

Here it is obvious enough that the singular pronouns are of EA orlgin; the other numbers are bullt with dual ending - ra and plural ending -ida on other roots: and the third person links with the Northern Kimberleys, e.g. as seen in Ngarinfin bi-ra, bi-ri, they, whereas the second person $g i$ - root recalls the Ngarinjin prefix form gur-.

2. Garawa

\begin{tabular}{|c|c|c|c|}
\hline Person & Singular & Dual & Plural \\
\hline 1. Incl. & - & nungala & nambala \\
1. excl. & nayu & nali & nuru \\
2. excl. & nindji & nimbala & nari \\
3. excl. & njulu & bula & yalu \\
\hline
\end{tabular}

Here the combinations are more elaborate: nayu is the normal ergative but, in this case, is not necessarlly ergative at all; indji is also ergative in form; njulu is found, for example, in South Australia (Diyar1); bula is EA *buladj, two; nimbala recalls (but not certainly) 
the WD njun-bala, you-he; nuru is usually second person plural and nambala seems to be $I$-they or perhaps $I$-he, whereas nari and yalu remain opaque.

3. Galgadungu

\begin{tabular}{|l|c|c|c|}
\hline Person & Singular & Dual & Plural \\
\hline l. Incl. & - & nali & gada \\
1. excl. & gay & - & - \\
2. excl. & gini & mbaya & nudu \\
3. excl. & laa, bagi & buyu & dina \\
\hline
\end{tabular}

This set is very difficult to analyse. There is no inclusiveexclusive distinction in the first person dual and plural; first and second person singular are recognisably EA; second plural recalls Gunwinjgu juda which is both singular and plural, and has cognates in V1ctorla (Wembawemba etc.) and dina seems to be a form of EA tana. The other forms remaln quite strange.

It should be added that the vocabularles of all three languages differ radically from each other, and thelr percentage of $\mathrm{CA}$ and even EA words seems to be almost negligible. The 100-word list has been provided here to show that from the view-point of vocabulary there are three language isolates. The existence of such 1solates is part of the argument that there is no one proto-language 'Australian' or even $\mathrm{EA}$ or $\mathrm{CA}$ that is basic to the whole continent. Words at present recognised as $C A$ or $E A$ are added in a final column for comparison, showing that there are extremely few of these present in the languages under discussion. 


\begin{tabular}{|c|c|c|c|c|}
\hline English & Yugulda & Garawa & Galgadungu & CA (where known) \\
\hline ashes & djulguwa & djolorina & bumba & \\
\hline bandicoot & wadunda & galdgadu & biwali & \\
\hline bark (n) & gal uwa & Dinir & & \\
\hline bathe & $g u: d j a$ & wagadaba & djara & \\
\hline beard & duganda & d jamoga & Janbad & Danga $(r)$ \\
\hline belly & badaga & mowa & buru & \\
\hline$b i g$ & badanu & walgora & jawn & bulga, bunda \\
\hline black & Dumuwa & gogodo & $\operatorname{madjin}$ & mawru, malu \\
\hline bird & bu $\mathbb{b} b u \underline{\square} u \underline{u}$ & djolagi & duruun & \\
\hline \multicolumn{5}{|l|}{ blind } \\
\hline blood & ganduwa & Dolja & ulei & \\
\hline blow & & & & bu- \\
\hline bone & djulda & noli & gunga & darga \\
\hline boomerang & wanalga & nobono & jalgabari & gaLi \\
\hline breast & kundunga & Damolo & mimi & Daman, bibi \\
\hline burn & ganadja & jondidjba & duwi & gamba \\
\hline bring, take & dj i rmadja & gojo & $\operatorname{man} \mathbf{i}$ & \\
\hline
\end{tabular}




\begin{tabular}{|c|c|c|c|c|}
\hline Engl1sh & Yugulda & Garawa & Galgadungu & CA (where known) \\
\hline camp & nadaRa & bandar $\mathrm{i}$ & muu (earth) & Dura \\
\hline cloud & mananda & Dalo & juruma & \\
\hline come & waradja & badadjba & inga & \\
\hline crow & dj ad a $\underline{r} g a$ & wangola & wagala & wagura \\
\hline cry, weep & ligigaradja & Dindoga & luna & \\
\hline die & buguwada & djanjba & uli & \\
\hline $\operatorname{dog}$ & nawuwa & badjano & dugu & \\
\hline drink & gudamadja & naRaba & $a \mathbf{i} \mathbf{i}$ & \\
\hline eaglehawk & djarbagala & djalbaramba & ulujan & \\
\hline ear & maralda & gowaDa & inda & binan, guRu \\
\hline earth & du $\underline{\lg } \mathrm{a}$ & djamba & muu & guran \\
\hline eat & djiyadja & djarba & $a i l i$ & da-, na- \\
\hline egg & & & & gambu \\
\hline emu & djadabu & gaNanandja & udinad & guninj \\
\hline excrement & $\underline{d u} \underline{l d a}$ & mirda & unu & gunan \\
\hline eye & mibulda & yami & $m i \underline{i d i}$ & milin \\
\hline fazl & baldidja & wirba & gui & \\
\hline
\end{tabular}




\begin{tabular}{|c|c|c|c|c|}
\hline Engl1sh & Yugulda & Garawa & Galgadungu & CA (where known) \\
\hline father & gandadu & bogaganja & gula & \\
\hline fire & Dida & djano & udjan & waru \\
\hline fish & yagu l i & gago & wagari & gwijan \\
\hline fly $(n)$ & girouda & goN ima & yumumduru & \\
\hline food & wul anda & mama & maa & $\operatorname{maj} \mathbf{i}$ \\
\hline foot & djara & $n \circ g a m i$ & dabandu & dinan \\
\hline give & $w u: d j a$ & wadjba & anj $\mathrm{i}$ & $(w) u$ \\
\hline go & waradja & balba & ga and ja & jan \\
\hline good & miraRa & gonjba & burur & \\
\hline hair & bulda & njonga & warabu & \\
\hline hand & malda & $\operatorname{maNi}$ & $\operatorname{mag} a \underline{d} \mathbf{i}$ & maRan \\
\hline head & nalda & goladj i & ganda & gada, walu \\
\hline$h i t$ & ba lada & daba & la $\mathbf{i}$ & bu- \\
\hline hot & Daranara & Daranara & bujud & \\
\hline hungry & Damanda & birgalidjba & ba i & \\
\hline kangaroo & bidiriga & walidji & madjumba & \\
\hline know & & & & \\
\hline
\end{tabular}




\begin{tabular}{|c|c|c|c|c|}
\hline English & Yugulda & Garawa & Galgadungu & CA (where known) \\
\hline leaf & djindiya & wandjir & bulindi & \\
\hline Ziver & garmida & djanayi & udundu & \\
\hline Zong & yulmbura & wonanjbala & ulguuri & \\
\hline \multicolumn{5}{|l|}{ make } \\
\hline $\operatorname{man}$ & dangaRa & Dananj i & juru & baNbun \\
\hline many & mudara & goDogoDo & malda & \\
\hline meat & yalbuda & banganj $\mathbf{i}$ & adi & minja \\
\hline \multicolumn{5}{|l|}{ milk } \\
\hline moon & waldara & yagal & dundal & gagari \\
\hline mother & Damadu & Dada & $\operatorname{mad} u$ & \\
\hline mouth & wa lara & djanji & anda & dagan \\
\hline \multicolumn{5}{|l|}{ navel } \\
\hline neck & dawura & doga & galaa & \\
\hline no! & walira & migo & gunaan & \\
\hline nose & girga & molo & $i d j i n d j i$ & muran \\
\hline one & djadara & y inamal i & a jad & gudju \\
\hline rain & wunda & $d j a n d j a$ & guu & galini? \\
\hline road & wayini & yobal & waru? & \\
\hline run & djawidja & wilgo & duna & \\
\hline
\end{tabular}




\begin{tabular}{|c|c|c|c|c|}
\hline English & Yugulda & Garawa & Galgadungu & CA (where known) \\
\hline \multicolumn{5}{|l|}{ sand } \\
\hline see & guridja & nadjba & nanji & $n a, n j a-$ \\
\hline skin & doraRa & wad joLgi & wagu & gulan \\
\hline sleep & minda lidjada & golodjaridjba & I 2 ie & down) \\
\hline smazz & gunyaRa & bayagaDa & minasara & djulan \\
\hline smoke & njuraRa & goNnar & bulu & buyu, burin \\
\hline snake & dira & miya & duad & \\
\hline speak & gabuRidja & yand jba & bunbadi & wanga \\
\hline spear & miyalda & won $\mathbf{i}$ & jugu & guridada \\
\hline spearthrower & murugu & odjola & & \\
\hline stand & daldidja & garindja & naa & gaRa \\
\hline sit & $\mathbf{d} \mathbf{i}: \mathbf{d} \mathbf{j} \mathbf{a}$ & d jongo & naRadad i & \\
\hline star & guRuba & warawidji & dj irga & b i NDi $\mathrm{ri}$ \\
\hline stone & gamara & donala & ndia & badu \\
\hline sun & warguwa & gamba & wanaga & djindu \\
\hline take & gurgada & goyo & $\operatorname{man} \mathrm{i}$ & ma- \\
\hline throw & nudidja & ranimba & $\mathbf{i d} \mathbf{i d i}$ & \\
\hline
\end{tabular}




\begin{tabular}{|c|c|c|c|c|}
\hline English & Yugulda & Garawa & Galgadungu & CA (where known) \\
\hline tongue & djalnaña & $d j a l i n j i$ & mali & dalan \\
\hline tooth & damanda & mayi & adinda & \\
\hline tree & diwalda & goNDa & gunga & yirara \\
\hline two & giyarnga & godjara & luad $i$ & buladj; gudara \\
\hline water & nuguwa & nowo & guu & Dugu, gabi \\
\hline urine & gunbugu & Dodjalo & gulgai & gumbu \\
\hline what? & Daga & wanjdja & naga & minan \\
\hline when? & djinamulun & & & \\
\hline who? & gaga & wan j i & nani & Dana \\
\hline woman & maguwa & djibari & marabai & \\
\hline yes & $D i$ & yogo & Daa & \\
\hline you & nini & Dind $\mathbf{j} \mathbf{i}$ & njinga & $n j i n-$ \\
\hline you \& I & pa $1 \mathbf{i}$ & gali & Dara & gali \\
\hline
\end{tabular}


Linguist1c structures are present in each of these languages which set them apart from the normal Australian types of EA and CA. Comparison may be made here with the $\mathrm{EA}$ and $\mathrm{CA}$ forms by anticipation, detalls of which will be filled in later.

Word order is st1ll rather free: SVO and SOV are much interchanged; what gives the Impression of strangeness in these languages is the application of morphological particles within the sentence rather than the syntactic patterns. Each of the languages combines morphological markers in an unusual manner, which it is hard to take as local varlant of such markers, even when they have cognates in $\mathrm{CA}$ or EA - and In many cases they do not!

Yugulda, unlike some of the nelghbouring languages, 1s ergative, but 1ts nouns have a set of nominative endings which appear even when nouns are given in 1solation. Yet these are not noun classes in the sense in which the term is generally found in Australla (see the paper on noun classification in this volume). The endings are phonologically not semantically determined, and there are elght of them. Case endings elther replace these suffixes or change thelr form to allow for them. There is also a set of case endings which is partly influenced by the stem final of the noun; the genitive case is 1tself capable of taking further inflection under certain circumstances.

It is differentiation such as this plus an almost complete difference in vocabulary from $C A$ that suggests that here we have one of the layers of $\mathrm{EA}$ that underlie the modern situation.

In Garawa the structures differ somewhat, but do point to a similar conclusion. References to this language are based on Christine $E$. Furby's paper (1972). She summarlsed the marks of this language, stating that 'eleven distinctions of person and number are marked in personal and possessive pronouns...' Unusual features of Garawa pronouns are the ab1lity of personal pronouns to be marked for aspect, mood and tense, and the ablilty of demonstrative and interrogative pronoun stems to take further suffixation and their function as different parts of speech. This language is also ergative, indicating that the phenomenon reached 1 t at some date after settlement into 1 ts present situation, for 1 t is an area bordering on the accusative language and there is every evidence that 1 t was once such 1 tself. Word order also seems relatively free - another marker of early linguistic date. It is noticeable that the verb in Garawa is frequently unmarked, as in Yugulda and Galgadungu, owing to the tense marker appearling in some other part of the utterance, usually in the head complex, whether noun or adverb, as 1llustrated in the examples of 
Yugulda. In Garawa, the tense marker tends to remain on the verb, but the verb appears first in the sentence, e.g.

$$
\begin{array}{ll}
\text { wilgu-yi wajga nanama } & \text { naninji } \\
\text { run-past down that (nonspecifled) man-nom. } & \text { That man ran down the hilz. }
\end{array}
$$

as against

$$
\begin{aligned}
& \text { wanji-nanji njuli baDadjba } \\
& \text { Interr-subj:benef he:subj-past come } \\
& \text { Why did he come? }
\end{aligned}
$$

The third language, Galgadungu, is also to be grouped with this early stage of Australian, as some part of EA, and certalnly earlier than CA. Vocabulary alone would suggest this. The information for this rests on Blake (1969).

Part from the marking of tense in the NP as well as in the VP, it is the verbal pattern which chlefly differentlates these languages from other Australlan languages, not only in method but in the actual morphemes. Tense markers depend on four factors: trans1t1vity, aspect, and realis and 1rrealis forms of the verb. Moreover, the transitive is marked within the body of the verbal complex, not by an ending or set of person markers, but by a marker which indicates transitivity as such and forms one 1tem within the verbal complex.

The tense markers given in the grammar (Keen 1972:199) are as follows:

Table 9: Verb Markers in Yugulda

\begin{tabular}{|l|l|l|l|l|l|l|}
\hline \multirow{2}{*}{} & \multicolumn{3}{|c|}{ Trans1t1ve } & \multicolumn{3}{c|}{ Intrans1t1ve } \\
\cline { 2 - 4 } & Present & Future & Past & Present & Future & Past \\
\hline Real1s & $-r i$ & $-n t i$ & $-n t a$ & & & $-(y) i \eta k a$ \\
\cline { 1 - 2 } & $-(t i)$ & & & $-(t i)-$ & $-y i$ & \\
& $-\eta k a(t i)$ & $-i \eta k i$ & $-n t i$ & $-\eta k a(t i)$ & $-\eta k i$ & \\
& & & & & $-(y) i \eta k i$ \\
\hline
\end{tabular}

The problem then to be solved is the order of such suffixes in the total verb complex, and this is a point at which not only Yugulda but other languages part from normal Australian usage. A few examples from Keen (1972:200ff.) show this effect: Keen's spelling has been retalned for these examples: 


$$
\begin{aligned}
& \text { tiyatja- na- ri wulanta } \\
& \text { eat-Vtr-I (tr)-pres-food (nom) } \\
& \text { I'm eating food. }
\end{aligned}
$$

(and the noun endings - $t \mathbf{j a}$ and - ta come into play)

$$
\begin{aligned}
& \text { walira-ta-yi kapata gum-aninjtja miya!injtja } \\
& \text { neg-I (1ntr) find-fut-Vtr your-benef spear-benef } \\
& \text { I wizl not find your spear. }
\end{aligned}
$$

There is a full study of these peculiarities in McConvell 1976 which will repay detalled study, and they show that here is a question of a variant linguistic type, rather than modification of a general Australian type. Some of the many variations which appear include Sentence $=\left\{\begin{array}{l}{[N-\text { erg }]+[\text { Tr-pres }]+N(\text { nom })+V} \\ {[\text { neg-1ntr-pres }]+N(\text { nom })+N(\text { dat })+V} \\ {[\text { dem }(\text { nom })]+\left[N(\text { nom })+p_{1}+p_{2}+t a\right]+[\text { pron }(o b j)+V b]}\end{array}\right.$

What is more unexpected is the use of ergative and nominative: objective does not always mean 'accusative': some other case may be required in some instances, as reference to McConvell's analysis will show. This language can definitely be set down as a different type, not as a variation on EA or CA models. At the same time, it is an AT language, but the AT processes are by no means the same as those of the WD languages or other $C A$ languages.

The radical separation of certain groups of languages in Australia is stressed by 0'Grady (1966:120) in his setting out of a density matrix between twentyseven Western Australian languages. The result is a very low density display. He remarks in the discussion of these languages that 'The results of the comparison of Nyulnyul, a non-PamaNyungan language spoken in the Kimberley District of Western Australia, are included by way of pointing up the extreme dearth of cognates (or rather, putative cognates) shared between languages of different phylic families of the postulated Australian Macro-phylum. In fact, almost the only convincing cognate in many such comparisons turns out to be the first person singular pronoun, with inftial syllable /na-/ in the vast majority of Australian languages'. This complexity of origin is largely increased when the scope of comparisons is increased. For the moment, it is time to pass on to consider the na- set of pronouns. Before this is done, however, three other rather exceptional languages need to be passed under review, all of which use the root na- for $I$. These languages are Lardil, Bidabida and Gurnu (Guṇu). 


\subsubsection{Lardil, Bidabida and Gurnu}

Outslde the 1mmediate sphere of these three languages there are three others in which tense is shown in the pronoun and noun object, but in which the syntax is not as elaborate as in the other languages. These three are Lardil of Mornington Island, Bldabida (P1ttap1tta) of Boulia district and Gurnu (Gunu) west of the Darling River in New South Wales and, to some lesser extent, Murawarl not far from Gurnu. The principle of indicating tense in non-verbal categorles is common to all these languages (Wurm 1972:133,146) and is not found in other parts of Australia. As the shared vocabulary both between the languages shown above and these others 1 s small, and their CA/EA content is also very small, these look strongly like an early language group (EA) later flooded by eastward moving peoples. It is of course possible that each occurrence of this phenomenon was independent of the others, yet hardly likely, especlally as the future marker is the EA *-gu, Indicating purpose - 'for' with nouns and 'Intention' with verbs (see Blake et al., In D1xon, ed. 1976:421-82) in two out of the three languages. These languages wlll be revlewed brlefly:

1. Lardil is the language of Mornington Island, to the north of and clearly related to Yugulda and Gayard1ld. Here object NP is marked for the future as against the non-future. The examples below are from Hale 1970; others may be found in Capell 1942:47-50. In the c1tations from Hale his spelling is kept:

$$
\begin{aligned}
& \text { tajka ka-nkur pirnen-kur } \\
& \text { man speak-fut woman-fut } \\
& \text { The man wizl speak to the woman. }
\end{aligned}
$$

Here the future marker - nkur is added not only to the verb but also to the following noun. There is no ergative, and it is possible to turn the sentence into the passive volce in ways that are not relevant here. Further examples from Hale (1967:63ff.) w1ll make the correspondences clearer:

$$
\begin{gathered}
\text { Data kupaRi-kun ma:ṇi } \\
\text { I made a spear }
\end{gathered}
$$

$$
\begin{gathered}
\text { Data kupaRi-țu ma:n-ku } \\
\text { I will-make a spear }
\end{gathered}
$$

Word order in such sentences is not fixed; all possible orders are acceptable provided the requisite endings are in their places: Hale has shown the variations that are possible (p. 67). The pronouns then take on the following forms in the singular (Capell 1942): 


\begin{tabular}{|c|l|l|l|}
\hline \multirow{2}{*}{ Person } & \multirow{2}{*}{ Subject } & \multicolumn{2}{|c|}{ Object } \\
\cline { 3 - 4 } & & Non-future & Future \\
\hline 1 & nada & nida-n & nida-nda \\
2 & $n j i n g i$ & nimbe-n & nimbe-nda \\
3 & $n i j a$ & niwe-n & niwe-nda \\
\hline
\end{tabular}

The pronouns themselves belong to the EA set na(n)-njin, but the point of interest is that the objective second and third singular seem to Involve the forms suffixed by *badj (here becoming -we-) which will be discussed in 3.4 .

2. Bidabida - Information 1s gathered from Blake and Breen (1971), the authors' spelling again belng retalned. The situation is a little more complicated as there are dlalect varlations within the region. Moreover, the language is ergative, so that three forms of each pronoun appear: nominative, ergative (operative) and future. In the singular number these forms are

\begin{tabular}{|c|c|c|c|}
\hline Person & Nominatıve & Ergatıve & Future \\
\hline 1 & nanjtja & gațu & ganju \\
2 & inpa & intu & ingu \\
\hline
\end{tabular}

It will be seen that the -*badj ending appears in inpa, the nominative, not in the objective, as in Lardil. The ergative in each case belongs to the $-* l u$ serles. A serles of case endings adds to the difficulties in B1dab1da, e.g. the objective is

\begin{tabular}{|r|l|l|}
\hline Person & Non-future & Future \\
\hline sing. 1. & nanja & ganjt ju-ku \\
2. & ina & inku \\
\hline
\end{tabular}

whereas the dat1ve does not distinguish tense, but has nanjaRi or nanjai for me; inkaRi or inkai for you. All these forms are in radical 
agreement with Lardil, but it would appear that Gurnu is radically different. A few sentences will show the system at work:

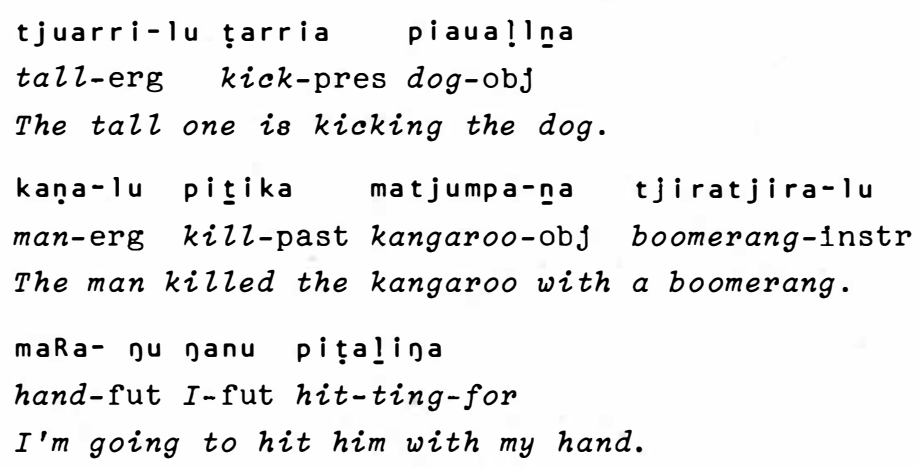

It is possible to have more than one simultaneous case-ending:

$$
\begin{aligned}
& \text { tinta-ma-na kanta-nja } \\
& \text { yam-for-obj <she> went }
\end{aligned}
$$

3. Gurnu was recorded by R.H. Mathews as being spoken on the west bank of the Darling River, near Bourke in New South Wales, and links with Murawarl Just to the north of 1t. Ne1ther has been fully studied since, but some work has been done on Gurnu by Wurm (1976), and Oates has done unpublished work on Murawar1. The present writer, going through Oates' fleld notes, had observed the non-verbal tense marking phenomenon there also. It appears also furtier west in $\mathrm{Ba}$ :gundj1 (Wurm and Hercus 1976). The great difference here is that the tense is indicated by a variation in the initial consonant of the pronoun, not by a suffix to 1t. A few sentences may be quoted from Wurm (1976):

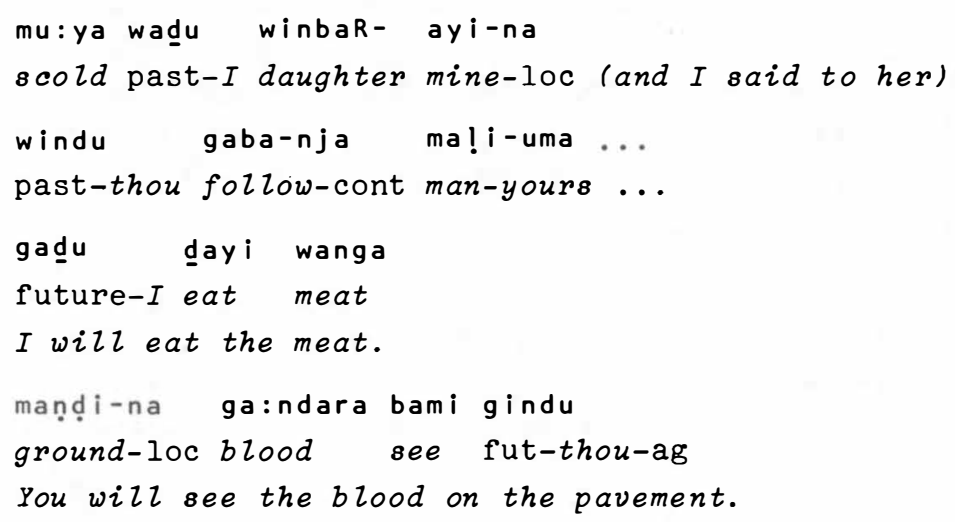


the changing of pronouns for tense is present in that dialect as well as will be shown by the following examples:

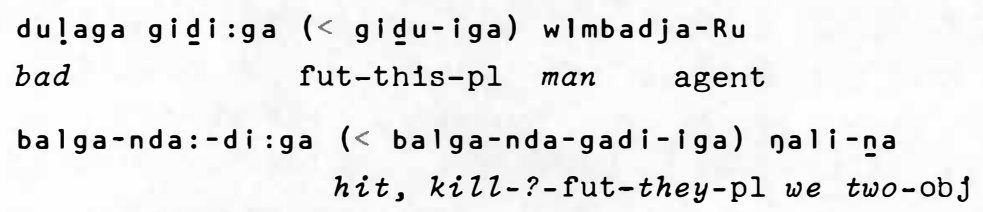

In these languages the tense marking is prefixal throughout: the normal *nan/njin sets with their nasal opening being replaced by a $w$ - set for the past and a $g$ - set for the future tense. Here also $1 t$ is a full declension substitute, e.g. Murawarl wunda, him past, with suffixal form - $(\mathrm{m})$ ba, he.

In these areas too, some of the older Australlan words are found, e.g. Murawar1 wi:, fire < *wiyin, a south-eastern root ch1efly, of EA orlgin; $g(w) i j a, f i s h<E A{ }^{*} g w i j a n ;$ ma-ra, hold, take<EA *ma-.

\subsection{The EA na- Series of Pronouns}

Next comes the set of pronouns resting on the bases $\star_{n a}(n / j), I$ and gun- njin-, you. The third person varles, mostly *ba or *dana, with originally undefined difference, but *ba finally settling down to singular and *dana mostly to plural. These are by far the most widespread in Australia, and in the author's earlier writings (1956 onwards) they have been treated as CA. Present evidence makes 1t doubtful whether they can be more than a type of EA, and in this case, the nominal roots used as pronouns in the ways fust discussed would be an older stratum, so far conjoined in EA. It must be remembered that $E A$ need not be regarded as a single stratum, so that the nounpronoun roots could be $\mathrm{EA}_{1}$, and the na- serles $\mathrm{EA}_{2}$.

The na-serles is fuller than the $\mathrm{EA}_{1}$ serles (in the sense just defined), and may be tentatively restored as follows:

\begin{tabular}{|c|l|l|l|}
\hline Person & \multicolumn{1}{|c|}{ Singular } & Dual & Plural \\
\hline 1 & ga(n/j)- & gali & ja-nan \\
2 & gun- $n \mathbf{n i n -}$ & & $\begin{array}{l}\text { gura } \\
\text { (dana) }\end{array}$ \\
3 & (ba) & & \\
\hline
\end{tabular}


That this serles may historically have overlapped with 1 ts predecessor is clearly suggested by the Gadhang, New South Wales, set, as delineated in Holmer (1966:61-3): In first person alongside nom. jaduwa is found obj. baRanan, poss. baRaba, dative baRay(i) and, for that matter, second person sing. biyay(i), parallel obj. binan and poss. bi:nba, whlle njuwa is third sing. and baRa third plural - a type of confusion not present in the nelghbouring Dhanggadi. In the languages of the Yaralde Group along the lower Murray, jur-, jura has become second singular.

In general, however, throughout large parts of Australla, the $-r-$ has been a marker of plurality in the pronouns, as in Awaba nu-ra, you and ba-ra, they; the dual number is first person bali, second bula, third bul-wara. Agaln, these pecullarities of the extreme south reappear in the Northern K1mberleys and some languages of Arnhem Land. In Gunwinjgu juda is you in all numbers, and fourteen other languages of the area have a similar - $r$-formation in the second person plural pronouns. Nor is 1 t confined to these groups; Diagram I shows the distribution of $-r$ - as a pluraliser throughout the continent and, in fact, 1t occuples all the strateglc points of the country. More is sald of this at the end of the present section.

The majority of Australian languages use pronouns which are based on these roots. In ergative languages the first two pronouns - the only original pronouns - take the form of gaju gadju and jindu njundu respectively and one of two roots - ba-lu or elther nulu njulu or nu-wa $\sim$ njuwa for third person singular. The ba- root is western, the other nu- root mostly eastern. Th1s in the form nuwal njuwa is *nu-badj and belongs to the *badj root yet to be discussed. The forms in -du/dju suggest that the root ended in a consonant, elther palatalised or not, a CVC base.

The phonological shape of $\star_{\eta a-j u}$ as an ergative ralses some difficulties, for -ju is not a normal form of $\star-l u$. If the base is *nanj the formation would be ganj+lu nanjlu nan-lju naju. Yet such a base as *nanj would be expected to produce *nanjdju and actually often does so. Perhaps 1 t 1 s needful to postulate $\star_{\eta j}$ as well as $\star_{\eta}$ anj, and such forms as DJ1rbal najba support this double form of the root. It may then be taken that there were at an early stage two forms of the first and second person pronouns: *naj and *nanj, and similarly $*_{n}(j) i n$ and $*_{0}$ in for the second. Both are widely found and 1 is difficult to separate them elther geographically or historically. A change of any one into another is possible, but only if there was such early varlation between *naj and *nanj, and also *nan. This is possible 
Diagram I: The Distribution of - - - as a pluraliser in Australian Pronouns

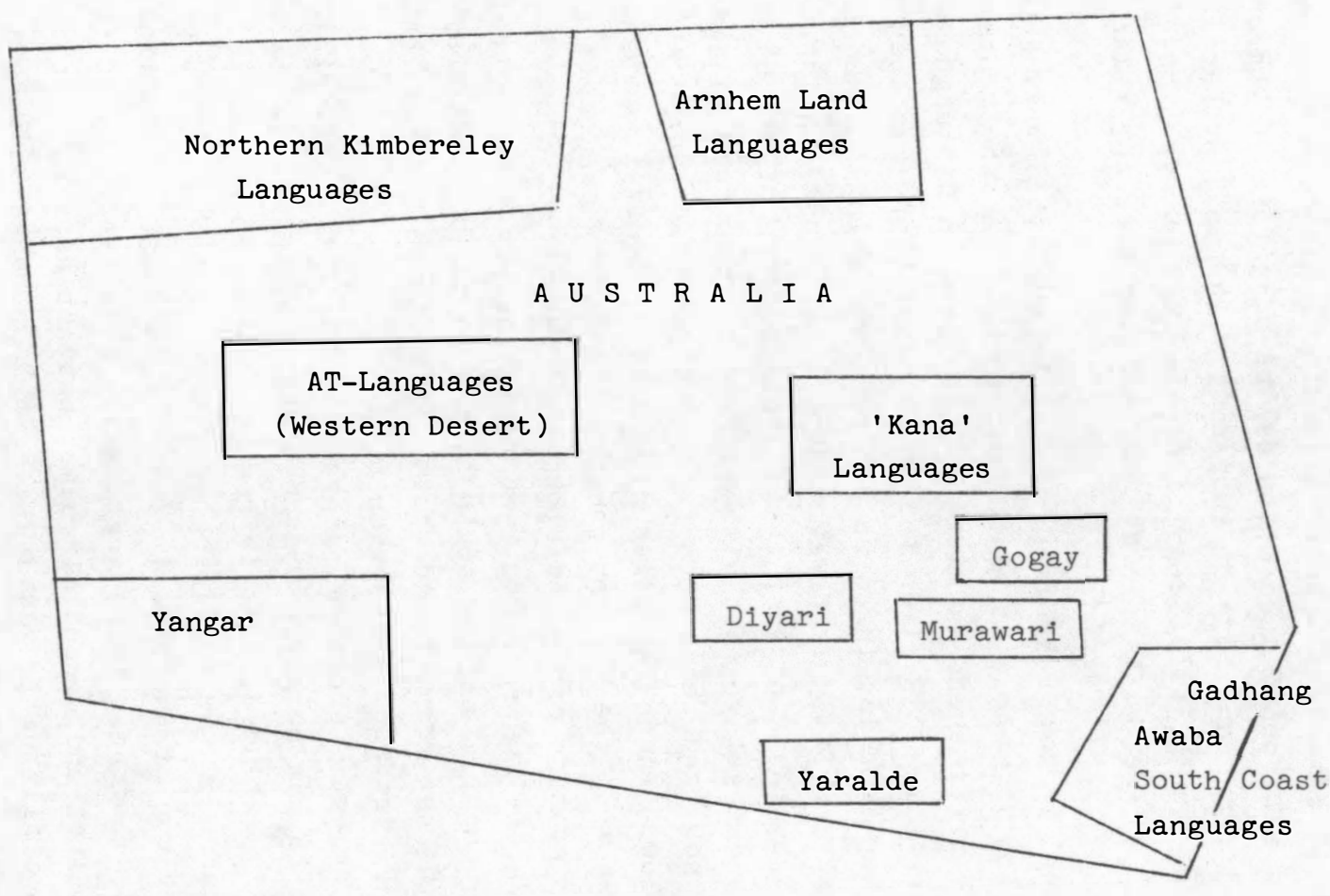


If there was the development of the laminal series that Dixon (1970b) has postulated, and this would seem right. Alternatives for the second

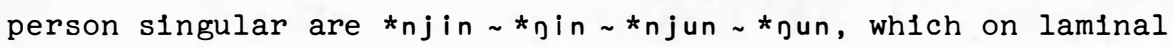
varlation is also likely.

The WD languages have a set *na-ju-lu, *njun-du-lu which show that the variants mentioned above were once current in the west also. These are, however, formally double ergatives. In practice they may not be ergatives at all, being used often as the only form of the pronouns in use, with elther transitive or intransitive verbs. Archaeological evidence (see Capell 1972:32-35) suggests that WD types moved eastwards about 6000 B.P. and westwards at some earlier date for which there is no evidence.

In the West before that date, it can be suggested only approximately what the situation was. It is to be presumed that the roots mentioned above were current there as EA forms, replaced in CA languages later by double ergatives. Earlier in non-EA times there had been languages of the Warnman type lacking true pronouns and using instead noun bases with possessive suffixes. However, the languages of the north-west (O'Grady's Ngayarda) and west coast present forms of the EA roots without double ergative, but with different forms such as gada, I ergative or not, and these need further explanation which will be ventured below. These languages also have decldely lower frequency of $C A$ vocabulary than the WD, and support the theory suggested by Thorpe that early migration proceeded along the coast, from north Australia round towards the modern Perth, and eastwards via Torres Stra1t down the eastern coast, along the south to the mouth of the Murray and then inland towards the great river basins of Victoria and New South Wales. These will be discussed in section 6 .

Thus the study of pronouns, especlally the first two, will provide such answers as can be given to the historical question. Warnman, geographically excluded, must be regarded as an island of earlier speech by reason of the smallness of 1 ts $C A$ content. It is perhaps the sole survivor of the interior western languages of earlier date.

In all the languages there are usually ergative forms of the pronouns of first and second singular, but not as a rule of dual and plural - especially gali, you and $I$. It is strange that this does not seem to be included in the ergative serles but it is generally true. It has already been pointed out above that the ergative form *oju is difficult to explain, but there are other ergatives of this root that do not fit into the general pattern of noun ergatives at all. These are such as gaja, gada which can be seen in many of the lists. Such 
ergatives do not occur with nouns as a rule, except in the Arandic languages. This fact may give the clue: in these languages a final -u frequently becomes -a. It would seem therefore that at some early stage this $-u$-a was commoner, so that possibly gaja *jan-lju which at an intermediate stage became *nalju may give the explanation. In some cases there is the suffix *-badj, to be explained below, which elther took the place of the ergative (as in Yaralde nab(i), Niwadja jabi, and others in Table 12) or survived in a different usage. Where *-badj is used with an ergative in northern Australia and Cape York Peninsula, it follows the ergative stem, as in Anindilfawgwa ga-ju-wa, Nunggubuyu na-ju-wadj) and in New South Wales in Awaba na-du-wa, njin-du-wa, where these are the only pronouns. These do raise some historical problems, but the explanation seems to be that here offered. The addition of *-badj to an ergative suggests that it ought to be written as a separate particle after the pronoun, and not as part of 1t: jaju wa, jadu wa, etc. This also brings out the real meaning of *badj, as set out below.

There results therefore a Table like the following, adumbrated by Schmidt but not fully worked out:

\begin{tabular}{|c|c|c|c|}
\hline Area & Erg. Suff. & Root & Erg. Form \\
\hline is & $-\mathbf{j a} /-\mathbf{d j a}$ & Danj, gin & naja/nadja; ninda/ninda \\
\hline est & $-j u /-d j u$ & Danj & naju/nadju; nindu/nundu \\
\hline
\end{tabular}

There are two other endings to pronouns other than those which mark the ergative. These are *-badj (which usually by loss of final consonant appears as -ba, -wa, and In Cape York -va), and *-galig, which appears as such in Victoria, but elsewhere -gari, -gal. The second is less common and phonemically more regular, so that it is convenient to take it first.

The suffix -galig in Victorian languages forms a trial number or a pausal plural with pronouns. It may be 1llustrated from Djadjala of north-western Victoria, as given in Mathews (1902):

\begin{tabular}{l|l}
$I$ & jurwe-g \\
we (plur.) & jurwe-garag \\
we three & jurwe-gara(g)-galig
\end{tabular}

Possessive suffixes may be superadded: 


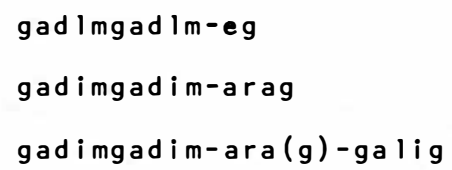

my boomerang

our (excl.) boomerangs

our-three boomerangs

In this usage, this suffix is limited to western Victorla. In some other areas of Victoria there are substitutes for 1t, so that the idea is retained elsewhere, but trial indication in Australia is rare, even though not limited to the south-east. There is, however, another use which is very widespread, 'group of people', which occurs in languages in which the suffix does not occur with pronouns at all. Hercus (1966) has shown that it appears as -gari in Arabana, meaning 'a group of connected people'. A third usage is as the ending of a tribal name in the form of $-g a l$, and a glance at any tribal map of Australla will show how common it is as -gal, -wal, -bal; the most distant from Victoria being Wunambal of the northern Kimberley. To be so widespread as this, *-galig must be a very early element in Australian language, even though now so limited in 1ts original meaning.

The suffix *-badj has also quite a wide range of occurrence, though it is chiefly in north Australia and in the central New South Wales coast. It may occur along with the ergative as *na-ju-wa in Anindilfawgwa; the full form *-badj is established on the basis of Nunggubuyu only: najuwadj. In Djirbal it occurs as najba, I (nom.). Here Dixon first put forward the opinion that it was a phonological element only: '-ba has been added to roots in a number of languages for PURELY PHONOLOGICAL REASONS, e.g. so that every word should be at least disyllab1c' (Dixon 1972:245). Th1s would not be true for all languages, even in the same part of Queensland as DJirbal, to which 1t really refers. It seems doubtful whether such meaningless syllables ever occur in Australia. The explanation of -ba added to WD words which otherwise would end in a non-permissible consonant, as just such a 'nonsense syllable' is quite needless: 1t would be ba the third person pronoun intransitive in these languages, used redundantly like $i$ In New Guinea Pidgin man $i \mathrm{kam}$, the man came. However, in the later A Grammar of Vidif Dixon himself has a better explanation: -ba Indicates 'one of a group of people' (Dixon 1977:145). Surely this is precisely what it does mean as added to a pronoun, and even in nonsingulars, such as Nunggubuyu nuguruwadj, you pl., it is most natural to take 1 t as 'you as individual members of a total group'.

The distribution of *-badj (Map 2) is interesting: 1t is found in Arnhem Land east, Cape York north, along parts of the Queensland coast 
(In these frequently with the bilabial $v$, -va peculiar to them), central New South Wales coast (Awaba, etc.) and once in Victoria in Bungandidf naduwadj. It is thus a predominantly northern element; centred about Rose River and reaching westward in the form -bi, -b (see Table 12), and north-eastward in the form *-ba. This supports the 1dea of a move from north Australia along the eastern coast southwards already suggested earlier in this section. The fact that it is added to an ergative in so many languages - in fact all the languages that have ergatives, points to 1 ts being an emphatic or discriminatory particle, not part of the pronoun. It should be written separately from the pronoun. In Nunggubuyu it is omitted in certain instances. On the other hand, where both intransitive and transitive pronouns exist, *-badj is often added to the ergative only: in Djirbal first singular jajba (intr.), jadja (trs.); and second singular nin-dja and nin-ba correspondingly. This is not the normal ergative ending: In nouns that is $*-1 u>n g u$. Here again are problems that lie outside the range of the present research. Moreover, there are languages in which *-badj functions, and which are ergative, but do not use *-lu in the pronouns, e.g. Yaralde na-bi, I. So there would seem to have been historical difficulties as between this suffix and the ergative, and they were resolved differently in different areas. The WD languages w1th the na-ju-lu type of pronoun (see 3.5.) are doubly ergative in form though perhaps not ergative at all in function. The suffix is essentially, it would seem, a property of the non-ergative languages. It needs also to be mentioned that there is no occurrence of *-badj on the west coast of Western Australia. It is a purely eastern and northern phenomenon.

It is not the intention of this study to work in detall the position actually held by the writer, which would require much greater space. For the non-singular numbers of the na- serles of pronouns, a few leading points only will be made. They comprise the following:

1. As stated earlier, only the first and second person singular pronouns are claimed as being in any way original Australian. Third person, though patterning falrly well, is a demonstrative, not a true pronoun. Two roots are common, ba, erg. ba-lu in the west, and nu- nju- nu- in the east.

2. Second person plural is of special interest. It also has a root that appears to be nu-, but is probably the singular nju-, nji-with an added -r-pluraliser giving 
Table 10: Enclitic Pronoun Subject Markers in Western Desert Languages

\begin{tabular}{|c|c|c|c|c|c|c|c|c|c|c|c|}
\hline \multirow{2}{*}{ Language } & \multicolumn{3}{|c|}{ Singular } & \multicolumn{4}{|c|}{ Dual } & \multicolumn{4}{|c|}{ Plural } \\
\hline & 1 & 2 & 3 & 1. Incl. & 1. excl. & 2 & 3 & 1. Incl. & 1. excl. & 2 & 3 \\
\hline $\mathrm{Baljgu}$ & -ṇa & $-n b a$ & $\mathrm{Ja} / \varnothing$ & $-1 \mathbf{i}$ & $-1 i j a$ & -nbula & -bula & $-1 a$ & -guda & $-n j u$ & $-j a$ \\
\hline Inggarda & - ṇa & $-n b a$ & $-\varnothing$ & $-1 \mathbf{i}$ & $\emptyset$ & $\emptyset$ & $\emptyset$ & $-1 a$ & $\emptyset$ & $\emptyset$ & $\emptyset$ \\
\hline Garadjari & - ṇa & $-n$ & $-\emptyset$ & $-1 \mathbf{i}$ & $-1 a$ & -nbula & -bula & $-n j a$ & - j.ạna & -juru & $-\mathbf{j a}$ \\
\hline Njangumarda & $-n ! V$ & $-n$ & $-r V$ & $-1 \mathbf{i}$ & $-1 \mathbf{a j} \mathbf{i}$ & -njunbulu & -bulu & $-n j \mathbf{i}$ & $-j i n i$ & -njuru & $\mathbf{j} \mathbf{i}$ \\
\hline Warnman & & & & $(n \circ t$ & $u$ s e d ) & & & & & & \\
\hline Julbaridja & - ṇa & $-n$ & $-\varnothing$ & $-1 \mathbf{i}$ & $-1 i d j u$ & -1 unbula & -bula & $-1 a$ & $-\operatorname{ladju}$ & -njura & $-\mathbf{j a}$ \\
\hline Bidjandjadjara & - ṇa & $-n a$ & $-\emptyset$ & $-1 \mathbf{i}$ & $-1 i d j u$ & -bula & -bula & $-1 a$ & - ladjh & $-1 a$ & $-1 a$ \\
\hline Walfbiri & - ṇa & $-n b a$ & $-\emptyset$ & $-1 \mathbf{i}$ & - lidjara & -mbula & -bula & $-1 i b a$ & $-n a l u$ & gulu & $-1 u \sim-i$ \\
\hline Mangala & - ṇa & $-n$ & $-n a$ & $-1 a$ & -yara & $-m b a l a$ & -bala & $-1 a$ & -nani & -njuru & $-n i y i$ \\
\hline Walmadjar1 & - ṇa & $-n$ & $-\varnothing$ & $-1 i$ & -djara & $-n$ & $-b i l a$ & $-1 i b a$ & $-n a$ & $-n$ & $\emptyset$ \\
\hline Djaru & -ṇa & $-n$ & $-\varnothing$ & $-1 i$ & -djara & -nbula & -bula & -liwa & $-n a l i$ & -ndalu & $-1 u$ \\
\hline Malngin & $-n a$ & $-n$ & $-\varnothing$ & $-1 i$ & $-n d j a$ & -nbula & -wula & $-1 a$ & -nda? & $-n d a$ & $-1 u$ \\
\hline Mudbura & - ṇa & $-n$ & $-\emptyset$ & - liwula & $?$ & -nbula & -wula & $-1 a$ & $-n a l u$ & -nda & $-1 u$ \\
\hline Ngand1 & - ṇa & $-n$ & $-\varnothing$ & $-1 \mathbf{i}$ & & -nbula & -balu & -1 iba & - nalu & -nda & $-1 u$ \\
\hline
\end{tabular}


Table 11: Free Pronouns of Western Desert and West Coast Languages of Western Australla

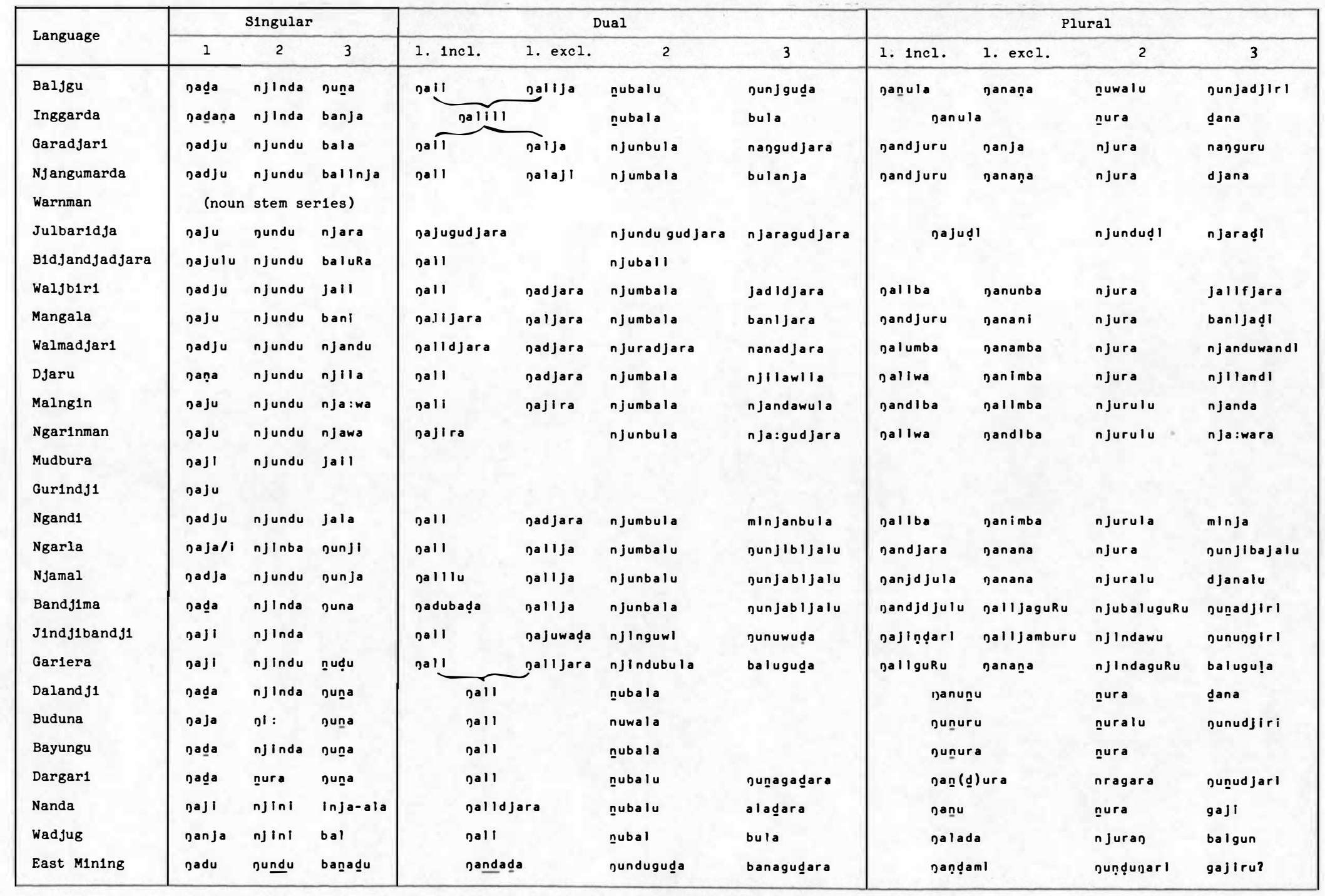



Table 12: Pronoun Sets 1n Languages of Arnhem Land and Barkly Tablelands ${ }^{1}$

\begin{tabular}{|c|c|c|c|c|c|c|c|}
\hline Language & \multicolumn{3}{|c|}{ S1ngular } & \multicolumn{4}{|c|}{ Plural } \\
\hline Mult1ple Class1fy1ng & 1 & $\hat{2}$ & 3 & 1. $1 \mathrm{ncl}$. & 1. excl. & 2 & 3 \\
\hline $\begin{array}{l}\text { 1. Larag1ya } \\
\text { 2. Gagadju } 2 \\
\text { 3. Gunw1njgu } \\
\text { 4. Manger1 } \\
\text { 5. Urn1ngangg } \\
\text { 6. Burera } \\
\text { 7. Mawng } \\
\text { 8. Nunggubuyu3 } \\
\text { 9. Wandarang } \\
\text { 10. Ngand1 } \\
\text { 11. Ngalagan } 4 \\
\text { 12. An1nd11jawgwa } \\
\text { 13. Anjula }\end{array}$ & $\begin{array}{l}\text { ga:nagga } \\
\text { ganjma } \\
\text { gaje } \\
\text { ga:b } \\
\text { go:g } \\
\text { gajbe } \\
\text { gabi } \\
\text { ga:Ja- } \\
\text { glga } \\
\text { gaja } \\
\text { gajga } \\
\text { gajuwa } \\
\text { gana }\end{array}$ & $\begin{array}{l}\text { Idana } \\
\text { DInjama } \\
\text { guḍa } \\
\text { no:w } \\
\text { no:wu } \\
\text { DIglbe } \\
\text { nuji } \\
\text { nuga- } \\
\text { njinju } \\
\text { nuwan } \\
\text { gindja } \\
\text { nunguwa } \\
\text { Jinda }\end{array}$ & $\begin{array}{l}\text { Ja:ba } \\
\text { na:wuna } \\
\text { nuilga } \\
\text { no:g } \\
\text { no:g } \\
\text { nibe } \\
\text { Janad } \\
\text { niga- } \\
\text { niwa } \\
\text { ninarl } \\
\text { nindja } \\
\text { napa:ga } \\
\text { Jiwa }\end{array}$ & $\begin{array}{l}\text { darandira } \\
\text { manemanama } \\
\text { ga: } \\
\text { garga } \\
\text { garagu } \\
\text { gajlribe } \\
\text { garwurl } \\
\text { naguru- } \\
\text { galbur } \\
\text { njarggara } \\
\text { Durga- } \\
\text { na'guruwa } \\
\text { gambala }\end{array}$ & $\begin{array}{l}\text { Jarajara } \\
\text { ga:dama } \\
\text { ga:d } \\
\text { Janeminu } \\
\text { ganiminun } \\
\text { njajirlbe } \\
\text { gael } \\
\text { nuru- } \\
\text { njibur } \\
\text { njIra } \\
\text { Jirga- } \\
\text { Jiruwa } \\
\text { janu }\end{array}$ & $\begin{array}{l}\text { gurangura } \\
\text { namanama } \\
\text { guda } \\
\text { Jiniminu } \\
\text { Jiniminun } \\
\text { nijiribe } \\
\text { nuwuri } \\
\text { nuguru } \\
\text { gudbur } \\
\text { nugara } \\
\text { nurga- } \\
\text { nun'guruwa } \\
\text { Jiru }\end{array}$ & $\begin{array}{l}\text { bidenbira } \\
\text { nu'womanama } \\
\text { beda } \\
\text { miniminu } \\
\text { minuminun } \\
\text { buribe } \\
\text { we:nad } \\
\text { wuguru } \\
\text { wudbur } \\
\text { banari } \\
\text { burga- } \\
\text { aburuwa } \\
\text { alu }\end{array}$ \\
\hline $\begin{array}{l}\text { Dual Classifying } \\
\text { 14. Wogady } \\
\text { 15. Nagara } \\
\text { 16. Gunav1dj1 } \\
\text { 17. Mara } \\
\text { 18. Djawan } \\
\text { 19. Alawa }\end{array}$ & $\begin{array}{l}\text { gadjana } \\
\text { ga: raba } \\
\text { gajaba } \\
\text { gina } \\
\text { garg } \\
\text { gina }\end{array}$ & $\begin{array}{l}\text { ganja } \\
\text { nJe:Jaba } \\
\text { nJinjdJaba } \\
n I: J a \\
\text { gin } \\
\text { nJangana }\end{array}$ & $\begin{array}{l}\text { dJanjldJ } \\
\text { na:gaba } \\
\text { nagajaba } \\
\text { naggaja } 5 \\
\text { ga:Ju } \\
\text { danja }\end{array}$ & $\begin{array}{l}\text { narera } \\
\text { nubaraba } \\
\text { naragajaba } \\
\text { naruwinja } \\
\text { njaran } \\
\text { njalu }\end{array}$ & $\begin{array}{l}\text { Jara } \\
\text { Dlbaraba } \\
\text { njaragajaba } \\
\text { niruwinja } \\
\text { njaran } \\
\text { galu }\end{array}$ & $\begin{array}{l}\text { nawara } \\
\text { nubaraba } \\
\text { naragajaba } \\
\text { nuruwinja } \\
\text { njuran } \\
\text { wulu }\end{array}$ & $\begin{array}{l}\text { baramldJ } \\
\text { be:baraba } \\
\text { barabajaba } \\
\text { walaja } \\
\text { buran } \\
\text { Juludanja }\end{array}$ \\
\hline $\begin{array}{l}\text { Non-Classify1ng } \\
\text { 20. J1wadja } 6 \\
\text { 21. Margu } \\
\text { 22. Amarag } \\
\text { 23. Ranjbarngu } \\
\text { 24. Buwan }\end{array}$ & $\begin{array}{l}\text { Jabl } \\
\text { Jada } \\
\text { Jauwa } \\
\text { JInda } \\
\text { JeJ I }\end{array}$ & $\begin{array}{l}\text { nujl } \\
\text { niḍl } \\
\text { wamba } \\
\text { danda } \\
\text { njin }\end{array}$ & $\begin{array}{l}\text { djanad } \\
\text { nIJad } \\
\text { wandjag } \\
n l ? d a \\
n I n\end{array}$ & $\begin{array}{l}\text { Jaga- } \\
\text { jor }\end{array}$ & $\begin{array}{l}\frac{\text { jarl }}{\text { wadab }} \\
\text { Janda- } \\
\text { nJe: } 1\end{array}$ & $\begin{array}{l}\text { nuwuri } \\
\text { vanani } \\
\text { nurawa } \\
\text { nagunda- } \\
\text { no: } 1\end{array}$ & $\begin{array}{l}\text { wanad } \\
\text { nagaginja } \\
\text { Jirimbag } \\
\text { bunda- } \\
\text { bunda }\end{array}$ \\
\hline $\begin{array}{l}\text { Suff1xing Languages } \\
\text { 25. Gubabw1yngu } \\
\text { 26. Wan'gur1 }\end{array}$ & gara & $\begin{array}{l}n 1 \\
\text { nunu }\end{array}$ & $\begin{array}{l}\text { naj } 1 \\
\text { na:n }\end{array}$ & $\begin{array}{l}\text { (na) II muru } \\
\text { galma }\end{array}$ & $\begin{array}{l}\text { (na) naburu } \\
\text { ganabu }\end{array}$ & $\begin{array}{l}\text { numa } \\
\text { numa }\end{array}$ & $\begin{array}{l}\text { walala } \\
\text { danal }\end{array}$ \\
\hline $\begin{array}{l}\text { Barkly Tablelands } \\
\text { 27. DJ1ng1l1 }\end{array}$ & Daja & $n(\mathrm{~J})$ ama & - & Duruwala & Dlriwala & guruwa l a & - \\
\hline
\end{tabular}

1. Only masculine forms are given here.

2. Gagadju has feminine forms for all but f1rst singular.

3. These add -wadj when independent.

4. The plurals suffix gabbul = 'three'.

5. Feminine gajara.

6. See Mawng forms also. 

*nura commonly, but probably more anclently *nu-run.

Forms of this *nurun are found in the northern

Kimberley and Arnhem Land on one side, and In Awaba of New South Wales central coast on the other. In Ngarinfin, for example, the plural pronouns are:

$$
\begin{array}{ll}
\text { 1. Incl. } & \text { na-run } \\
\text { 1. excl. } & n j a-r u n \\
\text { 2. excl. } & \text { nu-run } \\
\text { 3. excl. } & \text { bin-dun }<\text { bin-run }
\end{array}
$$

In Awaba there is no inclusive-exclusive distinction, but the pronouns are (1) plural jeen (probably for naj-un < ja-run; (2) plural nu-r-a < nu-r-un (genitive case nu-run-ba). The wide occurrences of this form In Australian are set out on Dlagrams $I$ and II, and they are instructive. It might be added that the -rplurals have still other occurrences in addition to these with *nurun. These forms also w1ll probably enable the pronoun for thou to be set down as *nu rather than *nun, $n i n$ or any of the forms that have been used hitherto.

3. Plural forms did not orlginally, even when established, distinguish between inclusive and exclusive, and it is possible to trace the methods by which they were produced, although outside the scope of the present writing. Some of these can be worked out by study of Tables 10 and 11, which refer to the WD languages.

These outline remarks must suffice for the present moment. They establish the main features of the pa- set of pronouns, of EA perlod, wh1ch are not only basic to the languages involved, but are basic to Australian language in general. The languages which do not share them are not to be reckoned within either $\mathrm{EA}$ or $\mathrm{CA}$.

\subsection{Pronouns of the Western Desert Languages}

The third serles of pronouns is that of the WD languages, and these are to be regarded as $C A$ : Judging from Warnman, they w1ll be replacements for an earlier - now lost - set of pronouns formed by adding a possessive suffix to a noun. The present sets are not only later than those of EA (of any kind at all), but are bu1lt on EA2 roots, and their constitution as constructed forms is obvious as soon as they are 
Diagram II: Distribution of - $r$ - Pluraliser in Arnhem Land Languages

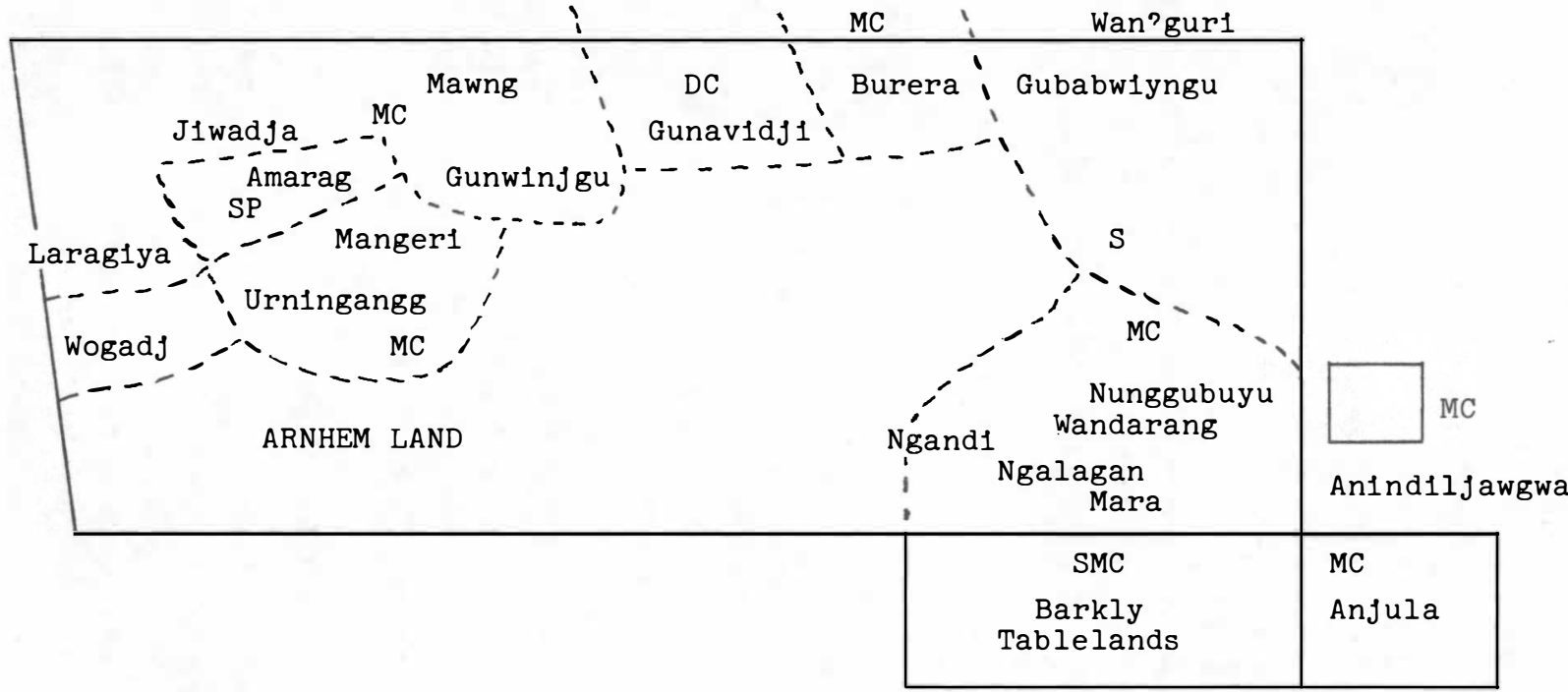

\footnotetext{
MC = Multiple Classifying (prefixing)

$\mathrm{DC}=$ Dual Classifying

SP $=$ Simple Prefixing

$S=\operatorname{Suff} 1 \times 1 \mathrm{ng}$
} 
analysed. Capell offered an analysis of these as early as 1955 (Capell 1955). So far this has not been controverted, and it is here taken as correct in outline, with a little more detall added. It would seem that the WD languages originally lacked pronouns as a category, but the situation here was not the same as elsewhere. The word order in these languages was at least a preferred Vso, and the pronoun subject or object, was added to the initial verb. Certain languages began to depart from this usage and evolved a 'catalyst' which carried the pronouns - but this is another story and will be dealt with in 3.6. The chlef thing about it was that pronouns did not begin an utterance. It was only at a later stage, when svo order came to be accepted, that the problem of a sentence initial that was not a verb arose and a way was found to deal with 1t. Whereas the EA pronouns (whether $\mathrm{EA}_{1}$ or $\mathrm{EA}_{2}$ ) could begin a sentence and the verb might not bear any marker of person at all, the earliest CA utterance with initial verb carried a person marker as a suffix to the verb and was therefore second in order in the sentence. Tables 9 and 10 show the fully developed systems of $C A$ pronouns as found in the modern WD languages. It remains to discuss and explain the tables, and to show the history of the AT system that characterises these languages. The origin of the AT system and 1ts real meaning belongs to the study of CA syntax and is not dealt with at this point.

It w1ll be seen 1mmediately that Table 10 contains only suffixed pronouns, 1.e. there are no free forms. Th1s is the basis of the claim that WD pronouns were originally only suffixes to verbs and, by reason of the syntactic rules of these languages, were affixed at times also to non-verbs. The main rule is that a pronoun must stand second In the sentence if $1 t$ is a subject and, if it is an object, must follow immediately on this subject pronoun: $\mathrm{V}+\mathrm{P}_{\text {sub }}+\mathrm{P}_{\text {obj }}$. This holds good whether a language has catalysts or not. The development of Independent pronouns came about with the adoption of SVO or SOV order, and this happened under the influence of the earlier language type. A set of independent pronouns was then developed; and 1t may be called a set because its membership was so much alike in all the languages that it can hardly be regarded as arising at more than one point of time or place. Moreover, the developed forms are mostly ergatives, whether the verb is transitive or not, and some are even double ergatives. Th1s would suggest that the original CA languages (whatever they were; they can be Judged only by Warnman nowadays) did not have an ergative: this came later, but its orlgin was then so well forgotten that another ergative ending could be added to 1 t. 
Th1s theory 1s directly opposite the one propounded by K.L. Hale who says he does not regard the Warnman pronouns (as added to verb stems) as re-creations. One example (G.N. O'Grady and C.F. and F.M. Voegelin 1966) shows uses of -na in more than one part of a single utterance, as in the following case (In which O'Grady's spelling is retalned, but the elements of the utterance are 1solated):

$$
\begin{array}{ccc}
\text { para-lu-ṇa-nku paral }{ }^{y_{i}} t^{y} \text { inka-ṇa para-nku-ku } \\
I-\text { erg.-I-for-you boomerang make-I you-for }
\end{array}
$$

There are other ways given by O'Grady for expressing the same 1dea but this one 1s enough for the 1llustration. Here there is a typical WD repetition of bound pronouns, which are added to the noun (para-), the verb (tyinka-) and subjected to AT treatment. The language has been as definitely transformed by the WD element as English structure by certain features of French, as in the case of Old English 'me was given a book' which gave way to 'I was given a book' because French demanded that the subject begin a sentence. Old English could allow Inttial dative + verb; French demanded subject + verb.

What Hale says (referring to Waljbirl but held to be general) is: 'I think it is reasonable to propose that the source of pronominal clitics in Walfbirl is in fact independent pronouns which, at some stage in the prehistory of the language, became unstressed and were attracted into clitic position (that is, second position) in accordance with a principle of clitic placement which is extremely widespread among the languages of the world' (Hale 1973:340). If the probab1lity of the theory depends at all on 1ts simpliclty, that offered here seems simpler than Hale's and is therefore more likely.

If the present explanation is accepted, the Warnman ergative paralu, $I$, would be a comparatively modern use. If the writer's theory (Capell 1972:32-5) is right, then the CA languages began to spread eastwards about 6000 B.P. Th1s proposition is advanced on archaeologlcal grounds; the tribes probably spread westwards at an earlier. date, and has a more profound effect, as Warnman structure, compared with vocabulary, suggests.

Ultimately, a full set of Independent pronouns developed, which could be sentence-initial, and take case endings in oblique cases just like nouns. These independent forms are shown in Table 1l. They seem to be based on those of the north-west and west coast languages, which are finally EA in origin. From this point of view also, CA appears to be the latest level of Australian development. The disagreement between Hale and the present writer is concerned with the 
actual process of formation. Hale regards the free pronouns as basic and the clitic forms as secondary; Capell takes the opposite point of view as regards development. In regard to final result there is no difference.

Whatever their origin, within the set of $C A$ pronouns there are some differences that suggest stages of development, along the following IInes:

1. First and second person singular are practically universal, and they are in ergative form but not restricted to ergative meaning. The various ergative endings are all present (-da, -ju, -lu etc.) and their distributions are probably not haphazard. The distribution of singular forms also is not haphazard. Glass and Hackett (1970:49) point out an interesting fact in Bidjandjadjara when they say: 'There are only two personal pronoun stems in Ngaanfatfara (sc. dialect): the first person stems /nayu/ and /nanku/ and the second person stem /nyuntu/'. There is no third person pronoun, and non-singulars are built on these two stems which were originally without specific dual and plural forms. This was earlier noted as a feature of early Australian language, and 1t means that although the WD languages are 'late' in many regards they are still quite anclent in terms of absolute history.

2. In the plural there is common use of *nura for second person. In some languages it serves also as a singular. What has been sald about EA pronouns therefore holds good in these WD pronouns also as regards the marking of a plural by $-r-$, and the Arnhem Land sets agree in this apparently basic Australian feature also. In the third person there is a regional separation between ba and nu- or pu- forms which is found likewise in the eastern EA languages. Inclusive-exclusive distinction occurs on a regional basis and something more will be sald about this. Where both are present, formation and patterning can be mapped.

3. The construction of the dual can be analysed in an instructive way, when 1 is noticed that in some of the WD languages one says $I$ two, not we two, e.g. 
Julbaridja naju gudjara, I two; njundu gudjara you two; njara gudjara, he two. In this language there is also the suffix-di, which shows plurality in nouns and also in pronouns (the pronoun is still apparently a noun subcategory): ga-ju-di, I-erg.plur.; njundu-di, you-erg.-plur., gara-di, he-erg.plur. This makes it perfectly clear that the original pronouns, even in WD were only first and second person singular - and in Bidjandjadjara they are still such. This phenomenon is even older in WD languages, it would seem, than in the Altalc languages. In these latter, although they do have a set of plural pronouns, the older Chagatay Turkish may superadd the plural -lär to biz, we, and make a double plural bizlär. A careful survey of Table 11 will make these varled processes of 'fllling in the gaps' clear; also 1t will bring out two further Important points:

1. Some languages bulld a dual with *buladj, the $E A$ word for two, while others use the CA equivalent, * gudara.

2. Some languages have no distinction of inclusive and exclusive in the first persons non-singular, but others have 1t. Those that do not have the distinction, use *nali for you and $I$ and also he and $I$, and *na-na for we as a plural. Where the distinction has been developed, it rests on some alteration in the use of the base words; *nali becomes only inclusive, and *nali-ja provides for he and $I$; in the plural *nana-na becomes he and $I$, using the older -na for $I$. It is the inclusive that is the Innovation, although the Table gives very little indication as to the method of 1ts formation. Th1s appears more clearly in the EA lists already discussed. There are several instances involving the nominal pluraliser, showing clearly that the pronoun throughout of WD remains a subcategory of the noun, as mentioned above.

It 1 s not necessary to discuss these forms further; reference to Capell 1955 will show the possibilities from the historical viewpoint. 
The lack of inclusive-exclusive distinction may not be a measure of age: such distinctions may be linguistic rather than historical, as Hollenbach (1970) has shown: such a feature may be of phychological origin.

The elaborate process of development undergone by the original two pronoun roots - first and second person singular - of the Australian languages stands out clearly in the central area of the Western Desert, a point that has been recognised and emphasised by Glass and Hackett (1970:49-50) in their grammar of Bidjandjadjara, in which they remark:

'There are only two personal pronoun stems in Ngaanyatjara: the lst person stem /ngayu/ and /nganku/ and the 2nd person stem nyuntu. These occur with slot-markers as shown below following an accusative system.

\begin{tabular}{|c|l|l|l|l|}
\hline Person & Subject & Ablative & Object & Possessive \\
\hline $\begin{array}{c}\text { 1. } \\
2 .\end{array}$ & $\begin{array}{l}\text { ngayu-lu } \\
\text { njuntu-lu }\end{array}$ & $\begin{array}{l}\text { ngayu-la } \\
\text { njuntu-la }\end{array}$ & $\begin{array}{l}\text { ngayu-nya } \\
\text { nyuntu-nya }\end{array}$ & $\begin{array}{l}\text { ngayu-ku } \\
\text { njuntu-ku }\end{array}$ \\
\hline
\end{tabular}

These pronouns do not distinguish number. However, number distinctions can be made by the use of the enclitics which occur after the slot-marker. Forms without enclitics may be assumed to be singular. However, singular enclitics do also co-occur with the pronouns, when they may be regarded as having an emphatic sense.'

Glass and Hackett then list the whole serles of dual and plural forms. The inclusive-exclusive distinction is accounted for also. These are produced by adding the suffixed pronouns to the stem:

\begin{tabular}{|c|c|c|}
\hline Person & Subject & Object \\
\hline 1. sing. & naju-lu-ṇa & $\eta a j u-1 u-n ̣ i$ \\
\hline 1. dual & & \\
\hline Incl. & gaju-1u-1i & $\eta a j u-n j a-1 i-n j a$ \\
\hline excl. & Daju-lu-lin & $\eta a-j u-n j a-1 i-n j a-d j u$ \\
\hline 1. plur. & & \\
\hline Incl. & $\eta a-j u-1 u-1 a$ & $\eta a-j u-n j a-l a-n j a$ \\
\hline excl. & $n a-j u-1 u-1 a n$ & $\eta a-j u-n j a-l a-n j a-d j u$ \\
\hline
\end{tabular}


The second person is treated similarly, and the process of agglutinative expansion becomes clear, including the fact that the object is indicated by $-n j a-t w i c e$ over in the dual and plural forms. It is perfectly clear that these languages have adopted a system entirely different from that of their own nature and have done it so clumsily that the steps are all perfectly clear. The writers of the Ngaanyatjara Grammar have not hyphenated the forms as is done above: had they done so, the dlagram would have been so much the clearer.

That this was not only the basic process of pronoun expansion is clear; comparison with other languages shows that each has proceeded in 1ts own way. The dual number is especially interesting in this connection, for in some WD languages there is for you two njunbula

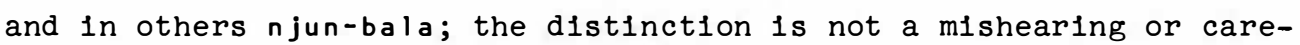
less spelling, but a pointer to a different interpretation: njun-bula is you-two, whereas njun-bala is you (and) he - a different concept of duality, a kind of inclusive-exclusive second person distinction.

In studying these forms, it is impossible to miss the fact that something has gone wrong: the ergative is present throughout whether the pronoun is subject of a transitive or an intransitive verb - the distinction is levelled out altogether. Not only so, but the pronoun is a double ergative form: $(\eta a+j u)+l u$. The verbal person marker Is then superadded: $\{[(\eta a+j u)+1 u]+n a\}$. It is, therefore, necessary to study this extraordinary phenomenon, and this will be done below. A few phrases. In Bidjandjadjara will show how the system functions in general; reference should be made to Capell (1972) for detalls of the various languages. There are in fact several ways of saying the same thing - with some change of emphasis, but not of meaning. Examples will be used from Waljbirl:

$$
\begin{aligned}
\text { I wizl hit you: } & \text { (a) bu- ngugu- na -nda } \\
& \text { hit-wizl- I- you } \\
& \text { (b) gajulu-na-nda bu-ngugu } \\
& I-I \text {-you hit-will }
\end{aligned}
$$

In the second case the emphasis is on $I$ as actor: for non-emphatic actor the (a) example is valid. If there is an actor indicator it comes immediately after the first word of the sentence

$$
\begin{aligned}
& \text { djila -na- ngu ba-ru } \\
& \text { kangaroo-I-for-you shoot-will }
\end{aligned}
$$

This type of sentence involves the head word as the base to which the actor is added: if it is a full pronoun, the actor is added to it but, 


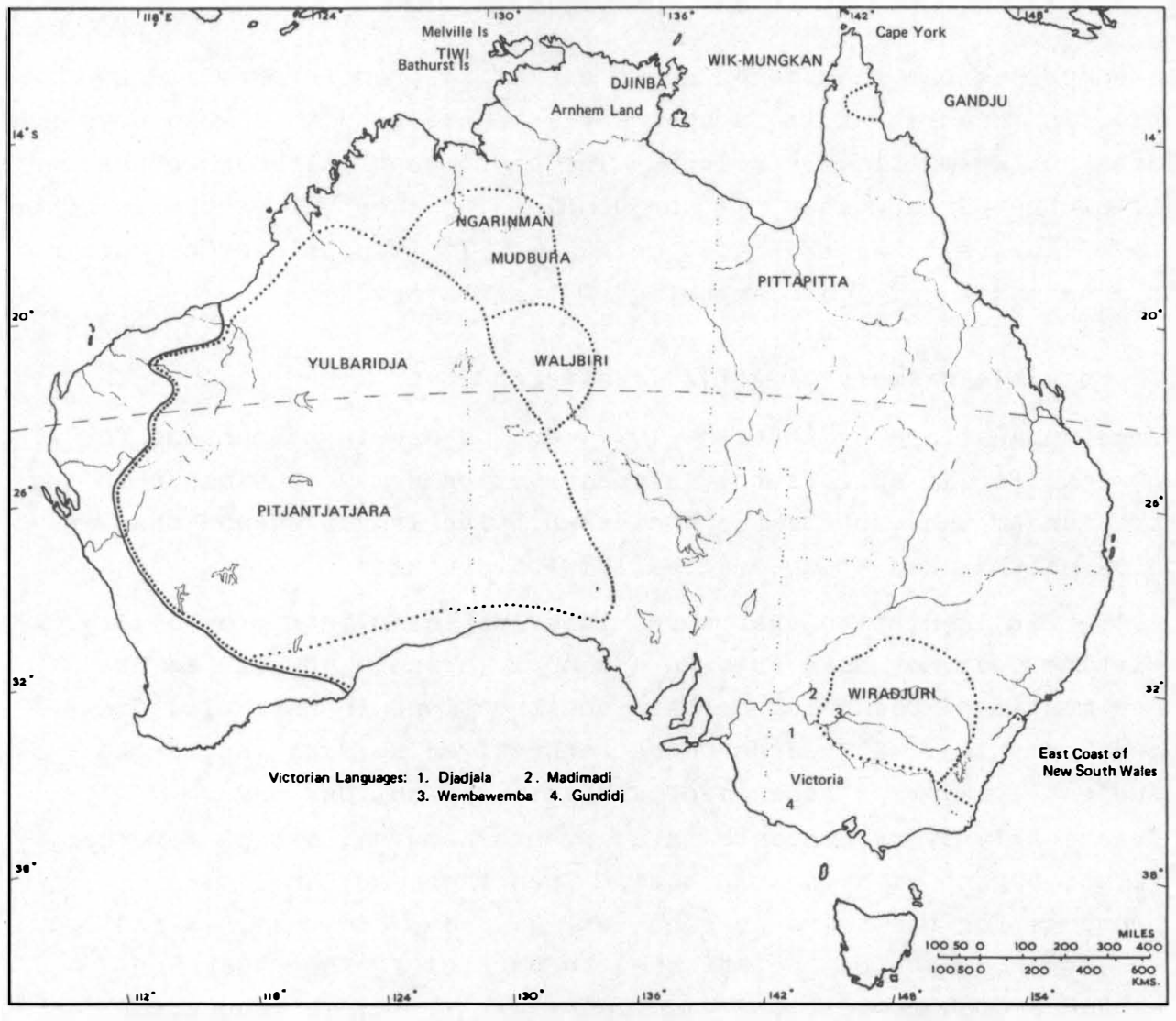

Map 4: Tentative Map Showing Distribution of Affix-Transferring lenguages in Australia (besed on informotion from Capell's mep, linguistica 87, 1973, p.7) 
in this case, there is extra emphasis on 1t. Certain other types or classes of word take the suffixed pronoun when they are headwords amongst them negatives and interrogatives:

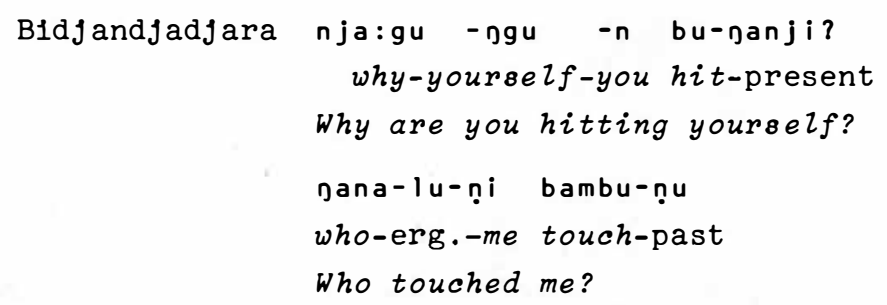

Th1s comprises the phenomenon known as 'affix transference' (abbreviated as AT), in which an affix is apparently transferred to a word to which it does not grammatically belong. The phenomenon, although character1stic of the WD languages, is not confined to them but occurs in other areas of Australia as indicated on Map 4. Is 1t possible to explain this phenomenon and learn anything of its history?

\subsection{Possible History of Affix Transference}

Some suggestions by Anttila (1972) are of use in accounting for AT phenomena, for 1t appears that a construction somewhat similar to the Australian AT was part of the ancient Hittite language, and that in both cases this has to do originally with syntax:

'But it is Hittite that turns this suspicion into probability. Hittite does not have such an anaphoric pronoun at all [as he has mentioned regarding certain constructions in Sanskrit, Greek and Germanic]. It has sentence connectives su, and (unchanged subject), ta, then (change of subject) and nu, and now. Practically every sentence in a given discourse, except for the first, begins with one of these. Then there are enclitic pronouns for the third person, -as, he, -an, him, -at, it and -us, them, which can be attached to particles other than the sentence connectives, for example, -wa( $r)-$, 'direct quotation': nu-war-as, and now he said: "...", or nu-smas-an, and now you him. But when no other particles intervene we get the following conglomerates of the sentence connective plus the enclitic pronoun:

$\begin{array}{lccl}\text { nas } & \text { tas } & \text { sas } & \text { and he (nom. masc. sing.) } \\ \text { nan tan san } & \text { and him (acc. masc. sing.) } \\ \text { nat tat } & - & \text { and } i t \text { (neut. sing.) } \\ \text { ne } & - & \text { se } & \text { and they (nom. masc. plur.) }\end{array}$


The formal simllarity of the last two columns to the pronoun *so/*to is obvious. There must be a historical connection. The best inference is that the Indo-European pronoun is a fusion of the earlier sentence connective plus the enclitic pronoun' (Antt1la 1972:359).

Something very similar will have happened in the Australian languages, where enclitic pronouns occur in the WD-CA group, entirely different in form (at least as regards the singular number) from the other Australian pronouns, at any rate when used as suffixes. It is not a case of a sentence connective leading to a base to which the person markers are added, though the 'catalysts' of some WD languages may well be such (see 3.8.). In the WD languages, the tendency to place subject and object pronouns before the verb has led to the markers belng attached to the headword by a process which is ultimately one of loss of stress. Even if the cardinal pronoun happens to begin the sentence, WD languages w1ll add the pronoun suffixes to this, e.g. Bidj and $j$ adjara:

$$
\begin{array}{ll}
\text { Bidjandjadjara } & \text { gajulu-na-nda bambu-ṇu } \\
& I-I-\text { you } \quad \text { touch-did } \\
& I \text { touched you. }
\end{array}
$$

In such a case the subject is strongly emphasised.

A detalled study of AT phenomena, together with an attempt to reconstruct an outline of their probable history will be found in Capell 1972. Since then, however, he has had further thoughts on the matter, and 1t seems that another explanation arises from the comparison with Hittite, namely, that the 'transfer' is more a matter of pronunclation than of grammatical change; the following paragraphs will show what is meant by this.

Generally in Bldjandjadjara the order $S+0+V$ holds good:

$$
\begin{array}{ccc}
\text { Franklu linyatju yalti-ranjtjul } \\
\text { Frank called }
\end{array}
$$

If third person singular is zero, the pattern can still be considered to hold good:

$$
\begin{aligned}
& \emptyset \text { pitja-nu } \\
& \text { he came he tjananya nja-pu }
\end{aligned}
$$

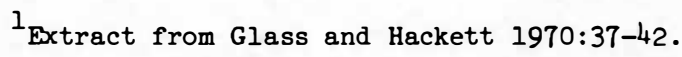


Conjunctions call for an extra person marker:

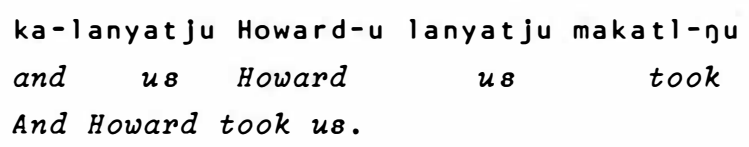

There may have been a feeling that someone was needed to be talked about, and the indicator was given along with the confunction.

Interrogatives can be thought of as not requiring any change of position if the pronoun, even though only a single consonant, is regarded as preceding the verb:

$$
\begin{gathered}
\text { wanyatjatja }-n \text { tuju-nu } \\
\text { where you put (it)? }
\end{gathered}
$$

A seeming double transposition is to be explained along the same IInes:

$$
\begin{gathered}
\text { wanyatjatja-na-nta nja-nu? } \\
\text { where I you saw? }
\end{gathered}
$$

In this case the AT phenomenon is more apparent than real; but it has carried over into many other languages, in addition to the original WD group where 1t originates. But - and this is the important point which sets these languages apart - the actual forms of the enclitic pronouns are different from those in other areas of Australia. They would be: 


\begin{tabular}{|c|c|c|c|c|c|c|c|c|}
\hline \multirow[b]{2}{*}{ Singular } & \multicolumn{4}{|c|}{ Subject } & \multicolumn{4}{|c|}{ Object } \\
\hline & $\begin{array}{c}\text { 1. Incl. } \\
-\end{array}$ & $\begin{array}{l}\text { 1. excl. } \\
\text { ṇa }\end{array}$ & $n^{2}$ & $\emptyset^{3}$ & 1. Incl. & $\begin{array}{l}\text { 1. excl. } \\
\text { ni }\end{array}$ & nta & $\mathrm{lu}$ \\
\hline Dual & $1 i(n)$ & $1 \mathrm{itju}$ & pula $(n)$ & pula & linja & linjatju & pulanjanta & pulanja \\
\hline Plural & $1 a(n)$ & latju & ya $(n)$ & ya & lanja & lanjatju & tjananjanta & tjananja \\
\hline
\end{tabular}

If this set of suffixes is broken down into its primal forms, the result is:

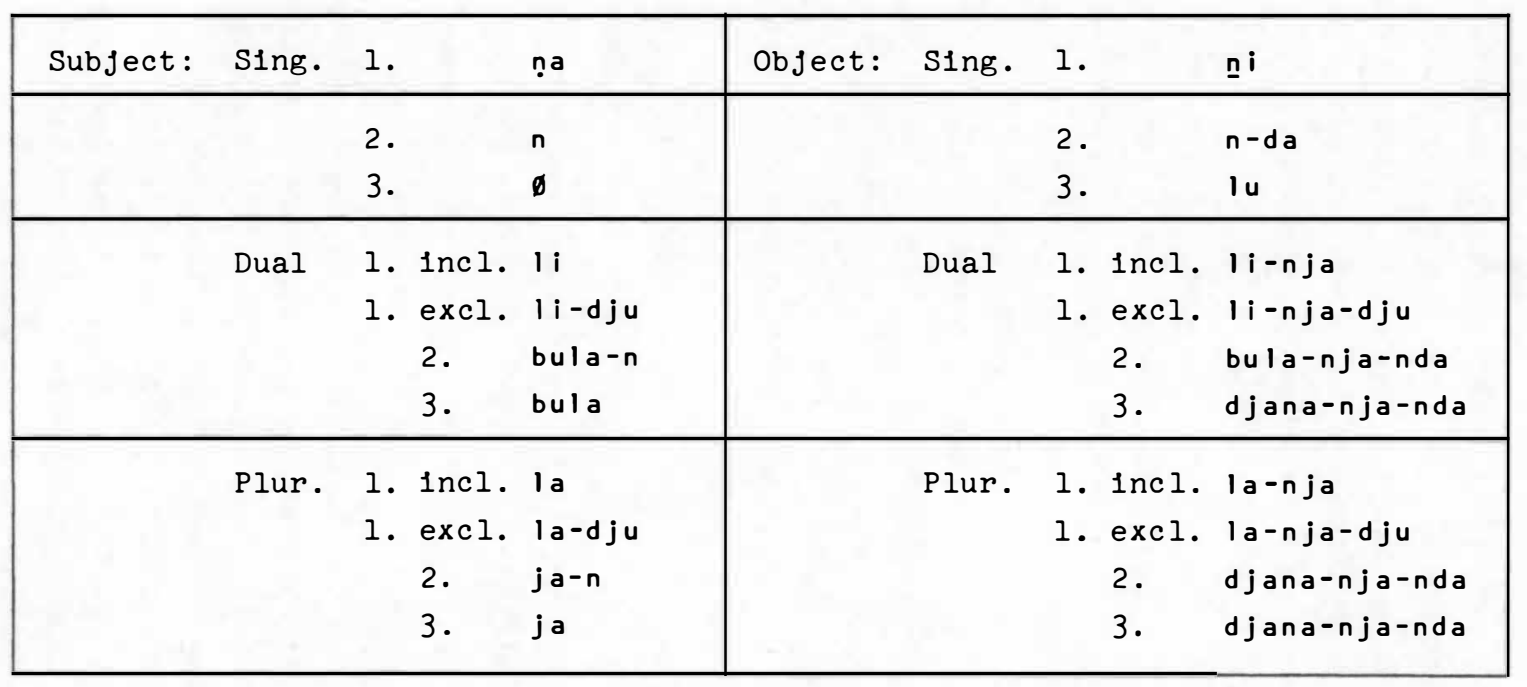


These sets show a composite history wh1ch 1s rather complicated. Firstly, *bula-n is two-thou, as in the non-WD *buladj, two with suffixation of $-n$, 'second person singular'. Yet this *buladj is not a numeral in these languages, and the original final palatal plosive has already been lost before the numeral came into use in the eastern WD languages. The true CA numeral for two 1s *gudara; *buladj appears in some WD languages but not as a free numeral, only in suffix form with dual number. The plural object non-first person is djana, also taken to be a CA form, but possibly, from 1ts eastern occurrences, also EA. Each set points back to a time when there was as yet no division into three persons: 1t was an inclusive-exclusive person, as 1t still is in the Kiwal area of New Guinea. There are, then, three steps to be reconstructed: (1) inclusive-exclusive person system, (11) second person - $n$ developed along with -na first person, and (111) distinction of three persons. The 'objective' $-n j a$ is then taken over from the declension of nouns - which pronouns historlcally are - and another exclusive person marker, $-d u,-d j u$, and th1s, basically meaning $m e$ and so is by 1tself the first person singular possessive marker in most WD languages.

If there is any truth in this analysis, the example first given w1ll simply be

$$
\begin{aligned}
& \text { na-ju-lu-na-nda bambu-pu } \\
& \text { I-erg/-erg-I-you touch-past }
\end{aligned}
$$

In this, jajulu is an emphatic subject, not necessary, and not disturbing the sov order. However, such an utterance as

$$
\begin{aligned}
& \text { nja-pu- na-nda } \\
& \text { see-past-I-you }
\end{aligned}
$$

may seem to upset the scheme, but does not really do so, if it is remembered that the pronouns are enclitics, and as such they must have a support. They obtain this through change of position if there is nothing preceding them. Th1s prefixing - suffixing interchange is apparently of old standing in Australla dating from times of free order. If the verb stands first they must follow 1t just because they cannot stand alone: nelther can they be proclitics. There are therefore the two patterns:

$$
\text { 1. njánunanda }
$$

wh1ch are equivalent. The main stress in each case 1 s found at the beginning of the utterance. 
Abolition of a special AT phenomenon does not remove the need to explain the peculiarity hitherto discussed under that name. The explanation now required 1s: where did the set of pronouns come from? For the singular person markers are different from those generally used in other Australian languages.' Th1s w1ll be demonstrated below. How did bula two come to be involved in them when in WD languages *gudara is two? Why did this group begin from an inclusive-exclusive person type when apparently *EA distingulshed three persons?

The last question is further complicated in that in the independent pronouns these WD languages (= CA languages) do have three persons. It is only in the verb that the distinction is lacking, and this has been overcome more or less 'artificlally'. In the K1wal languages of New Guinea the same thing occurs. There are two separate persons in the verb but three pronouns. In the WD languages the pronouns are composite and far from 'primitive'. In a paper by Capell (1955:288), they have been studied and certain findings made. These findings are briefly:

1. Australian languages did not orlginally have a dual number. The earliest developed are found in some of the language 1solates and then there is only an inclusive dual of first person: Tiw1 muwa; EA developed nali which is now almost universal.

2. Inclusive-exclusive distinction is also absent from the earliest stratum of languages. Where 1 t is found, there is more than one type. In some WD languages, Walmadjar1, DJaru, Malngin, Ngarinman, Ngard1 and Wanayaga form one group; Garadjar1 and Mangala form another, and both are geographical blocs. Bidjandjadjara stands in fairly close relationship to the second set. In Mudbura the bulk of the cardinal pronouns are not used as subjects at all.

3. Two types of dual second and third person are found, one of which means you and he (*nju-bala), and the other you-two (*nju-bula), and in the third person a term which means they two, where the numeral is expressed by elther bula or gudara, and these numerals represent $\mathrm{EA}$ *buladj and $\mathrm{CA}$ *gudara respectively. The two systems cross each other geographically, showing that both are relatively early within WD even though the whole 1dea of a dual is late. 


\subsection{Cape York Pronominal Systems}

A study of these languages shows that they are relatively late, for in them *buladj often ceases to be a numeral at all, and the derivative bula may be a plural, they. Table 13 shows a selection of these languages. In the extreme north the suffix *-badj appears as a suffix-va (one of the few areas where the bilabial $v$ appears), and this has been studied in 3.4. above. Another mark of the lateness of the CY languages is the heavy loss of inftial consonants in some of them. For these see Hale (1976a) and Sutton (1976a).

The search for forms corresponding to the WD 'short pronouns', however, may well begin from $C Y$ also, for there the Wik-Mungkan language presents a set of suffixed pronouns which are rather like them. They are subject markers to verbs, and are set out as follows:

\begin{tabular}{|ll|cccc|}
\hline Person & 1. 1ncl. & l. excl. & 2 & 3 \\
\hline \multirow{2}{*}{ Number: } & singular & - & $-n a$ & $-n a$ & -wa \\
& dual & $-1 i$ & $-n a$ & $-w a$ & $-b u l a$ \\
& plural & & $-m b u$ & $-n a$ & $-w a$ \\
\hline
\end{tabular}

These forms look strange at first, but if they are regarded as originally enclitics, something of the strangeness disappears. The - ga form then shows * $\eta$ a as a suffix: the -na suggests the original syllabic form of WD $-n$, while - wa may quite well answer to EA ba, third singular, ergative -ba-lu found in parts of Western Australia; -bula retains its original value as a dual marker (two being most easily applied to the third person), and the only unexplained part is -mbu, we, showing no distinction of inclusive-exclusive.

There is much resemblance to the WD forms, and the absence of an inclusive-exclusive form occurs also in the languages of the extreme south-west, in the Narrinjeri group, Banggala, Meyu Gaurna and in the east coast languages such as Bandfalong and Durubul. In North Queensland it is lacking also in the Gugu- languages as a whole.

\subsection{The 'Catalyst' Systems}

\subsubsection{The Western Desert Languages}

In most WD languages there are person markers almost identical in form (and in the singular entirely so: the singular seems to be the basic set, dual and plural being later developments, as elsewhere in 
Table 13: Some Cape York Peninsula Pronouns

\begin{tabular}{|c|c|c|c|c|c|c|c|c|}
\hline & & Uradh1 & Kant $j u$ & Lamalama & Yalandf1 & Oykangand & Thayorre & Mungkan \\
\hline \multirow[t]{3}{*}{ Sing. } & 1 & a juva & gaja & ya & gaju & a J & $\eta \mathbf{j}$ & gaj \\
\hline & 2. & anduva & Duno & tuy & jundu & inan & nunt & nint \\
\hline & 3. & olovo & gula & luy & njulu & il & ñul & nil \\
\hline \multirow[t]{4}{*}{ Dual } & 1. Incl. & aliva & Dali & lata & ) & a $1 \mathbf{i j}$ & na & Dal \\
\hline & 1. excl. & - & Dana pa'amu & la 1 a & Id & a $\operatorname{linj}$ & gali & gan \\
\hline & 2. & anava & gu'ul pa'amu & pol & jubaj & upal & nI p & nip \\
\hline & 3. & ebura & pula pa'amu & 10 & bula & u 1 & $p u l$ & $p u l$ \\
\hline \multirow[t]{4}{*}{ Plur. } & 1. Incl. & ambo & Dampula & lapal & nand j in & ampul & namp & gamp \\
\hline & 1. excl. & - & Dana & lada & Dana & anjtan & Danjn & gan \\
\hline & 2. & anava & gu'ula & ro & jura & urr & nur & $n \mathbf{i} \mathbf{j}$ \\
\hline & 3. & ebura & pula & dey & djana & etn & peln & $\tan$ \\
\hline
\end{tabular}

References: Urað1: Bandj1 dialect, A. Capell fleld notes; S.H. Ray (1907b:272-3), w1th some differences and apparent contamination with Yaraikana.

Kantfu: Capell fleld notes.

Lamalama: D.C. Laycock (1969).

Yalandf1: R. Hershberger (1964:55-68).

Oykangand (Kunjen): B.A. Sommer and E.G. Sommer (1967).

Thayorre: A.H. Hall, unpublished thesis (1972).

Mungkan (W1k-Mungkan): M. Godfrey and H.B. Kerr (1964:13-34). 
Austral1a). These are set out in Table 10. In the languages north and south of these, no markers appear: the verb is invarlable for person. In Njamal, only the first singular is found: -na. The other known languages, Bandj1ma, Jindj1bandj1, Ngarluma-Gariera, Dalandj1, Buduna, Dharag1, Bayungu, Njungar, and the Mirning group, have none. In Nanda, the person suffixes occur in two forms, but they mark goal and benefactive, not subject.

Full sets of pronominal subject affixes occur in Baljgu, Inggarda, Warnman, Julbaridja, Bidfandjadjara and the closely related dialects, as shown in the Table. In the WD groups occurring in the Northern Territory, person markers are present, e.g. Walfbiri, but in certain of these they are added not to the verbal stem (which takes on tense/ mood indicators) but to certain particles which serve only as carriers and have been called 'catalysts'. These languages are found on the northern edge of the WD group (see Map 5).

Catalysts are bases which carry no lexical meaning but serve to support the markers of person both subject and object. Thus in Mudbura, let $\mathrm{C}=$ catalyst,

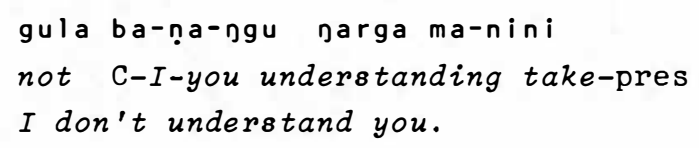

Here the auxillary verb ma-, take, is marked for tense, and subject and object are carried by the catalyst ba-. Note also that the pronouns are not shifted to the headword of the sentence but only to the catalyst. The sentence could then be arranged as:

$\begin{array}{lccllc}\text { Neg. Cat. Sub. } & \text { I.obj. } & \text { Dir.obj. } & \text { Verb-pres. } \\ \text { gula ba- } & \text { na- } & \text { ngu } & \text { narga } & \text { ma-nini } \\ \text { not } & - & I & \text { you } & \text { understanding } & \text { take }\end{array}$

keeping the same relative arrangement of parts, as in the WD languages, and the S-O-V word order.

Catalysts are found in the northern WD languages. In Walfbiri, the southernmost of them, both direct suffixation and catalysts are present (and not. Interchangeably); north of Waljbirl catalysts only are found in Djaru, Malngin, Mudbura, Gurindj1 and Ngarinman.

A quotation from NAAL may be helpful at this point:

'Thus an original freedom of arrangement came to be gradually limited in varlous ways in different areas. At scattered points outside the WD area a similar elasticity of order is still found in languages which have developed a fixed morphological system 


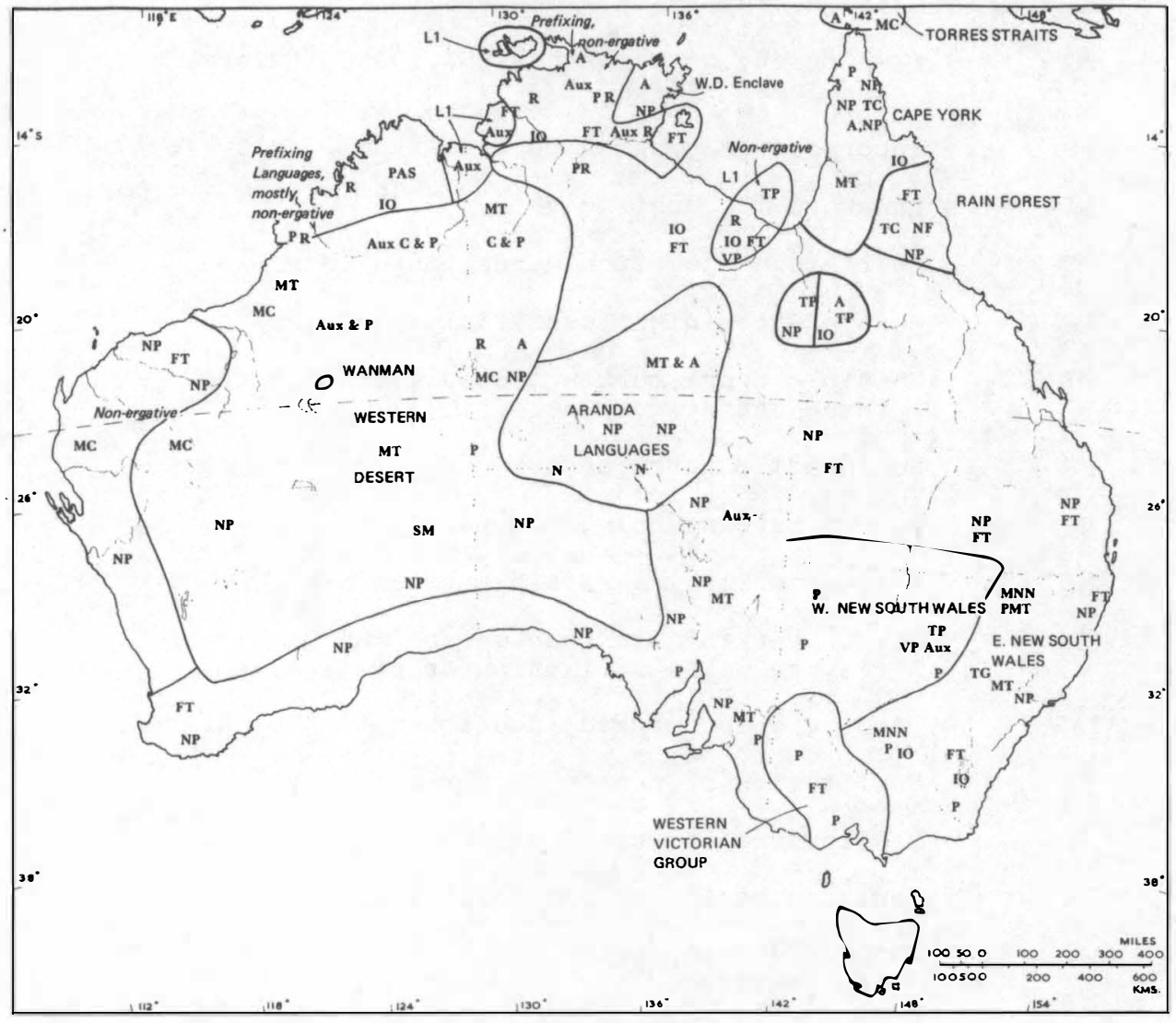

Map 5: Austratian Verbal Systems 


\section{LEGEND TO MAP 5: \\ AUSTRALIAN VERBAL SYSTEMS}

\begin{tabular}{|c|c|}
\hline Symbol & Explanation \\
\hline A & Aspect stressed rather than tense. \\
\hline Aux & Auxiliary verbs carry maln markers. \\
\hline C & Catalysts carry main markers. \\
\hline FT & $\begin{array}{l}\text { Few tenses, normally present, past, future } \\
\text { and Imperative. }\end{array}$ \\
\hline IO & Incorporated pronoun object as well as subject. \\
\hline LI & Language isolate(s). \\
\hline MC & Multiple confugation types (more than two). \\
\hline MNN & Morning-noon-night subdivisions of tenses. \\
\hline MT & $\begin{array}{l}\text { Multiple tense marking, subdivision of the } \\
\text { three main tenses. }\end{array}$ \\
\hline $\mathrm{NF}$ & No formal future (past and non-past only). \\
\hline $\mathrm{N}$ & Number marking only, not person. \\
\hline NP & No person marking within a tense. \\
\hline $\mathrm{P}$ & $\begin{array}{l}\text { Person marking for each person and number } \\
\text { (may go with suffixation or prefixation). }\end{array}$ \\
\hline PAS & Passive volce marked (subject not in ergative). \\
\hline $\mathrm{PR}$ & Prefixation of person markers. \\
\hline $\mathrm{R}$ & Realis-irrealis distinction made in moods. \\
\hline SM & Sentence medial or participial forms found. \\
\hline $\mathrm{TC}$ & $\begin{array}{l}\text { Two conjugation types, transitive and } \\
\text { intransitive. }\end{array}$ \\
\hline TP & Tense marking in pronoun as well as verbs. \\
\hline
\end{tabular}


so far as the regular suffixes are concerned. In the middle of South Australia Arabana can express $I$ am hot by anda nardanda or by gardanda anda; bad girl by gwija madlandi or madlandi gwija; my house may be wali andena, and my ear anden jirari.

'In this connection a useful concept is provided by Z1pf (Z1pf 1936:154) In his phrase "degree of ... configuration". He says: "the degree of ... configuration implies little more than this: the more firmly agglutinized, that is, the more immutable in arrangement, the constituent morphemes are in a word, the greater is the degree of crystalization. The differing degrees of crystallization of configurations can perhaps be best apprehended by comparing the crystallization of phonemes in a morphemeconfiguration, of morphemes in a word-configuration, and of words in a sentence-configuration; phonemes are normally far more crystallized in their configuration in a morpheme, than morphemes in a word, and morphemes in a word more crystallized than words in a sentence. In the decreasing order of crystallization from phoneme through sentence, there is increasing degree of cholce in arrangement. We shall find that these differences of the degree of crystallization are closely assoclated with other phenomena of language." What appears in the Australian languages is a gradually increasing "degree of crystallization".' (Capel1 1962:11-12.)

The catalysts found in the relevant languages of WD and Northern Territory are set out in the following table; for the present purposes there is no need to specify their exact usages in each language. Sometimes ba and na distinguish tense. Only Mudbura has a serles of speclal forms which need a note. The catalysts, then, are usually:

ba Julbaridja, Mangala, Walmadjar1, Mudbura, Ngarinman

Da Mangala, Walmadjiri, DJaru, Warnman

ju Malngin, Ngarinman, Ngard1, Gugadja

The two forms ga and gu are identical in origin and do not meet in the same language. There is also a ga in Bidjandjadjara and Walfbiri. In the latter language and in Wanayaga, the catalysts share the fleld with suffixation of the pronouns directly to verbal stems. In this use the time is always past. The form ba is also past, and there seems 
to be no difference between ba-ṇa Jani and Jani-ṇa, I went; but ga-ṇa jan-1s non-past; whether it is present or future depends on the ending of the verb, jan-i past or jan-gu future. In the neighbouring Gugadja, the catalyst alone is used

$$
\begin{aligned}
& \text { djaljgu gula nu-na-la nja-ngu } \\
& \text { today not C- I-him see shall }
\end{aligned}
$$

Two Arnhem Land languages also have this system: DJinba and DJinang. Of these 1t was written (Capell 1942, Part 2, p. 46):

' In DJinba, the verb is confugated in the present tense by means of the particle ba, which takes the shortened pronouns of the subject, and to them may be added those of the object in the transitive verb. Comparison with Mudbura may be made as follows: I shall go, I am going:

\begin{tabular}{|c|l|l|}
\hline Person & DJ1nba & Mudbura \\
\hline Sing. 1. & ba-nar garme & ba-ṇa janduru \\
2. & ba-ngarme & ba-n janduru \\
3. & ba-n garme & ba janduru \\
Plur. 1. Incl. & ba-lim garme & ba-!a janduru \\
1. excl. & ba-nanj garme & ba-nali janduru \\
2. & ba-ngej garme & ba-nda janduru \\
3. & ba-ndjan garme & ba-li janduru \\
\hline
\end{tabular}

The object forms differ somewhat in that DJinba then drops ba: Mudbura ba-na-ngulu I see you, but DJinba njur njane, (I) you see.'

In Mudbura, the most elaborated of these languages, combinations provide for more exact semantics.

'It has (1) ba, aorist; (2) bi, hypothet1cal; (3) $n j$, futurity; (4) nja...ba, with infixed pronouns, conditional;

(5) ba...ba, contingency. Thus, ba-n gana-ni majarima?

Have you eaten food? wandjuga ba? where is he? bi:dja njanana, he might see me (-dja = me); bi-nalanalu lananara, they would like to kill us; nja-na junguru, I'm going to give it to him; nja-na-ba ginanguja jali garu, ba-na baru-ru, if $I$ catch that boy I'll beat him; ba-ṇa-ba wandula, nja-na-ba njangala, I would catch him if I saw him (Capell 1940:426). 


\subsubsection{Catalysts other than Western Desert}

Another fact, however, is important. Catalysts are not confined to the WD set of languages. In NAAL, simllar phenomena occurring in other parts of Australia were not classified as catalytic in nature, but it is better that they should be. They appear in western V1ctoria, and in eastern and central New South Wales - both areas strongly affected by CA influence (as will. be shown later). They were found in Awaba by L.E. Threlkeld although he did not designate them by this term. They appear also in the Guringgay materlal complled but not published by him (Capell 1970). The area of their occurrence is thus prolonged to south and east of the WD. In Awaba and Guringgay there are catalysts ba-, ga-, ma- and na-. Threlkeld sought to analyse these (Threlkeld 1950). Such usages, to him, suggested certain basic 1deas:

'ba, actuality of verbal belng; the verb is in a verbal sense only; ga-, actuality of being personal, in any state, $i s$; ma-, actuality of causation, done; na-, actuality of personality. The person is the actual.' Capell suggested (NAAL:70): 'action as such, being as such, making, causing, and personal action' respectively. The WD pa- and pu- forms are the same as New South Wales ga-, purely vowel variants such as are very common in the Australian scene.

In Iyora (Sydney, New South Wales), ba-, ma- and da- are present, but here they serve as tense markers, and to the south and west of Sydney ma- is frequent but not the others. From their spread they seem to be CA forms only, though borrowed into other languages.

When ma- is considered, however, a transition is being made to auxiliary verbs and compound confugations, which are found in Queensland, Arnhem Land, and Northern Kimberley languages on a large scale. The phenomena are not quite the same but historically they may well be connected. The CA root for take is ma- and ga- is the root for bring, hold; these are used elther independently or as auxiliaries/catalysts in a wide scatter of languages. The important difference is that in these eastern languages, the WD $(=C A)$ person markers do not accompany them, but other sets of suffixed markers yet to be discussed are found.

\subsubsection{Auxiliary Verbs}

When ma as catalyst is considered, a transition to auxiliary verbs is being made, for this is the CA root ma-, take, as well as appearing as a catalyst in the WD languages and others. The two uses are not quite the same. When ma- is being used as a catalyst, there is no semantic factor involved; when it is being used as an auxiliary, the 
lexical meaning retains its force to a noticeable degree. For example, in Iyora ba- marks a present tense, and ma a future tense; the lexical meaning of either does not appear. Where it is used as an auxiliary, its meaning appears as 'action by carrying' or some such meaning. Moreover, it can in many languages appear as an independent verb, in some as an auxiliary, and in others as only a catalyst: the independent status would seem to be prior, as was probably the case of the other catalysts if they could be recognised. In the eastern languages where such forms occur, the WD person markers do not accompany the catalysts (ba-na, ma-na, etc.) but other sets of suffixes, yet to be discussed, take their places.

\subsection{Summary Survey}

There are thus three sets of languages on a geographical basis which do not possess true pronouns, one in Western Australia and two in eastern Australia. Warnman, in the WD area, stands quite by itself as might be expected: its noun-root is not the same as those in the east and could hardly be expected to be so if it is truly primitive or early Australia. In the east, western and central Victoria share two roots, *baN and *jurw- respectively. The former is a recognisable EA root which the preceding section has shown to be very widespread, in fact almost continent-wide; the latter seems to be local and isolated. Eastern New South Wales has been shown to have another EA root, *gulan, skin, as the basis of its pronouns, and these languages are not coastal but some distance inland - Just far enough inland to be forced away from the coast by later comers - and this suggestion is going to have 1ts value later, for the actual coastal languages will appear to possess

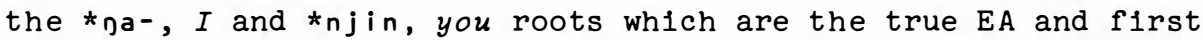
developed pronouns in Australia. The two sets of Victorian noun bases for pronouns are clearly separate and therefore represent the oldest forms found within the continent. If Warnman bara- is looked at in the light of EA bara, they, it might seem that here we have evidence to link it with the New South Wales central coast; but there is not enough definite evidence to support the suggestion and Warnman must be left to stand alone at least for the present.

The present theory is therefore that these three isolated regions represent the oldest Australian method of constructing pronouns, and that they were followed by the $\star_{n a-,} \star_{n j} j i n$ languages. Seeing that in the O'Grady-Voegelin maps, Arnhem Land contains all but one of the phyla projected for Australia, it might look as though Arnhem Land ought to contain many sets of aberrant pronouns. In actual fact, 
however, it does not and this is one of the strange points about that classification. Even languages like Margu and some of the Daly River languages seem to agree with EA in their pronoun systems. The pronouns given by Tryon (1974:294-5) are in all conscience aberrant enough, like the bulk of Daly River linguistics, but at least they should be EA sharing: more will have to be sald about them later.

\subsection{Evolution of the Pronouns in Australia}

There has been a general process of evolution of non-singular pronouns in Australia. The third person has always been indicated by a delctic and some languages have distance marking forms (Aranda, Bidabida, Northern Kimberley, etc.). It is only for the first and second person that pronominal roots appear, and these are fairly

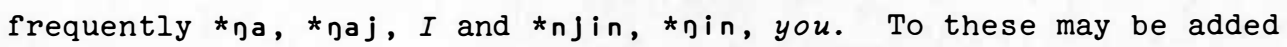
*nali, you and $I$. In some areas the first inclusive is the only dual form (Tiw1, Dampler Land). The others show clear marks of later manufacture. Similarly, plurals are of later production. In some areas inclusive-exclusive distinction has never been made. Even where 1t is found, dialects may lack 1t; in the WD languages it is absent from certain of the dialects but present in others.

For the process of evolution of number, certain evidence may be produced. In Aranda and Bldabida, suffixes to the verb indicate dual and plural not person, although there is a full set of pronouns. In Nglyamba and other languages of the northern interior of New South Wales the patterning is falrly clear. The verbal suffixes are:

\begin{tabular}{|c|c|l|l|}
\hline Person & Singular & Dual & Plural \\
\hline l. Incl. & - & $-1 \mathbf{i}$ & pa-jani \\
l. excl. & $-\underline{d u}$ & $-1 \mathbf{i - n a}$ & pa-jani-na \\
2. & $-n d u$ & $-n d u-b u l a$ & $n d u-g a l$ \\
3. & $-l u$ & $-l u-b u l a$ & $-l u-g a l$ \\
\hline
\end{tabular}

This language belongs to the group that adds the ergative case ending of the pronoun to the verb. The singular is, therefore, clear; dual is based on gali for the first person, and the plural on pa-jani, 1.e. first singular root with an unidentified suffix; the second and third person dual and plural are simply the singular (1solated ergative case ending) with a number suffix - bula < *buladj, two for the dual and $-g a l<* g a l i g$, group of people for the plural. 
This is actually a very peculiar type of formation. The use of the ergative case ending in the singliar only marks the late development of a confugation system; but the two suffixes used to form the second and third persons are both *EA.

In the far north, Wik-Mungkan (Cape York) has a different set of suffixes to the verb, but a rather similar process seems to lie behind them:

\begin{tabular}{|c|c|c|c|}
\hline Person & Singular & Dual & Plural \\
\hline 1. Incl. & - & $-1 \mathbf{i}$ & \\
\hline 1. excl. & -na & $-n a$ & mo \\
\hline 2. & $-n a$ & -wa & $-n a$ \\
\hline 3. & - wa/-na/ø & -bula & -wa \\
\hline
\end{tabular}

1.e., there is no plural exclusive pronoun but there is one for dual, and bula is used to mark (they) two. The suffix -wa seems to be 'exclusive person', used in singular to mark he, she, in the dual to mark you (not us), and in the plural to mark they (neither you nor us). The -na would perhaps be the exclusive marker in the Ngiyamba set (na-jani-na), here used as exclusive singular-na, not $I$, therefore you; dual not you with me but he and $I$, whlle the first plural is to be sought elsewhere.

In the Northern Kimberley languages there is a regular but different system of building up, in which the singular-plural contrast is basic, and the dual and trial are marked by suffixes to the plural. To take Worora as an example:

\begin{tabular}{|c|c|c|c|c|}
\hline \multicolumn{2}{|c|}{ Singular } & Plural & Dual & Trial \\
\hline 1. Incl. & - & Dari & gari-ndu & gari-uri \\
\hline 1. excl. & gaju & ari & ari-ndu & ari-uri \\
\hline 2. & gund ju & $n j i r i$ & $n j i r i-n d u$ & $n j i r i-g g-u r i$ \\
\hline 3.1 & in-dja, awa & $a r-g a$ & in-g-andu & in-g-uri,aw-uri \\
\hline 3.11 & in-ja,njgunga & & & \\
\hline 3.111. & g-awa & & & \\
\hline
\end{tabular}


There is also awa-ndu, they two; class of noun complicates the situation, but the basic indication for dual (-ndu) and trial (-uri) is clear. These numbers are indicated by suffixes in a predominantly prefixing language. In the Victorian languages in which dual and trial are indicated, suffixes also are used, but these are entirely suffixing languages. The first two pronouns in Worora are of CA (or probably WD) origin. Other NK languages are constructed similarly to Worora, though there are significant variations.

\section{MORPHOSYNTACTIC HISTORY IN AUSTRALIAN LANGUAGES}

\subsection{Basic Concepts}

One of the outstanding weaknesses in the study of Australian languages lies in the fleld of syntax. Th1s fact was brought out by Dixon (1976b:413-14). The frequent absence of text material in a given language is undoubtedly one of the reasons for this weakness. W1th the recognition of such a weakness the present author is in complete agreement, for 1 t has long seemed to him that such a study can provide much understanding of the present structures of the languages, as well as their present-day syntax. It seems clear that a process of crystallisation has operated on an orlginally free word order in the utterance. Such a process would not only result in a stricter syntax, as found in many of the modern languages, but would also account for the peculiar morphological complexities of some verbal systems, especially in the prefixing languages as against the suffixing, and the incorporation of pronoun subjects and objects into the verb complex. Even the occasional incorporation of noun objects can be explained on such a hypothesis. For the 1dea in general see Capell (1956:11-20) and Wurm (1969).

At the present time some languages still allow very great flexibility of arrangement within the clause, although there is normally a variation of emphasis accompanying variant arrangement, as might be expected. In others, there is a tendency for pronouns of subject and object to keep together until they are finally blended into compound affixes to the verb. Where they have both come to precede the verb, they have formed the 'prefixing' group, elsewhere they have formed a sometimes quite complex set of suffixes.

It would seem that originally the Australian verb carried no person markers, and there is a broad stretch of languages in which still the actor (whether noun or pronoun) comes before the verb, which carries as 
markers only tense and mood or volce. In some few languages the actor follows the verb and this practice would seem to have been more general at an early stage. It is the placing of the actor after the verb that leads to the abbreviation of the pronoun as a suffix to the verb, thus marking person. The process would have been gradual. In Banggala, for Instance, Schürmann (1844:22) mentions that th1s language st1ll allows of both methods of confugation.

If such was the process, one would expect to find verbs in which the transitive and intransitive nature would appear in the pronominal endings, if the language is ergative. This appears to have been the case in Garnay (Kurna1) of eastern Gippsland. In the notebooks of R.H. Mathews one finds forms such as wanga-nadj, I hear and janga-nadj, $I$ go, as against juga-jada, I give (and incidentally these are all CA roots). In Darginjung also the distinction is made, but only in the singular. If early Australian had only singular pronouns, this may be correct. On the other hand, there came a period in some areas where the fact that *na-du could only be an ergative form of the pronoun $I$ was forgotten, and the ending - du became the first person marker of a verb, as in Wangaybuwan (northern New South Wales) jeradu, I speak, which is really ne-ra-du, speak-present-I. At the same time it is possible here to have jadu yanana, I go - but this is still an intransitive verb with an 'ergative' subject.

In the Australian case at least, this independence of syntax is of tremendous importance, because syntactic rules developing at different times and in different languages seem to have exercised a great influence over morphological developments, and in turn modified subsequent syntactic patterns.

Perlmutter (1971:87) has set up a proposition that seems to be Justified, when he says that (a) phonological properties of formatives have no relevance for syntax, and (b) as a corollary, the syntactic component of grammars does not refer to phonological information. He might perhaps have expected morphophonemic changes across word boundaries, which usually have syntactic origins. However, those two propositions being accepted, it is possible to study Australian syntax before the details of morphology and lexicon. The examples given immediately above, however, make the propositions themselves doubtful, at least for Australia.

The subjects of this section are arranged in the following sequence:

1. Free arrangement controlled only by semantic emphases.

2. Development of a preferred order, e1ther os or so being 
the controlling facts: the position of $\mathrm{V}$ is irrelevant to them. If both $S$ and $O$ are pronouns, the situation is less flu1d, for a hlerarchical pattern is developed, based on phonology, and $S$ and $O$ develop a falrly close coherence between themselves, without relevance to $\mathrm{V}$.

3. Modifled markers are st1ll free forms, but governed as stated at the end of the preceding paragraph. Yaralde and Wiradjuri show two shapes of this stage. Yaralde provides a pattern on which seemingly Yanjuwa and some languages in Arnhem Land and Northern Kimberley built. Waramunga provides a special case of the same development. In Yaralde in particular, ergativity and affix transference have combined to produce, through freedom of word order, a considerable flexibility, e.g.

$$
\begin{aligned}
\text { lag-in adi go:je } & \\
\text { make-P I basket } & =\text { gadi lag-ingo:je } \\
& =\text { go:j'adi lagin } \\
& =\text { lag-in-ab go:j-il } \\
& =\text { gabi lagin go:jil } \\
& =\text { go:jil-ab lagin }
\end{aligned}
$$

This list shows sufficlently the possibilities of word order change without more than change of emphasis in a language which is ergative in method and agglutinative in structure.

4. Bound markers develop, showing varying patterns, such as

$$
\begin{aligned}
& \text { 1. } \mathrm{V}+\mathrm{S}+\mathrm{O}>\mathrm{V}(\mathrm{S})+0 \\
& \text { 11. } \mathrm{V}+(\mathrm{S}+\mathrm{O})>\mathrm{V}(\mathrm{SO})
\end{aligned}
$$

1.e. bound suffixes formed of abbreviated pronouns, either subject only attached to verb, with object free, or both subject and object bound. There is a third development with use of catalysts (3.8.), combined suffixes hierarchically arranged: $C((\mathrm{SO}) \mathrm{S})+\mathrm{V}(\mathrm{t})$, where $t$ means not only tense but also mood, and the doubly bracketed pronouns show that either order may eventuate - but of course, not both in one language.

5. From this stage arises rigid suffixation as a derivative or shape. There are also examples of incomplete development, e.g. DJingili and Guwamu. 


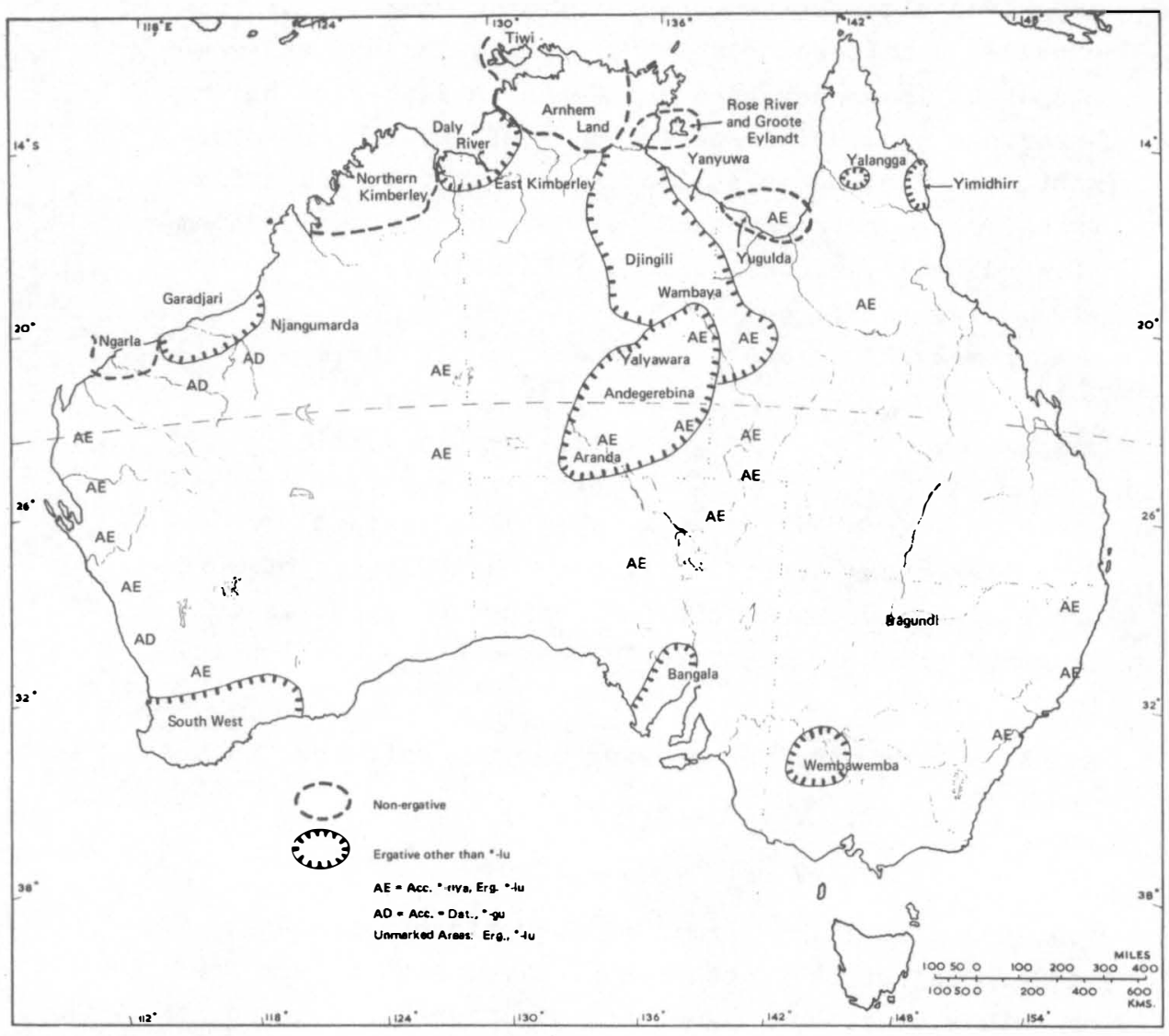

Map 6: Oocurrence of the Ergative Construction 
The questions that arise from this scheme are concerned chiefly with knowing what determined which type would prevall in an area. Undoubtedly the processes were controlled by the preference for sov or svo type of utterance, or any of the other possibilities, some permutation of the elements of each, especially the practice of putting the VP first. It needs to be realised also that a distinction between noun subject and pronoun subject seems to have begun falrly early, and this is rather surprising when it is also realised that pronouns developed non-singular forms at some period quite late after the settlement of Proto-Australian speakers, and in some areas nouns have not developed such distinctions to the present day.

This line of thought leads to another development which is of paramount importance in Australia: the formation of an ergative case and with it ergatively orlentated languages. Some believe that ergative languages historically preceded nominative languages, but reasons will appear that make this concept more difficult than the thought that the earliest Australian was nominative, and developed into ergativity at a later period. The problem needs to be discussed next.

\subsection{Ergativity}

The last general statement ended with the assertion that modern Australian languages are elther nominative-accusative or ergative in type. The term 'ergative' is derived from Greek ergein, to work, to bring about a result: it is a process therefore limited to transitive verbs. Some languages in Australia carry a case-ending marking a given word as actor of a transitive action: these usually do not mark the goal of the action. They are at present in the vast majority in Australia. There are others which do not distinguish an intransitive subject from a transitive, and in some cases these also mark the goal of the action of a transitive verb by a case ending (accusative) and are hence referred to as nominative-accusative languages. These are a minority in Australia, but this does not necessarily mean that they always were a minority or that they have developed from an earlier ergative type. An example of each type follows:

1. Accusative language: Ngarinfin (Northern Kimberley)

$\begin{array}{llll}\text { aru maRa ajo:n } & \text { v. } & \text { aru maRa nanbun } \\ \text { snake seeing } I \text {-do-to-it } & \text { snake seeing it-does-to me }\end{array}$

The noun aru, snake remains the same whether as object or as subject. 
2. Ergative language: Walfbir1 (Northern Territory)

$$
\begin{array}{ll}
\text { wana-na nja-ju } & \text { v. wana-ngu-dju ja!gu-nu } \\
\text { snake-I see-past } & \text { snake-ERG-me bite-past }
\end{array}
$$

Here snake as actor takes a marker (ERG) -ngu, as goal it takes none.

The second example is typical of an ergative language. It happens to be chosen from a language in which affix transference takes place, so that the subject (-ṇa) is transferred from the verb (ja!gu-nu-naa) to the head word of the sentence (see 3.5.). Th1s does not affect the principle of ergativity.

In Australia the ergative marker is usually shared with either the instrumental or the locative case, and there may be history involved in this cholce. It does not call for examination at this point, but because of $1 t$, it is sometimes argued that the verb in an ergative sentence is passive, e.g. by me the snake is seen. This is possible in Indian languages but wrong in Australia, and at least in some cases demonstrably wrong for Caucasian languages also. In Australia ergative languages do not have a passive formation - some accusative languages at least do. The Russian linguist Bokarev (1959:60-2) was very emphatic that ergatives are not passives. In his grammar of Gunzib, a northern Caucasian language, he says: 'Ergative construction is not passive...In Gunzib, the ergative case does not colncide with the instrumental: the ergative ends in -1 and the instrumental in $-d$; the ergative serves exclusively to express the subject of a transitive verb', and he proceeds to give examples that seem quite conclusive. One warning must be given: some languages such as Mullul-Mulluk on the Daly River, have a suffix that marks the agent (in this instance -wan) whether the verb is transitive or intransitive, e.g. alalk yikpi-wan kaptararma, child little-agent plays around; and alwar-wan akana mul nuntano, woman-agent does/did not ask him. Such a language is not ergative. It is taken in this present work for granted that an ergative is not passive: the author prefers to follow Bokarev in calling it 'neutral' as regards volce.

The limitation of an ergative to past time occurs in some languages although in Australia this is rare. Blake (1976b) has pointed to Alawa (eastern Arnhem Land), Galgadungu (central Queensland, where the nonpast has the agent in the nominative and the patient in the dative), Bandjalong (north-east New South Wales), while in Yugulda (Gulf country, Queensland) the ergative is not used 'where the goal has not been achieved'. Even in Western Desert languages such as Walfbirl and 
Bidjandjadjara, some verbs such as speak are used with the same limitation. Blake then adds: 'Logically, the patient of a verb in the future, conditional, etc. is not affected by the activity described in the verb'. Yet at the same time, the absence of an ergative construction does not automatically mean that the language has a passive volce. In some Northern Kimberley languages one would say, e.g. the canoe made itself at me as equivalent for the canoe was made by me, the agent going into the locative and the verb into the reflexive.

On the Daly River the Murinbada language is a true ergative language in that there are no signs of a passive marker. This means that many of the Australian languages are what has been called by K.L. Hale 'pseudo-ergative', as the verb in an ergative sentence usually carries an -1-transitiviser (see 4.5.4.) that looks like having been earlier a medio-passive marker. Thus, Hale would hold, it is possible to demarcate three language-types in regard to this feature - (1) nonergative languages, (2) true ergative languages and (3) pseudo-ergative languages. It has recently been argued by Dixon (D1xon, ed. 1976:9-12) that it is not quite a question of ergative-or-not: there are gradations of ergativity to be found in different parts of Australia. Reviewing the papers on ergativity collected in the volume, Dixon says: There is surely too much attempt to force each language into a straightjacket of "strictly ergative" or "strictly accusative" deep syntax. Silverstein's pioneering work on hierarchies (paper 6 [in this volume]) was unfortunately not avallable for precirculation to contributors; he shows that surface "ergativity" proceeds on a sliding scale, rather than in terms of absolute pigeonholing, and 1t may well be that Silverstein's ideas could be extended to provide a more fluid and appropriate typology of deep syntaxes'.

In form, there are quite a number of ergative markers in Australia but the commonest is $*-1 \mathrm{u}$ which apparently started from one area and spread. There is a locative ending also which is very similar, $\star-1$ a, seen, for example, in the non-ergative Ngarinjin (western) mandja-ra, on a stone. The two suffixes have a number of allomorphs in common:

$\begin{array}{lllll}\text { Ergative } & -l u & - \text {-gu } & -m b u & -n j d j u \\ \text { Locative } & -l a & -g g a & -m b a & -n j d j a\end{array}$

(Hale 1976b). In the article referred to here, Hale seeks to lay down phonetic rules for the occurrence of these allomorphs, and no doubt these are correct, but actually they are more than phonetic rules, for they point back to ancient final consonants of the stems to which they are attached, and these forms have led the present writer to posit 
final consonants for Proto-Australian roots: he has generally been led by the form of these suffixes to posit a final -n for a root which In modern languages takes -ngu/-nga, etc., e.g. *mula-n, nose. In many languages, especially in V1ctorla and other parts of eastern Australla, such finals are st1ll present, but there are cases in which the consonants are lost but the ergative forms of the roots take one or another shape that a final vowel would not 1mply, 1.e. a root may take -lu where there seems no justification for 1t. It is easier in such cases to presume that the orlginal root ended in a certain consonant than to work on the basis of the elaborate phonological rules Hale suggests. These may be perfectly right as concerns the historical processes, but they point back finally to certaln earlier shapes of the words concerned.

In some cases results are interesting. A language may show variant forms not expected, e.g. In Dharawal, on the south-east coast of New South Wales, -1 u is not found but -dju is present after a final palatal consonant preceded by a low vowel; in addition there is $-j \mathbf{i}$ after a final vowel instead of $*-1$, - $n g a$ after a velar nasal, -la after final lateral (Capell 1969:51). In the historical setting, such variations can be of interest: the CA root *badun, man has an ergative wadi-lu in a few WD languages, but wadi-ngu in others: the one ending 1s secondary, the other primary; the final velar nasal will have been lost before the word came into a given language, where only final vowel was permitted.

In the Arandic group of languages a final - $u$ becomes -a as an allomorph, so that $-1 \mathrm{u}$ appears as -la in Aranda, while Aljawara uses-ila. Apart from such allomorphs, however, there are other ergative endings that are not cognate with $*-1 u$. Blake lists certaln of these, e.g. Murinbada -te/-Re, Njungar -ag, Ba:gundj1-wa, WikMungkan -aj. It would thus seem that ergativity was present in Australla apart from the EA and CA languages as a whole, and took on various means of expression. Examination of each in 1ts setting would be necessary to produce a final decision and this is not possible here. The areas in which ergatives are limlted to perfective verbs would also need study from a comparative point of view, but this also must be overlooked here. There is finally an ergative ending -ja which is practically limited to pronouns, and of this a few words will be sald in the following section. The only language in which - ja functions as ergative with nouns seems to be Yugulda.

The writer has argued previously that Australian languages were originally not ergative, but that the process of history has led to development of ergativity. Hale and others, on the other hand, have 
held that ergativity was primitive and has been lost from some of the languages. The question is of historical importance, and a further study has led the writer to change his view to the extent of saying that they may have been ergative, although, of course, this is a view that cannot be historically proved in the absence of documentation. Experience elsewhere, however, suggests that there is more than one type of ergativity. There is the type in which the ergative is used with all transitive verbs, but another type in which it is limited to past tenses. Gilbert Ryle (1949:149ff.) has spoken of 'verbs of achlevement' and these are the types of verb that require an ergative in such languages. If the action is completed, the subject goes into the ergative. If 1 t is in process or future, the ergative is not required. This type of construction is found in parts of Australia and in other areas of the world as well. It seems appropriate to a language in which the construction is either not developed or is going out of use - the latter more likely. If Australian languages may be regarded as originally ergative, but in some regions losing the quality, this could well be a stage in the process of loss, and it seems more likely than a gradual development of 1t. The author is therefore inclined to feel that the Australian languages as a whole may have been ergative, but have lost the construction.

It is noticeable that the oldest recorded languages were ergative. This is so in the Middle East, in the case of Sumerian and Hurrian. It is still so in Basque, Eskimo and the Caucasus. In America the languages do not show any trace of original ergativity. In PIE also there is no such tradition, but the Indo-Iranian languages have a construction with the passive participle which points rather in that direction. In Sanskrit it is possible to say mayā kanyā dṛșā, by-me (was) the girl seen for I saw the girl - and here the construction is rather emphatic (P1rejko 1968:61 et passim). Australian could well have developed rather similarly, but one cannot definitely claim that this is what happened.

\subsection{Case Formation in General}

Case marking in Australian languages is not universal. In the NK languages it is possible to regard at least some of the case markers (In their functional sense) as independent words, and in Worora and Unggumf amongst these languages such markers can be subject to being marked for class. In Gunwinjgu there are a few prepositions, such as guRe, at, and Jiman, as: guRe gunRed, at the camp and jiman gunwade, 
like a stone. In the case of Worora and Ungguml, the fact that such a postposition as nanga, of is really a noun governing the preceding noun, stands out clearly. Two examples in Worora will show this:

(1) if a noun is involved in a possessive expression, such as

$$
\begin{aligned}
& \text { djuwalja a-nagga-ja } \\
& \text { paths he-poss-plural } \\
& \text { His paths. }
\end{aligned}
$$

then nagga is preceded by a Cl. I prefix, and takes the plural indication of possession, referring to the plural noun path-s as a suffix-ja.

(2) If the possessed and the possessor are of different classes, the former is marked on -naga- by a prefix, and the latter by a suffix (as $-\mathrm{m}$ for $\mathrm{Cl}$. V) while the number of possessors is marked by a suffix preceding that of the class, as -ndu, 'dual', thus:

$$
\begin{aligned}
& \text { ma-jaru-m inala-ndu a-nanga-nda-m } \\
& \text { Cl.V.-house pupil-two Cl.I.-poss-dual-V. } \\
& \text { The house of the two pupils. }
\end{aligned}
$$

Diagrammatically, something like the following might represent the scheme :

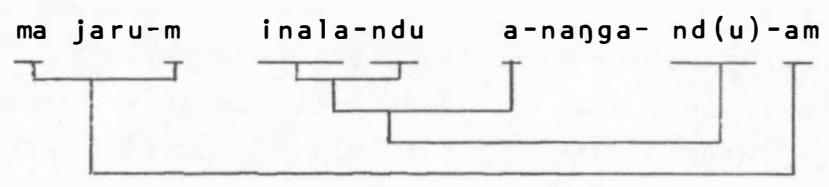

which serves to make clear that originally -nanga- had complete independence of status, whether as noun or (more likely) adjective.

It is not hard to think of later case endings in other parts of Australia as being postpositions, at first free, and only later bound. In many cases no doubt morphophonemic changes have taken place, as indeed they still do - e.g. East Ngarinjin mandjan da, on the stone: West Ngarinjin mandja ra, where there is no final consonant to influence the form. The other Northern Kimberley languages sometimes show similar forms without influence from the classes: Ngarinfin, aRu nagga, man's, Cl. I. but wogay nagga, woman's, Cl. II. The latter

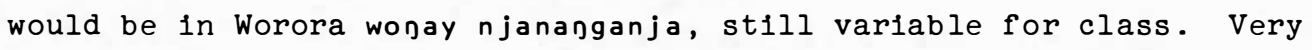
occasionally one finds both preposition and a case ending together, as in Madimadi (Victoria) gunda gada-ba, under stone-oblique (Hercus 1969:182). It seems thus possible that morphemes that subsequently became postpositions or case endings earlier had some form of freedom.

In general the case system as such in Australian languages is fairly consistent throughout. In most of the languages there are possessive 
and dative cases, ablative and locative. If the language is ergative there will be an ergative case ending. A nominative marker is very rare, but there is a set of such in Yugulda, and this is one of the features that set that language apart in the way that is discussed in an earlier section (3.3.4.1.). Blake (1976b) states that the suffixIng languages have from about four to elght cases, occurring with nouns, pronouns, adjectives and demonstrative pronouns and adjectives, and 1llustrates from Galgadungu in western Queensland:

$$
\begin{gathered}
\text { madjumba-ana jabadjara-ana tjaadigaja-ana } \\
\text { kangaroo-to lively-to these-dual-to }
\end{gathered}
$$

It w1ll appear later that there is not always the use of the ending on each member of a phrase, but that customs differ in this regard (see following section). Blake's count includes nominative and ergative, apart from which there may be an accusative, frequently limited to animate or even personal nouns and pronouns, a genitive, dative, locative, allative and ablative. Von Brandenstein has also written about an abessive in Proto-Australian (Von Brandenste1n 1965:647-62), and later mention will be made of this.

It is needful to distinguish between form and coverage of cases, and this is not always easy. In seeking the history of developments In Australia it is especially difficult to do this, because there is no evidence to trace the history of a usage or of a case form. Blake's tables do not suggest that any set of case markers is e1ther EA or CA, much less goes back farther in history, and it is wiser not to try to establish more than the princlple of case marking as part of ProtoAustralian speech. Even this is not easy, and 1t has already been shown that a time can be visualised when free forms had not become bound forms at all. In fact, some morphemes that are falrly commonly f1xed at present do not seem to have been so in the past. The bivalent suff1x -gu is such (Capell [1956]/1962:77-79; Blake et al. 1976). The bivalency concerns the type of root with which the ending -gu is used. This is elther nominal or verbal. In the former case the basic meaning is for, or to; in the latter 1t marks a decision for action or to act and thus 1t becomes e1ther a purpose or futurity marker in the verb.

It is desirable to make some mention of indicators of having and not having or with and without, since these are present in almost every language of Austral1a. Sutton (1976b:299ff.) remarks about the 'proprietive affixes' that they 'show reasonably high cognation, while privative affixes do not'. Th1s may imply that the former were evolved 
at an early stage of language in Australia, while the negatives of them were not evolved so soon. He proceeds to give lists of fifty languages and their forms of proprietive affixes, and summarises them by the following list of proto-forms:

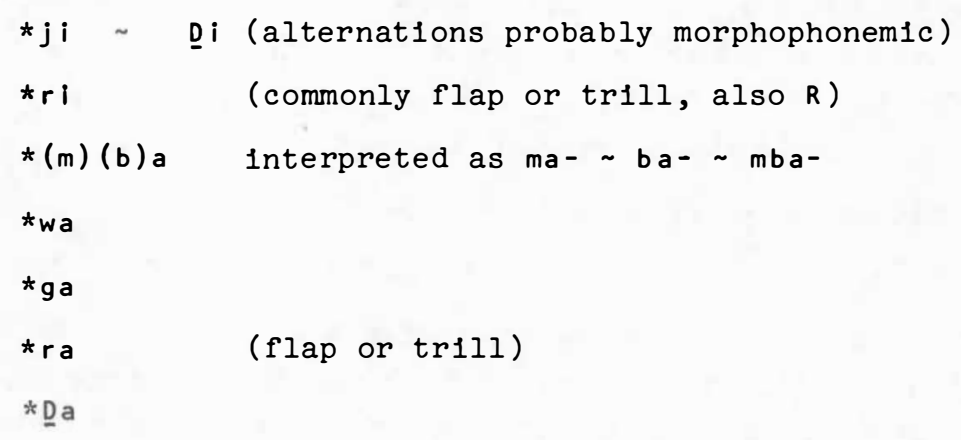

The list might concelvably be shortened by bringing some members together: ra and $* \underline{D} a, j i, \underline{\mathbf{D}} \mathbf{i}$ and $r i, \underline{R} \mathbf{i}$ could coalesce at an earlier period. Dixon as rapporteur in the pages following makes some suggestions and further analysis (Dixon 1976a).

Von Brandenstein's paper on the abessive, already mentioned, makes a good case for such a form as common Australian. The most detalled evidence he gives is concerned with Meyu (Gaurna), on the Middle Murray River, but he cites quite a number of other areas in other parts of Australia, viz. Ranfbarngu, Dalabon, Ga'angulu (Queensland), Waga (Queensland), Bandfalong, Wiradjur1 and Dharawal (New South Wales), Ngarluma, Njangumarda, Mangala, DJaru, Jangman (Western Australia), and southern Victorla. If the claims can all be accepted, there seems to be a real case for an abessive. The form, however, leaves something to be desired: It is $\star d j i$, In von Brandstein's spelling -t'i. This immediately becomes amblguous with the commonest form of the proprietive: So something further needs to be sald about the presumed abessive. After all, the proprietive with a negative verb would produce the affect of an abessive.

The marking of possession, including genitive case forms, needs separate attention. The bivalent suffix -gu is not only a marker of dative, but is widely found as a possessor marker also. 'Quite a number of Australian languages use the dative to mark their possessor in a possessive construction. For example, in Bidjandjadjara we find wadi-gu baba (man-DATIVE dog), the man's dog. In other languages a separate genltive suffix is used to mark the possessor' (Blake 1976a: 422). On the following page, Blake has a diagram setting out a presumable scheme of development of the uses of -gu: 


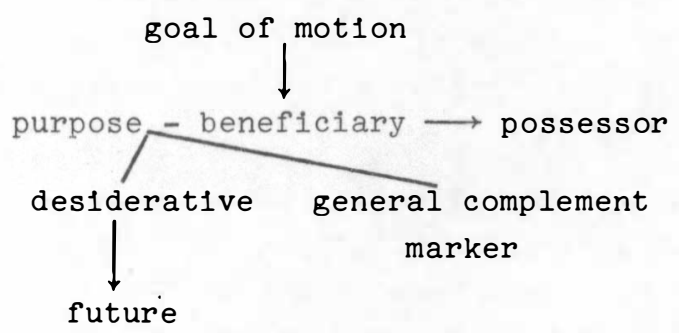

to which he adds a final comment: 'The fact that gu appears in different morpho-syntactic slots in different languages...may well reflect an earlier stage when gu was a free (probably adverb-like) form'. This is undoubtedly correct, and case endings in general may be of a similar origin.

The possessive construction as a whole 1s much more complex. It is dealt with in Capell ([1956]/1962:66). In many languages pronominal possession is marked by suffixed pronouns, abbreviations of the cardinal pronouns. Sometimes these are subdivided into classes: In the NK languages and some others, body parts take pref1xes, which are almost the same as the subject markers to verbs; kinship terms take suffixes which are equivalent to indirect object markers to verbs and all other nouns use the marker -nanga, added to a pronominal base: Ngarinjin pi-oru, my ear; yid-nagga, his or her father, jindani-nanga, my spear. In other areas, such as Victorla, pronominal suffixes are added to nouns in general: Madimadi galg-eg, my spear; Djadjala gadigadim-ara-galig, spear (belonging to) us three (excl.). Where nouns alone are concerned, 1 t is frequently a case of A's $B$, or B A-of; but occasionally there is a double possession: man-of boomerang-his, Djadjala wudju-ga gadigadim-ug, Dharawal juwinj-guli warangan-naj. The order may be reversed, but the correct endings must occur on the correct word. It is doubtful whether any one form of genltive is universal: it is again a matter of historical stages, which cannot be worked out in full here.

In summary now it may be suggested as a historical view, that (1) the earliest Australian languages probably did not have case systems at all. They sometimes used prepositions, it would seem, but the evidence is far too meagre for any positive assertion. The occurrence of such forms in Arnhem Land and Victorla (Gunwinjgu and Madimad1) suggest this, and form another link between extreme north and extreme south, which is to be investigated in a later section. 
(2) The EA languages seem to have used postpositions which originally had Independent meanings, but later became simple case endings, with significance in a syntactic setting rather than meaning in a lexical setting.

(3) These case endings, as they finally became, show considerable varlation from area to area and may help in later research to 1dentify grades of $\mathrm{EA}$, some of the steps between $\mathrm{EA}_{1}$ and $\mathrm{EA}_{\mathrm{n}}$ which can only be suggested at this stage. They can be defined only by a detalled study of lexicon, which lies outside the present scope.

(4) The problem of the priority of nominative-accusative languages over ergat1ve languages also requires more study. While 1 t seems to be in Australia a case of spread of ergative case systems, probably from one central point - as suggested by the prevalence of $\star-l u$ forms this is far from certain, because other endings are found in some parts of the continent. The author's feeling is that $*-1 \mathrm{u}$ is a WD legacy, whlch replaced other endings as the WD languages (CA languages to be exact) advanced eastwards: yet the ergative as such is prior to this spread.

\subsection{Number in Nouns and Adjectives}

Number seems to have developed first in pronouns, although even there 1t is not an element of the earliest EA groups. It has already become falrly clear that number developed in pronouns in different ways in different languages, and that it came latest in the $C A$ languages in the western WD languages. To the present day, however, there are no formal plurals in quite a number of the languages, so that it can safely be sald that number indication in NP is comparatively late. Moreover, there is very little agreement in the shapes of formatives, so that it cannot be sald that any one method of indication is 'primative'. What is more regular is to find a dual number as well as a plural: this nearly always involved suffixing *buladj, two in EA languages and *gudara in CA languages. Number indication as such, however, is very early in some parts: Victorla has not only dual and plural indication, but also a trial form which has been discussed under Pronouns (3.4.). Yet the languages in north Australla that link best with V1ctoria, although they do indicate trial as well as dual, do not use the same indicators as those in the south. The latter - so far as they have this system - Indicate dual by *buladj and trial by *galig, but this is not the case in Arnhem Land or Northern Kimberley. In the latter, the forms are suffixal as in Victoria, but vary in 
shape: Worora dual -ndu, trlal-( $(0)$ guri, apparently also in Ungguml, In Umida and Unggarang1, -du and -geri, but in Ngarinj1n -diri and $-(n i) n a$, Wunambal $-m i j a$ and $-n a$, as also in Gwinl. These are involved with local forms of the numerals, whlch cannot be discussed here. But the Eastern Kimberley languages differ in their forms. There is no trial, but nouns fall into two classes, Cl. I ending in -in and $\mathrm{Cl}$. II in -1 , but both forming a plural in $-m$. In place of this the dual of both has -warin. In Arnhem Land methods of indicating plurals vary Immensely, and though duals are usually present (often forms of the cardinal numerals), trials are not. Specimens of these formations can be seen In Capell (1942) passim. The use of *galig as ending for tribal names has been already discussed (3.4.): 1t is found in the -bal of 'Wunambal' apparently in complete 1solation, a remainder of whose history nothing can be sald.

In brief, number indication is by no means universal in Australia. It 1 s absent from such areas as the Daly River - so far, that 1s, as nouns and adjectives are concerned, and these generally show themselves to be early in the EA list. It would seem to have developed first in pronouns. In many languages, number indication in NP is done by means of affixed pronouns in VP, and this is probably a later development to clarify references within the utterance as a whole. Trial number can also be a paucal plural in Victorla, but does not seem to have this extension in the NK area, although 1t may sometimes have it in Arnhem Land. A summary of forms, together with some local deta1l, is given in Capell (1955/62:61-3).

\subsection{Case in the NP}

In phrases, as against single words, two types of concord are found: one in which only the last word of the phrase takes case markers: this will be called group declension, and one in which each word in the NP takes a case ending in parallel with the others. Th1s will be called parallel declension.

\subsubsection{Group Declension}

Group declension is the term used to indicate a phenomenon in which any marker is used only once in a phrase, usually on the final element, as against 1ts recurrence on each unit of the phrase. In English, in a good house is a phrase; In Latin in bon-a dom-u contains an ablative case marker required after in on both noun $(-u)$ and adjective $(-a)$, and the two markers in this case are actually not morphemically 1dentical. 
In some languages such a case marker would be required only on the final unit: in (a-good-house)-loc. Some Australian languages exhibit this feature. In Waljbiri and other WD languages (of CA type), narga njambu, man-this, as nominative with an intransitive verb, ergative garga njambu-lu, man this, with a transitive verb. In the neighbouring Bidjandjadjara,

$$
\begin{aligned}
& \text { baba nanjiri bulga-ngaDara } \\
& \text { dog wild large-for-fear-of }
\end{aligned}
$$

In each example the case marker appears only once although referring to both units. The tree diagram which sets this out would be of this nature:

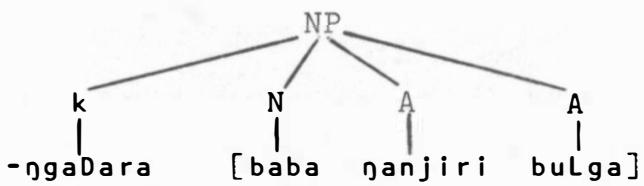

which would need a transposition of $k$ to the final position and a means of indicating that it refers to each unit of the phrase though used only once. If the word order is changed, and the unity broken for any reason, group declension ceases and the case marker must be repeated. A Walfbirl example will make this clear:

$$
\begin{aligned}
& \text { garga njambu-! u gabi wawiri bandi-ni } \\
& \text { man this -ERG FUT kangaroo spear-NON-PAST } \\
& \text { This man wizl spear a kangaroo. }
\end{aligned}
$$

This can be stylistically varied to become

$$
\begin{gathered}
\text { garga-ngu gabi wawiri bandi-ni njambu-! u } \\
\text { man-ERG FUT kangaroo spear-NP this -ERG }
\end{gathered}
$$

where -ggu is an allomorph of the ergative suffix. The whole has the same general meaning but with a different emphasis (Hale 1973).

\subsubsection{Parallel Declension}

In parallel declension, each element of an NP takes the case sign. Thus in Murawar1

for example,

$$
\begin{gathered}
\text { guNunj-dja bidala-nga } \\
\text { coal-on good-on, }
\end{gathered}
$$

[The fish is cooked] on good coal(s). 


$$
\begin{aligned}
& \text { me:n-gu durda-gu mall } \\
& \text { man-of big-of boomerang } \\
& \text { The big man's boomerang. }
\end{aligned}
$$

Once again there are areas in which each type of declension is predominant. It is particularly noticeable that sometimes an embedded clause may take an adjectival case marker in a way that is not possible In English, as in Murawar1

$$
\begin{aligned}
& \text { minjan (dadira-ji-ju)-gu } \\
& \text { what (drink-can-I) for } \\
& \text { What is there for me to drink? }
\end{aligned}
$$

The embedded verb is to all intents and purposes a noun: 1t can syntactically be treated as one and take a case ending.

It also occasionally happens that case endings, in retaining individuality, can be combined with each other in certain specified groups, e.g. In Murawar1

$$
\begin{array}{lll}
\text { danj deri-mi-ya diyawi-mi-na (mayi-nga)-gu } \\
\text { hither back-it-comes turns-round } & \text { (ground-on)-to } \\
\text { wara-numbu mugu-nga bi:bun-gu c bungi-la } & \text { falls-it inside-at cotton-bush-of flower-in }
\end{array}
$$

1.e. on to the ground and in to the flower of the cotton bush.

This combination of case endings is very rare. It occurs in Bilua, of the western Solomon Islands, and it occurs - like group declension in Sumerian, one of the oldest recorded languages of man.

\subsubsection{Cumulative Declension}

Cumulative declension is a name that may be given to a special type of declension found in comparatively few yet widely scattered languages of Australia. In this type, some case serves as a base on which other cases are constructed by an additional suffix. In Gubabwiyngu of northeast Arnhem Land, for instance, while to me is gara-gu (which also serves as my, as in bala? haragu, my house), if my is used with a noun In an oblique case, the stem for my is not naragu, but the dative gara-gala, to me to which first - pu- and then the appropriate case ending is superadded, e.g. Dara-gala-nu-bili, at my..., e.g. bala?bili naragalanubili, at my house.

In Gubabwiyngu this type of declension 1s limited to possessives used with nouns in oblique cases. Thus, my father is baba naragu, but of my father is nara-gala-nu-wa baba-wa. Here gara-gala is to me: 
when the possessive is used as an adjective in an oblique case the dative nara-gala serves as the base, to which a set of suffixes is added, to a lengthened base nara-gala-nu-. In the dative to my... the case suffix is actually doubled but in a phonetically somewhat different form: nara-gala-nu-wala; other final case endings are unchanged. The ergative is nara-gala-ju-ji, as In garagalanuji babaji, my father (did so and 80). Sentence examples are seen in the followIng: naji dja:! wana-narawa baba-wa naragalanu-wa, he wants to speak to my father; but wananarawa nara-gu, to speak to me; nara nanala nanu-galanu-na bala'na, I saw his (her) house; dunaba-nuRa naragalanujuRa mirinu-nuRa, in the presence of my enemies; naragala-nu-nuRa bala'puRa, from my house. No suggestion can be offered as to why this cumulative declension of possessives has arisen, but the facts are as stated.

A somewhat more complicated kind of cumulative declension was present in Awaba, Lake Macquarle district, Newcastle, New South Wales. Here nouns are divided into two main groups: common and proper, the pronouns forming parts of the proper noun section. The language has a system of classification of nouns (for which see the paper on the classification of nouns in Australia, later in this volume). In Awaba, declension by simple suffix covers only the ergative and dative cases (which may often be formally one) and the ablative, common-din, proper-gay, from, on account of; all the rest carry double suffixes whose true nature is often difficult to 1dentify. There seems to be some sort of vowel harmony at work. Thus ergative -du, and locative -duwa, but personal locative (with a person, near a person), -ga-ba and not-gu-ba. The two sets of suffixes are shown in the following table, in which the case names are those introduced by Müller (Müller 1882, II, I:5ff.). 
Table 14: Cumulative Declension in Awaba

\begin{tabular}{|c|c|c|c|c|}
\hline Case & Common & Personal & Threlkeld's & Spelling \\
\hline Nominative & (no flxed & Alng) & & \\
\hline Ergative & $-d u$ & $-g u$ & - to & $-k o$ \\
\hline Dative & $-g u$ & $-g u$ & - to & $-k o$ \\
\hline Locative I & -du-wa & -gu-wa & - toa & -koa \\
\hline Genitive & - guba & -guba & $-k o b a$ & - koba \\
\hline Locative II & $-g a-b a$ & -gin-ba & $-k a b a$ & $-k i n b a$ \\
\hline Abessative & -da-birun & -ga-birug & -tabirug & -kabirug \\
\hline Adessative & $-g a-g u$ & -gin-gu & -kako & -kinko \\
\hline
\end{tabular}

The pronouns in this system are suppletive: nominatives work on stems different from those of other cases - which means that they probably have entirely different linguistic historles. Most of them have two stems in the singular, but one with phonemic variation in dual and plural thus pointing to a later development of non-singulars here as in other parts of Australia. The forms are as follows:

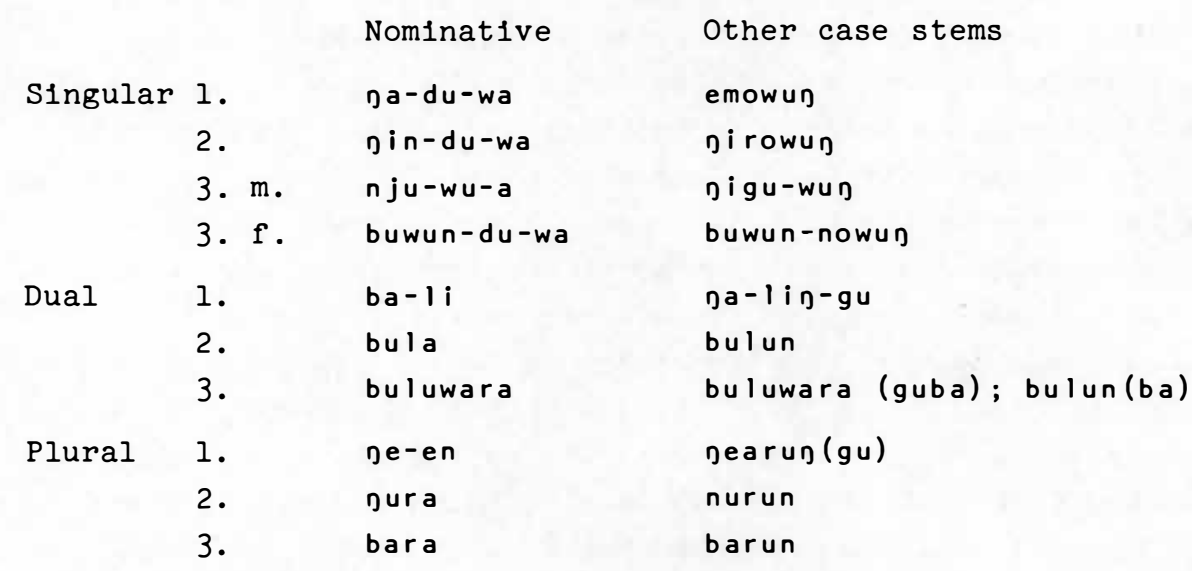

The historical implications of these forms, especially their obvious connection with Ngarinjin in the Northern Kimberleys, has been discussed earlier and will need to be referred to in the next section, so that no discussion of them will be given here. It is to the second forms that other case endings - those of the Personal Nouns series are added, e.g. emowunginbirun, from me. The inflected forms of the plural pronouns are obviously derivatives from the nominatives, whereas 
those of the singular pronouns are not, and this strengthens the 1dea already put forward that plural pronouns in Australia are late historically. Full historical analysis cannot be entered into here: it needs a separate paper.

Apart from these examples of cumulative declension, the syntactic pattern in Awaba is that of parallel declension: noun and adjective take the same case endings when they are semantically connected. An example is dira-gu giguwumba-gu, with his teeth; here his is already compounded as shown above. Again, Threlkeld's (1892:133) translation of Luke 2:32, küri ko lthärael giroúmba ko (= guRigu ldirael girowumbagu), for his people Israel. Th1s usage contrasts with Wiradjuri iraggun duradu, with his teeth, where only the final word of the phrase takes the instrumental ending - du.

A full historical grammar of Australian languages would be necessary to show how far these three types of declension are spread, and this cannot yet be written. The connection, however, between north and south that has appeared in this brief study, is quite important and can no doubt be filled in, in a wider study.

\subsubsection{Transitivisation}

The distinction between transitive and intransitive verbs is of considerable importance in Australian languages. It is at the base of the distinction between nominative and ergative cases. Most of the distinctions rest on semantics, but there are some morphological indicators of transitivity. In general these indicators are language bound, but there is one at least which is widespread. This is -1-, which is added to the final phoneme of the verb stem, and is followed by a vowel. Some discussion of this $-1-$ suffix is called for. It was mentioned and developed to some extent in Capell (1956/1962), and there is a discussion in Breen (1974:28ff.). Capell regarded it as a gerund, a verbal noun, used as a means to extending the action of the verb.

Evidence from Donaldson (1976) is also to be added. All these studies suggest that the original treatment by Capell and Breen was basically correct, with one limitation: -L- by itself is not a noun formative but is used only in combination with (1) an auxiliary verb and (2) another case ending to the gerund. Of the two uses -1 ma- is common in many languages of eastern Australia in the role of causative verb formation, while -l-gu marks future time not only in eastern but also in western Australia. Actually this is one of the cases in which we seem to get a 'look behind the scenes' in the history of the 
formation of language in Australia. The present section of this study is therefore essential both to explain the usage of the - !- and to take the history of these languages back one stage further.

There is a third usage which is commoner in the western regions, and that is that -1 forms the base of a transitive against an intransitive verb. In these cases it is added directly to a verb stem, not to a stem which is to be compounded with an auxillary to form a derived verb. The evidence suggests that as this usage is commoner in WD languages, which are mostly CA in status, it would seem to be later than the other uses, and so again serves as a time indicator tending to mark the comparative lateness of the WD languages as a whole and hence of the CA stratum.

The starting point is the proposition that - 1 is a gerund marker or formative. The instances given in NAAL seem to make this clear. They can be reviewed briefly.

$$
\text { On the Functions of }-L-
$$

NAAL, 67: (- 1 - as gerund format1ve)

In Dharawal the - 1 - 1 s added to link a root with an auxiliary; in central New South Wales 1 it is added to the auxiliary to Iink the tense and other suffixes to the latter. These are the New South Wales uses:

Dharawal bu-l ma-i-a, hitting he-brought-him

Wiradjur1 bu ma-l-awan-ni, strike causing-present strike causing-immedlacy-past, I was striking just now. bu ma-1-nari-n, strike cause-this-morning-I.

It is used along the coast only in Dharawal, 1.e. It is inland Yuwin but it does occur in Awaba and has special uses there. It is found also in Gogay.

In WA -1- appears as one of the verbal affixes:

1. -1-ba, far or historic past

11. -1-gu, intention

Garadjar1 djinga-l-gu-li, killing-for-we-two, let us two kill him, we two are for killing him, we two kizl him.

Glass and Hackett (1970), 'punctiliar 1'.

$$
\begin{aligned}
& \text {-1- with gidja, imminent -gịja } \\
& \text { gidja-munu-ḍu, negatıve future } \\
& \text { djara, cessative -djara- }
\end{aligned}
$$




$$
\begin{array}{ll}
\text { bayi, hab1tual } & \text {-bayl- } \\
\text { djagu, purpose } & \\
\text { djagu-munu, Inab1l1ty } & -d j a-g u \\
\text { djagu-djara-du, Zest } & \\
\text { djiradja, unfulfilled desire } & -d j i r a-d j a
\end{array}
$$

Even here it is only lst conj. and purpose requires-dja-gu, not-gu. In Walfbirl the -1 - forms are consecutives.

Kab1, J. Mathew's 'verbal noun' yeli:nba, calling looks like yeli-l-ba with dissimilation.

*-li- marking a middle volce, reallsed usually as reflexive but sometimes as passive.

Dj1ringanj present - li-ma; past -li-ba; (future ya-bala) reflexive. Lard1l: -yi-passive. Gogay: -ilana, reflexive

Awaba: gi-1-

Murawar1: $-r i-$

Dharawal: $-i l(i, y a, a)$

There 1s, then, a distinction between languages in which - L- is a simple formative added to a stem, and languages in which 1 t 1 still a formative, but conjolning two stems, such as a verb and a noun. There is also a third type of case, that instanced by Wangaybuwan, In which the formative is added not to the basic root but to the auxillary. Th1s is similar to the usage in Dharawal, of the type of bu-l ma-. In Wangaybuwan, a similar formation would take the shape of *bu ma-1-.

It would seem that the more anclent usage is the simpler one, 1.e. the gerundial. Yet the same formative can be added to a simple stem to form, e.g. -1-gu, a future marker to a simple verb. It thus jolns the ranks of bivalent formatives, and this 1s the point of Breen (1974). In the process, 1t raises the question whether there may not be other such bivalent formatives, and such would carry the history of the formation of Australian languages back a stage further.

There is a noticeable phonetic feature in all these cases: $\star-1-$ seems to remain as 1 , not undergoing phonem1c transformation; the ergative marker $*-1$ u can be modifled into $-n i,-y u$, etc., but the gerundial -1 - does not do this.

Breen (1974:22-59) suggests the possibility of reaching behind existing Australian languages to an earlier stage in which grammatical organisation was st1ll incomplete. Later formatives, case and other endings may have begun life as independent particles which were not limited to one category of word, but could be blvalent or even 
multivalent. This could not, of course, be proved categorically but only within the range of likelihood.

Breen, then, enlarges the definition of bivalent affix to be 'stem forming or inflectional affix which combines with noun stems and with verb stems and/or abstract nominalised verb stems (e.g. participles)' (p. 50). The whole of Breen's paper is really only an expansion and elucidation of this proposition, but it seems to be substantially true, although the examples are all taken from living usages in modern languages. They do, however, point to a time when the existing fixed usages were still in the course of formation, and thus seem to conceal or partially reveal historical processes which are difficult to state with any degree of security at present. Yet similar processes can be seen in some of the anclent languages of the Middle East and elsewhere.

\subsection{Historical Development of the Noun Phrase}

The points to which attention should be given in regard to the noun phrase (NP) are five:

1. Absence of number marking and the stages of development. The historical aspect of a numeral system in Australia would be included here.

2. The absence or presence of an ergative system - and perhaps also its nature - combined with the presence or absence of a passive in the VP, are matters of some importance historically.

3. The loss of a passive (if such was the case) along with the development of the ergative system needs to be examined. 4. The case systems in Australia (starting from absence of a formal case system, or its virtual absence, as in the NK languages) need to be considered, together with the flelds of group declension and parallel declension.

5. Classification in nouns: this is the subject of a separate paper in the present work.

These are all developments within the NP that may be expected to have historical importance. However, the parallel development of the VP is interconnected (especially in regard to ergativity) with that of NP. While each must be studied separately, both must finally be woven into one in the tracing of history. 
A. CAPELL

\section{THE VERB PHRASE}

\subsection{Theoretical Development of the Verb Phrase}

The standard study to date on the construction of the Australian verb phrase - both syntactically and morphologically - is that of Wurm (1969). The historical aspect of this study, as well as of the present one, is the assumption that grammatical structure in Australia has advanced from simpler to more complex. This seems to hold good in both the noun phrase and the verb phrase.

Verb formations - In the sense of the syntactic order of stem, person of subject and/or object, and other features present actually or by implication in the VP - may be traceable to an underlying syntactic arrangement of $S, V$ and $O$ in the sentence in which the VP plays 1ts part. The VP complex, that is to say, may well be a microcosm to which the sentence as a whole is the corresponding macrocosm.

To 1llustrate this proposition, let three elements be considered: the source of the event, the event 1tself, and the goal of 1t. The symbols $S, E$ and $G$ will indicate these phenomena - the different use of $S$ in this connection needs to be noted. Various syntactic patternings of these elements are possible, of which a language usually chooses one as basic but allows others as stylistic or semantic variations: witness the difference between statement and question in English, and the same with the addition of order in Romance pronouns. But in the verb complex itself the basic sentence pattern of the language usually obtains, the variations are not permitted free interchange with each other. The following table shows the possibilities of arrangement of a three element statement in which each element is morphemically independent. The event (E) is seeing, the source ( $S$ ) is $I$, and the goal (G) is you. This brings about:

$$
\begin{array}{lrr}
\text { I saw } & \text { you } \\
\mathrm{S} & \mathrm{E} & \mathrm{G} \\
\text { you } & \text { I } & \text { saw } \\
\mathrm{G} & \mathrm{S} & \mathrm{E} \\
\text { saw } & \text { I } & \text { you } \\
\mathrm{E} & \mathrm{S} & \mathrm{G} \\
\text { I } & \text { you } & \text { saw } \\
\mathrm{S} & \mathrm{G} & \mathrm{E}
\end{array}
$$

as the usual types in Australia. A pronominal $S$ and $G$ were deliberately chosen in the above examples because complex verbal systems are usually 
inflectional, and the elements of $S$ and $G$ are in this case pronominal. Even in such a sentence as the man saw a dog, the verb in many languages incorporates within itself an $S$ and a G element, such as he-saw-it in the man he-saw-it dog, which is a typical Austronesian order. A nominal $S$ is not subject to abbreviation - it may even have an ergative case or other indicator.

Many languages are not limited to a VP in a simple sentence but allow for compound and complex sentences in which a subordinate clause may have a special verb shape such as sentence-medial (SM) or a participle (which in principle is the same thing), or an inversion as in German.

The question is now: where in Australia do such variant patterns occur and with what modifications? Can they be connected with a corresponding sentence pattern in the given language or languages?

For the purposes of the present outline, Wurm's paper of 1969 seems to give the clearest summary. He divided the pronouns $S$ and $G$ into two main groups: free forms and bound forms, crossing in regard to their position vis-à-vis the verb 1tself. They are summarised by Wurm (1969:68-9) thus:

I. Free forms: (a) Free in syntactic position. Type language: Dungidjaw.

(b) Free still but in a preferred order whether before or after the verb. Types: Juwinbara (and most -bara languages); Gungar1.

(c) Abbreviated or modifled person markers still functioning as free form. Type: Narrinjeri.

II. Bound forms: (a) Short or modified person markers functioning as free forms still retaining possibilities of interaction. Type: Wiradjuri.

(b) Fused units which are themselves free forms before or after the verb 1tself. Type: Waramunga. In this instance $S+G$ is basic.

(c) Bound morphemes without abbreviation, added to the final of the verb stem or to catalysts, with a strong tendency to observe an order of lst before 2 nd or 
3rd person. These are characteristic of the CA languages of the Western Desert and regions to the east of 1 t. The AT languages are part of this group - and this gives perhaps a historical key.

(d) Subject markers only are bound and suffixal; objects are free and generally follow the verb. Type: Guwamu.

(e) The verb forms a complex of bound forms of elther $(S+G)+E$ or $(G+S)+E$ type. This is true of the multiple classifying languages and of some others such as Wardaman.

(f) A rather unusual type where bound forms which are $E+(S+G)$ as in Dharawal or of similar but more flexible type as in Awaba.

To produce order in this rather complicated array of possibilities a map is needed: for this see Map 5. Even this map does not clarify entirely the historical sequences. It would seem that many local influences have been at work.

Working on the presumption that the historical basis of increasing complication is right, the 1tems on the map are arranged in a manner somewhat different from Wurm's. Moreover, what has been sald above crosses with another feature of Australian verbs: simple or compound confugation. The 1dea may be 1llustrated from English where it is possible to say I killed him or I did kill him - this is stylist1c only: in an Australian language a verb is either a simple stem conjugated by the method the language chooses, or a compound verb which consists of an invariable verbal stem and an auxiliary which is specified for given classes of verbs. This feature has been studied separately in another paper in this volume (see 'Classification of Verbs in Australian Languages'). Th1s feature does not determine which type a verb will follow in regard to the S-E-G situation; either type may belong to any subgroup.

What type of syntax is implied in each case? What is the underlying structure? Taking $S$ as always pronominal, it would seem that the 
following patterns might follow: the symbols $S$ and $G$ are now replaced for the sake of convenlence by the more usual symbols $p_{1}$ for subject pronoun and $\mathrm{p}_{2}$ for object pronoun, and $t$ for tense:

\begin{tabular}{|c|c|c|c|}
\hline & & Verb Phrase Structure & Syntax Underly1ng \\
\hline vso & $\begin{array}{l}1 . \\
2 . \\
3 .\end{array}$ & $\begin{array}{l}v+p_{1} \\
v+t+p_{1} \\
v+t+p_{1} p_{2}\end{array}$ & $\begin{array}{l}\operatorname{vS}(0)+t \\
\operatorname{vs}(0) \\
\operatorname{vs}(0)\end{array}$ \\
\hline $\begin{array}{r}\text { svo } \\
\text { OSV , sov }\end{array}$ & $\begin{array}{l}4 . \\
5 .\end{array}$ & $\begin{array}{l}p_{1}+v+t \\
p_{2} p_{1} v+t\end{array}$ & $\begin{array}{l}\text { SV }(0), \text { SOV } \\
\text { OSV }\end{array}$ \\
\hline
\end{tabular}

The only pattern not covered here is that of some Daly River languages:

$$
\pm V S x \pm V S+S \pm 0+V S+t \pm V S
$$

In which, according to Tryon, 'the kernel of the sentence, the verb unit, which 1s made up of the actor ( $S$ ), and optional object ( 0 ), the bound form of the verb stem, plus the tense marking suffix' (Tryon 1971:9). VSx stands for the free verb stem.

When these schemes are applied to the languages themselves, several tendencles are observable in the confugation types. Taking as material for examples, marked with asterlsks because they are purely theoret1cal, some proto-AN roots, the patterns may be set out as follows, using $\mathrm{R}=\operatorname{root}$ and $\mathrm{p}=$ pronoun:

$$
\begin{aligned}
& \mathrm{p}+\mathrm{R}: \text { *ga + *jan, } I \text { go } \\
& \mathrm{R}+\mathrm{p}: \text { *jan+*na, go I }
\end{aligned}
$$

and similarly for other persons, e.g. *njin, you: *njin jan and *jan $n j i n$. The addition of $t$, tense marker, using ${ }^{n}$ a as a past tense sign, gives

$$
\begin{aligned}
& \text { * na jan na } \\
& \text { *jan na na }
\end{aligned}
$$

for $I$ went, the time marker clinging to $\mathrm{R}$.

If the VP Is transutive and the language ergative, then a form such as *na-ja, for example, might be called for, and using the root *ma, 
take, the result would be *naja ma > *aja ma na or *ma na gaja, I took. A next possible step would be *mana (na)ja, and this seems actually to be the case in northern New South Wales, where the root forms of the pronoun were apparently *nan+lu> $>$ gadju and the verb became *ma-na-(na)dju > *manadju, of the pattern $R+t+p$. A transitive, however, presupposes an object. So long as the object is a noun there are no complications, and 1t comes either before or after the verb. But if it is a pronoun further coalescence can occur in more than one way, as set out in the diagram above.

The relative infrequence of $\mathrm{V}+{ }^{*} \mathrm{na}(\mathrm{j} \mathrm{a})$ points to a prevaling historical pattern of initial verb in Australian languages and this is borne out for existing languages also. It can be 1llustrated for many, but it is perhaps rather noticeable that these include languages such as Garawa, already used in this study as an example of aberrant languages (2.2.). On the other hand, the pattern *na(ja) + V points to a prefixing type language such as those found in the Northern Kimberley and Arnhem Land, and these again prove to be aberrant in vocabulary. They include the Victorian languages, however, which have lexical connections with those of the far north (5.2.).

While the final patternings have remained fairly simple in most cases, there has been development to polysynthesis in some areas, and all this would not seem to have been a straight historical path. The most complicated polysynthesis in Australia is found in T1w1, which is a language 1solate, but the Daly River languages are all quite elaborate. A study of Tiw1 polysynthesis will be found in Capell (1967a), where it is shown that the processes involved are exactly the opposite in order to those of Eskimo. In Australia quite a number of languages can form extremely elaborate verbal phrases of this type and the gradation to polysynthesis as the term is used in Amerindian languages is capable of being studied almost step by step. It remains to be investigated whether there is historical order in these gradations, or whether they have sprung from local causes in different areas.

In point of fact, complicated processes of combination are by no means limited to such isolates as Tiwi; among the WD languages, for instance, it is possible to produce a compound such as the Bidjandjadjara

nindi- bu- gula- nj- -dja- maal- du know-causative-continuity-connective-infinitive-negative-noun teaching, involving only a verb stem and a number of suffixes; in 
Gunwinjgu and many other languages it is possible to involve an object noun in the complex, as in

$$
\begin{aligned}
& \text { nari-bene- mane- djal- djarg- gole-manbo-ji } \\
& \text { we them for continually together spears-make-habit } \\
& \text { We used always to get together and make spears for them. }
\end{aligned}
$$

.In the far east of the continent Wiradjuri can produce:

$$
\begin{aligned}
& \text { nu- } 1-\text { gidjllinja-nari- awa- -giri- -li } \\
& \text { give-link each other morning tomorrow future we two } \\
& \text { We two wizl exchange it tomorrow morning. }
\end{aligned}
$$

\subsection{Historical Development of the Verb Phrase}

The historical development of the verb phrase in Australia is therefore partly linked with the development of morphology - interlocked with 1t perhaps, rather than causally connected, for the syntax apparently played its part.

It may be thought of as development from simple verbal systems, without person marking (for noun subject) or only number marking (as in Aranda), with subsequent development of person marking from sentences with pronoun subject and/or object. The best starting point here is the paper by S.A. Wurm (1969), combined with that of Capell (1972). The processes of development of systems as a whole will then need to be correlated with the actual morphemes involved in them, whereby the relationships within groups of languages may be discerned. Modal and other distinctions are involved in this process. Here again involvement with NP must be taken into account in determining subgroupings of languages.

Map 5 shows how these various types are located in the continent. The indications given on the map are to be read as follows:

1. Verb invariable for person and number unmarked

2. Verb variable for person and number:

1. Suffixes for number only. NN

11. Variation for person and number. PN

111. Markers transferable to head word of clause. $P M$

1v. Personal suffixes added to catalysts. PC

v. Incorporation of object pronouns. IN

v1. Tense indicated in the pronouns. TP 
2. v1. Is really a subgroup of (1), in which the verb itself does not mark person, but pronouns vary for future $v$. non-future according to the tenses of the verb. In Gurnu this affects only the subject marker; In Bidabida and Lardil, however, it affects also the object pronoun (not an object noun), and in Bidabida some other cases of the pronoun share the variability also.

Although there is both simple and compound confugation, the types listed above are not confined to simple or compound confugation: each may occur in each kind, but it is most usual for invariable verb forms to be found where there is no compounding. The simple verb type may be best 1llustrated from a language such as Gadhang, on the central coast of New South Wales. Reference may be made to Holmer's account (Holmer 1966:73-86).

Coming now to details of specification, the following features of a verbal system call for mention:

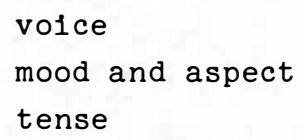

These will occupy the next subsection of this paper. All these features depend chiefly on the agglutinative character of the Australian languages, with morphophonemic principles frequently complicating the actual processes. The degrees of intricacy in the various languages differ greatly, and in some cases independent morphemes do duty instead of inflection.

\subsubsection{Voice in Verbs}

It is not entirely easy to define how the term 'volce' should be used in Australian languages. It is usual, for instance, to speak of an 'active volce', yet as in most instances there is no contrast with a passive volce, the term loses part of 1ts force. It is only in certain of the non-ergative languages that a formal 'passive' volce is found, so that it is perhaps better to speak of a 'neutral' volce in the case of ergative languages. Moreover, there is sometimes, though not often, a formal contrast between 'active' and 'stative' verbs. On the whole, it seems better to speak of a netural volce where there is no formal contrast with active and passive expressions. A normal power of the Australian verb is to express reciprocity and reflexivity by means of formal modifications in the verb, and where these can cover more than one 'mood' It is perhaps desirable to refer to these as volces, otherwise they are 'moods'. In general, volce is concerned 
with the relationship between actor and goal. When an actor recelves the action upon himself, the fact is sald to be expressed by the passive volce; when he performs the action upon or for himself, the verb is sald to be in the reflexive or middle volce. When the action is performed by more than one upon each other for each other, it is sald to be in the reclprocal volce.

This 'neutral' volce will be taken here as baslc and not discussed as such: moods and tenses and aspects w1ll be consldered as expressions of the 'neutral' volce unless otherwlse stated.

A formal passive volce has been found in Lardil, of Mornington Island, which is not an ergat1ve language. Here the marker is a first position suffix to the verbal stem, -ji-followed by the marker of future or non-future as required: e.g. be-duR, bites > be-ji-duR, will be bitten; be-da-gun, bit > be-ji-gun, was bitten. The formal arrangements are simple, the uses have given rise to much discussion (Hale 1970, Kloke1d 1976).

The other area in which a formal passive is found is on the northwestern coastal area of Western Australla (see O'Grady, Voegelin and Voegelin 1966, von Brandenstein 1967). The former mention it as present in Garlera-Ngarluma and Gurama-Jindj1bandf1: the latter gives a contrastive list of languages in which passives are found as against ergat1ve languages. One of Von Brandensteln's examples from Nfamal is

$$
\begin{aligned}
& \text { nadja wia-n -na njuna-gu } \\
& \text { I see-it-past you-object } \\
& \text { I have seen you. }
\end{aligned}
$$

another:

$$
\begin{aligned}
& \text { nada-lu wia -n-na -na njuna-na } \\
& \text { me -by see-it-past-me you } \\
& \text { I have seen you. }
\end{aligned}
$$

Von Brandenstein, however, has a different interpretation of the phenomenon, for he writes: 'If I call the two opposed terms relating to "transitive action" of verbs PVC and AVC, which stand for "Passive Verbal Concept" and "Act1ve Verbal Concept", to name the older one first, it should be emphasised that the two well worn classical terms "passive" and "active" have been retalned malnly so that they may not lose their polarity potential in any comparative study'. Others, however, have not agreed entirely with the author in this attitude, but see in the contrast something that is as real for the west and for Mornington Island. The method expressing the agent of the passive 
is different in the two instances also, and it can well be accepted that the distinction does exist.

In languages in which there is no ergative, there is also no passive formation, but what may be called a passive substitute, a construction which enables the passive idea to be expressed. In the NK languages, for instance, the house was built by John would be expressed by

the house built itself at John: here the action is expressed as affecting the house, and John is referred to not as the actor but as the 'location', so to speak, where the action took place. Parallel to this, and no doubt historically related, is the use, in some ergative languages, of an ergative suffix identical with the locative, though it is more commonly 1dentical with the instrument, as might be more naturally expected. It does not seem possible from purely synchronic evidence, to trace the historical processes involved, but there are undoubtedly some such processes at the back of these usages.

Reflexive and reciprocal will here be treated as volces because it 1t possible to include moods as well as tenses within their ambit.

\subsubsection{Reflexive and Reciprocal}

It is normal in Australian languages for the reflexive to be marked by a first rank suffix, though there are occasionally other ways of doing 1t. Tense and person markers will be then second and third rank suffixes after the reflexive marker. Thus in Jindjibandj1 (northwestern Australia), marker -djangu- is a separate particle in

$$
\begin{aligned}
& \text { naji manguna djangu walunga ga:ndu } \\
& \text { I grabbed to-myself my thigh } \\
& \text { I grabbed my thigh. }
\end{aligned}
$$

This is the less common usage. The commoner usage is exemplified in several sets of markers used in New South Wales and Victoria. In the Wiradjuri-Gamilaray areas of New South Wales (languages between the Dividing Range and the Darling River) the common marker is -ana-for

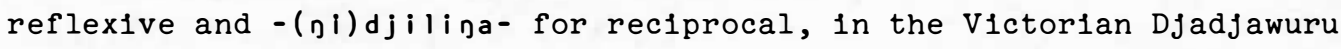
-ana- and djeranu-. The use of -ana is found almost as far north in Queensland as Bidabida, which replaces 1t by -mali-. A problem arises whether the marker should be written as -1-ana-, -1-ana-, for it is usually preceded by an $-1-$. This $-1-$ however seems better taken as the nominaliser -1 of which something was sald above, for 1t plays

a wider part in the languages and is at least $C A$ if not $E A$. If that is so and the suffix is really *-lana-, *-lana- then probably Aranda $-1 a-$ is to be reckoned with 1 t. 
The WD languages stand apart from the eastern groups, having a form of $-n j a n u(n)$ as reflexive marker. There is also the use of a particle, as 1llustrated above for Jindjibandf1, and this is present also in the far north-east, e.g. Gandju (Kantju) -dja which is verb final, or perhaps to be regarded as a particle immediately following the verb: galga nadangu naju ma'obl-dja, spear my I make-for-myself. In the Dampler Land languages both infix in the verb pattern and suffix to the verb are employed simultaneously, e.g. Njulnjul-ma-...indj, with which-mi...indj as a reciprocal marker is parallel. It has already been shown that these languages stand apart in pattern from those outside their region, as they do in lexicon.

There is close overlap between reflexive and reciprocal, and in some languages the two are marked in the same way: Bldablda -maliis both reciprocal and reflexive. In other languages the same marker may be reciprocal in one and reflexive in a nelghbouring language. This is so, for Instance in Dhurga in southern coastal New South Wales.

Outside the normal EA-CA groups, other methods appear. In the NK languages, for instance, there is a reflexive confugation with endings different from those of the neutral volce - here perhaps the term 'active' volce is in place. For Ngarinjin the forms are set out in full in Coate and Oates (1970:48, and appendices). In Mawng there is a similar system: the verb is marked by a special set of pronoun prefixes, although the tenses are marked in the same way as for the neutral or active verb: nejan, I see him (with open / $/$ /), jajan, I see myself (Capell and Hinch 1970:80-2). Further east in Arnhem Land, in Ranjbarngu, where reflexive and reclprocal combine, McKay states that they both 'may be derived from Rembarnga differential verb (and from some mono-differential verbs) by means of the reflexivereciprocal suffix - tt, with variants for confugation class'. In the Roper River area, Mara presents - lana as a final suffix: from ran+nang-anjl, he hit me, there is ran+n-anji-lana, he hit himself (Heath 1978:362), and the eastern EA(?) pattern is restored but in an unexpected syntactic position. In NE Arnhem Land, Gubabwiyingu has -miri as a suffix, which is sufficiently close to -mali for possible relationship. In Diyari however, -mali is reciprocal, showing the continual interchange of the two concepts.

It may be sald briefly that although the concepts of reflexive and reciprocal are both found in Australian languages as a whole, there seems to be no really common root that can be assigned to any stratum, though some are falrly widely spread. 


\subsubsection{Tense}

Australian languages indicate as a rule time present, past and future: variations on the theme are presented by languages in which the distinction is one of present against non-present, and this sometimes takes the form of a tense which indicates non-future as against another that indicates the future. This is the case in Lardil, where there are two tense distinctions, the first of which marks future and the other present + past. From such a basis as this, other languages develop more deta1l: some languages divide time into smaller segments, such as morning, noon and night (T1w1), while others subdivide the day even more subtly - Wiradjurl and the inland languages of eastern New South Wales mark morning, and a number of other subdivisions of the day, for each of the three standard tenses. It is possible to outline on a map the locations of these various time schemes (see Map 5).

In still other languages, there is a distinction of aspect intertwined with tense: a Realis and an Irrealis aspect may both have a series of tenses, usually not as elaborate in the Irrealis as in the Realis. This is the case in north Australia - the Kimberleys and Arnhem Land, for instance. In some cases there is not a strict division into tenses, bur aspect seems to have the controling influence. The Yulngu languages (otherwise called Murngin) in northeast Arnhem Land exemplify these.

It is therefore not possible to set out the tense schemes of modern Australia in any short and clear form. Moreover, the morphemes differ so much that it would seem that there is no common pattern - at least in early Australian (EA). In CA there is a more clearly cut formation. It is interesting to observe that even in prefixing languages as a whole most tense indicators - like those of volce, mood and aspect are suffixes. It would seem that throughout the languages, the actor was first thought of, then the action and last of all the time. There are indeed exceptions to this generalisation, for vos is a not uncommon sentence type in Australia.

A distinction of imperfective-perfective is found in some parts of the continent as well. It is not, however, as normal in Australia as in other parts of the world, though implied, of course, in the expression of a formal difference only between past and non-past (as in Lardil and elsewhere).

In the formation of tenses, as in most other features of conjugation, the WD languages stand as a group. Two sets of examples drawn from Capell ([1956]/1962:73) are typical: DJaru and Mudbura: 
1. Djaru: ju-give and ma-take, say

\begin{tabular}{l|l|l|l|c|l} 
Present & Near Past & Far Past & Future & Future & Imperative \\
ju-nan & $\mathbf{j i - n j a}$ & $\mathbf{j u - n a n i}$ & ju-ngu & ju-na-ngu & ju-nga \\
ma-nan & ma-ni & ma-nani & ma-ngu & ma-na-ngu & ma-nda
\end{tabular}

2. Mudbura: ju-give, na- eat

\begin{tabular}{|c|c|c|c|c|c|}
\hline Present & Near Past & Far Past & $\begin{array}{l}\text { Near } \\
\text { Future }\end{array}$ & $\begin{array}{l}\text { Far } \\
\text { Future }\end{array}$ & Imperat1ve \\
\hline ju-nan & ju-jana & ju-nana-ni & ju-ggu & & ju-na-nda \\
\hline ga-nan & ga-nani & na-nana-ni & $\eta a-\eta g u$ & $n a-1 u$ & na-nga \\
\hline
\end{tabular}

In the WD languages the verb either takes the suffixed pronoun as suffixes or 1t is transferred to a forward position through an AT process, leaving the verb 1tself indicating tense but not person. In the catalyst subgroup the person marker will naturally be carried by the catalyst, not by the verb. Mudbura and Djaru are both catalyst languages.

These languages frequently have up to four verb classes (as in, for example, Bidjandjadjara) and often also sets of participial endings which are characteristic of the group.

Another characteristic group is that of Wiradjurl languages of New South Wales in which there is a proliferation of tenses, chiefly in the indicative positive mood. In wiradjuri itself the following are found, and are lllustrated with the EA verb root bu, hit: in Wiradjuri this is confugated by means of the auxiliary verb ma, take (as though to say I take him a blow).

General Present: bu m-ara, hit him.

Specific Present: bu m-ala:wana, I am even now hitting him.

Aorist: bu me: I did hit him (some time).

General Perfect: bu-m-algwajn, I have hit him.

Hodlernal Perfect: bu m-alna:rin, I have hit him today.

Yesterday Perfect: bu m-algura:ni, I hit him yesterday.

Far Perfect:

bu m-algunan: I hit him long ago.

Pluperfect:

bu m-alejni, I had hit him.

General Future:

bu m-algiri, I shall hit him.

Near Future:

bu m-al-awa-giri, I shall soon hit him.

Hodlernal General Future:

bu m-al-nari-giri, I shall hit him sometime today. 
Hodlernal Definite bu m-al-gari-awa-girl, I shall certainly hit Future: him today.

Exact Future: bu m-e:giri, I shall certainly be hitting him.

The names used here are Müller's. There 1 s no space to discuss them in detall. In addition, the language has also an optative, an Imperative and an Infinitive. Other languages using a simllar system are Gamilaray, and other northern languages.

Some of the modern languages have a number of verb classes or confugations, and this arrangement is not limited to any one part of the continent. These arise partly from phonological accommodations and so for purely phonetic reasons, but this does not account for all the varlations. Verbs may take certain tense markers and it is fust as Impossible to say why they should do so, as 1 t is in IE languages such as Germanic, Greek, Latin or other. Th1s kind of division among verbs is therefore falrly anclent and 1ts orlgin probably now out of reach to the historical linguist. In the isolated Tiwl language this phenomenon is not found and moreover, in this language tense markers are largely prefixes, not suffixes as in most other languages.

While thelr existence needs to be noted, their nature lies beyond the scope of the present study. Their comparative antiquity needs also to be noticed, along with the fact that they appear to be absent from such regions as the New South Wales coastal and anterlor coastal languages such as Ngunawal, Dharug, Dhanggad1, and in Queensland Durubul and 1 ts nelghbours.

\subsubsection{Non-Finite Forms of the Verbs}

Some of the northern languages of Arnhem Land have points of structure which recall features of the Papuan languages of New Guinea. One of these is the use of sentence-medial forms of the verb as against sentence-final forms. In such a sentence as $I$ saw him and then called out to him, the typical Papuan structure of the Central Highlands and parts of Irlan Jaya is Having seen him I called out to him. Similarly, When I saw him he called out to me becomes he having seen me called out to me. In the flrst instance the sentence medial verb $I$ saw him does not change for person: In the second instance 1t does change, for the actor could not be indicated otherwise. The first clause in each case becomes a participle, which the present writer long ago called SM I, where no change of actor 1s concerned, and SM II where the actor changes between the clauses. The terms have been very generally adopted in Papuan grammatical description. 
There are a few languages in Australia where SM I and SM II forms occur: these are mostly WD languages, and this feature helps to set of $f$ the WD languages from those of other parts of the continent. While there is no cause to analyse these in detall here, they may be briefly 1llustrated. Reference can be made to Capell 1962:31-2 for Waljbiri, where the constructions are treated as participial, and to the similar treatment of B1djandjadjara by Trudinger (1943:215-17). Summary examples in each of the languages are given here.

Bidjandjadjara examples:

$$
\begin{aligned}
& \text { angula-na nja-gugu } \\
& \text { having-gone-I see-shall } \\
& \text { I shall go and see. } \\
& \text { njundu angu-njanga, najulu nja-gugu } \\
& \text { you having-gone I see-shall } \\
& \text { When you go, I shall see. }
\end{aligned}
$$$$
\text { udulu-ra njananba gajulu ma gadi-ndja-gu }
$$$$
\text { having-gathered these (SM II) I can take-them-away }
$$$$
\text { Gather these up and I can take Gather these up so that I can }
$$
them away. take them away.

$$
\begin{aligned}
& \text { udulu-manji-na njananba ma gadi-djigi-dja-ngu } \\
& \text { gather-process-I (SM I) these so-that I-may-take-them-away } \\
& \text { gaRanji-na njananba ma gadi-ndjigi-dja } \\
& \text { I-am-staying these so-that taking-them-away } \\
& \text { I am staying so that I may take these away (SM I). }
\end{aligned}
$$

Various time sequences are dealt with in different ways in these languages, which can be illustrated here only in outline and therefore not with the degree of clarity really desirable: what is sought here is not the formation of the structure but really 1ts syntactic use. Thus for $I$ shall go and see, Bidjandjadjara has:

$$
\begin{aligned}
& \text { an-gula-na nja-gugu } \\
& \text { go-ing- I see-shall }
\end{aligned}
$$

by contrast with when you go I shall see (SM II);

$$
\begin{aligned}
& \text { njundu an-gunjanga gajulu nja-gugu } \\
& \text { you go-having I see-shall }
\end{aligned}
$$


Purpose constructions are treated similarly, in a way which is difflcult to reproduce word for word in English. Taking again the previous example I am staying so as to take these things away, Bidjandjadjara shows

$$
\begin{aligned}
& \text { na-Ranji-na njananba ma ga-dindjigidja } \\
& \text { stay-pres.-I these away take-for the purpose-of }
\end{aligned}
$$

The same type of SM constructions are used as in the time clauses, but with different suffixes. The pronoun subjects are suffixes to the verb, as these are WD languages of the type previously discussed. Similar examples can be produced in other languages such as Walfbiri.

It is noticeable that these non-finite constructions do not include infinitives, which have no exact correspondence in Australia. They differ from the New Guinea types in including purpose clauses rather than only temporal clauses, and there is no reason to doubt that they developed in Australia itself.

\section{THE AUSTRALIAN LEXICON}

\subsection{Introduction}

It has been mentioned at the beginning of this study that quite a number of Indications that Australian languages are not independent of each other came to light during the last century. Some such are found in various places in Curr's Australian Race. The examination seen in Schmidt's two works (Schmidt 1919a and b) represent further work in this fleld, and this work is important, in spite of 1 ts leaning on the anthropological Culture Circle Theory, because it is the first to give full place to the study of sound laws as enunclated in the theory of Indo-European philology. Kroeber (1923) also added to the work, setting out maps of the occurrences of various words for the same thing in different parts of Australia. The same task now falls to this study.

Australian vocabulary is regarded here as consisting of four main strands, or five if 'Common Australian' is subdivided. Regional vocabularies which are apparently language isolates or family isolates are placed first; then EA groups and finally CA groups. The plan may be set out as follows: 


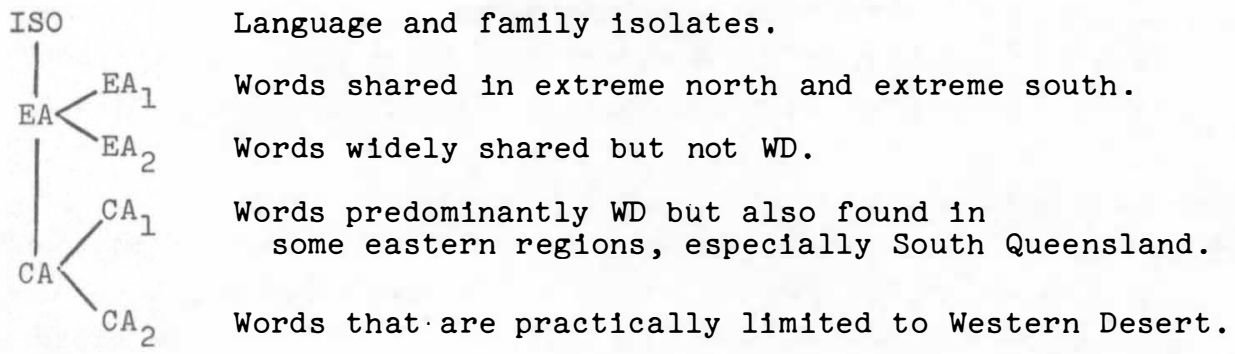

When all is sald and done, the number of words either EA or CA is not large. This is probably due to the time depth, which makes possible cognates often hard to recognise. O'Grady has shown this clearly in his essay in the present volume. Great time depths are not actually documented and are difficult even to guess at. What speech was like 30,000 years ago is completely unknown for any part of the world.

It seems desirable to take the isolates - whether individual languages or families - first, not that much can be sald about them historically but that something must be sald. Mention was made earlier (3.3.2.) regarding Tiw1, and very little more can be sald about it here, except that it is obviously such a language 1solate. Yet at the same time 1ts phonology and many of 1ts grammatical methods are Australian, however aberrant they may seem. Something also was sald about some languages of the Gulf country in Queensland (3.3.1.) and Dampler Land (3.3.3.) where at least some EA elements are present in the construction but very little in the vocabulary. Some enlargement of discussion about these isolates is now possible. They are in some cases rather 'regional' languages than 1solates, and connection with EA is obviously present, though hard to define in detall.

It is desirable to say something about the phonetic structure of the Australian word. This has generally been taken to have been b1syllabic, of the type $\operatorname{CVCV}(C)$. In some instances it has seemed there might have been a monosyllabic language type in some areas, especially in Arnhem Land, but comparison, where such is possible, suggests that this was not so. Gunwinjgu presents a considerable number of monosyllabic roots, when the noun-class or other prefixes are removed, e.g. gun-dan, mouth; gun-djen, tongue; gun-gom, neck; gun-mim, eye; gun-geb, nose, face; man-me, food. One is at first tempted to record such forms as perhaps earlier or original but in point of fact it can be shown that they seem to have developed in isolation from longer forms which are found in other parts of Australia. 
In Gunwinjgu stress falls on the initial syllable, and when class markers came to be prefixed, this stress will have drawn the original stress back, leaving a tendency to shorten the complete word by loss of a final syllable. Bisyliables in Gunwinjgu tend not to take the class prefix: duRug, dog; dalug, woman; dunin, man. They do not always do this, however, as in gal-duRug, bitch, gal-dalug, woman, and in related languages this is regular, e.g. DJawan nalmugo, woman. Other nouns which take the possessive prefixes do not take the class marker, as -' jejo, name: ga-'nejo, your name, etc.

The suggestion of loss of a final vowel is borne out by Gunwinjgu gun-dan, mouth as compared with Badj1r1 dana, mouth, gun-mim, eye with $C^{*} m i R i n$. More complicated changes also seem to have occurred, if Gunwinjgu gun-RuRg, country, camp, is to be taken as a form of EA knura.

In classifying languages, noun class developed later. This is shown in the paper in this volume on noun classification in Australian languages, and the development was later than the separation of the languages from EA or CA originals: man-me, food represents EA *maj(i), food, and gun-mim, eye is paralleled by a Cl. V form man-mim, seed of plant, also in Gunwinjgu.

Gunwinfgu may help to bulld up EA or CA vocabulary if examples like -dan, parallel to Badjiri dana are allowed for. However, it remains possible that the Badjirl word may show an added vowel and in fact the $C A$ root is generally *da.

Other types of difficulty arise also: e.g. Wagaya jindal, tongue, which seems to answer to Northern Kimberley mindjal, mouth, and both to EA *dalan, tongue (and *da, mouth). Th1s last example also raises the question of a possible relation between *da and *dalan. It is here also that Gunwinjgu gun-djen belongs - but to which root?

Some points raised in the opening section of this essay need to be recalled at this juncture. One of the many difficulties connected with tracing vocabulary in Australia is that not only are the small number of shared words chlefly basic vocabulary, such as would appear on any lexicostatistical list, but these words tend to be found in widely scattered areas throughout the continent, including languages which actually show a very small common content. If the lexicostatistical argument is accepted - that basic vocabulary tends to remain in use the longest - why should such words as mouth, tooth, etc. appear thus among those that on any ordinary theory of linguistic development would appear to be native in the given language? It is not to be presumed that speakers of language A or B had not words for such concepts unt1l the $\mathrm{EA}$ or $\mathrm{CA}$ vocabulary came to them. Why, then, 
should such words be found among the common borrowings? It is possible to point to word replacement by taboo, but this argument should not be invoked indiscriminately. The author is not prepared to answer the question, but it must be raised and an answer sought. E1ther for some special reasons, lexicostatistical processes are not valid in Australia, or some better reason must be found.

One or two thoughts may be put forward. It is not just the total number of words of several languages compared that counts. Of the basic vocabulary, words used in the normal business of dally life are presumed to be surest for retention. If there is any high degree of disagreement in these between two languages, it seems hardly likely that the less used vocabulary, where there is generally most difference, will agree to any large extent.

Certain historical circumstances may alter the picture. Invasion or conquest may affect the vocabulary of dally life. English provides a historically attested case of such a happening. The cow or the ox become beef on the nobleman's table, and the sheep becomes mutton, as Sir walter scott pointed out long ago in Ivanhoe. Changing legal and social orders were reflected in English language as in history, and the imported religion showed its external origin in the vocabulary.

Here a difficulty arises from the angle of general historical linguistics. In this sphere the term 'internal reconstruction' has long been in use, but does not mean just what is intended here. Internal reconstruction aims at explaining changes in terms of regular sound changes and other processes traceable within a number of languages, not by the movement of words from region to region on a geographical basis under social or religious impulses. Thus Antt1la (1972:264) says: 'Internal reconstruction...1s exactly the same as morphophonemic analysis'. This is something that cannot be demonstrated under Australian conditions. The words in question are not traceable along a regular trail from a (probable) point of origin to a destination; they are sporadic and word A is not usually found in the same set of languages right across the continent as words B, C or D. The time depth in Australia, once again, is so much greater than that involved in Proto-Indo-European reconstructions, and there is absolutely no historical documentation such as is usually avallable in PIE. Hence the situation is not entirely unexpected. At the same time, the inferences must always fall short of actual demonstration, but they are sufficiently likely to be probable, and conclusively form a strong argument. 
There are areas in which certain common words are not found at all. One such was l1sted by Schmldt (1919a:222), of words wh1ch m1ss out the eastern languages, and the southern (Narrinjer1) group: mouth, *da; tooth, *liran; breast, *naman; blood, *gududu (form doubtful but approximate); egg, *gambu. On the other hand, quite a number of words not recognised yet as $\mathrm{EA}$ or $\mathrm{CA}$ are found scattered over Australla, such as gagara, gagari, moon, wh1ch occurs in the NK, Narrinjerl, Upper Murray, north-central group languages, and near Cape York, Schm1dt (1919a:224) draws attention to th1s word but has no explanation for 1 t - and there are many such. It 1s words of this sort that led Elkin to postulate his channels of movement or 'corridors', which are discussed in the following subsection of this essay (6.2.).

In the case of words such as *gagara, whlch seem to occur in certain 'corridors', it is possible to suggest (a) that they are the remains of anclent Australian words that have been mostly replaced, or (b) that they have spread along such 'corridors' from a central region. In e1ther case, they are not CA words but EA, if it is true that CA speakers were the group that spread over eastern and southern Australla about 6000-5000 B.P.

Th1s group seems to have spread from about the modern Wave H1ll and Victorla River and perhaps Ord River area, where archaeological sites such as Stonewall Creek and Miriwun (Mulvaney 1975:133, 135, 194) are found, dating from about 18,000 B.P. Quite a number of such sites in Arnhem Land go back to simllar periods, and these would seem to be connected with EA speakers.

The CA groups, on the other hand, are more unifled: the languages are more closely related to each other, and could well be results of the movements of one set of people, mixing with earlier peoples in different parts of the continent. Its movement can well be correlated w1th the outward spread of a new hafting technique (Mulvaney 1975: $125 \mathrm{ff.}$ ) that spread out towards Queensland and is found at the Keniff Cave in the centre of Queensland, about 6,000 B.P., overlaying an older c. 18,000 culture (Mulvaney 1975:288-9). The linguistic evidence suggests that at one period this movement, which is apparently CA, moved south-east through central Australia and western Victoria, into coastal New South Wales and thence north agaln. Its vocabulary and, still more, 1ts grammatical type are quite different from those of the EA groups wh1ch do not agree among themselves. There may well be one CA (differentlated by outward migrations at different periods), but not one EA foundation group. The whole argument being set out here suggests small early migrations into Australia from 'Sundaland' of 
bands of Australo1ds physically similar but not necessarily akin to each other.

As far as the migration routes are concerned, there has been a tendency to recognise a general north to south movement, to which Aboriginal traditions point. Curr says of these '...the late Edward Stone Parker,...formerly Assistant Protector of Aborigines in Victoria, in a lecture delivered in Melbourne in 1854, speaking of the tribes of Victorla..., remarked that they all claim a northern origin. The late Rev George Taplin also mentions in one of the several accounts he published of the Narrinjeri tribe...that they have a tradition that they originally came down the Darling, which river and the lower Murray they descended to the sea'. He mentions as verbal evidence words for 'dog, opossum, Blackfellow, water, laughing jackass (kookaburra) and heat' (Curr I:198). Th1s, of course, is the reverse of Thorne's theory, according to which they would, Indeed, have migrated along the coast from north to south, but finally entered the interior of the continent through the Murray mouth and so proceeded northwards up the Darling. Curr quotes Ridley in the Kámilarbi, and other Australian Languages as saying on $\mathrm{p}$. 118: 'On the other hand, the Aborigines in various parts of the continent point to the northwest as the quarter from which their tribes came'. Dixon, however, (private communication) states that 'the DJirbal have stories about the first man, Girugar, who was the first man to travel over the country', and who gave names to all the places - having come from the south. This may be quite true for the Dfirbal tribe - and probably 1s - without being necessarily true for others, and st1ll less, all.

\subsection{Corridors - the Paths of Peoples and Languages through Australia}

During the periods in which they came to occupy Australia, the peoples moved about freely, later settling each in a certain area which later became the tribal country, sanctified by myths which grew up. Professor Elkin has suggested that some of these movements can be at least partially recognised. He speaks of 'corridors of communication' (Elkin 1970:707ff.). This seems to be the place in which to investigate these suggestions and make them more detalled and precise (if possible), especially as the present writer has discussed with him these suggestions and had the benefits of notes drawn up by him in preparation for the paper.

Before this, however, another suggestion put forward by Dr Ian Thorpe is also worth mentioning because it deals with how the people may have 
spread round before spreading inwards across the continent. According to his 1deas, they would have avolded plunging directly into a cross walk through to the interior of the continent. As they had come by sea, it might be easier to travel round the coast first, settling where they would rather than tolling across an interior completely strange to them, not very friendly in 1 ts terrain, producing foods to which they were not yet accustomed. So he thought of them as passing from North Australia (or the north-west - the actual place of the first landing can never be ldentifled, of course) around the coast as far as Cape York, then following a southerly direction down the eastern coast In the direction opposite to that taken in 1770 by Captain Cook - unt1l they reached the southern limit, then following westwards along the southern coast, as far as the one great water opening into the interior now called the Murray River. Some of them might still have continued westwards, but others might have turned and followed upstream along the Murray, leading to the populating of the western interior of New South Wales. The discoverles at Lake Mungo, in the Menindee district, which date to about 28-30,000 B.P., do not in this way imply an earlier crossing through the interior from the present north-west or Arnhem Land, though of course they are not inconsistent with such a process. This 1dea of a settlement of the fringes before the interior is quite possible, and the distribution of $\mathrm{EA}_{2}$ pronoun systems along the coast of west Australla as far south as modern Perth and Cape Leeuwin seems to support 1 .

Later would have come the interior spread suggested by Professor Elkin and there is much linguistic evidence to support this. Whilst the various tribes became settled each in 1ts own region of the continent, and developed myths of origin, etc., concerning such areas, they often met their nelghbours for ceremonial and trading purposes. The trade relationships and paths of interchange were studied much earlier by McCarthy (1939); the ritual paths have not been worked out in such detail. However, in the article mentioned, Elkin has shown that certain words tend to follow broad paths of transmission - not only ritual and kinship terms, which do not 1mply the migration of a tribe with 1ts language, but words of common and dally speech that do just this.

In more than one place Elkin mentions the spread of ritual practices within his own experience, and the writer has seen similar movements taking place. That they took place also in earlier perlods seems perfectly logical: In many cases words have spread at the same time. 
Elkin suggests three corridors of communication - a western, a central and an eastern route. He adduces words that seem to occur around arcs of clrcles from north to south-west and north to east, as well as one that can be traced directly southwards from the north. Such a word as *nandi, mother, for instance, can be found in the middle reaches of the Murray River as well as in Arnhem Land, and in parts of South Australia between the two. So an attempt is made here to enlarge on this pattern of thought in an endeavour to trace the internal history of Australian languages. It is not the normal method of comparative philology at all - this is admitted, but in this continent with its vast time depths normal methods just break down and must be replaced by others if any results are to be obtained.

Even so, more than one stratum must be allowed for, even apart from $\mathrm{EA}$ and CA. There is clear evidence that these EA and CA strata have met in the formation of the dual pronouns in the WD languages. In the western branch of these, *gudara, two has been the formant and in the eastern section it has been replaced by *buladj. Yet both subdivisions of WD are still WD languages.

1. A start will be made with the Central corridor, which seems in some ways to be the most prolific of the three. This is the corridor which represents the north-south movement, and the southern cognates tend to be found chiefly in Victorla and New South Wales, and to have their northern relationships in Arnhem Land and in the Northern Kimberley. The point of Immediate interest is that the Kimberley and Arnhem Land sections do not correspond well to each other: roots shared between NK and V1ctorla and usually not also Arnhem Land, while those of Arnhem Land (Gunwinjgu is the chief area of comparison) found in Victoria are not usually NK also. Why this is so is impossible now to state.

Th1s statement can be easily 1llustrated: Schmidt called certain languages of west and central Victoria 'kulin', after the word gulin, man, or Kurl for a corresponding group in coastal New South Wales. The word corresponds to Ngarinjin of NK gulin, lay an egg, hatch, produce, which answers to it phonologically and apparently also etymologically. It is also found in the Perth area as adjin, with the same meaning as verb. Yet this root seems to have no place in the Arnhem Land languages.

Another example may be taken from Elkin's ga:giri, moon. This is falrly widely spread in the Kimberley languages, and the root, allowing for weakening of final vowels, may be taken as *ga:gara or at least *gagara. Various forms of it are found in south-west Queensland 
In Wagabara and Bundj1l (using Schmidt's term for one of the languages Inland from Cooktown), and Gaurna (Adela1de) and Murund1 (gagiri). It may also be Wadjiginf and Badjamal (Daly River) gare, Amarag and Jiwadja (western Arnhem Land) guRan, and Dangbon gurupa, Mawng gurana, and even Margu rana may be related. In NK there is Gambera guRa, Wulfamidi gagiri. This word does not penetrate as far south-east as Victoria. Such a word may be (a) the remains of ancient Australian words that have been mostly replaced, or (b) spread along the corridor from a central region, marked here probably by *guRana. In either case, they are not $C A$ words but $E A$ of some type or stratum.

Alongside but in contrast with this root there are others occurring in other parts of Australia. Two of these can be used by way of illustration:

(1) *giban, central New South Wales: Wiradjuri-Gamilaray, parallel but apparently not the same as Yuwinj *gubandun, though 1t could be derived from 1t. The Gamilaray here has another root *balu(n) also.

(2) *bira, 'Luridfa' Including Bindub1, South Australian Lakes language: Mirning, wila-ra. Th1s exemplifies the set of suffixes listed by O'Grady (1966:97-8) whose status is undecided.

(3) and (4) two different words found at each side of the continent, Yungar miga on the west and western Victoria manji(n) on the east.

There is a larger set of comparatives possible between Gunwinjgu and western Victorla, though at this stage some of them are doubtful because of the distance between them and unavallability of vocabularies of languages in between. They are used here simply for the sake of suggestive comparisons between them, some of which may be proved, others rejected. They include:

1. *gabun, nose: Gunwinjgu gun-geb, cf. Yaralde gobi, Yodayoda gowo, DJabwuru gabun, eastern Victoria, Garnay Na, Ngarigu gun. Here there is also in north-eastern Queensland DJ1rbal guwu, Gundjen owe, Gugubera gau, and others.

11. *bereb, a bird name of varying significance, occurring in Gunwinjgu as berebbereb, plover, and one closely related, *bered in the same language as beredbered, kingfisher, Bungandidj as birubir, redbizl, Wembawemba 
as beredbered, plover and in Yulngu languages as

birgbirg, plover. These all seem to be related.

111. werg, quick, in Gunwinjgu weRgweRg, quick

Wembawemba werga, to hurry, possibly in WD Bindub1 war-bu, hurry (where -bu is the verbalising

auxiliary bu, hit, cause).

1v. *wida, whistle, Gunwinjgu wid-me (with intransitive

auxiliary: see *balun below): Wembawemba, Madimadi

wiḍa, cf. Yulngu wari'jun.

v. *jaRga, search for: Gunwinjgu jawa-, Djadjala jaRga, Madimadi jaga.

v1. *dara, stand, Gunwinjgu -di (past tense da-nj), Yulngu dara, Djadjadjala and Wembawemba djari-ga.

vi1. *balun, turn, in Victoria often wil-na, Gunwinjgu balun-me with auxiliary as in (1v) above, Yulngu bil-, turn.

v111. nali (or nari), what?: Narinari narl, what?, who? Bungand1df nau, what?, nanu, who?

It is noticeable how many words of this group contain apparent cognates within the Murngin or Yulngu languages: this requires further research, especially in view of the fact that these languages of northeastern Arnhem Land are clearly from the angle of structure closely related to the WD languages and therefore should contain a CA ingredient. There is also a set of compounded verbs, seen in (1v) and (v11). In Gunwinjgu me answers to EA - ma, take, have, perhaps the most widely distributed auxiliary in Australia: it has already been mentioned a number of times.

It would thus appear that this corridor is not a simple group in 1tself, but consists of two parts which have coalesced somewhat on the way south. One group of words is Kimberley-Central Australla-Victoria; the other is Arnhem Land - Victoria. Cognates between extremes still have to be sought, but that there is such a corridor seems clear. In Elkin's paper there are several traits included with the linguistic also. In regard to the words of this corridor, he notes that 'of 18 Kimberley words 12 are also in the south-east, that 1s, east and south of a line joining Port Augusta in South Australia, and Maryborough in Queensland, and two of these are also in west-central Queensland; two others are in Central Australia and seven in the south-west of 
Western Austral1a. Likewise, elght Arnhem Land words are in the same 'south-east' region, and one of them in west-central Queensland. Further, nine of the fifty words appear in both the south-west corner of the continent and in the 'south-east', two of these being also in the Kimberley Division' (Elkin 1970:707).

2. The western corridor - mapped rather differently from Elkin's has been studied in some detall by O'Grady (1966) and called by him the Ngayarda family. His word-list of proto-Ngayarda stems, from page 99 to page 103, consists of 'reconstructions without known cognates in non-Ngayarda Australian languages'. This list of 137 words, then, does not occur elsewhere, at least so far as present investigation has gone. They are peculiar to the north-western area of Western Australia. It may be that in the future some cognates may be found for some of these, but at present they stand as a group, stretching from a point a little east of Port Hedland, round North-West Cape and Inland, taking In Baljgu in the east and Dalandj1 in the west - quite a respectable area. Moreover, similar groups extend along the west coast towards Perth. These have all been heavily influenced by EA overlays and in the east by $\mathrm{CA}$ also, and in some of them constructions proper to these later strata are found. The vocabulary is not only peculiar to this area, but in so being has nothing to do with similar isolated groups to the east. This area, then, forms another major subdivision of Australia. It gives evidence of spread from east to south-west. O'Grady's remaining subgroups show words of other strata, which makes clear the degree of mixture to be regarded in the subsequent work. It will not be further discussed in this study.

3. The eastern corridor remains for discussion. This is probably not to be regarded as a unity. Elkin 1llustrates it with two different words for boomerang, to which a third may be added, gali, which is a WD word. The other two are *bar(a)gan and *wanal, and both have quite a number of phonetic variations. The word *wajal is found in north Queensland and central Queensland, through New South Wales in the direction of Bourke and Swan Hill on the River Murray, also on the Goulburn River and in eastern Victorla - Garnay. Elkin notes that it is paralleled by a very similar distribution of *gwijan, fish, and in the field of ritual life, by the practice of mummification and a belief in sky heroes. These words and some at least of the usages, go as far west as Flinders Range in South Australia. The other word for boomerang, *bar(a)gan, is chiefly south-east Queensland and the New South Wales coast north of Newcastle, but also inland with change 
of meaning: In Wiradjur1, for instance, the root is applied to the sickle moon and to a tendril; in Biribay of Port Macquarle it is applied to halr cord and in Dharug to the stringy bark. The point of interest in this case is that the same root is found in the Northern Territory, in languages round about Katherine: Mangaray, DJawan and Yangman, as balgan.

Apart from these words for boomerang, there is great varlety and no agreement at all. This is usually the case in Australla: similar words are usually nested amongst great varlety, whlch suggests that the original peoples, while raclally simliar, spoke a great variety of unrelated languages. This may be expected in terms of anything except monogenet1c theory of language origin. It must be remembered here again - even if 1 t seems the reminder is ad nauseam - that research Into Australian languages carries the student back beyond the period of record of human language altogether. Wh1le there is no evidence anywhere that language had a monogenetic orlgin, Australla seems to show positive reasons for suspecting that it did not.

The present study is only suggestive, not exhaustive. It is not possible in the avallable space, nor within the present degree of analysis to answer fully the question concerning the development of Australian languages. A brief list of words will be offered here, which it is hoped will bear out the 1deas put forth in the present essay. They are arranged alphabet1cally in each group - western, central eastern, EA and CA. They are meant merely to 1llustrate. Much more work is needed yet to produce a fully analysed Australian dictionary.

\subsection{Regional Vocabularies}

Two types of subdivision within this section may be made: the present concern is with vocabulary, as agalnst structure which has been consldered in the earlier part of the study. Many of the structural differences have developed in the continent 1tself, but vocabulary differences of the present kinds can be regarded as already existent when the speakers of the languages arrived in Australia.

It must not be presumed that the divisions here discussed represent all the apparently non-EA/CA groups. Some may be language or famlly 1solates, as has already been mentioned, and T1w1 is one of the former types - language-1solates. The Queensland Gulf group (3.3.4.1.) is an example of the family 1solates. Moreover, there has frequently been cross influence from EA/CA on orlginally non-local groups. Again, EA has already been defined as 1tself a conglomerate, not a single 
ancestor. The diagram in O'Grady's article in this volume represents this state of affalrs. Most of his languages on the lines dated earlier than 10,000 B.P. are types of EA, and perhaps some of those between that date and 5,000 B.P. also are. The problem, which cannot be faced in this present work is to determine what is $\mathrm{EA}_{1}, \mathrm{EA}_{2}$, etc., as far as subgrouping may be required. Only certain of the regional vocabularles will be discussed at present. The full working out would result in an Australian comparative dictionary, for which the time is not yet ripe.

The list used here is a short list in which the words of the various subgroups are tested against a certain number of EA/CA roots whose existence has been shown by the author in other writings. They will serve to show how far the varlous tested languages (representative of their subgroups) deviate from EA/CA standards. No attempt is here made to distinguish between $E A$ and $C A$ - this remains for a later study to do with any degree of certainty. They simply serve to show what recognised Australian standing the various words tested may have.

\subsubsection{Tiwi}

Osborne's finding as to the 'Australian' nature of Tiw1 (Osborne 1974 ) has been already mentioned in 3.3.2. The vocabulary appended here shows that while in general he is right, there is a slightly higher occurrence than this would indicate. At the same time, it cannot, of course, be proved that other EA/CA words are not loans from mainland languages. For instance, his kukuni, water, could well be a loan from Jiwadja: - $n i$ is the masculine ending. Hence no historical conclusion is presented at this stage.

\begin{tabular}{|c|c|c|c|}
\hline English & $\mathrm{EA} / \mathrm{CA}$ & Tiw1 & Comment \\
\hline beard & Danga $(r)$ & kumuti & $\begin{array}{l}\text { taken by Osborne as } \\
\text { Malay kumis }\end{array}$ \\
\hline$b i g$ & bu!ga, bunda & aRikuia-ni & $\begin{array}{l}\text { - } n i \text { is a masculine } \\
\text { ending }\end{array}$ \\
\hline black & ma ! u & tunuwini-ni & \\
\hline bone & dargu & pwat a & \\
\hline breast (female) & Daman,bibi & puia-ți & $\begin{array}{l}-t i /-t i \text { is a } \\
\text { mascuiline ending }\end{array}$ \\
\hline burn (1ntr.) & gamba & țurumumi & \\
\hline & nuran & $\begin{array}{l}\text { țapața, } \\
\text { tanaRima }\end{array}$ & \\
\hline
\end{tabular}




\begin{tabular}{|c|c|c|c|}
\hline English & $\mathrm{EA} / \mathrm{CA}$ & Tiw1 & Comment \\
\hline crow (n.) & wagan & wakwaki-nl & Australian root \\
\hline ear & binan,kuru & mikantan-na & $\begin{array}{l}\text {-na is a feminine } \\
\text { ending }\end{array}$ \\
\hline earth & guruan & kal uwa ț i & \\
\hline eat & Da-, da- & - apa- & \\
\hline egg & gambu & 'karaka & turtle egg \\
\hline$e m u$ & gunin & & not found \\
\hline excrement & gunan & $k i n i-R i$ & possible Australian \\
\hline eye & mirin & pitaRa & \\
\hline father & baNbaN & $-r i n a-n i$ & \\
\hline fire & waru, guran & $j i k w a-n i$ & \\
\hline fish & gwijug & $\operatorname{minu}-\mathrm{t} i$ & \\
\hline food (veg.) & $\operatorname{maj} \mathbf{i}$ & $j i n k i-t i$ & \\
\hline give & $j u-, w u-$ & akəRai & \\
\hline$g o, w a l k$ & ja $(n)-$ & $-u R i$ & \\
\hline hand & maRan & jikaRa & \\
\hline head & gada, wa lu & punitaka & \\
\hline hear & wina-, wuna- & -munuma & \\
\hline hit & bu - & pingi- & possible cognate \\
\hline $\operatorname{man}$ & badun & awuri-ni & possible cognate \\
\hline meat & minja & puninkapa & \\
\hline moon & gagara & tapara & \\
\hline mouth & dagan & $j \quad r$ puntaRa & \\
\hline nose & mura $(\eta)$ & j $R$ D'tamura & \\
\hline one & $?$ gudju & jati & \\
\hline see & na- & $-\operatorname{mani}$ & \\
\hline $\operatorname{shin}$ & daran & jinuwana & \\
\hline sit, seated & $n i(n)-$ & $-m u$ & \\
\hline skin & gulan & mipura & \\
\hline smazz & dugu & $k i R i \underline{t} i-n i$ & \\
\hline
\end{tabular}




\begin{tabular}{|c|c|c|}
\hline English & $\mathrm{EA} / \mathrm{CA}$ & Comment \\
\hline smoke (n.) & burin & kumiripi-ni \\
\hline speak & wanga & an raka \\
\hline spear & guridada & a rawuninkiri \\
\hline stand $(i n g)$ & DaRa & $-i n t i$ \\
\hline star & bing $i r i$ & tapali-na \\
\hline stone & buli & $\begin{array}{l}\text { possible but with } \\
\text { drastic vowel change }\end{array}$ \\
\hline sun & dindu & jimi-na \\
\hline take,grasp & ma - & maru'Ri \\
\hline they & dana & wuta \\
\hline tongue & dalan & jimita!a \\
\hline tooth & liran & jinkana \\
\hline tree & ? yiwara & purint rina \\
\hline two & $\begin{array}{l}\text { buladj, } \\
\text { gudara }\end{array}$ & juraRa \\
\hline urine & gumbu & pwat $i-n i$ \\
\hline water & $\begin{array}{l}\text { gugu, gabi; } \\
\text { gaba }\end{array}$ & Australian \\
\hline we two & Dali & mu-wa \\
\hline what? & minan & $\begin{array}{l}\text { kami-ni; } \\
\text { aunwa-na }\end{array}$ \\
\hline who? & Dana & kuwa-ni \\
\hline you (sing.) & $n j i n$ & probably Australian \\
\hline you (plur.) & nura & probably Australian \\
\hline \multicolumn{3}{|c|}{$\begin{array}{l}\text { The words marked 'probably Australian' are of interest, especially } \\
\text { the pronouns, for it has already been suggested that the word for } \\
\text { water may be a loanword. The pronouns, however, are less likely to be } \\
\text { so, for these are amongst the basic words of a language. The point of } \\
\text { especial interest is the ending -wa, which is found in mu-wa, we two, } \\
\text { nu-wa, you (plural), and also in na-wa, we. If the plural pronouns of } \\
\text { lst and 2nd plural are compounded of Australian roots with the addition } \\
\text { of -wa, this would seem to be the -*badj already mentioned as } \\
\text { characteristic of certain areas of Australia and presumably EA. }\end{array}$} \\
\hline
\end{tabular}


It may seem that basically this language is not Australian, especially when 1ts greatly divergent grammar is considered, but it must be remembered that the same impression was made earlier by the northern languages of Cape York Peninsula unt1l K.L. Hale was able to demonstrate that they had merely undergone a particular set of sound changes - then they could be shown to be Australian. The same may be true for Tiwi also. It is as yet too early to make a final judgment.

\subsubsection{Arnhem Land Languages}

In the original classification in terms of lexicostatistics by O'Grady and F.M. and C.M. Voegelin in 1966, the Australian languages were divided into 29 phylic families, of which 28 were found in Arnhem Land. Th1s implies extreme variation in this part of the continent. Although the present study may lead to some modification of this scheme, there can be little basic disagreement with 1 . According to Dyen's principles of relationship (Dyen 1956) the original 'homeland' should be sought here. It is not within the scope of the present study to do this but only to point out (a) that there is more interrelationship between the languages of Arnhem Land than was at first thought, and (b) that the eastern languages fit in fairly well with the great mass of Australian languages, although with a basis that is strange and local. Some languages which are now almost extinct, such as Amarag and Gagadju, still stand apart: they may be regarded as the first stratum of Arnhem Land languages; others, such as Gunwinjgu, which has practically supplanted them in the west, as a second, and one with more EA content than the older ones. Th1s will not be 1llustrated here. The next vocabulary to be used here will represent the element that is common to the eastern languages, the so-called Murngin or Yulngu Group. This has many features of the WD languages, and looks like an enclave of these languages in Arnhem Land.

A similar comparative vocabulary of the same set of words as was used for Tiw1 now follows.

\begin{tabular}{|c|c|c|c|}
\hline English & $\mathrm{EA} / \mathrm{CA}$ & Yulngu & Comment \\
\hline beard & Danga $(r)$ & da-warag & $\begin{array}{l}\text { da is a common root for } \\
\text { mouth, eat (probably EA) }\end{array}$ \\
\hline big & bu!ga, bunda & jindi & \\
\hline black & ma ! u & gurnan, mo: 1 & \\
\hline $\begin{array}{l}\text { blow with } \\
\text { mouth }\end{array}$ & bu - & daggur?jun & \\
\hline bone & d̦arga & gaRga & not related: $d>0$ unlikely \\
\hline
\end{tabular}


A. CAPELL

\begin{tabular}{|c|c|c|c|}
\hline English & $\mathrm{EA} / \mathrm{CA}$ & Yulngu & Comment \\
\hline boomerang & ga! i & ga!' ga!i & $\begin{array}{l}\text { this is a specifically wD } \\
\text { root }\end{array}$ \\
\hline breast & naman,bib i & gumur & \\
\hline burn (intr.) & gamba & danalguma & transitive form \\
\hline camp & guran & wa : na & \\
\hline crow (n.) & wagan & wa: g & $\begin{array}{l}\text { Australian, but also *wagura } \\
\text { possible relative }\end{array}$ \\
\hline ear & binan,guRu & buduru & \\
\hline earth & nuran & munada,dju!ga & \\
\hline eat & da-, na- & luga & \\
\hline$e g g$ & gambu & mabu & \\
\hline emu & gunin & wurban & \\
\hline eye & mirin & mil & $\begin{array}{l}\text { EA, but there is also } \\
\text { manudj } i\end{array}$ \\
\hline father & baNbaN & baba & $\mathrm{EA} ?$ \\
\hline fire & waru & guRda, gurdja & $\begin{array}{l}\text { the second may relate to } \\
\text { guran }\end{array}$ \\
\hline fish & gwijan & gwija & $\mathrm{EA}$ \\
\hline food (veb.) & $\operatorname{maji}$ & Dada & seems to link with *na, eat \\
\hline foot & dinan & nugu & \\
\hline give & ju-,wu- & guruban & \\
\hline go,walk & Jan- & $\operatorname{mardj} \mathbf{i}$ & \\
\hline hand & maRan & gon & \\
\hline head & gada, wa lu & !iya,gongu & \\
\hline hear & wina-, wuna- & Da-ma & \\
\hline $\begin{array}{l}\text { hit with } \\
\text { hand }\end{array}$ & bu- & wuddun & \\
\hline $\operatorname{man}$ & badun & uמulu & \\
\hline meat & $\operatorname{minja}$ & Danag & \\
\hline moon & gagara & ga! indi & \\
\hline mouth & dagan & da & $\begin{array}{l}\text { shorter form da in some } \\
\text { languages. }\end{array}$ \\
\hline
\end{tabular}




\begin{tabular}{|c|c|c|c|}
\hline English & $\mathrm{EA} / \mathrm{CA}$ & Yulngu & Comment \\
\hline nose & mura( $(0)$ & guru & In contrast with guRu, from \\
\hline one & ? gudju & wangan $\mathbf{j}$ & \\
\hline see & na- & na-ma & agreement w1th EA \\
\hline shin & daran & $\begin{array}{l}\text { wombal, } \\
\text { balwag }\end{array}$ & \\
\hline sit & nin- & nina & agreement w1th EA \\
\hline skin & gula (D) & galna & possible agreement \\
\hline smazz & djugu & & no common root \\
\hline smoke (n.) & burin & diliwur & \\
\hline speak & wanga & wa : na & $\begin{array}{l}\text { apparently cognate in spite } \\
\text { of } \eta g-D\end{array}$ \\
\hline spear & guridada & gaṇa & \\
\hline stand & DaRa- & dara,daja & \\
\hline star & bing̣iri & ganju & \\
\hline stone & buli & guṇda, baṇda & \\
\hline sun & dundu & wa ! u, wa lir & \\
\hline take & ma- & mara-ma & cf. EA maRan, hand \\
\hline they & dana & $\begin{array}{l}\text { walala, } \\
\text { danali) }\end{array}$ & $\begin{array}{l}\text { dana (1) forms in northern } \\
\text { subgroup }\end{array}$ \\
\hline tongue & dalan & mada, nanar & \\
\hline tooth & liran & lira & $\mathrm{EA}$ \\
\hline tree & ? yiwara & daRba & \\
\hline two & $\begin{array}{l}\text { buladj, } \\
\text { gudara }\end{array}$ & marma,bulal & bulal in north \\
\hline water & $g a b i$ & gabi,gabu & \\
\hline we two & ga 11 & nali & In all the languages \\
\hline what? & minan & na & \\
\hline who? & Dana & jol & \\
\hline you (sing.) & $n j i n$ & $n i:$, nunu & \\
\hline you (plur.) & nura & numa & \\
\hline
\end{tabular}




\subsubsection{Other Areas}

A longer vocabulary of Gulf languages has already been given: its message of lexical diversity is the same as the two immediately preceding this section: varying degrees of common vocabulary, from eightyelght or so percentage for WD down to a practically negligible amount. All this has surely the historical message that there is no one common ancestor for Australian langliages. Structurally, too, the same message is recelved: there is a certain amount of structural similarity, a certain amount of structural development, but not one hundred per cent. The division into prefixing and suffixing languages may be explicable historically in ways previously suggested, and there is enough common material in the languages of the two types to justify a feeling that once there was ultimate unity of type, and that syntactic change can account for the dichotomy. Even so, this accounting is incomplete when 1 t comes to the level of lexicon, and the conclusion is nevertheless almost inevitable - that Australian languages fall into strata defined by different periods of entry into the continent. All are old, and perhaps O'Grady's diagram to which reference has already been made offers the best picture of the process at present available. In the absence of written history, and in view of the antiquity of the languages, perhaps nothing further can be concluded, and it is wise to accept the limitations.

However, one further set of words is given in comparison with $\mathrm{EA} / \mathrm{CA}$ - from the extreme south of the continent: Yaralde, in the extreme south-east of South Australia. The alm is to show that the great divergences from a possible common ancestor are found not only in the north and east but also in the south. The languages of Victoria eastward from Yaralde almost as far as Gippsland are similarly divergent, but each in 1ts own way. No study has yet been done on a language-to-language basis, as the lexicostatistic method demands, but the inter-resemblances are not great and the resemblance to EA/CA standards no greater than in the north. The great interrelationships between the EA/CA languages occupy the centre rather than the circumference of the continent. Yaralde is given here without a 'comments' column. An asterisk before a Yaralde word does not mean in this instance that it is a reconstruction, but that it is or seems to be in the $\mathrm{EA} / \mathrm{CA}$ sequence. 


\begin{tabular}{|c|c|c|c|c|c|}
\hline Engl1sh & $\mathrm{EA} / \mathrm{CA}$ & Yaralde & Engl1sh & $\mathrm{EA} / \mathrm{CA}$ & Yaralde \\
\hline beard & nanga ( $r$ ) & meragi & mouth & dagan & dor i \\
\hline$b i g$ & $\begin{array}{l}\text { bulga, } \\
\text { bunda }\end{array}$ & gra:wi & nose & $\operatorname{mura}(\eta)$ & gobi \\
\hline black & ma ! u & gineman & one & $?$ gudju & Jama li \\
\hline $\begin{array}{l}\text { blow with } \\
\text { mouth }\end{array}$ & bu - & gemb- & $s e e$ & na- & *nag- \\
\hline bone & darga & badbadi & shin & daran & guri \\
\hline boomerang & ga! i & baygadj i & $s i t$ & nin- & lew- \\
\hline breast & nama n, bibi & numbura & skin & gula (g) & wayandi \\
\hline burn & gamba & guld- & smazl & djugu & muralagi \\
\hline crow & wagura & waranani & smoke & burin & $\begin{array}{l}\text { gari, } \\
\text { nawuldi }\end{array}$ \\
\hline ear & binal & b lomb i & speak & wanga & jaṇ- \\
\hline earth & nuran & belebi & spear & guridada & ja:ṇdi \\
\hline eat & da-, Da- & yay-, dag- & stand & IaRa & daju l- \\
\hline egg & gambu & beladi & star & bingdiri & duldar \\
\hline emu & nunin & binjali & stone & bu $1 \mathbf{i}$ & medi \\
\hline father & baNbaN & nanay & sun & dundu & nugg \\
\hline fire & waru & gen i & take & ma- & bindame l- \\
\hline fish & gwijan & mami & they & dana & gar \\
\hline food (veg.) & maj i & nuni & tongue & dala & *dalangi \\
\hline foot & dinan & duni & tooth & liran & *duri \\
\hline give & $w u^{-}, j u-$ & bemb- & tree & ? Jiwara & jab i \\
\hline$g o, w a z k$ & jan- & no- & two & buladj & *bu ladj i \\
\hline hand & maRan & duṇi & water & gabi, gugu & * gugi \\
\hline head & gada, wa lu & gu ! i & we two & gali & *nel \\
\hline hear & wina-, wuna- & gun- & what? & minan & *minj i \\
\hline$h i t$ & bu - & memb- & who? & Dana & *nangi \\
\hline $\operatorname{man}$ & badun & go:ṇ & you (sing.) & $n j$ in & *り ind i \\
\hline meat & minja & gald & you (plur.) & nura & *nu! \\
\hline moon & gagara & margeri & & & \\
\hline
\end{tabular}


The vocabulary of the Dampler Land languages differs from dialect to dialect, although they form a single group, but the proportion of $E A / C A$ material is not large. The 100 wordlist gave an average of some $30 \%$. Moreover the occurrences vary from dialect to dialect. Thus, *gambun, egg appears only in Njigina, but there is a parallel gambin elsewhere: this word has been discussed as a multiform root in 2.4.2.

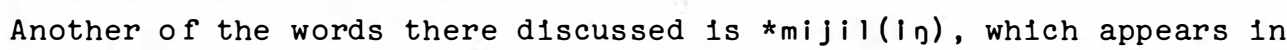
Yawur as -min but Nj1gina as -milgar, with an unexplained addition; *maji, vegetable food is in Njulnjul maj. *BaNbaN, man appears in all the languages as a form of wamba, as already discussed, and has close parallels in Cape York; see again 2.4.2; *bibi, mother In Yawur 1s a local varlant for breast, but Bard has namara, which seems to be a form of $\mathrm{CA}$ *naman. Bard bala, here looks like a form of the EA ba (ergative ba-l(u), he, she). There are occasional direct links with $\mathrm{CA}$ as na, wa, $\mathrm{mi}$, give (wa is also $\mathrm{CY}$ ), and in other parts of Australia there are wu, ju (Including Victorian Wembawemba and Djadjala) wu, a presumably EA root to whlch CA answers w1th *ju: -mala, -malj, hand is EA *maRan: Yawur and Njulnjul in this case, cf. CY mala, CA *maRan and perhaps Njulnjul ari(jag), no, not, may answer to CY kari.

In other cases, disagreement among DL languages is radical: good is in Yawur mabu (found also in Garadjar1); Njulnjul laib. Yet the common auxillary *bu, hit is entirely absent, even from the heavily NK-Influenced Warwa. Confugation by auxiliary is well developed (Capell 1953 ) though with a totally different serles of auxillarles from those generally in use in Australia, and with prefix confugation but without object incorporation.

The CA words found include the following: *bibi, mother (Yawur) *liran, tooth here mouth, *naman, breast, *dalan, tongue, here djalanj or djanalanj, a southern word for which Nj1gina has angal. Within the 100 wordlist, aside from CA cognates such as the above there 1s much disagreement: Yawur, Njulnjul and Nj1gina share 56 words, some of which are CA but the majorlty are not. Some typlcally WD words are found, such as djingu, fire, cf. Bidjandjadjaradjun-ba, ashes, gular, west, cf. WD wuluRara.

Other words are CA but w1th change of meaning; not only is this so, but two different $C A$ roots may occur in DL languages with the same meaning, e.g. mouth: (1) $-1 \mathrm{ir},-1 \varepsilon r$, In Yawur, Njulnjul, Nj1gina and Warwa $=\mathrm{CA} \star$ IIraj, tooth; (2) Yawur djawa $=\mathrm{CA} * \mathrm{da}($ wa), mouth, but Immediately to the south Bunara has djalanj, tongue $=\mathrm{CA} \star d a l a n$, and In Yawur and Warwa, djalan = tongue. Where the languages agree, there often seem to be no links with other parts of Australia, as is the case 
for fall and fish. Yet there are of ten agreements with regions far distant, e.g. Bard buRu, mainland DL bur(u), earth, camp, which occur In Murawar1 (New South Wales) as well.

Of the numerals wandjari, one, of which Bard aRindji seems to be an inversion, seems to be independent, but gudjara, two is $C A=W D$.

In the field of general vocabulary there is an interesting word gulin, sleep, which may connect with NK gulin, lay egg, which recurs in Perth district as adjinj and Wembawemba (Victoria) as gulin, man (Schmldt's 'Kulin languages') as well as Ngarinfin (NK) gulin, Zay an egg.

\subsection{The EA/CA Element: Corridors Revisited}

Schmidt (1919a) sets out for each of his subgroups a set of words to be traced as characteristic for that subgroup. These words - or In some instances varlable shapes of shared words - are usually EA/CA, although some do not seem to belong to elther group. Such words, of course, may represent a stage of language earlier than most of our EA: this question cannot be looked at here but needs to be studied at some stage of investigation. They may help to untangle the stages represented by the symbol $\mathrm{EA}_{\mathrm{a}} . . . \mathrm{n}$.

Such being the case, the only possible further work is to deal with lexicon that can be called elther Early Australian or Common Australian. As to. whether languages of the types just considered owe any characteristics to external origins or external influences, no clear conclusions seem attainable. For discussion of possibilities in this field, see Wurm 1975:915ff.).

Therefore leaving the 'substrata', if the term is right, it is best to consider the various strata that can rightly be called Early Australian first of all, and then proceed to consider the real nature of Common Australian. It is true that the author when he proposed this term had wider 1deas for 1t than he has now, but the term 1tself need not be discarded. The next step therefore is to take these two subdivisions of the Australian language totality and deal with them separately.

Before passing on to individual 1tems, it is worth noting that in Australia there has been a considerable tendency to change meanings of a root, Just as in New Guinea and other places. Indeed, it is sometimes difficult to determine which was the earliest meaning of a root, e.g. breast, mother (*bibi, *naman); which was earliest? And the former - *bibi - can even mean father occasionally, and other kinship terms can change gender in a similar puzzling manner. A single root 
may mean head in some languages and eye in others; mouth, tongue and tooth seem to interchange meanings indefinitely. In less frequent cases, even wider changes of meanings can occur. According to O'Grady (1966, word 628) the root meaning of *narga is beard, in some of his Ngayarda languages, but in Walfbiri jarga is man. Amongst adult aborigines, the man is marked by his beard. This is not an isolated instance and others will be recalled. O'Grady, in his contribution to this volume, also develops the 1dea of antonyms, as one of the causes of change of meaning, and this raises still more difficulties, even if also the possibilities of more common words.

To 1llustrate the interaction of phonological rules, it is convenient to look at the widespread word *badun for aboriginal adult male (without reference to social status) in 1ts local occurrences. It is a CA root occurring widely in the Western Desert areas, where one of the groups has been called by O'Grady 'the Wat1 Group'. Looking first at the changes of the initial consonant, we see:

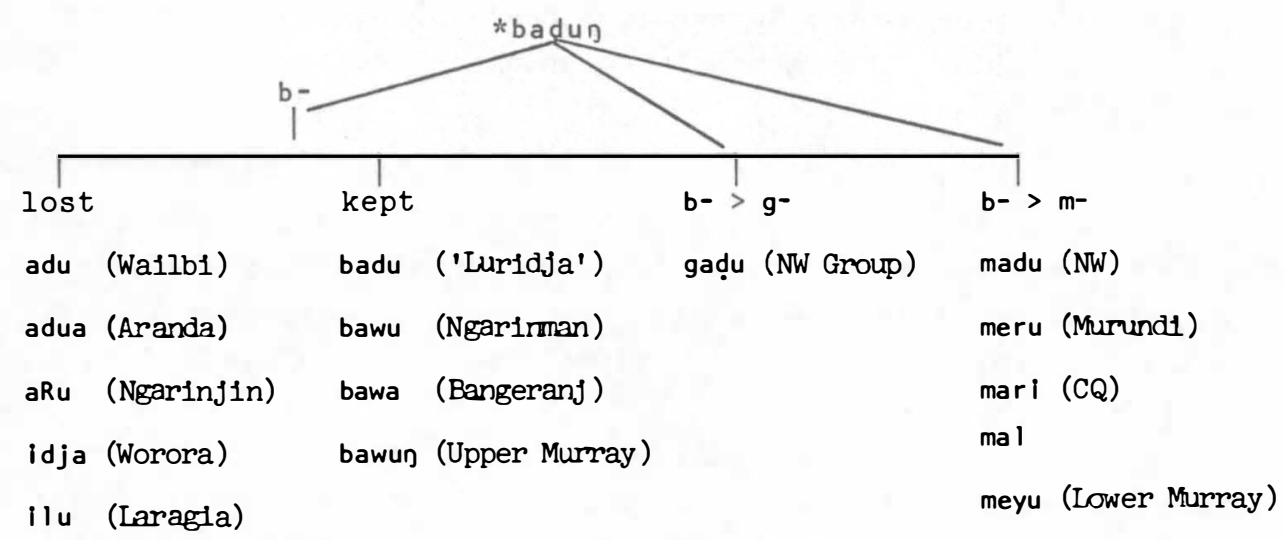

Other incidental changes (in the middle consonant) can be seen here as well as occasional changes in the vowels. St1ll other minor variations are noticeable elsewhere, such as Marawra mali, S.E. Bungandidf mara, Inland Yuwinf marin (where, as usual in this area, the final consonant is preserved but in the unusual form of $n<0)$, Gamilaray marl, where 1 t contrasts with gibir, initiated man which has relatives elsewhere, including apparently, Tasmanian wibar (Plomley 1976:317), but this could be a loanword after settlement in Australia of the whites. There is also a group of Daly River languages showing meri (Tryon 1974:271). 
As against this, there are other quite widely spread forms for man, e.g. *bama, which has been used in the hypothetical 'Pama' languages in the Pama-Nyungan Family. In Dampler languages, as in Cape York there are forms of wamba, wamb, amb, abm and some other variants. It 1s hard to connect these 1mmediately with *badun but they can be connected w1th *baN ( 1 which $N$ stands for any nasal consonant), reduplicated as baNbaN. This baN could, Indeed, represent *ba(du)n but this cannot be proved. In Victorla there are forms of ben, ban, which seem to belong too, while in Iyora (Sydney) and some nelghbourIng languages bijana = father, the senfor 'male' of the family. Such further connections as these remain, of course, problematical but quite possible within the time depth.

In south-west Queensland there are forms of gana(j) from which Schmldt named his Kana Group: gana is the usual form in these languages, but G1ppsland ganay (In the 'Kurna1' language) may link with 1 t.

The most notable word, however, is *gulin, already mentioned, and in the form Kulin used by Schmidt as a title of the western Victorian groups. Th1s appears in the Central Corridor in Ngarinjin gulin, bear offspring, in the far south-west in Wadjug and Njungar adjin, hatch, as well as in western Victorla gulin, man, eastern New South Wales guRi, man (here sometimes contrasting with guri, ear). It is just possible that Schmidt's yuwin form in these areas may link with 1 t.

There are st1ll quite a number of other words for this concept, which cannot be listed here: the whole set serves to 1llustrate the unity-1n-diversity which is the Australian Group of languages. They must wa1t for further discussion unt1l an Australian comparative dictionary can be worked out. The Victorian languages are of particular interest in such a scheme, for they seem to have three strata: local words, which show considerable differences, local plus Northern Kimberley vocabulary through the Central Corridor, and a CA element which appears in the structure of some of the languages, especially in the AT phenomenon.

\subsubsection{Regional Studies of $E A / C A$}

The preceding lists wlll have stressed the varlety within EA/CA. This varlety has been 1rregularly studied. The two fullest studies to date are O'Grady's (1966) on the north-west and the desert languages of central Western Australla and Kenneth Hale's on Cape York (Hale 1964, 1966). In the former some hundreds of words have been studied a group of 137 wh1ch O'Grady has found only in the Ngayard1c languages: 
these have been referred to earlier; further, some hundreds more which can be traced in other parts of Australia. These latter are of particular importance for declding the scope of EA/CA. They link up with Hale's study which begins from the other side of Australia, so that between them the entire northern half of the continent recelves good inftial covering. Sommer (1969) has complled a vocabulary of proto-Australian, 'proto-Paman' based on Hale's list which makes interesting comparison with others complled from other sources. Only the briefest results can be set out here.

The lists from the two sides of the continent do not by any means colncide. For example, Hale's *kuuku, speech, language, is limited to Cape York, and the term 'proto-Australian' needs to be reinterpreted if applied to such regional lists. It must be read merely as 'proto-Cape York' and there is no basis for treating such limited words as proto-Australian. They may actually be so, but 1t cannot be proved. To treat them as such gives a quite false 1dea of present attainments in such studies, and if the present work accomplishes anything at all, it is an attempt to introduce proper perspectives Into what must be at all times a difficult reconstruction of completely lost languages - which almost by definition is in any case impossible. Some of the lists of Hale and Sommer, if valid beyond Cape York, point to at least dialectal differences at the proto-Australian level. Sommer gives wa-, give: elsewhere the root is restored as *wu- or *ju-, not *wa-, and this points to an as yet not understood variability of vowels even in the three-vowel languages.

Schmidt in his Gliederung is ultimately the source from which the present author first gained his 1dea of a 'Common Australian', now subdivided Into Early and Common Australian, so it is fitting to return to his work, for by plcking out reglonal varlants, something can be added to our present knowledge of common words including pronouns. Schmidt in the second part of that work really indicated possible local - or temporal - subgroups that may be of importance in the further development of the historical linguistics of Australia.

\subsubsection{Distribution of EA Material}

Thorpe's suggestion has already been mentioned, v1z., that early migration may be presumed to have followed the coastline before breakIng into the interior and crossing the continent. This had been adumbrated already by A.L. Kroeber (1923). H1s distribution charts showed that 'a general distribution of one stratum' (usually placed 
first in his lists), with a 'tendency to spread nearly all round the coast and eastern interior, missing the north-west coast, north coast and Cape York'. Th1s, of course, supported the 1dea of entrance via Cape York and the spread southwards and southeastwards through the Immediate hinterland, and this seems natural inasmuch as these are well watered areas inviting habltation. Here, too, the languages are numerous and cover comparatively small areas. It is worth looking at a linguistic map of the area to see that this is actually true at the present time. He also suggested that the entrance point was later swamped by - possibly - Papuan 1mmigrants. Though there may have been such a later entrance, the 1dea of 1ts Papuan orlgin - in the modern sense of 'Papuan' - needs rewelghing. He also suggested that the Kimberley peoples really came via the north-western sea route, but combined with an earlier branch of the common Australian race, who are still represented by the peoples of Forrest River region and others around them. Th1s suggestion 1s more eas1ly open to doubt.

A study of Kroeber's very useful maps of word occurrences is perhaps a help to test out Thorpe's later theory and at the same t1me to suggest relative ages of certain roots, although this must always be risky. To some early stages of EA movement some words may tentatively be attributed in terms of their occurrence along the coasts or inland. The weakness lies in the impossiblilty of deciding whether a coastal word represents an early movement and an inland word something later, or whether an inland word represents a group of people driven from coast to inland at some later stage. Here the frequency of occurrence is a possible guide. Thus the common $\mathrm{mil}$, eye $<*_{m i j i l(i n)}$ is by far the commonest of the names for this part of the body; *guRu is chlefly western with a predominance in WD languages, so that 1 t would seem to be $C A$ and later; *dili occurs chlefly in Cape York and 1nland Queensland. These cover most of Australia, but there are st1ll other words of very limited occurrence, at whose origin 1t is at this stage hardly possible to guess.

With this introduction it is perhaps possible to set out some lists of words, not mapped, as done by Kroeber and 1deally needed in the present instance but suggestive of historical reality in varying degrees. In some cases words appear over widely separated areas, and here it may be that lack of information prevents identification with any surety: there may be further agreements in intervening areas, e.g. seagu 2 : Njangumarda dara, Gubabwiyngu dara:g, Ump1la djara (0'Grady 1976:63); and in the same art1cle Bandj1ma mirilji, Ngarluma miri:dji; Ump1la mi?in, string; and NJangumarda njara, P1ntup1 njara, 
Gumbainggar djaran, Umpila na?a:l, that, in the distance. In many cases further examination is needed, for examples such as these show presumable cognates from west to east coast, inland and in the northern part of New South Wales. None of this can be quite accidental. Similarly, Curr (1886,II:426) quotes from Hallfax Bay (NJawag1?) mero, wommera, and adds 'which prevalls so extensively on the west coast, two thousand miles of $f$, is also found in this and in the languages of Hinchinbrook Island and Port Mackay'.

The original list of ' $C A$ ' words was worked out to the number of 48 , and from those a map was constructed showing their local occurrences in a large number of languages. The same method is applicable to others. To date the figures for occurrence in each language have not been published. The map simply shows the percentage of ' $C A$ ' words to be found in different areas. These words are now recognised to be a mixture of $E A$ and $C A$ and at this stage are better referred to as ' $E A / C A$ ' as has been done above. We now proceed to set out the lists by the numbers of the words themselves. This enables a further subdivision to be made in terms of the local occurrence of each word, by which EA can better be distinguished from CA. In this way the work can be expanded by any number of subsequent additions, even to the full length of a dictionary.

One comment suggests 1tself immediately. It does not look as though CA is radically different from EA but rather that the former is a later stage of the latter, much as Middle English is a later stage of Old English. Much as many Old English words disappeared, whether from local disuses or through replacement by such as Norman French, so CA may function in the history of Australia. The loss of a final - $\rightarrow$ in $C A$ where it is documented in EA, simplification of phonological patterns in WD languages as compared with those farther east, fit quite easily into such a process. There will still remain the 1solates, whether in northern Australia or in the south or anywhere else, and judgment on them will be made independently. It is even possible - at least theoretically - that Tasmanian languages may have occupled the mainland of the continent: no such proposition is put forward here, but neither is 1ts possibility denied.

If $\mathrm{CA}$ is in the main a later stage of $\mathrm{EA}$, then the grammar of the languages in which $\mathrm{CA}$ rules will have been radically changed. The formation of pronouns in the $C A$ languages suggests strongly that the pre-languages were structurally different. They may well have resembled Warnman in having pronouns based on noun roots with possessive suffixes to distinguish person, a set of markers which were 


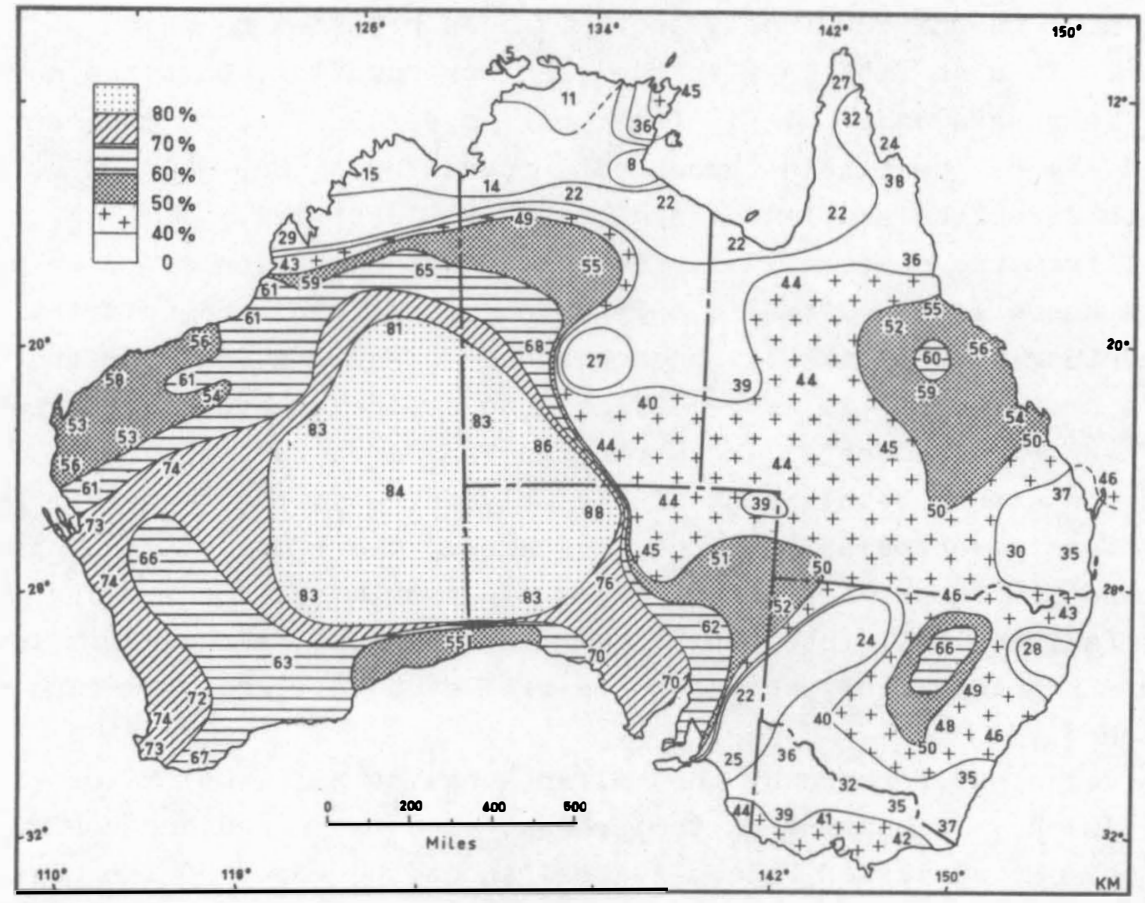

Map 7: Distribution of Common Aust. Vocabulary Reflexes 
delctic and numeral indicating, and perhaps also different syntax, leading some languages to develop AT constructions owing to a preference for svo over an earlier SOV. These two types of syntax would simply have resulted from different crystallisations of an originally free order which is still attested in parts of Queensland.

There is one presumption in the preceding paragraph: that WD languages (which are the basis of $C A$ ) are later than EA. This can be Justified especially if such maps as those supplied by Kroeber are studied. In these most of the agglomerations of words are in the eastern half of the continent, and this does not seem to be an accident. It also fits in with the other presumption, that the movement of languages came chlefly from west to east. If this movement occurred, as has been held throughout, round about 6000-5000 B.P., then both direction and lateness of date are justified.

Apart from the comparatively few words that have been set down as EA or CA there is in Australia only a set of regional vocabularies, held together by a remarkably common scheme of grammatical construction. Why this should be so is extremely hard to decide or even to suggest. It has been remarked on as in Amerindian languages, all of which exhibit the strong development of the polysynthetic type, however much they differ in vocabulary. Within a subgroup there may be much closer resemblance in vocabulary and grammar. In aboriginal America the various families fall into obviously related groups, although it is much more problematical whether there will ever be a proto-Amerindian established.

Some views put forward by the Polish linguist Milewsk1 (Milewsk1 1965:158-9) have a bearing on the present discussion and are worthy of quotation. He speaks of Palaeo-Australian as the group of languages predominant in the south-east of the continent and describes them in the following terms, which are not an impossible solution of the problem. His views are based on a study of Schmidt's Gliederung analysed according to the Czekanowsk1 method (M1lewsk1 1948, English translation summary p. 389):

' Up to the middle of the nineteenth century the site of present-day Melbourne was occupled by languages of the Palaeo-Australian family (Kulin, Kolinon, Buand1k) and on the River Murray dialects of the Narrinjeri family ruled. This was the southern edge of the continent. They had not ylelded to the process of unification, which ate into the rest of the area and led to the rise of the great Central 
Australian family. In the full process of time it occupled the whole of Australia except 1ts southern limits. The proto-family crossed over from New Guinea through the 1slands of the Torres Stra1t and Cape York Peninsula. A second expansion in full strength of a completely different linguistic type, 1t imposed on the whole area of unity in grammatical principle. The unification of vocabulary did not spread so far, and led to the establishment of some peculiarities with regard to dialectal groups.

'Between the two great families of Central Australia in the south and Austronesian on the north there stretches a region of about 150 small language families, which we divide from geographical viewpoints into two sets: northern Australian and Papuan. To the Central Australian set we assign the Aranda family, which intruded from the north into the very centre of Australia, and in addition to that about 30 small families, which came from New Guinea into Arnhem Land, on the coast of the Gulf of Carpentaria and Cape York Peninsula. In all these regions they overlaid the dialects of the Central Australian family.'

Serlous doubts may be cast on the last few sentences but at least in the absence of definite information to the contrary, they are at any rate worthy of thought.

Wurm (1975:290ff.) has already suggested connections between Cape York and south-western New Guinea - and Indeed elsewhere in New Guinea whether by borrowing from south to north or not, and some at least of the cases seem genuine. Capell also (Capell 1942:29) showed relationship likely between Gunavidj1, on the central north coast of Arnhem Land, and the languages of the western Torres Stra1t. These are set out again here:

$\begin{array}{lll}\text { English } & \text { Gunavidj1 } & \text { Torres Strait } \\ \text { one } & \text { Rabana } & \text { warapone, urapon, etc. } \\ \text { tongue } & \text { dajal } & \text { dan (tooth) } \\ \text { ear } & \text { gala- } & \text { goura } \\ \text { hand } & \text { gudji- } & \text { geta } \\ \text { bone } & \text { ida- } & \text { rida } \\ \text { kangaroo } & \text { ridjbara } & \text { udjar (Mawng) gudjbarari } \\ \text { egg } & \text { jo:gara } & \text { gagura } \\ \text { ground, camp } & \text { wiba } & \text { aba } \\ \text { what } & \text { nale } & \text { nalu (Gumulgal) }\end{array}$


He remarked on the distance between the languages as making the comparison less sure, as well as the uncertainty of any regular sound change; yet it is possible that further examination of southern New Guinea and North Australia may strengthen the possibility, and Justify Milewsk1 to that extent.

Amongst the examples c1ted by Wurm, however, a number seem to be exclusively Cape York regional language, for some of the words are ne1ther EA nor CA, e.g. hair, *janan, for wh1ch *maRa seems to be EA, and O'Grady gives *kulku-Ra as proto-Pama-Nyungan; for hear, CY *kuli 1s WD, 1.e. CA, but there is also CY *nami, and CY *kuman, thigh answers to EA daran. There is therefore st1ll much uncertainty, and Sommer (1967), based on work of Hale which is 1tself included in Hale (1974), shows a great deal of disagreement between Cape York and the languages to the south and west. Th1s means that there is a Cape York regional language to be reckoned with also.

When Australia is examined as a whole - which cannot be done here what appears is a mass of regional vocabularies, with a falrly common grammatical pattern in the languages, and an extraordinarily similar phonology throughout the continent. This is precisely what Schmidt had suggested in his two works, and Milewsk1's interpretation seems to make clearer.

\subsection{Summary}

The present paper is only a first approach to a vast subject, and this is more difficult in the field of vocabulary than in that of structure. It is now time to present a summary of the whole problem. Certain propositions are therefore put forward, all of them still awalting proof or disproof. The propositions are:

1. The proto-Australian linguistic pattern consisted of a number of apparently unrelated languages. These would all have come in at various times from various directions, but all ultimately from the north-west, via the now lost Sundaland. Little resemblance can be traced now between them: all are classified as Early Australian (EA), and even if the terminology $\mathrm{EA}_{\mathrm{a}} \ldots \mathrm{n}$ is used, this does not mean anything in practice, as the component elements cannot be isolated into a series of languages belonging to different times. As shown in O'Grady's diagram, many languages probably died out without descendants at all, and cannot now be traced. Presumably they set the phonological pattern which developed later only in certain points: 
the common basic Australian phonology goes back to such early languages, indeed may represent the pattern of phonologies in many parts of the early stages of human speech. This is where it is important to recall the fact that proto-Australian languages antedate any exisiting languages by many thousands of years. Such developments show in the absence of a volceless-volced contrast between plosives, such as still appears in. some other parts of the world as well as Australia. The development of more than one set of laminals would also have begun in these unrecorded times, and in some, especially WD languages, distinctions of the laminal series is still uncertain, as for Instance between Ooldea and parts of the Western Desert farther north. A late movement will have brought in the three vowel languages, but even in this there is considerable phonetic variation. During this stage, which could have included Tasmanian (unprovable but by no means impossible), distinction of number in nouns and pronouns was probably absent. The elements which are used to distinguish number in the modern languages all have a local appearance, and all seem to have developed locally. At a much later stage there is still confusion, as for instance in the use of *buladj to mark duality in most languages, but actually to produce also bula as they plural, in some languages of Cape York Peninsula, where the duality is no longer expressed by the word, but simply non-singularity. Syntax would have been relatively free and uncomplicated: different patterns crystallised out later in different areas.

2. One group of such languages spread, as again suggested in O'Grady's diagram, and this is the group here referred to specifically as Early Australian (EA). It was perhaps never simply a unity, or at least suffered very early dialectal modifications. The commonest vocabulary throughout the continent marks this group. This is the group to which the present author referred in his $1956 / 1962$ work as 'Common Australian' or CA. It would now seem that this term is better kept for a language or for a group of languages which moved from west to east at a date later than the EA stage. Again, this was probably never a single language, but a group of related languages developing about the Ord River-Wave $H 1 l l$ region. It is relatively later than the others, and may be connected with the cultural development that Mulvaney has shown to have moved eastward about 6000 B.P. or earlier. If Dixon's figure of about 10,000 B.P. for the Rain Forest languages of north Queensland has any value, this would mark a stage of the EA spread before that of $\mathrm{CA}$. In fact $\mathrm{CA}$ may be even older. The archaeological evidence for improved hafting techniques demonstrated 
by Mulvaney and others would be part of this movement or an outcome of $1 t$, and the date of about 18,000 B.P. for the Mirlwun findings in the Ord Valley would be part of the same picture.

An extension of movement from one or more centres in this region is noticeable in the spread of $\mathrm{CA}$ vocabulary (and perhaps certain structures also) in three directions: westwards along the north coast of Western Australia, along the Ninety Mile Beach and the interior of that region, southwards along the centre of the continent into northwestern V1ctorla and thence Into New South Wales, both coastal and interior and eastwards into the Cape York area. In the last mentioned there were already reglonal languages which could have entered via New Guinea, but belong to the EA period described in the preceding paragraph (1). These will be mentioned agaln below. Th1s Cape York movement would be earlier than the 10,000 B.P. mentioned by Dixon.

3. The preceding paragraph suggests that the so-called protoPaman 1s post-CA, 1.e. very late. The Raln Forest is estimated to have come 1nto belng before 7600 B.P. (D1xon 1970a:351 et a1.). The north-east route of $\mathrm{CA}$ would then have been covered during the period between these two dates, but Cape York Peninsula was by then already Inhablted, and proto-Paman represented an amalgam of earlier and later peoples.

There has been earlier discussion about this word *pama, from which two points emerged. The first that 1 t is shared by the Regional Isolates of the Dampler Land area with the Cape York languages (3.3.3.), and that 1ts ancestry is not quite clear (2.3.1.). It seems a very unsat1sfactory designation for a large language fam1ly, and especially for that of Cape York. It appears (see Sutton 1975 passim) that the Cape York languages have Indeed a considerable element of CA, but also a large element that is not $C A$. Such a word as *dunga, weep appears In CY as *Runga, but it also appears in the north-west of Western Australla (O'Grady 1967), and along the eastern coast of Queensland and as far south as Sydney, where dunga is given by the early writers in the same sense. Th1s looks like EA and quite clearly so. Some of the $C Y$ vocabulary can Indeed be so classifled, as EA rather than $C A$, while much is entirely different, e.g. *djamal, foot, as against EA/CA *dinan. At the same time the final -n of such EA words as this make the CY examples seem to have come through the later CA rather than EA, for a final consonant, including - $n$, is not forbldden in this area.

The CY pronouns are diagnostic in a high degree. While the actual roots are $E A$, the forms they assume are frequently not so and are of ten not CA e1ther. In CA (especially 1ts WD forms - see 3.5.) there are 
not common Independent pronouns beyond the second person singular and the dual and plural substitutes are bullt on very definite and peculiar lines. Hale is certainly right in holding that the WD pronouns are late manufactures though it has been argued that they are from a factory different to that to which he assigns them. Th1s assertion applies also to $\mathrm{CY}$, and in this case $1 \mathrm{t}$ is clear from what follows. The CY pronoun roots are,already in the ergative form, e.g. *na-ju, *nun-dju etc. but these are usable with intransitive verbs as w1th transitives. In the northern languages they also carry a postfix -*badj, as for example, In Uradh1 aju-va etc. (3.4.). It appeared there that this is a very specific suffix common to ergative and other languages, as far apart as Arnhem Land (Nunggubuyu, Mawng, etc.). South Australla (Yaralde, Meyu) and in Cape York and north Queensland (DJ1rbal). It is some form of EA and early at that, for 1t seems to have belonged to a language that spread widely in a way not character1stic of $\mathrm{CA}$. The dual marker *buladj plays a special part in CY, as has been ment1oned, and the 1mplication of this part 1s that 1 ts nature as a dual marker had elther been lost or was just not understood. It refers to locality - over there, not to two as a number, and frequently *bula is they plural. On the other hand interrogatives are built on a toana root rather than the wa- form which characterises $E A$ and is found in the Sydney area where wa is where? Yet in other parts of $\mathrm{CY}$, *wanja/i/u is found as who? and *wanjdja as where? and even an ergative form *wanjdju as who? There has been much intercrosing and mixing in this region of Australia.

Apart from these pronouns, that show considerable admixture from varlous sources, much of $C Y$ seems to be early, earlier in fact than the development of four laminals; yet there are meaning changes in some EA words adopted, e.g. *liran, tooth > tongue (Sutton 1975:107), suggesting the misunderstanding of a forelgn language coming into the region.

Subgroups of Cape York languages have developed later, in situ; 'Central Paman' would seem to be the earliest form. There is a considerable amount of non-EA/CA vocabulary in the region as a whole.

In general, the nomenclature at present in use for Australian languages as a whole is not satisfactory. The Pama-Nyungan family is particularly badly named. The word *pama is not a CA word; the root for man is *badun, and the suggestion made above that *pama may = *ba (ma)dun is insecure (see 2.3.1.). Rather *pama looks like a derlvative of *baNbaN, reduplicating a root that appears in Victoria and New South Wales as bej, biana, elther as man or as father. 
'Paman-Nyungan' is therefore quite an unsultable word. 'Pama-Maric' Is worse, as *mari is a Queensland form of *badun 1tself! Not only are such terms uneven yoke-fellows, they are rather like yoking a horse with an ox to pull the plough! In fact, the whole classification on the present language maps, as used in Wurm (1970) 1s unsatisfactory, but it cannot be improved unt1l vocabulary comparison is done on a much wider scale than at present. Australia is much more than a dichotomy of Pama-Nyungan $v$. the rest. But PP and western CA are key elements in the solution of the problem; the lock into which they fit is the non-EA/CA sector that has been partly studied here.

4. The extra-continental relationships of the Australian languages have never been worked out - most feel that there are none. For certain possible connections with New Guinea, reference should be made to Wurm (1975). The next stage is the full vocabulary comparison and the time 1s ripe for this task. 


\section{BIBLIOGRAPHY}

ANTTILA, Raimo

1972 An Introduction to Historical and Comparative Linguistics. New York: Macmillan.

BERNDT, R.M. and C.H. BERNDT

1964 The world of the First Australians. (Second edition 1968.) Sydney: Ure Smith.

BLAKE, B.J.

1969 The Kalkatungu Language: A Brief Description. AAS 20, L8. Canberra: Australian Institute of Aboriginal Studies.

1976a 'The Bivalent Suffix -ku: Rapporteur's Introduction and Summary'. In: D1xon, ed. 1976:421-4.

1976b IO Ergativity and the Notion of Subject:

Some Australian Cases'. Lingua 39:281-300.

BLAKE, B.J. and J.G. BREEN

1971 The Pitta-Pitta Dialects. Linguistic Communications 4.

BLAKE, B.J. et al.

1976 'Topic C: The Bivalent Suffix -ku'. In: Dixon, ed. 1976: 421-82.

BOKAREV, E.A.

1959 Cezskie (didojskie) jazyki Dagestana [The Tsezi (Dido) Languages of Daghestan]. Moscow:

Akademia Nauk. 


\section{BRANDENSTEIN, C.G. vON}

1965 'Ein Abessiv 1m Gemein-Australischen'. Anthropos $60: 646-62$.

1967 The Language Situation in the P1lbara - Past and Present'. Papers in Australian Linguistics 2. $P L, A-11: 1-20 a,+7$ maps. Canberra: Pac1fic Linguistics.

BREEN, J.G.

1974 'On Bivalent Suffixes'. In: B.J. Blake, ed. Papers in Australian Aboriginal Languages.

Linguistic Communications 14.

\section{CAPELL, A.}

1940

'The Classification of Languages in North and North-West Austral1a'. Oceania 10/3:241-72; $10 / 4: 404-33$.

1941 'Notes on the Wunambal Language'. Oceania $11 / 3: 295-308$.

1942 'Languages of Arnhem Land, North Austral1a'. Oceania 12/4:364-92; 13/1:24-50.

1943 The Linguistic Position of South-Eastern Papua. Sydney: Australasian Medical Publishing Co.

1944 'Methods and Materials for Recording Australian Languages'. Oceania 16/2:144-76; and as a separate interleaved book.

1951 'Bantu and North Australian: A Study in Agglutination'. African Studies 10/2:49-57.

1953 'Notes on the NJ1gina and Warwa Tribes, North-west Australla'. (Part 2.) Mankind 4/11:450-69.

1955 'Forchheimer and the Pronoun'. (A review article.) Oceania 25/4:283-91. 
1956 A New Approach to Australian Linguistics. Oceania Linguistic Monographs 1. (Also referred to in text as NAAL.) 1962: new edition [page references in text are from this edition]. (Third impression, 1966, is a reprint of the 1962 edition.)

1962 (New edition of Capell 1956: sometimes referred to in text as Capell 1956/1962.)

1962 Some Linguistic Types in Australia. Oceania Linguistic Monographs 7. (A continuation of NAAL.)

1965 'A Typology of Concept Domination'. Lingua 15:451-62.

1967a The Analysis of Complex Verbal Forms w1th Special Reference to Tiw1 (Bathurst and Melville Islands, North Australla). Papers in Australian Linguistics 2. $P L, A-11: 43-61$. Canberra: Pacific Linguistics.

1967b 'Sound Systems in Austral1a'. Phonetica 16:85-110.

1969 'Économie des changements phonétiques en Australie'. In: Linguistic Studies Presented to Andre Martinet. word 25/1-3:39-58.

1970 'Aboriginal Languages in the South Central Coast, New South Wales: Fresh Discoveries'. Oceania 41/1:20-7.

1972 'The Affix-transferring Languages of Australia'. Linguistics $87: 5-36$.

CAPELL, A. and H.E. HINCH

1970 Maung Grammar, Texts and Vocabulary. The Hague: Mouton.

CHADWICK, $\mathrm{N}$.

1968 'Djingili (North Australia) in a Comparative Perspective'. Oceania 38:220-8. 
COATE, H.H.J. and L.F. OATES

1970 A Grammar of Ngarinjin, western Australia. AAS 25, L10. Canberra: Australian Institute of Aboriginal Studies .

CROWLEY, T.M. and R.M.W. DIXON

1979 'Tasmanian'. In: R.M.W. Dixon and B.J. Blake, eds The Handbook of Australian Languages, vol.2:

Canberra: Australian National University Press. (forthcoming)

CURR, E.M.

1886-87 The Australian Race... 4 vols. Melbourne:

John Ferres, Government Printer; London: Trübner.

DIXON, R.M.W.

1970a 'Languages of the Calrns Rain Forest Reg1on'.

In: Wurm and Laycock, eds 1970:651-87.

1970b 'Proto-Australian Laminals'. Oceanic Linguistics 9/2:79-103.

1970c Olgolo Syllable Structure and What They Are Do1ng About It'. Linguistic Inquiry 1/2:273-6.

1972 The Dyirbal Language of North Queensland. Cambridge University Press.

1976a 'The Derivational Affix "having": Rapporteur's Summary'. In: D1xon, ed. 1976:306-10.

1976b 'Ergative, Locative and Instrumental Case Inflections: Rapporteur's Summary'. In: D1xon, ed. 1976:411-14.

1977 A Grammar of Vidin. Cambridge Studies in Linguistics 19. Cambridge University Press.

DIXON, R.M.W. , ed.

1976 Grammatical Categories in Australian Languages. AAS, L22. Canberra: Australian Institute of Aboriginal Studies. 
DONALDSON, T.

1976 'Wangaybuwan'. (Topic E: 'Simple and Compound Verbs: Conjugation by Auxiliaries in Australian

Verbal Systems'.) In: D1xon, ed. 1976:763-8.

DOUGLAS, W.H.

1958 An Introduction to the Western Desert Language... Oceania Linguistic Monographs 4. (2nd edn 1964.)

DYEN, I.

1956 'Language Distribution and Migration Theory'. Language 32:611-26.

EADES, D.K.

1976 The Oharawal and Dhurga Languages of the

New South wales South Coast. AAS, RRS8.

Canberra: Australian Institute of Aboriginal

Studies.

ELKIN, A.P.

1970 The Aborlgines of Austral1a: "One in Thought, Word and Deed"'. In: Wurm and Laycock, eds $1970: 697-716$.

FURBY, C.E.

1972 'The Pronominal System of Garawa'. Oceanic Linguistics 11/1:1-31.

GLASS, A. and D. HACKETT

1970 Pitjantjatjara Grammar: A Tagmemic View of the Ngaanyatjara (warburton Ranges) Dialect. AAS 34, L13. Canberra: Australian Inst1tute of Aboriginal Studies.

GODFREY, M. and H.B. KERR

1964 'Personal Pronouns in Wik-Munkan'.

In: P1ttman and Kerr, eds 1964:13-34.

HAAS, M.

1969 The Prehistory of Languages. The Hague: Mouton. 


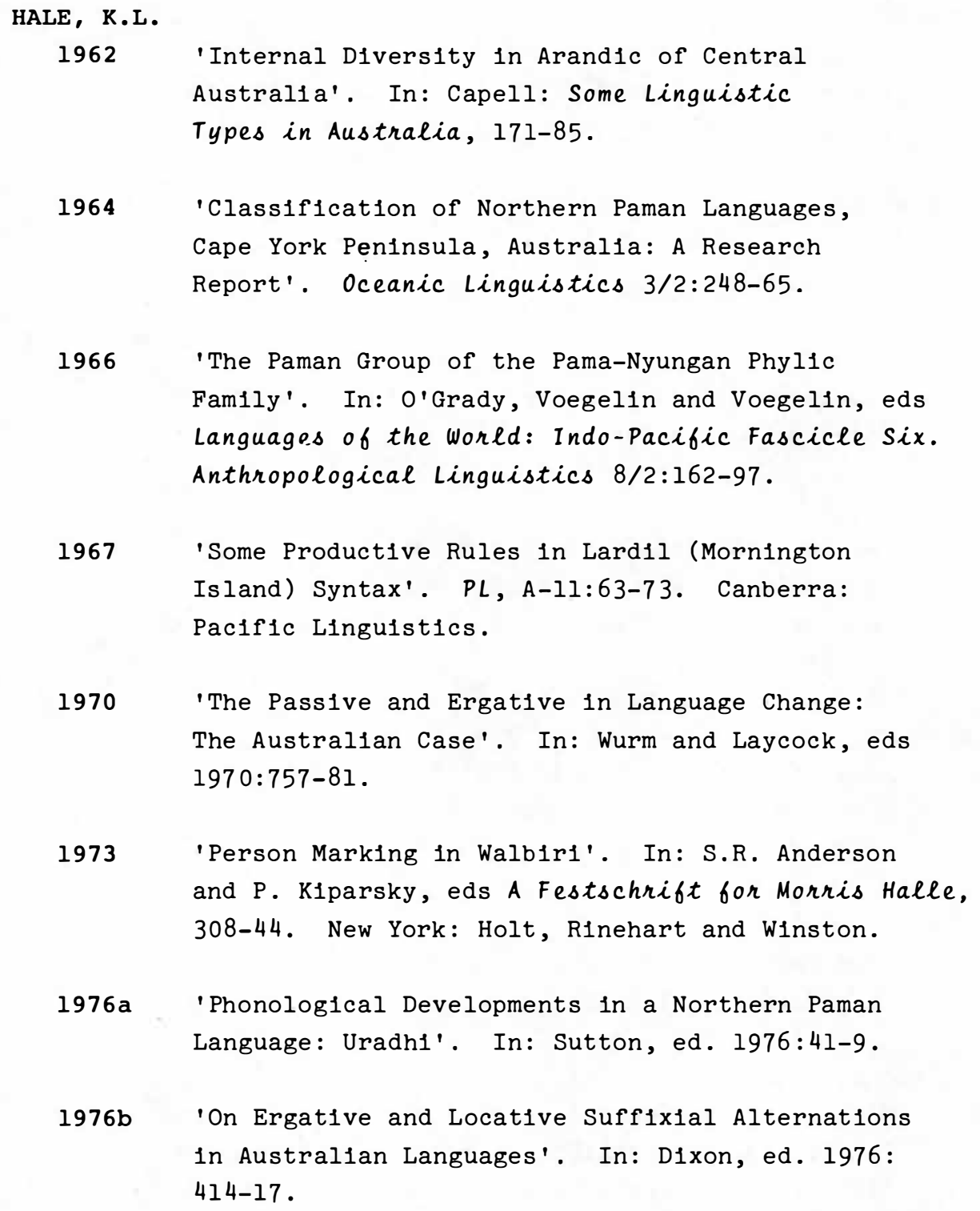

HALL, A.H.

1972 A Study of the Thaayorre Language of the Edward River Tribe, Cape York Peninsula, Queensland. Ph.D. thesis, University of Queensland. 
HANSEN, K.C. and L.E. HANSEN

1969 'Pintup1 Phonology'. Oceanic Linguistics

8/2:153-70.

HARMS, R.T.

1968 Introduction to Phonological Theory.

Englewood Cliffs, N.J.: Prentice-Hall.

HARRIS, J.K.

1969 'Preliminary Grammar of Gunbalang'. Papers in

Australian Linguistics 4. PL, A-17:1-49.

Canberra: Pacific Linguistics.

HEATH, J .

1978 Linguistic Diffusion in Arnhem Land. AAS, RRS13.

Canberra: Australian Institute of Aboriginal

Studies.

HERCUS, L.A.

1966 'Some Aspects of the Form and Use of the Trial

Number in Victorian Languages and in Arabana'.

Mankind 6/8:335-7.

1969 The Languages of Victoria: A Late Survey.

AAS 17, L5 and L6. Canberra: Australian

Institute of Aboriginal Studies.

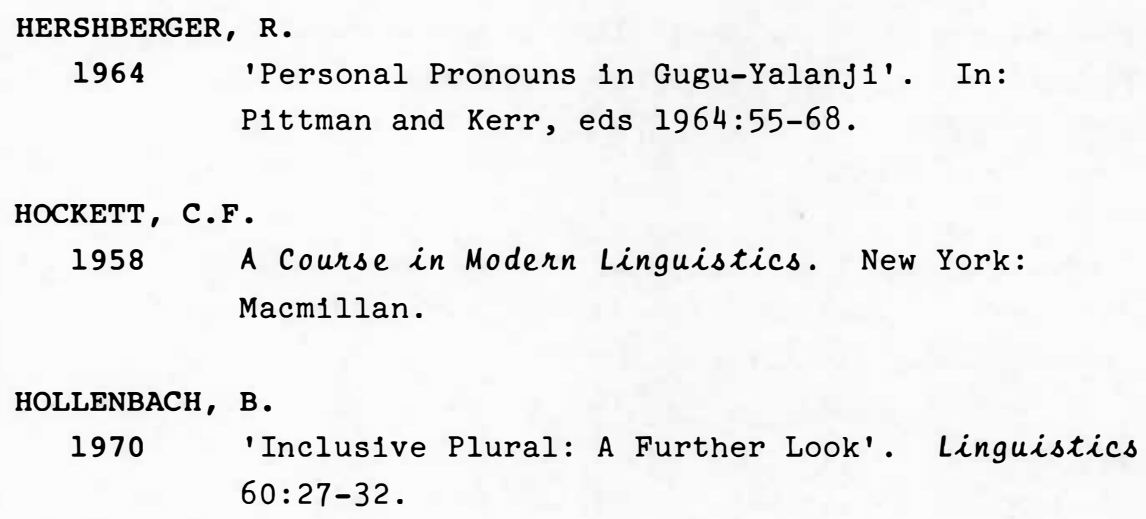


HOLMER, N.M.

1966 An Attempt towards a Comparative Grammar of Two Australian Languages. AAS 5, L3, part 1. Canberra: Australian Institute of Aboriginal Studies.

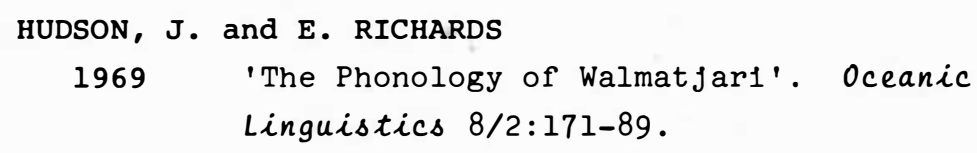




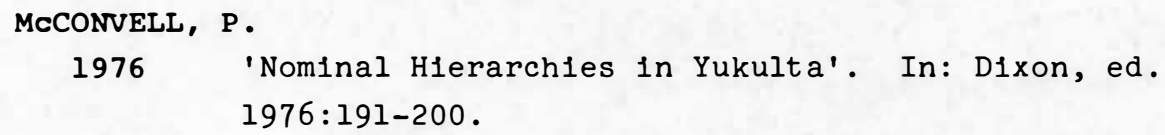

1904 'Langage des Kurnu, tribu d'Indigènes de la Nouvelle Galles du Sud'. Bull. Mem.Soc.d'Anthrop. Paris 5/5:132-8.

\section{MILEWSKI, T.[adeusz]}

1948 zarys jezykoznawstwa ogblnego. 2 vols and atlas. Lublın-Kraków.

1965 Językoznawstwo [Linguistics]. Warsaw: Państwowe Wydawnictwo Naukowe.

MOORHOUSE, M.

1846 A Vocabulary, and Outline of the Grammatical Structure of the Murnay River Language, Spoken by the Natives of South Australia... Adelaide:

A. Murray.

MÜLLER, F.

1882 Grundriss der Sprachwissenschaft. 4 vols. Australian in vol.2, section 1 . 
MULVANEY, D.J.

1975 The Prehistory of Australia. Ringwood, Vic.: Penguin Books. (lst edn London: Thames and Hudson, 1969.)

NAAL see Capell 1956/62

OATES, L.F.

1964 A Tentative Description of the Gunwinggu Language. Oceania Linguistic Monographs 10.

n.d. Murawar1. Unpublished notes.

OATES, W.J.

1967 'Syllable Patterning and Phonetically Complex Consonants in Some Australian Languages'.

PL, A-10:29-52. Canberra: Pacific Linguistics.

O'GRADY, G.N.

1956 'A Secret Language of Western Australia - A Note'. oceania 27/2:158-9.

1966 'Proto-Ngayarda Phonology'. Oceanic Linguistics $5 / 2: 71-130$.

1976 'Umpila Historical Phonology'. In: Sutton, ed. $1976: 61-7$.

1979 'Preliminaries to a Proto Nuclear Pama-Nyungan Stem List'. (In this volume.)

O'GRADY, G.N., C.F. VOEGELIN and F.M. VOEGELIN, eds

1966 Languages of the world: Indo-Pacific Fascicle Six. Anthropological Linguistics $8 / 2$.

OSBORNE, C.R.

1974 The Tiwi Language. AAS 55, L21. Canberra: Australian Institute of Aboriginal Studies. 
PERLMUTTER, D.M.

1971 Deep and Surface Structure constraints in Syntax. New York: Holt.

PIREJKO, L.A.

1968 Osnounye voprosy ergativnosti na materiale indoiranskich jazykov. Moscow: Nauka.

PITTMAN, R. and H.B. KERR, eds

1964 Papers on the Languages of the Australian Aborigines. AAS 3, L2. Canberra: Australian Institute of Aboriginal Studies.

PLOMLEY, N.J.B.

1976 A word-List of the Tasmanian Aboriginal Languages. Launceston: author in association with the Government of Tasmania.

RAY, S.H.

1907a 'Linguistic Position of the Australian Languages'. In: Ray, ed. 1907:512-16.

1907b 'The Yara1kăna Language of Cape York'. In: Ray, ed. $1907: 271-6$.

RAY, S.H., ed.

1907 Reports of the Cambridge Anthropological Expedition to Torres Straits, vol.3: Linguistics. Cambridge University Press.

RIDLEY, $W$.

1875 Kámilarói, and other Australian Languages. 2nd edn. Sydney: T. Richards, Government Printer.

RYLE, G.

1949 The concept of Mind. London: Hutchinson.

SCHEBECK, B.

1972 Les systèmes phonologiques des langues Australiennes. Doctoral thesis, Paris. 
SCHMIDT, W.

1919a Die Gliederung der australischen Sprachen.

Vienna: Mechitharisten Buchdruckere1.

1919b Die Personalpronomina in den Australischen Sprachen. Vienna: Akademie der Wissenschaften.

SCHÜRMANN, C.w.

1844 A Vocabulary of the Parnkalla Language Spoken by the Natives... of Spencer's Gulf. Adela1de:

George Dehane.

SILVERSTEIN, M.

1976 'Hierarchy of Features and Ergativity'. In:

Dixon, ed. 1976:112-71.

SOMMER, B.A.

1969 Kunjen Phonology: Synchronic and Diachronic.

PL, B-1l. Canberra: Pacific Linguistics.

SOMMER, B.A. and E.G. SOMMER

1967 'Kunjen Pronouns and Kinsh1p'. Papers in

Australian Linguistics 1. PL, A-10:53-9.

Canberra: Pacific Linguistics.

STREHLOW, T.G.H.

1944 Aranda Phonetics and Grammar. Oceania Monographs 7. (Reprinted from Oceania 1942-44.)

SUTTON, P.J.

1975 Australian Language Names. Australian Institute of Aboriginal Studies typescript.

1976a The Diversity of Initial Dropping Languages in Southern Cape York'. In: Sutton, ed. 1976:102-23.

1976b 'The "having" Affix and Other Morphemes in Fifty Austral1an Languages'. In: D1xon, ed. 1976:297-305.

n.d. Wordlist: Gugu-Badhun. Unpublished. 


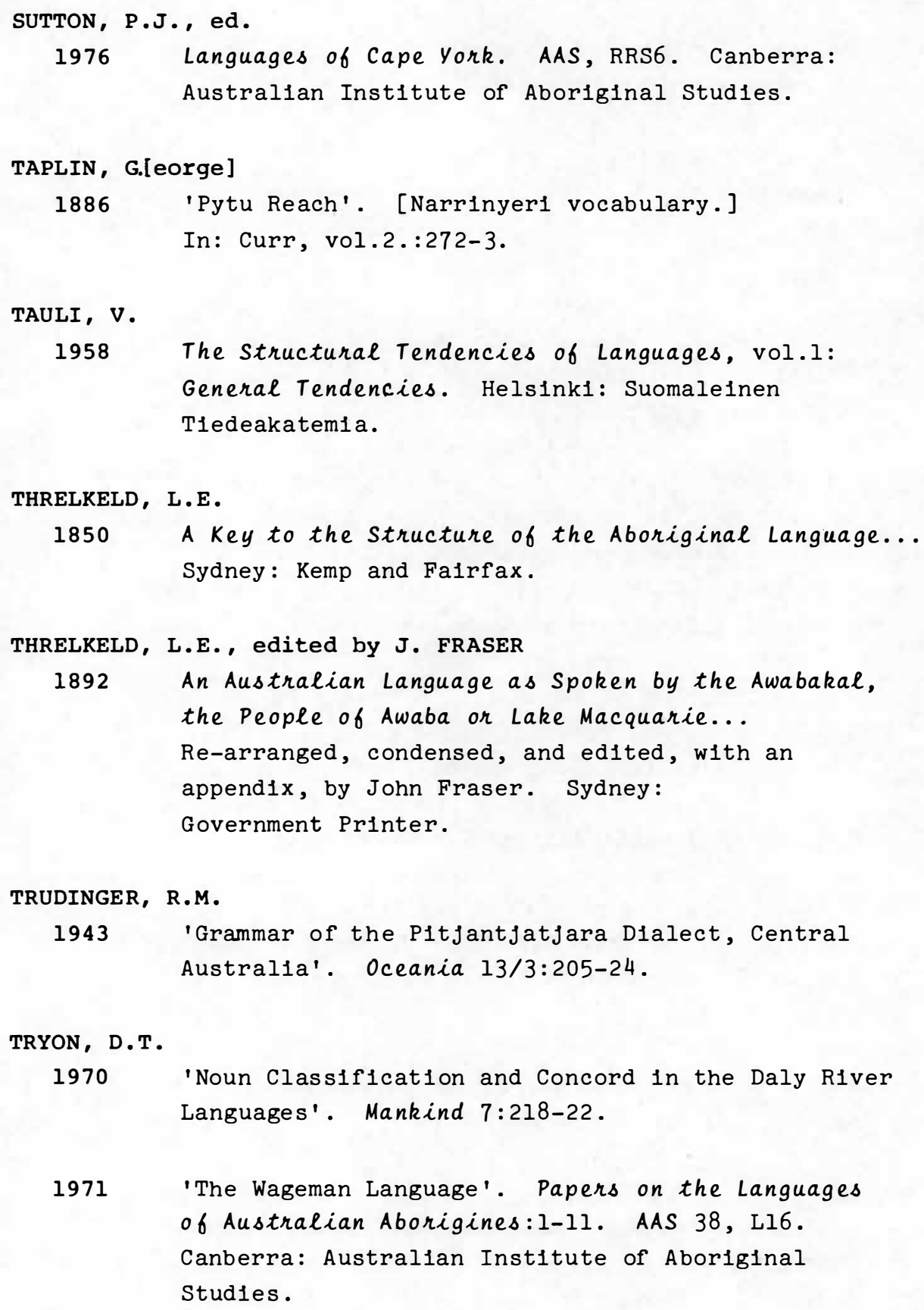


1974 Daly Family Languages, Australia. PL, C-32. Canberra: Pacific Linguistics.

WOOD, R.

1977 'Some Aspects of Galpu Phonology'. Talanya 4:24-9.

WURM, S.A.

1969 'Person Marker Sequences in Australian Languages'. Papers in Australian Languages 4. PL, A-17:51-70. Canberra: Pacific Linguistics.

1970 'Linguistic Classification and the Prehistory of Austral1a'. In: D.C. Laycock, ed. Linguistic Trends in Australia: Papers Presented to the A.I.A.S. Linguistics Group May 1968. AAS 23, L9. Canberra: Australian Institute of Aboriginal Studies.

1971 'Classification of Australian Languages'. In: T.A. Sebeok, ed. Current Trends in Linguistics, vol.8: Linguistics in Oceania, 721-78.

1972 Languages of Australia and Tasmania. The Hague: Mouton.

1975 'Possible Wider Connections of Papuan Languages: Torres Stra1t and North Australia'. In: Wurm, ed. 1975: 915-24.

1976 In a Review of S.A. Wurm: Languages of Australia and Tasmania'. Oceania 47/1:74-7.

WURM, S.A., ed.

1975 New Guinea Languages and Language Study, vol.1: Papuan Languages and the New Guinea Linguistic Scene. PL, C-38. Canberra: Pacific Linguistics.

WURM, S.A. and L.A. HERCUS

1976 'Tense Marking in Gunu Pronouns'. Papers in Australian Linguistics 10. PL, A-47:33-55. 
Canberra: Pacific Linguistics.

WURM, S.A. and D.C. LAYCOCK, eds

1970 Pacific Linguistic Studies in Honour of

Arthur capell. PL, C-13. Canberra: Pacific

Linguistics.

YALLOP, C.

1977 Alyawarra. An Aboriginal Language of Central

Australia. AAS, RRS 10. Canberra: Australian

Institute of Aboriginal Studies.

ZIPF, G.K.

1936 The Psycho-biology of Language. London:

Routledge. 


\title{
IN THE MARGINS OF AN ARABANA-WANGANIIRU DICTIONARY: THE LOSS OF INITIAL CONSONANTS ${ }^{1}$
}

\author{
L.A. Hercus
}

0. ABBREVIATIONS

$\begin{array}{ll}\text { A } & \text { Arabana } \\ \text { ANC } & \text { distant past } \\ \text { excl } & \text { exclusive } \\ \text { intrans } & \text { intransitive } \\ \text { TR } & \text { transitory aspect } \\ \text { trans } & \text { transitive } \\ \text { W } & \text { Wanganuru }\end{array}$

\section{INTRODUCTION}

In his work of 1956 ( $p .84$ ) A. Capell complained of the difficulty of 'establishing sound-laws for Australian languages' and of the 'lack of consistency that marks Australian languages' in their phonological development. Since those days important progress has been made in the study of historical phonology, initiated by O'Grady (1966): the advance made in these studies over certain relatively small areas is evident from the historical contributions to sutton, ed. (1976)

The Languages of Cape york. The general approach is now different: we have become more aware of regional diffusion and of Aboriginal multilingualism, and can see how much these have obscured the operation of strict sound-laws. Yet even in this context some of the inconsistencles still remain puzzling and unexpected: this can be illustrated by the Arabana-Wanganuru words beginning with a-. 
MAP 1: GENETIC AFFILIATIONS OF LANGUAGES IN SOUTH-CENTRAL AUSTRALIA

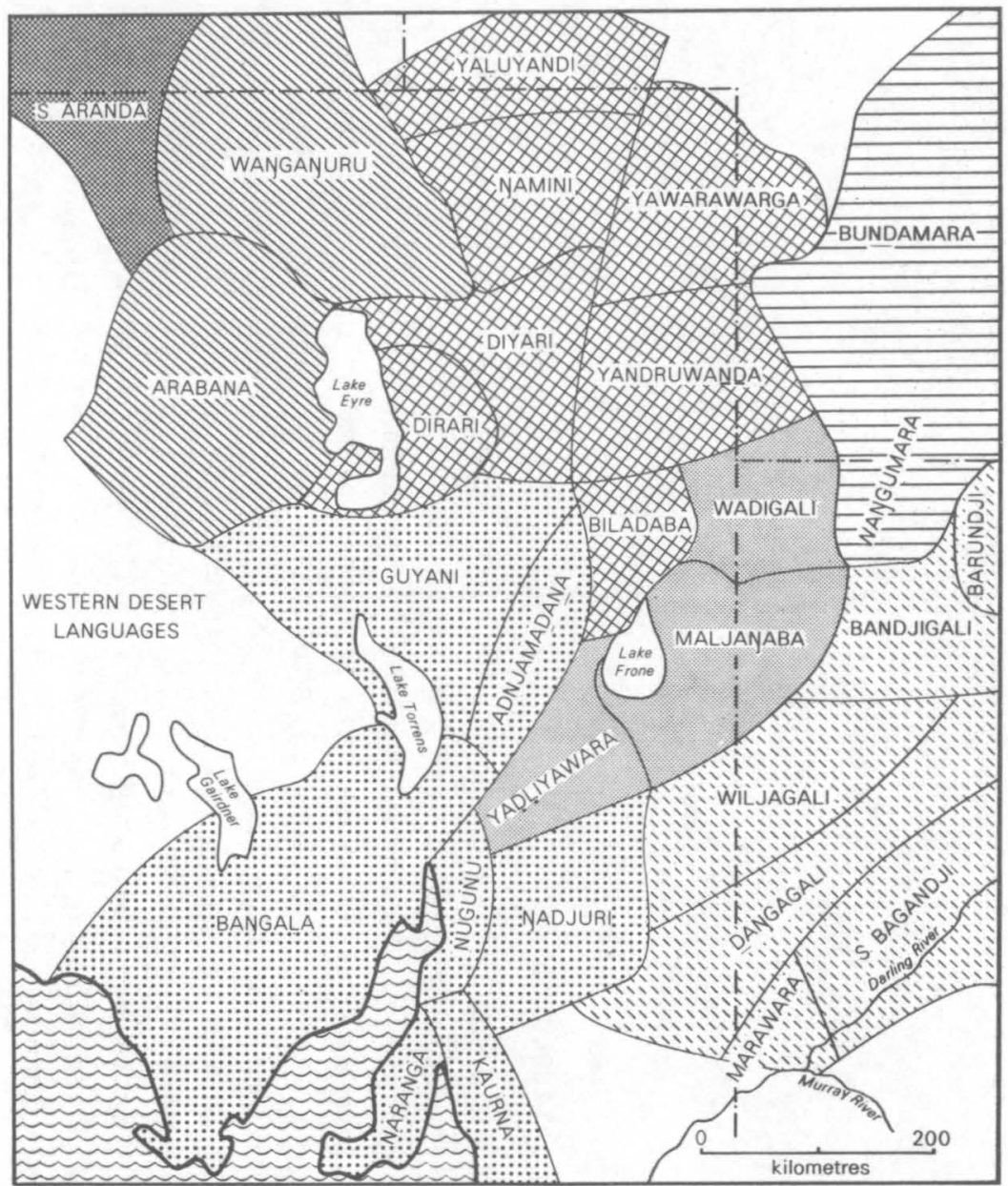

Arandic

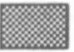

Arabana-Wanganuru

Diyaric

Yura languages

Yali languages

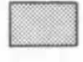

Nura languages

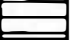

Bāgandji 


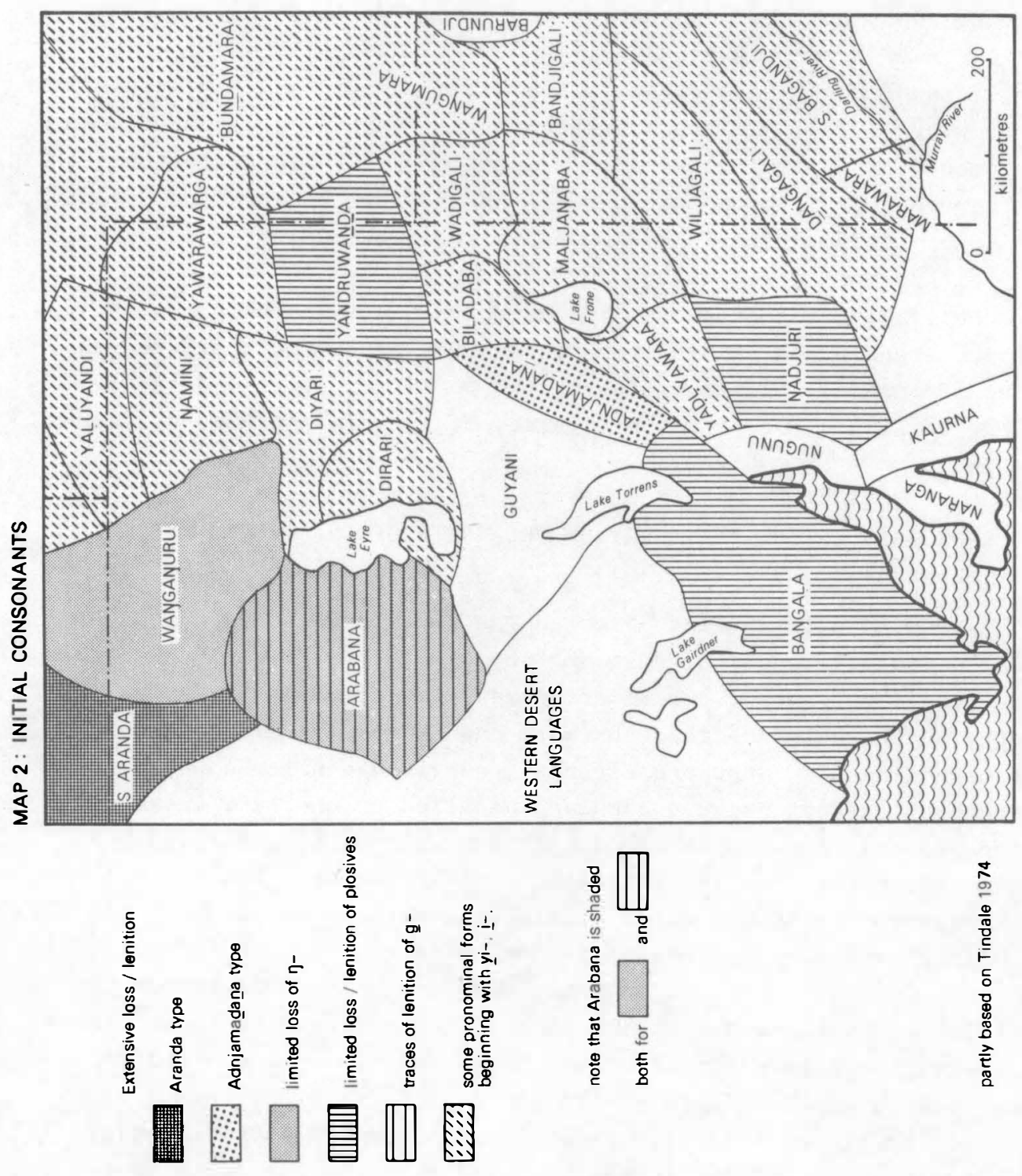


It is generally agreed that all Original Australian words began with a consonant (Capell 1956:100). There are areas where it is clear that certain initial consonants were dropped bringing vowels into the initial position. This situation is found, for instance, in Cape York and parts of Western Queensland, in Central Australia and in two languages of North-eastern New South Wales, Anewan and Yaygir as shown by Crowley (1976). In these areas initial dropping and the related phenomenon of initial softening or lenition are regional features that cut across genet1c boundaries. Th1s has been shown for Cape York by B. Alpher (1976). The following pages are a summary of the SouthCentral Australian situation.

Genetically, the languages in the South-Central area belong to two groups, Arandic and Karnic (the Arabana-Wanganuru and the Yura subgroup of Karnic); the languages on the periphery of this area also belong to Karnic, forming the Diyaṛic, Yạ̣ı, Nura and Bāgandf1 subgroups.

2. LANGUAGES ON THE PERIPHERY OF THE SOUTH CENTRAL AREA 2.1. Bāgandj $i$

The Bāgandj1 or Darling River sub-group consists of a number of related dialects once spoken along the Darling River south of Bourke and in adjacent areas. There are some major differences between the northern and southern dialects (Wurm and Hercus 1976). The two northern dialects, Gunu and Bārundj1, survived until recently. Throughout the extensive vocabulary recalled by the last speakers there was only one single word that began with a vowel: ilägu yesterday, apart from idi this and ina that (present tense).

Ten years ago 1t was still possible to record two southern dialects, Bandj1gall and Southern Băgandj1 from Pooncarle. It is typical of the way that initial consonant dropping cuts across genetic boundaries that In Bandjigalı and Southern Bāgandj1, as opposed to the northern dialects, there is evidence of the occasional loss of the initial velar consonants $g$ - and $n$-before $-i$ - in the free forms of pronouns: $n i m b a$, imba you sg. Intr. subject, gindu, indu you sg. tr. subject, gigi, igi this one; (g)idu and (g)inu that one and that one further away are in fact the preferred forms. The same loss of the velar consonant in this environment is found also in pronominal adverbs (g)inara, (g)idana there and here and less frequently in $(g) i l a ~ n o t$. Apart from the adverb ilägu yesterday (which probably shows loss of an initial g-) and the exclamation of surprise iläguai lit. my yesterday there is also a small group of verbs which show optional loss of initial $\eta^{-}$, (n) imato lie down, (n)iba- to put down and (n)inga- to sit. 
Bagandf1 1llustrates the point that velars are particularly liable to be lost initially. But the situation is complicated by the fact that there is also a quite specific regional restraint against the occurrence of initial $D+i$ : this combination is totally absent from both the Yal1 and the Diyarl subgroup (Austin MS and Hercus MSb). Bāgandj1 is in fact the westernmost language in this particular area to permit initial $n+i$ at all.

The most important feature 1llustrated by Bāgandj1 is that initial dropping does not necessarily affect the whole vocabulary uniformly: certain classes of words, particularly pronouns are more prone to this change than the rest of the vocabulary.

\subsection{Yali Languages}

The comparison of cognates from neighbouring languages shows that in the two very closely related and both recently extinct Yal 1 languages Maljanaba and Yaḍllyawara (Hercus MSc, Austin and Wurm MS) initial $g$ - and $\mathrm{D}$ - have been lost before $\boldsymbol{i}$ in pronouns and pronominal adverbs, hence inigi this, idni, ini you sg., as in:

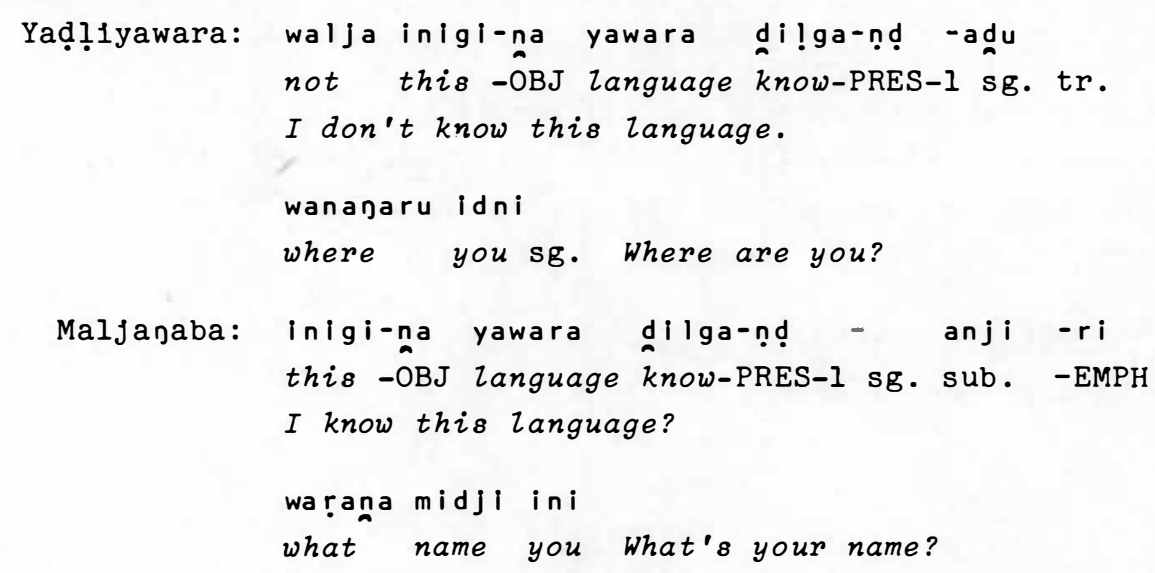

There are no words beginning with a- or wu-, u- In the Yaḷ languages, and there appear to be only a few words beginning with yi-, i- apart from the pronouns: the kinship term ibulu sister's daughter, mother's sister (see also Beckett, 1967), and ibi-to lift up.

The presence of initial yi-, $i$ - in pronouns is widespread, far beyond the Yalı languages, as can be seen readily from the tables published long ago by Schmidt (1919) and from the recent investigations of Queensland languages by Breen (197la and 1973) and by Blake and Breen ( 1971 and forthcoming). It is of significance, however, that inftial yi-, $i-$ is found only in the second and third person singular 
pronouns and in adverbs derived from them and not to any extent in any other classes or words in the Yal1 languages and in the Nura sub-group (Wangumura, Bundamara and Gạ̣al1). In Southern Bāgandj1 and in the Diyarı subgroup (Austin MS) not only pronouns, but also a few verbs begin with yi-, i-.

\section{CENTRAL LANGUAGES}

It is in the Central languages that initial dropping is most prominent.

\subsection{Aranda}

Comparative data show that in Southern Aranda as in the entire Arandic group initial $b^{-}$and usually also inftial g-, w- and d- have been lost:

$\begin{array}{lll}\text { S. Aranda } & \text { Arabana } & \text { English } \\ \text { abma } & \text { wabma } & \text { snake } \\ \text { ada } & \text { adu (Diyari gadu) } & I \text { (tr. sub.) } \\ \text { alinja } & \text { dalinji } & \text { tongue }\end{array}$

There are a number of exceptions and irregularities, as has been pointed out by A. Capell (1956:100). But there can be no question about the fact that Aranda has the most general loss of initial consonants of any of the languages in the area.

\subsection{The Yura Languages}

The Yura languages are:

Kaurna
Naranga
Nadjurı
Nugunu
Bangaḷa
Guyanı
Adnjamadana

They were once spoken over a vast area in South Australia, from Adela1de to Lake Eyre. They are all very closely related: they must in fact be regarded as dialects of one language. Adnjamadana of the Flinders Ranges and Guyani from the plains to the west and north-west of the Flinders are especially close according to recent recordings (Hercus MSc). This is evident from both the morphology and the 
vocabulary, which is over $80 \%$ cognate. There were close soclal links between all the Yura group: they shared the same kinship system, which is reflected in the complex pronouns (Hercus and White 1973). They shared some major ceremonies, in particular the Wiljaru cicatrisation rite, and they all had the same system of birth-order names. It is clear that Nadjuri can be included in this respect, as Tindale mentions (Tindale 1937:149) that his main informant was called Waria. This means in fact second Son and corresponds to Bangaḷa, Warl and Guyan1, Nugunu, Adnjamadana (and even Yaḍllyawara) wariya. Naturally there were some minor differences in social behaviour (Schebeck 1974:173) but Yura people were consclous of their basic solidarity and they sensed a kind of continuity between the various Yura 'tribes'. As an elderly Adnjamadana man, Angus McKenzie once explained: 'There were really two kinds of Guyan1, there were the Adnja-Guyani 'H1lls-Guyan1' they were fust like us Adnjamadana 'Hills people' - and then there were the Vata-Guyan1 'the Plains Guyan1'. The same way there were really two kinds of Vangala (Bangaḷa), the Adnja-Vangaḷa 'H1lls Bangala' they were nearly the same as the Nugunu - and there were also the Vața-Vangaḷa ('the Plains Vangala').' This shows how closely, in the eyes of a most knowledgeable man, the Guyani and Adnjamadana were assoclated on the one hand, and the Bangala and Nugunu on the other (cf. Tindale 1974:213). Yet the changes involved in the dropping and lenition of initial consonants cut across those close links.

Guyani and Nugunu, and from older evidence, the extinct Kaurna and Narajga maintained all their initial stop consonants:

but

Adnjamadana shows loss of initial g- and lenition of initial d- to $y$ and $b$ - to $v$-.

Bangaḷa (Schürmann 1844 and also Hercus MSc) is in an intermediate position: there is weakening of initial d- to $y$-. There are therefore words beginning with yi-, i-, but not wu-, u- or a-. We were able to record only the one 1solated proper noun Ara-bangala, the name of the northern group of Bangala (w1th $n$, not $\eta$ ) as opposed to the Bangala proper, from Eyre Peninsula. Tindale (1974:216) and Green (in Curr 1889) quote also the name Arkaba-tura which should be translated as the red ochre men from their proximity to the red ochre mine at

Parachilna. The written records of the extinct Nadjuri (Berndt and Vogelsang, 1941) also show evidence, though sporadic, of weakening of intial d- and b-, and loss of $g-$.

The situation is summarised in the following table: 


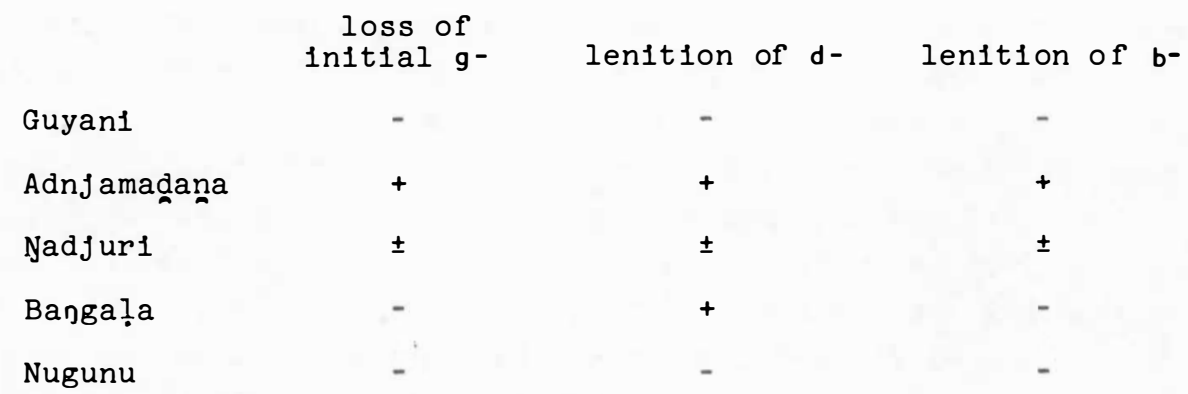

Because of the high proportions of cognates between the Yura languages, there is spectacular evidence for these changes. They took place throughout the vocabulary and in any kind of vocalic environment. Examples are:

\begin{tabular}{|c|c|c|c|c|c|c|}
\hline & Guyan1 & Nugunu & Bangaḷa & Nadjurs & Adnj amadana & English \\
\hline & gaḍa & gadla & gadla & 'gadla' & aḍa & fire \\
\hline loss & gaḍu & gaḍu & gadu & 'atuni' & a țuna & wife \\
\hline of & gudnju & gudnju & gudnju & 'winju' & $u d n j u$ & $\begin{array}{l}\text { white } \\
\text { man }\end{array}$ \\
\hline g- & & & & & & ghost \\
\hline & gubmana & gubma & gubma & & ubmana & one \\
\hline & gudlu & gudlu & gudlu & 'wudlu' & udlu & kangar \\
\hline
\end{tabular}

$\begin{gathered}\text { lenttion } \\ \text { of } \\ d-\end{gathered} \mid \begin{array}{lllll}\text { dadna } & \text { yadna } & & \text { yadna } & \text { they } \\ \text { daba- } & \text { dabadja- yaba- } & \text { yaba- } & \\ \text { diga } & \text { digadja yigada } & \text { 'ikana' yiga } & \text { to sit } \\ \text { dinda- } & \text { dindadja- yinda } & \text { 'indata' inda- } & \text { to die } \\ \text { dura } & \text { dura } & \text { yura } & \text { 'juru' yura } & \text { man }\end{array}$

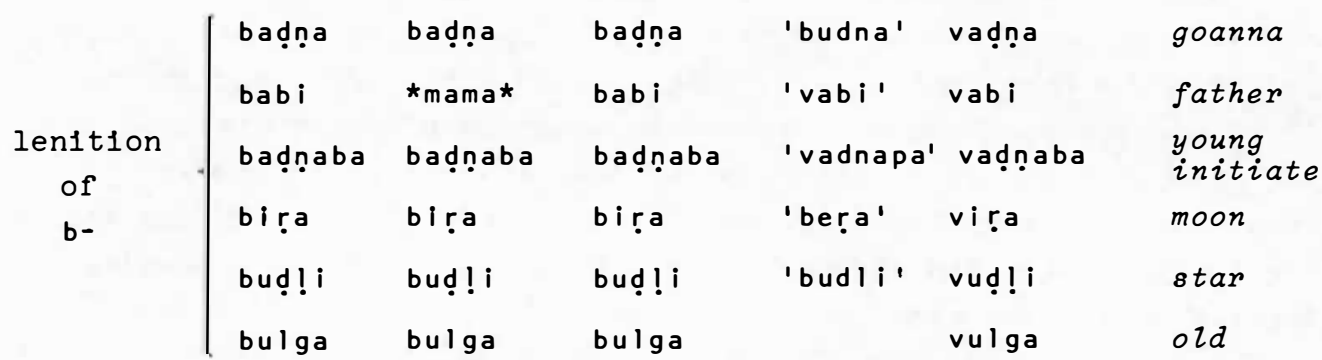


It is clear that the loss of initial consonants must have occurred after the separation of the Guyani and Adnfamadana dialects, and there is every likelihood that it is a relatively recent development. The change was not felt to be very profound: Guyani people could still understand what the Adnjamadana were saying and vice versa.

\subsection{Diyari Sub-group}

The languages of the Diyari sub-group were once spoken throughout the far north-east of South Australia. They have been studied extensively over recent years by P. Austin and by J.G. Breen (see Austin MS, Breen MS). The sub-group comprises the following languages:

$$
\begin{aligned}
& \text { Diyarı } \\
& \text { Diraṛı } \\
& \text { Namını } \\
& \text { Yaḷuyand } 1 \\
& \text { Yawarawarga } \\
& \text { Yandruwanda } \\
& \text { Blladaba }
\end{aligned}
$$

Apart from the pronominal forms quoted in 2.1. and a few 1solated words beginning with yi, i- (malnly verbs) and wu, $u$ - there is no general evidence of any loss of initial consonants in Diyari, Dirari, Yaluyand1, Naminl and Yawarawarga, but in the languages closest to Yawarawarga, namely Yandruwanda, there is evidence of weakening of Intial dj- to $y$ - (Breen 197la).

$\begin{array}{lll}\text { Yandruwanda } & \text { Yawarawarga } & \text { English } \\ \text { yiwa } & \text { djiwara } & \text { woman } \\ \text { yimba } & \text { djimba } & \text { black } \\ \text { yara } & \text { djara } & \text { boomerang }\end{array}$
djugur̃u
djugur̃u
kangaroo

From the limited evidence we have, it appears that this development was not shared by the nelghbouring Blladaba (Hercus MSc). Again we find that the weakening of the initial is a feature that must be of relatively recent origin. 


\section{ARABANA-WANGANURU}

\subsection{Plosives}

Arabana and Wanganuru were two dialects of one language once spoken west of Lake Eyre and in the Simpson Desert, 1.e. Immediately to the west of the Diyari sub-group. In Arabana-Wangaguru the situation with initials is most complex, and there are differences in this regard even between these two very similar forms of speech. In Arabana there is inciplent weakening of initial plosives, in Wanganuru there is not. In Arabana:

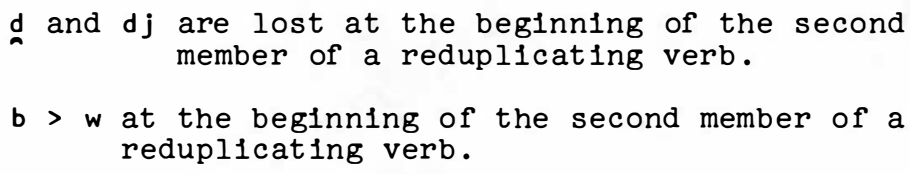

Examples are:

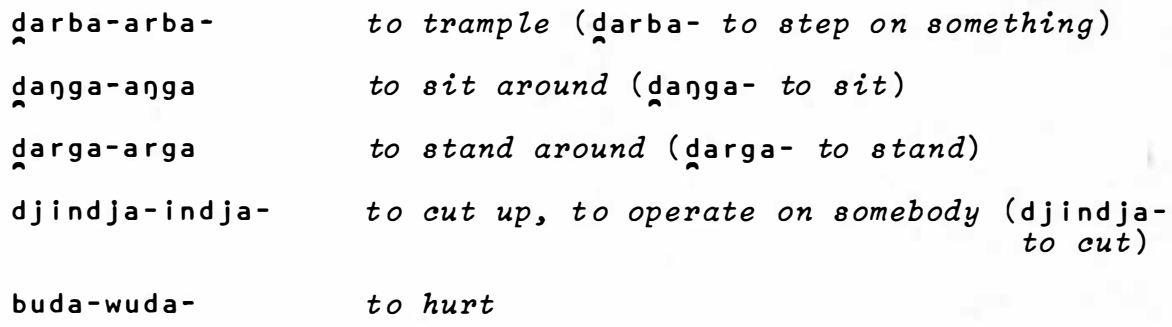

This development has not spread to reduplicating adjectives and nouns, e.g.:

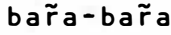
Zong
dja $\mathbf{a} a-d j a ! a$
Zizard species

9- is lost in Arabana at the beginning of the word gadi seed (Austin, Ellis and Hercus 1976) when this is used as a compound formative and in the stem-forming transitory aspect marker -ga after verbs ending in -a. This leads to a long vowel in Arabana, a language where distinctive length is otherwise unknown.

$\begin{array}{lll}\text { Arabana } & \text { Wangaguru } & \text { English } \\ \text { gadna-aḍi, gadnāḍi } & \text { gadna-gạ̣i } & \text { money (lit. stones) } \\ \text { gudna-ạ̣i, gudnāḍi } & \text { gudna-gaḍi } & \text { guts } \\ \text { bandja-ạ̣i, bandjạ̣i } & \text { bandja } & \text { knee } \\ \text { danga - a - bugana } & & \text { they used to sit } \\ \text { sit - TR - ANC } & & \text { around for a while }\end{array}$


but
daṇi - ga - bugaña
they used to eat as
eat - TR - ANC
they went

This weakening of initial consonants is very restricted, as can be seen by the fact that 1 t is confined to reduplication, to stem-forming suffixes and to -gadi: the past tense marker -ga is never affected by the change.

\subsection{Initial $\mathrm{N}$}

Initial $D$ has not been dropped generally in Arabana-Wanganuru. There are numerous words beginning with na-, $\eta u-$ ( $\eta \mathbf{i -}$ is absent as mentioned in 2.1.). In fact over $8 \%$ of the vocabulary begins with $n-$ : this includes rare and obscure words just as much as some of the commonest words in the language. At first sight there appears to be no system in the loss or retention of initial $n^{-}$, but on closer examination $1 t$ would appear that $n$ - is retained except in particular categories of words.

\subsection{Pronouns}

In Arabana-Wanganuru there 1 s loss of $n^{-}$(and rarely $m_{-}$and $\mathbf{n j}^{-}$) initially in some circumstances as shown by cognates. As there is no phonemic distinction between $y \boldsymbol{i}$ and $i^{-}$, and wu and $\mathbf{u}^{-}$, the clearest decisions with regard to consonant dropping can be made when this results in initial a. The present discussion will therefore centre on words beginning with a- in Arabana-Wanganuru.

n has evidently been dropped in all pronominal forms as for Instance:

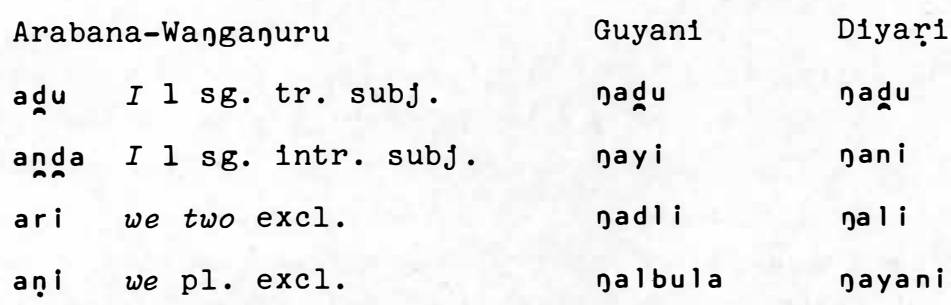

and in the special kinship pronouns, e.g.:

$$
\begin{gathered}
\text { alanda we two of the same nadlaga nalanda } \\
\text { moiety but different } \\
\text { generation levels }
\end{gathered}
$$

nj-, n- was lost in the dual and plural forms of the second person 
pronoun: urubula you two, urgarl you pl. as opposed to Guyani nura you pl. This sound-change was absolute: there are no pronominal forms in Arabana-Wanganuru where initial $n^{-}$(and $n^{--,} n^{-}$) are retained.

\subsection{Kinship Terms}

The loss of initial $\eta$ - is absolute in both Arabana and Wangaguru in certain other categorles of words apart from pronouns, notably in kinship terms. . This is not surprising as kinship terms are closely associated with pronouns particularly in south-central Australia (Hercus and White 1973). As the whole of soclety is viewed in the light of kinship, these terms are used in Aboriginal languages where Europeans would simply use a pronoun. This is even carried over into Aboriginal English and sentences like the following can be heard frequently: My brother is no good, or Go and change your uncle's nappy!, where Europeans would say: He's no good, or Go and change the child's nappy.

I Is lost in:

Wanganuru abila female cross cousin, Guyan1 nabala father's mother

Eastern

Wanganuru adabiyaga son (man speaking) Diyaṛ nadamur̃a

Wanganuru a! uwa child

Guyan1 nalu (father's elder brother, like son, refers to a person of the opposite molety and of the adjacent generation level)

Wanganuru adada mother's father Diyari gadada

Wanganuru anja father

Arabana abidji father Dirari gabidji

The word for mother is of interest: Arabana has a term luga which does not appear to have cognates in neighbouring areas and which is the only ordinary Arabana word to begin with !-. In Wagganuru there was originally a word *nama which had two meanings: breast, as in Diyari, Guyan1 and a number of other languages, and mother which corresponds to nami in Guyan1, Adnjamadana and nelghbouring languages, and to namaga in Băgandj1. This Waggaguru word split in two according to 1ts meaning: nama was retained in the sense of breast, whereas the kinship term lost the initial $n$, hence ama mother. This is a clear indication of the fact that kinship terms occupled a distinctive position in Arabana-Wanganuru speech. 2 


\subsection{Interjections and Adverbs}

Interfections, and particularly the words meaning yes and no in Aboriginal languages are often 'irregular': they, like kinship terms may contain phonotactic and phonetic features that are not found elsewhere in the language. Thus in Maljanaba naga [naya] yes contains the sound [y] otherwise unknown in Maljanaba. In Eastern Wanganuru [kj] yes contains the otherwise unknown [j]. It is therefore not surprising that interfections as opposed to the bulk of the vocabulary were affected by the loss of initial $n$ - In Arabana-Wanganuru.

Examples of such interfections are:

$\begin{aligned} \text { ana oh yes, you don't say! } & \text { (Diyarl nana oh yes! Guyani nana dura } \\ & \text { lit. yes people!, you really mean } \\ & \text { that!) Both the Arabana-Wanganuru and } \\ & \text { the Guyani interfections are used to } \\ & \text { encourage someone telling a story. }\end{aligned}$

anagu I don't know (Diyari gana guwu)

ar̃u hey there! ar̃u 'nba hey you there, what about you?

arayi yes, certainly (Arabana)

aradja right, correct. This word is also used as an adjective straight, correct.

alada ready! alada yugalugu ready to go!

aga!i wrong!, in contradiction (adv.)

a! a truly, indeed! This is also used adjectivally.

When musing to himself over a campfire, Mick McLean, the last Simpson Desert Wanganuru, sometimes sald a!a, a!a, pa!a. This was surprising as a! a is equivalent to Diyari mala and represents one of

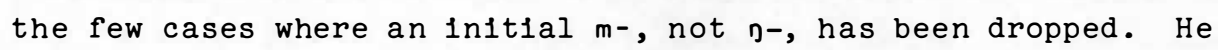
explained that he was saying this only in fun, playing with words: yet his fun indicates that the loss of initial consonants was recent enough for speakers to feel that a consonant really could be present and that this consonant normally should be $0-:$ pala is simply a back formation.

There are a number of words that are frequently used in single word utterances as if they were interjections, but they also have an adverbial function. A high proportion of these begin with a-, as for Instance:

$\begin{array}{lll} & \text { andi } & \text { soon, directly } \\ \text { andilimba for the first time } & \text { for there }\end{array}$




$\begin{array}{lll}\text { Wanganuru } & \text { awada } & \text { over there } \\ \text { Arabana } & \text { arada } & \text { on top, up! } \\ \text { Arabana } & \text { ambada } & \text { in the middle, get in! } \\ & \text { anari } & \text { this way } \\ & \text { arura } & \text { quickly! } \\ \text { Wanganuru } & \text { awula } & \begin{array}{l}\text { anyhow, it doesn't matter } \\ \text { how! never mind }\end{array}\end{array}$

As a category, interfections and interfectional adverbs show total loss of initial n-. Just as there is no kinship term or pronoun beginning with $n$ - In Arabana-Wanganuru, there are no interfections, or adverbs that may be used as interfections, which begin with $0-$.

\subsection{Proper Nouns}

As has been well known, particularly since the days of Dauzat (1926), place-names contain archalc features, and Arabana-Wanganuru is no exception to this. Archalsms are found in vocabulary: Naba-mar̃a fresh water, the name of the lower Neales, contains the word gaba, a widespread word which has cognates in Diyaric but is no longer found in Arabana-Wanganuru where the word for water is guda. Place-names also show archaisms in phonetics and in phonotactics: Dandji-wanbada Grandson-carrying the name of the most important Arabana rain-site stands for dandi-wanbada and takes us back to the days of a single laminal phoneme, with allophones conditioned by the vocalic environment (Dixon 1970); Wudmara, the Woodmurra Creek contains the cluster - dm- not found elsewhere in the language. Pre-stopping of nasals and laterals, which is a recent development, is sometimes absent from place-names (Hercus 1972). One would therefore Nor expect to see the loss of inftial $\mathrm{D}$ - In place-names, and indeed there are only a few instances of place-names beginning with a-. Borrowing is not unheard of in place-names, particularly where the locality involved belongs to a history that traverses several tribal areas. This may be the explanation of the few place-names beginning with a-; none of these names is easily analysable: Argaringa (Arckaringa Ck.) actually has 1ts source in Western Desert country and the name may come from there too, while Aldaguwana (in Peake country), Andiridja a plain near Mt. Robinson and Adabunaga (near Peake) are all northern Arabana sites that show the Influence of Aranda, whlle Arildji-bagana (Algebuckina) would appear to be half Aranda, half Arabana: this is not surprising as it is a site connected with the ancestral red-bellied black snake 
and the green snake who travelled from Coolata Springs (NT) through southern Aranda to Arabana country.

There are a few names of people which are taken from part Aranda, part Arabana-Wanganuru song-cycles, and not surprisingly some of these begin with a-: Arabalga (from the grass-seed cycle), is the name of an Arabana woman; an old Arabana rain-maker was called Anindjola after the Aranda rain-man who travelled to Mt Kingston. There was obviously some give and take between Arabana-Wangajuru and nelghbouring languages, particularly Aranda, over place-names and personal names, and this would account for the few proper names beginning with a-. There are no indications of any loss of initial consonant in proper names within Arabana-Wanganuru.

There is one important exception and that is the word Arabana. The nelghbouring Guyani and Diyari say Narabana. Tindale (1974:210) indicated that the older accepted pronunciation among the Arabana themselves was Narabana, and this was hesitatingly affirmed in recent recordings. Tribal names in many parts of Australia resemble kinship terms with regard to 'irregular' phonological and phonotactic features (e.g., the presence of initial -) $^{-}$and the name Arabana can therefore be classed with the kinship terms. It gives a particularly clear proof that the loss of initial $n$ - was recent and was still in process at the time of European occupation.

\subsection{Song Language}

One of the stylistic features of the difficult and not always analysable song-language is the repetition of words and parts of words. Frequently this is accompanied by alternation between initial nasals and 1- (not used as an initial in the ordinary language) or $y-$. The form without nasal always comes first; it is in the initial position. Thus in the songs that accompany the Wanganuru myth Djalba Bargulu Two Trees:

$$
\text { badla lamburu - namburu nayi (meaning uncertain) }
$$

and

wabaḍabạa ila - ni langurume

1.e. wabaṇa i!̣nguru

he is searching like this

and

yalbara-nalbara

thirsty (Goanna History)

This may simply be a game with words, such as English 'doggie-woggle', but the fact that it happens mainly with initial nasals and particularly with $n$ - would seem to indicate that initial nasals were felt to be more dispensable than other consonants. 


\subsection{Special Words}

This category comprises terms which have a ritual, mythological or trade significance. Some of these words are shared by people over a large area, and they do not necessarily conform to the phonotactic system of Arabana-Wanganuru: for instance they frequently begin the third syllable with a plosive, which is unusual in Arabana-Wanganuru. There are several such words which begin with a-. Examples are:

$\begin{array}{ll}\text { argaba } & \text { red ochre } \\ \text { ambaga } & \text { malicious mythological being } \\ \text { abalga } & \text { dream } \\ \text { adidjumba } & \begin{array}{l}\text { wizd honey (connected with the Adidjumba } \\ \text { myth which ends in Southern Aranda Country } \\ \text { near Finke) }\end{array} \\ \text { aruguda } & \begin{array}{l}\text { bush boy (young initiate not yet allowed } \\ \text { back into camp) }\end{array} \\ \text { amira } & \begin{array}{l}\text { woomera (of the Aranda and Western Desert } \\ \text { type, see Spencer and Gillen 1899:582) }\end{array}\end{array}$

As these are 'special' words, their vocalic inftial is not immediately connected with the loss of initial $p$ - In Arabana-Wanganuru.

\subsection{Other Words}

Apart from the particular categories comprising pronouns, kinship terms and interfections there are very few words in which the loss of D- has brought about an initial a-. None of these are simple verbs. There are some secondary verbs based on adverbs such as aradja-mato straighten, ala-widji- to come true and one single rare reduplicating verb andji-andji-to cajole, to try to organise an (illicit) meeting with a girl. There are only about a dozen other words beginning with a-. As they do not have reliable cognates it is difficult to prove that they originally had an initial $n-:$ examples are Arabana ambalda cloud, Wanganuru abada the eastern side of a sandhizl, Arabana alba tepid, alga colour, appearance, algidjira dead finish tree. The word abira river gum is highly unlikely ever to have contained an Initial $D-$ as is shown by the cognate Guyani bira, Adnjamadana wira. Outside the categories listed, therefore, words beginning with a- and showing loss of an original initial $\eta^{-}$form an insignificant portion of the Arabana-Wanganuru vocabulary. 


\section{CONCLUSIONS}

The data connected with loss and weakening of initial consonants in south-central Australia show that these changes are relatively recent and regional, cutting across genetic boundaries. As in the case of several other conspicuous linguistic features, such as the pre-stopping of lateral and nasal consonants, and kinship pronouns, there appear to have been two areas of maximum development which were also the two main centres of diffusion: Arandic and Adnjamadana. The changes involved differed in detall between the two centres. A simplified schematisation of the situation would be as follows:

region of general

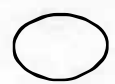
disposition towards loss and weakening of Initials

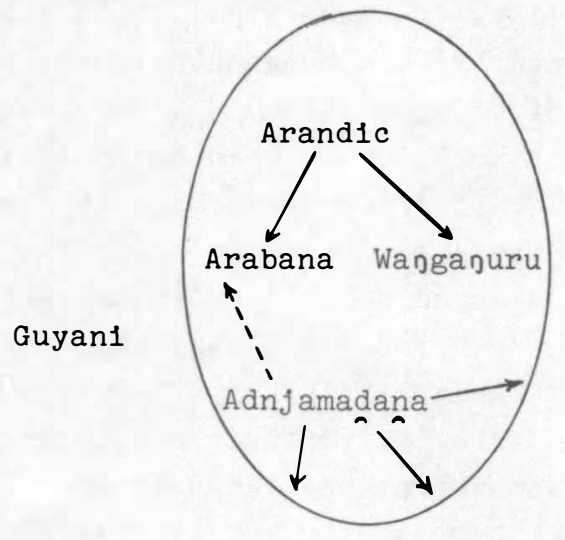

The rules regarding the loss of initial consonants in Adnjamadana are invariant: they correspond to Labov's Type I rule where exceptions and violations do not normally occur (Labov 1972:111). But in Arabana-Wanganuru the changes were still in progress.

The intricacies of the loss of initial plosives in Arabana reduplicated verbs and in certain bound morphemes make it likely that a Type III rule was operating, that is a rule subject to certain varlations. As regards nasal consonants there was already an invariant rule:

$$
\begin{aligned}
& + \text { kinship term } \\
\text { initial } D>\phi \quad & \text { pronoun } \\
& + \text { interfection or adverb }
\end{aligned}
$$

As shown by the term Arabana, by the back formation nala, and by the verb andji-andji-the rest of the vocabulary was governed by a varlable Type III rule but the details of this are no longer evident. 
The question that arises 1s: 'Why should pronouns, kinship terms, interfections (and adverbs that can be used in single word utterances) be affected by the loss of initial consonants ahead of every other class of words?' The following answer may be suggested. The feature that is shared by these three categories of words is that in ArabanaWanganuru they are precisely the words found most frequently at the beginning of an utterance. Their initial consonant was therefore in the initial position par excellence and most liable to loss.

Labov's work shows the operation of sound-changes still in progress; 1t shows the fine gradients that are noticeable in the essential variability of these Type III rules. The situation in the remnants of modern Arabana-Wanganuru is invariable; what we have here is an 'atrophled' Type III rule. The loss of initial n- was halted fust as 1t was starting to spread to the rest of the vocabulary beyond those speclal categorles of words that occur frequently at the beginning of an utterance.

The Arabana social system was totally disrupted in the period around the First World war; this was through European influence and through the great influx of Western Desert people and subsequent strife. The 1919 influenza epidemic killed most of the old people. Those who learnt the language then learnt 1t 'correctly' from their elders, there was no longer a sense of 'fashion' and none of the pressure for change that comes with a young peer group. There was nothing left of the vitality that makes a variable rule of Type III. The Arabana language was as 1 were halted in 1 ts tracks around 1915-1920, the Wanganuru language even earlier, at the time of the migration from the Simpson Desert, around 1900, whlle the loss of initial $p$ - was still in progress. It could be safely said that were these languages to be re-vitalised, the impulse for this particular change, loss of initial $n-$, would no longer be felt: quite different sound-changes might occur. The Arabana-Wanganuru example shows that perlods of total social disruption and atrophism of the 1mpulses for change may well explain some of the partial sound-changes that are so bewlldering in historical linguistics. 


\section{NOTES}

1. Fieldwork was carried out under the auspices of the Australian Institute of Aboriginal Studies and the Australian Research Grants Commission. I am indebted to Mr P. Austin for advice and for information on Diyari.

2. According to the list of kinship terms given by Elkin (1939:63) there was a similar development in Southern Yawarawarga, where, as opposed to Northern Yawarawarga, these terms lost an inftial velar nasal: 'atatji' wife's mother's brother (Northern 'ngatatji') and 'alari'sister's child (Northern 'ngalari'). Elkin's lists contain even a few examples from Yandruwanda, e.g. 'aparti' for nabiri father. None of these forms have been confirmed in recent work by Breen and by S.A. Wurm (Breen MS, Wurm and Austin MS). Elkin's lists, if accurate in this respect, would therefore indicate the fact that even sub-dialects may differ from each other with regard to the loss of Initial consonants; the lists would also confirm the special development of kinship terms. 


\section{BIBLIOGRAPHY}

ALPHER, B.

1976a 'Phonology Pecullarities of Y1r-Yoront Song Words'. In: Sutton, ed. 1976:78-83.

1976b 'Some Linguistic Innovations in Cape York and their Soclocultural Correlates'. In: Sutton, ed. 1976: 84-101.

AUSTIN, P.

1978 A Grammar of the Diyar1 Language of North East South Australia. Ph.D. thesis, Australian National University, Canberra.

AUSTIN, P., R. ELLIS and L. HERCUS

1976 'Fruit of the Eyes": Semant1c Diffusion in the Lakes Languages of South Austral1a'. Papers in Australian Linguistics No. 10:57-77. PL, A-47. Canberra: Pacific Linguistics.

AUSTIN, P., L. HERCUS and S.A. WURM

to appear 'Basic Materials in Malyangaba: Grammar, Sentences and Vocabulary'. To be published in Pacific Linguistics $\mathrm{B}$.

BECKETT, J.R.

1967 'Marriage, Circumcision and Avoldance Among the Maljangaba of North-west New South Wales'. Mankind 6:456-64. 
BERNDT, R.M. and T. VOGELSANG

1941 'Comparative Vocabularies of the Ngadjuri and

Dier1 Tribes, South Austral1a'. Transacations

of the Royal Society of South Australia 65:3-10.

BLAKE, B.J. and J.G. BREEN

1971 The Pitta-Pitta Dialects. Linguistic Communications 4.

BLAKE, B.J. and J.G. BREEN

forth-

'P1tta-P1tta Grammar'.

coming

BREEN, J.G.

197la 'Aboriginal Languages of Western Queensland'.

Linguistic Communications 5:1-88.

1971b A Description of the Wạ̣uwara Language. M.A. thesis, Monash University.

1973 Bidyara and Gungabula: Grammar and Vocabulary. Linguistic Communications 8 .

n.d. As 1t was. Yandruwandha Text. MS.

CAPELL, A.

1956 A New Approach to Australian Linguistics. Oceania Linguistic Monographs 1 .

CROWLEY, T.M.

1976 'Phonological Change in New England'. In: D1xon, ed. 1976:19-50.

CURR, E.M.

1886-87 The Australian Race... 4 vols. Melbourne: J. Ferres, Government Printer; London: Trübner.

DAUZAT, A.

1926 Les Noms de Lieux. Par1s.

DIXON, R.M.W.

1970 'Proto-Australian Laminals'. Oceanic Linguistics 9/2:79-103. 
DIXON, R.M.W. , ed.

1976 Grammatical Categories in Australian Languages. AAS, L22. Canberra: Australian Institute of Aboriginal Studies.

ELKIN, A.P.

1938 'Kinship in South Austral1a'. Oceania 9/1:41-78.

GREEN, W.M.

1886 'Wonoka Vocabulary'. In: E.M. Curr The Australian

Race, vol. 2:124-5.

HERCUS, L.A.

1972 The Pre-stopped Nasal and Lateral Consonants of Arabana-Wanganuru'. Anthropological Linguistics 14/8:293-305.

n.d. Arabana-Wanganuru Grammar and Dictionary. MS.

to appear 'Ba:gandj1 Grammar'.

n.d. Transcriptions of Guyan1, Nugunu, Yaḍliyawara, Blladaba and Maljanaba Recordings. MS.

HERCUS, L.A. and I.M. WHITE

1974 'Perception of Kinship Structure Reflected in the Adnjamathanha Pronouns'. Papers in Australian

Linguistics No. 6:47-72. PL, A-36. Canberra:

Pacific Linguistics.

LABOV, W.

1972 'The Internal Evolution of Linguistic Rules'. In: Linguistic Change and Generative Theory, 101-71. Indiana.

O'GRADY, G.N.

1966 'Proto-Ngayarda Phonology'. Oceanic Linguistics 5/2:71-130.

SCHEBECK, B.

1974 Texts on the Social system of the Atynlamatana 
People. With Grammatical Notes. PL, D-2l. Canberra: Pacific Linguistics.

SCHMIDT, W.

1919 Die Personal-Pronomina in den Australischen Sprachen. Vienna: Mechitaristen Buchdruckere1.

SCHÜRMANN, C.W.

1844 A Vocabulary of the Parnkalla Language. Adela1de: Dehane.

SPENCER, W.B. and F.J. GILLEN

1899 The Native Tribes of Central Australia. London. MacMillan and Company.

SUTTON, P.J., ed.

1976 Languages of Cape York. AAS, RRS 6. Canberra: Australian Institute of Aboriginal Studies.

TINDALE, N.B.

1937 'Two Legends of the Ngadjurl Tribe from the Middle North of South Australia'. Transactions of the Royal Society of South Australia, 61:149-53.

1974 Aboriginal Tribes of Australia. Berkeley: University of California Press.

WURM, S.A. and P. AUSTIN

1978 Notes on Yandrruwanda. MS.

WURM, S.A. and L.A. HERCUS

1976 'Tense-Marking in Guṇu Pronouns'. Papers in Australian Linguistics No. 10:33-55. PL, A-47. Canberra: Pacific Linguistics. 



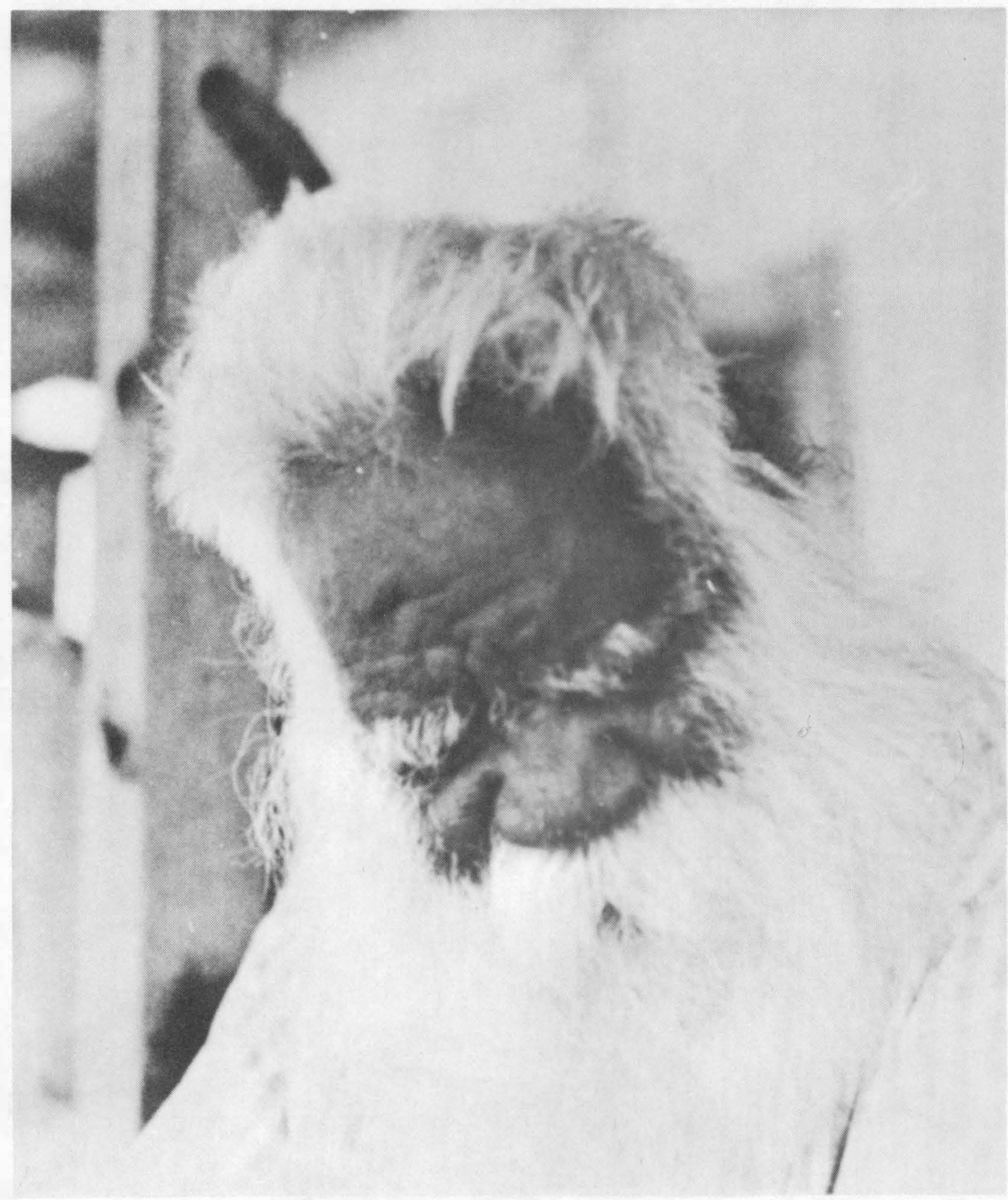

Murtee Johnny (dec. 1976) born at Murtee Station, in about 1880 , the last speaker of Yandruwanda (Innamincka dialect), at Lyndhurst in 1972 . 


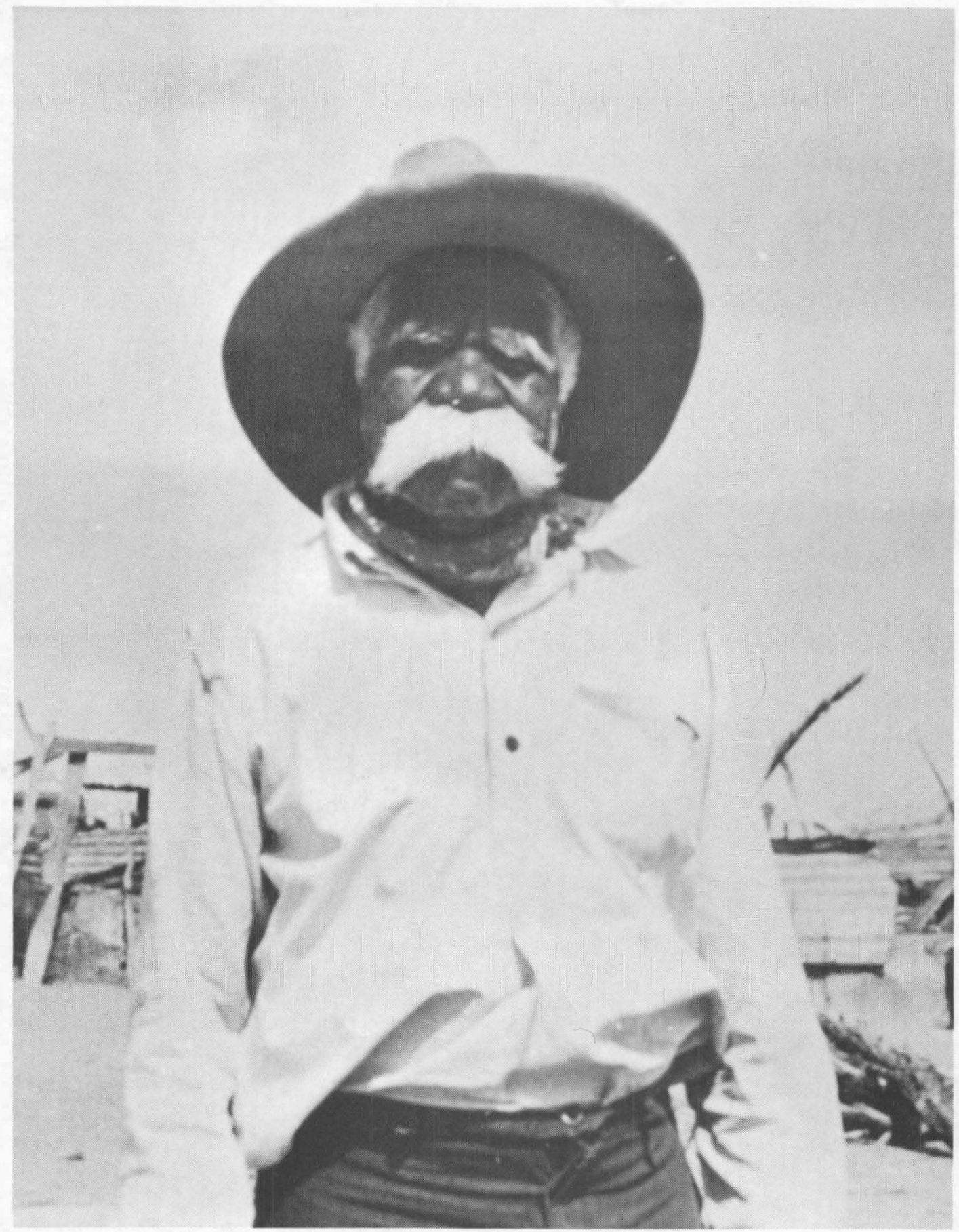

This is Murtee Johnny, the last Yandruwanda from Murtee Station, when working on Mt Hopeless Station. 


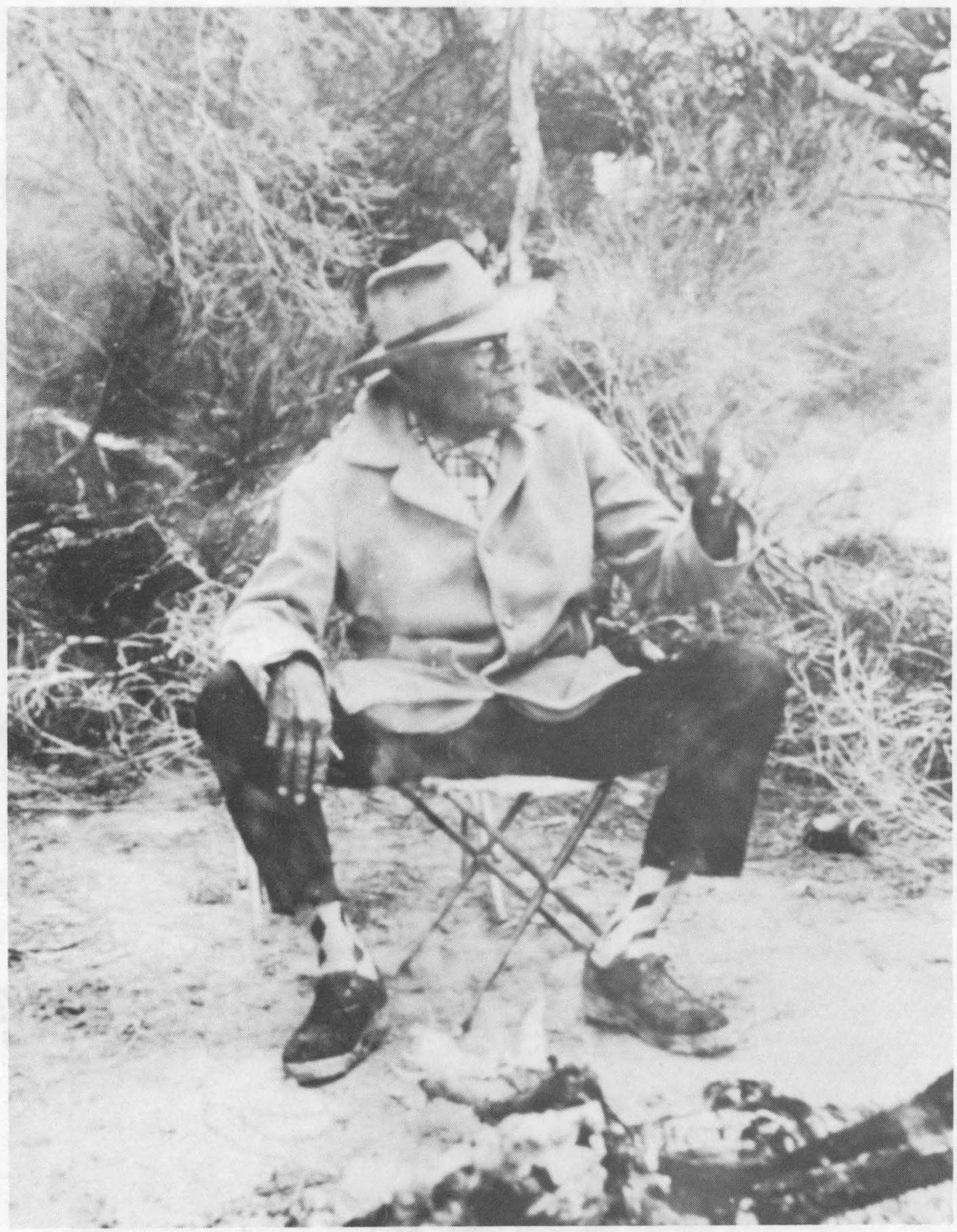

Mick Mclean Irinjili (dec. 1976), Simpson

Desert Wanganuru, at Dalhousie Springs in

August 1975 . 


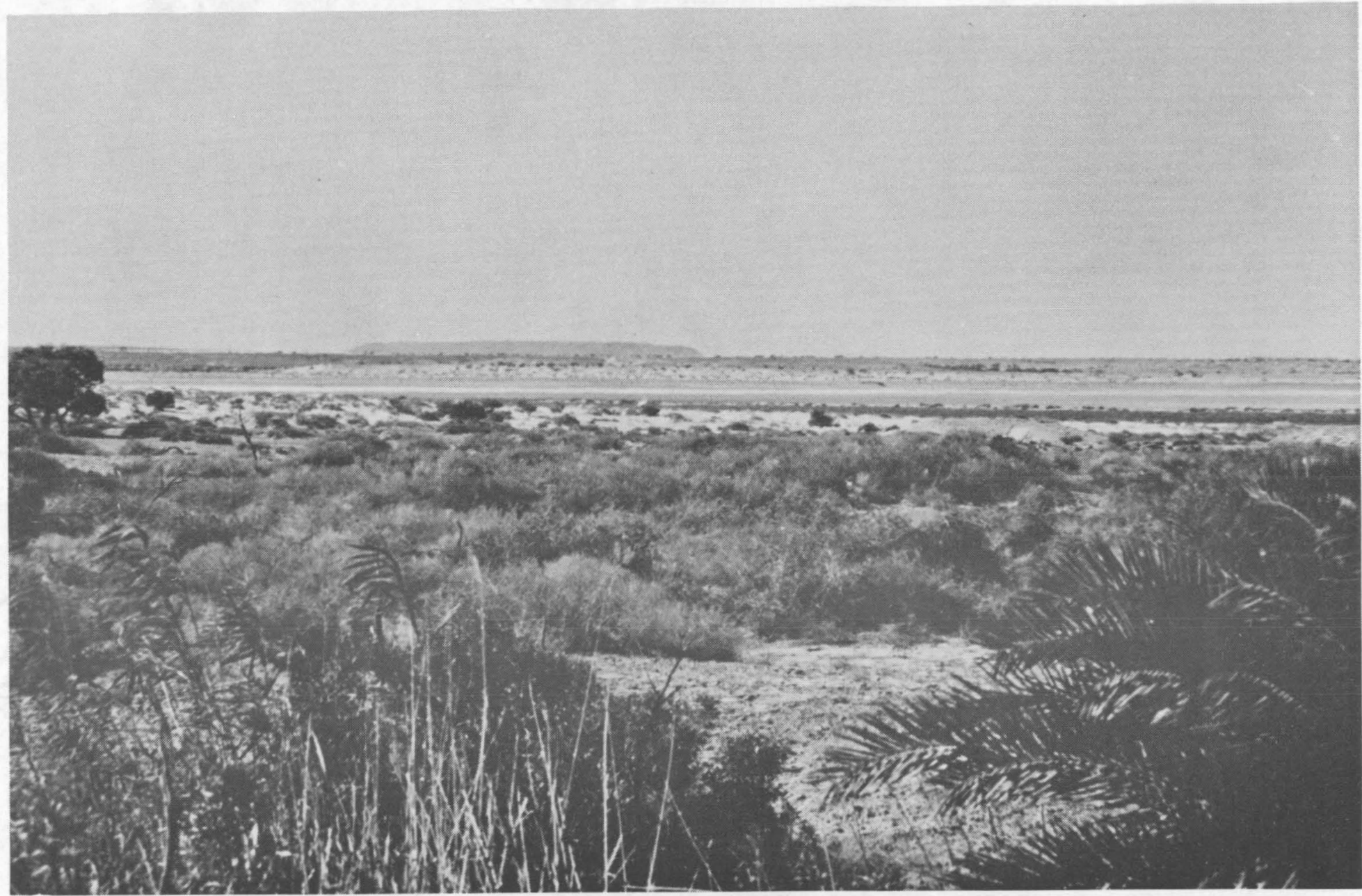

Where Aranda and Wanganuru country meet: looking towards the desert (Wanganuru country) from the Idnjundura

(Kingfisher) spring at Dalhousie, in Aranda country. 


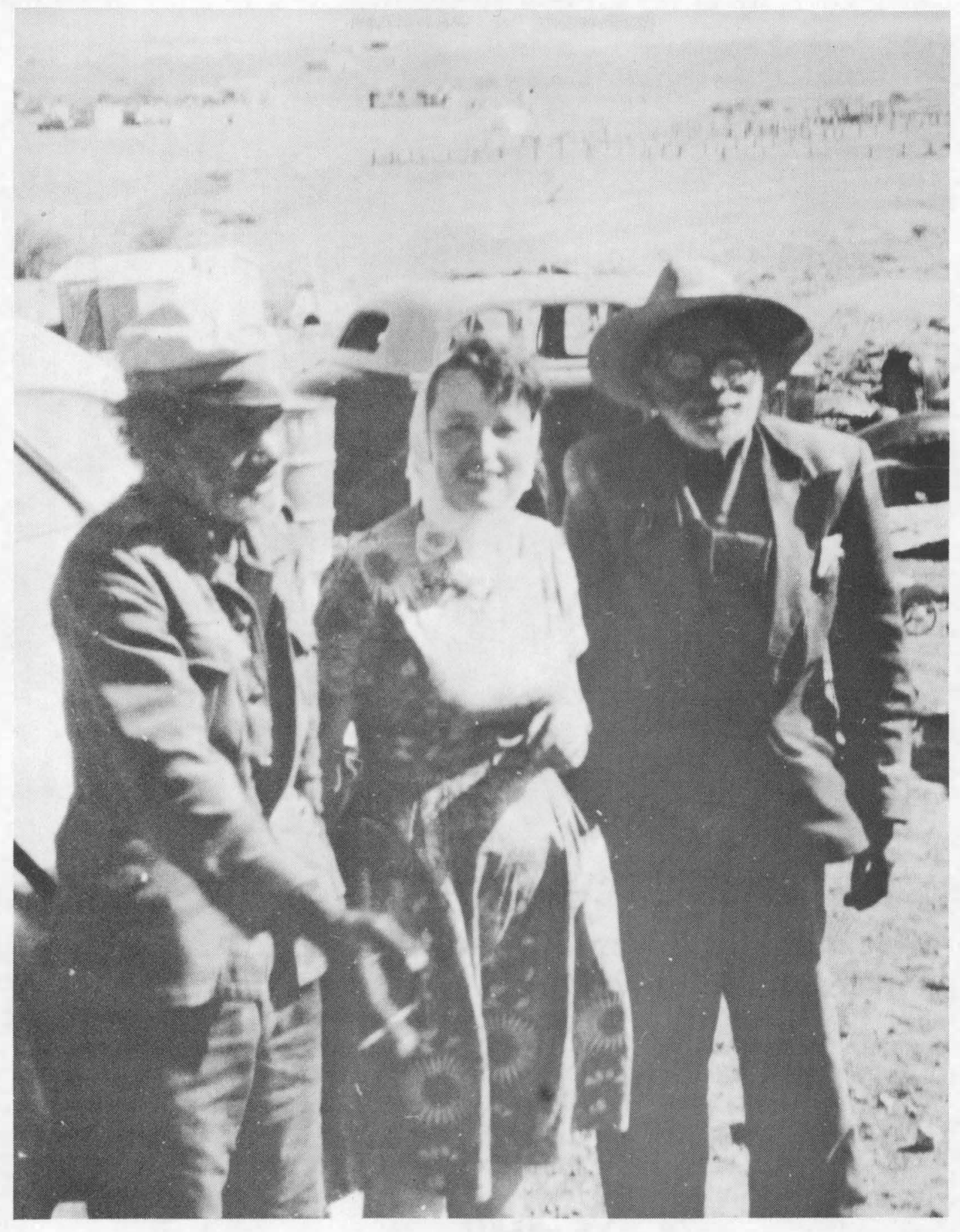

Gilbert Branfield (1eft) (dec. 1973), the 1ast Nugunu, and Tim Strangways (dec. 1972), the Arabana fish-history man, at Andamooka opal field in August 1965. 


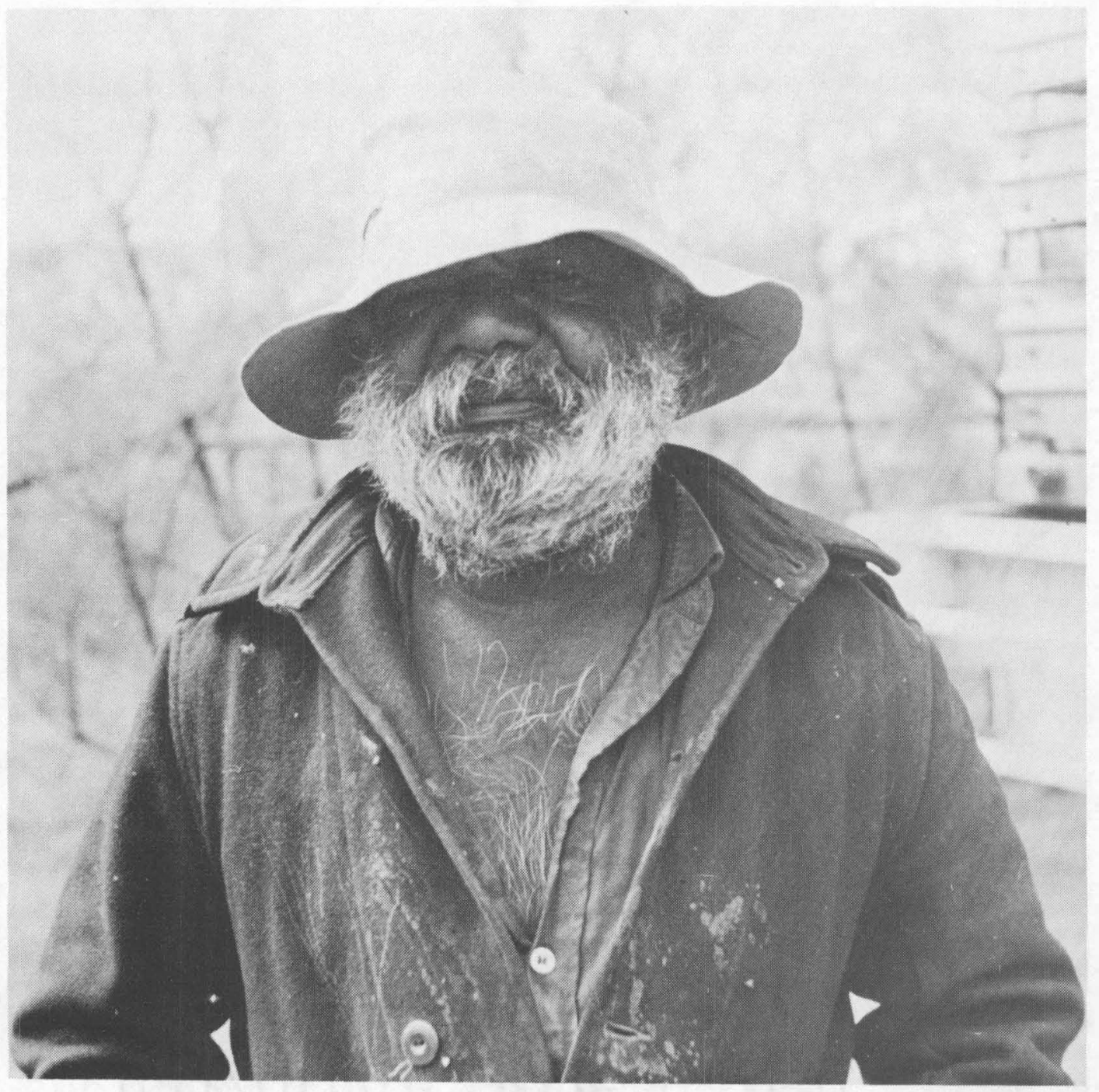

Archie Allen, the only northern Arabana, at Finke in August 1974. 


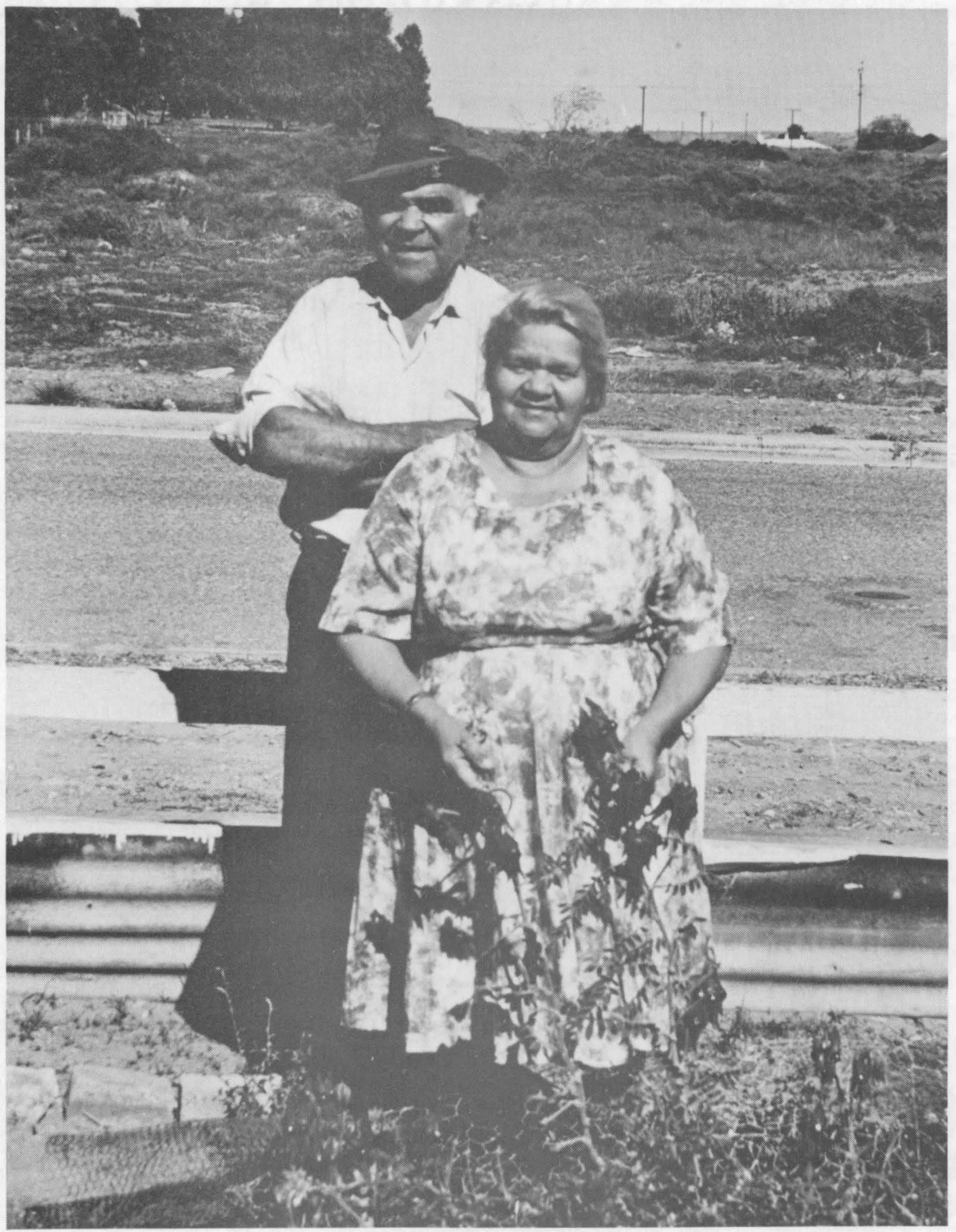

Angus MacKenzie (dec. 1975) and his wife Eileen in their garden at Port Augusta, August 1973. 


\section{THE WEST BARKLY LANGUAGES: \\ AN OUTLINE SKETCH \\ Neil Chadwick}

\section{LIST OF ABBREVIATIONS}
A. Language Names
W.By WEST BARKLY
G GUDANDJI
E.Gp. EASTERN GROUP
B BINBINGA
DJ DJINGILI
Ng NGARNGA, NGARNDJI
Djmn. DJAMINDJUNGAN FAMILY
MC.Sb. MCARTHUR SUBGROUP
DJa. DJAMINDJUNG
W WAMBAYA
$\mathrm{Nu} \quad$ NUNGALI
Ngwu. NGALIWURRU

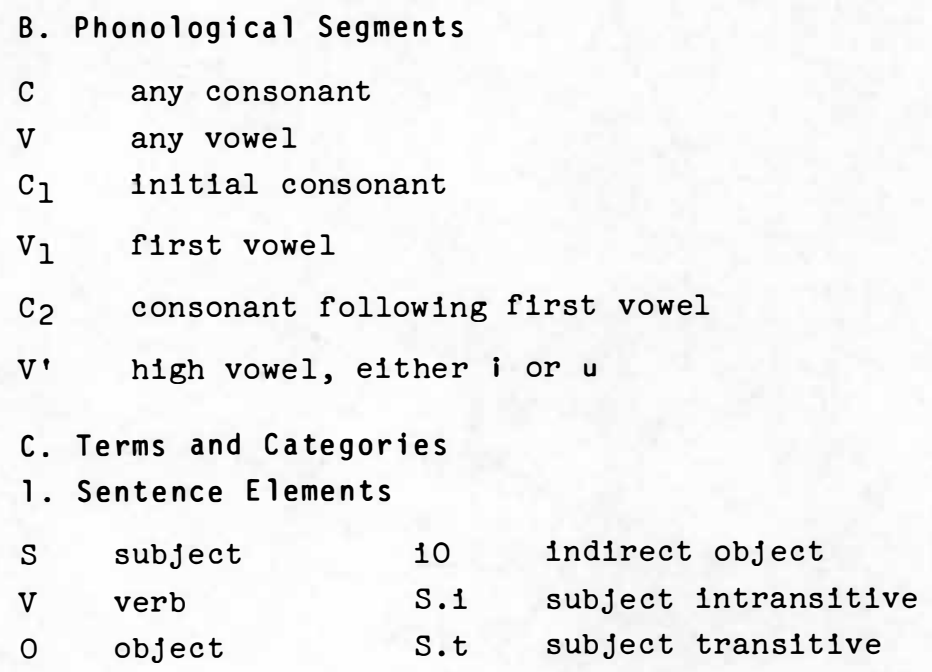

B. Phonological Segments

C any consonant

$\mathrm{V}$ any vowel

$\mathrm{C}_{1}$ Initial consonant

$\mathrm{V}_{1}$ first vowel

$\mathrm{C}_{2}$ consonant following first vowel

$\mathrm{V}$ ' high vowel, either $\boldsymbol{i}$ or $u$

C. Terms and Categories

1. Sentence Elements

$\begin{array}{llll}\mathrm{S} & \text { subject } & 10 & \text { indirect object } \\ \mathrm{V} & \text { verb } & \mathrm{S.1} & \text { subject intransitive } \\ \mathrm{O} & \text { object } & \mathrm{S.t} & \text { subject transitive }\end{array}$

2. Others

$\begin{array}{llll}\text { lp } & \text { first person } & \text { MV } & \text { main verb } \\ 2 p & \text { second person } & \text { nom } & \text { nominative }\end{array}$


THE WEST BARKLY LANGUAGES: MAP OF REGION

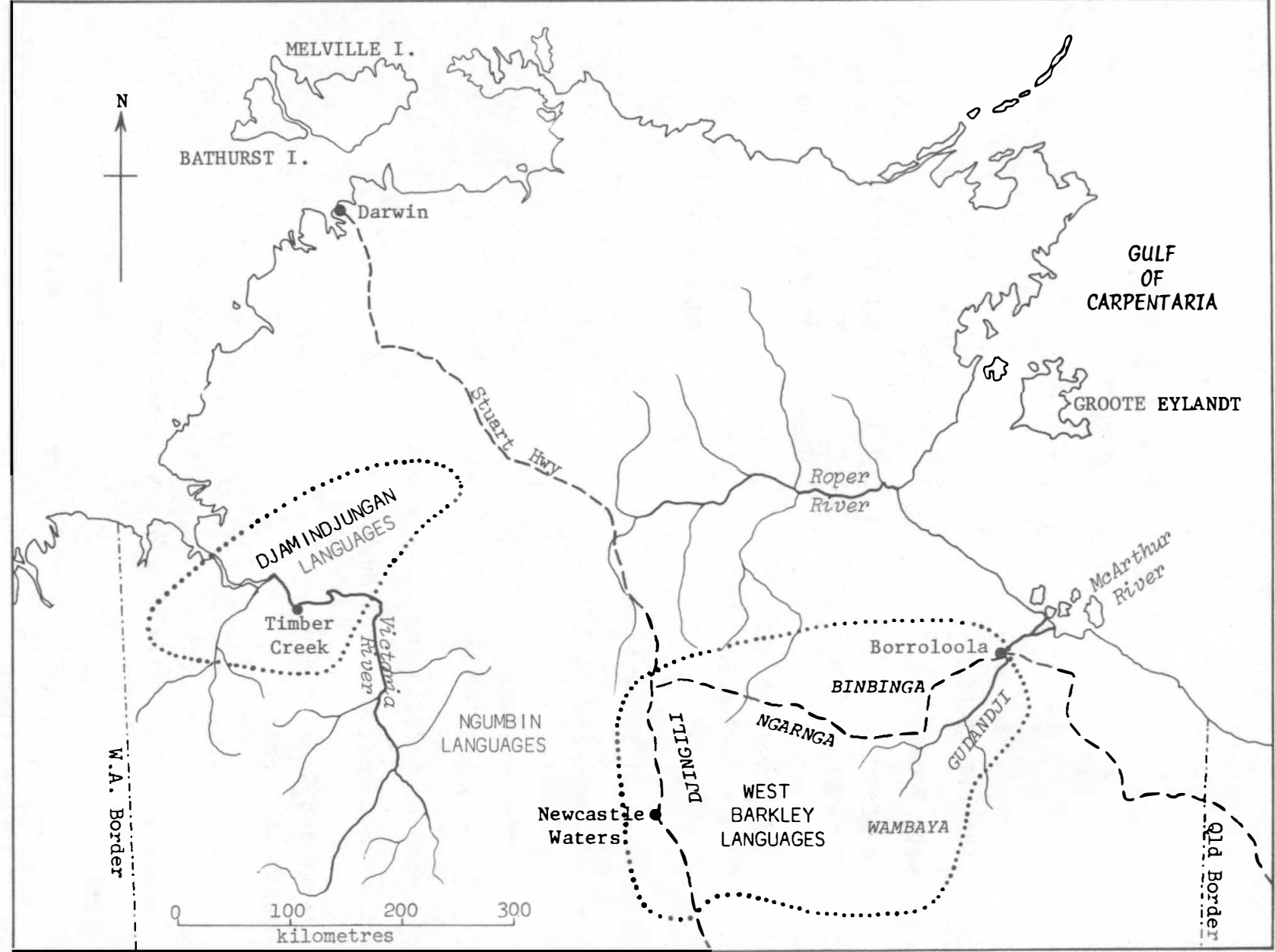




$\begin{array}{llll}\begin{array}{l}\text { 3p } \\ \text { bound s.1. }\end{array} & \begin{array}{l}\text { third person } \\ \text { bound subject } \\ \text { Intransitive }\end{array} & \text { obj } & \text { object } \\ \text { erg } & \text { ergative } & \text { pl } & \text { plural } \\ \text { ex } & \text { exclusive } & \text { pres } & \text { present tense } \\ \text { f., fem } & \text { feminine } & \text { ptu } & \text { person-tense unit } \\ \text { free n. } & \text { free nominative } & \text { sg } & \text { singular } \\ \text { gen. neut. } & \text { general neuter } & \text { subj } & \text { subject } \\ \text { Inc. } & \text { inclusive } & \text { veg } & \text { vegetable class } \\ \text { m., masc. } & \text { masculine } & & \end{array}$

\section{INTRODUCTION}

The West Barkly languages are located in the east-central part of the Northern Territory. Most of the communalects are located on the western half of the Barkly Tablelands, giving the original name Barkly Tablelands languages.

There are two main groups. In the west a single language DJINGILI (DJ) makes up one group whilst to the east of DJ there are four communalects named the EASTERN GROUP (E.Gp.). Three of these communalects, WAMBAYA (W), GUDANDJI (G) and BINBINGA (B), are sufficiently closely related to one another to be considered one subgroup. Since the territories of all three touch on the McArthur River, which flows into the south coast of the Gulf of Carpentaria, they have been named the McARTHUR SUBGROUP (Mc.Sb.).

Between the territories of DJinglli and the McArthur Subgroup lies the territory of NGARNGA ( $\mathrm{Ng})$. $\mathrm{Ng}$ is sufficiently closely related to members of the McArthur subgroup to be included with them in the Eastern Group. It 1s, however, quite separate lexically from the surrounding languages.

The Western Barkly languages are not closely related to any other family of languages in Australia. The family showing the most consistent similarities with W.By. is the DJamindjungan family in an area around the Victorla River quite distant from the Barkly Tablelands and separated from the W.By. languages by other languages of the Ngumbin group of the Western Desert family.

\subsection{Characteristics of the West Barkly Languages}

Geographically the W.By. languages lie between prefixing languages, many of which are multiple-classifying, and languages related to 
Western Desert and other Pama-Nyungan languages. Languages to the south and east are malnly of a suffixing type of morphology and are generally non-classifying (Wagaya to the immediate south-east is an exception, having two noun classes).

Many of the prefixing languages to the north are multiple-classifying, 1.e. have more than two noun-classes. The distinctive characteristics of the W.By. languages were that they were multiple-classifying but non-prefixing adjacent to an area where all other multipleclassifying languages exhibited prefixes.

In the decade of the 1960's the fact that the four noun-classes of the W.By. languages were marked by suffix was considered unusual for the region.

All other multiple-classifying suffixing languages were found in areas on or near the east coast of Australia very distant from the W.By. languages and belonging to quite separate genetic sub-groupings.

DYIRBAL, north east Queensland, is more than $700 \mathrm{mlles}$ ( $1100 \mathrm{~km}$.) from the W.By. region. Dylrbal also has four classes marked partly by suffix (Dixon 1972). The BANDJALANGIC languages, also with four noun classes, are situated more than 1200 miles $(2000 \mathrm{~km}$.) from the W.By. languages around the eastern border between Queensland and New South Wales (Geytenbeek and Geytenbeek 1971). Both DYIRBAL and BANDJALANGIC are clearly of the Pama-Nyungan family of languages.

\section{THE PEOPLE}

Over the last century the speakers of members of the W.By. languages have undergone drastic economic and social change. The region is one of rich and extensive cattle-raising development with some of the largest cattle properties in the world. Almost all of the fluent speakers have worked as stockmen on cattle stations. Early industrialisation of the region resulted in massive internal migration from one language territory to another and to a consequent mixing of different language groups in towns and on cattle stations. There is also much oral evidence that large numbers of some language groups were executed by early European settlers alded by Aboriginal policemen from other areas. These population losses were increased later by the effects of disease, migration, intermarriage, mixed population and change of economic life-style. These processes have resulted in the deterioration in the use of some languages. Two languages in particular are no longer spoken fluently by people under sixty. These are BINGINGA, which quite possibly has no fluent speakers left, and NGARNGA which 
has only three or four old people still competent in the language. Most speakers of GUDANDJI, all to my knowledge, over fifty, can no longer recall the original form of the language but speak varieties mixed largely with WAMBAYA or with BINBINGA or NGARNGA. In turn WAMBAYA has, at most, only four or five speakers still competent in the original form of the language but has a number of younger speakers, all over forty, who have a good hearer's grammar of the language but cannot compose correct sentences unmixed with Pldgin English and other languages.

DJINGILI has survived best of all the five; but fluent speakers who can remember the old morphology are all over forty and would number probably less than twenty.

Younger people under forty years of age have gone through a process of gradual language shift during the industrialisation of the region. Patterns of employment according to European traditions have caused widespread migration of people of differing backgrounds into towns and and cattle stations resulting in a multilingual situation in every centre. Languages and cultures, formerly separate, are now mixed together. All people over forty and under seventy are to some extent multilingual in two or more Aboriginal languages. Few people under fifty can remember how to speak the original distinct form of any Tablelands language. Most people under forty who can still speak an Aboriginal language $\mathrm{mix}$ lexical 1tems and some grammatical items from other languages into their speech. Dfinglli discourse amongst younger people contains many 1tems from nelghbouring Mudburra. Gudandj1 discourse, amongst speakers of all ages, usually contains items from Wambaya, Waany1 and Ngarnga. There are, for the eastern group, only a few old men who can speak the original distinct form of the languages.

In addition, there has been a marked shift towards the use of Pidgin English in camp situations and the use of varieties of rural English in towns. Many of the younger people under twenty now use Pidgin or English in all domains of soclal life. The older people can all speak a varlety of Pidgin known in the northern districts as 'heavy' Pidgin. This P1dgin English is largely incomprehensible to Europeans, has a grammar quite different from standard English and a phonology very similar to certain local Aboriginal languages. Since the time of early European settlement heavy Pidgin has been used amongst Aborigines as a contact vernacular between people of different language backgrounds. The type of Pidgin used by Aborigines when talking to Europeans is much closer to rural English in sound-system and grammar. This variety is usually termed 'light' Pidgin. There seems to be a continuum between light Pldgin and standard English. 
The process of language shift which also reflects differences of age-group has been, and so far continues to be, from a distinct separate language to partially mixed Aboriginal language then to mixed Aboriginal language with Pldgin items to heavy Pidgin to light Pidgin. All these varleties are well within the repertolre of some older speakers. The further process of shift amongst some older speakers and most very young speakers is from light Pidgin to substandard rural English then to standard English. The result is that some of the younger people have a speaking repertolre which includes varieties of Pldgin and English but no Aboriginal language. Most of these young people do, however, have a hearer's grammar of at least one of the local languages. They can understand what is sald to them in the language but cannot give a correct reply.

It is difficult to say what will become of the languages in the future. Much will depend on the economic self-sufficlency of the speakers. At present the demands of an industrialised society ensure the use of varieties of English and Pidgin at school and at work. DJingili may survive for another generation, possibly longer. Languages of the Eastern group are tending to become mixed with one another and with Pldgin. It is likely that this process will continue and that young people will shift to English and Pidgin, losing any competence in the local language.

\section{GRAMMAR}

3.1. Consonants, Vowels and Stress

Except for one characteristic of three of the languages, the phonemic inventory of the W.By. languages is not unusual for the North-central part of Australia. There is only one laminal series with the major allophone belng palatalised. There are stops and nasals at the bilablal, alveolar, lamino-palatal, retroflex and velar places of articulation and laterals at three places of articulation.

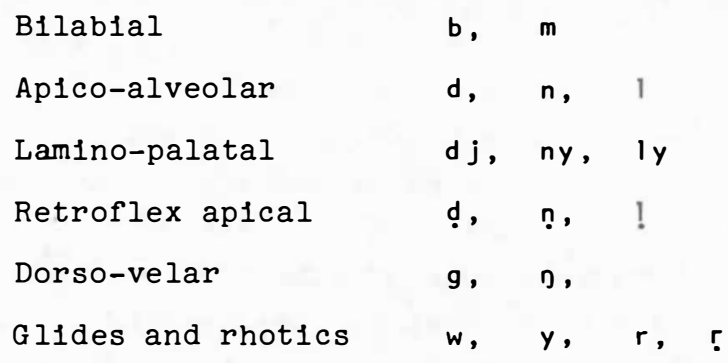


A three-way opposition in vowels:

u

a

The unusual characteristic is a palatal stop which has an onset on the hard palate and the front part of the soft palate with a palatal offglide release.

The sound, written gy, is contrastive in DJ., cf. djadjami wait, djagyami ask.

It also occurs in $\mathrm{Ng}$. (extensively) and in B. (rarely) but there are no examples of minimal pairs. A similar consonant sound is reported from Yanyula (Jean Kirton 1971a and 1971b) and Garruwa (Furby 1972).

Stress normally falls on the penultimate syllable of the word-unit. There are few exceptions. With the addition of suffixes to a stem, stress moves to the penultimate vowel of the series of suffixes, e.g.:

$$
\begin{array}{ll}
\text { Dj. ṇayúlu } & \text { two women (nom) } \\
\text { ṇayuilina } & \text { two women (erg) } \\
\text { ṇayuilinánga } & \text { towards two women }
\end{array}
$$

\subsection{Noun Classification}

\subsubsection{General remarks}

In all Western Barkly languages there are four noun classes marked on nouns and adjectives by suffixes.

In the semantic content of the noun classes there is a basic distinction between fauna/humans and non-fauna/non-human. The fauna/ humans category is further divided into masculine and feminine and the non-fauna or neuter category into vegetable and miscellaneous, yielding four noun classes:
A. Fauna/human
1. Masculine
2. Feminine
B. Non-fauna
3. Vegetable 4. Miscellaneous or general neuter

\subsubsection{Are the classes natural or arbitrary?}

The classes are natural in the following sense:

All 1tems denoting humans and fauna belong to the two classes of the fauna/human category. All items for male humans belong to the 
masculine class and for female humans to the feminine class. Where there is both a masculine and a feminine form for an animal, each form is marked by the appropriate suffix.

All 1tems for flora, with the exception of a tree name (lancewood) in DJ., belong to the two classes of the non-fauna category. All 1tems for melons, fruit and root vegetables belong to the vegetable class. Most 1tems for trees, grasses, leaves and inanimate objects belong to the general neuter class.

The classes are arbitrary in the following sense:

The classes of the fauna/human category both include 1tems for celestial bodies and inanimate objects, e.g.:

\begin{tabular}{|c|c|c|c|}
\hline sun & $\begin{array}{l}\text { uli:djiṇi } \\
\text { gambada } \\
\text { gaarana }\end{array}$ & $\begin{array}{l}\text { fem. } \\
\text { fem. } \\
\text { fem. }\end{array}$ & $\begin{array}{l}(\mathrm{DJ} .) \\
(\mathrm{G} . \mathrm{W} \cdot \mathrm{G} .) \\
(\mathrm{Ng} \cdot)\end{array}$ \\
\hline moon & $\begin{array}{l}\text { baḍangara } \\
\text { aḍanari }\end{array}$ & $\begin{array}{l}\operatorname{masc} . \\
\operatorname{masc} .\end{array}$ & $\begin{array}{l}(\mathrm{DJ} .) \\
(\mathrm{Ng} \cdot)\end{array}$ \\
\hline hunting boomerang & $\begin{array}{l}\text { gurubaḍu } \\
\text { djuguli }\end{array}$ & $\begin{array}{l}\operatorname{masc} . \\
\operatorname{masc} .\end{array}$ & $\begin{array}{l}(\mathrm{DJ} .) \\
(\mathrm{Ng} .)\end{array}$ \\
\hline stone axe & $\begin{array}{l}\text { giṇbiliḍi } \\
\text { ganybalinya }\end{array}$ & $\begin{array}{l}\text { fem. } \\
\text { fem. }\end{array}$ & $\begin{array}{l}(\mathrm{DJ} .) \\
(\mathrm{G} .)\end{array}$ \\
\hline
\end{tabular}

In addition most items for species of fauna are classified as either masculine or feminine regardless of the sex of the individual bird or animal, e.g.:

\begin{tabular}{|c|c|c|c|}
\hline emu & $\begin{array}{l}\text { giṇinindjiṇi } \\
\text { gaṇanandjaṇa }\end{array}$ & $\begin{array}{l}\text { fem. } \\
\text { fem. }\end{array}$ & $\begin{array}{l}(\mathrm{DJ} .) \\
(\mathrm{W} \cdot \mathrm{Ng} \cdot \mathrm{G} .)\end{array}$ \\
\hline yezrow goanna & $\begin{array}{l}\text { wa landja } \\
\text { mainandji }\end{array}$ & $\begin{array}{l}\operatorname{masc} . \\
\operatorname{masc} .\end{array}$ & $\begin{array}{l}(\mathrm{DJ} .) \\
(\mathrm{W} .)\end{array}$ \\
\hline
\end{tabular}

The so-called 'vegetable' class includes, in addition to vegetable food, 1tems for inanimate objects. Many of these objects could be regarded as 'rounded', e.g. string and others as full and rounded, perhaps resembling certain vegetables, e.g. shield, nose. But a few Items such as thunder are hard to classify by physical extension.

Items for body parts can fall into any of the four classes. In DJ.:

$\begin{array}{lll}\text { shin } & \text { udilyi } & \text { is masculine } \\ \text { elbow } & \text { mundjuni } & \text { is feminine } \\ \text { knee } & \text { bangirimi is vegetable } \\ \text { ear } & \text { lana } & \text { is general neuter }\end{array}$




\subsubsection{Divisions of case}

In all W.By. languages nouns follow an ergative/absolutive pattern. This means that the form which functions as subject of a transitive sentence is distinguished from another form which functions both for the subject of an intransitive sentence and the direct object of a transitive sentence. The latter called the absolutive form can usually be analysed as unmarked. The former called the ergative form is marked by suffix.

Other case functions, all marked by suffix are:

Indirect object
Possessive
Benefactive
Purposive
Locative
Allative
Ablative
Comitative

Sometimes one suffix combines the marking of two, three or four functions.

\subsubsection{Suffixes for Noun Class}

\subsubsection{Direct/oblique distinction}

In all W.By. languages there is a clear formal distinction in the masculine and feminine between DIRECT and OBLIQUE class suffixes. Direct suffixes occur in the absolutive case as described above (often called nominative) and oblique suffixes occur in all other cases including ergative.

In $D J$. the distinction between direct and oblique occurs also in the vegetable class.

\subsubsection{The most commonly occurring masculine and feminine class suffixes}

Feminine

\begin{tabular}{cccc}
\multicolumn{2}{c}{ Direct } & \multicolumn{2}{c}{ Oblique } \\
DJ. & E.Gp. & DJ. & E.Gp. \\
- nุi & - nga & $-\eta a$ & $-\eta a-$
\end{tabular}


Masculine
Direct
Oblique
DJ.
E.Gp.
Dj.
E.Gp.
1. - a
1. $-\mathrm{i}$
1. $-(V) n \underline{i}$
1. $-(V) n i$
2. $-d j i$
2. $-d j i$
2. $-d i$
2. -nyi

The direct suffixes can occur as the last or only suffixes in a word. The DJ. oblique suffixes can occur also as the last or only suffixes in a word. But in the E.Gp. the feminine oblique suffix must always be followed by a case suffix and the masculine oblique suffix must usually be followed by a case suffix. Examples:

Direct Feminine

1. DJ.

$\begin{array}{ll}\text { ṇayuni } & \text { woman, direct, absolutive case } \\ \text { ṇayu- } & \text { stem } \\ \text {-ṇi } & \text { direct feminine class suffix }\end{array}$

2. E.Gp. (Gudand 1 )

naduna girl, direct, absolutive case

ṇadu- stem

-na direct feminine class suffix

Oblique Feminine

1. DJ.

$\begin{array}{ll}\text { nayuna } & \text { woman, oblique, ergative/benefactive case } \\ \text { nayu- } & \text { stem } \\ \text {-na } & \text { oblique feminine class suffix }\end{array}$

2. E.Gp. (Gudand 1 )

$\begin{array}{ll}\text { ngaduani } & \text { girl, ergative/locative } \\ \text { nadu- } & \text { stem } \\ \text {-nani } & \text { suffix combination, feminine ergative } \\ \text {-na- } & \text { first-order oblique feminine class suffix } \\ \text {-ni } & \text { second order case suffix, ergative/locative }\end{array}$

Direct Masculine

1. Dj.
d juṇma
wallaby (species), direct, absolutive case
d juṇm-
stem
-a
direct masculine suffix 
2. E.Gp. (Gudandj1, Binbinga)

djugi boy, direct, absolutive case

djug- stem

- $\mathbf{d} \quad$ direct masculine class suffix

Oblique Masculine

1. DJ.

djuṇmiṇi wazlaby, oblique, ergative case

djungm- stem

-iṇi oblique masculine class suffix, ergative case

2. E.Gp. (Gudandj1, Binbinga)

djuginini boy, oblique, ergative/locative case

djug- stem

-inini suffix combination, masculine ergative/locative

-ini- first order oblique masculine class suffix

-ni second order case suffix, ergative/locative

3.2.4.3. Lists of class suffixes (most commonly occurring)

1. Oblique suffixes

Djing1li vegetable class: -ma, -ba

Others:

\begin{tabular}{|c|c|c|}
\hline & DJ. & E.Gp. \\
\hline \multirow[t]{3}{*}{ Feminine: } & $-\eta$ & - クa- \\
\hline & $-g a$ & -nya- \\
\hline & -gya & \\
\hline \multirow[t]{7}{*}{ Masculine: } & $-n i$ & $-i n i$ \\
\hline & $-d \underline{i}$ & - iṇi \\
\hline & $-d i$ & $-n i$ \\
\hline & $-1 i$ & $-n i$ \\
\hline & $-n i$ & $-d i$ \\
\hline & & $-1 \mathbf{i}$ \\
\hline & & \\
\hline
\end{tabular}


2. Direct and general suffixes
DJ .
E.Gp.

$\begin{array}{cll}\text { Masculine: } & & \\ \text { Common } & -a & -i \\ & -V-d j i & -V-d j i \\ \text { Rare } & -n y d j i & -n y d j i \\ & -i & -a \\ & -u & -u \\ & -l y i & -l y i \\ & -C & -n . d j i\end{array}$

Feminine:

\begin{tabular}{|c|c|c|}
\hline Common & $-n i$ & $-n$ \\
\hline & $-d \underline{i}$ & -nya \\
\hline Rare & $-! i$ & $-n a$ \\
\hline & $-1 i$ & $-d a$ \\
\hline & & -da \\
\hline & & $-1 a$ \\
\hline & & פa \\
\hline
\end{tabular}

Gen. Neuter:

Common

$-u$

$-a$

-a

Rare

$-\mathbf{i}$

$-u$

Vegetable: $-\mathbf{m i}$

- ma

$-b i$

Examples:

Gudandj 1

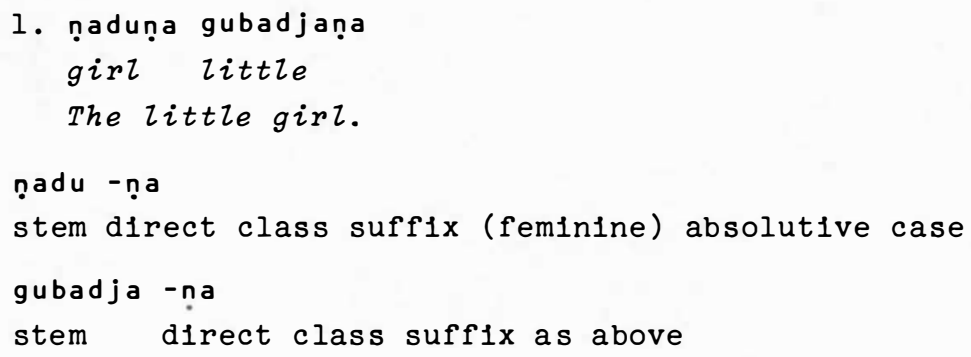


2. madjbi giyinama nadunani gubadjanani

The little girl hit me.

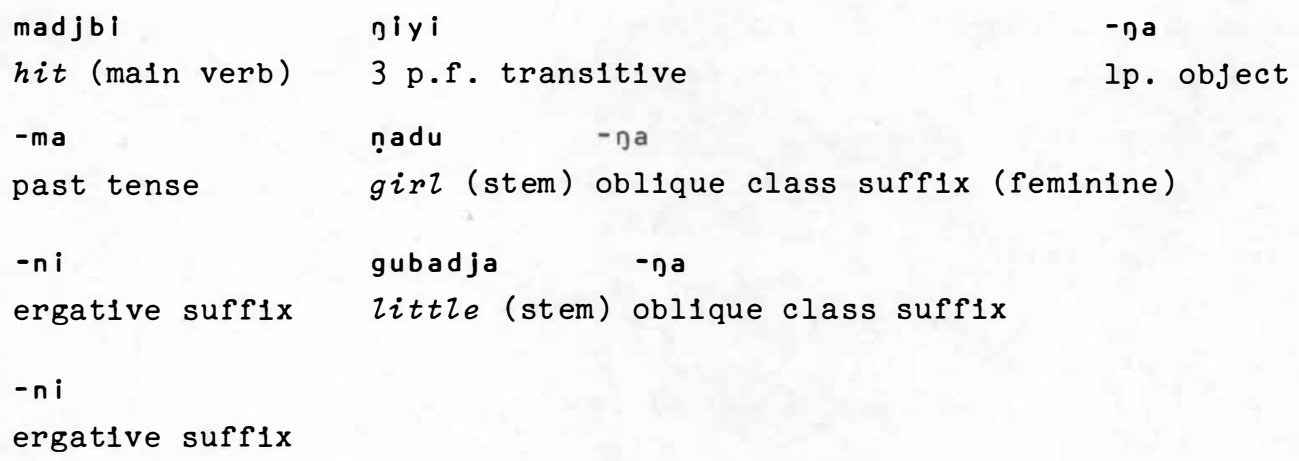

\subsubsection{Extent of concord for noun-class}

In all W.By. languages, adjectives agree with the noun qualified for number, noun-class and case. There is also some concord in the verbphrase.

Th1s verb-phrase concord is most noticeable in Ngarnga and Binbinga. The B. third person singular verb-phrase shows different forms for all noun-classes in the present tense. The $\mathrm{Ng}$. present tense shows feminine and vegetable forms distinct from a combined masculine/neuter form. 
B.

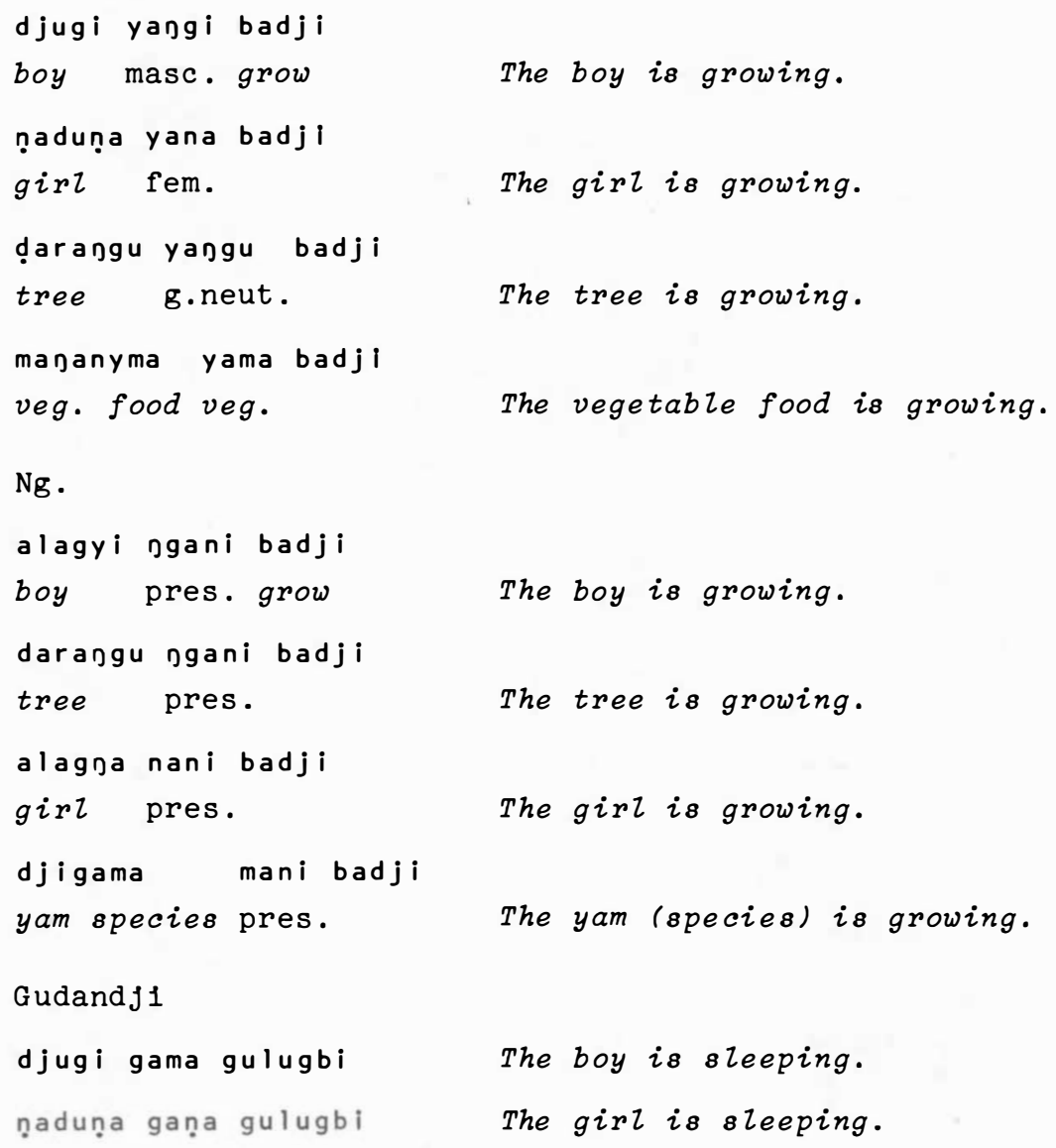

$\mathrm{Ng}$.

alagyi ngani badji

boy pres. grow The boy is growing.

\subsection{Pronouns}

\subsubsection{General}

All W.By. languages exh1b1t both free and bound forms of pronouns. Free forms do not occur for all persons in the nominative. Demonstratives often function for third person nominative pronouns.

Demonstratives are the only third person nominative forms in DJ., and the only singular third person forms in the Eastern group.

There is similarity in form between free and bound pronouns. Normally the first syllable of the free nominative forms corresponds to the bound forms.

The pronoun systems are much the same in function across the W.By . languages. There are singular, dual, and plural forms for all persons 
(first, second, third) and in the first person non-singular, a distinction between inclusive and exclusive.

The following charts set out and compare the forms of free nominative (free n.) pronouns with bound subject intransitive (bound s.1.) pronouns. Alternative forms of free pronouns are in free variation whilst alternative forms of bound pronouns are morphologically determined - usually by tense or mood variations.

The symbol $\mathrm{V}$ stands for any of the vowels $a, i, u$ and the symbol $V$ ' stands for elther $i$ or $u$.

\section{CHART 1}

DJ1ng1l1 Free and Bound Pronouns

Free n. Bound s.1.

Singular

lp. Daya Da

2p. nyama/nama nya/na

Dual

1p. Inc. mindi:la mind

1p. ex. ginyi:la giny

2p. gunyilla guny

Plural

1p. Inc. guruala gur

lp. Dirlwala gir

2p. guruala gur

Th1rd person bound s.1. forms

$\begin{array}{lll}\text { Singular } & \emptyset & \begin{array}{l}\text { normally } \\ \text { following certain verbs } \\ \end{array} \\ \text { ga } & \text { ya } & \text { in isolation } \\ \text { Pual } & \text { uny } & \\ \text { Plural } & \text { ur }\end{array}$




\section{CHART 2}

Ngarnga Free and Bound Pronouns

Free n. Bound s.1.

Singular

Ip.

naṇidja

DV

$2 \mathrm{p}$.

nyama

nd jV/djV

Dual

lp. Inc.

miṇdianidja

mV' ṇ

lp. ex .

pulianidja

nu?

$2 \mathrm{p}$.

gu!ianidja

gu!

$3 p$.

u ! ianidja

u!

Plural

lp. Inc.

Durianidja

Dur

lp. ex.

oirianidja

oir

$2 \mathrm{p}$.

girianidja

gir

$3 p$.

irianidja

i $r$

Third person singular masculine bound forms intransitive subject:

$\eta g \mathrm{~V}$ present and past tenses

yV future tense 


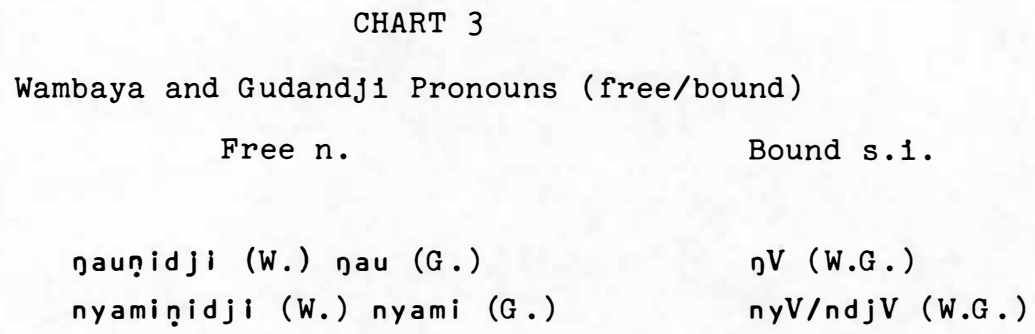

Dual

lp. Inc.

miṇdiani (W.) miṇdiwani (G.)

mV'ṇd (W.G.)

lp. ex.

guịuani (W.G.)

ou! (W.G.)

$2 \mathrm{p}$.

guluani (W.G.)

gu! (W.G.)

$3 p$.

uluani (W.G.)

u! (W.G.)

Plural

$\begin{array}{lll}\text { lp. Inc. } & \text { guruani (W.G.) } & \text { gur (W.G.) } \\ \text { lp. exc. } & \text { giriani (W.) giriwani (G.) } & \text { gir (W.G.) } \\ \text { 2p. } & \text { giriani (W.) giriwani (G.) } & \text { gir (W.G.) } \\ \text { 3p. } & \text { iriani (W.) iriwani/wiriwani (G.) } & \text { ir (W.G.) }\end{array}$

Third person singular bound subject intransitive form

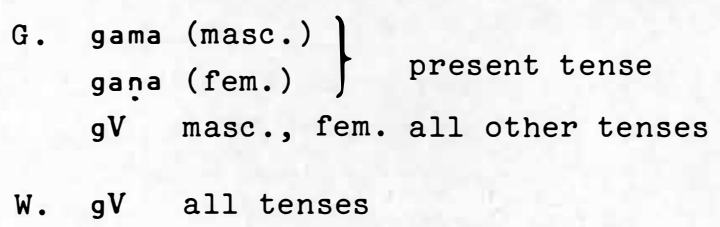




\section{CHART 4}

\section{Binbinga Free and Bound Pronouns}

$$
\text { Free n. Bound s.1. }
$$

Singular

lp.

Dau

¡V

$2 \mathrm{p}$.

nyami

ny V/ndjV

Dual

lp. Inc.

miṇdiwani

$m V^{\prime n g d ~}$

lp. ex.

yu luani

yu!/ou!

$2 \mathrm{p}$.

gu!uan $i$

gu!

$3 p$.

wu!uani

wu!

\section{Plural}

lp. Inc.

yuruani

yur/gur

lp. ex.

iriwani

ir/gir

$2 \mathrm{p}$.

giriwani

gir

$3 p$.

wiriwani

wir

Third person singular intransitive bound subject form

$\begin{array}{ll}\text {-ngi } & \text { masc. present tense } \\ \text {-na } & \text { fem. present tense } \\ \text {-ngu } & \text { neuter present tense } \\ \text {-ma } & \text { vegetable present tense } \\ \text { gV } & \text { other tenses, all classes }\end{array}$

The third person singular B. forms -ngl, -na, -ngu, -ma occur only

in the present tense and are prefixed by ya-.

The form gV- occurs in all other tenses. 


\subsubsection{Comments on the composition of pronouns}

The following regular patterns of structure can be observed in the pronoun forms.

The structure of the bound pronouns and also the first two or three segments of the free pronouns can be analysed as

where

$$
\left(\mathrm{C}_{1}\right) \mathrm{V}\left(\mathrm{C}_{2}\right)
$$

$C_{1}$ stands for first consonant, if any, $V$ for the vowel and $\mathrm{C}_{2}$ for the consonant following the first vowel.

$\mathrm{C}_{1}$ indicates person, sometimes person and number, $\mathrm{C}_{2}$ indicates number and $\mathrm{V}$ indicates person, number and sometimes inclusion

(1) In position $\mathrm{C}_{1}$ : n Indicates first person all numbers.

(1) In the singular forms:

ny indicates second person.

$g$ indicates third person.

(11) in the non-singular forms:

$g$ Indicates second person.

(2) In position $\mathrm{C}_{2}$ :

$r$ indicates plural number.

(3) In position V:

$i$ or u indicate non-singular number.

First person dual inclusive mind/mVng is excluded from this system.

Additional traits of Dfingili pronouns:

(1) In position $C_{1}$ :

$n$ Indicates second person.

(2) In position $\mathrm{C}_{2}$ :

ny indicates dual number.

(3) in position $\mathrm{V}$ :

- $\mathbf{i}$ - Indicates both non-singular number

and exclusion of addressee.

-u- indicates non-singular number and

following $n$ indicates inclusion of

addressee.

-a- Indicates singular number. 
Additional tra1ts of all Eastern Group pronouns:

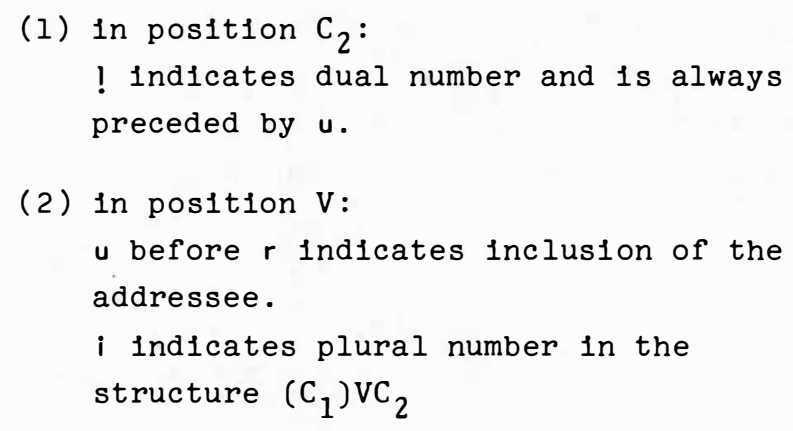

Additional traits of Binbinga pronouns:

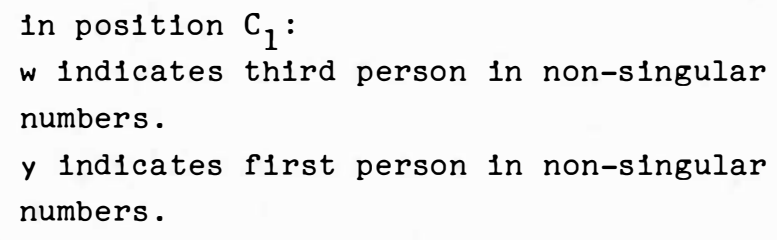

The first person dual inclusive form for inclusion of singular hearer

$$
\begin{array}{ll}
\text { DJ. mind } \\
\text { E.Gp. mVnd }
\end{array}
$$

does not follow the regular patterns of the other pronouns.

\subsubsection{Djamindjung pronouns}

The forms of certain bound pronouns of the DJamindjung language originally spoken in the vicinity of Timber Creek, Northern Territory, are set out below in Chart 5 .

It will be seen that the DJamindjung pronouns follow a system which is remarkably similar to that of DJingili and partially similar to that of the Eastern Group. The most noticeable similarities are:
(1) The Irregular form mind for the first person dual inclusive.
(2) The number markers at place $\mathrm{C}_{2}$, 1.e. ny dual and $r$ plural.

Naturally, similarities such as $n$ first person, ny second person and ur third plural are not distinctive, being found in other Australian languages, but the regular patterning of the system as a whole with the regular relationship between sound and function is somewhat distinct1ve. 
CHART 5

DJamindjung Bound Form Pronouns (from Cleverly 1968)

Singular

$\begin{array}{ll}1 p . & \text { na } \\ 2 p . & \text { na } \\ 3 p . & \text { ga }\end{array}$

Dual

$\begin{array}{ll}\text { lp. 1nc. } & \text { mind } \\ 1 p . \text { exc. } & \text { yiny } \\ 2 p . & \text { guny } \\ 3 p . & \text { buny }\end{array}$

Plural

$\begin{array}{ll}\text { lp. Inc. } & \text { yur } \\ \text { lp. exc. } & \text { yir } \\ 2 p . & \text { gur } \\ 3 p . & \text { bur }\end{array}$

Other languages of the DJamindjungan group show similarities of this nature. Other similarities can be found in descriptions of Ngaliwurru and Nungal1 by Bolt, Hoddinott and Kofod 197la,b.

3.3.4. Characteristics in common between Djamindjung and West Barkly forms

The most obvious characteristic in common is the form which does not follow the regular patterns of the other pronoun forms, 1.e. the first person dual inclusive:

$\begin{array}{ll}\text { Djamindjung } & \text { mind } \\ \text { Djing1li } & \text { mind } \\ \text { Eastern Group } & \text { miṇd /muṇd }\end{array}$

Other characteristics:

1. In common with all W.By. languages.

(1) In position $C_{1}$

(1) in singular number:

o for first person.

$g$ for third person.

(11) in non-singular numbers:

$g$ for second person. 
(2) In position $V$

$i$ or u for non-singular number.

in the first person plural

u for inclusive

$i$ for exclusive

(3) In position $\mathrm{C}_{2}$

$r$ for plural number.

2. In common with DJingili:

(1) In position $\mathrm{C}_{2}$ :

ny for dual number.

(2) In position $C_{1}$ :

$n$ for second person singular.

(3) In position V:

i for both non-singular number

and exclusion of the addressee.

$u$ for non-singular number and in

the first person plural for

inclusion of addressee.

a for singular number.

3. In common with Binbinga:

in position $\mathrm{C}_{1}$ for first person

non-singular.

$y$ Indicates first person.

3.3.5. Bound subject and object transitive pronouns

DJinglli exhibits certain fused subject/object bound pronoun forms which occur as suffixes on the verb-stem as follows:
1. Dandjana you (sg) subj/me obj
2. na:nga she subj/me obj
3. nana he subj/me obj
4. Dainyu she subj/you (sg) obj
5. ninu he subj/you ( $\mathrm{sg}$ ) obj
6. ninadja he subj/him obj 
Historically it seems that subject preceded object. The subject forms were probably

$$
\begin{aligned}
& \text { *nandj(a) you sg in } 1 \text {. } \\
& \text { * nayV in 2. - she } \\
& \text { *nayi in 4. - she } \\
& \text { possibly earlfer **nayi for both *nayi and *nayv } \\
& { }_{n \mathrm{nV}} \text { in } 3 .- \text { he } \\
& *_{n} \text { In } 5 \text {. and 6. - he } \\
& \text { possibly from earlier } \star_{*} n i \text { for both } *_{n} i \text { and } *_{n} V
\end{aligned}
$$

Object forms were probably

$$
\begin{array}{ll}
\text { * (a)na } & \text { In } 1 .-m e \\
\text { *ana } & \text { in 2. and 3.-me } \\
\text { *nyu } & \text { in 4.-you } \\
\text { *nu } & \text { in 5.-you (sg) } \\
\text { possibly from earlier **nyu }
\end{array}
$$

Throughout the W.By. languages the difference between transitive and intransitive subject shows in the third person singular bound forms.

3.3.5.1. Bound third person singular transitive subject pronouns DJ .

ni masculine

nai feminine

(occurring only with bound object pronouns)

$\mathrm{Ng}$.

nV masculine

oV'yV feminine

w.

$$
\text { gV'nV masculine }
$$

¡V'yV feminine 
G .

$$
\begin{aligned}
& \mathrm{gVnV} \text { masculine } \\
& \text { nVyV/nandji feminine }
\end{aligned}
$$

B.

$$
\begin{aligned}
& \text { gVṇ/na masculine } \\
& \text { ¡VyV/nd.jV feminine } \\
& \text { (occurring as } 3 \mathrm{p} . \mathrm{sg} \text {. subjects in all } \\
& \text { transitive sentences) }
\end{aligned}
$$

For first person singular and for dual and plural, there is no difference in form between bound transitive and bound intransitive subject pronouns.

For second person singular, Ng. exhibits some difference between transitive and intransitive subject when subject pronouns occur with object pronouns, 1.e.

$$
\begin{aligned}
& \text { nyv/djV second person singular } \\
& \text { transitive pronouns. }
\end{aligned}
$$

\subsubsection{Object pronouns}

There are both bound form and free form object pronouns in all W.By. languages. In DJ. bound dual and plural object pronouns are the same in form as subject pronouns. In each of the communalects of the E.Gp. bound object pronouns distinguish first from second person but not third person and not number.

\subsubsection{Bound forms}

Df. fused subject object forms have already been set out above. In addition there are two other bound object forms occurring with nonsingular subjects:

$$
\begin{array}{ll}
\text { lp. sg. ana/ana } \\
\text { 2p. sg. nyV' }
\end{array}
$$

All other bound object pronouns in DJ. are the same in form as intransitive subject pronouns. There is no bound object form for third person singular other than the limited fused form set out above.

The E.Gp. bound object forms

$$
\begin{array}{ll}
\mathrm{DV} & \text { first person all numbers } \\
\mathrm{nyV} & \text { second person, all numbers }
\end{array}
$$

are cross-referenced in the dual and plural by free object pronouns. 


\begin{tabular}{|c|c|c|c|}
\hline & \multicolumn{2}{|c|}{ Singular } & \\
\hline & DJ. & $\mathrm{Ng} \cdot / \mathrm{B}$ & W.G. \\
\hline $1 p$. & garu & Dari & Dara \\
\hline $2 \mathrm{p}$ & nangu & nani & \\
\hline $3 p . \quad m$ & gaṇu & nani & ṇapa \\
\hline 3p. f. & gaini & Dayani & Dayana \\
\hline
\end{tabular}

The non-singular free object pronouns can be formed by adding the following affixes to bound subject pronouns:

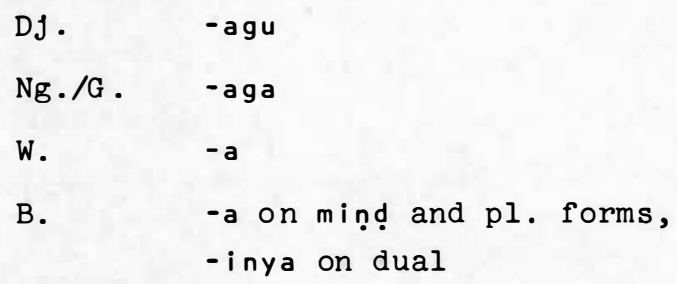

Binbinga has a third person plural form with b-, bira, which compares with DJamindjung bur-bound form.

\section{Dual Forms}

\begin{tabular}{|c|c|c|c|c|}
\hline & DJ. & $\mathrm{Ng} \cdot / \mathrm{G}$. & w. & B. \\
\hline lp. Inc. & mindagu & miṇḍaga & miṇda & miṇḍa \\
\hline lp. exc. & Dinyagu & gu! aga & Du!̣a & yu! inya \\
\hline $2 \mathrm{p}$. & gunyagu & gulaga & gu!a & gu! inya \\
\hline $3 p$. & unyagu & u laga & u! a & ulinya \\
\hline
\end{tabular}

Plural Forms

$\begin{array}{lllll}\text { lp. Inc. } & \text { guragu } & \text { guraga } & \text { gura } & \text { yura } \\ \text { lp. exc. } & \text { giragu } & \text { giraga } & \text { gira } & \text { ira } \\ \text { 2p. } & \text { guragu } & \text { giraga gira } & \text { gira } \\ \text { 3p. } & \text { uragu } & \text { iraga } & \text { ira } & \text { bira }\end{array}$




\subsection{Possessive Adjectives and Demonstratives}

Possessive adjectives agree with the noun qualified for class, case and number, e.g.

DJ.

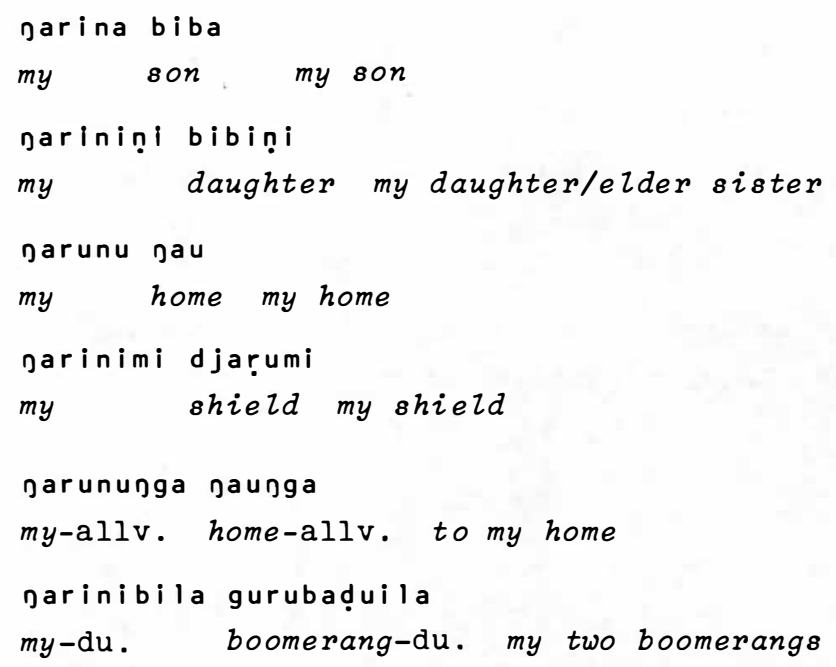

Possessive adjectives are similar in form to free object pronouns. With the exception of some forms in $B$., the nominative masculine singular can be formed by adding the following suffixes to the last consonant of the dual and plural forms of the free object pronoun in DJ., $\mathrm{Ng}$. and $\mathrm{G}$. :

Dj. -ina, e.g. mindagina our (du. Inc.) masc. nom.

Ng. G. -andji, e.g. miṇdagandji our (du. Inc.) masc. nom. and the suffix -gandji to the $w$. free object pronouns, e.g.

$$
\text { gulagandji your (du.) masc. nom. }
$$

and also to the B. dual forms, e.g.

$$
\text { gul inyagandji your (du.) masc. nom. }
$$

The B. plural forms follow a different system:

$$
\begin{array}{ll}
\text { lp. Inc. } & \text { yuragand ji } \\
\text { lp. exc. } & \text { iranygi } \\
2 p . & \text { girigandji } \\
3 p . & \text { biranygi }
\end{array}
$$




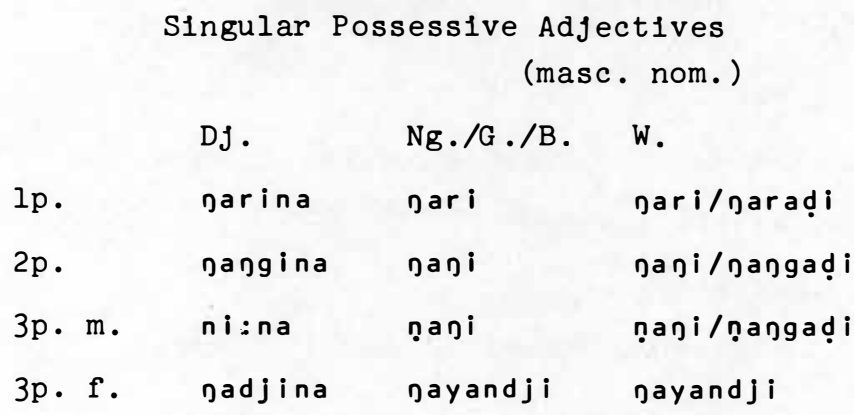

\section{Demonstratives:}

Demonstratives vary for class, case and number. The most striking variations are in the human reference demonstratives in the Eastern Group, where the difference between ergative and nominative is almost completely suppletive.

Singular forms are given below:

1. Eastern Group

Masculine

that - remote
$\mathrm{Ng}$.
W.
G .
B.

$\begin{array}{ll}\text { Nom. } & \text { 1. igai } \\ \text { alternatives } & \text { 2. nia } \\ \text { Erg. } & \text { 1. ṇungu } \\ \text { alternatives } & \text { 2. ṇingianga } \\ & \text { 3. ṇingiaga } \\ & \text { this - proximate }\end{array}$

Nom.

1. inga

1. iniaga

inia

djiriga

alternatives

2. ina:lu

Erg.

ñinga

2. inama

ṇingiaga

ṇingia

ṇungua

Feminine

that - remote

Nom.

1. กุa $i$

alternatives

Erg.

\section{2. nayanga}

nangi anga
1. ṇaniaga

nania

ṇaniga

2. ṇanama

nangiaga nangia nangua 
this - proximate

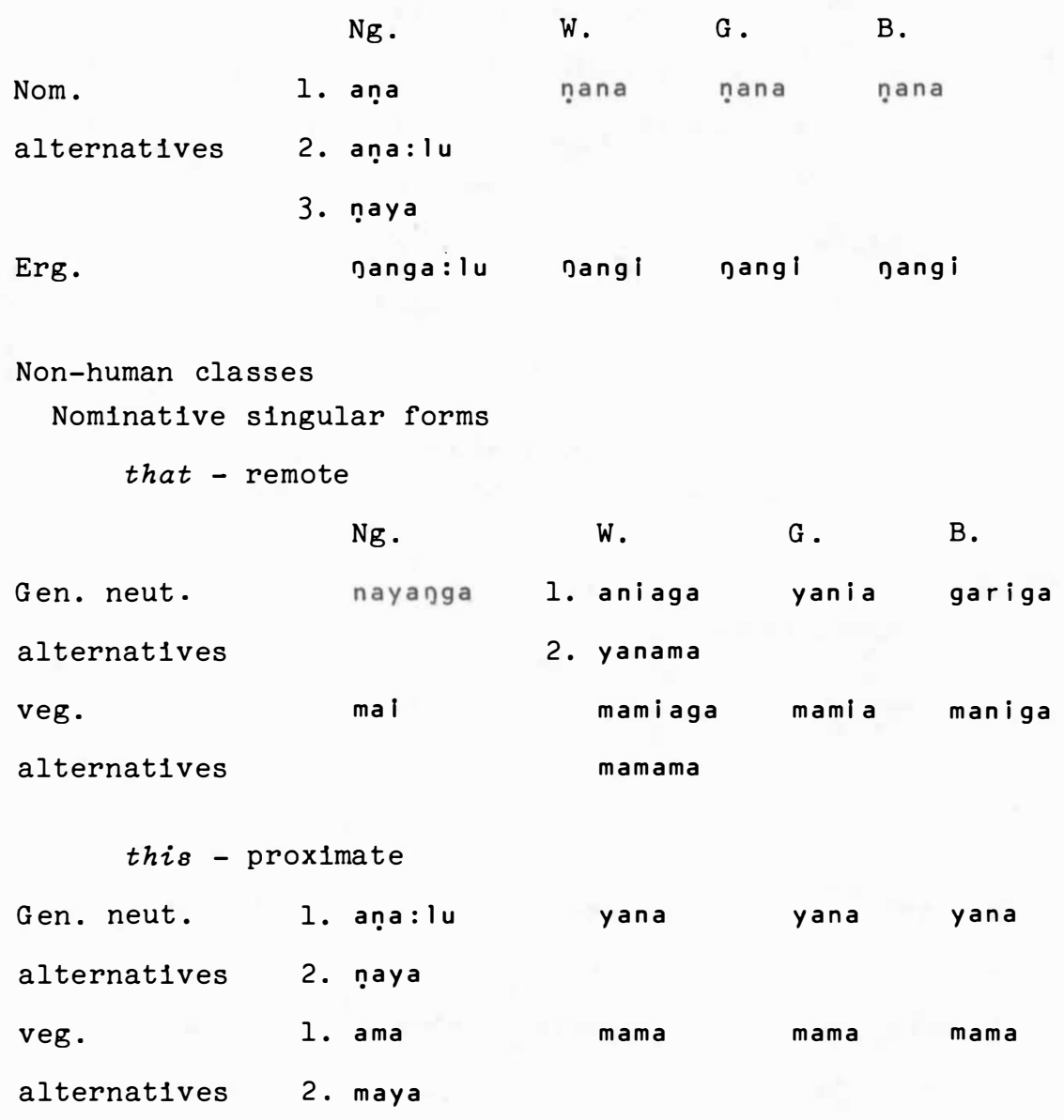

2. DJing1l1

Masculine demonstratives

that

this

Nom. djama

nyinda

Erg. djamiṇi

alternatives 1 . nyindiṇi

2. nyindaṇi

that/this/he

Nom. dj i :

Erg. dji:ṇi 
Feminine

$\begin{array}{lll} & \text { that } & \text { this } \\ \text { Nom. } & \text { nyamani } & \text { nyina } \\ \text { Erg. } & \text { nyamanina } & \text { nyinana } \\ & \text { that/this/she } \\ \text { Nom. } & \text { dji:ṇi } \\ \text { Erg. } & \text { djiana }\end{array}$

Non-human classes

$\begin{array}{lll} & \text { that } & \text { this } \\ \text { Gen. neut. guyu } & \text { nunu } \\ \text { Veg. } & \text { nyama } & \text { nyima }\end{array}$

\subsection{The Verb-complex}

\subsubsection{General structure}

\section{Eastern Group}

The Indication of person and time is contained almost completely in a combined unit (sometimes called elsewhere 'auxiliary') called here the 'person-tense unit' (ptu). This unit often also contains Indication of aspect, number, mood and $1 \mathrm{ng}$. and $\mathrm{W}$. - direction.

The person-tense unit may occur alone as a complete verb-phrase, e.g.:

$$
\text { W. nuba I shall go }
$$

Otherwise 1t either precedes or follows a main verb (MV), e.g.:

$$
\begin{array}{lc}
\text { W. nadjbi } & \text { nuba } \\
\text { MV } & \text { p.t.u. } \\
\text { see } & \text { I go ft. } \\
\text { I shall go and see }
\end{array}
$$

Following a sentence-initial word this order may be reversed, e.g.:

$$
\begin{aligned}
& \text { W. ida nuba nadjbi } \\
& \text { father } \\
& \text { I shall go and see (my) father }
\end{aligned}
$$


2. Djing1l1

A person-tense unit may occur alone as a verb phrase, e.g.: Dari: I shall go

Otherwise the verb-complex usually consists of a stem followed by a suffix or a combination of suffixes which may or may not correspond to separate person-tense units, e.g.:

$\begin{array}{ll}\text { Dadjanu } & \text { he/she saw } \\ \text { Dadja } & \text { nu } \\ \text { stem } & \text { suffix } \\ \text { see } & \text { past-tense } \\ \text { nadjagari: } & \text { I shall go and see }\end{array}$

Ordering of suffixes follows the following patterns:

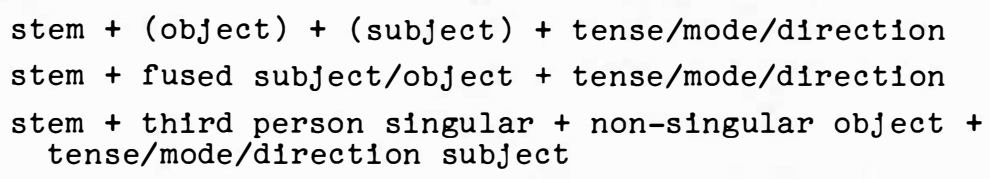

\subsubsection{Inflexion of the Main Verb in $\mathrm{W}$. and $\mathrm{Ng}$.}

In $\mathrm{W}$. and $\mathrm{Ng}$. there are variations of the maln verb for tense and $\operatorname{mood}$.

In $W$. the future (motion neutral) and imperative main verb ends in $-\mathrm{a}, \mathrm{e} . \mathrm{g}$.

$$
\text { jadjba see! }
$$

Otherwise for all other tenses, modes, aspects the main verb ends in -a, $-i$ or $-u, e . g$.

$\begin{array}{ll}\text { nadjbi } & \text { see } \\ \text { djiau } & \text { give } \\ \text { mira } & \text { sit }\end{array}$

In $\mathrm{Ng}$. the imperative main verb ends in -a, e.g.

$$
\text { Dadjba see! }
$$

but the main verb in future and past tenses ends in -ani, e.g.

Dadjbani see

Otherwise for all other tenses, the main verb ends in -a, - $i$ or $-u$, e.g.:

$$
\begin{array}{ll}
\text { nadjbi } & \text { see } \\
\text { manu } & \text { have, keep } \\
\text { mira } & \text { sit }
\end{array}
$$


3.5.3. Structure of the E.Gp. Person-tense Units

The most usual structure of the person-tense unit is:

person + tense/mood/direction

e.g.

$\begin{array}{ll}\text { nani } & I \text { present (Ng.) } \\ & I \text { past (B.) } \\ \text { person } & \text { ani } \\ \text { first person } & \text { tense } \\ \text { singular subject } & \left.\text { present ( } \mathrm{Ng}_{\text {. }}\right) \\ & \text { past (B.) }\end{array}$

Subject precedes object, e.g.:

$\begin{array}{lcl}\text { Dinyani } & \text { I/you present (Ng.) } \\ & \text { I/you past (B.) } \\ \text { ni } & \text { ny } & \text { ani } \\ \text { person } & \text { person } & \text { tense } \\ \text { subject } & \text { object } & \text { present (Ng.) } \\ \text { lst person } & \text { second } & \text { past (B.) } \\ \text { singular } & \text { person }\end{array}$

The structure:

tense prefix + person + tense suffix

occurs in B., e.g.:

yanula we du. exc. pres.

\begin{tabular}{lll} 
ya & \multicolumn{1}{c}{ nu! } & \multicolumn{1}{c}{ a } \\
tense & person & tense \\
prefix & subject & suffix \\
& first person & \\
& dual exclusive &
\end{tabular}

The structure:

person subject + tense + person object

occurs in the future tense in $\mathrm{Ng}$. and $\mathrm{B}$, , e.g.:

guyulana she/me future (Ng. B.)

$\begin{array}{lll}\text { puy (V) } & (\mathrm{u}) \mathrm{la} & \text { na } \\ \text { person } & \text { tense } & \text { person } \\ \text { subject } & \text { future } & \text { object } \\ \text { third person } & & \text { first person } \\ \text { singular feminine } & & \end{array}$




\subsubsection{Imperative}

Singular

$\mathrm{Ng}$. and $\mathrm{W}$.

There is an imperative stem which ends in -a, -nba, -djba, e.g.:

$\begin{array}{lll}\text { W. Ng. } & \text { gadjba } & \text { Zook! } \\ \text { W. } & \text { !adjara } & \text { Zight (it)! } \\ \text { W. } & \text { djiaudjba } & \text { give! } \\ \text { W. } & \text { miranba } & \text { sit! }\end{array}$

G.: The suffix -nya is added to the main verb, e.g.:

$$
\text { madjbinya hit (it) }
$$

B. : The suffix -nyina or $-i$ : is added to the main verb, e.g.:

$$
\begin{array}{ll}
\text { ya:rui: } & \text { go! } \\
\text { narabinyina } & \text { drink! }
\end{array}
$$

Df.: The suffix $-m i$ is added to the stem of the main verb, e.g.:

$$
\text { nadjami Zook! }
$$

Dual and Plural Imperatives

Ng.: gulu dual and giri plural are placed after the singular imperative form, e.g.:

$$
\begin{array}{ll}
\text { nadjba gulu } & \text { Zook! dual } \\
\text { nadjba giri } & \text { Zook! plural }
\end{array}
$$

W.: gu! dual and gir plural are placed next to the singular imperative form, e.g.:

$$
\begin{array}{lll}
\text { gu! miranba or miranba gu! } & \text { sit! dual } \\
\text { gir miranba or miranba gir } & \text { sit! plural }
\end{array}
$$

B. and G.: ga! a dual and gara plural are placed next to the unmarked maln verb, e.g.:

$$
\begin{array}{lll}
\text { Dadjbi gala or gala nadjbi } & \text { Zook! dual } \\
\text { gadjbi gara or gara nadjbi } & \text { Zook! plural }
\end{array}
$$

Df.: The suffixes -anyumi and -arumi are added to the stem, e.g.:

$$
\begin{array}{ll}
\text { mangiaanyumi } & \text { sit dual } \\
\text { mangiaarumi } & \text { sit plural }
\end{array}
$$


3.5.5. Vowel Harmony in DJ.

The vowels of $\mathrm{DJ}$. verb forms alternate between open and closed features, e.g.:

$$
\text { nadjanadju I see (present) }
$$

$\begin{array}{lll}\text { nadja } & \text { na } & \text { dju } \\ \text { stem } & \text { first person subject } & \text { present } \\ \text { see } & \text { singular } & \text { tense }\end{array}$

but gidjimindidju we two (Inc.) see (present)

$\begin{array}{ll}\text { nidji mindi } & \text { dju } \\ \text { stem } & \text { first person } \\ \text { see } & \text { dual inclusive subject }\end{array}$

Under normal conditions, the stem with open vowels is found in the singular and the stem with closed vowels occurs with dual and plural bound subject pronouns.

Except for a limited number of person and tense forms, the vowels of the singular person markers are open and the vowels of the nonsingular markers are closed. Further detalls of vowel harmony can be found in Chadwick 1975.

\subsubsection{Direction - Function and Suffixes}

In DJ., W. and $\mathrm{Ng}$. direction and motion are indicated by a set of tense and mood suffixes which are separate from other tense or mood suffixes unmarked for the indication of motion.

There are two sets of 'directive' tense/mood suffixes in each language. One translates the English verbs go or take - motion in a direction away from or around the source. The other translates to English verbs come or bring - motion in a direction towards the source.

Suffixes for go:

Dj.

$\begin{array}{llll}\text { Past } & \text { Present } & \text { Future } & \text { Imperative } \\ \text {-rugu } & \text {-ạ̣u } & -r i: /-w a & -\mathbf{i}: \mathbf{r i}\end{array}$

W. and $\mathrm{Ng}$.

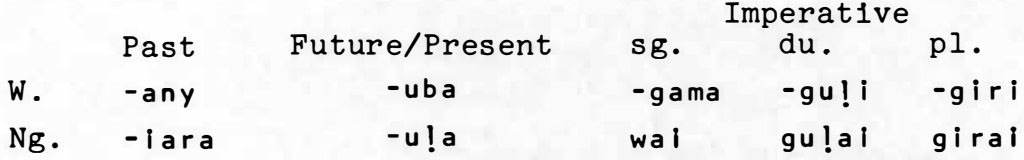


Suffixes for come

DJ.

$\begin{array}{llc}\text { Past } & \text { Present } & \text { Future/Imperative } \\ \text {-amigi } & \text {-Vdji:mi } & \text {-Vogu }\end{array}$

W. and $\mathrm{Ng}$.

\begin{tabular}{|c|c|c|c|c|c|}
\hline & Past & Future/Present & sg. & $\begin{array}{l}\text { derative } \\
\text { du. }\end{array}$ & pl. \\
\hline W. & -amany & -ulamany & $\begin{array}{l}-g a \\
-a\end{array}$ & gu l ama & girama \\
\hline $\mathrm{Ng}$. & -agyani & -ulagyani & $\begin{array}{r}a m a \\
-i m a\end{array}$ & gul ama & girama \\
\hline
\end{tabular}

\subsubsection{Other Tense Affixes}

In $G$. and B. separate directive affixes have not occurred so far in the corpus. In $\mathrm{W} ., \mathrm{DJ}$. and $\mathrm{Ng}$. the affixes given below are motionneutral, 1.e. If the verb phrase carries the meaning of coming, going, taking or bringing the directive affixes are used instead of the motion-neutral affixes.

\begin{tabular}{|c|c|c|c|c|c|}
\hline & Past & Present & & Future & Present habitual \\
\hline DJ. & $-n u$ & $-d j u$ & & $-\mathbf{i}$ & $-\operatorname{adi}$ \\
\hline $\mathrm{Ng}$. & - ina & $-a n i$ & & $-u 1 u /-i 1 i$ & $-u l i a /-i l i a$ \\
\hline w. & $-a$ & $-i /-u$ & & $-u /-i$ & $-a l a$ \\
\hline G. & $\begin{array}{l}\text { - ima/ } \\
\text { - uma }\end{array}$ & $-i /-u$ & $\begin{array}{l}1 . \\
2 .\end{array}$ & $\begin{array}{l}-u /-i l \\
-u / u /-i l i\end{array}$ & -ala \\
\hline B. & $-a n i$ & $\begin{array}{l}\text { ya-i } \\
\text { ya-a }\end{array}$ & & $-u ! a /-i ! a$ & -ala \\
\hline
\end{tabular}

3.6. Structure of the Noun-complex

3.6.1. General

The general structure of the noun-unit throughout the W.By. languages 1s :

$$
\text { stem }+\operatorname{suffix}(e s)
$$

1 1. and 2. are alternatives in free variation. 
Suffixes follow the sequence:

1

(number $)+$

2

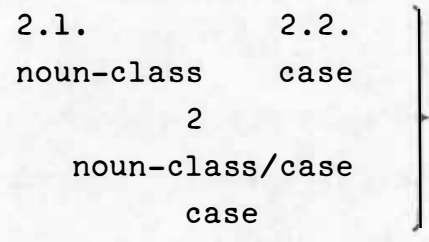

giving five basic patterns for the Eastern Group and four for DJ.

1. Stem + noun/class/case, e.g.:

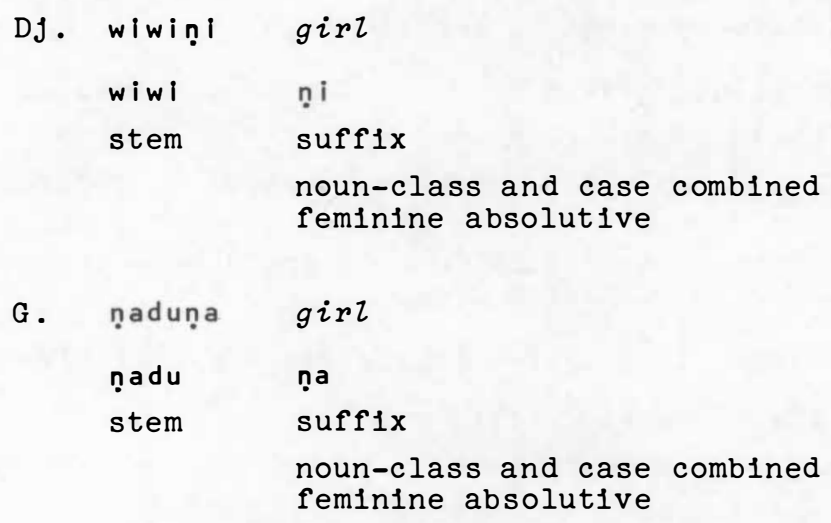

2. Stem + number + noun class/case, e.g.:

DJ. djunmaila two wallabies (species)

$\begin{array}{lll}\text { djungma } & \text { il } & \text { a } \\ \text { stem } & \text { number } & \text { combined noun-class and case } \\ & \text { dual } & \text { masculine absolutive }\end{array}$

G. ṇaduuiu two girls

$\begin{array}{lll}\text { naḍu } & \text { ul } & u \\ \text { stem } & \text { number } & \begin{array}{l}\text { noun-class and case combined } \\ \text { feminine absolutive }\end{array}\end{array}$

3. Stem + noun-class + case, e.g.:

DJ. wawaninga towards the boy

$\begin{array}{lll}\text { wawa } & \text { ni } & \text { nga } \\ \text { stem } & \text { noun-class } & \text { case } \\ & \text { masculine oblique } & \text { allative }\end{array}$


G. ngadunanma towards the girl

$\begin{array}{lll}\text { ṇadu } & \text { na } & \text { nma } \\ \text { stem } & \text { noun-class } & \text { case } \\ & \text { feminine oblique } & \text { allative }\end{array}$

4. Stem + number + noun-class + case, e.g.:

DJ. bainbilininga towards the two men

$\begin{array}{llll}\text { bain } & \text { bili } & \text { ni } & \text { nga } \\ \text { stem } & \text { number } & \text { noun-class } & \text { case } \\ & \text { dual } & \text { masculine oblique } & \text { allative }\end{array}$

W. alagmangininga for the boys

$\begin{array}{llll}\text { alag } & \text { maṇd } \mathbf{i} & \mathbf{n} & \text { nga } \\ \text { stem } & \text { number } & \text { noun-class } & \text { case } \\ & \text { plural } & \text { masculine oblique } & \text { benefactive }\end{array}$

5. Stem + number + case (this structure is found only in the Eastern Group), e.g.:

W. aiaguildi two boys/girls erg./locative

$\begin{array}{lll}\text { alag } & \text { buli } & \mathbf{d j} \mathbf{i} \\ \text { stem } & \text { number } & \text { case } \\ \text { child } & \text { dual } & \text { ergative/locative }\end{array}$

The suffixes -buli dual and $-d j i$ case, ergative/locative do not distinguish noun-class.

\subsubsection{Case Marking}

Case functions marked by suffix:

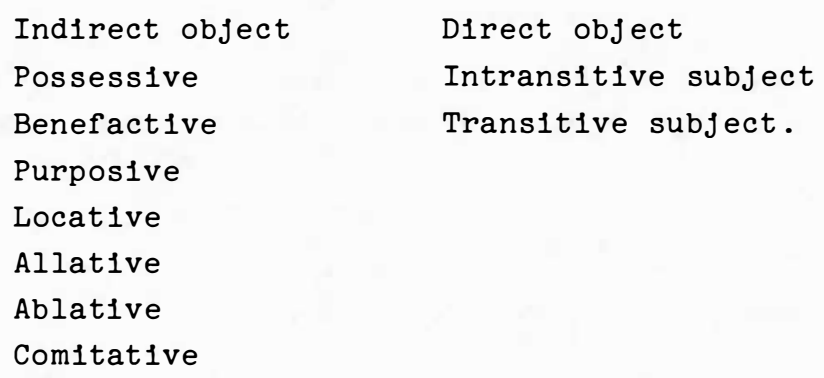

The marking of two or more functions by one suffix is found in all groups. 
McArthur Subgroup

One suffix morpheme for ergative, instrumental and locative.

The label used is 'ergative/locative'.

One suffix morpheme for benefactive, indirect object, purposive and possessive.

The label used is 'benefactive'.

Ngarnga

One suffix morpheme for ergative and locative labelled 'ergative/ locative'.

One suffix morpheme for benefactive, indirect object, purposive and possessive labelled 'benefactive'.

Djing1li

One suffix morpheme for ergative, indirect object, benefactive, purposive and possessive in the feminine class only.

The label used is 'feminine ergative'.

Masculine and Non-human Classes

One suffix morpheme for benefactive, indirect object, purposive and possessive.

The label used is 'benefactive'.

\subsubsection{The most commonly occurring Case Suffixes}

Benefactive

1. E.Gp.

$$
\begin{array}{ll}
\text { Ng. W. } & \text { G. B. } \\
\text {-nga } & -n g a /-n g a
\end{array}
$$

2. DJ.

Feminine ergative (inc. benefactive function)

$$
\text { -na/-ga/-gya }
$$

Masculine benefactive

$$
- \text { na } /-n a /-d a /-1 a
$$

General neuter benefactive

Vegetable class benefactive 
Locative

$$
\begin{array}{ll}
\text { DJ. } & \mathrm{Ng} \cdot \\
-m b i l i & -n i /-n b i /-m b i
\end{array}
$$

Ergative/Locative (E.Gp. only)

$$
\begin{array}{lll}
\text { Ng. } & \text { W. G. } & \text { B. } \\
-n i /-n i & -n i / n V & -n i /-n i / n V
\end{array}
$$

Allative

$$
\begin{array}{lll}
\text { DJ. } & \mathrm{Ng} \cdot \mathrm{W} . & \mathrm{G} \cdot \mathrm{B} . \\
\text { - } g \mathrm{a} & -n m a n d j i & -n m a
\end{array}
$$

Ablative

$$
\begin{array}{ll}
\text { DJ. } & \text { E.Gp. } \\
\text {-ngami } & -n g a
\end{array}
$$

Instrumental

$\begin{array}{lll}\text { Dj. } & \text { Ng. } & \text { Mc. Sb. } \\ -(w) \text { aṇdi } & (w) \text { aṇdu } & \text { same as Ergative/Locative }\end{array}$

Comptative

$$
\begin{array}{lll}
\text { DJ. } & \mathrm{Ng} . & \mathrm{Mc} . \mathrm{Sb} . \\
\text { same as locative } & -(w) \text { andu } & -n i / l i \\
\text { or Instrumental } & -n i / 1 i /-m b i &
\end{array}
$$

Ergat1ve

Same as ergative/locative in the Eastern Group.

Same as the oblique masculine and feminine gender suffixes in Djingili.

\subsubsection{Most commonly occurring Number Suffixes}

Indication of plural number is optional in all W.By. languages. Each noun has a basic form which is usually singular but may be plural in reference.

For certain body parts, e.g. 'ears', 'eyes', 'hands', 'breasts', indication of dual number is optional. Otherwise indication of dual number is obligatory.

Dual Suffixes

DJ.

The forms ulV, wulV, bulV and ilV, wilv, bilv are very common. 
E.Gp.

The most common suffixes are ulV, wulv, bulv but the form gulv also occurs in $\mathrm{Ng}$. and $\mathrm{B}$.

Plural Suffixes

DJ.

The most common suffixes are -ala, - $11 \mathrm{i},-a g^{-},-11 i g-$ but the forms -bala, badjV and -wur- also occur.

Eastern Group

The most common suffix is -mangl but the form-gundji with class variations is also common.

\subsection{Sentence Structure}

Abbreviations :

\begin{tabular}{|c|c|c|c|}
\hline$S$ & subject & MV & main verb \\
\hline V & verb & ptu & person-tense unit \\
\hline 0 & object & & \\
\hline 10 & Indirect object & & \\
\hline S.1 & subject intransitive & & \\
\hline s.t & subject transitive & & \\
\hline
\end{tabular}

\subsubsection{General sentence structure in all W.By. languages}

This section deals only with the ordering and relationships of a simple sentence involving, at most, subject, verb, direct and indirect object. It does not deal with adverblal phrases, subordination and nominalisation.

\subsubsection{General traits of W.By. languages}

1. Equational sentences occur without a copula in the present tense.

2. The ordering of subject and verb is not fixed.

3. The ordering of noun subject relative to noun object is not fixed.

4. Free object pronouns must always follow the verb.

5. The preferred position for interrogative markers is sentenceinftial.

6. The ordering of adjective and noun-qualified is not fixed, but adjectives normally follow the noun. 


\subsubsection{Sentence-structure in the Eastern Group}

The most common structure of the verb complex when occurring alone 1s :

$$
\mathrm{MV}+\mathrm{ptu}
$$

e.g. G. gulugbi gama he is sleeping

$$
\begin{array}{ll}
\text { gulugbi } & \text { MV, sleep } \\
\text { gama } & \text { ptu, third person singular masculine present }
\end{array}
$$

With a noun subject, the most common structure is:

$$
S+p t u+M V
$$

e.g. G. djugi gama gulugbi The boy is sleeping

$$
\begin{array}{ll}
\text { djugi } & S, \text { nominative case, boy } \\
\text { gama } & \text { as above, ptu } \\
\text { gulugbi } & \text { as above, MV, sleep }
\end{array}
$$

The ordering $M V+p t u+S$ is also very common. S never occurs between MV and ptu. Other orderings are extremely rare.

In transitive sentences in which both subject and object are indicated by nouns, the two most common structures are:

$$
\begin{aligned}
s \cdot t & +p t u+M V+0 \\
0 & +p t u+M V+s \cdot t
\end{aligned}
$$

e.g. W. djanyini gina daumimari The dog bit the snake

or mimari gina dau djanyini

$$
\begin{array}{ll}
\text { djanyini } & \text { S.t, dog, ergative } \\
\text { gina } & \text { ptu, he past } \\
\text { dau } & \text { MV, bite } \\
\text { mimari } & 0, \text { snake, absolutive }
\end{array}
$$

However,

$$
\mathrm{MV}+\mathrm{ptu}+\mathrm{O}+\mathrm{S} \text { also occurs }
$$

$$
\text { dau gina mimari djanyini }
$$

Other permutations are possible.

Where the pronoun object and subject are bound within the persontense unit the preferred order is:

$$
M V+p t u
$$

e.g. B. gudaibi ginagani he bit me

gudaibi main verb, bite

ginanani ptu, he/me past 


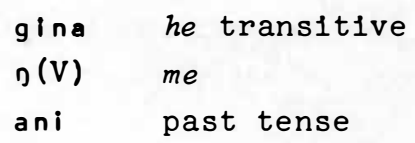

Where a noun occurs for transitive subject the preferred orders are:

$$
\begin{array}{cl}
\text { either } & S . t .+p t u+M V \\
\text { or } & M V+p t u+s . t .
\end{array}
$$

e.g. B. wangamaṇinl glnananl gudalbl gudalbl glnananl wangamaṇinl

$$
\text { wangamaṇini S.t., dog, ergative }
$$

Indirect object

Where a noun-phrase (free object pronoun and noun) occurs in the function of indirect object, the most common principle of ordering is that the indirect object follows the verb-complex (except where it is an interrogative). The subject noun, if any, usually occurs either before the verb-complex or between the verb complex and the indirect object.

In sentences without a noun subject:

$$
M V+p t u+10
$$

e.g. W. nalwi ga nayana alananga He/she spoke to the girl

$$
\begin{array}{ll}
\text { nalwl } & \text { main verb, speak } \\
\text { ga } & \text { ptu, third person singular, past } \\
\text { nayana } & \text { free object pronoun third person } \\
& \text { singular feminine } \\
\text { alananga } & \begin{array}{l}
\text { indirect object noun, 'benefactive' } \\
\text { case, girl }
\end{array}
\end{array}
$$

In sentences with a noun subject:

$$
\begin{array}{cl}
\text { either } & M V+p t u+\text { subject }+10 \\
\text { or } & \text { subject }+p t u+M V+10
\end{array}
$$

e.g. W. nalwi ga naida nayana alananga The woman spoke to the

$$
\begin{aligned}
& \text { naida subject noun, absolutive case, woman } \\
& \text { or naida ga nalwi nayana alananga }
\end{aligned}
$$

3.7.2.1. Sentences with both direct and indirect object noun phrases

Testing is not complete in this area, but from the corpus obtained so far, it appears that the direct object noun can appear in any position in a sentence containing an indirect object noun, the only 
constraint being that it cannot occur between the main verb and the person-tense unit or between a free indirect object pronoun and an indirect object noun.

\subsubsection{Sentence structure in Djingili}

The main difference in sentence structure between DJinglli and the Eastern Group is that there is no need in Df. to divide the verb complex into a main verb and a person-tense unit. Morphemes marking person, tense and other functions occur as suffixes on a stem. The verb complex, abbreviated as $\mathrm{V}$, is therefore treated as one 1tem.

Where a noun occurs for the function of subject, transitive or intransitive, the most common order is:

$$
\text { subject }+ \text { verb }
$$

e.g. wawa yuriadju the boy is playing

wawani mayanu the boy hit (it)

wawa (absolutive), wawaṇi (ergative), subject noun, boy

yuriadju verb, third person singular present, is playing

mayanu verb, third person singular past, hit

no overt object

But the order

verb + subject

is possible, though rare, e.g.

yuriadju wawa the boy is playing

mayanu wawani the boy hit (it)

In transitive sentences where nouns occur for both subject and object, the preferred order is s.t.OV but the order s.t.Vo occurs frequently, e.g.

$$
\begin{aligned}
& \text { wawaṇi walagu mayanu the boy hit the dog } \\
& \text { wawani boy, ergative } \\
& \text { wa!agu object noun, absolutive case, dog }
\end{aligned}
$$

However,

wawạni mayanu wa!lagu

also occurs and other permutations are possible.

Indirect object

A noun phrase consisting of a free object pronoun may occur in the function of indirect object. The interrogative phrase occurs sentenceinitially, e.g. 


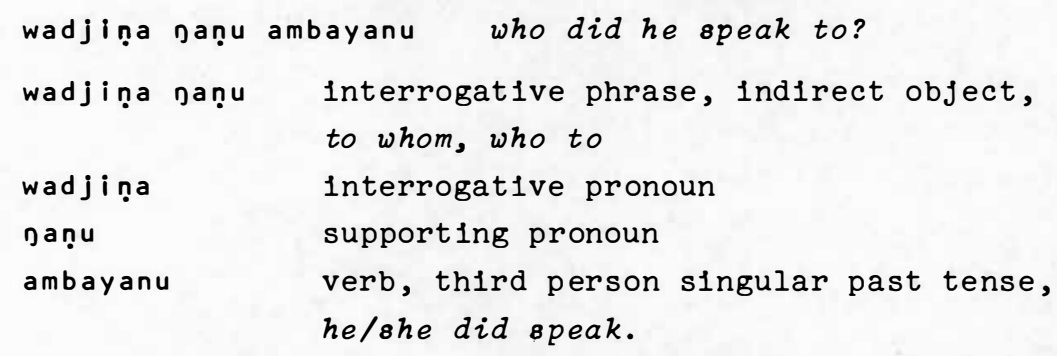

Otherwise the declarative indirect object phrase must follow the verb, e.g.:

ambayanu bainga nanu helshe spoke to the man
$\begin{array}{ll}\text { ambayanu } & \text { as above, he/she spoke } \\ \text { bainga nanu } & \text { Indirect object phrase, to the man } \\ \text { bainga } & \text { man (benefactive case) } \\ \text { nanu } & \text { supporting pronoun }\end{array}$

The declarative indirect object phrase occurs with the noun preceding or following the pronoun

$$
\text { or baiṇa naṇu }
$$

Where a noun subject occurs with an indirect object, the noun appears in the absolutive case with the verbs for speak and wait, e.g.

$$
\begin{aligned}
& \text { ṇayuṇi ambayanu naṇu the woman spoke to him } \\
& \text { ṇayuṇl subject, absolutıve case, woman } \\
& \text { ambayanu as above, spoke } \\
& \text { nanu Indirect object pronoun, to him }
\end{aligned}
$$

It appears in the ergative case with the verb for give, e.g.

$$
\begin{array}{ll}
\text { ṇayuna nunyanaananu mami the woman gave me food } \\
\begin{array}{ll}
\text { nayuna } & \text { subject, ergative case, woman } \\
\text { nunyanaananu } & \text { verb complex, she gave me } \\
\text { nunya- } & \text { stem, give } \\
\text { - naana- } & \text { subject/object form, she/me } \\
\text {-nu } & \text { past tense suffix } \\
\text { mami } & \text { direct object, food }
\end{array}
\end{array}
$$

The preferred order where both subject and indirect object occur as noun phrases is 
e.g. ṇayuṇi ambayanu bainga naṇu the woman spoke to the man

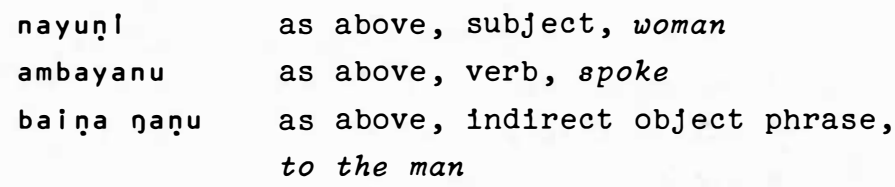

however, the orders VS1O. and ViOS also occur.

The direct object appears in absolutive case, e.g.

mami gunyanu baina ranu he/she gave the man food

mami as above, food

nunyanu as above, gave

baina nanu as above, to the man

Where noun phrases occur for both direct and indirect object the preferred order is OV10 as above, but the orders V010 and V100 are also possible. Normally a noun phrase subject occurs sentenceinitially but it may also occur sentence-finally or in any other position.

\subsection{Characteristics of Vocabulary}

3.8.1. Cognate densities within the W.By. languages based on a wordlist of 100 items

$\begin{array}{lllll} & \text { Df. } & \text { Ng. } & \text { G. } & \text { B. } \\ \text { W. } & 29 \% & 60 \% & 78 \% & 69 \% \\ \text { B. } & 21 \% & 61 \% & 88 \% & \\ \text { G. } & 21 \% & 62 \% & & \\ \text { Ng. } & 28 \% & & & \end{array}$

The cognate density between Df. and all the Eastern Group communalects is very low, the highest count being with Wambaya (29\%). The closest demonstratable relationship within the Eastern Group is between Gudandf 1 and Binbinga ( $88 \%)$; Gudand 1 is also closely related to Wambaya (78\%). If relationships can be demonstrated in morphology also, it may be possible to regard Wambaya, Gudandf1 and Binbinga as dialects of the same language.

Ngarnga is clearly separate as a language from all the communalects of the McArthur subgroup but is much more closely related to them than it is to DJingili. 


\subsubsection{Comparison with surrounding languages}

to the west: Mudburra, Guurrindj1;

to the north of DJing1li and Ngarnga: Alawa, Wardaman;

to the north of Binbinga: Wilangarra, Yanyula;

to the north and east of Gudandj1: Garruwa, Waany1;

to the east of Wambaya: Wagaya, Indjilaidja;

to the south of Wambaya and Dfingil1: Waramungu.

Depth studies are ava1lable on Alawa (Sharpe 1972) and Wagaya (Breen 1974 manuscript). Limited information is also avallable on Yanyula, Garruwa, Waramungu, Mudburra and Guurrindj1.

None of this information has revealed much lexical similarity between any of the surrounding languages and either DJinglli or the Eastern Group. New evidence on Mudburra has only recently become avallable. In spite of considerable lexical borrowing from and into DJingili the relationship is not close.

The closest relationship so far found has been between DJinglli and languages of the DJamindjungan Family, a family separated from the West Barkly languages by other languages including Mudburra and Guurrindj1 not closely related to elther DJinglli or DJamindfungan.

\subsubsection{Comparison of W.By. vocabulary with CA vocabulary}

Comparison with common Australian vocabulary 1tems as published on pp. 86-88 of Wurm 1972, reveals the following similarities.

It is not certain that the following are actual reflexes of the proto-forms cited but they are listed for their similarities to those forms.

1. Similarities in both DJ. and the Eastern Group:

$\begin{array}{llll} & \text { Dj. } & \text { E.Gp. } & \text { CA form clted } \\ \text { hand } & \text { mangamaṇa } & \text { mana (Mc.Sb.) } & \text { *maran } \\ \text { tongue } & \text { djalanya } & \text { nandja!a (Mc.Sb.) } & \text { *dalan } \\ & & \text { djalanya (Ng.) } & \\ \text { crow } & \text { wangulayl } & \text { waga!amari (Mc.Sb.) } & \text { *wagura/wagan } \\ \text { vegetable food } & \text { maml } & \text { maganyma (all) } & \text { *mayi } \\ \text { give } & \text { gunya } & \text { wldjbi (G.B.) } & \text { *wu/*gu }\end{array}$




\begin{tabular}{|c|c|c|c|}
\hline oee & gadja- & gadjbi (all) & *na/*nya \\
\hline two & $\begin{array}{l}\text { gudjara/ } \\
\text { gugyara }\end{array}$ & gudjara (all) & * gudjara \\
\hline dual affix & $\begin{array}{l}-b i l a-l \\
-b i l i-l \\
-b u l u-/ \\
-w i l a-l \\
\text {-wulu } \\
\text { and other } \\
\text { variations }\end{array}$ & $\begin{array}{l}\text { - bulu-l } \\
\text {-wulu-l } \\
\text {-ulu- } \\
\text { and other } \\
\text { variations (all) }\end{array}$ & $\begin{array}{l}\text { *bula }(d \mathbf{j}) \\
(t w o)\end{array}$ \\
\hline where & wadjua & windjan $i / i n d j a n i$ & *wanda \\
\hline$I$ & -na- & $D V-\quad(a l l)$ & *na- \\
\hline $\begin{array}{l}\text { you } \\
\text { singular }\end{array}$ & $\begin{array}{l}\text {-nya-l } \\
\text {-na- }\end{array}$ & nyV- (all) & *nyin- \\
\hline foot & yungu & $\begin{array}{l}\text { djana (Mc.Sb.) } \\
\text { yana (Ng.) }\end{array}$ & *dinan \\
\hline
\end{tabular}

2. Similarities in the Eastern Group but not Dfing1li

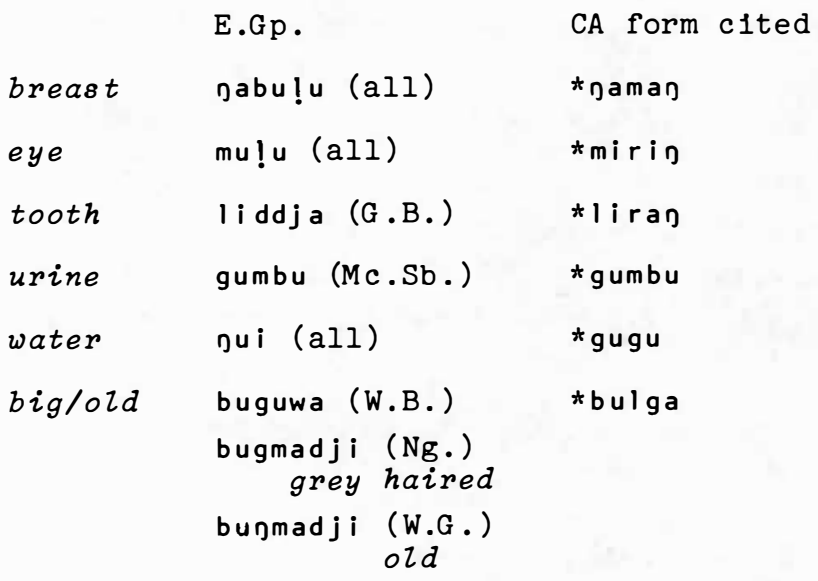

3. Similarities in DJ. but not the Eastern Group DJ. CA form cited

$\begin{array}{lll}\text { shin } & \text { udilyi (nom.) } & \text { *daran } \\ & \text { udala (oblique) } & \\ \text { brow } & \text { buya- } & \text { *bu }\end{array}$




$\begin{array}{lll} & \text { DJ. } & \text { CA form cited } \\ \text { eat } & \text { dara- } & \text { *da } \\ \begin{array}{l}\text { get, } \\ \text { pick up }\end{array} & \text { madja- } & \text { *ma (take) }\end{array}$

\subsection{Similarities with the Djamindjungan Family of Languages}

\subsubsection{Morphology}

DJinglli and other West Barkly languages show little relationship, elther lexical or otherwise, to any of the immediately surrounding languages. However, a number of similarities have appeared as a result of comparisons between the West Barkly languages and DJamindjungan (DJmn.). Geographically the W.By. languages are separated from DJmn. by a distance of over two hundred miles (320 km.). The languages in between (Mudburra, Guurrindf1, Malngin and others) show little structural relationship to elther DJmn. or W.By.

Similarities in certain bound pronouns (subject intransitive) between DJamindfung (DJa.) and DJinglli have already been set out in the section on pronouns (3.3.3. and 3.3.4.). These similarities are found to a slightly lesser extent in all types of pronoun and person markers, not only in DJa. but also in the related Ngaliwurru (Ngwu.) and Nungali ( $\mathrm{Nu}$. ) languages of the DJamindjungan family.

The most distinctive similarity is in the pronoun for first person dual inclusive

$$
\begin{array}{ll}
\text { mind- } & \text { DJa./Ngwu. and DJ . } \\
\text { ming-/mungd- } & \text { E.Gp. of W.By. } \\
\text { mind-/bid- } & \text { Nu. }
\end{array}
$$

which, in both the W.By. languages and DJmn., does not conform to the regular structural patterns of the other pronouns.

The pronoun forms of the DJamindjungan famlly are amply demonstrated in Bolt, Cleverly and Hoddinott (1970). Examination of this information reveals a number of striking similarities. The most salient of these are set out below.

The comparative information is not organised into a structured argument here. The similarities are merely listed in an unordered fashion for the purpose of display. A possible genetic relationship between DJamindjungan and DJinglil, and between DJamindfungan and the Eastern Group of West Barkly is strongly suspected by the writer. But it is not the purpose of this section to offer proof for this suspicion. 
A number of similarities have been deliberately discounted because similar forms are common throughout other regions of Australia.

Examples of similarities deliberately ignored:

1. First person singular

(1) Abbreviated pronoun

$\begin{array}{ll}\text { na } & \text { DJmn. } \\ \text { na } & \text { DJ. } \\ \text { nV } & \text { E.Gp. of W.By. }\end{array}$

Similar forms are found throughout Australia.

(11) Cardinal free pronoun

$\begin{array}{ll}\text { nayug } & \text { DJmn. } \\ \text { naya } & \text { DJ. } \\ \text { gau } & \text { G. B. } \\ \text { gaungidji } & \text { W. }\end{array}$

2. The first consonant of the second person singular abbreviated pronoun

$\begin{array}{lll}n- & \text { subject } & \text { DJmn. } \\ n-/ n y- & \text { subject } & \text { DJ. } \\ n y- & \text { object } & \text { DJmn. } \\ n y- & \text { object } & \text { DJ. and E.Gp. } \\ n y- & \text { subject } & \text { DJ. and Mc.Sb. }\end{array}$

3. Third person plural bound pronoun and stem of cardinal pronoun and object pronoun

$\begin{array}{ll}\text { bur- } & \text { DJa. Ngwu. } \\ \text { wir- } & \text { Nu. } \\ \text { wir-/bir- } & \text { B. } \\ \text { ur- } & \text { DJ. } \\ \text { ir- } & \text { Ng. W. } \\ \text { ir-/wir- } & \text { G. }\end{array}$

Forms of the type bur, bir, wur, wir occur in many parts of Arnhem Land (Burarra, Nunggubuyu), the Daly River Region and the Kimberleys.

The most salient similarities in grammar:

1. In the second person singular free pronoun first syllable na-/nya-, second syllable -mi/-ma

$$
\begin{array}{ll}
\text { nami } & \text { Dja., Ngwu. } \\
\text { namindju } & \text { Nu. } \\
\text { nyami } & \text { G. B. }
\end{array}
$$




$$
\begin{array}{ll}
\text { nyaminidji } & \text { W. } \\
\text { nama/nyama } & \text { DJ } \\
\text { nyama } & \mathrm{Ng} .
\end{array}
$$

2. Masculine third person singular cardinal pronoun in DJmn. and masculine singular demonstrative in W. By.

dji Dja. Ngwu. masculine third person singular pronoun

$\left.\begin{array}{ll}\text { dji: } & \text { DJ. } \\ \text { djiriga } & \text { B. }\end{array}\right\}$ masculine singular demonstrative (remote in B.)

3. Benefactive and object pronouns and possessive adjectives

(1) The base forms for first and second person singular

$$
\begin{array}{lll} 
& \text { DJmn. } & \text { DJ./E.Gp. } \\
\text { lp. } & \text { gar- } & \text { nar- } \\
\text { 2p. } & \text { gun- } & \text { nan- }
\end{array}
$$

(11) The suffix added to pronoun bases to indicate benefactive function

$$
\begin{array}{lll} 
& \text { Djmn. } & \text { DJ. } \\
\text { singular } & -g u\left(1 p . \text { and } 2 p_{.}\right) & -g u\left(2 p_{.}\right) \\
& & -u\left(1 p_{.}\right)
\end{array}
$$

Full forms for first and second person singular:

$$
\begin{array}{lll} 
& \text { DJmn. } & \text { DJ. } \\
\text { lp. sing. } & \text { gargu } & \text { garu } \\
\text { 2p. sing. } & \text { gungu } & \text { naggu }
\end{array}
$$

Dual and plural suffix:

$$
\begin{array}{lll}
\text { Djmn. } & \text { Df. } & \text { Ng. G. } \\
\text {-ag } & \text {-agu } & \text {-aga }
\end{array}
$$

Examples of full forms

First person dual inclusive:

$$
\begin{array}{ll}
\text { mindag } & \text { DJmn. } \\
\text { mindagu } & \text { DJ. } \\
\text { mingdaga } & \mathrm{Ng} . \mathrm{G} .
\end{array}
$$


Second person plural:

$\begin{array}{cl}\text { gurag } & \text { DJa. Ngwu. } \\ \text { - (w) urag } & \mathrm{Nu} . \\ \text { guragu } & \mathrm{DJ} . \\ \text { giraga } & \mathrm{Ng} . \mathrm{G} .\end{array}$

4. The suffix on possessive adjectives

First person singular:

$$
\begin{array}{lll} 
& \text { DJmn. } & \text { DJ. } \\
\text { suffix } & \text {-gina } & \text { - ina (masc. sg.) } \\
\text { full form } & \text { gargina } & \text { Darina }
\end{array}
$$

Second person singular:

$$
\text { DJmn. DJ. }
$$

$\begin{array}{lll}\text { suffix } & \text {-gina } & \text {-gina (masc. sg.) } \\ \text { full form guggina } & \text { gaggina }\end{array}$

Third person singular masculine:

$$
\text { Dja. Ngwu. Nu. DJ. }
$$

$\begin{array}{lllll}\text { suffix } & \text {-wina } & \text {-wina } & \text {-iyina } & -i: n a \\ \text { full form nuwina niwina niyina } & n i: n a \text { (masc. sg.) }\end{array}$

Dual and plural forms:

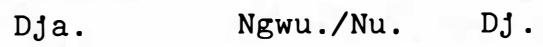

suffix -aydgina -adgina -agina (masc.sg.)

Example of full form

First person dual inclusive:

$$
\begin{array}{ll}
\text { mindaydgina } & \text { DJa. } \\
\text { mindadgina } & \text { Ngwu. Nu. } \\
\text { mindagina } & \text { DJ. (masc. sg.) }
\end{array}
$$

5. Bound transitive subject pronouns:

Third person singular masculine:

$\begin{array}{lll}\text { gan- } & \text { DJa. Ngwu. } & \\ \text { gan- } & \text { Nu. } & \\ \text { gani- } & \text { G. } & \text { present tense } \\ \text { gVnV } & \text { G. } & \text { several tenses } \\ \text { gV'nV } & \text { W. } & \text { several tenses } \\ \text { gVnV } & \text { B. } & \text { several tenses }\end{array}$


6. Combined subject/object pronouns

Second person singular subject, first person singular object you/me

$$
\begin{array}{llll}
\text { Dja. } & \text { Ngwu. } & \text { Nu. } & \text { Df. } \\
\text { gandin- } & \text { gandjin- } & \text { nadjan- } & \text {-gandjana- }
\end{array}
$$

7. Other similarities:

An examination of several other monographs and articles on the DJamindfungan languages, (Cleverly 1968; Bolt, Hoddinott and Kofod $1971 \mathrm{a}, \mathrm{b}$; HoddInott and Kofod 1976a, b and c) reveals several other similarities.

\section{(1) Ergative suffixation}

$-n i$ is the most common suffix for ergative in the Eastern Group of West Barkly. It functions also as locative and instrumental in the McArthur Subgroup and as locative in Ngarnga.

$-n i$ is the most common masculine suffix for ergative in DJingili; this may not be significant.

$-n i$ is a major allomorph for ergative, locative and instrumental in Ngaliwurru and DJamindjung, and this suffix occurs also in Nungal1.

Other allomorphs are $-d i,-g i$ and $-i$.

(11) Direct and oblique noun-class affixation

Nungall has noun-classes and a distinction between direct and oblique noun-class affixes.

The most striking similarity is between the oblique feminine prefixes of $\mathrm{Nu}$. and the oblique feminine suffixes of the Eastern Group of West Barkly.

In Nungal1 there are four noun classes. The classes correspond approximately to those in the W.By. languages. Class I is masculine, Class II is feminine and there are two neuter classes III and IV, one of which, IV, Includes vegetable food.

The classes are marked by prefixes.

Nungali class prefixes (from Bolt, Hoddinott and Kofod (B.H.K.) 197la,b typescript on Nungal1):

$$
\begin{aligned}
& \text { Direct ('object' (B.H.K.)) } \\
& \text { First order Second order }
\end{aligned}
$$

Class I

Class II

Class III

Class IV di -

nyanu- $/ n i-$

ma - 


\section{Oblique (ergative/instrumental/locative) \\ Class I nyi- Class II nanyi}

In the Eastern Group of West Barkly the most common combination of suffixes for feminine ergative is

$$
\text { - gan i }
$$

If the Nungali ergative/locative feminine prefix combination

$$
\text { nanyi - }
$$

Is divided into two syllables, 1.e.

$$
\begin{aligned}
& \text { 1. na- feminine ergative/locative class marker } \\
& \text { 2. -nyi- ergative/locative case marker, }
\end{aligned}
$$

then the correspondence with the suffix combination in the Eastern Group

$$
\text { - nani }
$$

for feminine ergative/locative looks quite close. For -nani too, is easily analysed into two parts

$$
\begin{aligned}
& \text { 1. -na- feminine oblique class marker } \\
& \text {-na corresponding to } \\
& \text { feminine oblique class suffix in DJingili } \\
& \text { 2. -ni }
\end{aligned}
$$

\subsubsection{Comparison of Vocabulary}

A full comparison of vocabulary between DJamindjungan languages and languages in the West Barkly area has still to be carried out. But a preliminary survey of vocabularies shows that the high proportion of correspondences found in pronoun morphology is not reflected in vocabulary. There is much less similarity in this area.

Not all 1tems in DJamindjungan languages are avallable for comparison on a lexicostatistical 100-1tem wordlist. Vocabularies are available to this writer only in Djamindjung and Nungali, not yet in Ngaliwurru. Even in DJa. and Nu. many 1tems needed for careful comparison are not listed in the avallable wordlists.

But a tentative preliminary investigation has revealed the following results:

Both DJingll1 and the Eastern Group reveal some shared cognates which are common to many areas of Australia. But there are other clear correspondences which to the writer's knowledge do not occur 
In other parts of northern Australia and probably do not occur in any other region of Australia. These distinctive correspondences are still very low in number, no more than seven for any one language-to-language comparison, and the total corpus of 1tems is very small, but further investigation may reveal additional correspondences.

In addition, there are a number of pairs of 1tems, for each pair of languages compared, which are probably cognate but for which proof cannot be established without further investigation into sound changes.

1. List of Correspondences (n.kn. for 'not known') Md.: Mudburra; Gur.: Guurrindj1

\section{Correspondences Non-corresponding}

\begin{tabular}{|c|c|c|c|}
\hline ear & $\begin{array}{l}\text { lana (Dfa.) } \\
\text { manga (Nu.) }\end{array}$ & $\begin{array}{l}\text { !aga (Df.) (Md.) } \\
\text { manga (Mc.Sb.) }\end{array}$ & \\
\hline heart & $\begin{array}{ll}\text { dulu } & (\mathrm{DJa} \mathrm{F}) \\
\text { dulu } & (\mathrm{Nu} .)\end{array}$ & gudulu (E.Gp.) & \\
\hline snake & $\begin{array}{l}\text { bulany (DJa.) } \\
\text { dulany (Nu.) }\end{array}$ & ulanydji (G. B. Ng.) & $\begin{array}{l}\text { mimari (W.) } \\
\text { miginydji (Dj.) }\end{array}$ \\
\hline fat $\mathrm{n}$. & $\begin{array}{l}\text { guridj (DJa.) } \\
\text { nurid (Nu. }\end{array}$ & $\begin{array}{ll}\text { guri:dja } & (\mathrm{Mc} . \mathrm{Sb} .) \\
\text { guri:gya } & (\mathrm{Ng} .)\end{array}$ & diga (Df.) (Md.) \\
\hline south & $\begin{array}{l}\text { ganigu (Nu.) } \\
\text { Dja. n.kn. }\end{array}$ & gaṇi (DJ.) & $?$ niṇi-? (E.Gp.) \\
\hline east & $\begin{array}{l}\text { gumugu (Nu.) } \\
\text { Dja. n.kn. }\end{array}$ & nubu (DJ.) & gagara- (E.Gp.) \\
\hline $\begin{array}{l}\text { skyl } \\
\text { cloud }\end{array}$ & $\begin{array}{l}\text { gulumara (Md.) } \\
\text { (Dja.) } \\
\text { sky }\end{array}$ & $\begin{array}{l}\text { gulumara } \\
\text { (DJ.) } \\
\text { cloud }\end{array}$ & \\
\hline moon & $\begin{array}{l}\text { dabaranara (Nu.) } \\
\text { Dja. n.kn. }\end{array}$ & $\begin{array}{l}\text { baḍangara ( } \mathrm{DJ} .) \\
\text { baḍanara (Md.) } \\
\text { aḍanari ( } \mathrm{W} . \mathrm{Ng}) \\
\text { waḍanari (B.) }\end{array}$ & $\begin{array}{l}\text { yagawi (B.) } \\
\text { yagai (G.) }\end{array}$ \\
\hline meat & yanara (Nu.) & yanadji (E.Gp.) & gana (Df.) \\
\hline fire & $\begin{array}{l}\text { guyug (Dfa.) } \\
\text {-yug (Nu.) }\end{array}$ & guwiyiga (Mc.Sb.) & $\begin{array}{l}\text { buba (Df.) (Md.) } \\
\left.\text { nawundja ( } \mathrm{Ng}_{\text {. }}\right)\end{array}$ \\
\hline
\end{tabular}




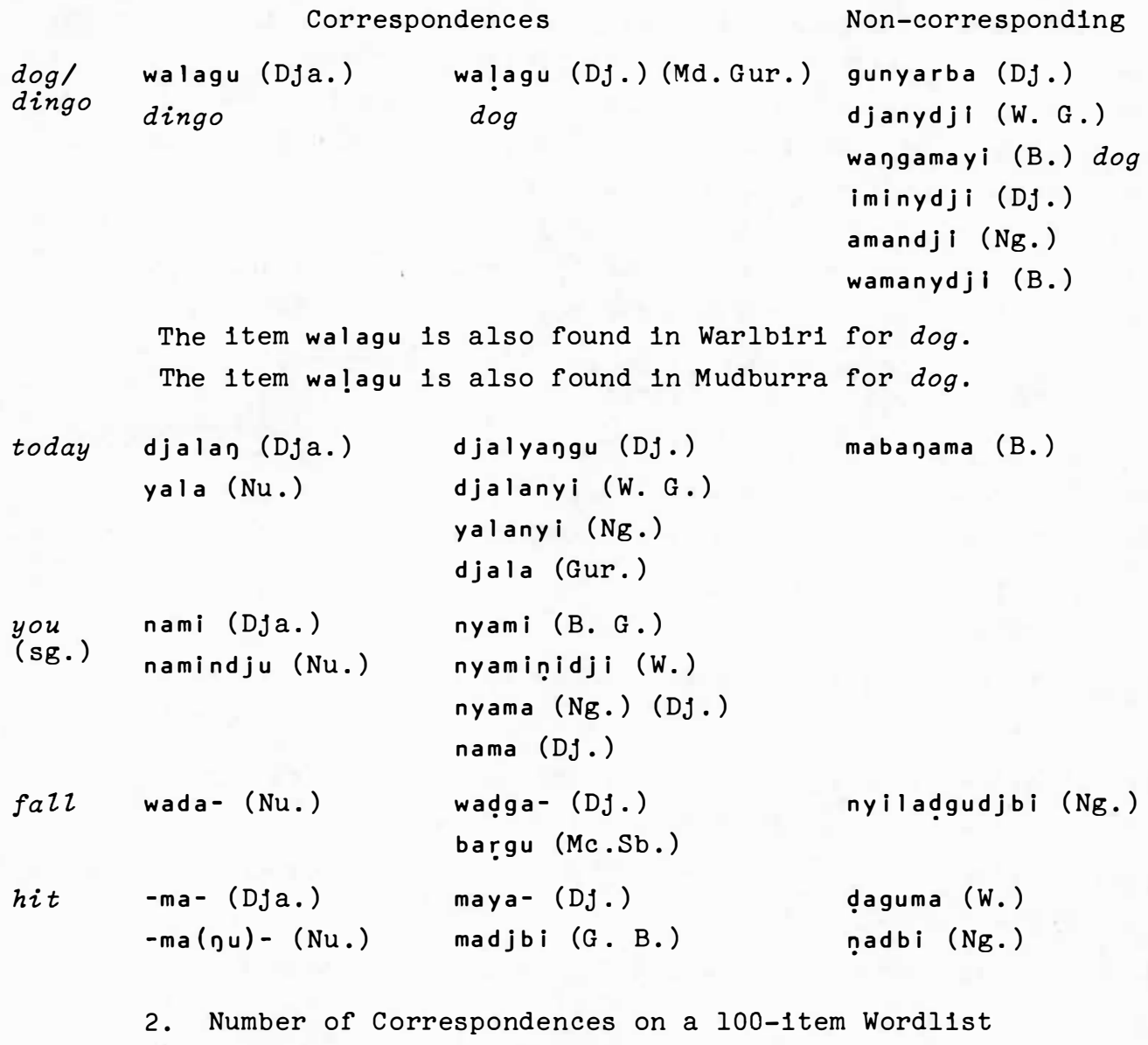

2. Number of Correspondences on a 100-1tem Wordlist

I. Clearly corresponding 1tems

(1) W1th Nungal1 Items

1. Total:

$\begin{array}{lllll}\text { B. } & \text { G. } & \text { W. } & \text { Ng. } & \text { DJ. } \\ 15 & 15 & 14 & 13 & 12\end{array}$

11. Number of common Australian 1tems in the total:

$\begin{array}{ccccc}\text { B. } & \text { G. } & \text { W. } & \text { Ng. } & \text { DJ. } \\ 4 & 4 & 4 & 2 & 2\end{array}$

111. Number of common regional items in the total:

$\begin{array}{ccccc}\text { B. } & \text { G. } & \text { W. } & \mathrm{Ng} . & \text { DJ . } \\ 4 & 4 & 5 & 5 & 3\end{array}$

1v. Number of distinctive items remaining:
B. G. W. Ng. DJ.
$\begin{array}{lllll}7 & 7 & 5 & 6 & 7\end{array}$ 
(2) With DJamindjung items

1. Total:

$\begin{array}{llllc}\text { B. } & \text { G. } & \text { W. } & \mathrm{Ng} . & \text { DJ . } \\ 14 & 15 & 13 & 12 & 8\end{array}$

11. Number of common Australian 1tems in the total:

$\begin{array}{ccccc}\text { B. } & \text { G. } & \text { W. } & \mathrm{Ng} . & \text { DJ . } \\ 4 & 4 & 4 & 3 & 2\end{array}$

111. Number of common regional 1tems in the total:

$\begin{array}{ccccc}\text { B. } & \text { G. } & \text { W. } & \text { Ng. } & \text { DJ . } \\ 4 & 4 & 4 & 4 & 5\end{array}$

1v. Number of distinctive 1tems remaining:

$\begin{array}{ccccc}\text { B. } & \text { G. } & \text { W. } & \text { Ng. } & \text { DJ . } \\ 6 & 7 & 5 & 5 & 1\end{array}$

II. Total of all similar items including both clearly corresponding 1tems and 1tems that are probably cognate

(1) Similar with Nungali Items:
B. G .
W. $\mathrm{Ng}$
DJ .
$\begin{array}{lllll}15 & 18 & 17 & 16 & 15\end{array}$

(2) Similar with Dfamindfung Items:

$\begin{array}{lllll}\text { B. } & \text { G. } & \text { W. } & \mathrm{Ng} \cdot & \text { DJ. } \\ 17 & 19 & 17 & 18 & 13\end{array}$

\begin{tabular}{|c|c|c|}
\hline Other & $\begin{array}{l}\text { Similarities in } \\
\text { Djamindjung }\end{array}$ & $\begin{array}{l}\text { Vocabulary } \\
\text { West Barkly }\end{array}$ \\
\hline string & munuggu & $\begin{array}{ll}\text { munuggumi } & (\mathrm{DJ} .) \\
\text { muṇugguma } & (\mathrm{E} . \mathrm{Gp} .)\end{array}$ \\
\hline Zick v. & Dalyag & Dalyala- (DJ.) \\
\hline eyebrow & yibidjibidj & $i b i d j i b i d j i$ (DJ.) \\
\hline flower & yuru & $\begin{array}{l}\text { yurgu }\left(\mathrm{DJ}_{\cdot}\right) \\
\text { yurga }\left(\mathrm{Ng} \cdot \mathrm{G} . \mathrm{B}_{.}\right)\end{array}$ \\
\hline grass & wanda & waṇḍa (G. B.) \\
\hline elder sister & babiny & $\begin{array}{l}\text { babanya (E.Gp.) } \\
\text { bibini (DJ.) }\end{array}$ \\
\hline shield & guwari & guwarimi (Df.) \\
\hline when & nanulan & $\begin{array}{l}\text { yanulu (Mc.Sb.) } \\
\left.\text { yanulanba ( } \mathrm{Ng}^{\circ}\right)\end{array}$ \\
\hline
\end{tabular}




\begin{tabular}{lll} 
& \multicolumn{2}{c}{ Ngumbin } \\
& Mudburra & Guurrindj1 \\
lick v. & n.kn. & nalyagab \\
eyebrow & milyjagariny & yimidjimidji \\
when & nyanula & nyanula
\end{tabular}




\section{BIBLIOGRAPHY}

BOLT, J.G., J.R. CLEVERLY and W.G. HODDINOTT

1970 'Pronominalisation in Djamindfungan'. In:

Wurm and Laycock, eds 1970:593-615.

BOLT, J.E., W.G. HODDINOTT and F.M. KOFOD

1971a An Elementary Grammar of the Ngaliwurru Language

of the Northern Territory. Mimeo. Canberra:

Australian Institute of Aboriginal Studies.

(Restricted)

1971b An Elementary Grammar of the Nungal1 Language of the Northern Territory. Typescript. Canberra: Australian Institute of Aboriginal Studies.

BREEN, J.G.

1974 Wagaya Grammar. MS. (Copy held at Australian

Institute of Aboriginal Studies, Canberra.)

\section{CAPELL, A.}

1956

A New Approach to Australian Linguistics. Oceania

Linguistic Monographs 1 . University of Sydney.

1962 Some Linguistic Types in Australia. Oceania

Linguistic Monographs 7 . University of Sydney.

CHADWICK, N.

1968 'DJing1l1 (North Australia) in a Comparative

Perspective'. Oceania 38/3:220-8. 
1975 A Descriptive Study of the Djingili Language. AAS, RRS2. Canberra: Australian Institute of Aboriginal Studies.

CLEVERLY, J.R.

1968 A Preliminary Study of the Phonology and Grammar of DJamindjung. M.A. thesis, University of New England, Armidale, New South Wales.

DIXON, R.M.W.

1968 'Noun Classes'. Lingua 21:104-25.

1972 The Djirbal Language of North Queensland. London: Cambridge University Press.

DIXON, R.M.W., ed.

1976 Grammatical Categories in Australian Languages. AAS, L22. Canberra: Australian Institute of Aboriginal Studies.

FURBY, C.E.

1972 'The Pronominal System of Garawa'. Oceania Linguistics $11 / 1: 1-31$.

GEYTENBEEK, B. and H. GEYTENBEEK

1971 Gidabal Grammar and Dictionary. AAS 43, L17. Canberra: Australian Institute of Aboriginal Studies.

HALE, K.L.

n.d. Sketch Grammar and Vocabulary of Warumungu. Unpublished fieldnotes.

HODDINOTT, W.G. and F.M. KOFOD

1976 'DJamindjungan'. In: Dixon, ed. 1976:397-401

(Top1c B); 437-41 (Top1C C); 698-704 (Top1C E).

KIRTON, J.F.

1971a 'Complexities of Yanyula Nouns: Inter-Relationship of Linguistics and Anthropology'. Papers in Australian Linguistics No. 5:15-70. PL, A-27. Canberra: Pacific Linguistics. 
1971b 'Yanyula Noun Modiflers'. Papers in Australian Linguistics No. 5:1-14. PL, A-27. Canberra:

Pac1fic Linguistics.

SHARPE, M.C.

1972 Alawa Phonology and Grammar. AAS 37, L15.

Canberra: Australian Institute of Aboriginal Studies.

WURM, S.A.

1972 Languages of Australia and Tasmania. The Hague:

Mouton.

WURM, S.A. and D.C. LAYCOCK, eds

1970 Pacific Linguistic Studies in Honour of Arthur Capell.

$P L, C-13$. Canberra: Pacific Linguistics. 


\title{
LINGUISTIC COMMUNITIES AND SOCIAL NETWIRKS ON CAPE YORK PENINSULA
}

\author{
Peter Sutton and Bruce Rigsby
}

Our major orlentation in the study of linguistic communities and social networks in Cape York Peninsula is at present more ethnographic than theoretical. That 1s, given the paucity of relevant sociolinguistic theory and the problematic, empirical nature of its main issues, we are primarily concerned with obtalning an adequate database. Having sald that, we nonetheless discuss below the kinds of data an adequate theory w1ll need to account for, and the kinds of questions we expect such a theory to answer.

The immediate alm of our research is to elucldate the linguistic dimensions of a unique and disappearing type of human social and ecological adaptation, the Aboriginal hunter-gatherer socleties of Australia, and in particular those of Cape York Peninsula (CYP).

Aboriginal people have lived on CYP (defined as mainland Queensland north of the 16th parallel) for at least 13,000 years (Rosenfeld 1975), and probably longer. For much of that time, what is now the Peninsula was merely the higher portion of a land-mass which was above sea level right across the present Gulf of Carpentarla to Arnhem Land and north across what are now the Torres Straits to New Guinea. The Torres Straits were formed by rising sea-levels about 6500-8000 BP (Jennings 1971). Linguistic and anthropological studies made in the area date from the late elghteenth century, but only in the last eighty years have they been made by specialists with extensive training and fleld experience. Most of what is known of the languages and cultures of CYP dates from field work between 1927 and 1935 - McConnel, Thomson and Sharp - and since 1969. Consequently, if we wish to understand the long-term dynamics of cultural and linguistic relationships and their development in the region, we have to rely on 
archaeological reconstruction, historical reconstruction of linguistic divergence, convergence and parallel developments, plus what we can learn about traditional patterns of socloterritorlal segmentation and communication networks (marriage and residence patterns, ritual alliances, totemic connections, warmaking groups, exchange cycles and so forth) from field ethnography with the traditionally-oriented Aborigines who live on the Peninsula. We are at present engaged with other workers (see below) in long-term studies of this type, concentrating on a transect across the middle Peninsula between Lockhart and Port Stewart on the east and Aurukun and Edward River on the west. We have also both worked in the Princess Charlotte Bay area.

CYP is characterised by high linguistic diversity in some areas (such as Princess Charlotte Bay, the far northern tip, and a narrow strip down the west coast), contrasting with low diversity in others (such as the Starcke River-Mossman area, or the even less diverse $250 \mathrm{~km}$ stretch from Cape Grenville to Massey River, on the east coast). Cultural diversity is also higher in some areas than in others: the west coast between the Archer and Edward Rivers has prominent, discrete ritual groups, while much of the central Peninsula north of Laura appears to have lacked such segmentation.

Cultural and linguistic diversity are not always closely correlated. Princess Charlotte Bay and environs (between the Stewart and Starcke Rivers) was inhabited by speakers of perhaps ten languages, between some of which there are significant grammatical differences, and between all of which there are striking lexical and phonological differences. Yet at least the Flinders Islands and Barrow Point peoples regard all the people of that region as 'countrymen', among whom they traditionally found spouses, with whom they jolned in ceremony, and with whom they shared distinctive cultural tra1ts. By contrast, the western coastal region between the Archer and Edward Rivers exhibits less linguistic diversity (there are many dialects, which may be clustered into a handful of distinct languages), but far greater segmentation socially. It is generally known as the wikspeaking area' by anthropologists and linguists. Like Princess Charlotte Bay, it could be described as a 'culture-area'. Such culture-areas, in spite of their diverse natures, clearly exist and will be treated by us as the widest meaningful soclal networks traditionally operating in CYP.

In the Wik-speaking area, regional segmentation is clear-cut along the coast, but becomes 1ll-defined 15-20km inland. The grossest segments are ritual groups, which are spoken of in English as 'tribes'. 
One such group, Apelech, Includes members of lineages with countries clustered about three rivers, the Love, the Kirke and the Knox. The three river-groupings constitute smaller segments within Apelech, each with a core of lineages sharing a major cult-totem. Even smaller segments consist of clusters of two or three lineages with contiguous estates known by a single 'nickname'. The smallest meaningful segment is the lineage, which is the land-holding unit. All segments greater than the individual lineage may be, and usually are, polylingual. That is, they consist of clusters of lineages afflliated to different dialects/languages. The countries of those lineages which speak the same language tend to be separated from each other by countries of lineages with different linguistic affiliations. Both territorially and politically, languages are 'discontinuously distributed'.

There is no significant dialectal or dialect-group endogamy. Seventy-six percent of marriages (excluding those of recent date which would not have been possible in pre-European times) have been between individuals affiliated to different dialects. Sixty percent have been between those afflliated to dialects of mutually unintelligible languages. Marriage clusters are bounded by two main features: geographical proximity within the coastal floodplain area, and - to a less clear extent - membership within the named ritual group. Elghty-seven percent of marriages by those with country on the floodplain have been contracted within the long, narrow coastal strip. About three-fourths of the lineages in the Apelech ritual group have contracted three-fourths of their marriages within that group. All residence-groups normally include speakers of several dialects. All people over about thirty years of age have multilingual competence, and younger people are at least bilingual in the lingua franca WikMungkan and English. Many people who are afflliated to the same dialect belong to separate regional groups and may have little contact.

In the light of such facts, the 'dlalectal tribe' model used in some Australian demographic and linguistic studies has no support whatever from the Wik-speaking area. This model (see Birdsell 1953, 1968, 1976 and Dixon 1970, 1972:330ff) posits a dialectally homogeneous speech community, predominantly endogamous, which constitutes a primary domain of social structure. It is a population isolate, a territorial unit, and a relatively bounded communications network. In the Wik-speaking area, such entities are not characterised by dialectal homogenelty. 
The same is true of other parts of Cape York Peninsula. The distribution of lineage-countries in the eastern Princess Charlotte Bay area is much closer to the stereotype, in that lineages with a single language have adjacent countries. However, such linguistic communities are not recognised as individual segments of political or demographic importance, and neither they nor the languages they speak have names. Most individuals, if asked to name their language, will give the name of their patriline or, sometimes, the name of a wellknown place (such as Flinders Island) in the relevant region. And they can do this in any one of several languages, since all lineages and most important locales may be referred to by different forms in each of the languages of the area. Multilingual competence and linguistic exogamy were again the norm.

An adequate model of Aboriginal sociolinguistics will have to explain these apparent 'exceptions' to what has been assumed to be the norm. Although we are not yet able to produce such an explanation, we would stress that Aboriginal belief-systems play the cruclal role in determining linguistic affiliation and the role of this affiliation in demography. Much more information on what Aboriginal people believe about language is needed.

It should be clear from the sketches just given that we are not attempting to treat CYP in toto as a sirgle culture-area, but as a geographical slice that has an ecological, cultural and linguistic diversity suited to our purposes as linguistic anthropologists. It is an eminently sultable area for comparative and historical study, both because of the wide diversity now to be seen, la1d over a common underlying heritage, and because in certain subareas we have the chance to integrate linguistic with non-linguistic data. In this way, we hope to elucidate the dynamics of linguistic affiliation, linguistic change and regional dialect patterns in relation to the pressures of traditional social structure, belief systems, politics, demographic patterns, and the environmental constraints of natural resources, seasonality and topography.

Much comparative linguistics has already been done in CYP, largely on lexical and phonological reconstruction, and genetic subgrouping (see Sutton, ed., 1976 for recent examples). We know, for example, that there has been extensive phonological diffusion across large areas, and that this may have been assoclated with soclocultural influences (Alpher 1976). Detalled work on other types of diffusion has yet to be done. From a study of Iinguistic diffusion in Arnhem Land, Heath (1978) concluded that traditional Indo-Europeanist historical 
linguistic models of diffusion were inadequate to explain the data he gathered and interpreted. It is unlikely that CYP w1ll be any more amenable to Indo-Europeanist interpretations than Arnhem Land. A sociolinguistic theory that will generate a powerful explanatory model will have to account for the patterns that emerge from studies of linguistic prehistory, and it cannot simply be synchronic.

Soc1olinguistic patterns on CYP have great implications for diachronic linguistic theory. We already know enough to state that social networks and linguistic groupings on CYP are not isomorphic. In other words, although $1 \mathrm{t}$ is more than likely that dialect and language differences and similarities somehow reflect social networks, this reflection is by no means instantaneous or simple. An adequate sociolinguistic theory must account for this discontinuity. To borrow some terminology from Silverstein (1972), but omitting some of his distinctions, speech communities may stand in relatively simple relationships to social networks, but language communities certainly do not. For the moment, we may define a speech community as a group of people who interact regularly by means of speech, and therefore belong to a communication network. A language community is a set of people who share a common grammar, as characterised by a (near-) 1dentical knowledge of syntactic, lexical and phonological rules. We recognise the problems of drawing boundaries around communities and of delimiting networks, and also the problem of distinguishing 'different grammars' using mutual intelligibility or quantitative measures as criteria. But we find the language/speech community distinction useful, one which has so frequently been ignored in the discussion of language in the Australian Aboriginal context.

A speech community is essentially the same as a soclal network, but we use the former term to emphasise its linguistic aspect. The character and history of languages is clearly more closely related to the structure of social networks than to the spatial distribution of people in on-the-ground aggregates. Different speakers of the one language may reside separately with speakers of other languages, but maintain contact with each other through frequent contact. We also find the converse, at least in Cape York: different speakers of the one language may belong to geographically and politically distinct social networks, and have little contact. We also find that the territories of those people who speak a single language are not always contiguous, and that we must speak of regional multilingual repertoires rather than 'dlalect areas'. Indeed, one of the main reflections of the boundedness of a social network is the range of multilingual competence of its members. 
Other defining features, which in CYP are typically (but perhaps not necessar1ly) compresent, are: relatively bounded patterns of marriage; patterns of coming together to perform rituals; relative freedom of movement over each others' countries, at léast during the dry season; and mutual aid in wider conflicts.

Thus, soclal networks are defined by patterns of countless smallscale interactions, rather than by the presence of single distributional traits such as 'sharing a common dialect' or 'possessing a common kinship system'. They may be named or un-named, but it is usually not too difficult to find a locution or two in local languages that recognise their existence; to find, for example, that they form the content of us/them-type pronominal references. Soclal networks are heavily political, hence labile and contractual, not fixed. 'Norms' of endogamy are constantly violated by famllies who seek political allies outside the network by 'marrying out' their girls. Lineages expand, contract, and die out. Our distinct impression is that 'countries' tend to be more stable entities than their personnel. When lineages become technically extinct, it is not uncommon for those who assume custodianship of their countries to be the children of their last female members. Because of a tendency for women to marry men who speak different dialects or languages from their own, and because the majority of children take their fathers' language as their own, the linguistic affiliation of a country's custodians is liable to switch slightly or even dramatically over time. And because of a tendency towards social network endogamy, such a change in 'dialect geography' would more often than not involve a switching to one of only a subset of the dialects/languages of a region. In an area of linguistic homogenelty, these changes would not be readily apparent to an outsider, and we would expect the resulting irregular or discontinuous distribution of dialects to be subject to falrly rapid regularisation or uniformising over time. However, where relatively heterogeneous dialects and languages are spoken by very small populations, multilingualism may be the crucial element which allows such varied speech-forms to survive. This survival would be precarious were it not for the strength of Aboriginal belief in the maintenance of differences, and the view that one's own patrilineage-dialect is the optimum linguistic form.

On western CYP we find grammatical and semantic unity, some phonological varlation, and considerable lexical diversity. This suggests that the same factors that may lead to the extinction of minor sub-dialectal differences and to near-total linguistic convergence in 
a case of relative homogenelty, may lead only to partial convergence in cases where there is linguistic heterogeneity within the same social network. On western CYP this means that we suggest convergence and parallelism in syntax and semantics have developed because of multilingualism in an area of very small language-communities. In other areas, such as from around the southern Northern Territory to the Adelaide region, one can demonstrate phonological convergence due to diffusion of common features over a recognised culture-area. In this latter region, not only phonology but the distribution of 'kinship-pronouns', birth-order names and trade routes, for example, can be shown to support the hypothesis of a culture-area (Hercus and White, 1973; Schebeck, 1973).

But trait-distributions do not define social networks. Social networks have to be established by more precise means, such as examining the statistics of marriages and adoptions, the composition of ritual-sharing groups, residential groups, etc. Trait-distributions merely establish the extent of sharing or transmission, and not (directly) the extent of regular communication. Thus we find languages in CYP which were spoken at great distances from each other, yet which share the diffused feature of initial consonant- or syllable-dropping (see Alpher 1976, Sutton 1976). We do not suggest that their speakers were part of a single social network, or in some cases even of a single culture-area, except in the nebulous and trivial sense that they belonged to a great chain of connected Aboriginal populations across which traits flowed. Our interest, in any case, is at a finergrained scale. We suggest that it is the structure and history of social networks of the limited type outlined, which cruclally determine lingulstic divergence, convergence and parallel development. However, our interest is in their ability to shed light on the relationships between culture, social organisation and human ecology, rather than in what they can explain about linguistic change. Language is only one of the many features of a soclal network, no one of which is necessarily diagnostic.

The anthropologist J.R. von Sturmer (1973:21), writing of Aboriginal people from the Kendall-Holroyd Rivers on western CYP, makes it clear that we would be unreasonable to assume neat 1somorphism of these features even at a native conceptual level:

... the modes of determining individual identity and group identification are related to at least five basic factors: kinship and marriage, territory, totemism, language, and ritual. There has been a strong tendency in the writings 
of McConnel, Sharp and Thomson, the chief ethnographers of the region, to see these principal factors as 'layers' which neatly overlap and profect without any discontinulty into each other. In short, the principal factors have been seen as reflections of a single system.

Von Sturmer notes that this view is rejected by older Aborigines, and that 'organisational principles do not simply overlap'.

Our findings elsewhere in CYP support von Sturmer's earlier conclusions. In view of this, we suggest that anthropologists cannot afford simply to select single conventional features of group identification as the basis for determining their fieldwork domain. We belleve that fleldwork should be selective among populations, rather than among categories of people, in order to avold prefudicing the conclusions that will be made about the relative salience of the different categories and their roles in reflecting and structuring social networks. The relative importance that Aborigines place on group labels, linguistic differences, etc. are part of the essential data, but they cannot be taken to be automatically a close reflection of demographic, political or other realities, except at the native conceptual level. Thus while the Berndts (1970:2) found that 'taking the label Gunwinggu as referring to a recognised tribal unit has a certain utility', and that 'it provides a convenient starting point, a natural unit of study, in the sense that it is a conceptual reality with some basis in empirical reality' (our italics), they also found that the reference of the label depended both on who was using it and In what context it was used (p. 10), that the salience of such labels has increased greatly since missionisation and the attendant need for grosser distinctions (pp. 7, 11, 208), and that 'socially the category of "Gunwinggu" is, to an appreclable extent, heterogeneous' (p. 211). Indeed, at least twelve of the twenty-seven land-holding patrilineal descent groups within the category 'Gunwinggu' also fall within the category of at least one other language, such as Maung or Gunbalang (pp. 237-9). This would lead us to question the usefulness of setting up 'Gunwinggu' or any other language-community label from this area as an empirically valid socioterritorial category, particularly one that defines the scope of an anthropological study of 'man, land and myth'.

Berndt (1959) presented the first well-documented counterargument against the use of the concept 'tribe' in Australia. In that paper he restricted his attack essentially to the Western Desert region, for which he provides a wealth of information of a soclolinguistic (albeit 
mainly native conceptual-categorlal) nature. This could have been the brilliant start to an ecologically-orlented study of language and territoriality in the Western Desert. Although Miller (1972) did some interesting work on 1soglosses in the southwestern area, and ten Raa and Woenne (1974) have assembled a large amount of invaluable computerised cultural-linguistic data, we have yet to see the kind of detalled, thorough, on-the-ground mapping of the area that will make it possible to reconstruct pre-settlement demography. Combined with thorough dialect-survey, as Douglas (1972:82) says, 'such studies would reveal, if it is not too late, both the extent and also the restrictions in movement of specific dialect-forming bodies'. We would want to say, however, that such studies would first reveal the major demographic and environmental aspects of social networks; it would then have to be established empirically whether or not these networks were 'dlalect-forming bodies', and to what extent they overlapped with them if they were not the same.

The notion that social networks and linguistic communities neatly overlap is a simplifying assumption that has strong appeal. Perhaps this explains why anthropologists have rejected the word 'tribe' in recent years, but have nevertheless continued in many cases to make use of 1 ts traditional meanings. Instead of saying 'the $X$ tribe', they often now say 'the $X$ ', where ' $X$ ' 1 s the name of a language. Even Berndt's own 'The Walmadjerl and Gugadja' (1972) speaks of 'the territorial range of a dialect unit' (182) and 'the dialectal territory' (137); and by stating that 'subsections categorise everyone within a given person's perspective, for example everyone within the "tribe" or language unit' (195) he suggests that a language unit is perhaps coextensive with a 'soclety' or social network. (Note that 'Walmadjer1' and 'Gugadja' are dlalect names, the latter being one of the Western Desert dialects.) Th1s suggestion is also explicit in expressions such as Stanner's 'Murinbata society' (1964:36), 'Murinbata opinion' (126), 'Murinbata tradition' (140), 'Murinbata history' (142), and we note that Stanner also talks of 'Murinbata territory' (82, 142). Similar examples can be easily drawn from the ethnographic literature. Hiatt (1965:1) likewise 1dentifles named languages with soclal units, but acknowledges that his informants never referred to themselves as a social group by the name of their language: 'They referred to themselves collectively as "we" and never by any name. I shall call them the Gidjingali for the sake of convenience'. In an area where landowning units may be of mixed linguistic affiliation, and where a third of a sample of people whose parents spoke different languages became 
affillated to their mothers' languages rather than to their fathers', we may ask just how of ten (outside discussions of language itself) the collective 'we' could indeed have referred to the Gidjlngali-speaking language community as a social unit.

One of the 'conveniences' of abstracting single language communities from polylingual speech communities is that the linguist or anthropologist only has to study a selected sub-part of the linguistic competence of the soclety he works in. This means he or she can avold the onerous task of trying to become multilingual, as are most of the people being studied. This simplifying device, used by virtually all fleld workers, is rarely made explicit in their writings.

Not only has the 'linguistic unit' (an 1ll-defined entity at best) been 1dentified with 'soclety' or at least the 'unit of study', it has also been considered to be a territorial unit. This may be the result of Aboriginal practice in certain areas, where sites apparently are sald to be affillated to dialect units. Berndt (1972, 1976) states, for example, that in the Balgo region of the Western Desert, sites belong to dialectal units and some sites belong to two different dialectal units. 'Dual-dialectal areas ... could be taken as points at which a falr degree of intercommunication took place' (Berndt 1976:139). In CYP, however, although 1t is possible to elicit statements of linguistic affiliation of sites, such statements are rare in free discourse, and where made, it is clear that the affiliation is by no means of the same order as that between a site and the one or more descent groups that rightfully lay claim to 1t. The latter relationship is one of 'keeping' and 'looking after' (1.e., custodianship rather than ownership), and is often validated by the storles that connect members of descent groups with the history of the landscape in their countries. Most descent groups have well-defined country ('country' belng the sum of named or recognised locales), and also well-defined linguistic affiliation, although some cases of possibly creole-like dialects, and of dual (primary and secondary) linguistic affiliation, are known. Since every descent group has both sites and a language, one can elicit a site/dialect relationship. But it is triadic, a by-product of the two elemental dyadic relationships of site/descent group and descent group/dialect, and so 1 t is not primary.

We refect the notion of the primacy of linguistic groupings in structuring and ordering the Aboriginal soclal/geographical landscape. Tindale's 'tribal' map (1974) cannot therefore be a map of Aboriginal Australia at a fundamentally meaningful demographic or politicalcultural level, even if 1 t were accurate (which, at least in CYP, it is 
not). We do not consider linguistic groupings (in the usual sense of populations that own and speak the same language, or believe they do) to be primary demographic or political units. Therefore they are not the units with which we are concerned in ecological or soclal-network studies. Nor are they prominent, in the CYP region, in the formation of alliances, whether as seen in the pattern of marriages, totemic links, ritual subgroupings or war-making groups. And although there is an indirect functional association between dialect, soclal network and seasonal range, we do not accept the view that dialect units (as language communities) are in any direct sense 'territorial'. Here we must keep separate the different 'ethnic' views and the 'scientific' view produced by an outsider's analysis of the evidence. (See Dixon (1976) for a clarifying discussion of this particular point.)

In the area of Aboriginal social organisation and behaviour, there has been a lack of close cooperation between lingulsts and social anthropologists. We belleve that the role of language in Aboriginal soclety must be redefined on the basis of carefully integrated, substantial evidence from comparative-historical linguistics, statistics on marriage patterns, genealogies showing assignment of linguistic affiliations, precontact demography, precisely mapped estates and ranges and the politics and composition of alliances, named groupings, etc. The current fleld studies of Anderson, Chase, Rigsby, Sutton, Taylor and von Sturmer in CYP will hopefully provide quality information and allow us to develop fairly powerful explanatory sociolinguistic models for the area. Their studies are currently being made partly or wholly in confunction with those of ecologists and blologists under the auspices of the Cape York Ecology Transect Project and the Australian Institute of Aboriginal Studies, although most of them have been active in CYP for some years. The ecological bent to our own sociolinguistic work arises from the probable high importance of environmental and economic factors in determining some of the characteristics of social networks and their territorial correlates. As we hope is by now clear, we belleve that complex social networks form a level of Aboriginal social and spatial organisation that has been rather neglected in anthropological clrcles so far.

Discussion by social anthropologists has concentrated on two major levels, those of 'local organisation' and 'the tribe', with the intermediate category of 'community' recelving some attention (Meggitt 1962:51; H1att 1965:25; Peterson 1976:68; Berndt 1976:145; note that Berndt's sense of the term is different from that of the others), and wider groupings of quite diverse types have usually been lumped 
together as 'ethnic blocs', 'nations', 'confederacles', 'alliances' and so on.

Ten years ago, local organisation was a major 1ssue in Australian anthropology (see Hiatt 1962, 1966, 1968; Stanner 1965), and was concentrated on the distinction between residence groups ('hordes', 'bands', 'foraging units', 'ranging groups', etc., congerles of which may form 'seasonal ceremonial units' and the less ephemeral 'communities'), and descent groups (sometimes 'patrilineages', 'clans', and if landholding units, then 'estate groups'). The former are observable demographic aggregations, semi-nomadic within a definable range, while the latter are social categorles defined by birthright and assoclated with a definable estate. There is an important difference between the levels of abstraction of the two classifications. The differences are not primarily those of membership, nor are the same personnel involved in both at any one time, since residence groups include only the living, while descent groups include all known members, living or dead, of a lineage. We say this, however, with the warning that when one steps beyond the simplest statements about Australian social/demographic structure, exceptions can usually be found for every generalisation.

Discussion of the wider construct of 'tribe' has recently been revived by the timely publication of Peterson's Tribes and Boundaries in Australia (Peterson, ed. 1976). Dixon was the only linguist to contribute a paper to this volume, in which he made a valuable distinction between the 'ethnic' or 'political' and the (scientific) 'linguistic' senses of the word language. At the same time, however, he did not make the necessary distinction between populations and social categories. His 'tribe', as defined for the rain forest area near Calrns, north Queensland, is a political structure with linguistic unity, and at the same time it is a population divided into local groups that come together in 'tribal gatherings for food procurement and recreation' (Dixon 1976:231). Dixon fails to distinguish between residence groups and descent groups, referring to an amalgam of both as 'local groups'. His 'tribe' is a highly endogamous ethnic-linguistic unit whose members can change 'local group' membership, and which only differs significantly from a European nation in the matter of population size. This description does not even faintly resemble what we know of the CYP region, for which we have detailed ethnographies to correlate with linguistic data.

To give one example well-known from the literature, viz. Sharp's work on 'the Y1r Yoront' (1958, 1968). Sharp rejects the notions of 
nation, tribe, horde, chlef and gerontocratic council, established in the Australianist literature earlier this century, as being irrelevant to the political behaviour of the people he lived with. The only corporate 1dentity among speakers of Yir Yoront is the named patrilineal totemic clan, which is the land-holding unit. There are thirty Yir Yoront-speaking clans. Each clan owns several separate tracts, and the tracts consist of from one to several score 'countries' (named locales). The Fresh Water Rainbow Serpent clan has, for example, over 150 countries in thirteen tracts, of which:

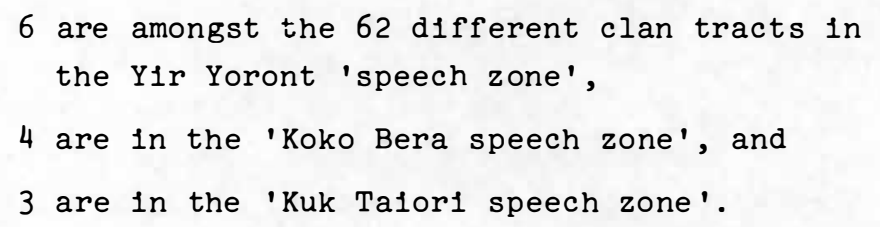

A man's countries may be widely separated and up to fifty or more miles apart. Clan membership, not speech affiliation, determines geographical assoclations. People never camped in localised patrilineal patrilocal hordes. The clan was not a residence unit. Through the kinship system one has access to more than one's own clan territory. Sharp found during many months in bush camps that 'Kuk Talor1' speakers were always present in the residence groups of the northern Y1r Yoront-speaking people.

Sharp (1968:159) also goes so far as to say:

In studying the Aboriginal population on Cape York Peninsula, I simply could not find a soclety; I would have to describe it in terms of an ego-centered set of socleties; no one Individual was the center of a system of networks which overlapped 1sotypically with anyone else's.

This statement colncides to a considerable extent with our own observations during fieldwork with populations still functioning socially, if not economically, in a traditional way. The existence of social groupings is mainly a matter of context, and (especially in the event of a crisis) an individual will 'choose' the alliance suited to the occasion or indeed he may choose none. However, the set of avallable or potential alliances and thelr realisations form a rough pattern in regional terms: 1t is this which we have been referring to as the 'social network'.

We have also referred to wider entities called 'culture areas'. Peterson's (1976) attempt to define culture areas for the Australian 
continent pursues a worthwhile end. There are obvious culture areas such as the so-called 'Murngin', 'Wulamba' or 'Yuulngu' block of north-east Arnhem Land (see Schebeck 1968 for a brilliant sociolinguistic analysis of this bloc), the 'Dieri nation' of south-central Australia, the Wik-speaking and Princess Charlotte Bay areas of CYP, and the spatially vast Western Desert bloc. In certain cases these blocs can be shown to belong to ecologically or topographically unified zones. But the existence of particular culture areas has to be demonstrated individually and empirically. It cannot be inferred from the pattern of linguistic subgroupings, with or without a further correlation with drainage basins. Peterson's proposed culture areas for Queensland (1976:66), the area on which we are qualified to comment, bear no relationship whatever to elther the known culture areas or to the language families in the region, with the possible exception of the rainforest zone, which has some cultural and linguistic homogenelty, but whose basins drain outwards radially in all directions.

We have no doubt that Peterson is right in stressing the fact that Aboriginal bands clustered together into larger networks with strong political dimensions, around which some sort of spatial penumbra can be drawn, and we would agree that their zonation in most cases was not clinal, but regionalised. We further accept the fact that degrees of similarity and difference between languages and their 'spatial distribution' (the spatial demography of their speakers) have been critically, though not wholly, determined by cultural-historical processes that result ultimately from social networks of different scales, the latter being related to the natural environment in a complex way. Such networks have been long neglected as soclocultural and demographic entities, and the understanding of them is most important to hunter-gatherer studies (for a detalled discussion of hunter-gatherer territoriallty, see Peterson 1975). However, we must reject the assumption that soclal networks are primarliy characterised by colncidences of linguistic type.

The integrity of 'linguistic units' is so frequently violated by the shape of social networks that we question the existence of the 'dialectal tribe' in Australia, even if it could be shown that in some areas linguistic affiliations were ostensibly isomorphic with such networks. It seems strange that 'dialectal tribes' can be assumed to exist in areas such as Princess Charlotte Bay, where many people simply have no names for thelr languages or language-communities. And in many other parts of Australia there are names for languages but 
not for their speakers as such. 'Dialectal tribes' do not seem to have been very universal, yet the much neglected speech communities, of varying composition, clearly existed everywhere.

There is good reason to pursue the study of linguistic communities and to attempt to place them in their environmental contexts in those parts of Australia where this is still possible. We know of several apparent topographical correlates of the seasonal ranges of speech communities that had contrasting linguistic compositions; take, for example, the contrast between inland linguistic unity and coastal heterogeneity in western CYP. However, to frame these relationships in terms of 'topographical barriers' (Peterson 1976) seems to us rather forced, unless 'barrier' refers to huge water-bodies such as gulfs or seasonally-flooded plains, sheer escarpments, snowfields, or areas virtually lacking in surface water like much of the Nullarbor Pla1n. These are elther rare or impermanent, and while it is clear from our field work that ecological and topographical factors are important to both demography and socio-territorial structure at descent group, band and band-aggregate (etc.) levels, it seems absurd to suggest that elther these or wider culture area structures are typically marked by 'topographical barriers' as obstacles to travel or communication. The bounding factors for major culture areas must be sought in the rationale for the shape and distribution of their component subparts along the culture area periphery. We suggest that the upper limits on the size of a culture area are basically determined by population distribution and density, given the existence of enough cultural unity and communication networks (1.e., you can marry, join a ritual or go trading, just so $f a r)$. The shape of the smaller communication-networks in a culture area will be determined partly by the pattern of annual range of the residence groups. It is at this level of estate and range that environmental factors become crucial and determinant for the grosser structures in which populations participate. There are also strong conceptual factors linking peoples who share similar environments and distinguishing them from ausländers.

The relative endogamy that characterises a social network in CYP is shaped by descent group exogamy, intergroup politics (ritual and other), previous marriages (1.e., alliances and 'payback') and the factor of physical distance. It is not, as Peterson suggests for culture areas (1976:67), the result of 'natural boundaries ... tending to restrict communication between them'. On western CYP, the smaller social networks and also the larger culture area arch across most of the 'natural barriers' of the area, such as rivers and salt plains. There 
is a primary coastal vs. Inland split, and only the lower reaches of rivers are included in the smaller coastal subgroupings. The people of the upper drainage basins have tenuous (or precious few) links with people lower down, but strong links among themselves. There are groups clustered about the lower reaches of rivers, but in this kind of country, where sand dunes run parallel to the coast, drainage basins are at a right angle to the courses of rivers.

We suggest, finally, that the size and shape of social networks, if defined as relatively bounded networks of interactions, will not necessarlly colncide with those of culture areas that are defined by shared cultural traits or site-language affiliations. However, we cannot yet give detailed definitive accounts of such networks. We need to do further fine-grained work on both territoriality (detailed mapping of countries, reconstruction of band composition, etc.) and socio-linguistic phenomena (linguistic communities, linguistic affiliation and competence of individuals, social categories and groups, etc.). With better case studies at hand, we may then be able to ralse the theoretical discussion of relationships between language, social networks and ecology above its present speculative level. 


\section{BIBLIOGRAPHY}

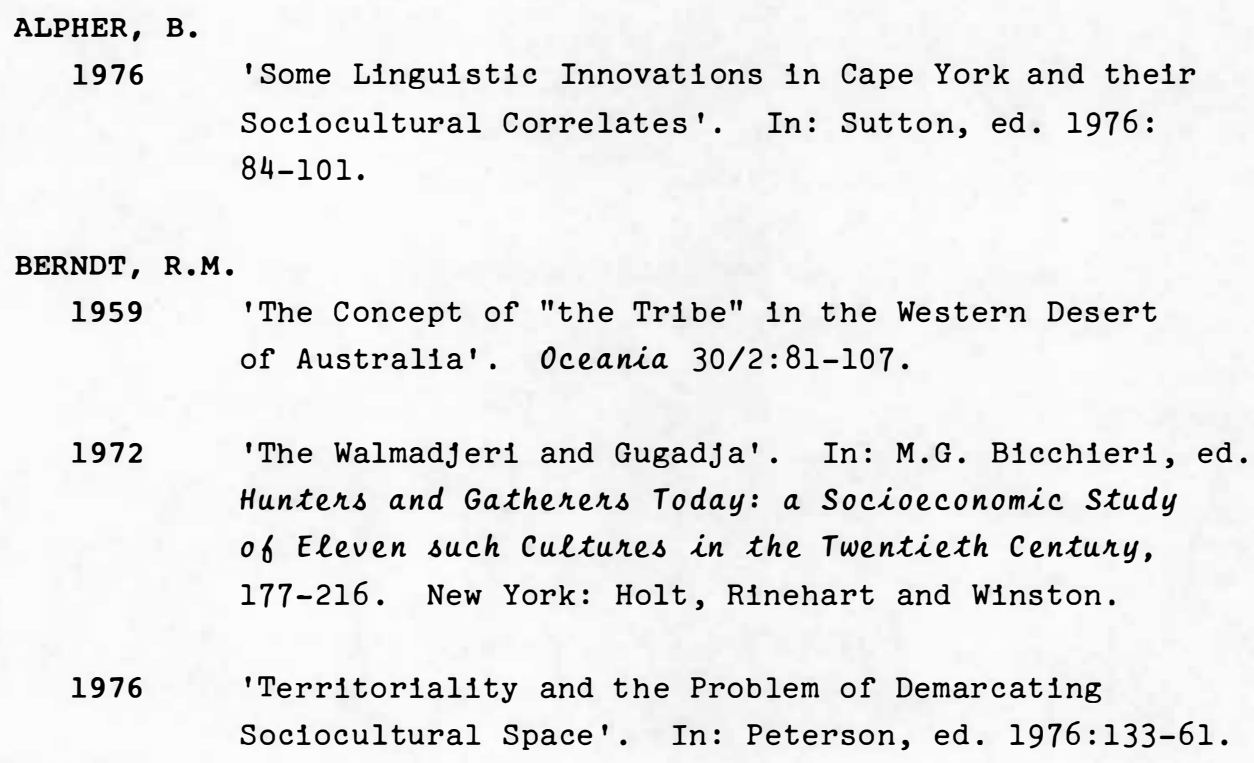

1972 'The Walmadjer1 and Gugadja'. In: M.G. Bicchier1, ed. Hunters and Gatherers Today: a Socioeconomic Study of Eleven such cultures in the Twentieth Century, 177-216. New York: Holt, Rinehart and Winston.

1976 'Territoriality and the Problem of Demarcating Soc1ocultural Space'. In: Peterson, ed. 1976:133-61.

BERNDT, R.M. and C.H. BERNDT

1970 Man, Land and Myth in North Australia: the Gunwinggu People. Sydney: Ure Smith.

BIRDSELL, J.G.

1953 'Some Environmental and Cultural Factors Influencing the Structuring of Australian Aboriginal Populations'.

The American Naturalist 87:171-207.

1968 'Some Predictions for the Pleistocene Based on Equilibrium Systems among Recent Hunter-gathers'. In: Lee and De Vore, eds 1968:229-40. 
1976 'Realities and Transformations: the Tribes of the Western Desert of Australia'. In: Peterson, ed. $1976: 95-120$.

DIXON, R.M.W.

1970 'Languages of the Calrns Rain Forest Reg1on'. In: Wurm and Laycock, eds Pacific Linguistic Studies in Honour of Arthur capell. PL, C-13: 651-87.

1972 The Dyirbal Language of North Queensland. Cambridge University Press.

1976 'Tribes, Languages and Other Boundarles in Northeast Queensland'. In: Peterson, ed. 1976:207-38.

DOUGLAS, W.H.

1972 'Dialect Differentiation in the Western Desert A Comment'. Anthropological Forum 3/1:79-82.

HEATH, J .

1978 Linguistic Diffusion in Arnhem Land. AAS, RRS 13.

Canberra: Australian Institute of Aboriginal Studies.

HERCUS, L.A. and I.M. WHITE

1973 'Perception of Kinsh1p Structure Reflected in the Adnjamathanha Pronouns'. Papers in Australian Linguistics No. 6:47-72. PL, A-36.

HIATT, L.R.

1962 'Local Organisation Among the Australlan Aborlgines'. Oceania $34: 267-86$.

1975 Kinship and Conflict, a Study of an Aboriginal Community in Northern Arnhem Land. Canberra: Australian National University.

1966 'The Lost Horde'. Oceania 37:81-92.

1968 'Ownersh1p and Use of Land among the Australian Abor1gines'. In: Lee and De Vore, eds 1968:99-102. 
JENNINGS, J.N.

1971 'Sea Level Changes and Land Links. In: D.J. Mulvaney and J. Golson, eds Aboriginal Man and Environment in Australia, 1-13. Canberra: Australian National University.

LEE, R.B. and I. De VORE, eds

1968 Man the Hunter. Chicago: Aldine.

MEGGITT, M.J.

1962 Desert People. Sydney: Angus and Robertson.

MILLER, W.R.

1972 'Dialect Differentiation in the Western Desert Language'. Anthropological Forum 3:61-78.

PETERSON, N.

1975 'Hunter-gatherer Territoriality: the Perspective from Austral1a'. American Anthropologist 77:53-68.

1976 The Natural and Cultural Areas of Aboriginal Australia: a Preliminary Analysis of Population Groupings with Adaptive Significance'. In: Peterson, ed. 1976:50-71.

PETERSON, N., ed.

1976 Tribes and Boundaries in Australia. SA 10. Canberra: Australian Institute of Aboriginal Studies.

RAA, E. ten and S.T. WOENNE

1973 Research Dictionary of the Western Desert Language of Australia. Computer printout. Perth: Department of Anthropology, Western Australia.

ROSENFELD, A.

'The Early Man Sites: Laura 1974'. Australian Institute of Aboriginal Studies Newsletter n.s. $37-40$.

SCHEBECK, B.

1968 Dialect and Social Groupings in North-east Arnhem Land. Typescript. 
1973 The Adnjamathanha Personal Pronoun and the "wa1lp1 Kinship System"'. Papers in Australian Linguistics No. 6:1-45. PL, A-36.

SHARP, R.L.

1958 'People w1thout Pollt1cs: the Y1r Yoront'. In: Verne F. Ray, ed Systems of Political Control and Bureaucracy, 1-8. Seattle: University of Washington Press.

1968 'Hunter Social Organisation: Some Problems of Method'. In: Lee and De Vore, eds 1968:158-61.

SILVERSTEIN, M.

1972 Goodbye Columbus: Language- and Speech-community in Indian-European Contact Situations. MS. Chicago.

STANNER, W.E.H.

1964 On Aboriginal Religion. Sydney University Press.

1965 'Aboriginal Territorial Organisation: Estate, Range, Domain and Regime'. Oceania 36:1-25.

STURMER, J.R. von

1973 'Changing Aboriginal Identity in Cape York'. In: D. Tugby, ed. Aboriginal Identity in Contemporary Australian Society. Brisbane: Jacaranda Press. 16-26.

SUTTON, P.

1976 'The Diversity of In1t1al Dropping Languages in Southern Cape York'. In: Sutton, ed. 1976:102-23.

SUTTON, P., ed.

1976 Languages of Cape York. AAS, RRS 6. Canberra: Australian Institute of Aboriginal Studies.

TINDALE, N.B.

1974 Aboriginal Tribes of Australia. Berkeley: University of California Press. 


\title{
ALICE SPRINGS ABORIGINAL CHILDREN'S ENGLISH
}

\author{
M.C. Sharpe
}

\section{INTRODUCTION}

From February to August 1976 (five and a half months) I spent time in Alice Springs for study of the English of Aboriginal children there. The project was funded by the Australian Institute of Aboriginal Studies, in response to a request by the staff of Traeger Park Primary School and a good number of the parents of Aboriginal children attending the school. In that time I recorded children interacting informally with each other and with white adults, and analysed the data gained. Analysis was speeded up by the use of a computer concordance. Detalled descriptions of the recording techniques are given elsewhere (Sharpe 1978), and a report of inftial results appeared in 1977 (Sharpe 1977a). Data from the sample was compared with extensive data obtained in Brisbane from elght and a half yearold white middle-class children by the Mt Gravatt C.A.E. Language Research Unit. Children in the Alice Springs sample ranged in age from four to thirteen, with a mean and median age of elght and a half. Two-thirds of the chlldren were at least six years old and under eleven years old. For this study I defined children as Aboriginal if they had some Aboriginal ancestry and a noticeably Aboriginal volce quality (see Sharpe 1970). With a couple of exceptions, all these children would have identified themselves as Aboriginal, although they may not have used the term 'Aboriginal'. (Children tended to use the term 'Aboriginal' in the sense 'traditional Aboriginal' or 'native'. They would, for example, refer to Aboriginal paintings or Aboriginal dances.)

Although only minor differences exist between different forms of Aboriginal English in Alice Springs, at least two main sub-dialects can be isolated. The division is between camp children's English and town children's English, the former including camps in the town area 
and outside, and the latter including children from children's homes run by the Anglican and Lutheran churches. There is perhaps a very slight difference between town and children's homes' English, and children from the Lutheran compound appeared to have some forms which differed from those of children from the Anglican children's cottages. Most camp children I was able to record were from Aranda speaking camps and the children were bilingual; unfortunately I was not able to obtain data about English from camps using another Aboriginal language. Some town and children's home children also spoke an Aboriginal language, most commonly Aranda, less commonly Pitjantjarra or another language from the centre, or (for a couple of children) from elsewhere.

Although I refer to two dialects of Aboriginal English, there is no clear-cut line of demarcation between Aboriginal English and standard English in elther dialect. Most children fluctuated between standard and non-standard forms, almost as though many non-standard forms behaved as additional optional contractions or variations on standard forms. This will be discussed further below. But some of the more complex standard English constructions are lacking by comparison with the elght and a half year-old white Brisbane sample, and sentences rarely had more than one subsidiary clause, although multiclause sentences, usually with and as connector, were common.

In the following discussion and description, standard English (SE) is taken to mean the dialect(s) spoken by middle-class white Australians, including their informal styles (1.e., not just their 'correct written' style), and including, where indicated, immature or developmental forms used by children with white middle-class upbringing.

\section{PHONOLOGICAL DIFFERENCES}

Phonological differences between Aboriginal English (AbE) and SE are of the type common among Aborigines, although some features may be specifically Centralian. Children tend to fluctuate between 'AbE' and 'SE' phonology. For forms most different from SE, the following summary applies:

Distinction between volced and volceless stops can be lost, particularly word finally, where the volceless forms are quite often used, and before nasals, where the volced forms are used. As the stops in Aboriginal languages of the area are more commonly volceless, volceless stops are rather more common in AbE than in SE. Children at school apparently absorb a reasonable knowledge of phonics, because they often spell words 
as they say them, e.g. bet bed, at had, etc. It does appear, however, on limited data, that words with volced final stops in SE take the volced plural and past tense allomorphs (-z, -d respectively), whereas words with volceless word final stops in SE take the allomorphs -s and -t respectively.

Stops /b/, /p/ sometimes replace the fricatives /v/, /f/ respectively in 1solated words (e.g., fibe, Beberly, will pigs wizd figs, Preezer Frazer). Other words have the fricatives as in SE. No substitution of fricatives for stops occurs.

An interdental stop is sometimes used where SE uses /ð/, and a /t/ is used where SE uses $/ \theta /$, e.g. wid with, dis this, dat that, ting thing.

An intervocalic / $/$ / in $S E$ is sometimes replaced by a flapped or trilled /ř/, e.g. gořit got it, puřit put it, etc.

The Aboriginal language sound / t/ sometimes replaces the affricates /tš/, /dž/, but most commonly English sounds are used. However, some children appear to substitute one fricative/affricate for another or to fluctuate, e.g. chuch/shuck chuck, shiraffe giraffe, secrets/checrets secrets. /s/ is occasionally used where SE has /t/, / $/$ /, or /ð/, e.g. das one, nasing nothing, and once sree tree, and once conversely, twitch switch (with varlant /w/ sound, see below). For some chlldren, the slbilants /s/, /š/, /z/, /ž/ are sometimes confused; these children may not recognize them as separate phonemes.

The aspirate /h/ is often dropped.

The lateral / // has a consplcuously different quality, which I find hard to define, particularly syllable finally after /u/. It is probably a lighter /1/ than English syllable final /l/.

$\mid w /$ at times sounds somewhat like $/ r /$, in such phrases as all-o-way alz the way, and twitch/switch/twitch switch (where w symbolises this $r$-like $w$ ).

Some children have only two short front vowels $/ i /$ and $|æ|$ where SE has three, /i/, / $/ \varepsilon /, / æ /$, e.g. Windy Wendy, pin pin/pen (the word biro is used by some to avold homonyms), pig pig/fig/peg (clothes pig is unambiguous, and wil' pig usually refers to a native frult, there being a scarcity of pigs around Alice Springs), and men men/man 
(number is usually clear from preceding articles, or the plural morpheme $-\mathrm{s}$ can be suffixed for men). Preceding $/ \mathrm{g} /$ a $S E / \varepsilon /$ or /æ/ can be pronounced /ey/, e.g. iyg/eyg egg and fleyg flag.

The /aw/ diphthong (as in down) is often pronounced as long /æ/ vowel, with little or no final /w/ glide. This is only slightly different from broad Australian pronunclation, but differs markedly from average Australian, and can cause some comprehension difficulties at times, especially when combined with a variant stress and rhythm, e.g. /dæ:n/ down, /mæntriyn/ Mt Doreen.

Some children insert a transition vowel between such clusters as /bl/, /kl/, /gl/ and /my/, particularly word Initially, e.g. /pə'riyza/ Frazer, /'imiyu/ emu, /pigoli wigoli/ Piggly Wiggly (one of the town's supermarkets).

Initial vowels or syllables can be dropped from such words as about, around, because; and you/your is contracted to /yə/ at times, it/at/that to /at/, and them to /əm/. Word final clusters /nd/, /nt/ are more often than not reduced to $/ \mathrm{n} /$, and $/ \mathrm{dnt} /$ to $/ \mathrm{dn} /$. Most chlldren also use the full forms. I have examples of the dropped / d/ being inserted as though 1t belonged with the next word phonologlcally: roun dan roun dan roun round and round and round, and she puttin er hans dup she's putting her hands up.

The vowel of the is always phonetically [ə], never changing to $[i y] /[$ oy] preceding vowels, which it does in mature SE. Similarly, a never has the allomorph an before vowels (with two exceptions in the data). The consonant in the can be assimilated to a preceding consonant in certain common prepositions, in, on, at, all. The definite article is still almost always phonologically distinct from a in such cases, as the assimilation lengthens the preceding consonant, and the vowel is neutral, whereas the vowel of la/ is usually more open, cf. [in:ə] in the, [ina] in a.

Stress and rhythm of speech was slightly different from $S E$, so whites need a period of tuning in to the dialect for easy comprehension. But after tuning in, problems were usually confined to isolated words, e.g. ['mæntriyn] Mt Doreen and confusion of 'probably' with 'properly' [probli] and [propli] respectively), etc. By this stage in 
comprehension, the white person has also tuned in to many grammatical differences and does not notice these very much e1ther.

\section{GRAMMATICAL DIFFERENCES}

As in phonology, so in grammar, $A b E$ speakers show fluctuation between standard and non-standard forms. In some areas of grammar however, $\mathrm{AbE}$ has standardised on certain non-standard forms. In others, contractions are permitted. These contractions include ones used in informal and sometimes immature SE speech. But as most children used the full SE forms at times, we can conclude that they recognise these as the underlying forms.

\subsection{Non-standard Forms used as Standard in $A b E$}

The past tense was copula is used almost exclusively preceding plural as well as singular pronouns. Was is often contracted, see below.

Bin is used frequently by camp children and infrequently by town children to indicate past tense, e.g. we bin go. Some 'wrong' verb forms are also used: seen for saw, brang, brangim for brought, drownded, etc., but there are insufficlent examples to draw firm conclusions on the use of these.

Some words used only as nouns in SE are used as verbs in $\mathrm{AbE}$. $\mathrm{AbE}$ speakers used photo, typewriter and taperecorder as verbs, paralleling the SE use of photograph and tape:

You gonna photo us?

Miss Marg'ret, cin I typewriter?

Thing/ting is also used both as noun and verb, and is used as equivalent to the expressions what's-it, thingummy, thing-oh, etc.

'E's um thingin' 'is tali up (of man placing section of harness under horse's ta1l).

P'renti's different, p'renti's got things.

Miss Ting, Miss Wilkins, ....

Eh uttered with falling intonation is the standard $A b E$ tag question marker, replacing $S E$ isn't it, is it, wasn't she, etc.

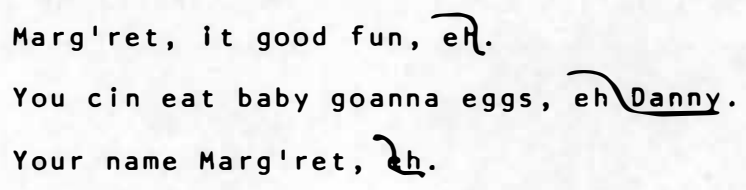


That's the biue one,

You do realiy, eh.

It is safe to assume that the SE tag forms are hardly ever used by $A b E$ speakers, although chlldren may well respond correctly to them when used by whites, particularly if the intonation is falling, as it is on the eh tag in $\mathrm{AbE}$.

Many mass nouns in SE occurred in the AbE sample as count nouns. Enough examples occur to be reasonably sure this is a general pattern for such nouns.

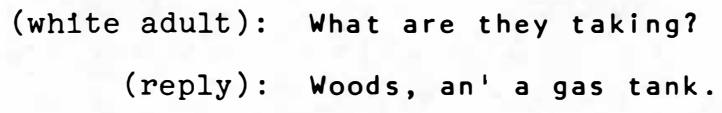

\subsection{Contractions}

Aborlginal English in Alice Springs allows a broader spectrum of contractions of the standard forms than does standard English. The evidence suggests all chlldren are famlliar with SE uncontracted forms, $\mathrm{SE}$ contracted forms, and some further contractions. The most obvious example of this is in the use of the present continuous forms like I am going, I'm going. SE speakers use and recognise these. Some SE speakers will even intermittently omlt the copula in casual speech, and produce forms I going or I goin' (and I gonna for I am going to with following verb), though most are unaware of their omission of the copula and would deny 1 t. 
AbE speakers use all forms 1 am goin(g), I'm goin(g), and 1 goln(g) (and their equivalents for other persons and numbers). They also use I'm gonna, I gonna and a further contraction I ng'na before another verb. The non-standard we was goin $(g)$ can also be contracted by loss of $/ w /$ and neutralisation of vowel to we'az goin(g). Enough of the children used the copula and forms in - ing to be reasonably confident all knew the standard forms. I have no figures on white children other than those I recorded in Alice Springs in interaction with Aboroginal children, but the Alice Springs evidence suggested town Aboriginal children and white children (including one recent arrival from Brisbane who would not have been heavily influenced by Alice Springs usage) used forms in - ing and - In' $^{\prime}$ in equivalent proportions. Table 1 shows the proportions of usage. The data suggests, for Aboriginal speakers, a very slight preference for the use of the form in -in' when the copula is omitted, and for -ing when the copula is used.

$\begin{array}{ccccc}\text { Table } 1: & \text { Proportions of }-i n ' \text { to }-i n g \\ \begin{array}{c}\text { Town } \\ \text { Aboriginal }\end{array} & \text { White } & \begin{array}{c}\text { Camp } \\ \text { Aborlginal }\end{array} & \begin{array}{c}\text { Lutheran } \\ \text { Homes }\end{array} & \begin{array}{c}\text { Anglican } \\ \text { Homes }\end{array} \\ 2: 1 & 2: 1 & 6: 1 & 1 \frac{1}{2}: 1 & 5: 1\end{array}$

Just as the copula can be omitted in continuous aspect verbs, so it can be omitted when it stands alone, and most children used forms with and without a copula. They also would use forms with or without third person singular verb agreement, as in:

Appie doesn't, apple don't.

(and in a game of school, successive questions from the one

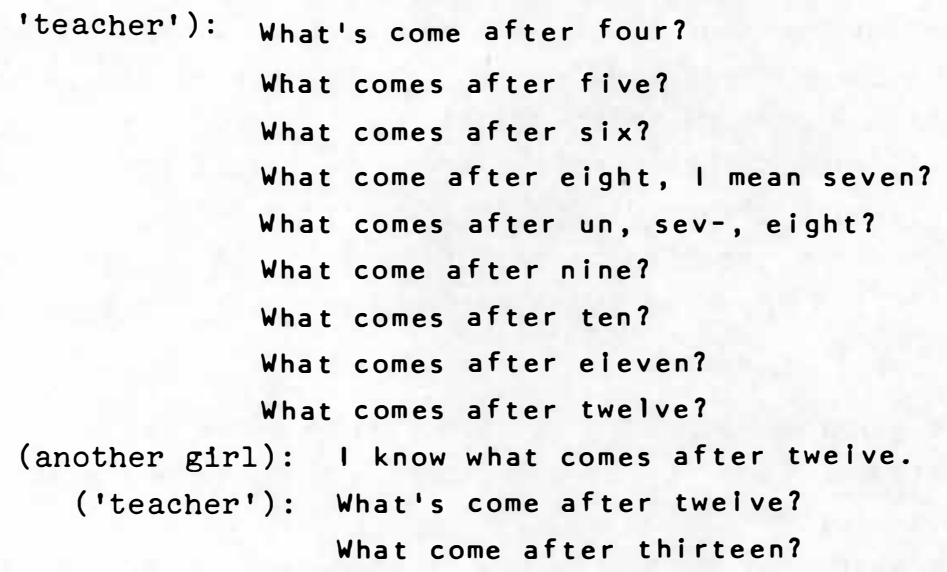

There is no obvious triggering mechanism to cause presence of absence of copula or third person singular verb agreement (or of misplacement 
of the latter), at least when chlldren are at ease. There is, however, evidence in the data of the deliberate use of some formal uncontracted use of English in 'formal' situations from camp children, for example when deliberately recording on a taperecorder.

Just as third person singular verb agreement can be omitted, so can the homophonous morphemes for plural and possessive, other plural morphemes, and the past. tense morpheme. Again there is no obvious triggering mechanism for presence or absence of these inflections, except that they sometimes are present or absent together, e.g.

That someone else house, an' this is someone else's house, an' this is my house.

In negative clauses using the copula in SE, there is a preference in AbE for copula omission and the use of the full negative form not rather than $n ' t$. Th1s is shown in Table 2. But in negative clauses with other auxiliarles in AbE, with the one exception of did not occurring once, the negative is contracted to $n^{\prime} t$ or $n^{\prime}$, e.g. can' $(t)$, couldn' $(t), \operatorname{don}^{\prime}(t), \operatorname{didn}^{\prime}(t),(h) \operatorname{aven}^{\prime}(t)$, won' $(t)$, wouldn' $(t)$.

Table 2: Use of negative with copula

not

(copula omitted)

9

$\quad$ not
(after
contracted
copula)

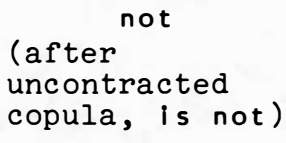

1 $n^{\prime} t$

(after uncontracted copula, is, was)

2

Brisbane white children and Allce Springs Aboriginal children all used the following forms for future tense: 's goin(g) to, 's gonna (and other persons and numbers, with omission of copula allowed in $A b E)$, will and 'll, except that camp chlldren never used the full form will. Shall, which occurred with low frequency in the white sample, only occurred in question inversion form in the AbE sample, and from camp chlldren, who used shall rather than will for questions:

Shall I switch it on/off?

AbE speakers used gonna more frequently for future tense, while Brisbane white children used 'll more frequently. Gotta was also used for future tense in $\mathrm{AbE}$.

Another phrase which can be contracted is want to. Most SE adult speakers are familiar with the contractions wanna and wanta, and young SE speakers often contract want to to -na after the pronoun 1 . AbE 
speakers in Alice Springs, Just as did AbE speakers in Queensland, could and did contract want to to -na after any pronoun; want to was also contracted to ona after we, but no examples of ona occurred after other pronouns. After don't, only the contractions wanna and wanta occur.

\subsection{Passives}

Passives are comparatively rare in children's speech, or even in mature SE speech, as opposed to written and formal English. In passives used by younger white children ( 1 ix and a half year-olds), according to the evidence collected by Mt Gravatt C.A.E. Language Research Unit, the belng undergoing the action is always first person, e.g.

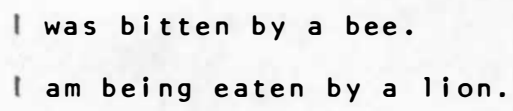

Older children use the passive with other subjects, e.g. he.

The AbE sample contains a number of 'agentless passives', which it Is unwise to classify as passives, as they parallel the structure of adjectival predicate constructions such as I'm hot, He's not dead, e.g.

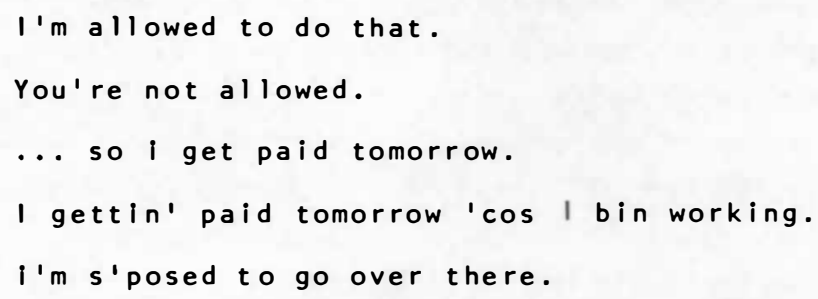

Only two examples of passives with stated agent occur in the Alice Springs sample, and got is used rather than be/was as the auxiliary verb. The same use of get/got occurred in the data collected at Palm Island in Queensland by the Van Leer Project team. The Alice Springs examples are:

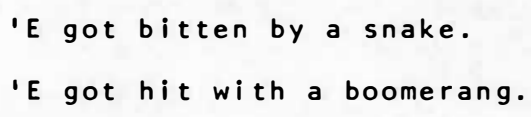

It is worth noting here that children with significant hearing losses rarely acquire understanding of the passive construction. Although only one of the children recorded in the Alice Springs sample had severe and current hearing loss, the undisputable fact that there is a higher proportion of children with hearing losses among Aboriginal children would lessen the possibility of the use of the passive by Aboriginal children even with normal hearing. 


\section{COMMENTS}

Argument has waxed hot over recent years on whether the English of such groups as urban Negroes in the U.S. and urban and fringe dwelling Aborigines is an adequate language of itself. Bernstein (1972), at least as commonly interpreted, regarded the language of such groups as 'restricted'. Berelter and Engelmann (1966) are of ten quoted as suggesting some children had virtually no language. As Labov convincingly showed ((1969) 1972, 1973), evidence to support these 1deas was often obtained by white investigators (and even coloured investigators) in situations which, as we see with more sociological insight now, put the child on the defensive. The child therefore was uncommunicative as a defensive action. When the children were at ease, they became most communicative. Similar responses have been noted in Australla with Aborigines. During research in the Van Leer Project in Queensland, teachers reported on children being shy and uncommunicative, though they were very talkative with Julla Koppe and myself. Koppe and myself used differing techniques which were equally effective in putting children at ease. In Alice Springs I found a most communicative camp child who was regarded as shy by a senior teacher. After implementation of the Van Leer Program in Queensland, teachers found children to be much more communicative and forward with them and with visiting V.I.P.'s. I attribute this to the change of attitude of the teachers to the children's English, from one of exasperation at what appeared to be a random bunch of errors, to one of acceptance of Aboriginal English as a language with its own rules.

When $A b E$ is compared with $S E$, we see a number of differences. AbE probably has a more limited vocabulary (although it does have some words not used in $\mathrm{SE}$ ), lacks some complex verb phrases present in $\mathrm{SE}$, used subsidiary clauses less, and a more limited range of confunctions. Based, no doubt, on these differences, and observations of researchers such as Bernstein, Bereiter and Engelmann on the communicativeness of lower class and coloured chlldren, educators and the general public, as a recent writer pointed out (F1sher 1977:18), favour a deficit model for these dialects, whereas linguists lean heavily on the difference side. As the linguistic evidence for Alice Springs AbE at first glance favours the deficit model, it is up to the linguist to present a case against the deficit model. How the linguist is going to convince educators and the general public to accept this, or how soclety is to be changed so that linguistic difference is not a handicap to some groups is another matter. 
Firstly let us consider the matter of vocabulary. I am sure other linguists have had, as I have, the experience of endeavouring to communicate an 1dea in a language they are just learning. Even with only the basic grammar, and a limited vocabulary, 1deas can be conveyed and often conveyed quite well. A shortfall in vocabulary of the type existing in AbE when compared with that of the average $S E$ speaker is no great handicap.

In verb phrases, Alice Springs Aboriginal children's English lacks some of the more complex phrases which at least some elght and a half year-old Brisbane white children use. Most phrases which are lacking from the AbE data involve the auxiliary have. Have is only used in the AbE data as an auxillary with got and had, and reduced to -a in other cases, e.g.:

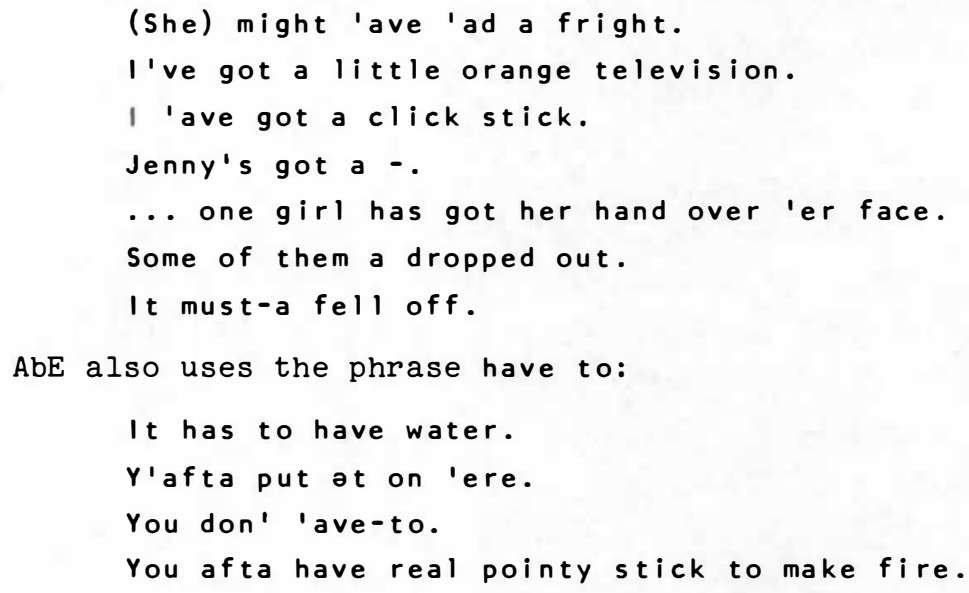

In addition to all uses of verb phrases occurring in $A b E$, elight and a half year-old SE uses both have and had with verb participles, e.g.:

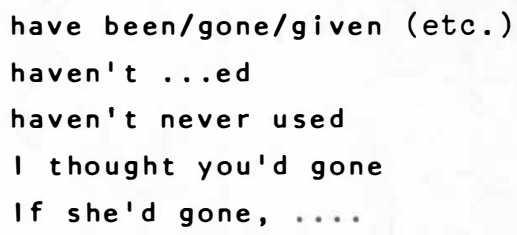

The elght and a half year-old SE data also has, in addition to these:

could (ha) ve had

might have been

should have

would have been terrible

would have been mucking up

wlll have (to be)

may 
The SE sample also has the negative forms hasn't (AbE data includes 'aven'(t)), hadn't, mightn't and mustr't. Must only occurs once in the AbE data, in the combination must-a quoted above.

May and might differ little in most English usage today, so the absence of may is no loss. Regarding have, not all languages have a perfect tense, and we do not regard such languages as inadequate. There are other ways of indicating completed action if required.

of twenty-four confunctions, including relative confunctions, used by children in the eight and a half year-old Brisbane white children's sample, the Alice Springs AbE sample lacks ten. Confunctions used in both are: and, as, because, but, if, or, so, than, till/until, how, that, what, where, while/whilst. Confunctions used only in the white sample are: except, instead, since, though, unless, whatever, whenever (not in Brisbane sample, but used by one white six year-old in Alice Springs, a Brisbane child), which, who.

Where SE uses which or who as confunctions, AbE gets by with no overt confunction, or with that, following patterns of relative clauses in some Aboriginal languages, and the meaning is quite clear. Circumlocutions with what or when can cover whatever and whenever. Instead can be handled by a circumlocution. Since can be replaced by because or after depending on meaning. Though can be deleted from one clause and but prefixed to the associated clause, e.g.:

Though he came I didn't see him.

He came but I didn't see him.

Except and unless can be replaced by other confunctions and a negative particle, e.g.:

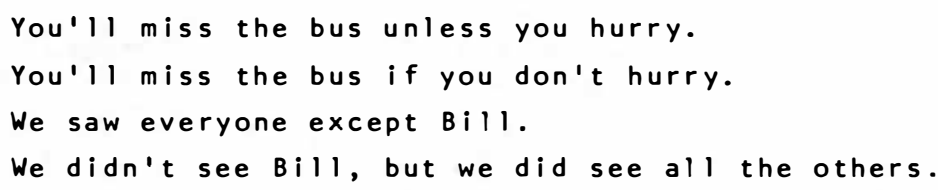

Hence I would suggest the absence of such confunctions causes no great problems in communication. Problems can arise of course, when AbE speakers, unfamiliar with these alternative ways of expressing certain sentences in SE, come up against words they do not know.

Teachers, oddly to the linguist, are most prone to cite the absence of the copula in equational clauses (e.g., 'E big one.) or in the present continuous tense ( 1 goin' now) as the most compelling evidence of language deficit, whereas there is no shred of meaning difference between the SE and non-standard forms in such phrases, and therefore such forms are no evidence at all for a language deficit. In any case, 
as I have shown above, these forms are optional contractions of standard forms for Aboriginal speakers, and are therefore no evidence of differing basic forms of English.

Further detall on Alice Springs Aboriginal English may be obtained from reports I prepared for Traeger Park Primary School, and are obtainable from the school.

My own 1mpression in interaction with the children was that their language was a full and flexible one, well able to be a vehicle for complex thought and reasoning. I do not feel the differences between $\mathrm{AbE}$ and $\mathrm{SE}$ are of themselves handicapping to Aboriginal children. Any language handicap suffered by the children would be due to the interaction between $\mathrm{AbE}$ and $\mathrm{SE}$ and the relative values placed on these dialects by the dominant white soclety. Fortunately teachers at Traeger Park School had a generally accepting attitude towards the different dialect of the children, and a creative way of introducing children to the skills of reading and writing, which lessened potential problems faced by these children. However, they would be the first to admit they do not have the full answer, and perhaps that they were not asking the right question. The problem, if problem we must call 1t, that these children face, is more a sociological one than a linguistic one. 


\section{BIBLIOGRAPHY}

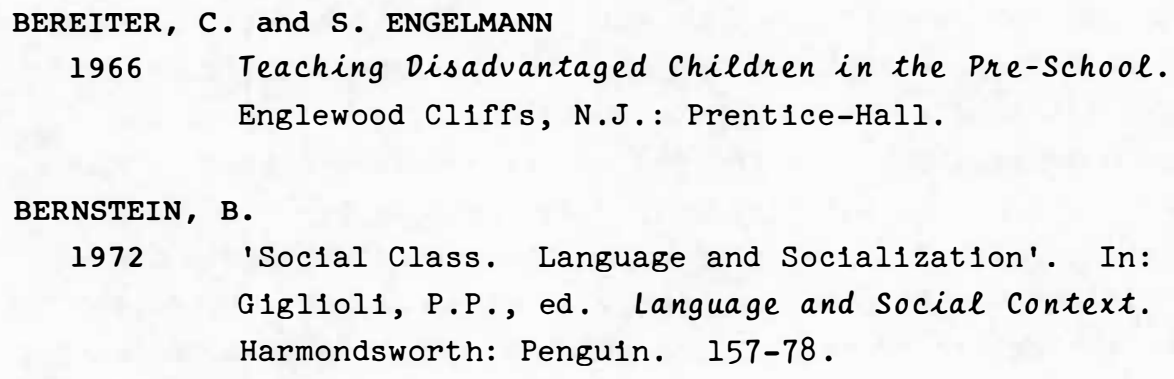


MT GRAVATT TEACHERS COLLEGE

1973

Language Research Reports 1973 and later.

QUEENSLAND DEPARTMENT OF EDUCATION

1970- Bernard van Leer Foundation Project Publications.

SHARPE, M.C.

1970 'Volce Qual1ty: a Suggested Framework for Description, and Some Observations'. In: S.A. Wurm and D.C. Laycock, eds Pacific Linguistic Studies in Honour of Arthur Capell. 1970:115-34. PL, C-13. Canberra: Pacific Linguistics.

1977a 'Alice Springs Aboriginal English'. In: E. Brumby and E.G. Vászoly1, eds Language Problems and Aboriginal Education. 1977:45-50. Mt Lawley College of Advanced Education, Perth.

1977b Alice Springs Aboriginal Children's English: Report to Parents. Allce Springs: Traeger Park School. Mimeographed.

1976-7 The English of Allce Springs Aboriginal Children: Report to Teachers, Parts 1 and 2. Allce Springs: Traeger Park School. Duplicated.

\footnotetext{
'Report on a Research Project on Allce Springs Aboriginal Children's English'. Australian Institute of Aboriginal Studies Newsletter n.s. 9:57-61.
} 


\section{BIOGRAPHICAL NOTES ON THE CONTRIBUTORS TO THIS VOLUME}

Barry J. Blake graduated from the University of Melbourne in 1954 (Arts honours in Latin and English Language). He completed an M.A. at Monash in 1968, his thesis being entitled A Brief Description of the Kalkatungu Language, and a Ph.D. In 1975 with a thesis on The Case Systems of Australian Aboriginal Languages. At present he is a senior lecturer in the Department of Linguistics at Monash, giving classes in phonology, syntax and Australian languages. His research work has been in the field of Australian languages.

Arthur Capell was educated at North Sydney Boys' High School and took his first degree at Sydney University in 1922 and his M.A. In 1931. He had meanwhlle taken up the study of Oceanic linguistics and recelved his $\mathrm{Ph} . \mathrm{D}$. In this subject in London in 1938. He then began fleldwork in Australia and in 1944 took up a position in the Department of Anthropology at the University of Sydney. He has carried out extensive fleldwork in Australia, New Guinea, the British Solomon Islands, the New Hebrides, and was the only non-American member of the Coordinated Investigation of Micronesian Anthropology expedition, working in Palau in 1947. He became the first Reader in Oceanic Linguistics at the University of Sydney in 1949. He retired from the University of Sydney in 1967 and worked as Visiting Fellow at the Australian National University in 1967 and 1973-4, and is now working privately in writing up the results of his research and fieldwork. He has produced a number of books and articles on various aspects of Pacific and general linguistics.

Lois Carrington was trained as a teacher of English as a forelgn language and worked for some years for the Australian Commonwealth Office of Education in various aspects of teaching English to Immigrants. Varled experience in the publishing field was acquired 
during this time and at others, while attached to various publishing houses. After a period of secondary teaching, she went to Papua New Guinea where she spent several years on the staff of the English Department of the Administrative College in Port Moresby. She is currently a Research Assistant in the Department of Linguistics, Australian National University.

Neil Chadwick recelved his Diploma in General Linguistics in Edinburgh, his M.A. In Linguistics at the University of New England, and at present is working towards a Doctorate of Philosophy at Monash University. He has held the following positions: Senior Teaching Fellow in Linguistics at Monash University, 1970-73; Lecturer in Linguistics, College of Advanced Education, Mount Lawley, Western Australia, 1974; Lecturer in General Linguistics, Darwin Community College, 1975; and currently (since 1976) Lecturer at the School of Australian Linguistics, Darwin Community College, Batchelor, Northern Territory. His research interests include: Description of Preliterate Languages; Comparative-Historical Linguistics; Sociolinguistics, Language Politics; Phonetics, Phonology; Dialectology. He has a particular interest in finding ways of distinguishing historical and diffusional linguistic groupings.

Jeffrey Heath was a linguistics research fellow at the Australian Institute of Aboriginal Studies between 1973 and 1977. While at the Institute he did fleldwork in southern Arnhem Land, and briefly at Tennant Creek. The Inst1tute has recently published his Linguistic Diffusion in Arnhem Land and is publishing a grammar-text-dictionary volume on the Ngand1 language; Pacific Linguistics will soon publish similar volumes on Ritharngu and Warndarang. Dr Heath has completed a similar volume on Mara, now pending with the publishers. He plans a volume of Dhuwal ethnographic texts, a major three-volume work on Nunggubuyu (the most difficult language in the world, he claims), and sketches of some other languages. He is currently organizing and editing a volume of papers by linguistic anthropologists on Aboriginal kinship terminologies. His theoretical interests include functional syntax, historical morphology, and sociolinguistics. He recelved his doctorate in Iinguistics from the University of Chicago in 1976 and in 1978 he took up his present appointment as Assistant Professor at Harvard University, where he teaches sociolinguistics. 
Luise A. Hercus is Reader in Sanskrit, Department of South Asian and Buddhist Studies, Australian National University. She was educated in England and got her first degree in Modern Languages in Oxford and subsequently graduated also in Oriental Studies (Sanskrit and Prakrit) at the same university. She was University Lecturer and Fellow of St Anne's College, Oxford, specialising in Prakrit. Since coming to Australia she has become interested in Australian Aboriginal linguistics and began work on Victorian and far western New South Wales languages in 1963; she has since worked extensively also on the languages of the north east of South Australia.

Geoffrey N. O'Grady (1928-) came to the formal study of linguistics after an initial six-year period in northwestern Australia, where he studied Nyangumarda and other languages of the area. He obtained his B.A. at Sydney University in 1959 and went on to a Ph.D. In Iinguistics at Indiana University in 1963. Since then, he has been resident in Canada. He held positions at the University of Alberta (1963-65) and at the University of V1ctoria, where he has been Professor of Linguistics since 1973. His publications and research have continued to reflect his interest in the Australian languages. With the support of the Australian Institute of Aboriginal Studies and the National Sclence Foundation, he returned to the fleld in 1967, 1970 and 1974. Since 1967 he has been involved in a project, hopefully to be completed before the end of the century, in which the alm is the reconstruction of the Proto Pama-Nyungan lexicon. Present indications are that the number of recoverable etyma will be in excess of 1,400 .

Bruce Rigsby is Professor of Anthropology at the University of Queensland. An American linguistic anthropologist, he moved to Australia in 1975 to pursue his research interests among the indigenous language varieties and English pidgin-creole varleties spoken by Aboriginal people on Cape York Peninsula. He is also a member of the Cape York Ecology Transect (CAYET) transdisclplinary research group that is studying man/land relations there. Earlier he worked among the Sahaptin and Nass-Gitksan peoples of North America, and he formerly taught anthropology and linguistics at the University of New Mexico.

Margaret Sharpe began her linguistic training with the Summer Institute of Linguistics in 1961, and studied the Ifugao language of the Philippines for a short time. In 1965 she accepted an Australian 
Institute of Aborlginal Studies funded research fellowship at the Unlversity of Queensland, carrled out some salvage work on Queensland Aborlginal languages, some study of the Roper Creole language of the Roper River-Katherine area, and a depth study of Alawa, spoken near Roper River, for which she galned her Ph.D. In 1970. As a fleld officer with the Van Leer Project in Queensland in 1969-70, she helped in research on Aborlginal chlldren's English in Queensland, then, whlle rearing a young famlly, she held part time and temporary positions at the UnIversity of Queensland and Mt Gravatt College of Advanced Education. In 1976 she carrled out the research reported here, and in 1977 was in the Northern Rivers area of New South Wales to co-ordinate a language-culture project requested by the Bundjalung Aboriginals of that area. In 1978 she took up a full time lecturing position in Multicultural Studies at Armidale College of Advanced Education. As time permits with her present duties, she is working on a grammar and dictionary in non-technical language for the Bundfalung people, and an Alawa-Roper Creole-English dictionary.

Peter Sutton is a graduate in Early English Literature and Language from the Unlversity of Sydney, and did an M.A. In Aboriginal linguistics at Macquarle University. After several years at the Australian Institute of Aborlginal Studies as lingulstics research officer, he moved to the University of Queensland where he has recently completed a $\mathrm{Ph} . \mathrm{D}$. In linguistic anthropology in the Department of Anthropology and Soclology. H1s research interests began with a fleld study of the English dialect of Cape Barren Islanders in Tasmania in 1969, and for several years he worked in north-east Queensland with the remalning speakers of a number of near-extinct languages, Including Kuku-Pathun and the Flinders Island language. Since 1975 his interests have malnly been soclolinguistic, and his fleldwork has concentrated on the polyglot Aboriginal community of Cape Keerweer, Cape York Peninsula. At present he is a post-doctoral research assoclate at the UnIversity of Queensland.

Michael Walsh recelved a B.A. (Hons) in Early English L1terature and Language with a major in Greek from the University of Sydney in 1969. After carrying out fleldwork on Australian languages in the Port Keats, Northern Territory area he was awarded a Ph.D. In 1976 for a dissertation on Murinypata, from the Australian National University. Since 1975 he has served on the staff of the Australian Institute of 
Aboriginal Studies, Canberra as Linguistic Research Officer. His chief interests lie in Australian linguistics, with particular interest in ethnographic semantics.

Stephen Wurm obtained his doctorate in Linguistics and Anthropology at Vienna University, and after holding university appointments in Altaic and Turkic linguistics at Vienna University and the Central Asian Research Centre (associated with St Antony's College, Oxford University), he Jolned Sydney University in 1954 and the Australian National University in 1957 where he is now Professor of Linguistics in the School of Pacific Studies and in charge of the University's extensive research program in Pacific Linguistics. His research interests have for many years been focussed on Papuan linguistics as well as on Austronesian, Australian and Pidgin linguistics, and he has published widely in these subjects and on interdisciplinary approaches involving them. 
